\title{
Our Nation and the Sea
}

\section{A Plan for National Action}

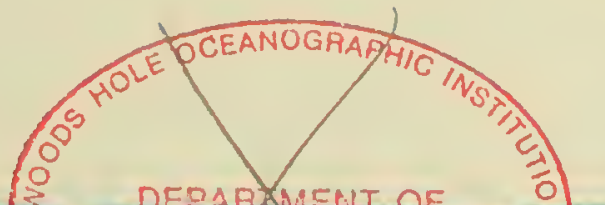

Report of the Commission on Marine Science, Engineering and Resources
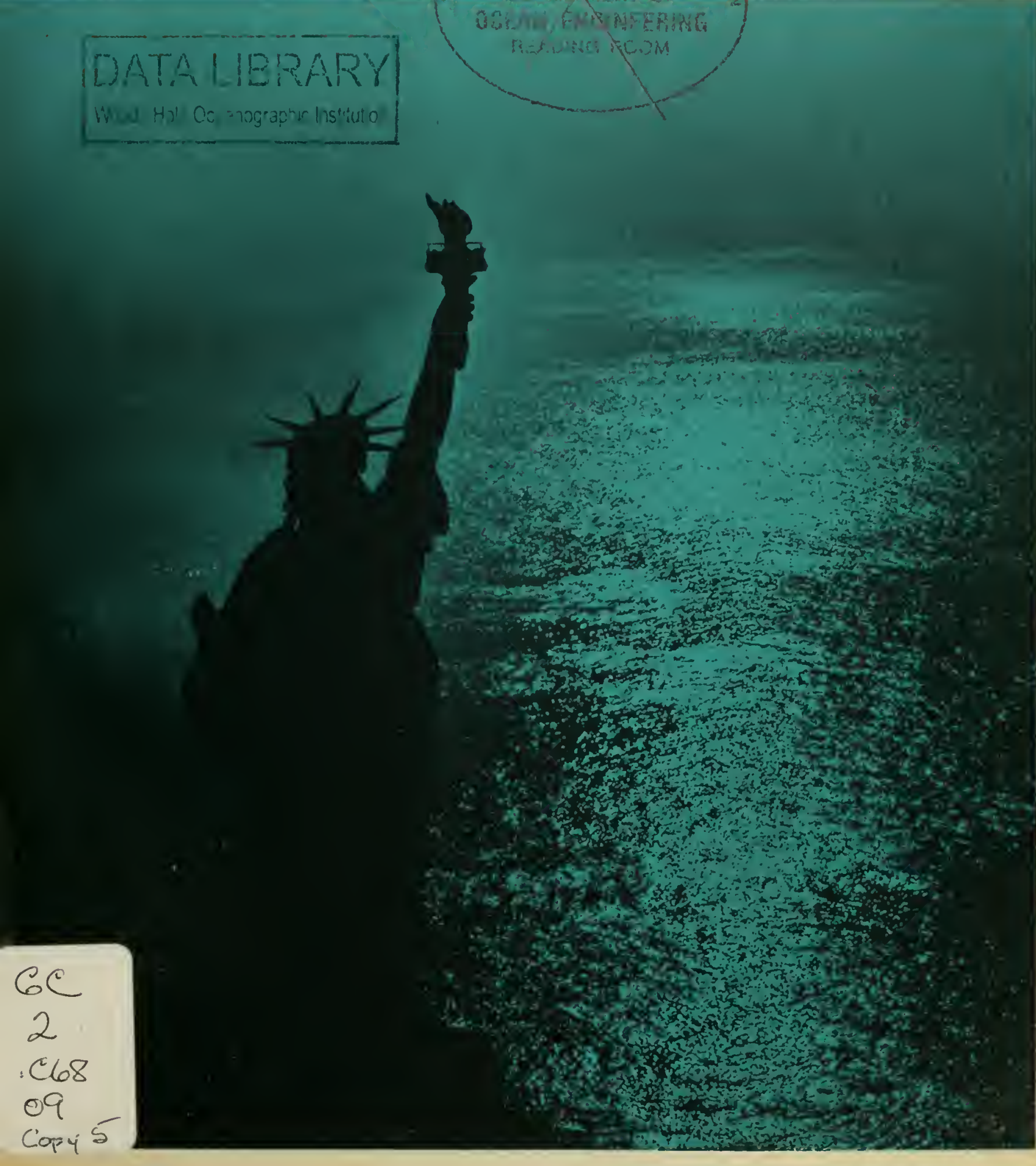


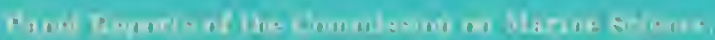

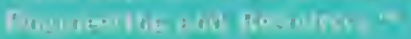

Ywonis 1

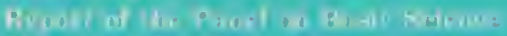

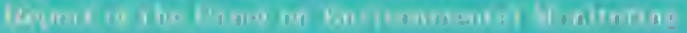

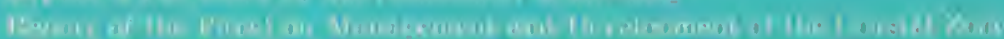

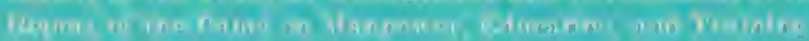

$\operatorname{xon} n=2$

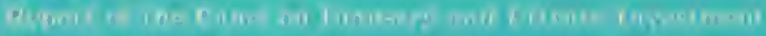

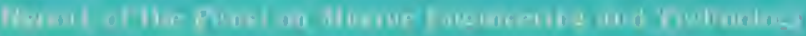

Tor tons 3

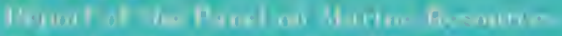

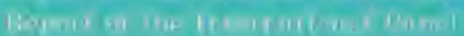

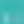

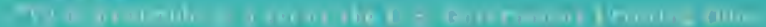




\section{Our Nation and The Sea}

\section{A Plan for National Action}

Report of the Commission

on Marine Science,

Engineering and Resources

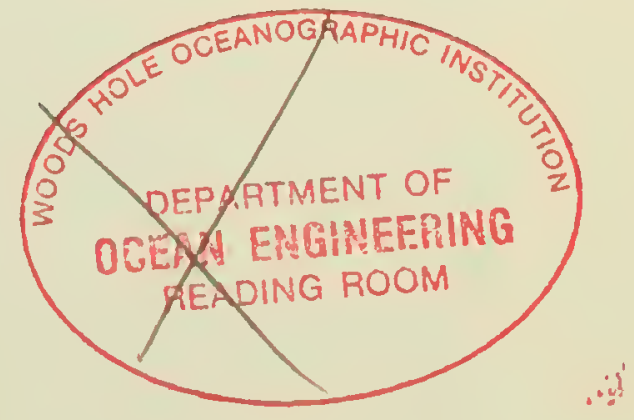

United States Goremment Printing Office

Washingtou, D.C.

January 1969 


\section{Commission on Marine Science, \\ Engineering and Resources, Washington, D.C., January 9, 1969.}

Jonn W. McCormack,

Speaker of the House of Representatives,

Washington, D.C.

\section{Dear Mr. Speaker:}

I have the honor to present the final report of the Commission on Marine Seience, Engineering and Resources, the establishment of which was authorized by Public Law 89-454, enacted by Congress on June 17, 1966. The members of the Commission were appointed by the President on January 9, 1967.

In response to its mandate, the Commission has undertaken an intensive investigation of a broad array of marine problems ranging from the preservation of our coastal shores and estuaries to the more effective nse of the vast resources that lie within and below the sea. The recommendations which have emerged from this study constitnte a program which we believe will assure the advancement of a national capability in the oceans and go far towards meeting the ineritable needs of the future.

These recommendations are the product of nearly two years of study and discussion, and they express the combined judgment of the entire Commission. On all major issues there has been unanimous conenrrence, although in formulating recommendations relating to govermment organization it has seemed proper for three members of the Commission to abstain-Undersecretary of the Nary, Charles F. Baird; Assistant Secretary, Water Pollution Control, Department of the Interior, Frank C. DiLuzio; and the Administrator, Environmental Science Services Administration, Department of Commerce, Robert M. White. These members were appointed as representatives from the Government but served on the Commission in their individual capacities as specified by statute. Their knowledge and experience in governmental and organizational problems were freely drawn upon by the Commission in its deliberations. However, recognizing that the organizational proposals of the Commission vitally affect the departments which they serve in their offieial roles, they have abstained from taking a position with respect to the final recommendations on these particular proposals as outlined in Chapter 7 and summarized or mentioned elsewhere in the report.

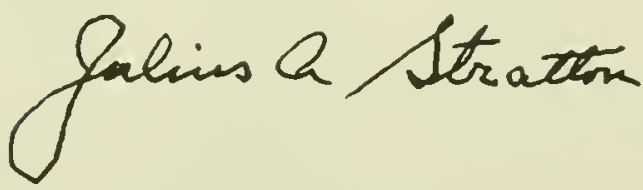

J. A. Stratton
Chaimman

JANUAKY 9, 1969 


\section{Commission}

\section{Chairman}

Julius A. Stratton

Chairman

The Fold Foundation

Viec-Chairman

Richard 1. Geyer

Head

Department of Oceanography

T'exas A\&M University

David A. Adams ${ }^{1}$

Commissioner of Fisheries

North Carolina Department of

Conservation and Derelopment

Carl A. Auerbach

Professor of Law

University of Mimnesota

Charles F. Baird?

Under Secretary of the Nayy

Jacob Blanstein

Director

Standard Oil Company (Indiana)

James A. Crutch field

Professor of Economics

University of Washington

Frank C. DiLuzio ${ }^{1}$

Assistant Secretary-

Water Pollution Control

UT.S. Department of the Interior

\footnotetext{
1. Adiliation as of time of appointment

- Appointed July 21. 1967 to succerd liobert II. B. lialiwin. former l'nder seneretary of the Nay, who served

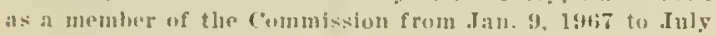
:1..1905.
}

Leon Jaworski

Attomey

Fulbright, Crooker, Freeman,

Bates and Jaworski

John A. Knamss

Dean

Graduate School of Oceanography

University of Rhode Island

John H. Perry, Jl:

President

Perry Publications, Inc.

Taylor A. Pryor

Presiclent

The Oceanic Folmdation

George E. Reedy ${ }^{1}$

President

Struthers Research and Derelopment Corp.

George H. Sullivan, M.D.

Consulting Scientist

General Electric Reentry Systems

Robert M. White

Administrator

Environmental Science Services

Administration

U.S. Department of Commerce

Congressional Atrisers

Norris Cotton

U.S. Senator

Warren G. Magnuson

U.S. Senator

Alton A. Lemnon

T.S. Representative

('harles 1. Mosher

U.s. Representative 


\section{Staff}

\section{Exccutive Director}

Samuel 1. Lalwrence

Deputy Dircetor

Lewis M. Alexander

Assistant Director.

C) rganization amel Management

('lifford L. Berg

John P. Alber's

WVilliam S. Beller

Bavid S. Browning

Lincoln D. Cathers

Timotlyy J. Coleman

Jolnn J. Dermody

Robertson P. Dinsmore

Kenneth H. Drummond

Andrew G. Feil, Jr.

Harold L. Goodwin

Amor L. Lane

H. Crane Miller

Holmes S. Moore

Sheila A. Mulvihill

Merlyn E. Natto

Leon S. Pocinki

Stmart A. Ross

Carl E. Rudiger"

William J. Ruhe

Carleton Rutledge, Jr.

Robert .J. Shephard

R. Lawrence Snideman II

Supporting Staft

William I. Banlss

Margaret R. Bickford

Lois $\Lambda$. Brooks

Josephine V. Haley

Louiso A. Jones

Linda .J. Kueble1"

Helen I. Mehl

Jean H. Peterson

Emily G. Reeres

.Joanne M. Schirk 


\section{Acknowledgements}

Those to whom the Commission has tumed for information, for guidinee, and for expert knowledge are so mumerous that it is heyond our ability to thank inclividually all who have contributed so much to our efforts and to the preparation of this report. In reaching our conclusions, we have drawn upon the idleas and the material assistance of more than 1,000 people. They have included marine scientists and engineers, leader's of business and industry, members of the academic community, and many marine specialists of the Ferteral, State, and local goremments. We are deeply indebted to then all.

The Marine Resources and Engineering Development Act of 1966 wisely made provision for Congressional advisers to the Commission. We are most grateful to Senator Warren G. Magnuson of Washington, Senator Norris Cotton of New Hampshire, Congressman Alton A. Lennon of North Carolina, and Congressman Charles $\Lambda$. Mosher of Ohio for their counsel, their encouragement, and their support.

This has been a working commission, and from the outset every member has been actively and continuously engaged. But the completion of a task of such magnitude and complexity conld never have been accomplished without the aid of a staff that has worked skillfully, effectively, and with extraordinary dedication. From the beginning to the end, this entire endeavor has profited from the leadership of our Executive Director, Samuel A. Lawrence, who has won the respect and admiration of all who worked with him. 'To Dr. Lawrence and to each member of our staff, the Commission expresses its profound thanks. 


\section{Foreword}

From the days of diseovery and colonization, America has looked to the sea. In times of stress the sea has been om ally, and in times of peace, a source of on prosperity. sometimes hostile and sometimes generons in its moods, the ocean always lias offered its abmulant resources in countless ways. But only recently have we begun to perceive its true potential.

The driving force and urgency of our new concern for the sea stem from the changing character of the world itself-from momuting economic needs, from congested populations, from onr own deteriorating shores. It is now nearly 10 years since reports by the National Academy of Sciences and the IT.S. Nary focmsed attention mpon the rital import of our underdereloped marine resonrces. The intervening decade has been marked by a mounting interest and activity. Further reports, studies, and statements have poured forth in profusion, representing the experience, the riews, and the best judgment of the outstanding experts of the count ry. Thronghont this period a voluminous legislative record testifies also to a growing Congressional concern, which eulminated in Jume 1966 in the Marine Resomrees and Engineering Development Act, expressing a conviction and defining a national purpose:

- A conviction that the time had arrived for this country to give serious and systematic attention to our marine environment and to the potential resources of the oceans

- A national determination to take the steps necessary to stimulate marine exploration, science, technology, and financial investment on a vastly angmented seale.

'The Act established two complementary bodies: the National Commeil on Marine Resources and Enwineering Development and the Commission on Marine science, Engineering and Resonrees.
With the Vice Presiclent as Chairman, the Comcil is comprised of the heads of the major Federal departments and agencies with marine missions. The Council was charged with the plamning and coordination of current maline progians and with advising and assisting the President. It cont inually surveys the state of marine affairs and has shaped and strengthened Federal marine programs.

In contrast, the members of the Commission, appointed early in 1967 by the President, represent diverse interests and areas of the comtry, and the Commission was left wholly lree of operating responsibility.

First, the Commission was asked to examine the Nation's stake in the development, utilization, and preservation of our marine environment.

Second, we were to reriew all current and contemplated marine activities and to assess their adequacy to achiere the national goals set forth in the Act.

Third, on the basis of its studies and assessment, the Commission was to formulate a comprehensive, long-term, national program for marine affairs designed to meet present and future national needs in the most effective possible manner.

Ind finaly, we were requested to recommend a plan of Government organization best adapted to the support of the program and to indicate the expected costs.

Consequently, the report which the Commission now presents goes beyond the confines of oceanography as a science to eneompass marine technology and the resonrces of the seas. 'The difficulties of om task were componnded by the dramatic rapidity with which changes and expansion are taking place thronghont all elements of the marine community. Since we set to rork, deep submersible eapability has been extended beyond a nantical mile in depth : man-in-the-sea proj- 
ects are measured in weeks instead of days; the oflishore petrolem exploratory well depth record has doubled from bito fret.to 1,300 feet. While ships have increased in size to wiant 300,000-ton tankers, onl advances have heen punctuated by occasional disaster's that presage the uriment need to nimimize the growing lazards of new techuology.

The National Sea Grant Program and the new water pollution control programs are notable examples of Federal efforts to spur beneficial marine activity. Progress in the production of fish protein concentrate has raised expectations about animal protein from the sea. On the international scene, the Malta Resolution to the Tuited Nations General Assembly highlighted the legal and political problems that will surromnd exploitation of the mineral resonrces of the deep seas which technology promises to bring within the reach of man. The U.S. initiative in proposing an International Decade of Ocean Exploration has further intensified interest in international scientific collaboration.

Although the Commission has treated its mandate broadly, it has not been possible within the time available to make an exhaustive examination and assessment of all majine activities. We have taken acconnt of the relationship between civil and military marine affairs in various sections of this report but have made no attempt to treat questions of military security as such. Nor has the Commission dealt with the immensely complex problems of the U.S. Merchant Marine, about which many studies exist. We have, howerer, considered the requirements which the use of the sea for transportation places upon our polts and upon services offshore.

The problems of pollution have taken a prominent role in the Commission's studies and recommendations. But we have been well aware that waste disposal and pollution in the ocean and estuaries are often inseparable from pollntion upstream and even pollution in the air and land enviromments; these ultimately must be treated as a single problem. Wo have deemed it appropriate to onr mission, however, to consider those pollution problems that affect directly the marine environment, inclnding the Great Lalies.

In approaching its task, the Commission resolved itself into seven panels to examine and assess well-defined areas of marine activity: basic science; marine engineering and technology; marine resonrces; environmental monitoring and the management of the coastal zone; industry and private investment; international issues; and education, manpower, and training. These panels held many hearings, traveled about the comtry to gain firsthand knowledge of activities related to their assignments, and finally distilled a tremendous mass of material into a series of reports. Throughout this period of study and drafting, the Commission met together regularly to review and evaluate critically the findings and recommendations of these task forces. The panel reports are to be published separately, and we commend them to the attention of all those who wish to go more deeply into the subject. They constitute the primary source material upon which the Commission based its own final conclusions.

We are convinced that the recommended national marine program will contribute materially to the mational economy and strengthen the national security. The pages that follow outline not a crash endeavor but one geared realistically to the means of the Nation. We realize that, in terms of timing, each element of this program must be considered in the context of overall national priorities. 
viii

Our proposal for reorganization, however, is urged for immediate adoption. We believe that it will mobilize the resources of our Govcomment in the most elective manner to lend strength and power to the Nation's marine commitment. The incremental cost in taking prompt action for consolidation will in itself be relatively small. The added effectiveness for the fulfilment of the national program should be enormous.

Guin a Strattore

Julius A. Stratton

Richard A. Beyer

Richard A. Gayer

Paid G. Glam

David A. Adams

Call a. Amenbace

Carl A. Auerbach
The Commission harbors no illusions that it has provided final answers to the multitude of questions that relate to the future use of the seas. Indeed, the legislation of 1966 itself was envisaged by the Congress only ats a first step, and we recognize that no report, no program, can be valid for all time. But we earneatly hope that the work of this Commission will lead to constructive action and a major advance for our Nation and the sea. 
James A. Sintetipere James A. Crutchfield

Dranke ntyis kerue : Reey

Frank C. DiLuzio

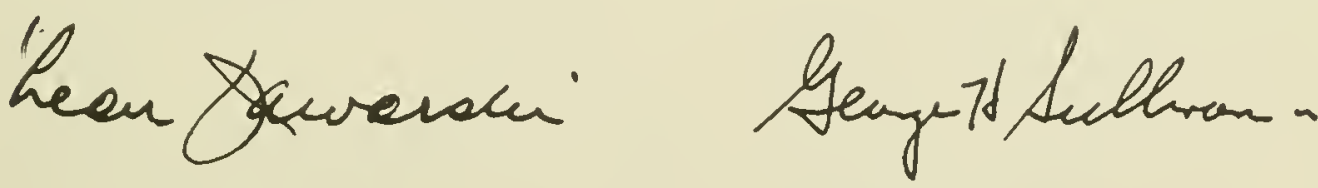

Ieon Jaworski

Goten A. Sraurs

John A. Knauss

fohusteny fi

John H. Perry, Jr.

Saluct mescite

Robert M. White 


\section{Contents}

Chapter 1 An Introduction and Summary.

Our Stake in the Uses of the Sea.

A Plan for National Action.

\section{Chapter 2 National Capability in} the Sea.

Advancing Marine Science

University-National Laboratories. .

Coastal Zone Laboratories. .

Federal Laboratories.

Naval Research

Diversity of Support.

Advancing Marine Technology . . . . . .

Fundamental Technology.........

National Projects

Industry and Universities in Marine

Techmology

The Navy in Marine Techmology . .

Manpower for the National Capability.

Information and the National Capability.

Costs for National Capability .......

Chapter 3 Management of the Coastal Zone.

The Nature of the Coastal Zone.....

Intensification of Coastal Zone Usage

A Proposed Coastal Management System.

Functions and Powers of State

Coastal Zone Authorities.

Management in Interstate Estuaries

Federal Role in Coastal Zone Management...............

Information Needed for Coastal Zone

Management................

Opportunities for Coastal Development.

Moving Operations Offshore..... Special Attention to Recreation. .

A Plan for" "Seasteads".

The Pollution Problem.

Program Costs.
Chapter 4 Marine Resources.

83

National Resource Policy..........

Development of the Sea's Living Resources............... 86

Marine Fisheries............ 86

The Ocean's Food Potential....... 88

World Production and Demand.... $\quad 89$

Principles of Fisheries Management...................

Rehabilitation of U.S. Domestic

Fisheries................. 94

International Fisheries Management. 104

Aquaculture . . . . . . . . . . . . . . 115

Sea Plants................. 118

Extracting Drugs from the Sea.... 119

Development of Nonliving Marine

Resources.................

Petroleum. ................ 122

Natural Gas................ 127

Other Marine Minerals. . . . . . . . 130

Fresh Water Resources......... 137

Pre-Investment Surveys . . . . . . . . . 139

Federal Agency Roles............ 141

An International Legal-Political Framework............ 141

Existing Framework......... 143

Recommended Redefinition of the Continental Shelf........

Recommended Legal-Political Arrangements for Subsea Areas Beyond the Shelf ...........

Relations between the U.S. Govermment and Private Firms in Registering Claims..........

A Proposed Course of Interim Action.

Industrial Activities and Attitudes.

Legal and Regulatory Framework. .

Technology and Services......... 161

Collaboration in Planning........ 166

72

79 
Chapter 5 The Global Environment.

Exploring and Understanding the Global Oceans...............

Research and Survey Programs...

Marine Geology and Geophysics................ 172

Murine Biologr. . . . . . . . . 172

Physical Oceanography ....... 173

Polin Seas. . . . . . . . . . . . . 173

Decade of Ocean Exploration. . . . 174

The Technology. . . . . . . . . . . . 175

The Global Monitoring and Prediction System

System Operations and Management Arrangements.

A Progran for Immediate Implovement......................

The Teehnology for NEMPS

Research. . .

Environmental Modification.

An International Framework: Organizational and Legal.

International Organizations. . . . . .

A Legal Framework for the Conduet of Marine Researeh...... .

Program Costs. . . . . . . . . . . . . .

\section{Chapter 6 Technical and Operat-} ing Services

209

Mapping and Charting the Ocems... 209

Nilvigation.................. 213

Safety at Sea............... 215

Control of Offshore Traffic....... 215

Certification............... 215

Senrelı and Resene............. 216

Recreational Boating. . . . . . . 216

Underwater Safety............ 217

Policing and Enforcement......... 217

Data Services................ 218

Instrument Testing and Cilibration. . 221

Program Costs.

224
Chapter 7 Organizing a National Ocean Effort............... 227

Federal Organization for Marine Affairs. . . . . . . . . . . . 227

A National Ocennic and Atmospheric Agency............... 230 Organization and Functions...... 230

Capabilities of the New Agency . . 234

Considerations Relevant to the Recommended Agency Transfers.

Overseeing the National Program.... Operational Planning and Coordination.................... National Advisory Committee for the Oceans.

236

244

244

245

Exeentive Office of the President. . 246

Congressional Oversight. ........ 247

Conchusion................... 249

Chapter 8 A Financial Plan for Marine Science.................

The Commission's Approach to Cost

Estimates............... 251

Present Funding Levels . . . . . . . . . . 252

The Commission's Estimates: An

Overview................ 254

A Budget for the National Oceanic and

Atmospheric Agency ... . . . . . . 258

Conclusion................. 258

Epilogue................ 260

Appendix 1 Public Law 89-454 ... 261

Appendix 2 Table of Recommendations............... 267

Appendix 3 The Operations and Task of the Commission........ 278

Appendix 4 Commission Studies and Reports............... 283

Photo Credits .............. 286
Index. 
Chapter 1

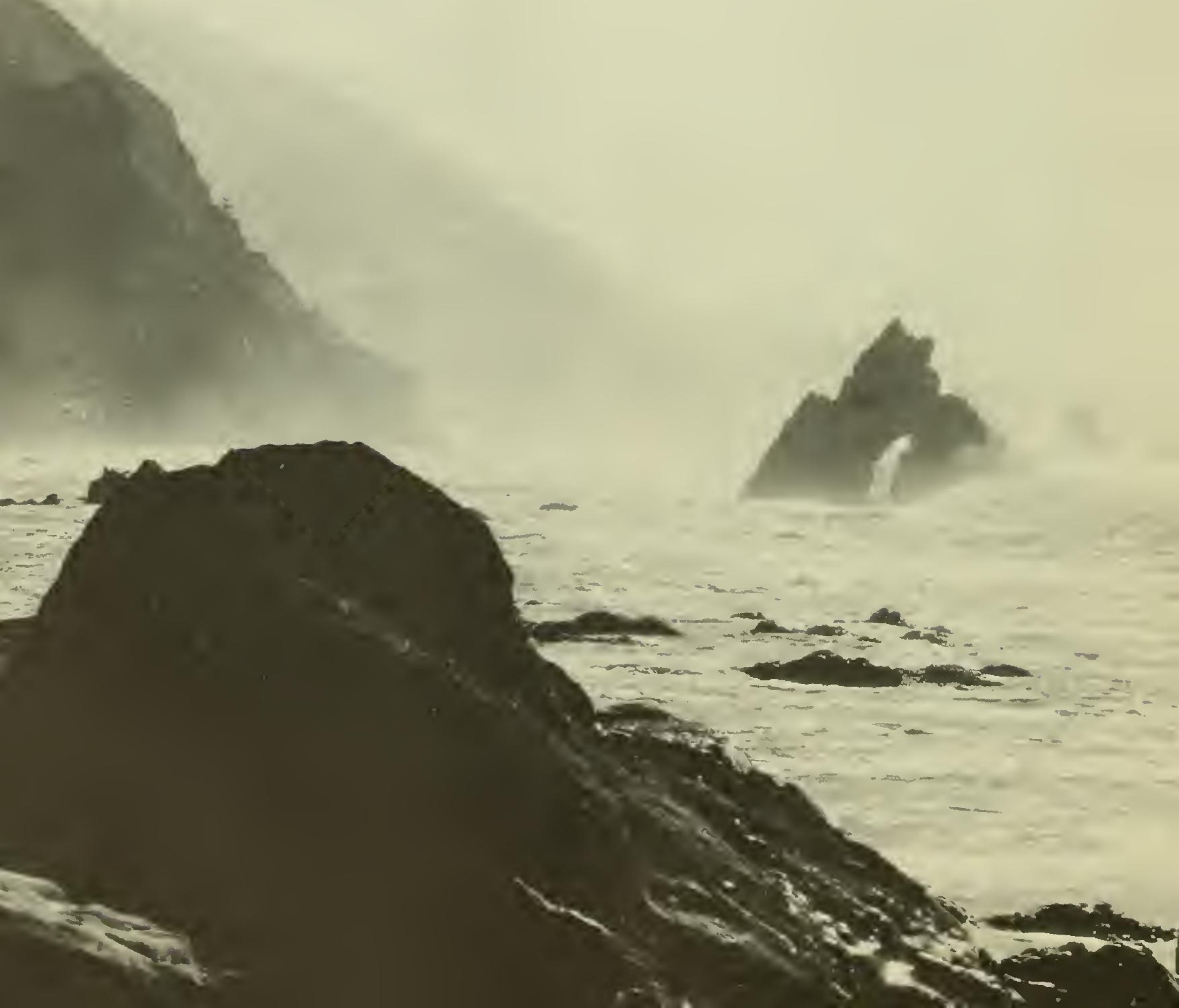




\section{An Introduction and A Summary}

\section{Our Stake in the Uses of the Sea}

llow fully and wisely the United States uses the sca in the deeades ahead will allect profoundly its seemrity, its economy, its ability to meet increasing demands for food and raw materials, its position and influence in the world community, and the quality of the enrijonment in which its people live.

'The neod to develop an adequate national orean program arises from a combination of rapilly converging and interacting forees.

'The world population is expected to apfroximately clomble by the vear :000, hut even a lesser rate of growth would intensify the already serious food supply problem. The need for supplemental animal protein sonrees is rritical and is growing daily. The sea is not the omly somrce of additional protein but it is an extremely important one.

The United States itself fices no serious protein shortage, and its rate of population growth shows a promising decline. Nevertheless, it is expected that by the end of the century the population of our comtry will reach :300 to :35) million people and that the Nation will rely increasingly on food from the sea.

Is the population grows, new means must be developed to expand the economy, to gencrate new johs and produets, and to pay the (osts of publicly rendered ser'vices. Although land-based activities will continue to dominate the economy for many years to come, new and expanded ocean industries offer some of the Nation's most inviting opportunities for eeonomic growth.

The recent achievements of technology in the sea havo focused national attention on ocean resources to a greater extent than ever before. 'The sea's potent ial as a sonree of food, drugs, and minerals has been much publicized, and the oceans have been depicted as a "last frontier" to be conquered lyy man. 'The Commission's appraisal is more modest than many of these glowing assessments, but even bard estimates show great possibilities for the future.

The potential for expanded economio activities is evident in today's marine industrial operations. Oll'shore petrolem, gas, and sulfur recovery attests that the wealth in the land under the sea is available to man; the mining of tin, diamonds, sand, gravel, and shell from the seabed shows the possibilities of recovering other important minerals. Deep submersibles and undersea labitats demonstrate the ability of man to live and work under the sea. Yet technological development for eeonomieally important work in the sea remains largely in the futmre.

Vital though marine economic development is, it must be tempered by other considerations. There is increasing concern over the need to understand our physical environment, of which the oceans are bnt one part. This concer'l is based on growing appreciation that the environment is being affected by man himself, in many cases adversely. It is critical to protect man from the vieissitudes of the enviromment and the environment, in turn, from the works of man.

'Today, man's damage to the environment too often is ignored beeanse of immediate economic advantage. 'To maximize the present economy at the expense of the future is to perpetuate the pattern of previous generations, whose sins against the planet. we have inherited.

If adequately protected, the sea and shoreline can provide unique and raluable opportunities for recreation. The growth of the country's population, most pronounced in urban areas along the shoreline, and the increased wealth and leisure of many of our people, are creating inexorable pressures for access to the sea. Contamination or destruetion of beach, marsh, waterway, and shoreline agraratrates these pressures by denying 


\section{Growth Patterns in the Nation's Coastal Population}

(Counties bordcring aceans and Great Lakes)

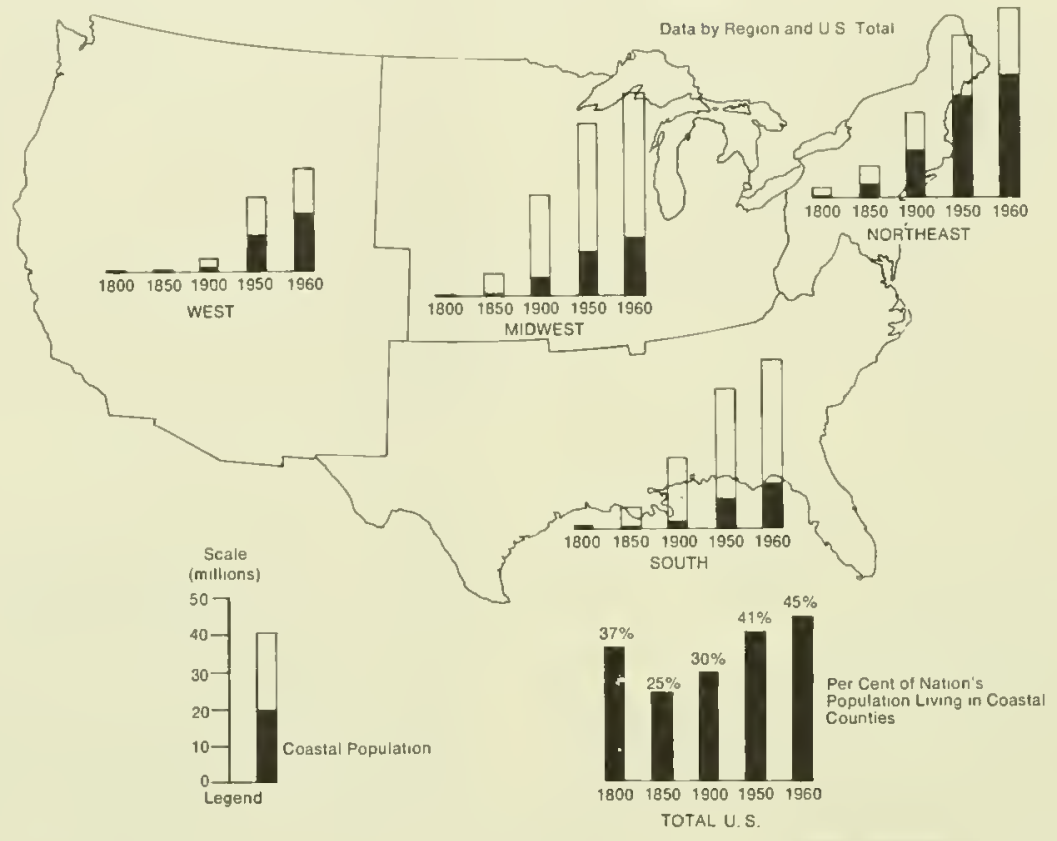

use of the sea and shore to a growing population.

The pollution problem pervades all aspects of om expanding technological society. Even with stronger abatement programs, it appears likely that pollution will increase alamingly in the years aluead. Inch of on mowanted waste will find its way into onr lakes and estuaries and ultimately juto the sea. Intensified use of the marine environment is also generating its own polluting effects, which must be kept in check in order to preserve the sea for a diversity of humali uses. Becanse the rate of marine-related activity is increasing very rapidly, delay may mean excessive, irreversible damage to some parts of the marine enviromment, particularly in the coastal zones near the great centers of population and in the esturies of major rivers.
The oceans and marine-related activities must be viewed in the context of the total land-air-sea enviromment. In many ways, the oceans are the dominant factor in this total environment. Howerer, intervention by man in any one element produces effects on the others, frequently through processes we do not yet understand. Mankind is fast approaching a stage when the total planetary environment can be influenced, modified, and perhaps controlled by human activities. The Nation's stake in the oceans is therefore an important part of its stake in the very futnre of man's world.

The oceans impartially wash the shores of most of the world's nations, whose interests in the uses of the sea mirror ours. Means for reaching reasonable accommodation of competing national interests must be found to achieve efficient and harmonions development 
of the sea's resources. The atmosphere, which is so influenced by the oceans, knows no national bonndaries; the nations of the world share a common interest in its monitoring and prediction and in its modification.

The Marine Resources and Engineering Development Act of 1966 recognized that the national interest in marine programs is intertwined with the interests of the peoples of the whole world. The United States has sought to "ally out the policy stated in the $\Lambda$ ct by adrancing a proposal to the nations of the world for an International Decade of Ocean Exploration. Through the President and the Congress, the United States also has given its support to the World Weather Program in which all nations of the world are seeking to explore and monitor global atmospheric processes.

The Commission shares the conriction that marine scientific inquiry and resonree development, as well as meteorological prediction, ofler many real opportmities to emphasize the common inferests of all uations and to benefit mankind. The gap between the living standards of the rich and poor nations is ever' widening. The world cannot be stable if a lund ful of nations enjoy most of the planet's riches while the majority exists at or below subsistence levels, and many of the efforts to aid the less fortunate nations will involve uses of the sea.

Because instabilities in the world situation camnot be remedied quickly, military power will continue to be a central factor in world affairs. As maval technology increases, the depth and variety of undersea operations require detection systems of ever increasing powel and complexity. Today's advances in militury undersea technology forecast an increasingly important role for IT.S. defense and deterrence capabilities in the grobal sea. Is the uses of the sea multiply, the Navy's defense mission will be complicated by the

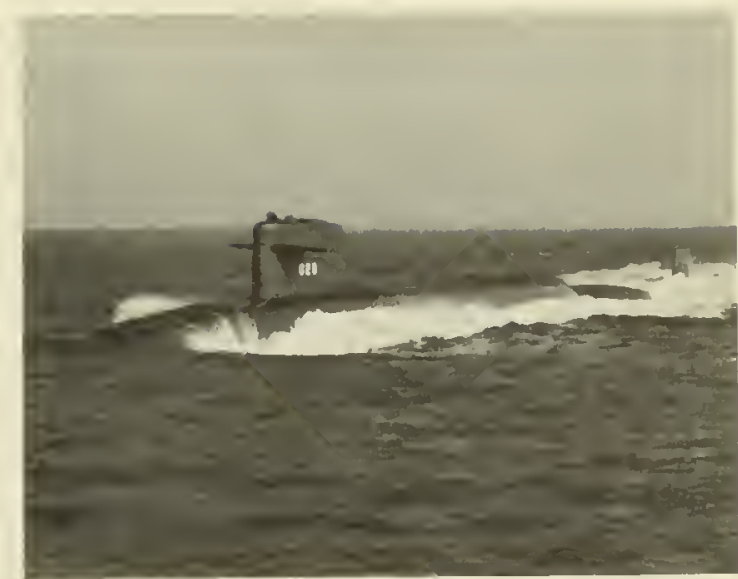

The United stutes requires a Navy rapable of carrying out its national defense missions anylhere in the necans, al any desired deplh, al any time. Herr the Polaris submarine

Daniel Boone eruises on ithe surface.

presence of structures, vehicles, and men. The resulting problems can be resolved only by the closest cooperation between civil and military users of the sea. Furthermore, military and civil science and technology for mudersea operations can and should be mutually supporting, emphasizing the need for cooperative action.

The Commission believes strongly that the Nation's stake in the uses of the sea requires a U.S. Nary capable of carrying out its national defense missions anywhere in the oceans, at any desired depth, at any time.

However, the oceans must not provide a new dimension for the nuclear arms race. The official position of the United States declares that the seabed and deep ocean floor should be used exclusively for peaceful purposes, with the understinding that the test of whether "an activity is "peaceful" is whether it is consistent with the Inited Nations Charter and other obligations of international law. Further, the [nited States has requested the IT.X. Disalmament Committee to take mp the question of ams limitation 
on the seabed and ocean floor with a view to defining those factors vital to a workable, verifiable, and effective international agreement which would prevent the use of this new environment for the emplacement of weapons of mass destruction. 'The Commission supports this position, as well as the T.S. proposal that any agreement prohibiting the deployment of nuclear and other weapons of mass destruction designed for nse on the berl of the seas should be negotiated in a broader arms control context and not in relation to devising international arrangements for the exploration and exploitation of marine resources.

\section{A Plan for National Action}

Like the oceans themselves, the Nation's marine interests are vast, complex, composed of many critical elements, and not susceptible to simplicity of treatment. Realization and accommodation of the Nation's many diverse interests require a plan for national action and for orderly development of the uses of the sea. The plan must provide for determined attack on immediate problems concurrently with initiation of a long-range program to develop knowledge, technology, and a framework of laws and institutions that will lay the foundation for efficient and productive marine activities in the years ahead. Ilthongl the Commission has addressed its proposals principally to the Federal Government, the States, the scientific community, industry, and others will need also to exercise initiative in their respective areas and participate fully in orrer that there may be a genuine national eflort.

The Commission has closen in this report to present its findings and recommendations in chaptel's that represent primary areas of national emplasis. To mobilize and impart (nergy to the total undertaking, and in keeping with its Congressional mandate, the Com- mission recommends the formation of a new, independent Federal agency, which might be called the National Oceanic and Atmospheric Igency (NOAA). The role of this new organization as well as its imperative need emerge more clearly with each successive chapter, and a detailed discussion is therefore deferred until near the end of the report.

Since a strong, solid base of science and technology is the common denominator for accomplishment in every area of marine interest, actions necessary to advance our technical capability are presented at the outset. Then follow chapters on the plotection and management of the coastal zones and estuaries, the development of living and nonliving resources of the sea, and the exploration and monitoling of the total global environment. In Chapter $i$ the proposals for strengthening organizations, built npon program needs, are brought together, and the report concludes with an estimate of costs. The remainder of Chapter 1 provides in brief, narrative form an overview of the total program proposed by the Commission together with an indication of ma jor recommendations.

\section{Improving the National Marine Capability}

I full realization of the potential of the sea is presently limited by lack of scientific knowledge and the requisite marine technology and engineering.

\section{Marine Science}

Support of basic marine resenrch is vital if we are to understand the global oceans, to predict the behavior of the marine environment, to exploit the sea's resources, and to assure the national security.

Marine science has become "big science," and our eflorts are limited by inadequate technology. The Nation is poorly organized to marshal the arrays of multiple ships, buoys, submersibles, special platforms, and aircraft, as well as the complex undersea 
facilities required for important oceanic inrestigations and experiments of a basic character. The Commission proposes that a small group of institutions, including the present leaders in ocean research, be designated by the Federal Government as I Tniversity-National laboratories and be equipped to umdertake major marine science tasks of a global or regional nature. The laborntories should be distributed geographically for adequate coverage of all parts of the ocenns and would be expected to commit their facilities to serve the needs of scientists affiliated with other institutions. The funds granted should be sufficient to support each laboratory, its facilities, and its staff as an on-going institu-

\section{The ('hesupeale Bay Instilule's rescarch catamaran and the ocean-fronl campus of the Scripps Instimfion of Occanography e.remplif! the far-ranging nature of l's. marinc scicnce researeh.}
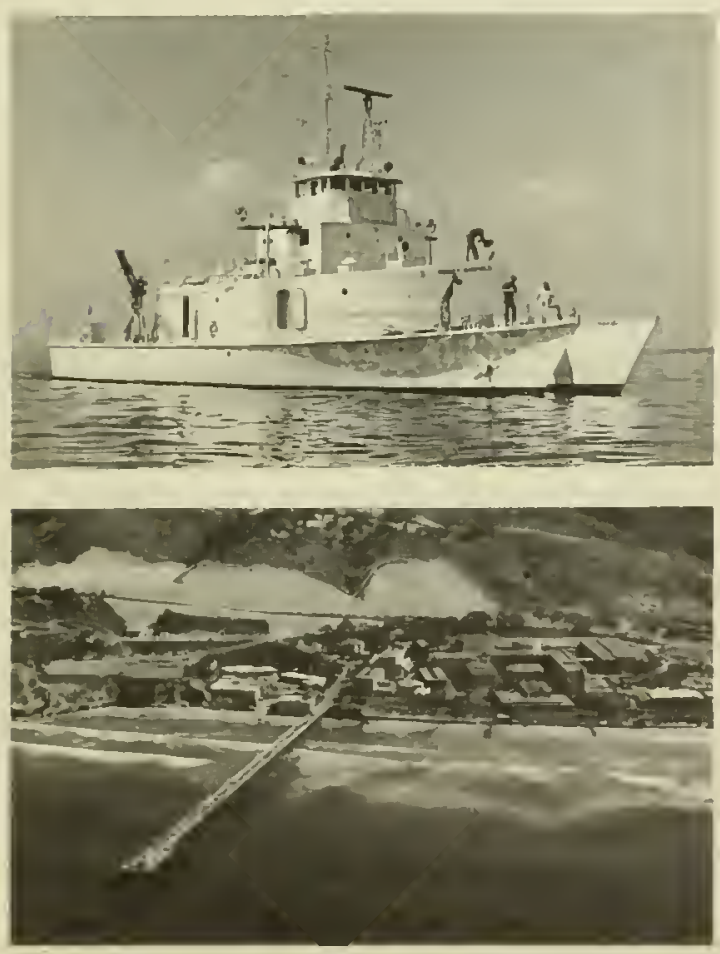

tion and to enable it to carry ont broad programs of research on a contimuing basis.

With such continuity assured, the laboratories also could seek additional funds for specific projects from the National Science Foundation, the Nary, and other public and private agencies.

Establishment of the Eniversity-National Laboratories should not, however, prechucte support of marine science research in other institutions, for a diversity of institutions and individuals working in these fields is essential to the health of marine science and should be maintained.

The Department of Defense for its part must continue to recognize the vital relationship of basic marine science to its own mission and support such scientific research as it has in the past.

\section{Marine Technology}

The Commission urges that the proposed National Oceanic and Atmospheric Agency initiate a major program to stimulate the development of funcamental marine technology and engineering in order to expand the scope and to lower the costs of undersea operations.

The Commission proposes two goals for a national effort :

- The development of the necessary technology to make possible productive work for sustained periods at depths to 2,000 feet.

- The development of a technical capability sufficient to allow useful access to depths to 20,000 feet, comprising more than 98 per cent of the world's ocean floor.

It is recommended that these two objectives be sought simultaneously.

\section{Fundamental Technological Development}

Fundamental technology is comparable to basic science in that it provides a foundation for many uses, and a lack of this basic technology currently limits potential 


\section{Landmarks in the Development of Ocean Technology}

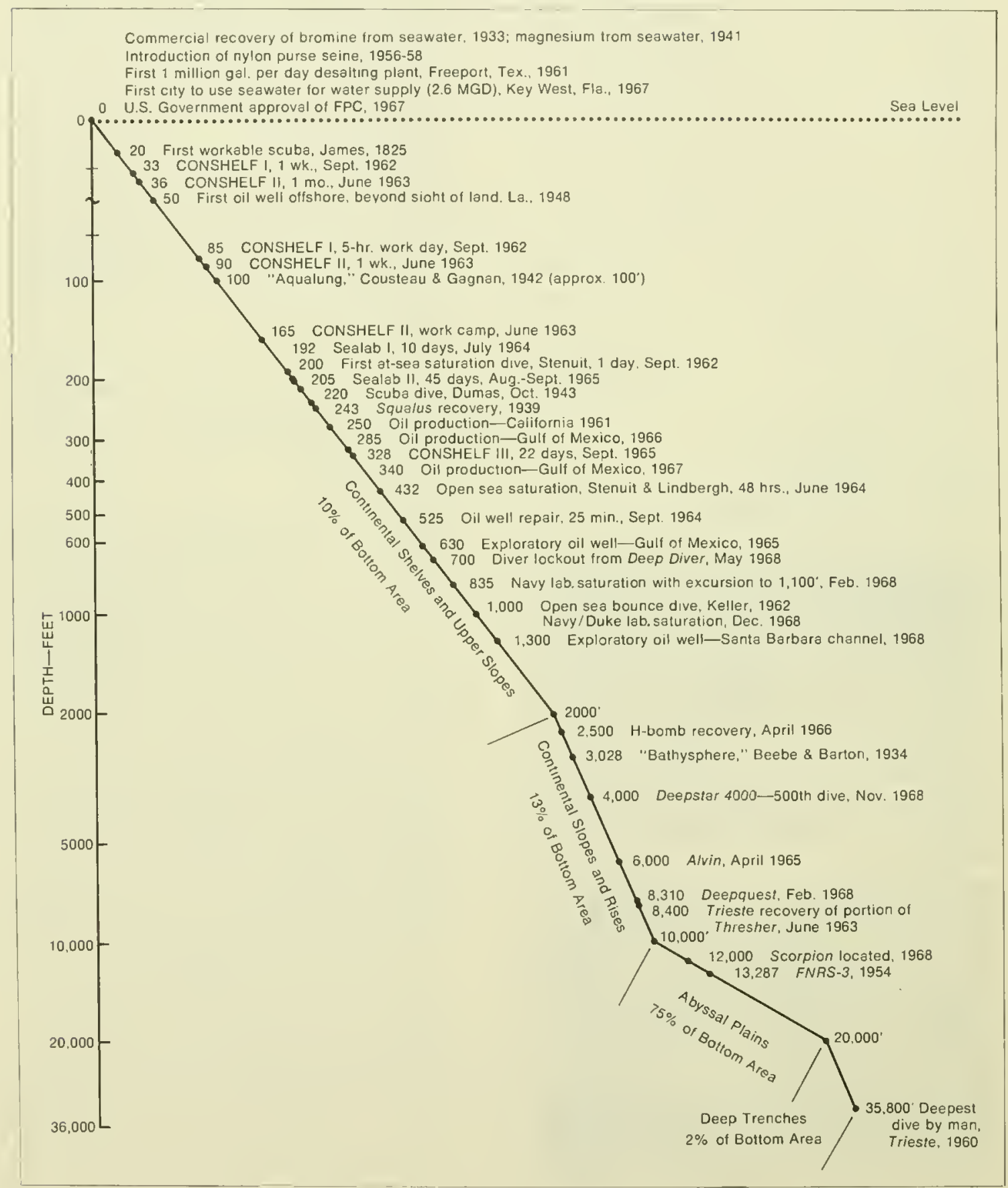


uses of the sea. For example, materials teclimolong has failed as yet to produce structures for deep orean use which possess the required low ratio of weight to risplacement. There are few high-strength, colrosion- and fouling-resistant components for sea use. The materials for supplenental huymoy are intdequate. Inderaea operations are handicapped by undependable power somress, electrieal systems, and free-flooding external equipment for vehicles and habitats. Instrumentation to observe and measure marine phenomena in the course of surface operations is renerally ineflieient, mreliable, and inalequate.

'The Commission reeommends that the Federal Government assume the task of over(oming these rleficiencies through developmental (ontraets and grants to industry and miversities and by Goremment-supported multipurpose projects in which private industry and the mirersities mould participate.

National Projects The Commission leeomments a series of National Projects to stimulate and support the adrance of marine science, technology, and uses of the sea. The projects should be Federally supported but performed by industry and universities. They should he designed to serve a rariety of needs and purposes. The National Projects are intenderl to create new facilities, to test and evaluate the eeomomic and teehnical feasibility of new mane operational methods and systems, and to put teehnolony at the service of scientific research and resonrce exploration.

The following projects merit ensideration for (arly implementation:

- 'lest Facilities and ()cenu Ringes (Chap)ter. 2$)$

- Great Lakes Restoration Feasibility Test (('halpter 3)
- Continental Shelf Iabolatories (Chapter 4)

- Pilot Continental Shelf Nuclear Plant (Chapter 4)

- Deep Exploration Submersible Systems (Chapter 5)

- Pilot Buoy Network (Chapter 5).

Role of the U.S. Navy in Marine Technology The U.S. Nary has been the Federal leader in marine technology, particularly in deep submergence and deep ocean teehnology. As Nary mission requirements permit, prorision should be made for other agencies to use Nayy facilities on a reimbursable basis. The Commission recognizes that military and eivil needs do not always coincide; nevertheless, because some elements of marine technology are common to both, cooperative efforts between eivil and Nary technologists should be pursued to the maximum possible extent. Opportunities to spin off civil applications from defense projeets should be identified.

\section{Scientific and Technical Information}

Improved communieations throughout the marine community are essential to a successful mational ocean eflort. Arailable information should be compiled in the most readily usable form for the various marine user groups and supplemented in some eases by extension services.

Marine data present a speeial problem, for they are too extensive and diverse to be hanlled through a single center. A number of general and specialized data centers exist, including the National Oceanographic Datal Center, the National Weather Reeords Center, and the Snithsonian Oceanographic siorting Center. 'There are also specialized collections in private institutions. It is important that relationships and responsibilities among the various centers be better de- 
fined and that the overloaded general-purpose centers refrain from involvement in aspects of data handling more suitable to a specialized center.

\section{Manpower for a Marine Effort}

It is difficult to identify the people currently engaged in marine-related work, and it is equally difficult accurately to project manpower needs for a total national marine effort. The rapidity and kinds of industrial derelopment and the level of Federal support, knowledge about which we can now only speculate, will have a profound effect on manpower requirements for engineers, technicians, and other marine-related personnel.

The Commission recommends that NOAA help to develop and maintain manpower inrentories, statisties, trends, and projections.

\section{Support Capability for Marine Operations}

Operations on and muler the seas depend upon an interlocking rariety of supporting services furnished primarily by the Federal Govermment. They include mapping and chating, aids to navigation, maintenance of waterways, salvage, safety, law enforcement, and certification of some types of persomel and equipment.

The Commission finds that the Nation's ability to provide such services, althongh satisfactory in some instances, requires considerable upgrading to meet even current needs; certainly the services will be inadequate to satisfy the demands of an expanded national effort. Supporting services must keep pace with development of the recommended national ocean program.

\section{A Plan for the Coastal Zone}

The coastal zone, where the rivers and shores join the sea and the Great Lakes, presents some of the most urgent environmental problems and the most immediate and tangible opportmities for improvement.

\section{Managing the Coastal Zone}

'Thirty States border on the sea coasts and Great Lakes: so far, it has been principally theirs to determine whether actions on or near our shores are beneficial or damaging.

The most serions barriers to effective State action are the conflicting and overlapping Federal, State, and local laws and regulations which attempt to control certain coastal zone activities as well as the lack of suitable laws and regulations for other activities of equal importance. Often the laws that do exist are not adequately enforced. Further, there is little coordination of the many Federal, State, and local agencies with partial responsibilities.

The Commission recommends that the primary responsibility for management of the coastal zone continue to be rested in the States but that Federal legislation be enacted to enconrage and support the creation of State Coastal Zone Authorities to carry out specified national objectives with regard to the zone. The Authorities should have clear powers to plan and regulate land and water uses and to acquire and derelop land in the coastal zone.

Althongh liaison and conperation among the Coastal Zone Anthorities and several Federal agencies will be necessary, the legislation should place primary responsibility in NOAA for working with the States on marine matters. This agency should support, review, and condinate activities of the Constal Zone Inthorities.

It will take time and the resolution of many organizational problems to bring the coastal zone under the effective management of the Coastal Zone Anthorities. Some traditional powers must be yielded; some traditional privileges and prerogatives must be abandoned. Imaginative leader's in the States must find ways to make compatible 

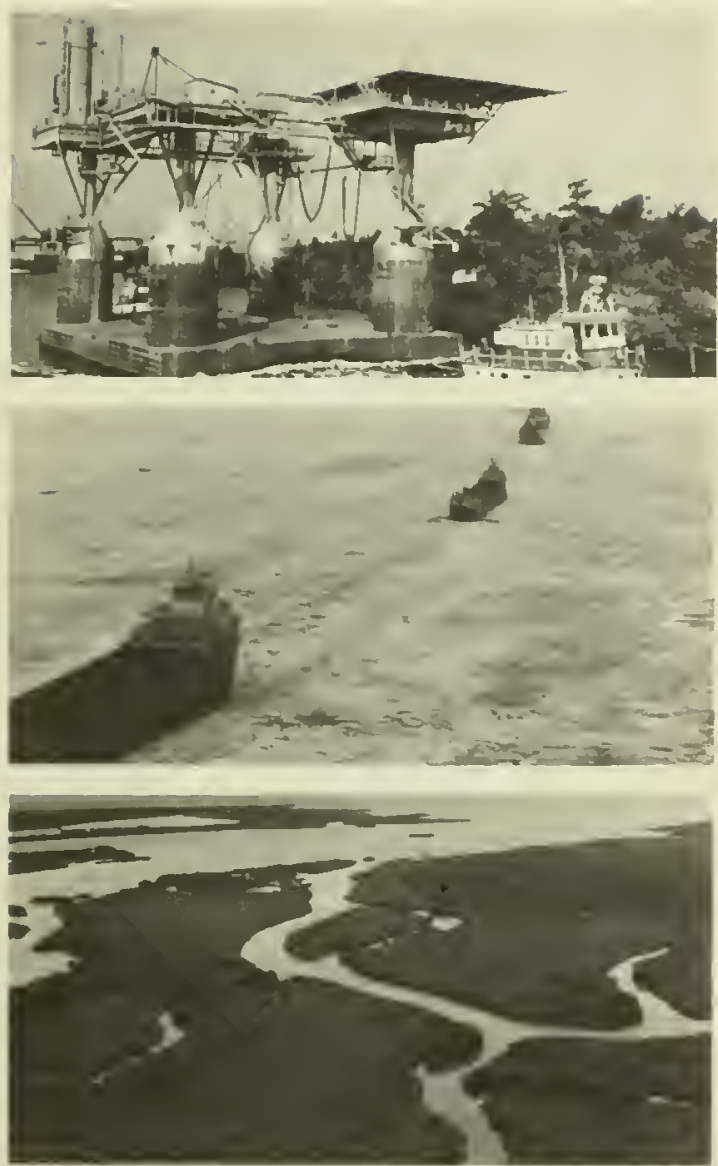

many of the multiple uses of the coastal zone, and, among those which remain incompatible, they must make difficult choices. The Federal Govermment can help, but the primary responsibility lies with the States: they are the key to a concerted effort.

\section{Science and Technology in the Coastal Zone}

There is not enough scientific knowledge about natural coastal zonc processes on which to base many important management decisions, and technical ability to implement decisions generally is lacking. Yet with the passinge of time. coastal zone problems will
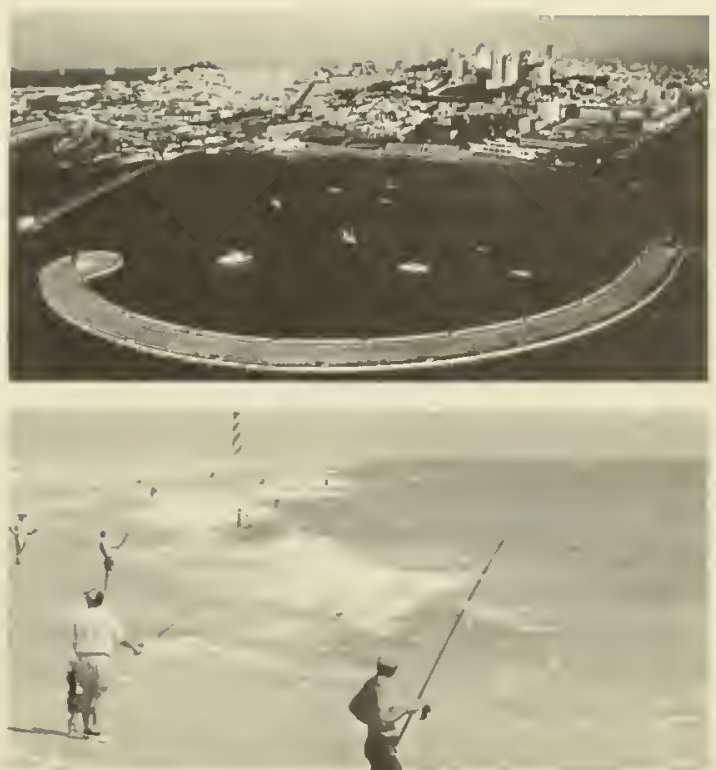

The Nation's coastal zone-whether its Gulf Coast oil country, the San Francisco waterfront, Great Lakes minter shipping lanes, Cape Hatteres, or the water-laced Florida coastland-presents the United States with urgent environmental problems as wcll as with immediate, tangible opportunitics to benefit its pcoptc.

become eren more complex and solutions more difficult. Present national competence for research and development in the coastal zone is scattered, and the total effort is far below the level required.

To bring resenroh and derelopment capability within the reach of the State Coastal Zone Anthorities, the Commission recommends designation and support of universityaffiliated Coastal Zone Laboratories to work on regional and local problems. These laborntories will perform functions analogous to agricultural reseurch stations and extension services, and the Commission recommends that they be developed and supported by 
NOA . Through coperation with State agencies, neighboring institutions, and such Federal agencies as the Federal WTater Pollution Control Administration and the U.S. Army ('orps of Engineers, each laboratory can develop scientific and technological prowrums most appropriate to its region.

1 serious handicap to scientific estuarine amd coast: l researeh is the diminishing numher of relatively unaltered areas where natirral processes can be observed. As an adjunct to the Coastal Zone Laboratories, the Commission recommends that representative (oastal and estuarine sites be established as nutural preserves for conduct of studies necessary to establish a proper base from which the effects of man's activities can be determined and ultimately predicted.

\section{Attacking Coastal Zone Pollution Problems}

Domping wastes into the Nation's livers, filling marshlands, and spreading the spoil from dredging have polluted the coastal waters everywherc. Research into the processes and consequences of this pollution must be accelerated and new methods fomd to handle waste collection and treatment. Federal Iaboratories, universities, and industry must concent rate on this effort, which should hegin far upstream; it cannot be accomplisherl in the coastal zone alone.

\section{Great Lakes Restoration}

The Great Lakes have deteriorated for more than 100 years mnder the assault of human activities that pollnte the water. To arrest and ultimately to reverse this detcrioration is an urgent national need. Preliminary studies indicate that restoration of damaged lakes may be possible. The Commission proposes a National Project to accelerate the scientifie research and technological development that will be necessary to extend this possibility to the Great Lakes.

\section{Interim Policies}

Organization, research, and development in the estuaries and coastal zones will take time, no matter how rapidly action is instituted. Meanwhile, matters must be prevented from becoming worse. Existing Federal and State laws affecting water quality must be strictly and aggressively enforced. The Federal agencies themselves must lead the way by rigidly complying with existing legislation and Executive Orders relating to pollution from Federally connected activity. Amendments to some Federal laws are desirable in order to increase their effectiveness. State executives and legislatures must exercise restraint in approving activities which may alter the coastal zone imtil better information is obtained about the consequences of such activities and until State plans for the coastal zone as a whole can be developed.

\section{Developing the Resources of the Sea}

Begimning at the shoreline and extending outward to the waters and bed of the deep sea are a great variety of resources, many of which already contribute substantially to the national economy. The need is to establish the institutional framework and the scientific and technological foundation for assuring that the Nation has access to those resources of the sea which it needs when it needs them. Some of these needs are immediate; others are long range.

Because the commercial exploitation of the sea's resources is the task of profit-oriented industry, the national plan should create a climate in which industry can operate effeetively with assistance from the Federal Govermment in those areas of scientific research and technological development where private investment cannot be expected to assume the full burden.

An example of the kind of research and development facility for which Ferleral as- 
sistance is needed is the National Project for Continental Shelf Laboratories. Through this project the capability to place man under the sea for useful work, both as a free cliver and in a protected enviromment, can be actvanced most rapidly. The research, technological development, and testing of equipment and techniques on the continental shelf will provide information and methods for industrial application in many fields. A relater need is for a rariety of power sources for resonrce derelopment. The National Projc't for a Pilot Continental Shelf Nuclear l'lant will help to meet this need and will pnovide the technology necessary to eraluate the desirability and feasibility of placing large (lumdreds of megawatts) nuclear stationary power plants offshore. Location of large mu('lear plants on the continental shelf rould allow raluable shore areas to be available for other uses, lessen the possibility of harmful thermal pollution, and provide greater satety.

\section{Improving U.S. and World Fisheries}

Despite the large volume of oil recovered from the sea and the increasing production of other marjue minerals, fisheries remain the largest economic harvest of the oceans. The annual value of the world catch of fish and shellfish is nearly one and one-third that of all other resources and has grown more than 6 per cent a year during the past decades.

While world fishing has increased, the relative position of our own country has declined. During the past 30 years, landings by U.S. fishermen hare remained almost constant; they now account for only 4 per cent of the world catch. At the same time, the United States consumes about 12 per cent of the total catch, making it the world's largest market for fish. Other nations take more fish from traditional U.S. fishing grounds than do U.S. fishermen, who harrest less than onetenth of the uscful sea species available in the waters adjacent to our Nation. Except for a few fisheries, like tma and shrimp, our fishing flect is technically outmoded. Onr fishermen suffer higher unemployment and lower incomes than other workers of comparable age and skills.

Though there is no compelling reason why American fishermen should catch all the fish consumed in the United States, major segments of the U.S. fishing industry can be restored to a competitive, profitable position with consequent benefit to the economy. The presence of technologically efficient U.S. vessels on the world's fishing grounds also will strengthen the ability of the United States to negotiate for a productive and equitable system to regulate international fisheries.

The Commission proposes a multiple attack on our fisheries problems with scientific research to improve understanding of the resources, exploration to determine quantities and locations, technology to develop efficient methods of harvesting and processing, and an improved framework (i.e., principles, rules, procedures, and institutions) that will enable U.S. fisheries to operate competitively withont subsidy or protection.

\section{A Framework for Fisheries Development}

To rehabilitate its domestic fisheries, the Nation must eliminate the orerlapping, conflicting, restrictive Federal, State, and local laws which have hampered even those fisheries with sufficient capital and technological skill to be truly competitive. Protectionism and parochialism, particularly in State Iaws, have impeded the derelopment and use of modem fishing technology. Federal support programs have not served their purpose.

It is time for a definitive review and restructuring of fisheries laws and regulations and creation of a new framework based on national objectives for fisheries development and on the best scientific information. The 
review, analysis, and recommendations should take into account sport fisheries interests.

The Commission proposes that the States continue to be responsible for managing fish stocks in the water's of the coastal zone but that NOAA be authorized to assume regulatory jurisdiction over endangered fisheries if the States fail to take necessary conservation measures. To rehabilitate U.S. fisheries, fishermen must be relieved of the requirement to use only T.S.-produced ressels in domestic fisheries; U.S. fishermen should be permitted to take adrantage of better gear, improved boats, and lower prices wherever they can be obtained.

Research, Technology, and Survey Programs Our knowledge of the availability and distribution of marine species is totally inadequate. We do not know the optimum annual harvest consistent with conservation of many valuable species. We lack information on life cycles and on the ecological relationships among species. We do not understand fully how estuarine-dependent species are affected by man-induced changes; yet about 70 such species accomt for about twothirds of the catch landed by U.S. fishermen.

The Commission recommends that NOAA initiate the studies necessary to supply this information and particularly that the agency seek to delineate underutilized fisheries off U.S. coasts. Once located and sustainable yield determined, the fish should be caught with maximum efficiency, carried to market in the best condition, and ultimately retailed or processed. New techmology is needed to improve each step along the way. 'To expand use, new fish stocks, new processes, and new markets must be created. The Commission recommends that NOA develop its survey and technology programs to accomplish these ends.

\section{Aquacultural Research and Development}

The controlled rearing of aquatic animals using aquaculture and animal husbandry techniques can produce enormous yields. Although the harrestable surplus of natural stocks is limited, cultured species harvests are limited only by the acreage to be farmed and the ability to compete economically with other marine stocks. For this reason, aquatic culture of certain species can contribute substantially both to the economy and to the war on hunger.

Aquaculture of marine animals has a long history, but its potential is still to be realized through the development and application of modern techniques. Sea plants already have proven of industrial value, but many promising commercial nses are still limited by the availability of seaweed supplies. There is evidence, however, that a number of useful seaweeds can be cultured.

Although research is rapidly demonstrating the feasibility of aquaculture, full-scale commercial application is limited by legal, organizational, political, and technical constraints. As these constraints are remored, aquaculture should become a powerful new global resource. The Commission recommends that NOAA be given explicit responsibility for advancing aquaculture.

Drugs from the Sea Both plants and animals of the sea contain active substances which are potential sources of drugs for the treatment of human suffering. The Commission lecommends that a new Institute of Marine Medicine and Pharmacology be established in the Department of Health, Education, and Welfare to screen these substances and to establish the basic information needed by the pharmaceutical industry to carry forward its work. 


\section{The Needs of the Oil, Gas, and Mineral Industries}

Daily worldwide production of subsen oil has reached about 5 million barrels, about 16 per cent of total world oil recovery, and is expected to reach one-third of total world production within 10 years. The search for new reserves is stimulated by forecasts of tripled consumption within 20 years and by political instability in some oil-producing nations.

The seabed also offers a great source of new reserves of natural gas. For the foreseeable future, oil and gas will be the most valuable minerals the nation can obtain from the sea.

Predicting the Nation's requirements for ocean minerals other than gas and oil is difficult. The time when it will be as economic to recorer hard minerals from the sea as from the land depends on such factors as rate of consumption, exploration and recovery technology, transportation costs, the availability of substitutes, re-ise techniques, discovery of new land deposits, and the reliability of import sources. Even the extension of petroleum operations into deeper water will depend to a considerable extent on how competitive such petroleum recovery may be with shale and tar sands.

While the offshore oil and gas industries are thriving, the offshore hard mineral industry is still in its infancy.

The Commission's recommendations seek to improve the institutional framework within which these industries operate, to identify promising sea bottom mineral areas. and to improve the fundamental technology that will make it possible to exploit undersea minerals commercially.

Surveys The Federal Gorernment should undertake a major effort to survey the geology and geophysics of the continental

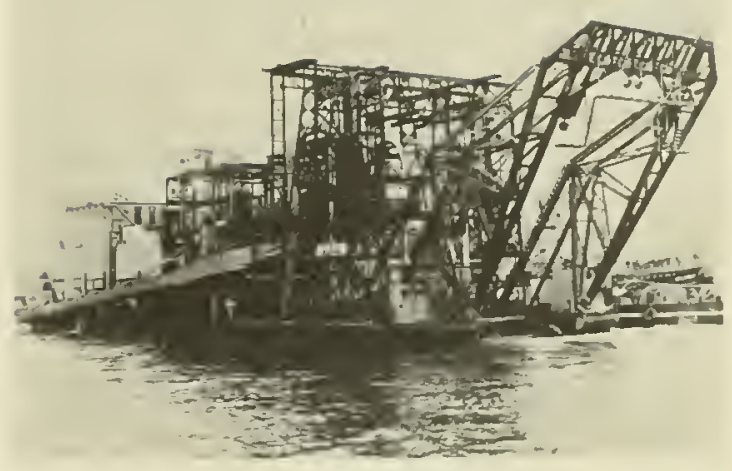

The open-ocean dredge

Pomona, which began diamond mining operations off the Coast of South Africa in 1966, is part of the pionerring equipment of the offshore hard mincral industry.

shelves and slopes in order to determine their mineral potentials. The basie survey clata will be invaluable to industry in its further exploratory work to identify and determine the economic value of specific deposits.

Institutional Arrangements One of the principal difficulties facing the off shore petroleum industry is uncertainty about the scheduling of Federal and State lease sales. The Conmission recommends that lease sales be amnounced earlier than is the present practice to permit industry to plan ahead in an orderly and efficient manner regarding its use of capital, manporrer, and technical resources.

The Commission also recommends that the Federal Power Commission recxamine its differential price policies for natural gas and adjust them, if necessary, to reflect adequately the increased cost of offshore production. Further, the Commission recommends that, in order to encourage research and develop- 
ment, the Federal Power Commission review its rules regirding accomnting practices for research and development expenditures to assure that they are clear and consistent with the legitimate needs of the gas transmission industry.

To encourage offshore mining, considerable flexibility is needed in policies under which outel continental shelf lauds are made available to industry for development. Accordingly, the Commission proposes modification of the Outer Continental Shelf Lands Act to permit the Secretary of the Interior to waive competitive bidding requirements when deemed necessary to stimulate exploration. The Secretary should be allowed similar flexibility for mineral resonrce development beyond the continental shelf.

Technological Development To encourage offshore mining ativity, the Commission recommends that the Federal Govermment support the development of fundamental technology which will facilitate exploration for and recovery of subsea minerals.

\section{Support for Marine Industry}

Industry's most frequently stated problem is the lack of a clear regulatory and legal framework for many aspects of marine operations. Industry also is handicapped by current and foreseeable conflicts over $\mathrm{mul}$ tiple use of marine areas and by lack of clear definition of the rights of individuals and companies to use coastal or offshore areas.

Private investment capital is available for ocean ventures, and industry neither desires nor requires direct Govermment subsidy. Industry must, of conrse, depend on the Government for many kinds of support and services. Surveys, environmental data collection, forecasts, protection of life and property, aids to navigation, and similar services are a proper responsibility of Government and scrve the total marine community. Government development of fundamental technology and support of the recommended National Projects also are necessary because no single firm or industry reasonably can be expected to bear their cost. The Commission urges that Govermment research and development programs be planned and administered to enable industry to assume the responsibility for the further development of technology at the earliest possible stage. Participation by industry in all phases of the recommended program will aid in identifying wholly new directions of commercial enterprise.

The territorial sea offers a new realm for individual and small business enterprises. 'The Commission recommends an experimental program to enconrage new uses of the ocean through State leases of submarine areas within U.S. territorial waters. Such a program might be called "seasteading." The lease would be contingent on useful cmployment of the leaschold and should be consistent with plans for the orderly development of ofl'shore regions.

\section{International Arrangements for Uses of the Oceans}

The Commission has not recommended a single framework for the management of all the uses of the oceans. In its view, this is neither feasible nor desirable in the immediate future. Different uses of the sea present different problems requiring different solutions. In time, as the uses of the sea increase and prohlems of conflicting use multiply, it may be necessary to create some overarching international framework to handle these problems. This time has not yet come.

Insteal, the Commission recommends that the Inited States take the initiative to propose :

- New international frameworks (principles, rules, procedures, and institutions) 
for the exploration and exploitation of the mineral resonrces muterlying the high seas and the conduct of scientific inquiry in the oceans

- Improvement and extension of the existing network of international fisheries agreements.

The considerations involved in these recommendations are ton complex for a brief summary and are given in detail in Chapters 4 and 5 .

\section{Exploring, Monitoring, Predicting, and Modifying the Environment}

The Nation must have a comprehensive system for monitoring and predieting the state of the oceans and the atmosphere. The Cnited States has the beginnings of such a system today, but it is inadequate to our needs and its organization is fragmented. Weather and ocean forecasts and warnings

Cnmanncd research buoys like the occan lata station Bravo, secn here under tow by the Coast Guard cutter. locona, are bcing used to gather and transmit occanographic and metcorological data automatically.

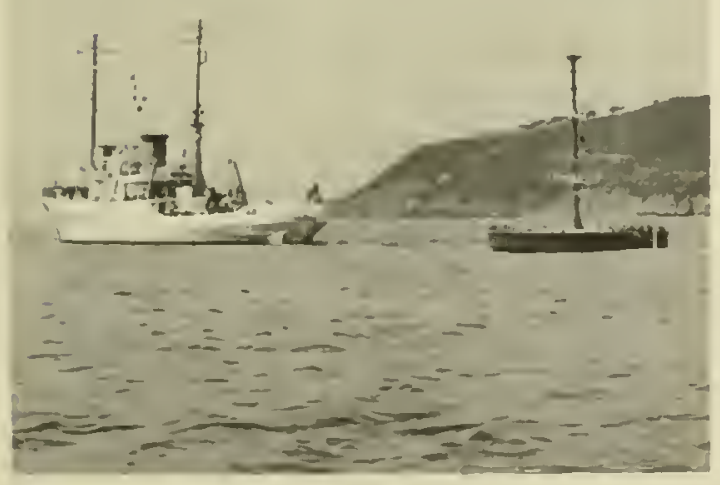

produced by such a system are essential to all one may wish to do in the sea and are critical to almost all human, industrial, agrieultural, and commercial activities on the land. They are essential for sea and air transportation, resource exploration and exploitation, aquacultural and water management, and above all, the protection of life and property. The Department of Defense also has pervasive needs for environmental services.

The oceans, the atmosphere, and certain aspects of the solid earth are interacting parts of the total geophysical environment. They cannot be understood, monitored, or predicted except as parts of a single system, and technology for their monitoring and prediction has major common elements. This system is planetwide. It determines weather and climate cverywhere and affects both land and sea operations.

The Commission has been impressed by the accelerating need not only to monitor and predict global environmental conditions but also to understand the nature of the many different kinds of modification of man's environment that are now taking place. Growing technological capabilities enable man to intervene in natural environmental processes for beneficial ends. Recent developments in weather modification indicate that we have embarked upon a course which can hold great promise for mankind. In the Commission's view, the problems of environmental modification are inseparable from those of environmental monitoring and prediction.

\section{Development of a Comprehensive Global Environmental Monitoring and Prediction Systemı}

New technological developments like satellites, buoys, horizontal sounding balloons, high-speed communications, and new data processing systems now offer promise for the development of a comprehensive national en- 
rirommental monitoring and prediction system which can meet the national need over the next decade. Design and development of the system will require improved Federal organizational mechanisms to provide for idequate plaming, integration, and management at the national level. The Commission proposes that the Nation's oceanographic monitoring and prediction activities be integlated with the existing National Weather Service to form a comprehensive National Environmental Monitoring and Prediction Srstem (NEMPS).

To achieve the essential global capabilities, the Commission endorses and encourages full T.S. participation in the World Weather Program of the World Meteorological Organization and the Integrated Global Ocean Station System of the Intergovemmental Ocennographic Commission.

\section{The development of ocean.}

technology, as cvideneed by

specialized rescarch submersibles

like the Ben Franklin, has as its

ultimate objective to give man

the ability to more freely and io

rork productixely in ann part of the

marine entironment.

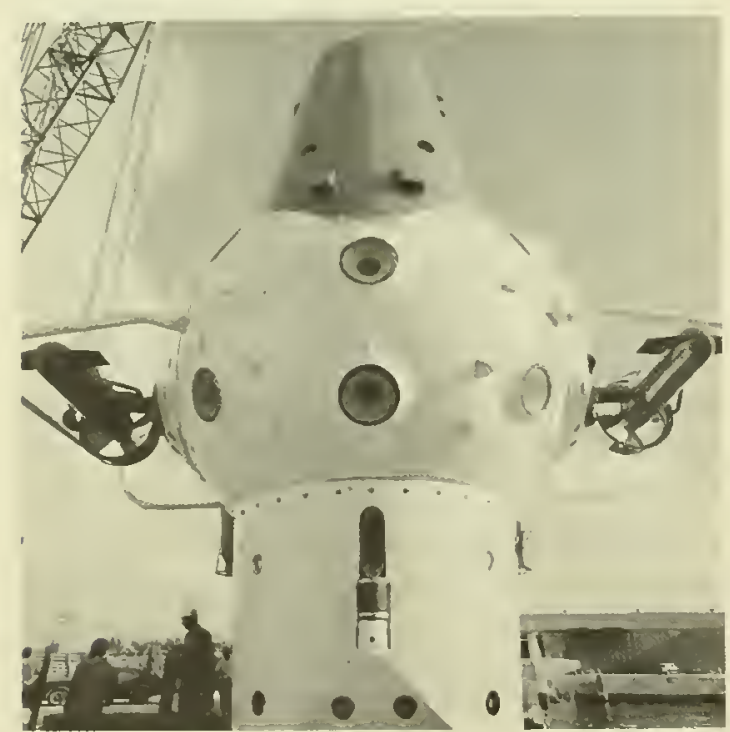

Military requirements for quick response to fast-changing operational situations dictate the need for specialized military environmental programs under the regis of the Department of Defense. However, there is no necessity for maintaining completely inclependent military and civil systems; both military and civil clata acquisition must be expanded, but the data should be pooled. Independent processing and forecasting services can be establisherl to meet different ciril and military needs.

Nithough bettel unclerstanding of the planetary enviromment, improred technology, and organizational changes are required for the future, some relatively inexpensive and simple steps can be taken now. Data acquisition can be improved immediately by expansion of the ship-of-opportunity program in which monitoring instruments are placed on cooperating merchantmen and other vessels and by more complete instrumentation of ailcraft and existing offshore platforms. Atmospheric monitoring equipment on ships can be supplemented by increased use of expendable bathythermographs to measure ocean temperatures.

The pressing need for new techmology to acquire ocennic and atmospheric data on a global basis should be met by a National Project to develop a pilot buoy network as well as the rigorous further development of the Nation's weather and ocean satellite monitoring and interrogation systems.

\section{Exploring the Deep Sea}

Present instruments to observe and measure in the depths are entirely inadequate. Except for occasional samples of the bottom and the living organisms of the abyss, little is known about the deep ocean. A drastic improrement in instrumentation is needed for a variety of purposes, including most importantly instrumentation for efficient and accurate surveys 
of marine resomrees. Instruments alone, however. ("annot perform all neeessary science and explonation tasks. Man himself must go to the ocean depths for observation, and he must remain for extended periods. The Nation should anticipate the future by starting now to develop deep submersibles with ocean transit capabilities for use as research and exploration platforms at depths to 20,000 feet under the sea and to study the feasibility of mannerl deep ocean stations.

\section{Environmental Modificalion}

The Nation needs a focus for understanding and exploring the feasibility and consequences of envirommental modifieation. It must also establish the scientific eapability, facilities, and monitoring networks to make possible an assessment of the global consequences of man's activities, such as the burning of fossil fuels, the use of pesticides and insecticides, and the effects of particulate and gasenus pollutants. Similarly, it is urgent that the Nation explore a wide range of possibilities for environmental modifieation that can be brought about by our new technological eapabilities. The Commission recommends that NOAA mindertake the necessary comprehensive efforts.

\section{Organizing for Action}

A plan for national action must be based oll mational poliey established by the President and the Congress and implemented by the exereise of Federal leadership and support. The very existence of the Commission is an expression of the intent of the Congress and the President to develop a national ocean progran worthy of a great sea nation.

Marine missions have proliferated throughout the Fecleral Govermment, lut most programs are ton small to achieve real effectiveness. There are voirls and overlaps. Until the advent of the National Sea Grant
Program, there was no broad Fedleral agency mission concernerl with using the sea mole eflectively to meet public needs. Yet the national objective is "to develop, encour"age and maintain a coordinated, comprehensive, and long-lange national program in marine seimce for the benefit of mankind," which presupposes an orientation of national marine activities to broad human needs, not simply to those eoneerned with food, transport, or minerals.

The Commission finds that the present Federal organization cannot meet the changing, broadening aspects of marine affairs. In the past, the Federal agencies have concentrated on seience, surveys, some techmology, supporting services, and minimal and frequently inadequate support for fisheries. By far the largest part of the Ferleral ocean budget has been that of the Navy. For the most part, the agencies have performed their fragmentary missions well, within the limits of inadequate funding and-too frequentlya lack of strong support from the heads of agencies with primary concerns other than the oceans.

Recognition of the lack of proper Federal organization is not new. Measures were taken, starting with the creation of the Interagency Committee on Oceanography by the Federal Council for Seience and Teehnology nearly a decade ago. In 1966 the National Council on Marine Resources and Engineering Development was established by the Congress to initiate and oversee Federal programs until such time as the Commission had completer its study and the President and the Congress had decided on the final organization required to neet the Nation's marine needs. The Couneil should eontinue to perform these functions until that decision is reached.

Despite the Council's value and the excellence of its staff and committees, experience 
has demonstrated that strength at the Presidential staff level eamnot compensate for weaknesses in the agency operating structure. A new, strong Federal foeus for marine activity is essential to a national ocean effort. The organization should direct a eivil ocean program to the Nation's economic and social needs, conducting the scientific, techmological, and management programs required to ensure that those needs are met. The organization should serve as stimulus, guide, and supporter for State marine activities and provide a central point in the Federal Gorernment to which industry can look for advice, cooperation, and some kinds of support in industrial marine enterprises.

Because the needs of people and of industry are affected and even determined by the interaction of sea, air. and land, it is not enongh to organize around the marine environment alone. Basic theory, experimental techniques, equipment, and even personnel are much the same for both atmospheric and ocean studies. The scale of effort needed, and the necessity of measuring interactions among the varions parts of the environment, make it imperative to organize within the larger context of the air-sea enviromment. This is sound both from the standpoint of good science and the prudent management of personnel, funds, and equipment.

The Commission recommends, as was briefly noted earlier in this summary, the organization of an agency :

- To explore the marine frontier and its interrelationships with the atmosphere

- 'To define its resourees

- To adrance eilpabilities for its use

- To provide supporting services including weather and ocean forecasts

- To minimize confliets over uses of the marine environment
- To coordinate scientific and technieal re quirements and recommendations in support of foreign policy objectives

- To serve marine industry and the marine interests of the American people.

Further functions ane defined in Chapter 7 . The proposed National Oceanic and Atmospherie Igeney should report directly to the President and should aequire through transfer those Federal organizations and programs integral to its mission but which do not provide close operational support to the departments and agencies in which they are presently loeated.

Any recommendation for reoranization has many eonsequences, and the Commission came early to the conelusion that a wholesale consolidation of marine activities within a single strueture would be unsound. Nonetheless, the Commission is conrinced that the value to the Sation of creating an independent ageney as the prime Federal center of marine strength out weighs the inevitable trauma and diffieulty of shifting agency elements and programs. ('reation of an independent ageney would not prejudge any future Federal organizational plans; the agency conld be moved as a whole.

The eentral purpose of the Commission in lecommending the formation of the National Oceanie and Itmospherie Ageney is to provide the means for undertaking the full range of actions needed to realize the Nation's glowing stake in the eflective use of the sea. In some cases, the existence of snch an agency is ritieal to implementation of the Commission's recommendation: in others, reeommended programs eould nppropriately be implemented through existing agencies. In these latter cases, the Commission in its recommendations has identified parenthetieally the appropriate aetion ageney. 
The reorganized Federal machinery must have provision for obtaining advice and information from the broad lational marine commmnty. The Commission recommends estalolishment of a Presidentially appointed. hroadly representative committee to provide contimuing advice in the development of the national marine program. The committee might be designated the National Adrisory Committee fol the Oceans ( $\mathrm{N}$. $\mathrm{CO}$ ). It would issue a comprehensive biemial public report on the status and progress of U.S. marine and atmospheric activities.

The Commission also recognizes the need for the Congress to olumine its committee activities in a mannel which will permit greater focus on marine actirities, but any reorganization or realigmment of Congressional committee functions and jurisdictions is for the Congress itself to determine.

\section{A Time for Decision}

The Nation's stake in the uses of the sea is synonymous with the promise and threat of tomorrow. The promise lies in the economic opportunities the sea offers, in the great stimulus to business, industry, and employment that new and expanded sea-related industries can produce. The promise lies also in expanding the Nation's horizons, in strengthening its international position and peaceful collaboration amongr nations, and in the possibility that action today will permit man to make a start toward ultimate control of his planetary enviromment. The promise lies in making available new reserves of important minerals and in ensuring new sources of food.

The threat lies in the potential destruction of large parts of the coastal environment and in the further deterioration of economically. important ports, recreational facilitics, coastal shellfisheries, and fisheries on the high seas. There is the threat inherent in any failure by the Nation to utilize successfully its fair share of a major planetary resource; the United States simply camnot afford less than its best effort to utilize the global sea. Finally, there is the threat that unbridled international competition for the sea 's resources may provoke confict.

I time of decision is here. Multiple pressures force the Nation to turn to the sea, and multiple opportmities await the seaward turning. The time of decision is not for the Federal Government alone, although Federal leadership is essential. State and local govemments, industry, academic institutions. and the American people must share in decision and action.

The ocean does not yjeld its food and mineral treasures easily; dlamaged environments are not restored by scattered attacks or the nood intentions of a few; the planet's doninant clcment cannot be understood, ntilized, enjoyed, or controlled by diffuse and uncoordinated efforts. The Nation's stake can only be realized by a determined national eftort great enough for the rast and rewarding task ahead. 


\section{('hapter 2}

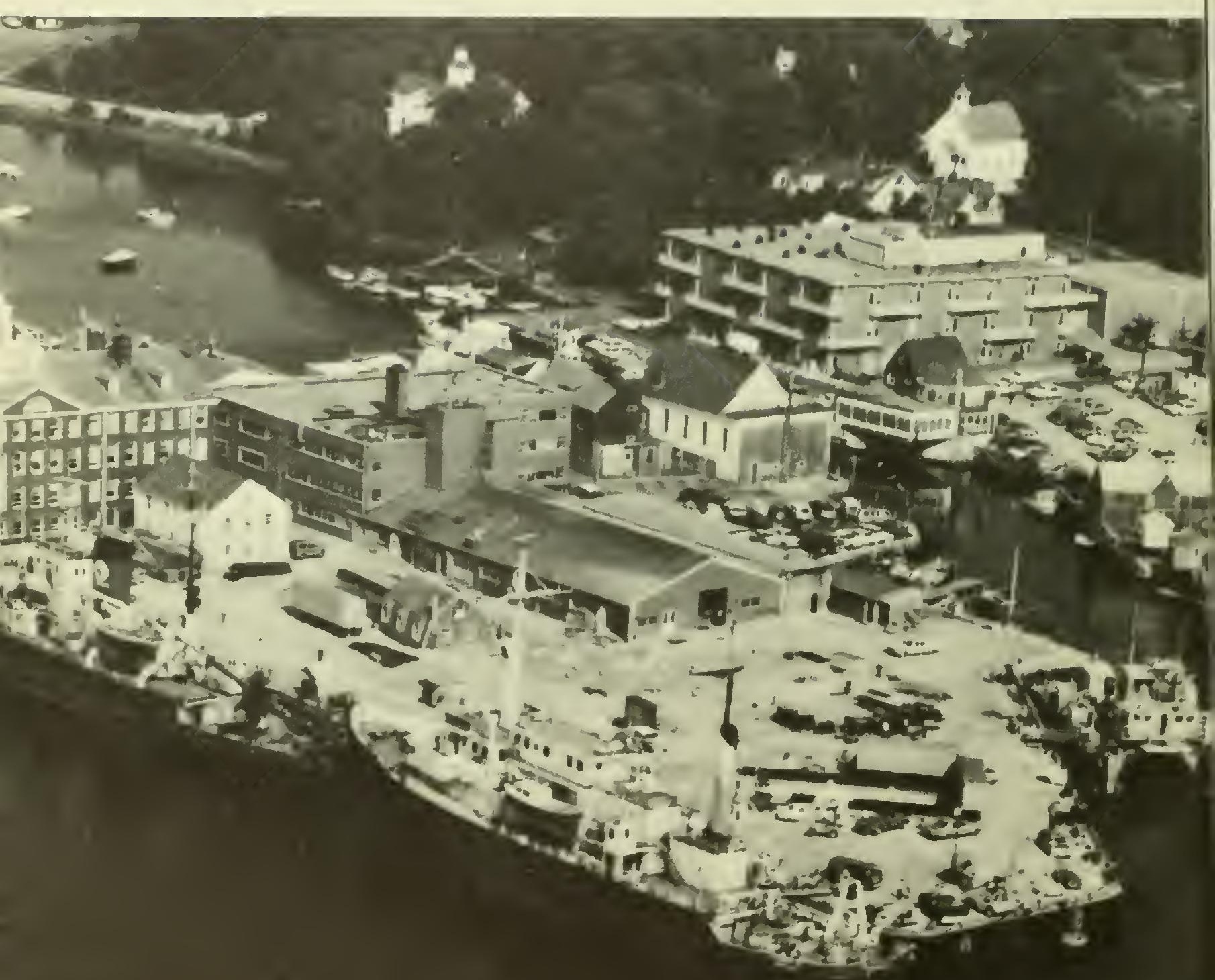


"lloe Nation's marine capability must be built npon an expanding bate of linowledge and practical skills. Inderstanding the seat is the task of marine science. Implovement of operational skils, equipment, and metlods is the responsibility of marine technologey.

There are needs for scientific and engineering knowledge common to nearly all marinc pogmans, although each marine activity has additional specialized requirements. The Nation must have very broad calpalility to sat isfy all these needs, incholing adequate facilities, the organization and know-how to accomplish specialized tasks, an assured supply of highly skilled and educated manpower, and close integration of the Nation's scientific and technological resources.

Alrangements to support marine science are well established on a strong base of competence in the miversities and in Government. Marine science could be improved, howerel, by creater continnity in funding and by provision for concerted attacks on big problems. In contrast to its fostering of marine science, the Federal Goremment has not yet assumed a mission to support the adrance of civil marine technology. There are no centers for technology derelopment comprable to the major institutions deroted to marine science.

Sufficient knowledge and experience do not now exist to permit hard decisions on altermative conrses of action for developing the lesoures of the sea. For example. before major capital imestments are made in mining at continental shelf depths or in enplacinge great number's of data-gathering and reporting buors for environmental monitoring and prediction, more basic scientific information and techunology will be needed.

The Commission concludes that a national program to build eapability in marine sci- ence and technology should (muphasize ac tivities basic to a very widle sprectrum of potential applications. The level of national inrestment in sucle a capability must be suffi (cient to maintain the leading position which the Tnited States now enjoy's in many aspects of marine science and technology, to advance in those fields in which it. lags, and to open new fields of endearor. No one can say precisely how much cxpenditure this will involve. But it is clear that the present lerel is below that which is appropriate to a newly dereloping field of such rast import to the future of our Nation.

A number of factors dictate assumption by the Federal Government of a major role in advancing the national capabilit $y$ :

- Basic science and graduate education, the foundations of an expanded effort, long have been acknowledged as fields of Federal interest and responsibility.

- Fundamental technology, like basic science, requires Gorernment support: acquisition of the totality of required engineering information and know-how from which a specific industrial application may be derived imposes too great a burclen to be assumed by any single firm or even any single industry. Furthermore, much basic technological development is nomproprietary in nature.

- Facilities for development and testing often are so costly that the eapital resources of even the lar gest firms would be stret clied, and the smaller ones eliminated from competition.

- Some elements of marine industry are poperly classed as small business and have neithes the ormanization nor resources to conduct resealeh and derelopment on a large scale: yet the total contribution of such small firms to the ecouomy is substantial. 


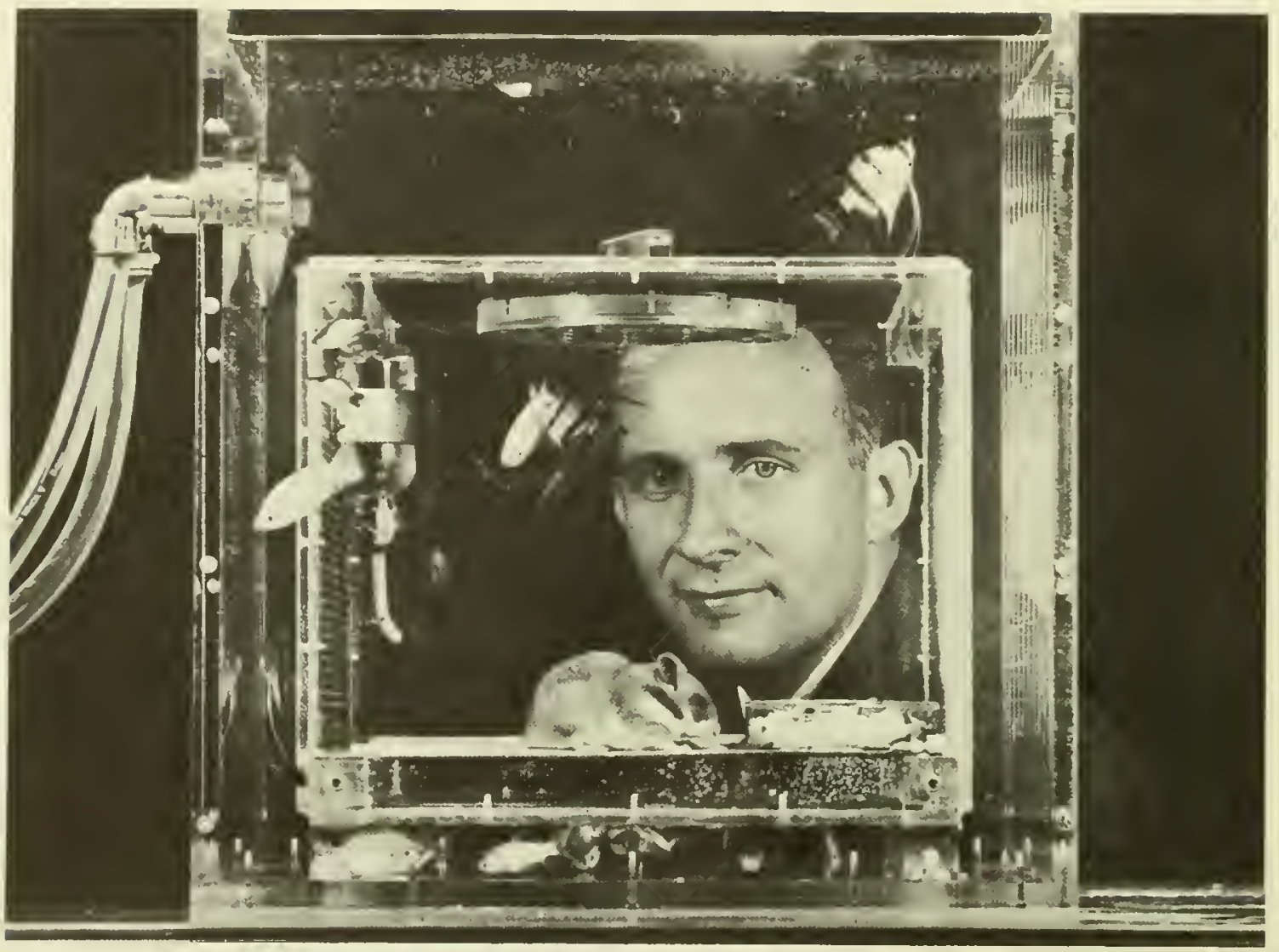

Understanding the marine environment, based on scicnlifie rescarch and unalysis, is rrurial to such national objetives as improving man's ability to $n$ ork in the sea. In this experiment, a small rodent lives normally in a tank romplrtely submerged in wuter. recriving its oxygrn from the water lhrough a synthetic tank membrane that acls like a fish gill.

The scope of the task, the cost, and the risks in marine seience and technology are so great that industry and the resea reh communities face a truly formidable task which cannot be aceomplished mless Govermment lends a helping hand. The Commission coneludes that public investment in building the national capability is warmanted by the prospect of substantial economic gains from the development of new resources to meet expanding human needs, by the emergence of new businesses and industries and revitalization of old ones, by the improvement of marine and at- mospheric prediction, and by the protection and development of the Nation's coastal zone.

The Commission believes it would be difficult to overstate the importance of basie science and fundaneutal technology to a national effort in the sea. Applied science and engineering a re vital, but they must be developed on a broad base of fundamental knowledge and skill. The rapid expansion of that base is a first requirement.

The growth of seientific understanding of the world oceans will not he accomplished quiekly or easily even with the greatly ex- 
panded effort recommended. The seas a re vast, complex, snbtle, and often hostile to man and his works. They will not yield their secrets in a decade or a generation. But, with deter" mination and imagination, understanding of ocean processes will increase continually, stimulating corresponding growth in the Nation's capability to use and harvest the seas.

The development of basic science and fundamental technology requires a proper institutional framework, establishment of programs, creation of facilities, supply of manpower, strong communications channels among the many segments of the scientific and engineering communities, and adequate funds.

\section{Advancing Marine Science}

\section{Importance and Objectives of Marine Science}

Scientific research and analysis must be supported to overcome inadequacies in our understanding which limit the Nation's use of the seas. The quest for basic knowledge has for many years received Federal support, because our people share the curiosity of scientists about the nature of man, his planet, and his universe and because they share the scientists' conviction that over the long term the quest will yield knowledge that can better man's condition.

The Commission notes with misgiving the recent tendency to condition Federal support of science on a prospect of imminent, tangible results of economic valne. Certainly a large body of research directed to such results is necessary, but it would be contrary to the national interest to overemplasize applied research at the expense of fundamental $\mathrm{mm}$ derstanding. Research motivated solely by the curiosity of scientists has produced, with compelling regularity, unanticipated applica tions which have improved man's lot and literally changed the face of the earth.
There is much to be learned about the planet earth, and many keys to learning are in and mder the sea. The total body of oceanic knowledge is advanced best by the pursuit of fundamental understanding of the biological, physical, geological, and chemical characteristics of the planetary occans without regard to immediate applications. Contimuing and substantial support of basic marine science is a national investment which will provide an underpinning for all future activities in the sea.

The Commission recommends that the advancement of understanding of the planetary oceans be established as a major goal of the national ocean program.

\section{Marine Science in the United States Today}

Marine science in the United States today is vigorous, diversified, competent, and at least the equal of marine science anywhere in the world. It grew rapidly in the first half of this decade, and if growth continues, will soon attain a productive maturity capable of serving the interests of the Nation and the world.

Scientists throughout the country are actively engaged in marine scientific research. They are concentrated in a few major institutions, but smaller groups and individual researchers are found in laboratories and unirersities in all the 50 States.

The Federal Government spent some $\$ 117$ million on marine research in Fiscal Year 1968. The U.S. Department of Defenseprimarily the U.S. Navy-accounted for about one-third the total. Other major funding agencies are the National Science Foundation (NSF) and the many marine-related bureaus and agencies of the U.S. Department of the Interior. Smaller but still substantial 


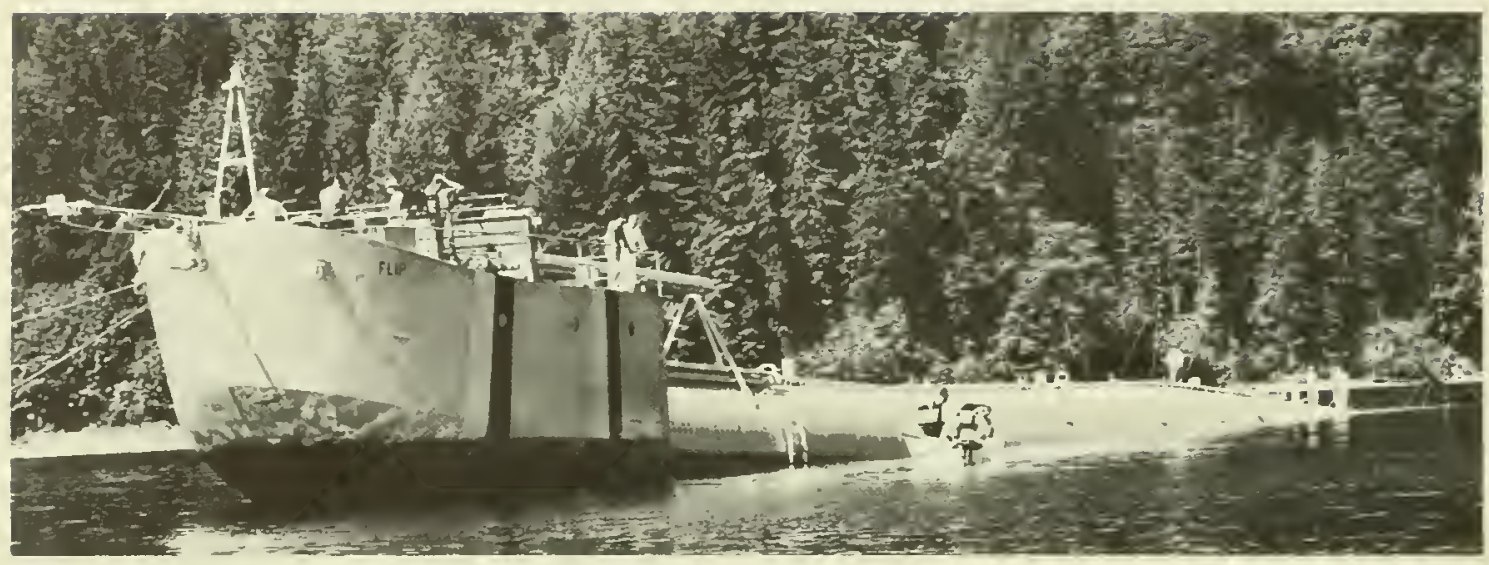

Unique oceanic research tools like the manned floating instrument plat form FLIP and the unmanncd, 354-foot scagoing platform for acoustics rescarch SPAR have been bwilt to help find answers to such vital problems as determining the propagation characteristics of sound in water.
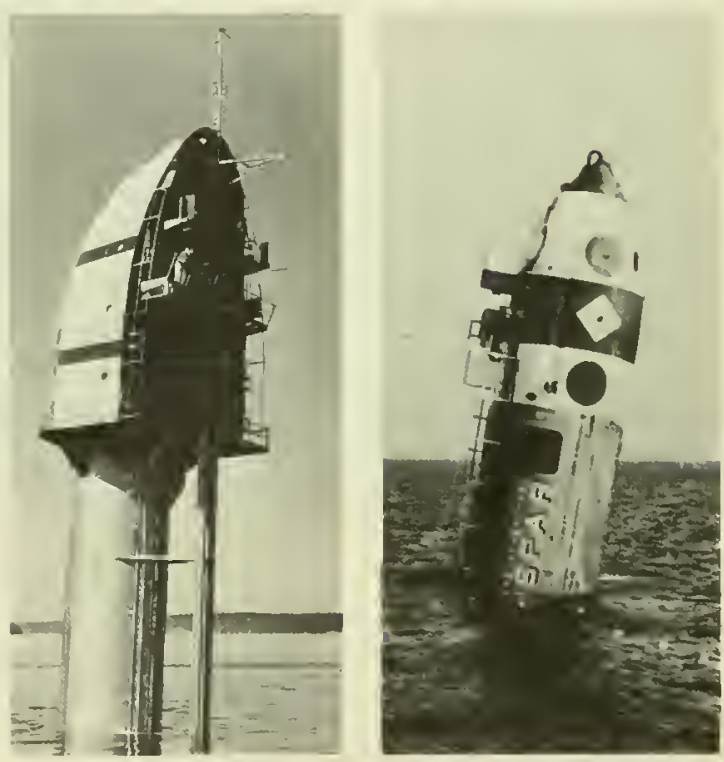

investors in marine science include the U.S. Department of Commerce, the U.S. Department of Transportation, the Atomic Energy Commission, and the National Aeronautics and Space Administration.

The U.S. Nary and the National Science Foundation have substantial prograns in basic marine scientific research, though most naval research supports operational missions. The research funded by the other Federal agencies is almost exclusively mission-oriented. Except for NSF, all Federal agencies supporting marine science maintain their own laboratories in addition to funding marine research at universities and in industry. Currently, 85 U.S. Government laboratories exist along the coasts and Great Lakes-some of them understaffed and underutilized, some involved in research somewhat removed from their agency's primary interests, but 
most with programs of high quality. These laboratories form a raluable component of the national capability in marine science.

A new and potentially rery important program in support of marine science and technology is that sponsored under the National Sea Grant College and Program Act of 1966 and currently administered by the National Science Foundation. The Sea Grant Program provides continuing support for broad-based multidisciplinary programs in training and research in a variety of areas not corered by the Navy or other NSF programs. Sea Grant can provide support for training, from the technician to the postdoctoral level, in all areas related to marine activities including the social sciences. It provides for information transfer programs of the kind pioneered a half century ago by the land grant college program of cooperative extension work, and it provides support for research on problems of resource deve]opment and other areas of applied research.

Although the general situation of marine science is good, there is ample room for improvement. Many researchers, particularly at smaller institutions, lack adequate facilities. Some ships of the U.S. oceanographic research fleet are or soon will be obsolete. Excellent cooperation between academic institutions and Government laboratories in some places is offset by poor cooperation in others. Cooperation between marine scientists and marine engineers is completely inadequate.

In recent years, the marine science actirities of the National Science Foundation and the Office of Naval Research, the two major funding agencies in this field, have not continued to grow as rapidly as they should. Since 1963, the annual rate of growth in support for academic marine science from these two agencies decreased from 7.3 per cent $(1963-1966)$ to 2.2 per cent $(1966-1968)-$ a growth rate insufficient to meet eren the

\section{Trends in Funding for National Science Foundation and Office of Naval Research}

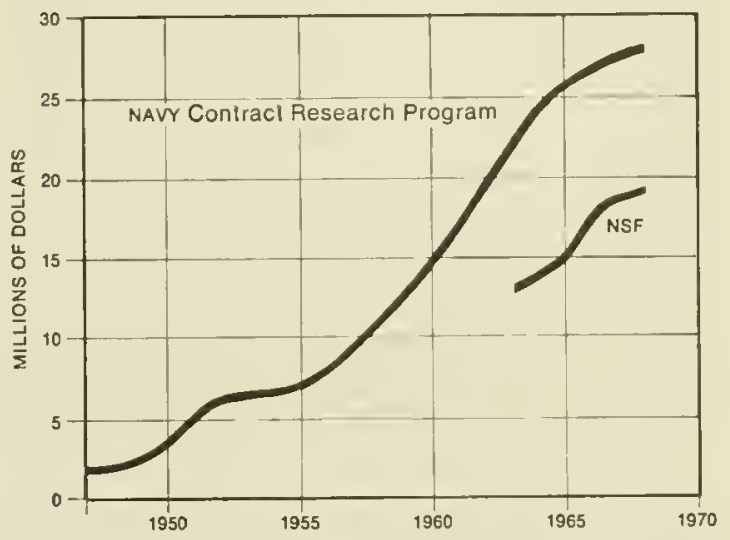

increasing costs of doing research and completely inadequate to the needs and opportunities of this priority field of scientific interest.

The Commission concludes that it is essential to regain the high level of interest and momentum that basic marine science attained during the past decade.

\section{Centers for Marine Science: University- National Laboratories}

The Commission finds that the U.S. position of world leadership in marine science depends mainly on the work of a small number of major oceanographic institutions. These few large, well-staffed, and relatively well-financed centers of oceanographic research have had a profound influence on scientists and programs at other institutions and have established criteria of excellence for the efforts of others. Such institutions as Scripps Institution of Oceanography, Woods Hole Oceanographic Institution, and Lamont Geological Observatory represent a major national in restment around which the Nation"s marine science program must be built.

The need for such major centers is the result of the very nature of the seis. One of 
the most demanding tasks of marine science is to conduct large, multidisciplinary efforts far from bases of logistic support and often in hostile cuvironments. The growing sophistication of research techniques under such difficult conditions requires large complex facilities, well-equipped ships, large stable platforms, deep-drilling ressels, deep submersibles, underwater laboratories, large arrays of buoys, experimental structures of several kinds, extensive shore facilities, and open areas where experiments in envirommental modification and control may be conducted.

In brief, marine science has become big science even though its facilities' requirements still may be modest compared to those for the space, nuclear energy, and national health programs.

Creation of big science capability in a few efficient centers is more economical than pursuing the major scientific tasks on a scattered project-by-ploject and facility-by-facility basis. Yet the nature of funding by the Federal Government often has hampered the development of such centers. In general, funds have been furnished to support specific projects or facilities rather than institutions. Sometimes capital grants have been provided without following up with sufficient operating funds to support the facilities' use. Funding limitations often have made it impossible to take advantage of mexpected derelopments or to support a scientist with an interest ont side the specified scope of the funded project.

To ensure the arailability of money and the ability to plan ahead, the laboratories must be assured of an adcquate lerel of institutional support for broad program purposes. Individual research projects could be funded separately, as at present.

Large facilities and guaranteed support are not needed by all institutions or scientists engaged in marine research. However, the

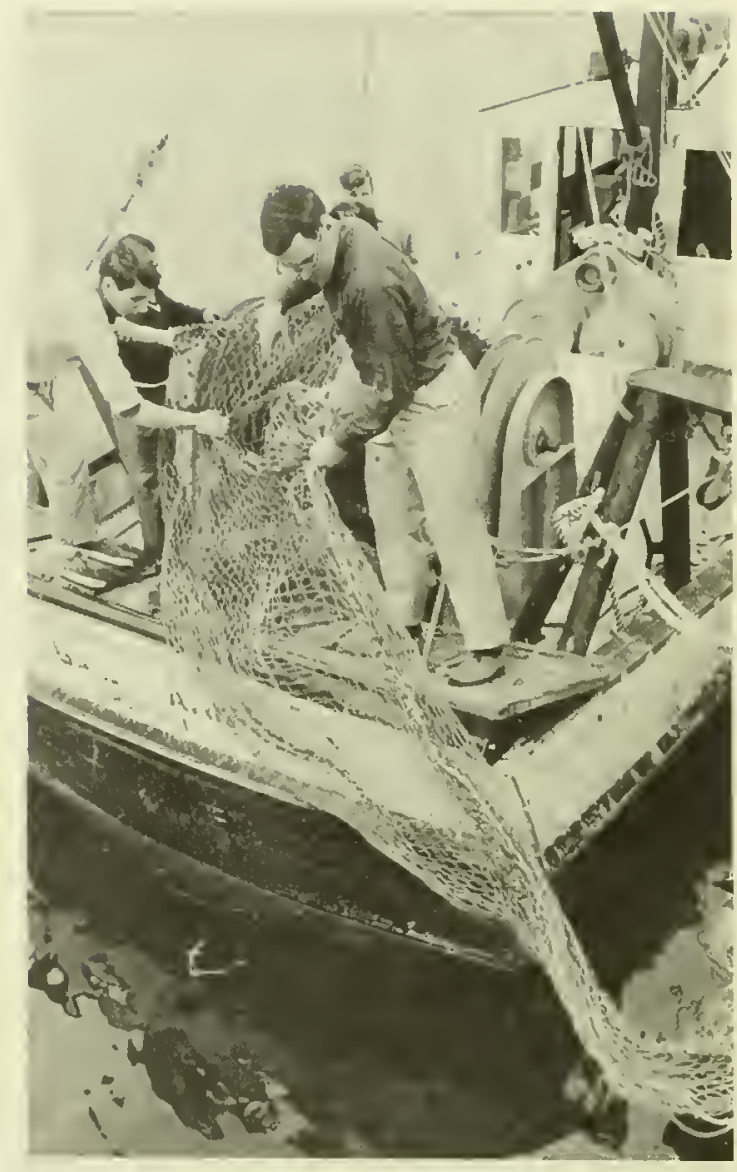

Marine scienee in the United States has undergone a natural growth in facilitic requirements.

Introduction of the schond of

Fisheries at the "nilersity of Rhode

Island in $196 \%$, for example, required

an additional research vessel and

her gear.

Commission concludes that the Nation does need a small group of geographically distributed laboratories that will be given such facilities and support to develop a high capability for ocean researcl. The laboratories should be located to cover different parts of the ocean efficiently and to be readily a vailable to other scientists and institutions.

The direct management of these laboratories, which might be designated as Univer- 
sity-National Laboratories, should be assigned to universities with a strong interest and demonstrated competence in marine atfairs. Under guiclelines established by the Federal Govermment, the University-National Laboratories would have formal provisions for making their facilities available to ontside investigators and for exchange of advice and assistance with other nearby institutions.

The relationship between the Federal Government and each university could vary from laboratory to laboratory, and the facilities and programs of the University-National Laboratories need not be identical either in size or form. The number, size, and scope of such major centers depend on the priorities ultimately assigned to various elements of the national ocean effort, the availability of funds in competition with other needs, the willingness of major universities to commit themselves to such programs, and other factors. The laboratories would include, but not be restricted to, the presently acknowledged leaders. Certainly, University-Nationa] Labolatories will be needed on the Atlantic, Pacific, and Gulf coasts, the Great Lakes, in the Aretic, and in the mid-Pacific.

The Commission recommends that University-National Laboratories be established at appropriate locations, equipped with the facilities necessary to undertake global and regional programs in ocean science, and assured of adequate institutional funding for continuity and maintenance of both programs and facilities.

\section{Centers for Marine Science: Coastal Zone} Laboratories

The major marine research institutions have focused their work in the oceans beyond the coastal zone. There are exceptions, of course, and excellent research in beach processes, marine biology, and coustal greology has produced results of national value. But the Nation lacks well-established and wellequipped research centers to investigate the problems of the estuaries and the coastal zone.

Though some problems are common to all estuaries and coastal zones, most are primarily of a regional or local nature and vary greatly. It is necessary only to compare the Hudson River estuary, the Mississippi Delta the Columbia River estuary, Lake Erie, the Maine shoreline, the beaches of North Carolina, and Alaska's Cook Inlet to appreciate the vast differences. Even in the same part of the country, regional and local population concentrations and geographical variations create quite different problems. The Delaware Bay and Chesapeake Bay are close together-even connected by a canal; yet they pose many different problems.

Multiple-use problems involving valuable living resources are almost entirely regional and local. The relationship of oil, gas, and sulphur recovery to the shrimp and oyster fisheries off Louisiana presents quite different problems than the relationship of the pulp and paper industry with its effluents to the salmon fisheries of Washington.

The Commission conclndes that the serious nature of the problems of the estuaries and coastal zones, discussed in Chapter 3, calls for the development of local and regional research centers specializing in their solution. Fortunately, a number of universities alveady are moving in the direction of research to meet local marine problems; Federal support will serve to accelerate and enlarge this trend. The direct involvement of the States is of great importance in solving roastal problems. The States will have to operate and maintain their own local environmental monitoring systems; management and some aspects of 


\section{Principal \\ Marine \\ Science \\ Laboratories \\ and \\ Institutions}

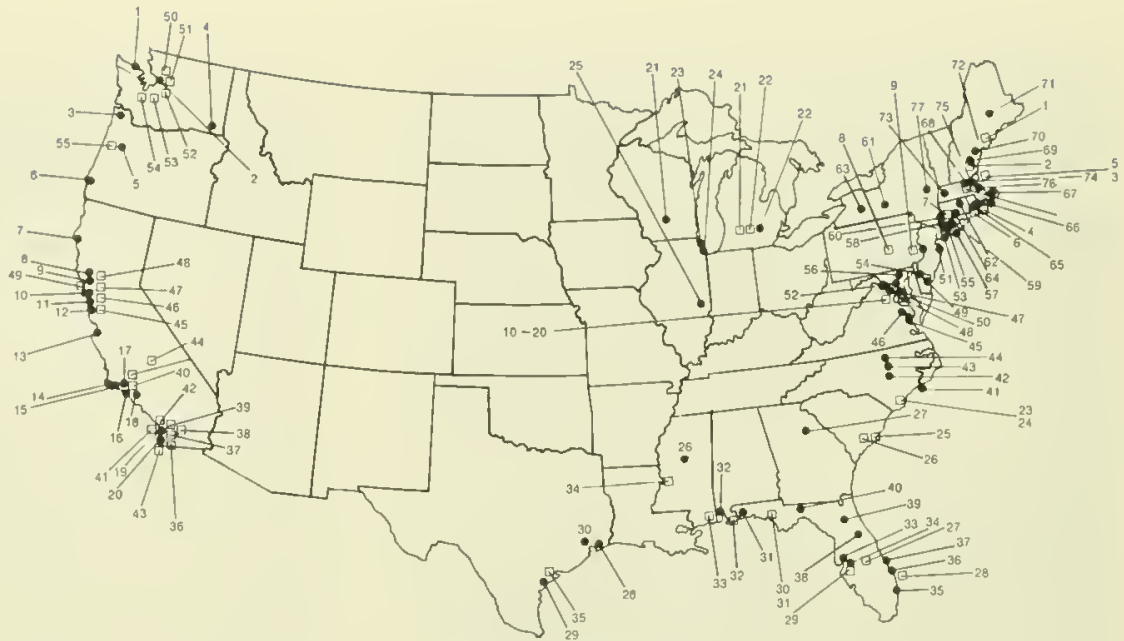

\section{University}

1 Peninsula College. 2 Lniversity of Washington. 3 Clatsop Community College, \& Walla Walla College, 5 oregon State Iniversity. 6 oregon Institute of Marine Biology. THun. boldt State College. \& California Maritime Acalemy. 9 University of California. To California State College of Hayward. 11 San Jose State College. I2 U.S. Naval Postgratuate School. 13 Stanford University. I4 University of Southern California. I5 l'omona College, I6 Fullerton Junjor College. 17 California Institute of Technology. Is Seripus Institution of Oceanograply. 19 San Dirgo State College. 20 Lniversity of the Facitic. 21 Lniversity of Wisconsin. 22 University of Michigan. 23 Illinos State College. 24 ['niversity of Clicago. 25 Iniversity of Illinois. 26 L'n1versity of Southern Mississippi. 27 Inversity of Georgia. 28 Texas A\&M University. 29 University of Texas Institute uf Marine Seience. 30 Twxas Maritine Acadeny. 31 Lini. versity of West Florida. 32 Lniversity of Alabana. 33 Cniversity of South Florida, 34 lilorida Presbyterian College. 35 I'niversity of Miami. 36 Nova University. 37 Florida Atlantic Iniversity. 3s Florida Institute of Technology. 34 Iniversity of Florila. 40 Florida state Iniversity. 41 ('ape Far Techulcal Institute. $\$ 2$ I'niversity of North Carolina. 43 North Carolina State University. 44 Duke Iniversity, 45 old Dominion College. 46 Virginia Institute of Mariue Scipnce. 47 U.S. Naval Academy. 48 Graduate School, U.S. Department of Agriculture. 49 Stevens In stitute of Technology. 50 Catholic Iniversity of America. 5 I Suffolk Connty Community College. 52 Jolns Hopkins Iniversity. 53 City College of the City rniversity of New Fork. 5t Lniversity of Mlawire. 55 lew lork Lniversity. 56 I,ehigh University. 57 Long Island University. 58 State University of New York Maritine College. 59 Columbia University, 60 University of Bridgeport, 61 Webb Institute of Saval Architecture. fiz T'niversity of Connecticut. 63 Conell Eniversity. 64 rale rniversity. 6.5 Euversity of Rhode Island. 6f Woods Hole Oceanographic Institution. 67 Southeistern Massaclusetts Trehnnlngy Institute. 68 Harvard Lniversity. Ga Lnisurity of New Hampsuire. 70 Southern Maine Vocational Terhnical Institute. 71 Univer. sity of Maine, 72 Maine Maritime Academy. T3 Lniversity of Massachusetts. T4 Massachusetts Institute of Technology. 75 Northeastern Lnlversity. 76 U.S. Coast Guard Academy. 77 Rensselaer I'olytechnic Institute.

\section{Federal Government}

I Biological Laboratory. 2 Exploratory Fishing and Gear Research Base. 3 Naval Lnderwater Weapons Research and Enginmering Station. $4 \mathrm{Navy}$ Lnderwater Sounil Labora. tory. 5 Biological Laboratory. 6 Hiological Iaboratory. 7 Naval Apllied Sclence Laboratory. S Naval Air Levelopment Center. 9 Naval Air Engineering Center. I0 Naval Shil Reserch and Development Center. 11 Naval Weapons Laburatory. 12 C.E.R.C. 13 Naval Research Lahoratory. 14 Naval Ordnance Laboratory. 15 Naval Slip Research and Development Laboratory, Annapolis. 16 Ichthyological Lahoratory. 17 Oceanographic rnit. 18 National Oceanographic Lata Center. If Biological Laboratory. $20 \mathrm{Biol}$ ogical Iaboratory. 21 Exploratory Fishing and Gear Resmarch. 22 Biological Laboratory. 23 Riological Lahoratory. 24 Raliobiological Laboratory. 25 Biological Laboratory. 26 Exploratory Fishing and Gear Research station. 27 Inderwater Sound Reference Division (NRL). 28 Tropical Atantic Biological Lahoratory. 29 Biological Field Station. 3n Exploratory Fishing and Gear Research Rase. 31 Navil Ship liesearch and Levelopment Laboratory. Panama City. 32 Biological Laboratory. 33 Exploratory Fishing and Gear Research Base. 34 Waterways Experinental Station (Corps of Engrs). 35 Biulugical Laboratory. 36 Tuna Resources Laboratory. 37 Biologteal Laboratory. 38 Biological Laboratory. 39 California Current Resources Laboratory. 40 Naval Civil Engineering Labolatory. 41 Naval Weapons Center, Corona Laboratories. 42 Naval Undersea Warare Center. 43 Naval Electronics Laboratory Center. 44 Naral Weapons Center, China Lake. 45 BioJogical Laboratory. 46 Geological Survey Resenreh Center. 47 Tiluron Marine Laboratory, 48 Bureau of Mines Kesearch Iaboratory, 49 Navy Radiological Defense Laboratory. 50 Salmon-Cultural Laboratory, Biological Lahoratory. II l'acitic ( ocen nography Institute. 52 Exploratory Fishing and Gear Research. 53 Marine Nammal Labora. tory. 54 Shullbsli Sanitation Resenreh Center. 55 Water Pollution Control Laboratory.

Socace : Interagency Committee for Manpower, Research, Education, anl Ficilities, Sational Conncil on Marine Resources and Engineering Development. 
enforcement are clearly State responsibilities. The laboratories will be able to assist the States to plan and manage their coastal zones effectively.

The activities of the Coastal Zone Laboratories outlined here and in Chapter 3 fall within the kinds of programs envisaged for the Sea Grant Colleges authorized in the National Sea Grant College and Program Act of 1966. The Sea Grant Program is an excellent vehicle for establishing and supporting the proposed Coastal Zone Laboratories. However, this will require amendment of the Act to allow funds to be used for construction of facilities and for ship support, both of which are excluded at present.

The Commission recommends that Coasta] Zone Laboratories be established in association with appropriate academic institutions to engage in the scientific investigation of estuarine and coastal processes and to be prepared to advise the States in managing the estuaries and Coastal Zones.

The National Oceanic and Atmospheric Agency (National Sea Grant Program) should have the prime responsibility to provide institutional support for the Coastal Zone Laboratories. The Sea Grant College and Program Act of 1966 should be amended to permit grants for the construction and maintenance of vessels and other facilities.

\section{Centers for Marine Science:}

Federal Laboratories

Most Federal agencies concerned with the marine environment maintain laboratory facilities of their own. Thile these laboratories conduct research primarily related to the missions of the agencies, they also engage in basic research. This is essential if the laboratories are to respond to future opportunities as well as present mission needs and if they are to attract and hold highly competent scientific staffs.

In recent years, Federal marine-oriented laboratories have been located near universities with strong marine programs. In fact this is a statutory requirement for the Federal Tater Pollution Control Administration. Active cooperation between the university and Federal laboratory usually has resulted, to the benefit of both. Such location and cooperation, of course, should be encouraged further.

A major deficiency in the organization of the present Federal in-honse laboratories of the civil agencies supporting marine programs is that many of the laboratories are too small to mount effective programs. A consolidation of such laboratories into a small number of stronger centers wonld permit bringing together resonrces at a scale needed for high quality research programs.

The Commission recommends that Federal marine science laboratories be strengthened by adequate funding and staffing. Selective consolidation of marginal laboratories is one way of achieving this purpose; however, it should be remembered that effectiveness is not necessarily a function of size.

\section{Naval Research}

The Government assigns a high priority to the military applications of marine science. This is to be expected. Basic marine science has been of the utmost importance in building the U.S. Navy's capabilities for defense and deterrence. The interests of the Office of Naval Research (ONR), which is responsible for the Nary's basic research effort, have been 
as broad as the seas; ONR has conducted its stewardship well.

As the Nary mores ever more strongly under the seas, it will need increasingly to enlarge its understanding in such vital matters as the propagation characteristics of sound in water. The Nary must continue its support of science to meet uniquely military needs. In addition, the Nary will be a prime user of all scientific information dereloped by non-Navy programs.

In a recent report, the Nary identified underwater sound among eight areas of interest singled out for priority attention. The acoustics program has been particularly important to the Navy and to the Nation, since underwater observation and communication depends on the understanding of the transmission of sound. Altlough impressive gains have been achieved in detection and communication capabilities, opportunities remain for further improvement through studies of the effects of acoustics reflections and refraction at the surface, at the bottom, and at the inter faces between different water masses.

The Commission conchides that the Department of Defense involvement in marine seience is necessary to its mission. The Department must have control over all the rital aspects of the task for which it is responsible, and basic research is one of those aspects.

The Commission recommends that the Navy maintain and, as required, expand its broad program of oceanographic research, in particular its underwater acoustics research program.

\section{Diversity of Support}

No single best way to conduct marine science has been found, and it is unlikely that a best way exists. The health of U.S. marine science derives in large measure firom its di- rorsity. Excellent marine science is to be found in laboratories and universities far remored from the sea and conducted by persons and institutions not generally thonght of as marine scientists or engaged in marine science. The Commission concludes that support of one institutional arrangement or method of education to the exclusion of others would hinder rather than aid the growth of marine science in the United States. The present variety of institutional arrangements is good and should be nurtured.

The Commission wishes to emphasize that the creation of the recommended networks of laboratories should not lessen in any way the Nation's support of the many other diverse sources of marine science competence. Good marine science should be supported wherever it is found. The proposed major centers for research should be so funded and managed that they encourage the marine activities of other public and private institutions and individuals.

The National Science Foundation, the Navy (Office of Naral Research), and other Federal agencies must continue funding marine science activities as their mission interests may dictate. Project funding will assist those laboratories designated to receive institutional support to respond effectively to ageney needs. It also will help to preserve the diversity in the support and conduct of marine research so essential to the health of science thronghont the Nation.

\section{Advancing Marine Technology}

\section{Importance and Objectives of Marine Technology}

While science provides the key to understancling, technology is the key to expanded utilization of the oceans. The Commission uses the term to embrace the totality of knowledge, equipment, techniques, and facilities 


\section{Sources of Funding for the Principal Marine Science Institutions}

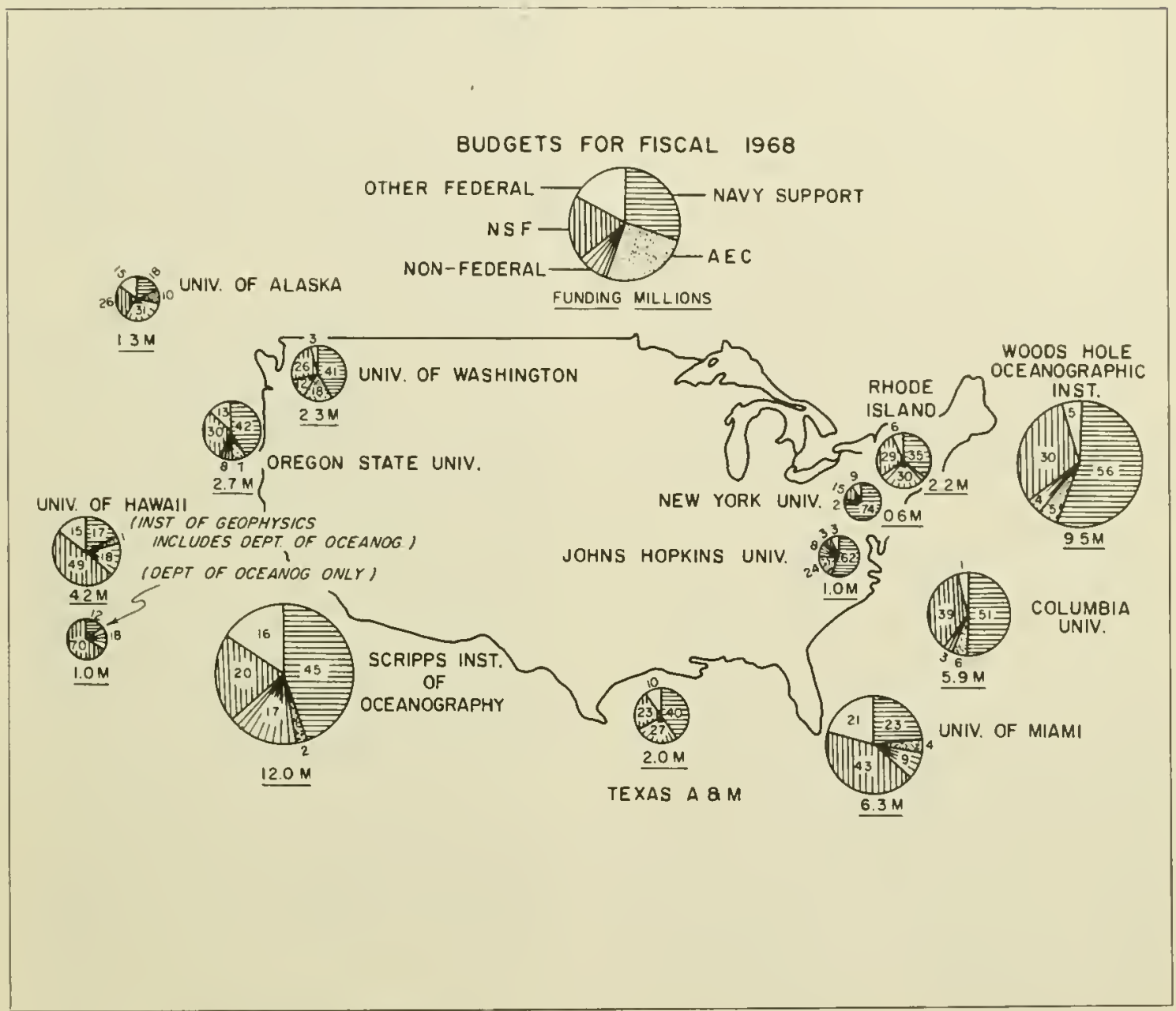

Source : W. Burt, Department of Oceanography, Universlty of Oregon.

necessary to develop more effective ways to make use of the sea.

The Commission's concern with technology appears throughout this report-in relation to coastal management, fresh water restoration, resource development, deep sea exploration, environmental monitoring, and a host of other marine services. Although each of these areas has special technological requirements, all draw on a common pool of knowledge regarding the sea and its effects and on a common reservoir of fundamental engineering skill.

The fundamental technology program reccommended by the Commission is geared to filling this common reservoir. The Federal 
Govermment will draw upon it for the conduct of activities for which it is directly responsible, such as the provision of environmental forecasts and the maintenance of waterways. State and local governments will draw upon it in managing their coastal zones and in grappling with water pollution problems generally. Industry will be called mpon to carry out many of the recommended programs and will use the fundamental technology in resomee development. The scientific community will draw on it to develop new ways to probe the sea's mysteries.

To advance the Nation's marine competence, the Commission conchudes that specific goals should be established which will challenge the Nation and accelerate its movement into the seas.

The goals selected by the Commission derive quite natmrally from the geography and bathymetry of the sea. The U.S. continental shelf presents the most immediate opportunity. So far as is known, the continental shelf is the most productive region of the sea. However, economically valuable marine operations already extend beyond shelf depths. and a deeper goal is warranted in seeking to improve national capability for productive operations. Beyond the continental shelf is the continental slope. Its potentially usable area diminishes below the 2,000-foot level. Present technological forecasts indicate that the Nation can achieve the capability to operate at the 2,000 -foot depth within a relatively short time if basic research and development are accelerated. Some ability exists now to work at that depth. Further, the 2,000-foot depth is close to current estimates of the working potential of free-swimming divers. As a primary goal, therefore, the capability to operate at the 2,000-foot depth is attainable and, because of the known richness of the resources to be found out to that depth, immediately rewarding.
The Commission recommends that the United States establish as a goal the achievement of the capability to occupy the bed and subsoil of the U.S. territorial sea. The Commission also recommends that the United States learn to conduct surface and undersea operations to utilize fully the continental shelf and slope to a depth of 2,000 feet.

The 2,000-foot contour encompasses most or all the shelf-like areas; at that depth the continental slopes drop rapidly to the abyssal depths. Nearly 00 per cent of the ocean floor lies between 2,000 and 20,000 feet, most of it in the open oceans. The abysal depths are perhaps the least known area of earth, but they are becoming increasingly important for basic scientific understanding, for military security, and for minerals after more easily reached resources have been tapped. Capability to operate at the 20,000 foot depth wonld bring all but a few ocean trenches within reach. That attainment of such capability is a practical goal is clear from the promising characteristics of adranced structural materials, new concepts in machinery and equipment, and better engineering methods. Man himself already has penetrated the oceans to even greater depths.

The Commission recommends that the United States establish as a goal the achievement of the capability to explore the ocean depths to 20,000 feet within a decade and to utilize the ocean depths to 20,000 feet by the year 2000 .

To effectuate these recommendations will require support for a rariety of technological programs. The Commission's proposals for a broadly based program of fundamental technology and for a series of National Projects 
are advanced later in this chapter. Programs to develop technology specifically applicable to marine programs are adranced in subsequent cliapters of the report.

\section{Marine Technology in the United States Today}

Like marine science, marine technology is where one finds it, scattered throughout the Nation, supported in a diversity of ways. Contributions to marine technology lave come from indiridual entrepreneurs, specialized companies, large industries, nniversities, and the Federal Govermment.

Private industry to date has done the most to develop civil marine technology. Because industry concentrates on areas of high economic return, petroleum exploration and exploitation technology has led the field. Other important areas in which technological clevelopment has grown rapidly include deep submersibles and the design and installation of desalination plants. There also have been rapid adrances in-merchant ship antomation, cargo packaging and handling, and tuna clipper design and equipment.

The Federal Govermment's role, apart from that of the Nary, has been modest. The U.S. Army Corps of Engineers has done the most

\section{Federal Support for Marine Technology 1969}

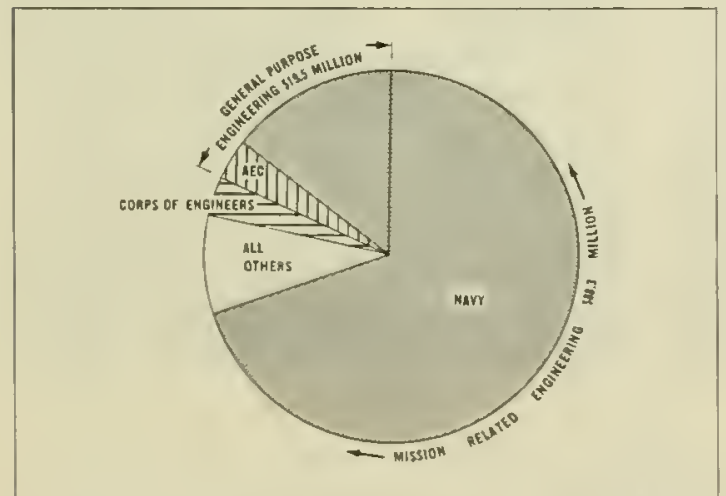

Socrce: National Council on Marlne Resources and Englupering Development. to develop coastal engineering methods, and its Coastal Engineering Research Center is the principal national research institution in this vital field. The Bureau of Commercial Fisheries has carried out valuable but limited derelopment of fisheries technology. For the most part, however, the Federal Government has failed to give serious support to civil marine technology.

The U.S. Navy, which long has had the largest Federal marine technology program, has produced results usable in many civil fields. The "spin-off" into the civil economy from naval architecture and ship propulsion research is well known. Valuable information and experience will be derived from Navy man-in-the-sea, deep submersible, and deep ocean technology programs. But it must be kept in mind that the specialized nature of the Navy mission bars a complete integration of Nary and civil interests. Further, the transfer of technological information from Nary sources will always be delayed because security requirements necessitate restrictions upon the public release of information.

Federal agencies have supported technological development primarily through contracts to industry and academic institutions, although some technological development has taken place in Federal laboratories. Most development that has taken place has been mission-oriented; even the Nary's programs are not comprehensive. Thus, there is no single agency within the Federal establishment with overall responsibility for the support and advancement of marine technology. In consequence, there are insufficient channels in the Nation through which the civil technological needs and interests of industry can be satisfied and industry's active participation in such technological development enlisted. Nor is there any systematic way of recognizing and filling major technological gaps. 

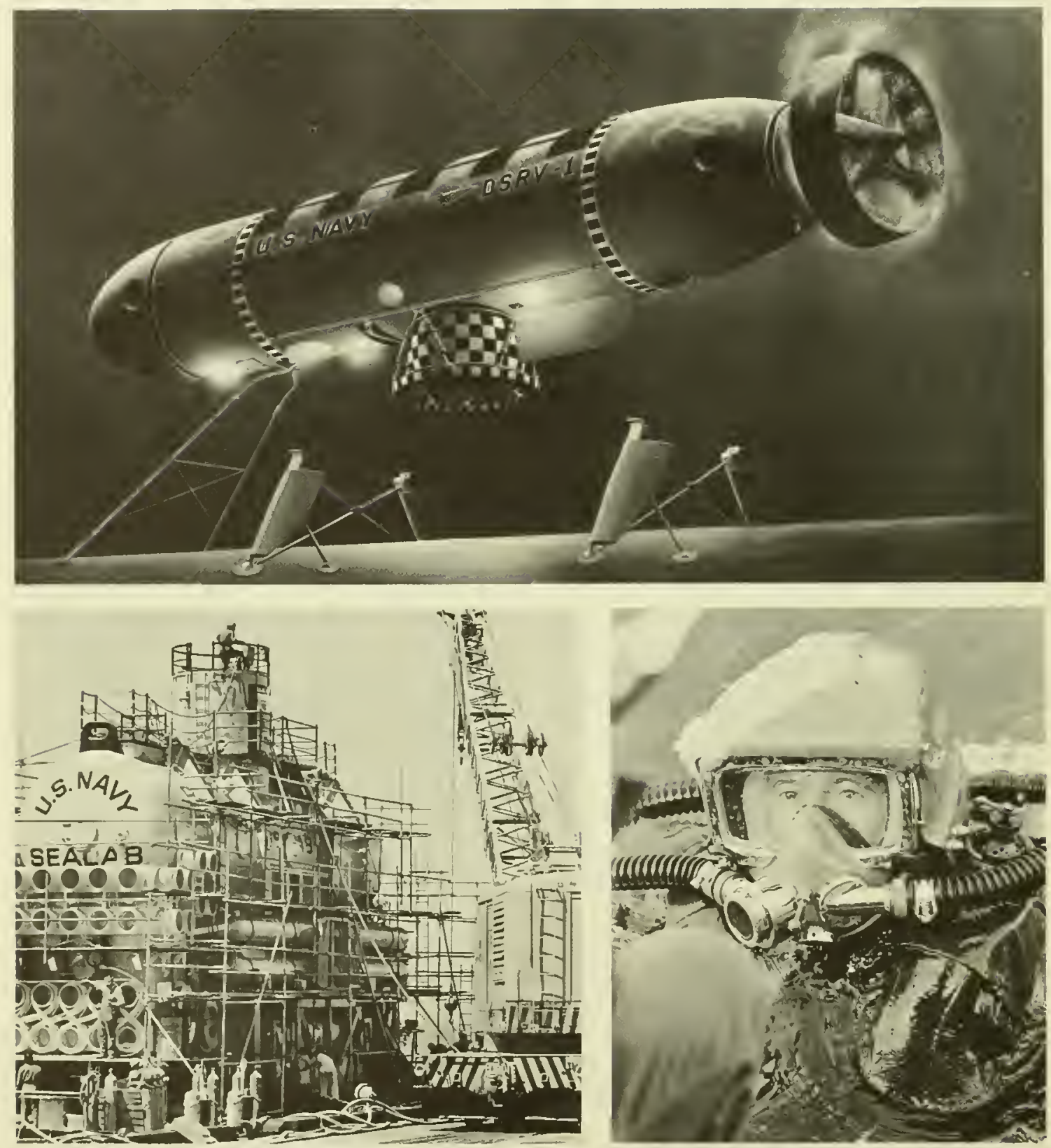

Taluable experience and information will be derived from civil application of Navy man-in-the-sea, deep submersible, and deep ocean technology programs-like the knowledge gained from the use of SEALAB habitats, the development of diving equipment, and the construction of Deep Submergence Reseue Vessels. 
The entire technology for fisheries and aquaculture remains relatively primitive in terms of its potential. Except for developments to meet Nary requirements, this is true also of the field of marine instruments for measuring, monitoring, locating, and data transmitting. Technological development to inprove recreational opportunities and facilities generally has been neglected except where there is a direet buyer-seller relationship, as in boating, sport fishing, and sport diving equipment. Marine hard mineral recovery techniques have been essentially extensions of shallow water dredging methods with few real innovations. The highly advanced food technology methods used in the transportation, packaging, and processing of fresh agricultural products have not been sufficiently applied to fresh seafoods, and manual processing methods continue to handicap growth in some seafood industries.

The Commission finds that the present national capability in marine technology, while substantial in some fields, is not broad enough to support an expanded national eflort in the sea.

In considering how the situation can best be remedied, the Commission has adopted the premise that capability in marine technology must be structured principally on the existing industrial base, but with Federal support and greatly increased participation by the academic community.

\section{Fundamental Technology}

The value of Government support of scientific resench is generally acknowledged, even if its only immediate aim is to increase man's understanding of his world. Yet technological development traditionally has been supported only to solve clearly defined problems or to meet known needs. Nevertheless, a paralle] can be drawn between basic scientific research and the more fundamental aspects of engi- neering science and technology. Both serve to advance the overall national capability to understand and use the total environment, and both provide a base from which may spring many forseen and unforseen applications.

The Commission does not suggest that fundamental technology should be supported purely for its own sake, but it should be supported to provide the Nation with a broad spectrum of expertise, instruments, and facilities to undertake the tasks which may prove necessary to effective use of the sea.

The Commission's concept of the difference between fundamental and applied teclnology is best illustrated by examples.

The problem of materials is basic to all activities in the sea, whether on or ander the surface. Salt water is an inhospitable medium for most of man's materials; yet marine activities presently depend greatly on materials developed for use on land and in the air. Improved materials technology would result in lower costs for construction, operation, and maintenance of structures and equipment and greater reliability, efficiency, and safety. Entirely new engineering methods, now foreclosed by the inadequacy or unsuitability of materials, would become feasible. Therefore, a wide spectrum of marine activities would be adranced through progress in the fundamental technology of materials.

Underseas operations, whether fixed or mobile, depend on power supplies. Underwater habitats at present are tied to land or to surface power sources. The time approaches rapidly when the umbilical cords to land or the surface must be cut. The undersea units must become self-sustaining. Deep submersible design also is handicapped by lack of light, efficient, economical, long-duration power sources. Power supply technology is fundamental to future development in all undersea activities. 


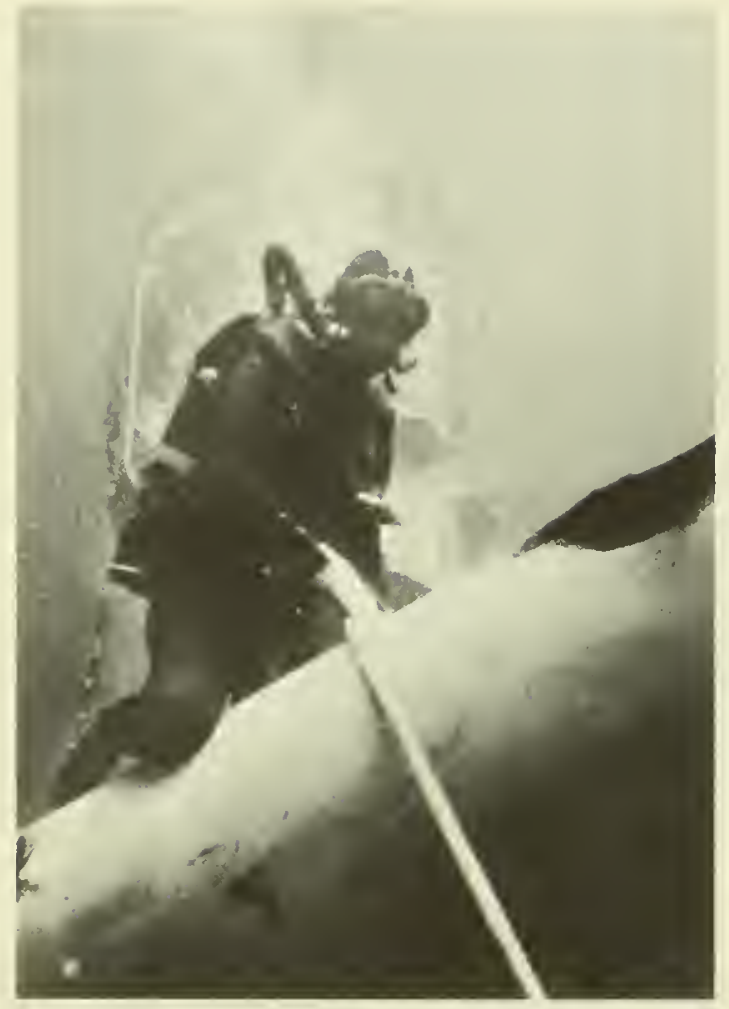

A commercial diver works on an offshore oil wellhcad wnit. Wost undersea work mesenlly takes place under arduous conditions combining limited visibility, low temperatures, and strong currents.

Men enter the sea as divers or in submersibles either to observe or to work. Both functions are sharply limited by available tools and equipment which are deficient in reliability, simplicity of operation, rnggedness, effectiveness, and cost. Most undersea work presently takes place in conditions combining dim light or darkness, murky water, low temperature, and strong currents. Adrances in the fundamental technology of basic tools, equipment, machinery, and devices to improve visibility and communications are essential to efficient, economical undersea operations.
One of the most pressing needs in fundamental technology is for better instruments. Much of the national investment in ocean programs for the foreseeable future will be devoted to measuring, mapping, defining, and monitoring the marine enviromment and to testing and monitoring ocean equipment. Good instruments dependable, accurate, and not too costly-are an urgent necessity.

To build fundamental capability requires an adequate level of support. The cost of dereloping the technology of underwater tools for man and vehicle may reach $\$ 100$ million over a 10 -year period. Improving basic design for underwater viewing techniques may involve $\$ 50$ million in 10 years. Needs in materials technology are so broad as to be essentially open ended, but an estimate of $\$ 250$ million over a decade does not seem unreasonable.

Development of fundamental technology calls for a full partnership among the Federal Govermment, industry, the academic engineering community, and the States. The Federal role is primarily one of leadership and support. While some Government facilities for marine technological development exist, the principal broad-based competence is found in industry, with the academic community as a prime source of theoretical engineering and leading center for some aspects of experimentation and testing.

Federal leadership requires that the National Oceanic and Atmospheric Agency (NOAA) be given a statutory mission to advance fundamental marine technology. The novelty and scope of the program proposed by the Conmission will require the agency to oversee the program's implementation and to have a mechanism through which the head of the agency may obtain advice on a continuing basis from industry, the States, and universities. 
The Commission recommends that the National $\mathbf{0}$ ce a n i c and Atmospheric Agency initiate a dynamic and comprehensive fundamental technology program. The objective of the program should be to expand the possibilities and lower the cost of marine technological applications by industry, the scientific community, and government.

\section{National Projects}

'The twin oljectives of a major national eflort in marine science and technology are (1) the expansion and improvement of overall mational capability and (2) the application of present skills and knowledge to immediate problems and opportunities. To impart a sense of priority to the ettort. a part of the national plan must be focused on clearly identified projects, facilities, and programs assigned the status of National Projects.

The National Projects should be concrete, definable activities broad enough in scope to force the rapid advancement of knowledge and technology. There should be provision in each National Project for the participation of industry, the academic community, and the States to the extent that their interests and competence are involved. The National Projects should be a training ground for scientists, engineers, technicians, and management personnel from all segments of the marine community. While National Projects should be responsive to current needs, they should be planned for maximum utility to future needs and opportunities.

Management and primary support for a National Project would be a Federal responsibility. Industry should participate in planning, implementation, and operation of the National Projects through contracts with the managing agency in some cases or through use of Federally owned facilities on a costreimburseable or cooperative arrangement in others. Participation by academic institutions and state agencies similarly would be determined by the nature of the project.

The Commission recommends that the National Oceanic and Atmospheric Agency :

- Establish, in collaboration with other interested Federal agencies, National Projects to focus the national marine effort on specific areas of need and opportunity and to advance the national capability

- Initiate an intensive and innovative effort to assess the feasibility of additional National Projects.

The Commission recognizes that technology is developing rapidly and that the precise definition and timing of National Projects necessarily will require detailed studies of engineering feasibility and utility prior to making funding decisions. Nonetheless, the Commission has selected six projects which it concludes merit early implementation and has estimated the approximate level of effort which it believes appropriate to each. Five additional projects have been identified as meriting more intensive study.

Each proposed National Project is discussed in greater detail in an appropriate chapter of this report and in the Report of the Commission's Panel on Marine Engineering and Technology. The projects are listed in Table 2-1.

Each of the recommended National Projects will contribute importantly to the overall adrance of the Nation's marine capability and will assist in meeting more specific needs. However, the National Project for derelop- 


\section{Table 2-1 National Projects Recom- mended by the Commission}

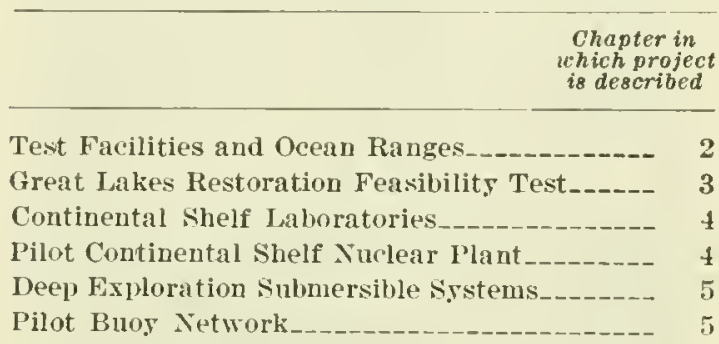

\section{National Projects for Feasibility Studies}

Pilot Harbor Development Project_-_-_-_-_--- 3

Deep Ocean Stations.

Seamount Station_-_-___- 5

Mobile Underiea Siuport Laboratory_-____- 5

Large Stable Ocean Platform

ment of adequate facilities for testing marine instruments and equipment on shore and at sea and for physiological research is essential to the total advance of marine technology. The need for such marine facilities is comparable to the need for similar facilities in aeronautical and space development. The design of adequate test facilities will challenge engineering ingenuity; their construction and use are matters of wide concern to both government and industry. Insufficient and frequently unsuitable test facilities and ranges have hampered advancement in equipment and instrumentation development and in submersible and habitat testing. Facilities for physiological research, medical training and testing, diver equipment development, and saturation diver training and testing are absolutely essential for orderly development.

As scientists and engineers probe deeper into oceans, test requirements will grow more stringent. Just as aeronautical engineers were compelled to design and build entirely new simulation facilities to test and evaluate air- craft systems for the rarefied conditions of the upper atmosphere, so radically different test facilities will be needed for the higher pressures of the oceans. There is no substitute for the economy and safety of simulation testing.

The Commission recommends that the National Oceanic and Atmospheric Agency establish a National Project to increase the number and capability of private and Federal test facilities for research, development, testing, and evaluation of undersea systems. The Project should include construction of high-pressure facilities on shore for testing equipment, biomedical pressure chambers for testing and evaluating man in undersea work, and ocean test ranges.

An eqrample of a projeet which the Commission believes merits further feasibility study is the large stable ocean platform. The utilization of semisubmersible drilling platforms by the petroleum industry has proved that, when further developed, such platforms can provide highly flexible, multipurpose, allweather islands capable of remaining on station in the open ocean for long periods. The size, stability, storage capacity, and long-endurance station-keeping capabilities of these platforms will permit them to be used in support of air and sea transportation, resource development, envirommental monitoring, and military missions.

\section{Industry and the Universities in Marine Technology}

The Govermment has a special role in the stimulation and support of fundamental technology and in the provision of national facilities. But the Commission emphasizes that these Govemment funded activities are to advance and stimulate, not replace, develop- 
ment by industry. It is essential that the distinction be clearly mate bet ween what private industry should do for itself mder profit motivation and what the Government should do to assist. The distinction must be reasonable and clearly understood by all participants. The advice and counsel of the broadly based National Advisory Committee on the Oceans (NACO) recommended in Chapter 7 will be of great valne in making this distinetion.

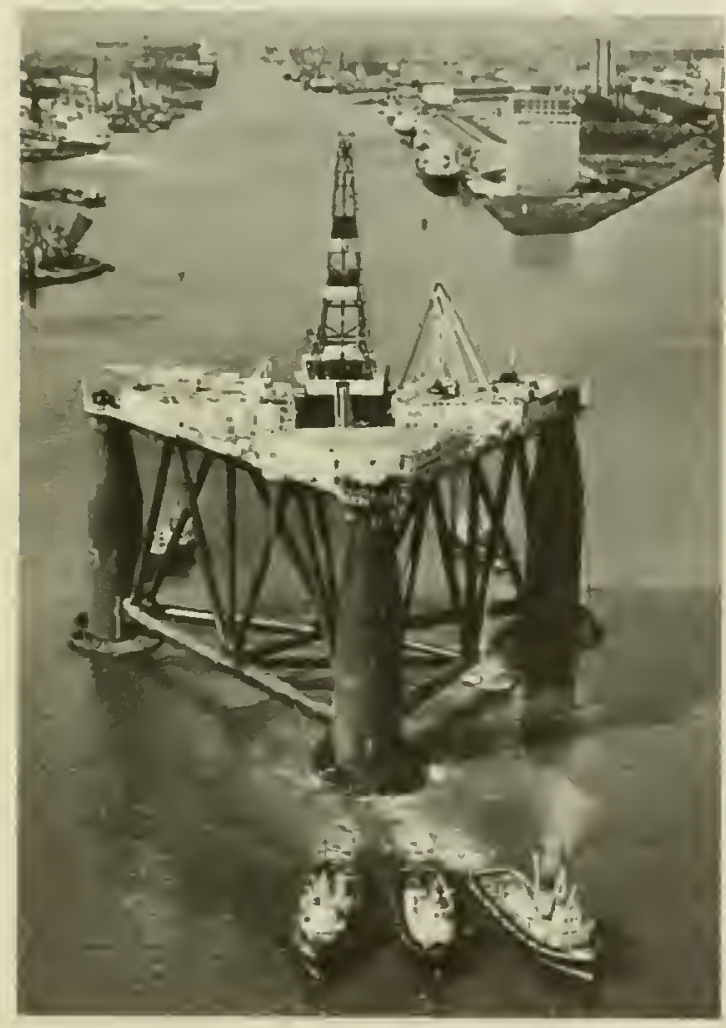

The 15,000-ton, scmisubmersible drilling rig Sea Quest is towed from her builder's yard in Northem Ircland curoute to work in the stormy North Sea. Usc of such platforms by the petrolcum industry has proved that this concept is trchnically sound and susceptible of further development to provide large, stable, multipurposc occun platforms for a varicty of uses.
The Commission recommends that industry participate in planning and conducting National Projects, in some cases under contract with the managing agency and in others by using a Federally owned facility on a cost-reimbursable basis or under other cooperative arrangement.

Effecting this recommendation will permit industry to become familiar with the objectives, characteristics, problems, and opportunities that become apparent through planning and development. In this way, too, industry will be stimulated to seek aggressively possible commercial applications of new technology. The Government's arrangements for industry participation should be highly flexible and consistent with the premise that the Govermment seek maximum utilization of private capabilities. Through similar reliance on private firms for military aircraft development, civil aviation was stimulated.

Participation of the academic community will be particularly valuable in applying its excellent research competence and facilities to the problems of fundamental technology. In many cases, industry has turned to academic scientists and engineers both for the development of design criteria and for the testing of principles and actual designs. Such cooperation should be enlarged and strengthened throngh cooperative programs to encourage industry's reliance on the academic community and through Government support to colleges and departments with ocean engineering competence. This also will contribute to the education of engineer's oriented to marine problems.

The role of academic engineers is of prime importance in the deployment of teclinological capability for scientific research. Increasing cooperation between the scientific and 
engineering faculties of a university must be encouraged and supported.

Whether a particular task in advancing technology (including a National Project) should be performed by industry, the academic community. or a Federal laboratory will depend on which element of the technological community is best suited for the task. The decisions will be made by NOAA with the assistance of the National Adrisory Committce on the Oceans. In all cases, prorision should be made for the exchange of information generated through Gorernmentsponsored programs, and for transferring sponsorship of technical projects to industry as soon as their development has advanced to a point that a reasonable return on private investment can be expected.

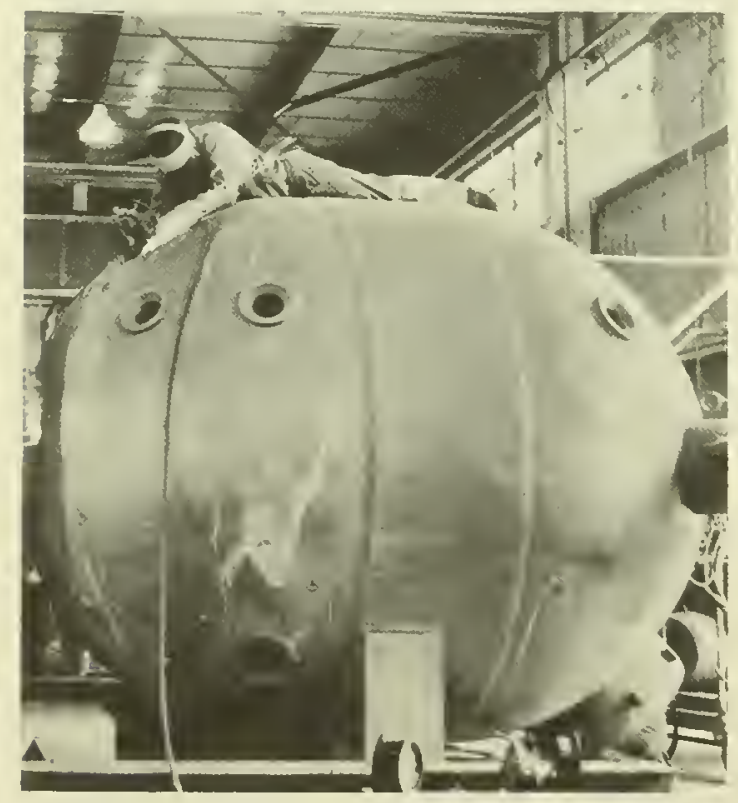

Laboratory test facilitics like this 9-foot high. man-rated pressure chamber can simulate the effects of pressure and time on divers and their equipment. This chamber, part of a larger complex being built by a company for its own use, will har' a marimum capability of 1.500 feet.
The Commission recommends that Government programs to advance marine technology be so planned and administered that they permit private industry to assume the responsibility for further technology development at the earliest possible time.

The Commission encourages the National Sea Grant Program to continue its efforts to stimulate cooperative multidisciphinary programs involving both scientists and engineers, including increased involvement of industry with university multidisciplinary activities. The Commission expects that provision would be made in funding the $U^{\top}$ nirersity-National Laboratories and the Coastal Zone Laboratories for the inchusion of technology development to support the laboratory programs, utilizing the competence and facilities of the universities and industry.

\section{The Navy in Marine Technology}

'The Nary's marine technology program is necessarily oriented to meet specific Navy mission needs, but the Commission is impressed by the important contributions which Navy competence and facilities have made and can continue to make to meeting overall national requirements. Close liaison should be established between NOAA and the Navy to ensure that the Navy benefits from developments in fundamental technology and, conversely, that the civilian effort promptly shares in the accomplishments of the Navy program.

The Commission recommends that the Navy's development capabilities and facilities be appropriately utilized through reimbursable arrangements with the National Oceanic and Atmospheric Agency in pursuing a national fundamental technology program. 

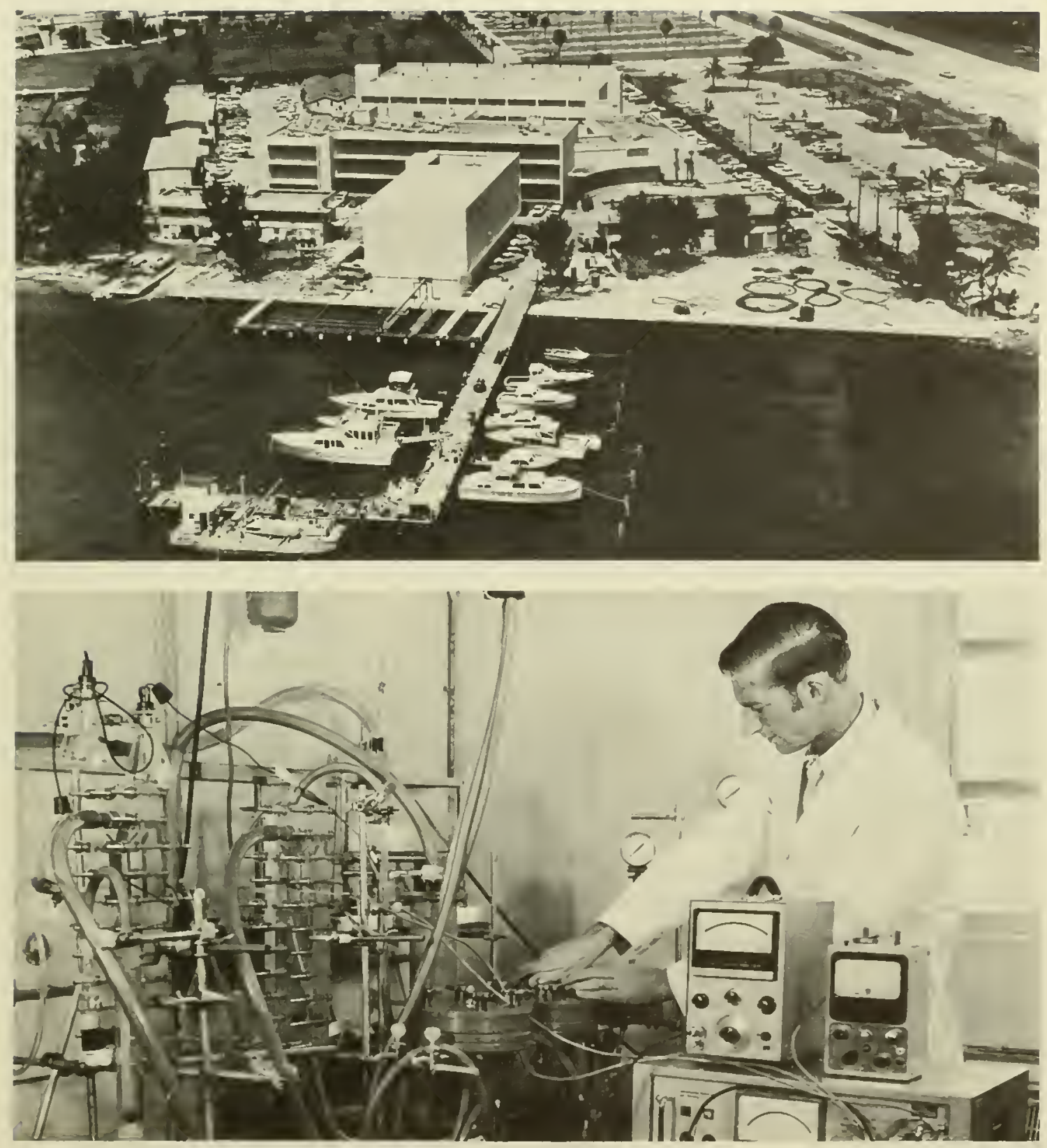

Institutions like the Iniversity of

Mirmi's Insfitute of Marine Sciences

curry forweurd researeh and development

proyrums to meet both eivil and military

neds. II rere an occan engineer eonduets

at murine corrosion experiment. 


\section{Graduates \& Enrollees in Marine Science \\ Education Programs}

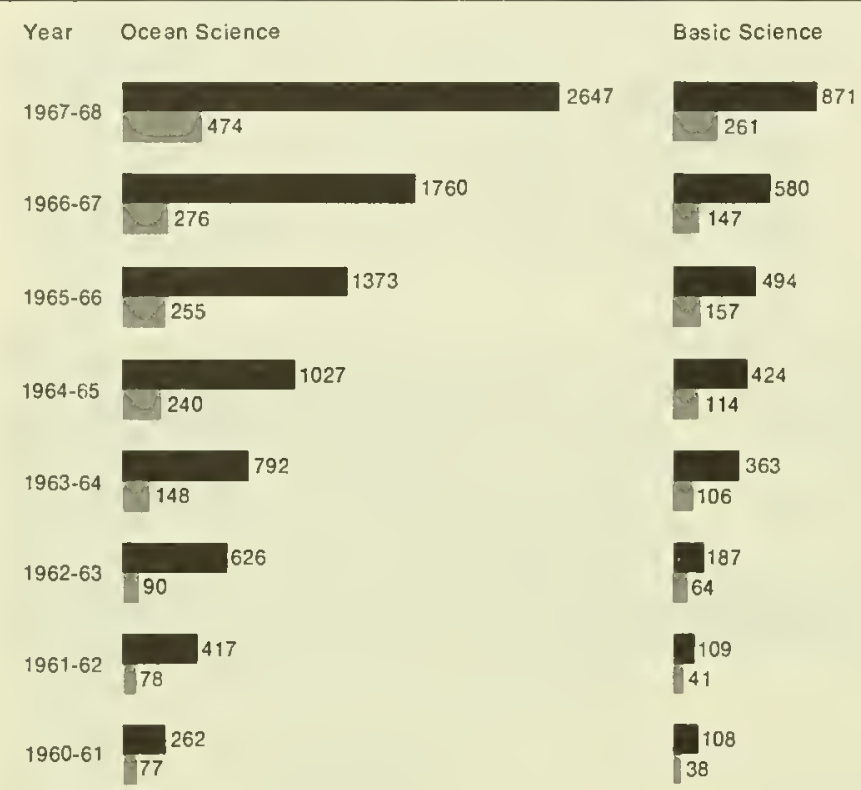

(Data for all degree programs combined)
Enrollees Graduates

Associate Enrollees Associate Graduates

\begin{tabular}{|c|c|c|c|}
\hline & Marine Food Scienct & Fisheries Science & Ocean Technology \\
\hline $1967-68$ & $\begin{array}{l}23 \\
11\end{array}$ & $6^{387}$ & {$\left[75^{311^{433}}\right.$} \\
\hline $1966-67$ & $\mid \begin{array}{l}14 \\
7\end{array}$ & $7^{374}$ & $\begin{array}{l}177 \\
0_{51}^{138}\end{array}$ \\
\hline $1965-66$ & 121 & 389 & $\begin{array}{l}167 \\
44^{131}\end{array}$ \\
\hline $1964-65$ & $\prod_{2}^{22}$ & 537 & $7_{13}^{153}$ \\
\hline $1963-64$ & $\left.\right|_{2} ^{20}$ & 298 & $021^{126}{ }^{388}$ \\
\hline $1962-63$ & 20 & $33^{252}$ & $27^{107^{372}}$ \\
\hline $1961-62$ & $\left.\right|_{1} ^{18}$ & $\square_{33}^{198}$ & $11^{1248}$ \\
\hline $1960-61$ & $\int_{7}^{13}$ & $a_{29}^{175}$ & $3^{51^{246}}$ \\
\hline
\end{tabular}




\section{Manpower for the National Capability}

Attempts to determine the number of trainerl and educated people available for marine operations or to forecast future requirements inevitably encounter serious difficnlty. The principal problem is one of definition. There seems to be no simple or widely accepted way to define a marine scientist, engineer, or technician.

Although degrees are granted in oceanography and their holders usually work as oceanographers, most marine scientists obtain their degrees in the basic scientific disciplines. Hence, physicists, chemists, geologists, meteorologists, geographers, and biologists who are working in marine research are not identified clearly as marine scientists.

The same is true of ocean engineering, which just now is emerging as an accepted term. An ocean engineer is simply an engineer who practices lis specialty in the marine enrironment or-in activities related to the sea. To a degree, the same problem exists in the technical specialties. Atthough it is possible to identify some specialties such as fisheries technician, oceanographic aide, or diver, others such as electronics technician or biological laboratory technician are skills in both land and marine activities. Also many technicians whose work relates entirely to marine matters never go to sea. Among the land-based marine technical specialties are biological sorters, laboratory technicians, mechanical and engineering technicians, chemical technicians, cartographers, and the great majority of electrical and electronics technicians. Very few of the industries that employ such personnel classify them as marine technicians.

There is no single Federal agency with overall responsibility for marine manpower matters, althongh several agencies, operating with minimal coordination, are supporting, initiating, or planning marine educational programs.

The Commission recommends that the National Oceanic and Atmospheric Agency be assigned responsibility to help assure that the Nation's marine manpower needs are satisfied and to help devise uniform standards for the nomenclature of marine occupations.

The new agency should be assigned responsibility to obtain, organize, and maintain marine manpower statistics, to analyze trends in manpower requirements in all marine fields, to project future requirements, to coordinate Federal agency marine education and training activities, and to maintain an inventory of marine educational facilities including ships and shore installations.

Special attention should be given to methods for updating mideareer skills and for aiding transfer across disciplines. The transfer of scientists, engineers, and technicians from land to marine activities will follow the opening of new opportunities in the sea. But in some specialties, the transfer requires reeducation or reorientation.

The Commission recommends that the National Science Foundation expand its support for undergraduate and graduate education in the basic marine-related scientific disciplines and plan postdoctoral and mideareer marine orientation programs in consultation with the academic and industrial marine communities.

The National Sea Grant Program, charged by the Congress with educating and training applied manpower, has encouraged development of ocean engineering at the marine technician, undergraduate, and graduate 
levels. Its decision to support graduate-level marine edncation in the social sciences that may contribute to an understanding of marine affairs is sound, but lack of funds has made it difficult to implement the decision.

The Commission recommends that the National Oceanic and Atmospheric Agency (National Sea Grant Program) expand its support for ocean engineering and marine technician training at all levels and that it aid selected universities in organizing graduate-level education in the application of social sciences to marine affairs.

The Commission appreciates that its proposed national effort will require large numbers of well-educated, well-trained people. The majority view among those whom the Commission has consulted on manpower problems is that an exciting, broad-scale marine program will generate its own personnel. The personnel will come principally through transfer from land-based scientific, engineering, and technical specialties, but also through increased enrollments in marine education and training programs.

The Commission does not imply that support for ocean-related education and training is umnecessary - only that it may be unwise to tailor large new education and training programs to our present limited perception of future needs. Certainly some programs to extend the national capability for production of manpower are required, and such capability should be expanded or created. But until it is possible to develop a better conception of future manpower needs, care must be taken not to overproduce manpower, particularly in fields in which transfer from land to sea activities is relatively simple.

\section{Information and the National Capability}

Information useful in inproving the national capability in the sea is developed by all elements of the marine community. But productive communications channels do not exist between the Gorernment and the private sector, between scientists and engineers within the private sector, or between all these groups and the working harvesters of the sea.

1 multitude of mechanisms for disseminating information is required-nationally, regionally, and locally. For example, the production and continned updating of engineering handbooks, data compilations, textbooks, and similar working publications is a primary need.

Such central activities should be complemented by field activities designed to facilitate the transfer of technical information to industry users, particularly in such industries as fishing, as noted further in Chapter 4, where there are a large number of small units lacking significant research and development capability.

The Commission recommends that the National Oceanic and Atmospheric Agency establish a strong scientific and technical information and extension program to meet industry and other civil needs.

\section{Costs for National Capability ${ }^{1}$}

An adequate base of fundamental science and technology backed by the necessary manpower and facilities is the cornerstone of the Nation's future activities in the sea. In basic science, the Commission is concermed to ensure adequate support for the Federal, Coastal Zone, and University-National Laboratories as well as other research facilities. Ta-

\footnotetext{
${ }_{1}$ The cost estimates presented in this and subsequent chapters are subject to certaln definltions and llmitations discussed in Chapter 8.
} 


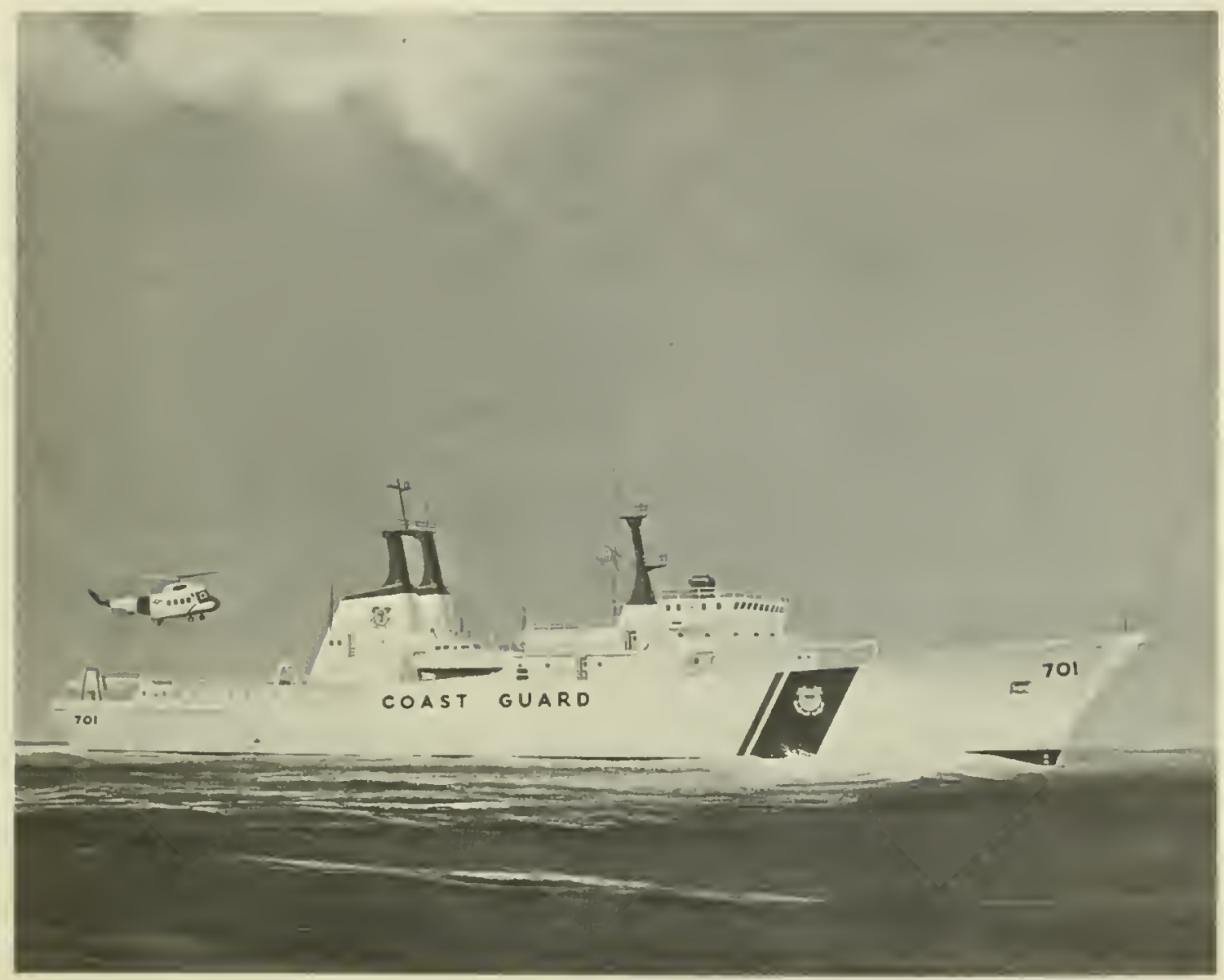

If maximum use is to be made of multidiscipline oceanic data taken uboard rescureh vessels such as the Coast Guard's planned High Endurance Occanographie C"utter, scheduled to rnter scrvice in 1972, inc United states must ensure that a productive fow of information is available to necunographic users throughout the Nation. 


\section{Table 2-2 Improving the National Capability ${ }^{1}$}

[Incremental costs in millions of dollars]

\begin{tabular}{|c|c|c|c|}
\hline & \multicolumn{2}{|c|}{ A verage annual costs } & \multirow{2}{*}{$\begin{array}{c}\text { Total } \\
\text { 10-yes } \\
\text { costs }\end{array}$} \\
\hline & 1971-75 & $1976-80$ & \\
\hline Laboratory Facilities & $\$ 32$ & $\$ 14$ & $\$ 230$ \\
\hline University-National Laboratories__. & 20 & 4 & 120 \\
\hline Coastal Laboratories... & 3 & 1 & 20 \\
\hline Federal Laboratories & 6 & 6 & 60 \\
\hline Other University Laboratories & 3 & 3 & 30 \\
\hline National Projects... & 50 & 70 & 600 \\
\hline \multicolumn{4}{|l|}{ Test Facilities and Ocean Ranges } \\
\hline Simulation Facilities_...... & 20 & 30 & 250 \\
\hline Biomedical Facilities & 8 & 12 & 100 \\
\hline Ocean Test Ranges & 15 & 15 & 150 \\
\hline Feasibility Studies of Future Projects. & 7 & 13 & 100 \\
\hline Fundamental Technology & 60 & 90 & 750 \\
\hline Education and Training & 7 & 11 & 90 \\
\hline Scientific and Technical Information & 3 & 6 & 45 \\
\hline Total, Improving Capability & 152 & 191 & 1,715 \\
\hline
\end{tabular}

${ }^{1}$ For explanation of amounts shown in this table, see accompanylng text and Chapter 8. 
ble 2-2 shows only the capital outlays which the Commission estimates (on the basis of an examination of the facility requirements of typical labolatories in each category) to be necessary to equip these laboratories. Requirements for institutional support for their operation and maintenance and for support of basic research are described in other chapters, together with estimates for specific research and exploration programs.

Adequate test facilities are a basic need in adrancing marine technology and will require substantial Government investments. In proposing an expenditure by NOAA of about $\$ 500$ million over the coming decade for the National Test Facilities Project, the Commission has assumed that the Navy will inrest a like amount in such facilities in response to military requirements.

In addition to this National Project and those described in succeding chapters, the Commission has recommended that the Gov. erument begin feasibility studies of other major technological developments identified in Table 2-1. Funding for such feasibility studies is estimated at $\$ 10$ million annually.

The Commission believes that the Nation should make a substantial commitment to advancing fundamental marine technology. Its funding estimates for this. program assume progressively increasing expenditures, averaging $\$ 1.7$ billion over the 10 -year period. However, this program will cover a wide range of activities and needs, and funds for its support ale shown in several chapters. Table 2-2 includes the amounts (under the entry for fundamental technology) which the Commission estimates will be needed to provide basic engineering data, including studies of materials and biomedical phenomena, production of handbooks, and support for discipline-oriented ocean engineering studies. Funds for fundamental technology directly relevant to undersea minerals recovery, such as corrosion-resistant hoisting cables and long flexible pipes, are included in Chapter 4. The estimated cost of developing basic capability for undersea operations, including amounts for power systems, machinery, life support, anchoring, and underwater viewing is allocated equally between resource and global exploration programs (Chapters 4 and 5), since such capability will be equally critical for both uses.

Additional amounts are estimated by the Commission for education, training, and technical information programs. The primary need in Government support of education and training is to assist in acquiring necessary facilities; initiating new curricula for micleareer training; and meeting specialized manpower needs in marine engineering, technician training, and the social sciences. The estimates for NOAA's scientific and technical information programs are geared to the costs of similar programs in other fields. 
Chapter

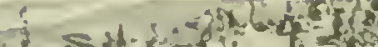

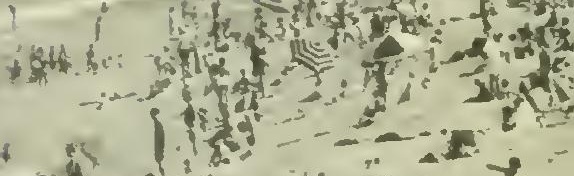

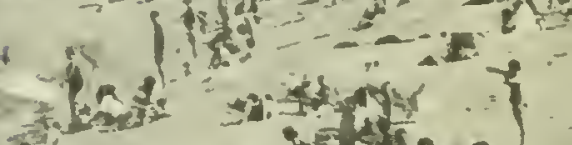

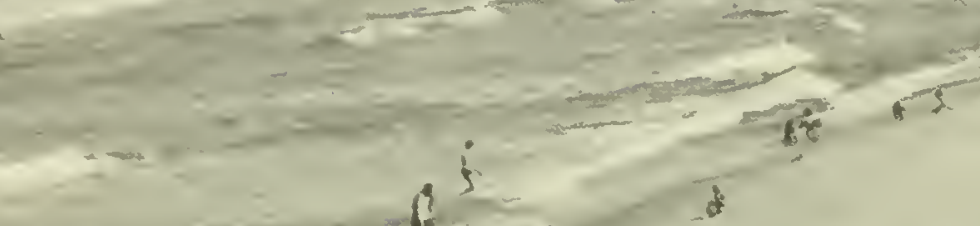

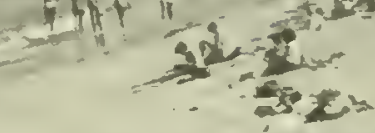

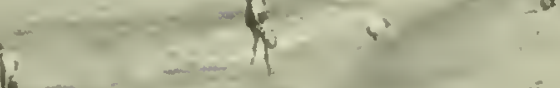

$x^{2}$

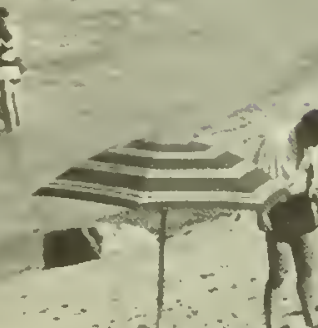

$c_{-\infty} x^{2}$

i $1+1$ $+2 \sqrt{2}$

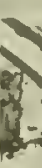
Q

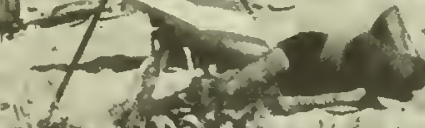
-

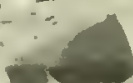
Elt

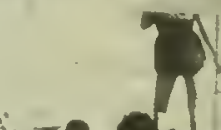

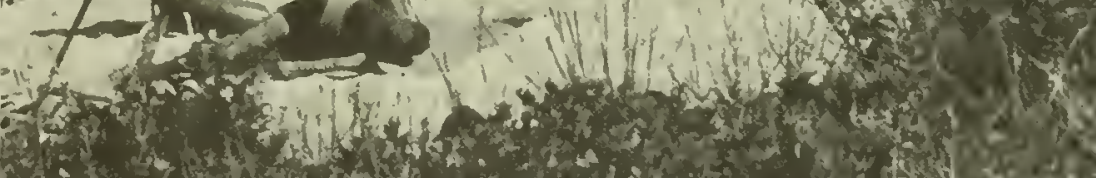

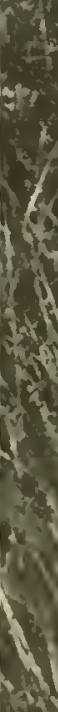

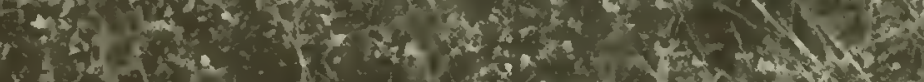

If

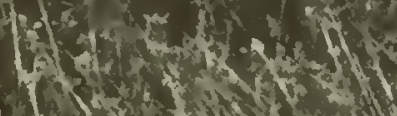

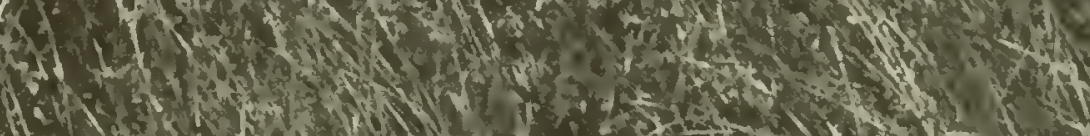

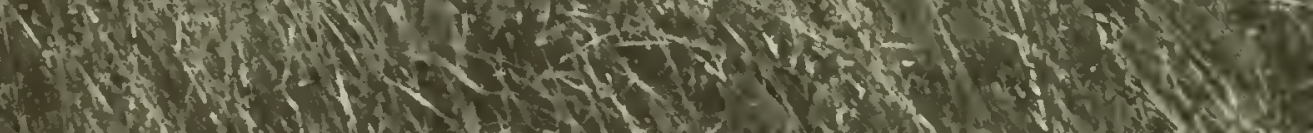

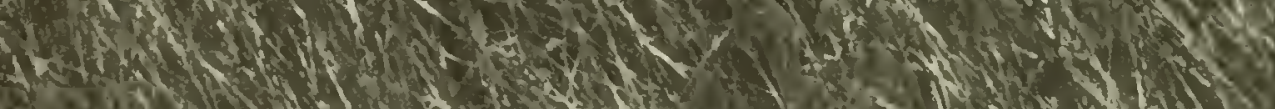

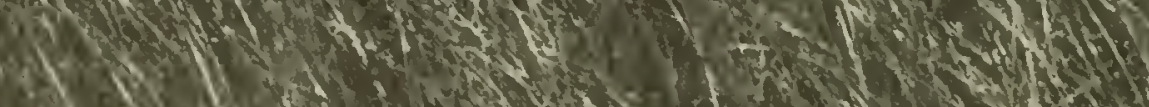




\section{Management of the Coastal Zone}

The coast of the United States is, in many respects, the Nation's most valuable geographic feature. It is at the juncture of the land and sea that the greater part of this Nation's trade and industry takes place. The waters off the shore are among the most biologically productive regions of the Nation.

The uses of valuable coastal areas generate issues of intense State and local interest, but the effectiveness with which the resources of the coastal zone are used and protected often is a matter of national importance. Navigation and military uses of the coasts and waters oflshore clearly are direct. Federal responsibilities; economic development, reereation, and conservation interests are shared by the Federal Govermment and the States.

Rapidly intensifying use of coastal areas alrearly has outrum the capabilities of local governments to plan their orderly development and to resolve conflicts. The division of responsibilities among the several levels of government is unclear, and the knomledge and procedures for formulating sound decisions are lacking.

The key to more effective use of our coastland is the introduction of a management. system permitting conscious and informed choices among development alternatives, providing for proper planning, and encouraging recognition of the long-term importance of maintaining the quality of this productive region in order to ensure both its enjoyment and the sound utilization of its resources. The benefits and the problems of achieving rational management are apparent. The present Federal, State, and local machinery is inadequate. Something must le done.

\section{The Nature of the Coastal Zone}

The U.S. Atlantic, Pacific, and Arctic coastlines total 88.633 miles, and there are 10,980 miles of U.S. poust bordering the Great Lakes. There are wide physical diversities- rugged shorelines with many indentations, offshore islands and rocks, and smooth coastlines with few offshore features. Sandy beaches, rocky headlands, or marshlands may be found along the slore, and water depths may slope gently from the shoreline or decline precipitously.

The zone is a region of transition between the land and the sea. Such activities as urban development, pollution of streams, and maintenance of recreation areas may affect the coastal area. Similarly, commercial fishing, shipping, and ocean pollution also may influence the constal zone's usage. Finally, there are numerous activities within the zone itself such as shellfishing, pleasure boating, off shore oil production, and sand and gravel dredging. The coastal zone management system must, therefore, grapple with a great diversity of related and other conflicting activities.

Oceanic Zones under International Law

The Commission in this report distinguishes between the internal waters and territorial sea of a nation, the high seas, the contiguous zone, the continental shelf, and the bed and subsoil of the deep seas-that is, the high seas beyond the continental shelf. These global areas are prescribed by existing international law of the sea and have no precise geographic references. It is important also to differentiate between the rights of the United States in each of these areas $r \cdot i s-a-r \cdot i s$ all other nations of the world and the division of anthority between the Federal Government and the coastal States of the United States in areas acknowledged to be within the Nation's jurisdiction.

\section{Internal Waters and the Territorial Sea}

Under the Intemational Convention on the Territorial Sea and the Contiguons Zone, each nation's sovereignty extends beyond its land territory "to a belt of sea adjacent to its coast, described as the territorial sea" and "to

The Nation must recognize the long-

term importance of maintaining

the quality of its coastlands. like

the Cape Cod Tational Seashore.

in orier to insure both their enjoy- 
the air space over the territorial sea as well as to its bed and subsoil." Although the Convention does not specify the breadth of the territorial sea, and claims rary from 3 nautical miles to 200 miles or more, the United States has maintained that no clain to a breadth greater than 3 nautical miles is sanctioned by international law. The rivers, lakes, and canals within its land area; the waters on the landward side of the baseline of the territorial sea (normally the low water line along the coast) : and the waters landward of closing lines across bays constitute the constal nation's "internal waters."

Except as limited by treaty, each coastal nation may prescribe and enforce its law in its internal and territorial waters and has permanent, exclusive access to the living and uonliving resources in these waters, on their beds, or in their subsoil.

\section{The High Seas}

The International Convention on the High Seas defines the "high seas" to inchude "all parts of the sea that are not included in the territorial sea or in the internal water"s" of a nation. It proclaims that they are "open to all nations" and no nation "may validly purport to subject any part of them to its sorereignty." Both coastal and noncoastal nations may exercise the freedoms of the high seas. According to the Convention, they comprise freedom of navigation, freedom of fishing, freedom to lay submarine cables and pipelines, freedom to fly over the high seas, and other freedons "recognized by the general principles of international law." Howerer, some of these freedoms are restricted or regulated pursuant to international treaties and other international agreements.

\section{The Contiguous Zone}

The Convention on the Territorial Sea and the Contiguous Zone specifies that within a zone of the high seas "which may not extend beyond twelve miles from the baseline from which the breadth of the territorial sea is measured," each coastal nation may exercise the control necessary to prevent infringement of its customs, fiscal, immigration, or sanitary regulations and may punish any such infringement committed within its territory or territorial sea.

Althongh the Convention seems to restrict the purposes for which national control may be exercised in the contiguons zone, the coastal nation's authority is not, in fact, so limited. This is true, because one way or another, coastal nations claim permanent, exclusive access to the living resources of the sea up to 12 miles and more from the baselines from which the breadth of the territorial sea is measured. Thus, the United States has passed laws and regulations prolibiting foreign ressels from fishing in its 12 -mile "exclusive fisheries zone" without its permission.

\section{The Continental Shelf}

The International Convention on the Continental Shelf recognizes the sovereign rights of the coastal nation to explore the shelf and exploit its natural resources. These rights are declared to be exclusive in the sense that, even if the coastal nation does not undertake these activities or make a claim to the continental shelf, no one else may do so without its express consent.

The Convention defines the continental shelf as "the seabed and subsoil of the submarine areas adjacent to the coast but outside the area of the territorial sea, to a depth of 200 meters ( 656 feet), or, beyond that limit, to where the depth of the superjacent waters admits of the exploitation of the natural resources of the said areas" and "the seabed and subsoil of similar submarine areas adjacent to the coasts of islands." It defines the natural resources to which the coastal nation 


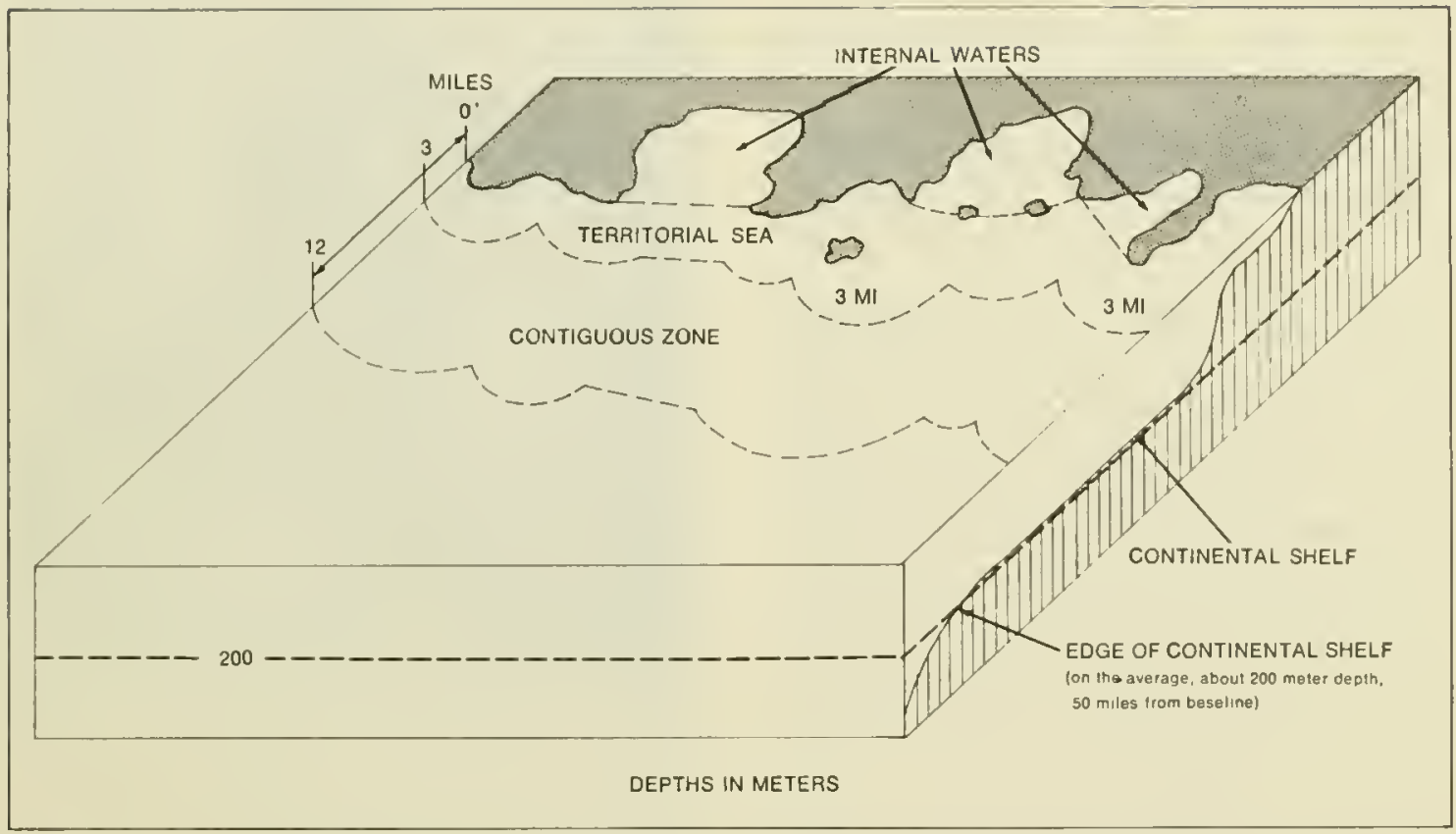

\section{Relationship of Internal Waters, the Territorial Sea, the Contiguous Zone, and the Continental Shelf}

is given permanent, exclusive access as including "the mineral and other nonliving resources of the seabed and subsoil together with living organisms *** which, at the harvestable stage either are immobile on or under the seabed or are unable to move except in constant physical contact with the seabed or subsoil."

\section{Geographic Scope of the Coastal Zone} and Division of Authority in the Zone

In discussing the problems of the constal zone, the Commission has aroided precise definitions, but for purposes of the proposed coastal management system, the Commission views the coastal zone as including (1) seaward, the territorial sea of the United States and (2) landward, the tidal waters on the landward side of the low water mark along the coast, the Great Lakes, port and harbor facilities, marine recreational areas, and industrial and commercial sites dependent upon the seas or the Great Lakes. Each coastal State, howerer, should be authorized to define the landward extent of its coastal zone for itself.

Subject to the constitutional porrers of the Congress (principally in this case, the power to regulate interstate and foreign commerce, including navigation), the States have prime responsibility and authority for managing the landward areas of the coastal zone. Seaward, the situation is more complicated. $\mathrm{By}$ rirtue of the Submerged Lands Act of 1953 , the coastal States, except for Texas and Floricla, own the living and nonliving resources of the seabed and subsoil of the sea out to 3 nautical miles from their constlines. Texas 
owns the resonrces ont to 9 nantical miles from its coast: and Florida, ont to 9 nautical miles from its Gulf coast.

\section{Intensification of Coastal Zone Usage}

The most intensive uses of the coastal zone occur at the water's edge. Seaward the problems hecome fewer if not simpler, and at the edge of the continental shelf, problems of conflicting uses are the exception today. But-and this is a point the Commission must stress - problems of multiple uses of the coastal zone are moving seaward. The Panel Report on Managenent and Development of the Coastal Zone ident ifies many areas where the nses of the coastal zone are increasing. As use of offshore lands is intensified, the need for better management practices will become more nrgent.

\section{Shoreline Development}

Patterns of shoreline derelopment vary widely from area to area depending mpon local topography and economic interests. Across the Nation and throughont the dereloped countries of the world, the pressures on shoreline space have mounted dramatically over the past 20 years and are certain to increase.

The reasons are clear: the shift of the population from rural areas to the cities (the Nation's seven largest metropolitan areas are on the Great Lakes or the sea coast), the spread of suburban development into coastal areas, and the increased afflnence and leisure time of a large part of our population.

Theoretically, the Nation's sloreline could be increased almost withont limit, and the construction of artificial islands and new harbors and the use of similar techniques to create shoreline will continne in those areas where demand warrants these actions. In San Diego harbor, for example, pressures for additional shoreline space have been partially

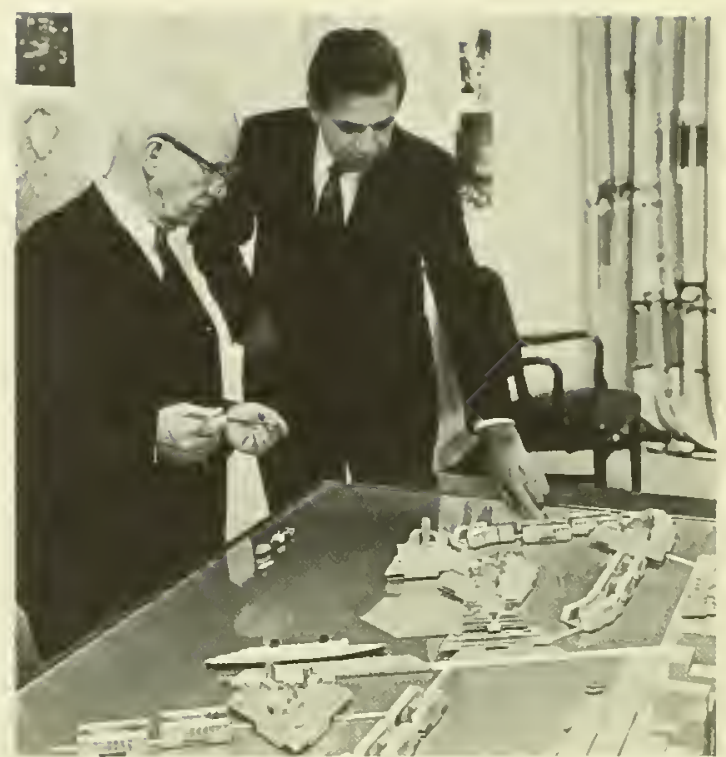

Theoretically the Nation's shoreline could be inereased almost without limit. For cxample, a study by the Department of Housing and Lrban Development has established the enginecring feasibility of mulitlevel, floating coastal citics.

satisfied by construction of two artificial islands from channel-dredging spoil.

Private honsing has exercised and will contime to exercise the greatest demand for $^{*}$ shore property; for example, the Boca Ciega Bay area off the west coast of Florida has been completely transformed by housing derelopments in the past 20 years. But there are other needs that must be met; heavy industry, traditionally located on the water's edge, seeks a cheap somrce of industrial water, a simple solution to waste disposal problems, and ready access to raw material. Pollution abatement requirements have lessened somewhat the desirability of a waterfront industrial location, but recent trends in shipping have increased the demand for deep water frontage. Deep water access will be essential to the future competitiveness of steel and other U.S. inclustries which process large 
volumes of heary raw materials. Any plan for the use of the constal zone must seek to accommodate heary industry.

Fnture shoreline development also must provide for additional transportation and power gencrating facilities. From the Civil IV ar through World Wrar II, a rast network of piers, warehouses, and railroads was constructed about the perimeters of the Nation's ports. Today, these facilities are being replaced slowly by freeways, airports, specialized bulk carmo and container loading facilitics, and housing. The transition is extratordinarily difficult and will require plaming and coordination of public and private activities on a wholly new scale.

Electrical power production has cloubled during every decade of this century. An increasing percentage of new power plants will use nuclear fuel, and the disposition of waste heat is an increasing problem. It is estimated that by 1980 the power industry will use for cooling one-fifth of the total fresh water runofl of the Inited States. An increasing numher of plants will be located along the shoreline, competing for valuable land, warming the local waters, and posing major threats to the regional ecological balance.
1 decent concern for preserving life's amenities as well as economic considerations demands that more adequate provisions be macle for recreational use along the Nation's crowcled shoreline. Today, marine recreation ranks high in economic importance (Table $3-1)$ : according to the Bureau of Outdoor Recreation, by the year 2000 , marine recreation in terms of user-days will quadruple.

Access to the shoreline for the populations that increasingly are concentrated in urban areas along the coasts and the Great Lakes will present a major coastal zone problem. Of all the uses of the costal zone, recreation uses are the most diversified and pose some of the greatest challenges to any coastal management system.

\section{Offshore Activities}

\section{Fisheries}

Seventy per cent of the present U.S. commercial fishing effort takes place in coastal waters. Coastal and estuarine waters and marshlands provide the nutrients, nursing areas, or spawning grounds for two-thirds of the world's entire fisheries harvest. Seven

\section{Table 3-1 A Comparative Summary of Recreational Activity in Coastal and Offshore Areas}

\begin{tabular}{|c|c|c|c|c|}
\hline \multirow[t]{2}{*}{ Type of recreation } & \multicolumn{2}{|c|}{$\begin{array}{l}\text { Participants, } \\
\text { millions }\end{array}$} & \multicolumn{2}{|c|}{$\begin{array}{l}\text { Annual expenditures, } \\
\text { millions of dollars }\end{array}$} \\
\hline & 1964 & 1975 & 1964 & 1975 \\
\hline Swimming .......... & 33. 0 & 40. 0 & $\$ 1,500$ & $\$ 2,000$ \\
\hline Surfing-_- & 1. 0 & 4. 0 & 50 & 200 \\
\hline Skin Diving & 1. 0 & 3.0 & 300 & 900 \\
\hline Pleasure Boating & 9.6 & 14.0 & 650 & 1,000 \\
\hline Sport Fishing & S. 2 & 16. 0 & 760 & 1,300 \\
\hline - & 52. $S$ & 77.0 & $\$ 3,260$ & $\$ 5,400$ \\
\hline
\end{tabular}

Sotrce: Battelle Memorial lastitute. A Study of the U.S. Coast and Geodetic Survey's Products and Services os Relaled to Economir Aclitity in the U.S. Continental-Shelf Regions, April 1966. 
of the 10 most valuable species in American commercial fisheries spend all or important periods of their lives in estuarine waters, and at least 80 other commercially important speries are dependent upon estuarine areas.

The high productivity of estuarine areas is illustrated by the following example. The maximum yield of Georgia estuarine waters has been estimated at 10 tons of dry organic matter per acre per year, nearly twice that of the best agricultural lands and seven times that of continental shelf fishing banks. But the estuaries are in danger. Pollution is an ever increasing threat. Iand fillings, dredging, dumping, and marsh draining reduce their areas. For example, 80 per cent of the 300 square miles of tidal wetlands that originally surrounded San Francisco Bay have been filled. In the past 20 years, dredging and filling have destroyed 7 per cent

\section{Table 3-2 Estuarine Habitat Areas Lost to Filling Operations}

\begin{tabular}{|c|c|c|c|c|}
\hline \multicolumn{5}{|c|}{ Acres of Estuaries } \\
\hline State & $\begin{array}{c}\text { Total Area } \\
\text { (Thousands) }\end{array}$ & $\begin{array}{l}\text { Basic Area } \\
\text { of Important } \\
\text { Habitat } \\
\text { (Thousands) }\end{array}$ & $\begin{array}{l}\text { Area of Basic } \\
\text { Habilat Lost } \\
\text { by Dredging } \\
\text { and Filing } \\
\text { (Thousands) }\end{array}$ & $\begin{array}{l}\text { Percent of } \\
\text { Habitat Lost }\end{array}$ \\
\hline Alabama & 530 & 133 & 2 & 1.5 \\
\hline A'aska & 11,023 & 574 & 1 & \\
\hline California & 552 & 382 & 256 & 67.0 \\
\hline Connecticut & 32 & 20 & 2 & 10.3 \\
\hline Delaware & 396 & 152 & 9 & 5.6 \\
\hline Florida & 1.051 & 796 & 60 & 7.5 \\
\hline Georgia & 171 & 125 & 1 & .6 \\
\hline Louisiana & 3.545 & 2.077 & 65 & 3.1 \\
\hline Maine & 39 & 15 & 1 & 6.5 \\
\hline Maryland & 1,406 & 376 & $i$ & 3 \\
\hline Massachusetts & 207 & 31 & 2 & 6.5 \\
\hline Michigana & 152 & 152 & 4 & 2.3 \\
\hline Mississippi & 251 & 76 & 2 & 2.2 \\
\hline New Hampshire & 12 & 10 & 1 & 10.0 \\
\hline New Jersey & 778 & 411 & 54 & 13.1 \\
\hline New York & 377 & 133 & 20 & 15.0 \\
\hline $\begin{array}{l}\text { New York State } \\
\text { (Great Lakes) }\end{array}$ & & & & \\
\hline $\begin{array}{l}\text { (Great Lakes) } \\
\text { North Carolina }\end{array}$ & 2,207 & 794 & 8 & 1.0 \\
\hline Ohio & & 37 & b & .3 \\
\hline Oregon & 58 & 20 & 1 & 35 \\
\hline Pennsylvaniaa & 5 & 5 & b & 2.0 \\
\hline Rhode Island & 95 & 15 & 1 & 6.1 \\
\hline South Carolina & 428 & 269 & 4 & 1.6 \\
\hline Texas & 1,344 & 828 & 68 & 8.2 \\
\hline Virgina & 1.670 & 428 & 2 & .6 \\
\hline Washington & 194 & 96 & 4 & 4.5 \\
\hline Wisconsina & 11 & 11 & 50 & .0 \\
\hline Total & $26.61 B^{B c}$ & 7,9886 & 5696 & 7.1 \\
\hline
\end{tabular}

Source : Estuarine Areas, II.R. Rep. No. 989 to accompany II.R. 25, 90th Cong., 1st Sess., n. 8. (more than a half million acres) of the Nation's important fish and wildlife estuarine habitats.

\section{Aquaculture}

Aquaculture today is of relatively minor importance, but its future role in the coastal zone will grow. As it grows, the problems of conflicting use will increase. Estuarine areas leased for aquaculture may be closed to sport fishermen and, in some cases, may be closed to navigation. A State attempting to develop a major program in aquaculture may be compelled to limit its shoreside industrial development.

\section{Oil and Mineral Exploration}

The offshore oil industry is growing rapidly. Several thousand offshore platforms have been built in the Gulf of Mexico alone. New developments are expected off Mlaska and the $\Lambda$ t] antic seaboard. Structures for 600 foot water depths are being designed. Pipelines for oil and gas have been laid more than 70 miles offshore.

Offshore petroleum derelopment has not been without conflict. Explosives used in exploring for oil on the Grand Banks have caused considerable concern among fishermen. The probability that oil will be produced generates additional concern about possible oil spills, pipelines, and other hazards to fishing. Although mincral development of the continental shelf is subject to U.S. control, the fisheries beyond the 12-mile limit are an international resource, cansing the potential oil-versus-fish confrontation to have still more serious overtones.

The density of oil drilling platforms in the Gulf of Mexico is so great that the U.S. Coast Guard and the U.S. Army Corps of Engineers, working cooperatively with the industry, have been compelled to establish fairways for shipping in and out of Gulf 


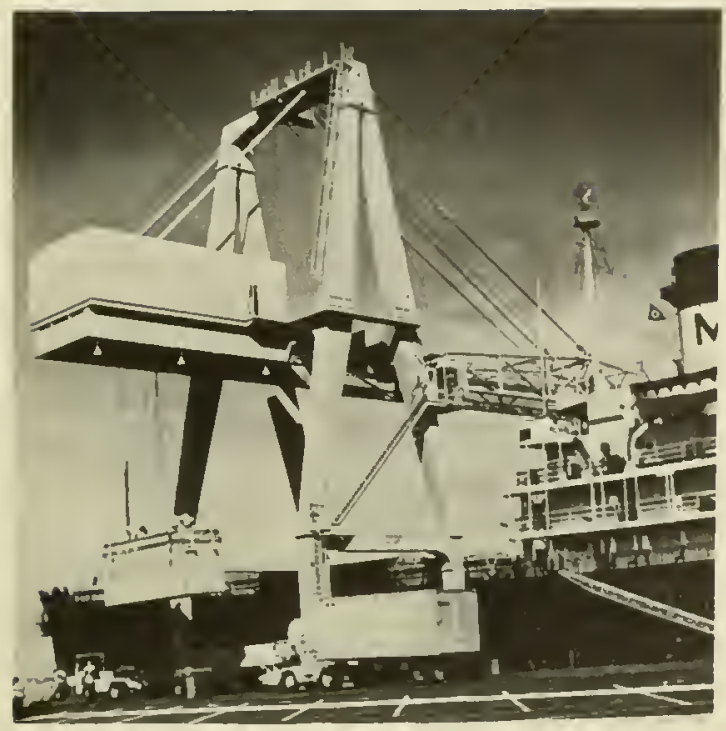

ports. Oil companies on the west coast frequently have placed their wells below the surface when aesthetic values were important. Subsurface structures, however, create different kinds of navigation hazards, particularly to fishing trawls.

\section{Uses of Offshore Waters}

In addition to resource exploitation in coastal areas, there is much use of the waters themselves. The U.S. Navy operates on and under the coastal sea performing various military operations; certain waters are reserved for this purpose. Merchant shipping, particularly with the growing use of very large smpertankers, soon will require the designation of reserved fairways. The introduc-

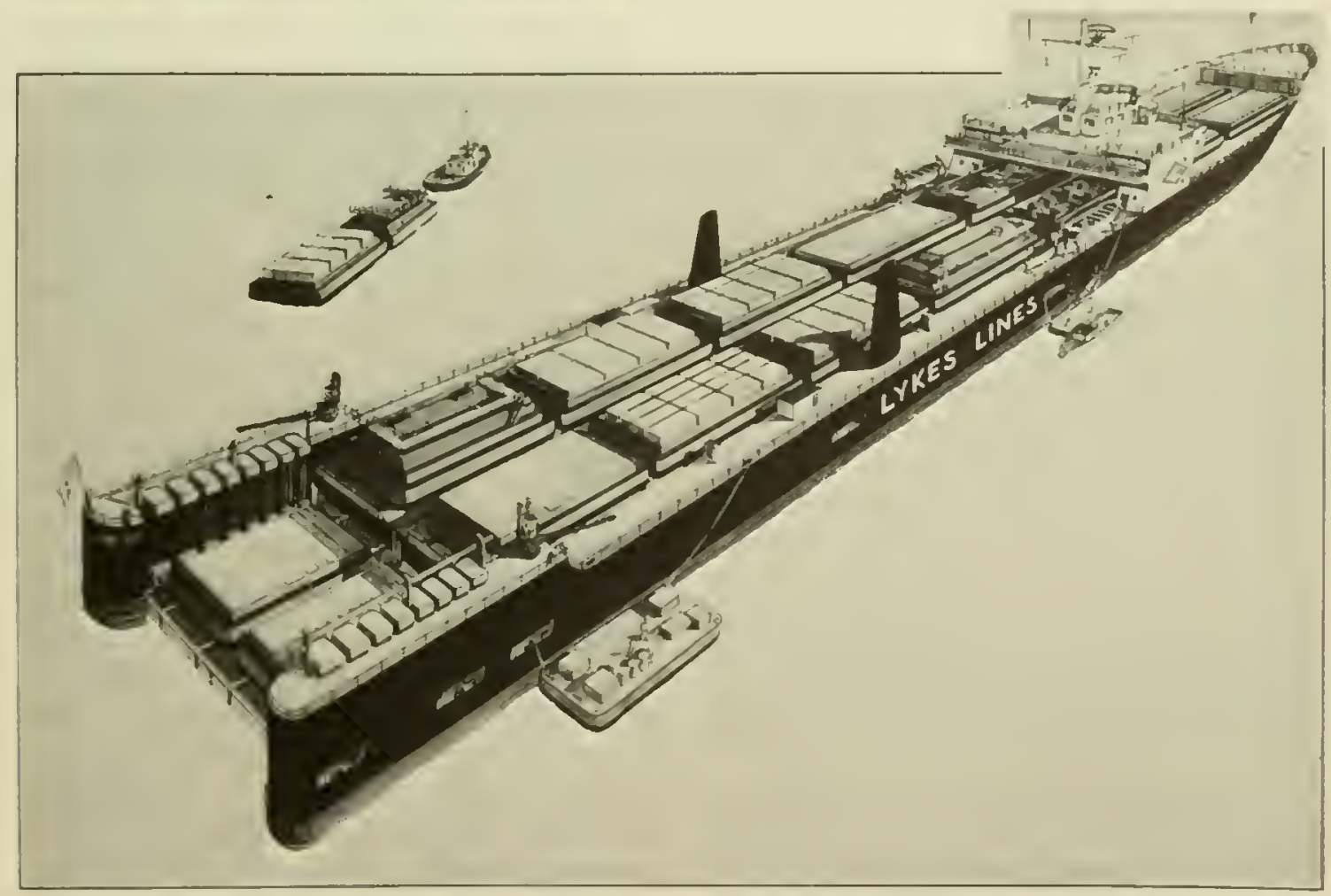

With the adrent of container ships has enme the requrement for new port facilitics, like this $26-t \mathrm{tm}$ container rrane. With increasing spccialization of maritime Iransportation such as float-on/foat-off bargc carricrs, cecr larger tankers. and hydrofoils, still further changes to the Nation's ports will be requircd. 
tion of high-speed hovercraft and hydrofoils will call for new safety measures. With actirities stretching across several jurisdictions, Ferleral, State, and even international policies must be coordinated.

\section{A Proposed Coastal Management System}

Federal, State, and local governments share the responsibility to develop for the coastal zone a plan which reconciles or, if necessary, chooses among competing interests and protects long-term values. Etlective management. to date has been thwarted by the rariety of government jurisdictions involved, the low priority afforded marine matters by State governments, the diffusion of responsibilities among State agencies, and the failure of State agencies to develop and implement long-range plans. Until recently, navigation-ovel which Federal authority is preeminent-has tended to dominate other uses of the coastal zone, and, perhaps for this reason, States have been slow to assume their responsibilities.

The Federal role in the coastal zones has grown haphazardly. Closely related functions are discharged by the I.S. Coast Guard, Army Corps of Engineers; Department of Housing and Urban Development, a number of bureaus of the Department of the Interior, and several other Federal agencies. The Fedelal Government sponsors planning activities in certain coastal areas throngh river basin commissions, established pursuant to Title II of the Water Resources Planning Act of 1965 , and in certain others through regional commissions established under Title $T$ of the Public Works and Economic Development Act.

At the Federal level, the Committee on Multiple Use of the Coastal Zone of the Marine Council considers the broad aspects of coastal management and serks effective and consistent Federal policies. The Water Re- sonrces Comcil, a cabinet-level coordinating and planning group analogons to the Marine Council but chaired by the Secretary of the Interior, also has an interest in the coastal zone, althongh its work is primarily directed to inland waters. But, of course, neither committee can be concerned with the detailed management of particular coastal areas.

The diffusion of responsibility has been reflected within State govermments, within which individual agencies deal directly with their counterparts at the Federal level. Too often States lack plans of their own based on an appraisal of all State interests in their coastal resources. In these cases, States have tended only to react to Federal plans.

The States are subject to intense pressures from the county and municipal levels, because coastal management directly affects local responsibilities and interests. Local knowledge frequently is necessary to reach rational management decisions at the State level, and it is necessary to reflect the interests of local governments in accommodating competitive needs.

After reviewing the varions alternatives (see the Panel Report on Management and Developnent of the Coastal Zone), the Commission finds that the States must be the focus for responsibility and action in the coastal zone. The State is the central link joining the many participants, but in most. eases, the States now lack adequate machinery for that task. An agency of the State is needed with sufficient planning and regulatory anthority to manage coastal areas effectively and to resolve problems of competing uses. Such agencies should be strong enough to deal with the host of overlapping and often competing jurisdictions of the varions Federal agencies. Finally, strong State organization is essential to surmomnt. special local interests, to assist local agencies 
in solving common problems, and to effect strong interstate cooperation.

In raying degrees, the States possess the resources, administ rative machinery, enforcement powers, and constitutional authority on which to build. Howerel, they will need Federal assistance and support, and the Federal (xovermment must assure the protection of national interests in the coastal zone.

The Federal Govermment camnot and, of course, shonld not compel a State to develop a special organization to deal with its coastal management problems. However, it can encomrage such actions, provide guidelines for the functions of such organizations, facilitate Ferleral cooperation with State anthorities, and provide appropriate assistance.

The Commission recommends that a Coastal Management Act be enacted which will provide policy objectives for the coastal zone and authorize Federal grants-in-aid to facilitate the establishment of State Coastal Zone Authorities empowered to manage the coastal waters and adjacent land.

To assist the States in developing coastal zone management programs, the Commission poposes that the Federal Government meet one-lalf of the operating costs of the new State Authorities during the first 2 years of their operation. Matching grants should be provided for planning studies, either through funds such as appropriated pursuant to Section 701 of the Housing Act of $1954 \mathrm{fol}^{\circ}$ State planning, Title III of the Water Resomces Planning Act, or through new legislation. Substantial technical assistance can be provided by Federal personnel. Opportunities for other Federal assistance, dis"ussed later in this chapter. also exist under the Land and Water Conservation Fund Act, the fish and wildlife restoration acts, the Clean Water Restoration Act of 1966, and urban renewal and econonic development legislation.

\section{Functions and Powers of the State Coastal Zone Authorities}

The key functions of the State Coasta] Zone Autliorities would be to coordinate plans and uses of coastal waters and adjacent lands and to regulate and develop these areas. The Coastal Zone Authorities should draw upon all available knowlecige of the physical, biological, and economic characteristics of the State coasts and estuaries. The Coastal Zone Laboratories recommended in Chapter 2 would support the Coastal Authorities by conducting research and special studies and by lielping to develop necessary technology.

The great diversity of resources, scope, and activities of coastal State govermments will prevent adoption of a miform administrative approach to State Coastal Zone Authorities. In some States a single Authority might appropriately be given jurisdiction over the State's entire coast : in others, several gromps might be established under a single Authority within a State to deal with separate estmarine. areas. The managoment of interstate estnaries will require agreements to be developed among adjacent States to delegate at least limited management authority to an intelstate body. The form of the State Authority may vary from a volunteer commission with a small staff to an agency like the New York Port Authority with major development authority buttressed by the power to issme bonds.

The guiding principles for the Anthorities should include the concept of fostering the widest possible rariety of beneficial uses so as to maximize net social return. When necessary, public hearings should be held to allow all interested parties to express views before 


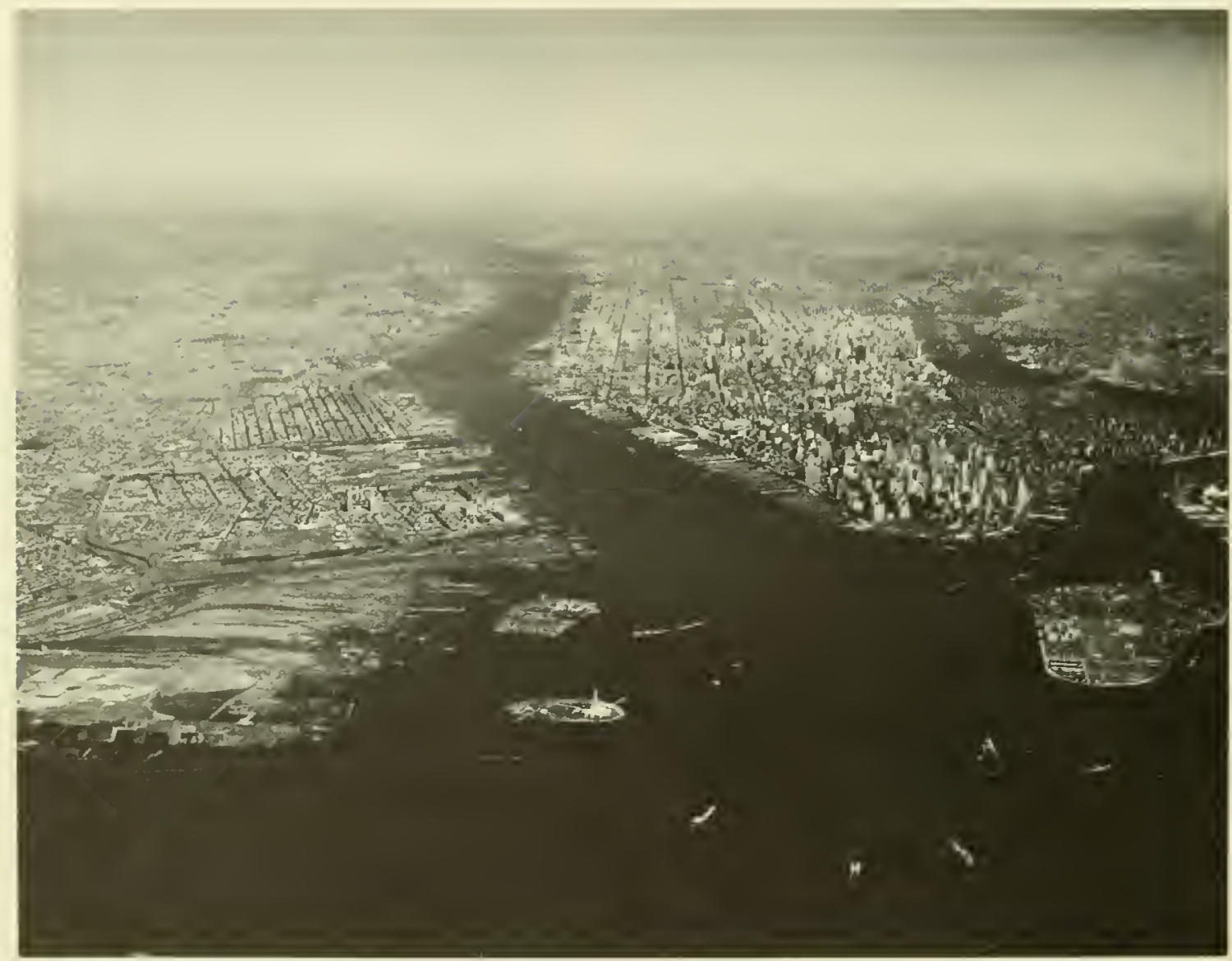

The form of a State Coastal Zone Authority might range from a volunteer commission with a small staff to a major agcucy like the Port of New Fork A uthority.

actions are taken or decisions are made changing or modifying the coastal zone. All information and actions shonld be a matter of public record.

The Coastal Zone Authority should be organized to prevent domination by State agencies charged with narrower responsibilities. However, the Anthority will have to work closely with other State agencies to achieve the objectives of its plan, becanse the activities of these other agencies in promulgating conservation and fisling regulations and water quality standards, for example, significantly affect coastline and offshore water use. Procedures must be established within each State to ensure that the actions of other State agencies are consistent with Anthority-approved plans. To strength the Authority, the Federal Gorermment should consider withholding grant-in-aid assistance from any project which contravenes plans of the Coastal Zone Authority. 
The channel and harbor improvements financed by the IT.S. A runy Colps of Engineers are important components of the local constal zone plan. Such improvements currently are approver by State Governors, who would benefit in making these decisions from expert advice of the proposed State Coastal Zone Iuthorities.

The Commission recommends that Federal legislation to aid the States in establishing Coastal Zone Authorities not impose any particular form of organization but should require that approval of each grant be contingent on a showing that the proposed organization has the necessary powers to accomplish its purposes, has broad representation, and provides adequate opportunities for hearing all viewpoints before adopting or modifying its coastal development plans.

The magnitude of coastal problems varies with the nature of the area; therefore, so will the powers necessary to carry out the plans. In certain relatively undeveloped areas, only planning will be required, but in others the entire range of State powers will be needed to preserve resources of statewide and national importance.

The following powers should be available to the typical Coastal Zone Authority:

- Planning-to make comprehensive plans for" the coastal water's and adjacent lands and to conduct the necessary studies and investigations

- Regulation-to zone; to grant easements, licenses, or permits; and to exercise other necessary controls for ensuring that use of waters and adjacent lands is in conformance with the plan for the area

- Acquisition and eminent domain-to acquire lands when public ownership is nec- essary to control their use (Condemnation procedures should be used if necessary.)

- Development-to provide, either directly or by arrangement with other government agencies, such public facilities as beaches, marinas, and other water front developments and to lease lands in its jurisdiction, including offshore lands.

Zoning, easements, and licensing are effective instruments by which local government and private activity can be regulated in accordance with the approved plan. (The Panel Report on Management and Development of the Coastal \%one discusses a variety of regulatory mechanisms.) In most places zoning powers have been yielded by the States to local jurisdictions. In such cases, the States may have to act to regain the zoning power for coastal areas. Water use zoning represents a practical and effective management tool for managing potentially conflicting uses. However, procedures by which shoreline and water zoning is coordimated present sensitive problems for each State.

States also may require that permits he granted for coastal land and water use. Permit systems are employed now by many States to govern the construction of fish weirs, culture of oysters, excavation of gravel, and similar activities. Permits might be required for docking facilities, marinas, housing developments, and other construction.

Additionally, it may bo desirable to delegate to the State Coastal Zone Authorities certain regulatory functions of Federal agencies, such as reviewing proposals for construction in mavigable waterways and advising Federal construction agencies.

Regulation will not always suffice to preserve the benefits of access to the coast for all the people within the State. For this purpose, the States shonld acquire ontright own- 
ership of lands, using condemnation procedures if necessary. If the coastal area in question can meet only the neerls of the local population, the local government should acquire the land if regulatory and other means prove inadequate.

Federal assistance for coastland acquisition is available through several existing programs, and the State Anthorities should work through established channels to utilize this assistance insofar as possible. The enhanced opportmities provided by recent legislation angmenting land acquisition funds with revenues from outer continental shelf leases should be exploited fully. Current legislation, however, makes limited provision for acquiring wetlands having no recreation benefit. To increase the availability of funds to acquire and set aside wetlands for future use,

The Commission recommends that the Land and "Water Conservation Fund be more fully utilized for acquisition of wetlands and potential coastal recreation lands. Legislation should be enacted authorizing Federal guarantees of State bonds for wetland acquisition when necessary to implement the coastal management plan.

In the Commission's view, States will respond rigorously to a Federal initiative to assist in the establishment of State Coastal Zone Authorities. There is growing evidence that the States are ready to act. In the San Francisco Bay area and in Nassau and Suffolk Counties of Long Island, New York, local planning commissions have recommended the formation of State authorities similar to those recommended by the Commission. Mensures taken by California, Oregon, Wisconsin, and Florida exemplify the public concern for planned management of coastal waters:

\section{Management in Interstate Estuaries}

Estuaries or coustal waters of concem to more than one State-for example, the Delaware and Chesapeake Bays or Lake Michigan-can pose special problems. Without nnderestimating the potential difficulties, the Commission is persuaded that in most cases sound planning and management undertaken by one State probably will not differ greatly from that undertaken by an adjacent State. When differences do arise, they may be settled by direct negotiations between the parties concerned or by the establishment of ad hoc interstate committees or an interstate commission or compact. Strong Coastal Zone Anthorities representing the variety of State interests will facilitate such agreements. The Commission believes that such interstate agreements are preferable to coordination throngh river basin commissions in which the Federal Government is a member. Not having management or enforcement authority, such commissions can only plan and advise.

\section{The Federal Role in the Coastal Management System}

The Federal Government has strong interests in the effective management of a State's coastal water's. First, a number of Ferleral agencies operate in the coastal waters and sometimes profonndly affect their nse. Is a contributor to the problem, the Federal Govermment has to share in the responsibility of coastal management. Second, the Federal Gorernment must ensure that such vital Federal interests as navigation and military security are not endangered by State actions and that the general national interest in effective coastal plaming is protected. It is in the Nation's interest to understand the natural processes occurring in the nearshore enviromment 

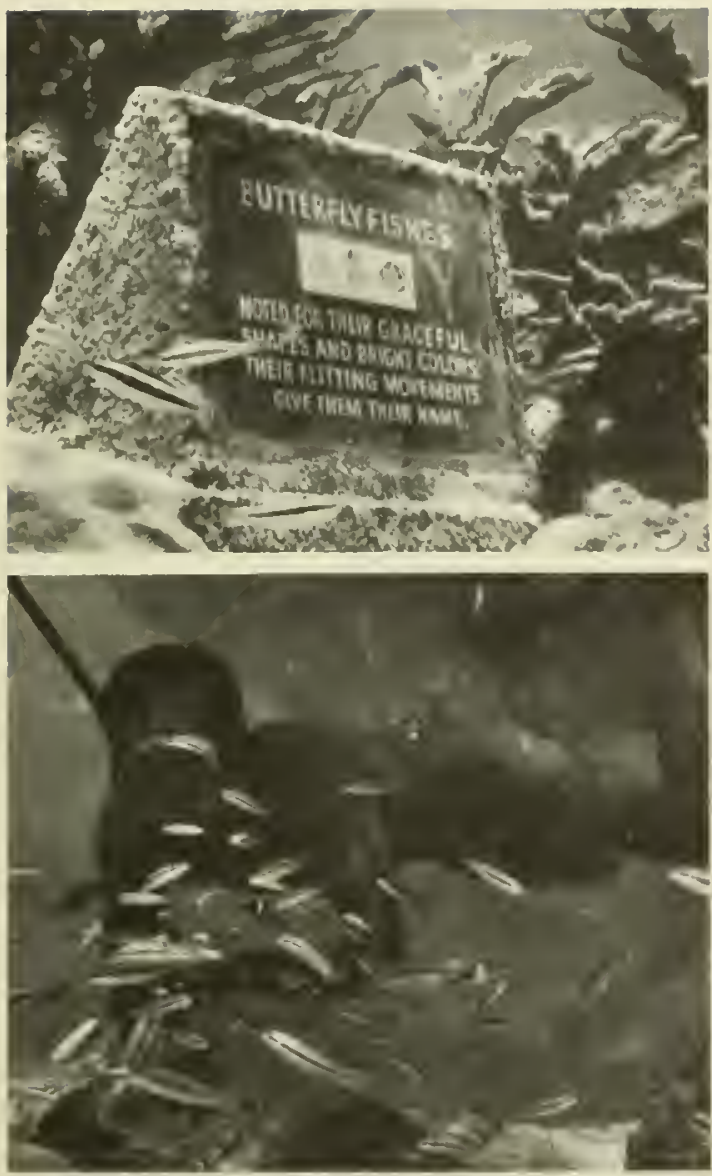

A tourist cnjoys the National Park serviec's underwater trail at Buck Island, the Jirgin Islands. Pro-

vision of such recerational facilities is part of the Nation's broad-

rangin! interests in the eoustal zone.

in order to prediet and to control man's effects on this environment. A related objective is to proteet and even to restore the environment.

The multiplieity of Federal interests calls for Federal review of proposed state plans and their implementation and for. Federal intercession if a Coastal Zone $\Lambda$ utlority fails to safegruard national interests. The Ferlerial Gorromment should not make decisions for the State. Iuthority, but it shonld orersee the
Authority and withelruw funding support and delegation of specific Federal fmetions if the Authority performs inadequately.

Federal review is possible at several stages-when the state first proposes a particular type of management authority; when the comprehensive coastal plan is submitted by the Authority; and, if the plan is approved, when further grants, contracts for aequisition and development, or bond guarantees are proposed.

Federal responsibitities for dealing with State Authorities should be centralized to assure that the Federal Govemment speaks with a single roice on coastal zone matters. The Commission eoneludes that the new National Oceanic and Atmospheric Agency (NOAA) would offer" a broader and more balanced perspective in meeting eompeting use problems than an alternative ageney. In addition, the new agency conld assist the State Authorities in researeh, environmental monitoring, safety, and enforcement functions. NOAA's commitment to more effective use of the seas would be fully compatible with the mission of the Coastal Zone Authorities.

Coordination of Federal and State roles must be espeeially close in relating the navigation and flood eontrol programs of the U.S. Army Corps of Engineers and the resonree managenent programs of the Department of the Interior to the plans of the State Coastal Zone Iuthorities. For eximple, the Authorities" land and water use plans must be eonsistent with coustal water quality standards established by State pollution agencies under the cognizance of the Department of the Interior. The Depantment of the Interior"s continuing recreation, wildlife, and minerals derelopment plans in coastal areas must be aceommodated by State Authorities in their plaming, regulatory, land acquisition, and derelopment fumetions. 
The Conmission believes it important that the Congress assign planning, coordination, and managenent for coastal zone beyond State jurisdiction to a single Federal agency. The Federal planning and management role would be analogous to that exercised within the limits of State jurisdiction by the Coastal Zone Anthorities. This assignment should complement the specialized responsibilities of the Burean of Land Management, the Federal Trater Pollution Control Administration, and the U.S. Army Corps of Engineers and should not modify in any way the overall responsibility of the Department of State for the Nation's foreign affairs.

The Commission recommends that:

- The National Oceanic and Atmospheric Agency administer the grants in support of planning and enforcement activities of the State Coastal Zone Authorities. It should be empowered to revoke or withhold the grants if the Authorities are not acting in compliance with plans NOAA has approved.

- All Federal agencies providing grantsin-aid to States or engaging in coastal activities review their projects for consistency with plans of the State Coastal Zone Authorities.

- NOAA assist the States in an effort to resolve problems resulting from the divergent objectives of other Federal agencies.

- NOAA develop and continually update its plans for the development and use of coastal areas not within State jurisdiction and coordinate the activities of other Federal agencies in these areas.

\section{Information Needed for Coastal Zone Management}

The coastal zone's many uses, occurring within a complex and delicately balanced biophysical system, will challenge the $\mathrm{Na}$ tion's capacity for effective planning and management. To establish an adequate basis for decision making, there is a need for broad surveys to establish basic national inventory information, there is a need for continuous and detailed studies of specific local conditions, there is a need for trained persomel, and there is a need for determining precise jurisdictional boundaries.

\section{State Boundaries}

Controversy persists regarding the location of the baselines from which to measure the territorial sea and areas covered by the Submerged Lands Act of 1953. Fixing these lines will be difficult and contentions, becanse valuable rights are at stake. The Supreme Court of the United States now has before it a dispute between the United States and Louisiana involving $\$ 1.1$ billion in mineral lease payments. In Califormia, the oil rights to approximately 500 acres of offshore land were leased at $\$ 10,000$ an acre; the rights are in contention becanse of disagreement about whether a low-lying reef some yards offshore is sufficiently high to be considered part of the coastline. It has been estimated that of the 18 seaward lateral boundaries between the States, only 4 are substantially defined.

It is important, too, that the boundaries be fixed once and for all in terms of geographic coordinates that can be portrayed on maps, rather than in terms of distances from the coasts. This would avoid the problem of baselines changing due to tidal effects, floating islands, migrating sandbars, and the deposit of riverborne sediments. 
The Commission recommends that the Congress establish a National Seashore Boundary Commission to fix the baselines from which to measure the territorial sea and areas covered by the Submerged Lands Act of 1953 and to determine the seaward lateral boundaries between the States. The boundary lines should be described in terms of geographic or plane coordinates for each State. The determinations of the Boundary Commission should be subject to appropriate judicial review.

\section{Surveys and Inventories}

Acquisition of better information about the physical, economic, and biological characteristics and potentials of the coastal zone is a first step toward more rational management. Survey information is needed nationally so planning for local development may support national objectives and be related realistically to national priorities. These data will provide the basic framework for more detailed State plans.

Because the many uses of the coastal zone are interdependent, there should be a single inventory embracing all aspects of coastal development. Port improvements and dredging plans then conld be dereloped with due regard for their effects on fisheries and recreation. The physical attributes of the coastal zone would be considered in the relation to economic and ecological implications.

However, a totally comprehensive analysis of national enastal potentials appears leyond present capabilities: the task is simply too large and romplex for a total approach. Instead, it is more realistic to pursue studies of port development, recreation, shoreline erosion, pollution, and estuarine ecological characteristics separately but in condination with one another. 'Three broad surveys are either underway or have been proposed: an estuarine inventory, a coastal erosion study, and a ports and liarbors study.

The Commission recommends that the National Oceanic and Atmospheric Agency participate in major coastal surveys, identify areas of common interest, and coordinate plans to avoid overlap and incompatibilities.

\section{Estuarine Inventory}

A surrey of estuaries was authorized by the Congress in the Clean Water Restoration Act of 1966. This broad survey is being conducted by the Federal Water Pollution Control Idministration of the Department of the Interior. Public Iaw 90-154, passed by the Congress in 1968, further extended the scope of the Department of the Interior's estuarine study to include a complete inventory of the Nation's estuaries (including the Great Lakes), their present uses, their ecological characteristics, and their potential in order to determine the desirability of acquiring estuarine retlands for public use. This study is to be made by the Fish and Wildlife Service. The 1966 Act requires that the Secretary of the Interior submit to the Congress $n o$ later than Jan. 30, 1970, a report of his study and recommendations for legislatire action. The report is to include recommendations regarding the feasibility and desirability of establishing a "nationwide system of estuarine areas, and the terms, conditions and anthorities to govern such a system."

The two estuarine surveys under the Secretary of the Interior should be complementary. For the surveys to be fully useful, their evaluation of conservation, land acquisition, and pollution problems should take account of conmercial, industrial, recreational, and residential uses. 

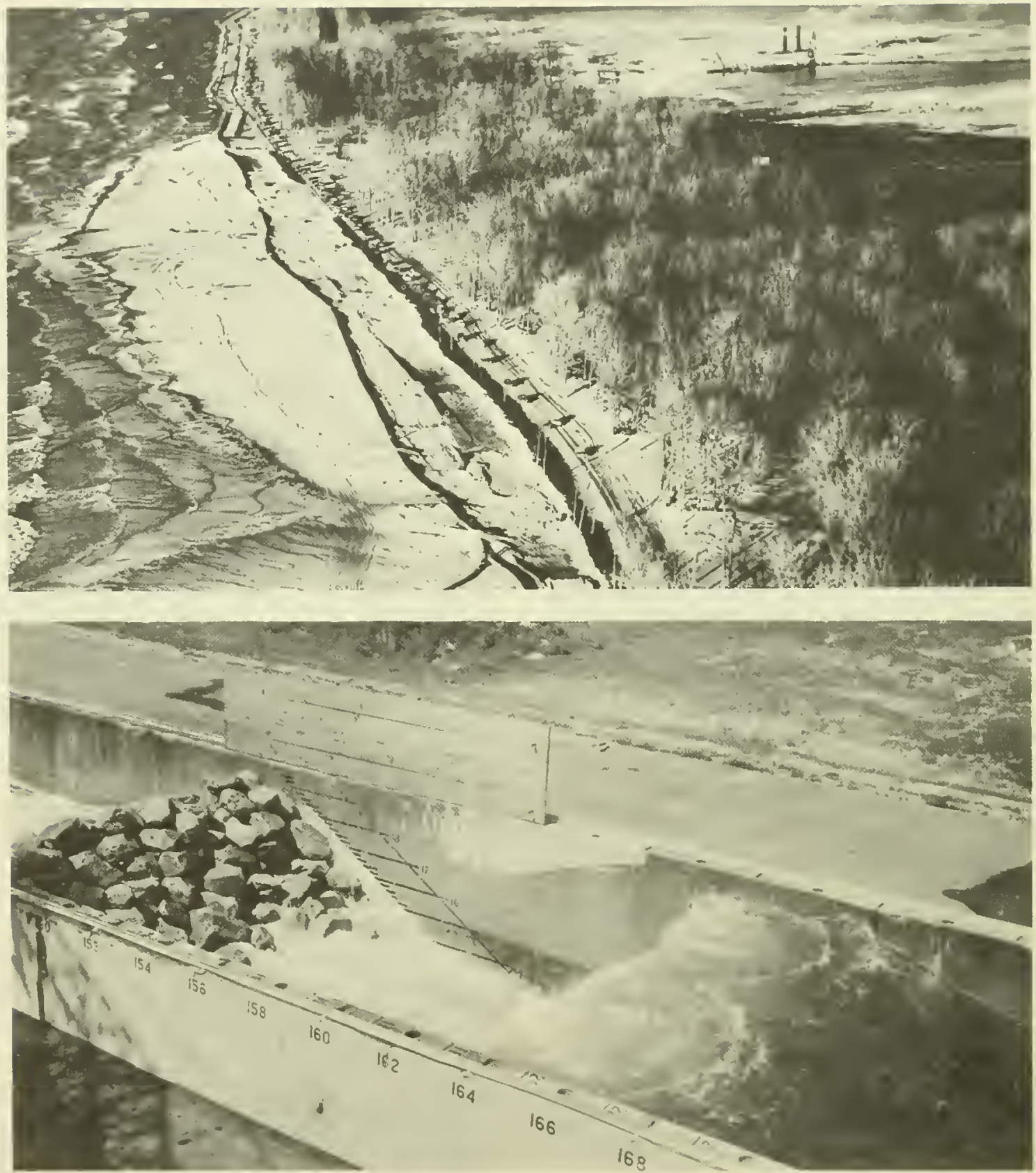

The Army Corps of Engincers is engaged in both beach restoration projects and slorcline crosion studies: the wave cxpcrimentation tank permits testing tupes of groins: a drcdge (upper right of top photograph) pumps sand via pipeline to an eroded bcach. 
The studies provide an opportmity to identify areas that should be reserved in an undisturbed state for studying the ecologr of different natural regimes. Bascline studies of such areas must be made against which to measure changes occurring over the years.

The Commission recommends that the estuarine studies being conducted by the Department of the Interior identify areas to be set aside as sanctuaries to provide natural laboratories for ecological investigations.

\section{Coastal Erosion}

Erosion of beaches and shorelines constitutes a serious national problem. Of the 100,000 miles of shoreline of the coastal zone States, the U.S. Army Corps of Engineers estimates that approximately 50,000 miles are vulnerable to erosion and require attention. The most critical areas are the shorelines of New Jersey, Florida, Texas, sonthern California, and southern Lake Erie.

Public Law 90-483, approved Aug. 13, 1968, authorized the Corps of Engineers to conduct a $\$ 1$ million study of national shoreline erosion. The 3-year study will deal with overall problems of beach erosion and will include surveys of State and local activities, types of remedial action possible, and preliminary cost estimates of such action. The Corps also proposes to expand the program initiated in 1965 to identify off shore deposits of material suitable for fill and beach restoration.

The Federal Government appears to be assuming the areater share of costs in projects involving shoreline protection, although benefits may be disproportionately local. Because the study undoubtedly will lead to recommendations for action programs to remedy shore erosion problems,
The Commission recommends that the Corps of Engineers beach erosion study include reexamination of the system for justifying projects and formulas for Federal-local cost-sharing.

\section{Ports and Harbors}

Marine transportation teclnology is in a period of rapid change. The two most dramatic developments-bulk carriers of cnolmous size and cargo containerization-liave important implications for the Nation's system of ports and harbors. A third development, the introduction of high-speed, localservice hydrofoils and hovercraft also will affect port facilities. Responsibilities for action are shared by Federal, State, and local govermments and the private sector, but surveys and overall planning for a national port system to accommodate cliange are chiefly Federal responsibilities.

In the early years of U.S. history, the major coastal cities were built around ports. Slthough an active port continues to contribute to the economy of a city, the maintenance of a major port in every major coastal city is no longer justified. With the increasing specialization of marine transportation, the concept of a port as a point at which all kinds of cargoes are assembled, loaded, and shipped needs revision. In the future, oil, other bulk cargoes, containers, and package cargoes are likely to find their separate gateways to the sea.

Drafts of 70 feet or more, which characterize the new generation of supertankers, will necessitate the development of new channels and offshore docking facilities. The ship channels in only about 10 percent of the Nation's ports are now greater than 40 feet deep. 
Serious obstacles will be encountered in deepening the Nation's waterways. For example, the tunnel recently built across the month of Chesapeake Bay is only 60 feet below low water. In New York harbor, dredging the channel deeper than the 45 -font depth means removing bedrock at a cost of about $\$ 20$ a cubic yard as compared with about $\$ 1$ for the softer sediments. In the east Texas area, the shallow and flat continental shelf would require that existing channels be extended 28 miles to dredge them to 50 -foot depths and an additional 30 miles to reach 70-foot depths. In other locations such as Philadelphia and Boston, the disposition of spoils from drerlging is a major problem.

Finally, there are risks which must be weighed in bringing a 100,000 -ton tanker into a crowded harbor area. But offshore docking also involves risks and high costs which must be weighed against the alternatives of dredging to accommodate the increasing drafts of bulk carriers.

The new container ressels pose a different kind of problem. The hearts of major cities already are clogged with vehicles. A port for container ships in the heart of the city adds to the traffic problem and to the cost of transporting goods out of the port.

Air cushion vessels and hydrofoils are not likely to become much involved in major cargo movements, but they do promise to assume an increasing role in short haul cargo and passenger transportation. Their high speeds and other operational characteristics will require traffic lanes to separate them from commercial shipping and other harbor activities.

Stock must be taken now of future trends in shipping and the Nation's requirements for major ports, offshore terminals, and other facilities for marine commerce. Such a study also should examine the Federal-local costsharing formulas. Traditionally, the Federal
Government has borne much of the cost of channel maintenance and harbor development. In accordance with its general view that the States must have more authority and must take more responsibility for the development of the coastal zones, the Commission concludes that the States should be stronger participants in planning, developing, and funding future port developments.

The Corps of Engineers, with the Committee on Multiple Use of the Coastal Zone of the National Council on Marine Resources and Engineering Development, is conducting an initial factfinding study of port modernization in cooperation with other Federal agencies, port authorities, and appropriate State and local interests.

The lead agency for the conduct of any ensuing study should be selected with care. An agency having a mission associated with the construction of port facilities may not be a wise ohoice, because a mission viewpoint can distort value judgments. Transportation should be examined as a total system and not just as ships and docks. The Corps of Engineers, Maritime Administration, Economic Derelopment Administration, and Coast Guard all have obvious advantages and disadvantages as lead agencies.

The Commission recommends that a major interagency study of the Nation's port and waterways system be initiated under the leadership of the Department of Transportation with the assistance of other interested agencies.

One of the results of such a survey might be a National Project for Harbor Development such as that recommended in the Panel Report on Marine Engineering and Technology. 


\section{Continued Monitoring and Research}

A concentrated, comprehensive effort to survey coastal zone resources will grather basic data and help to rectify years of inattention. Howerer, it will not meet the need for detailed, specific understanding of local opportunities and problems. Meeting these neerls requires systems for continued monitoring of coastal zone phenomena and vigorons support for basic and applied research in local areas.

Understanding the complex and often subthe biological and physical relationships and interactions of the coastal zone is not easy. Although understanding has improved markedly in the past 20 years, the accelerated pace of man's activities has increased both the complexity of the coastal zone system and the urgency for greater understanding.

Too often, actions have been based on ignorance. Water from the Santee River in South Carolina, for example, was diverted to the Cooper River to provide a source of hydroelectric power. The increased flow of the Cooper River into Charleston harbor altered the circulation of that harbor, with the result that the amomt of necessary dredging from the channel has increased from 100,000 cubic yards to 10 million cubic yards annually.

Sometimes planning is more foresighted. A recent study revealed in adrance that a flood control program which would have eliminated the seasonal variation in the flow of the Susquehanna River also would produce changes in circulation of Chesapeake Bay, increase its pollution problems, and perhaps destroy a part of its oyster fisheries.

However, there well may be possibilities for beneficially manipulating estuarine dynamics. It may be desirable in some places to store and release river water; divert huge volumes; or radically alter channels, currents, and tides. But proponents of such bold new proposals must be able to eraluate in adrance the total results of the changes. Opponents, often motirated by reasonable fear of the mpredictable consequences, might alter their position if sufficient knowledge permitted accurate prediction and evaluation of all results.

\section{Research Needs}

The urgent need to predict precisely and confidently the consequences of using and modifying the coastal zone makes it essential to focus coastal scientific and engineering capabilities. The proposal advanced in Chapter 2 for a net rork of Coastal Zone Laboratories is designed to achieve the needed focus.

There must be continuous interaction among the Federal. laboratories and the Coastal Zone Laboratories. The laboratories of the Fish and Wildlife Service, the Federal Water Pollution Control Administration, and the Coastal Engineering Research Center of the Corps of Engineers must work closely with the Coastal Zone Laboratories. Although problems differ from area to area. there also are many common classes of problems. A complex computer simulation model dereloped for one estuary may have more general applicability to others. The laws governing turbnlent diffusion processes are the same, even though their application may vary considerably from case to case.

An example of a cooperative research program has been initiated in the Chesapeake Bay, where the Corps of Engineers is preparing a three-dimensional model of the bay on a horizontal scale of $1: 1,000$. The model will aid in developing a mathematical procedure for predicting the effects of modifying natural circulation. Other Federal laboratories and miversity groups are participating in the project.

The inexorable trend toward more intensire use of the coastal zone is generating new research requirements throughout the Nation. 
The present level of funding support for such research, estimated at no more than $\$ 25 \mathrm{mil}$ lion annually from all sources (excluding fisheries projects), is inadequate. Additional funds and talent must be enlisted.

Developing the knowledge and techniques for maximizing the productive uses of the coastal zone is of such great importance that it cannot be left to a scattered and fragmented effort. Greater focusing of the diverse groups concerned with coastal zone research and development is needed to ensure that no significant gaps oceur in the national effort and that persommel, facilities, and fiscal resources are ntilized most efficiently.

\section{The Commission recommends that:}

- Federal and State agencies with coastal zone responsibilities provide more adequate support for scientific and engineering research on coastal problems.

- The National Oceanic and Atmospheric Agency take the lead in identifying and funding the diverse research programs needed to solve the problems of the coastal zone.

\section{Monitoring Needs}

State and Federal fisheries and pollution agencies need continuously updated data on water quality, flow, circulation, salinity, and biological content : beach erosion and siltation must be monitored in order to rletect changes hefore excessive damage is done. Effective management of the constal zone will require monitoring of such social and economic indicators as recreation usage and fisheries production.

Responsibility for monitoring systems currently is widely dispersed and in many respects is unclear. The Geological Survey, in collaboration with the FWPCA, operates more than 200 stations to monitor river inflow to estuaries and obtains water quality information at more than 100 coastal stream sites. Information from this network is suplemented by data from the Corps of Engineers, the Coast Guard, and the Environmental Science Services Administration. The Environmental Science Services Administration is primarily responsible for monitoring estuarine tides and currents. The Public Health Service and the Atomic Energy Commission have supported limited monitoring and special studies of estuarine circulation to meet their special needs. State agencies and universities have deployed still additional equipment in selected areas.

Little attention has been directed to developing instrumentation for monitoring estuarine parameters, and a special effort under Federal leadership is needed to meet the needs.

The Commission recommends that the National Oceanic and Atmospheric Agency in cooperation with other Federal agencies develop the necessary monitoring instrumentation for the coastal zone.

\section{Trained Personnel}

Improved understanding and management of coastal areas requires attracting and training personnel to carry forward expanded programs. The essential need is to expose persons from a variety of backgrounds to the specific problems of estuarine and coastal interactions and to develop programs embracing many disciplines. Coastal zone problems are not limited to the natural sciences but encompass the engineering and social seiences as well.

The relationship of the basic and applied research programs in universities to State arlministrative groups varies from State to 
State. Regardless of the form of the relationship, the existence of a strong researchoriented university gromp should bolster the State's administrative ability to formulate plans, to execute a rational policy, and to assist in the training and orientation of managrement personnel. Successful coastal zone management will require increased capabilities within State govermments and improved understanding by the general public. Most problems of alternative uses involve value judgments which should be reached by democratic processes. The expert can provide information regarding the consequences of the alteruatives, but he can seldom provide a complete answer. The officials responsible for action must be sufficiently trained to understand the significance and the limitations of the information available.

The Commission recommends that the National Oceanic and Atmospheric Agency (National Sea Grant Program) encourage universities affiliated with Coastal Zone Laboratories to provide for assistance to State officials on coastal issues and for their training.

\section{Opportunities for Coastal Development}

A management system for the coastal zone provides only a framework within which development may take place. The full potential of the coastal zone will be realized only when science and technology are coupled with imagination and sound management to make existing uses more efficient and to introduce new beneficial uses.

\section{Moving Coastal Operations Offshore}

Particular attention must be directed to projects which will relieve pressures on shoreline space and reduce the risk of disastrous accidents and storm damage.

Systems are being developed by the oil industry for underwater storage of crude oil and petroleum products, and the potential of such systems for storage of other bulky or dangerous products should be investigated.

Offshore and underwater cargo facilities inay provide attractive alternatives to expensive dredging of channels for new, deepdraft vessels. The need for docking facilities for completely submerged transport systems may emerge in the near future. The Federal

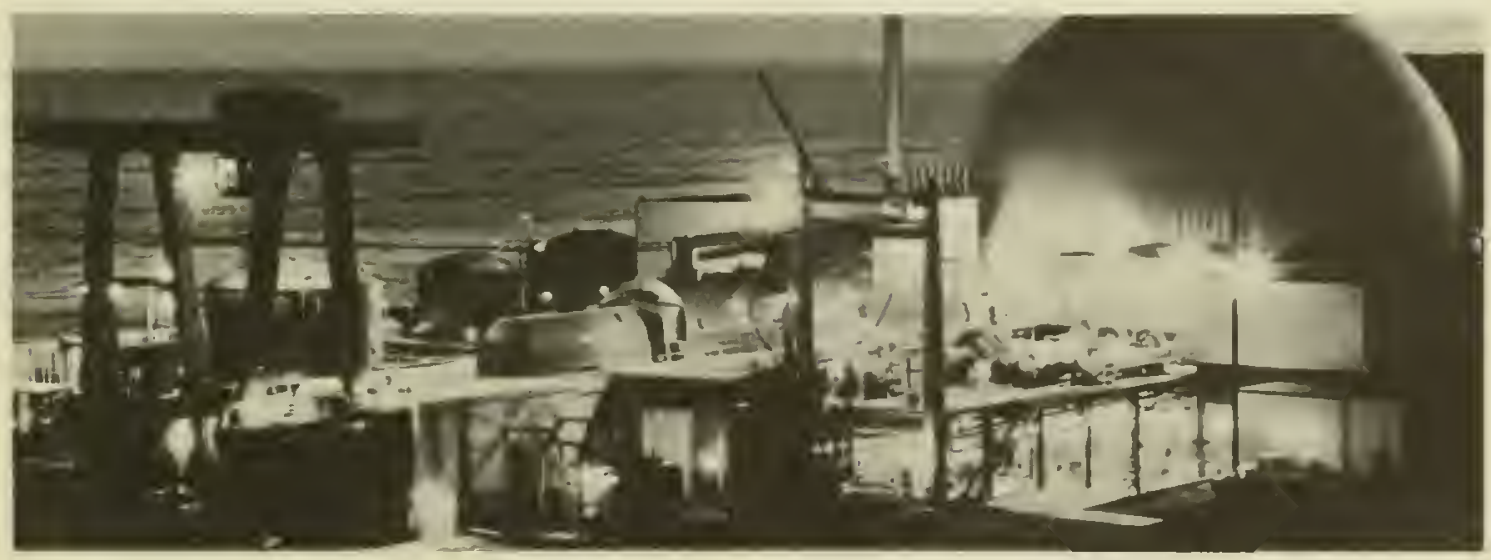

The effects of heating coastal waters with the discharge waters from large-scale nuelear poucerplants must be carefully considered in any coastal zone management system. 
Government has an interest in supporting these developments.

The feasibility of construction of largescale molerwater nuclear power facilities should be investigated with the aim of allowing viluable shore land to be used for other purposes, minimizing the effects of any possible accident, aroiching harmful thermal pollution, and perhaps enriching coastal waters by creating upwelling of mutrients A National Project to construct an experimental submerged nuclear plant for continental shelf operations is outlined in Chapter 4.

Opportunities for shifting transportation, storage, and power generation functions offshore are sufficiently near at hand and compelling to the national interest to warrant specific attention.

The Commission recommends that the National Oceanic and Atmospheric Agency, in collaboration with the Department of Transportation, the U.S. Army Corps of Engineers, and the Atomic Energy Commission, support feasibility studies and fundamental engineering relevant to the development of offshore terminals, storage facilities, and nuclear power plants.

\section{Special Attention to Recreation}

Ontdoor recreation is becoming a massive rush to the water; spearfishing and scuba diving have introdnced new forms of recreation into the sea, and the future may see recreation diving from under"water habitats and touring in glass bubbles and small submarines.

Establishment in 1962 of the Bureau of Outdoor Recreation in the Department of the Interior stimulated the inventory and planning of the Nation's recreation resources. Twenty-two national parks, seashores, lakeshores, and monuments are managed by the National Park Service, of which 14 have been acquired since 1958. Ten more are under study. Some States-for example, Oregon and California-also have made good progress recently in providing marine recreation opportunities. However, many States still lag in acquiring access to shoreline.

Identifying recreation potentials and requirements necessitates qualitative judgments which usually are exercised best at the State or local level. However, recreation planning must accommodate more than simply local interests; mique areas must be preserved as a national resonrce.

The public demand for marine recreation requires that governments be alert to new recreation opportunities as a byproduct of other projects. The Federal Govermment can assist through grants-in-aid for urban reneтal, model cities, and land and water conservation. The standards for such grants and for direct Federal programs should euconrage derelopment of recreation facilities as an integral element of such activities.

The Commission concludes that Federal, State, and local govermments shonld take steps to require provision for public access to the waters in many of the private development projects along the shore. Land fills which often provicle the means for shoreline construction may adversely affect a resource that belongs to all of the people. Consequently, approval for such private development land fills can properly be conditioned upon the requirement that the developer compensate for filling in wetlands by providing access to the public for the use of adjacent water's. The developer in certain circumstances might be required to build a road, a dock, or a picnic area that would be open to the general public.

Added recreational shoreline near nrban areas may be provided by developing artificial islands and embayments to increase ocean frontage. Vigorons programs to abate 


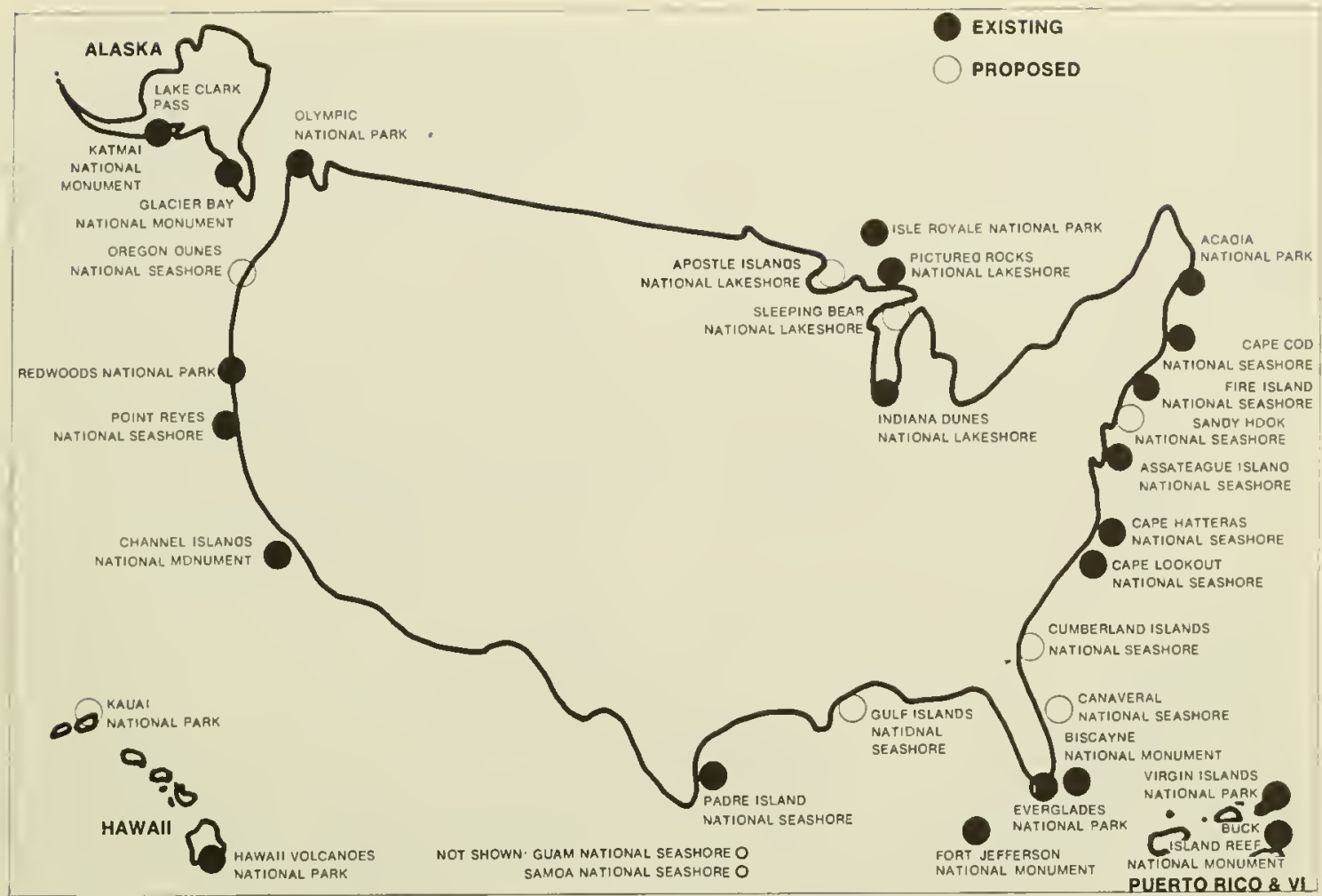

Sockce : Bureau of Outdoor Recreation, Department of the lnterlor.

\section{Marine Parks in the United States}

pollution or to cordon off recreation areas from polluted waters (as has been done in Cleveland) ofler a means to recover usable beaches near the cities. Shore areas of military reservations, frequently locaterl on prime land, might be opened for limited public nse. The use of easements, permits, rights-ofway, and zoning for areess to mban shorelines should be explored.

Trban renewal and port development also provicle opportunities to make nrban waterfronts avalable for recreation. In planning port facilities, for example, prorision conld be made for observation galleries enabling the public to riew dockside operations. Is new transportation technology renders some ports obsolete, the space may be used for recreation facilities. Such opportunities need to be identified and specific plans developed in advance. These actions could be accomplished by the exercise of the powers recommended for the proposed State Coastal Zone Iuthority.

The Commission recommends that provision for public recreation and public access to the water in urban areas be included in the planning of large-scale industrial projects, new beach shoreline, and transport facilities. Furthermore, Federal funding and grants-in-aid should be conditioned upon provision of such public recreation and access as well as maintenance of water quality. 


\section{A Plan for "Seasteads"}

Finally, coastal zone policies should recognize the desirability of providing an outlet for the energy and innovative talent of individual entrepreneurs. There are many ways in which these energies might be applied, including aquaculture projects and underwater tourism. Under existing law, uncertain and cumbersome procedures for approval of such enterprises effectively foreclose them in most States. Simple, inexpensive procedures are needed to permit individuals and small companies to lease submerged real estate and water rights when consistent with the overall plan of the State Coastal Zone Authority. State action is required most urgently for development within internal and territorial waters. As derelopment extends farther offshore and international legal arrangements are clarified, leasing to permit diversified, nonextractive seabed activities may become feasible.

The suggestion has been made that underwater leases might capture some of the excitement and public interest ignited by the Homestead Act of 1862. Such "seasteads" might be offered for extended periods on attractive terms, contingent upon the useful derelopment of the marine tract in a manner that would safeguard necessary navigation, fishing, and other uses of the superjacent waters and would be integrated with the overall plan for derelopment of the coastal zone. Oil, gas, and mineral rights would not be conveyed through a "seastead" plan.

The Commission recommends that States develop procedures to permit the leasing of offshore areas for new uses consistent with the overall plan of the State Coastal Zone Authorities for the development of these areas.

\section{The Pollution Problem}

Pollution in the constal zone prevents effective use of the waters and threatens their future. Understanding pollution effects is a prime concern of science; controlling the disposition of pollution is a challenge to engineers.

Man easily surpasses nature in energy and inventiveness in polluting the environment. A river may abrade its banks and muddy the downstream waters; a hurricane may disrupt a shoreline and bury a few acres of shellfish under the debris. But it takes a man to create the devil's brew of pollution-oil spreading into the ocean from a stricken tanker, phosphates from washday detergents leaching into the estuaries, phenol and cyanide streaming from industrial processing plants, waste-laden effluents pouring from some sewage treatment plants so poorly designed or so badly operated that they are barely worthy of their name. Pollution in one sense is a measure of affluence. A higher standard of living, more efficient farming, more complex industry, more diverse leisure actirities-all these represent greater capabilities to pollute. Although pollution can be minimized, it probably can never be eliminated completely.

The disposition of wastes in estuaries and offshore waters is both a major economic use of the oceans and, at the same time, a growing national disgrace. Every body of water can assimilate certain amounts and kinds of waste products, but every body of water, including the ocean, has a limit. The pollution load in many coastal waters already has exceeded the limit. An estimated 1.2 million acres ( 8 per cent) of the Nation's shellfishing grounds have been declared unsafe for the taking of shellfish for human consumption. The pollution load still is growing. Industrial pollution alone is increasing 


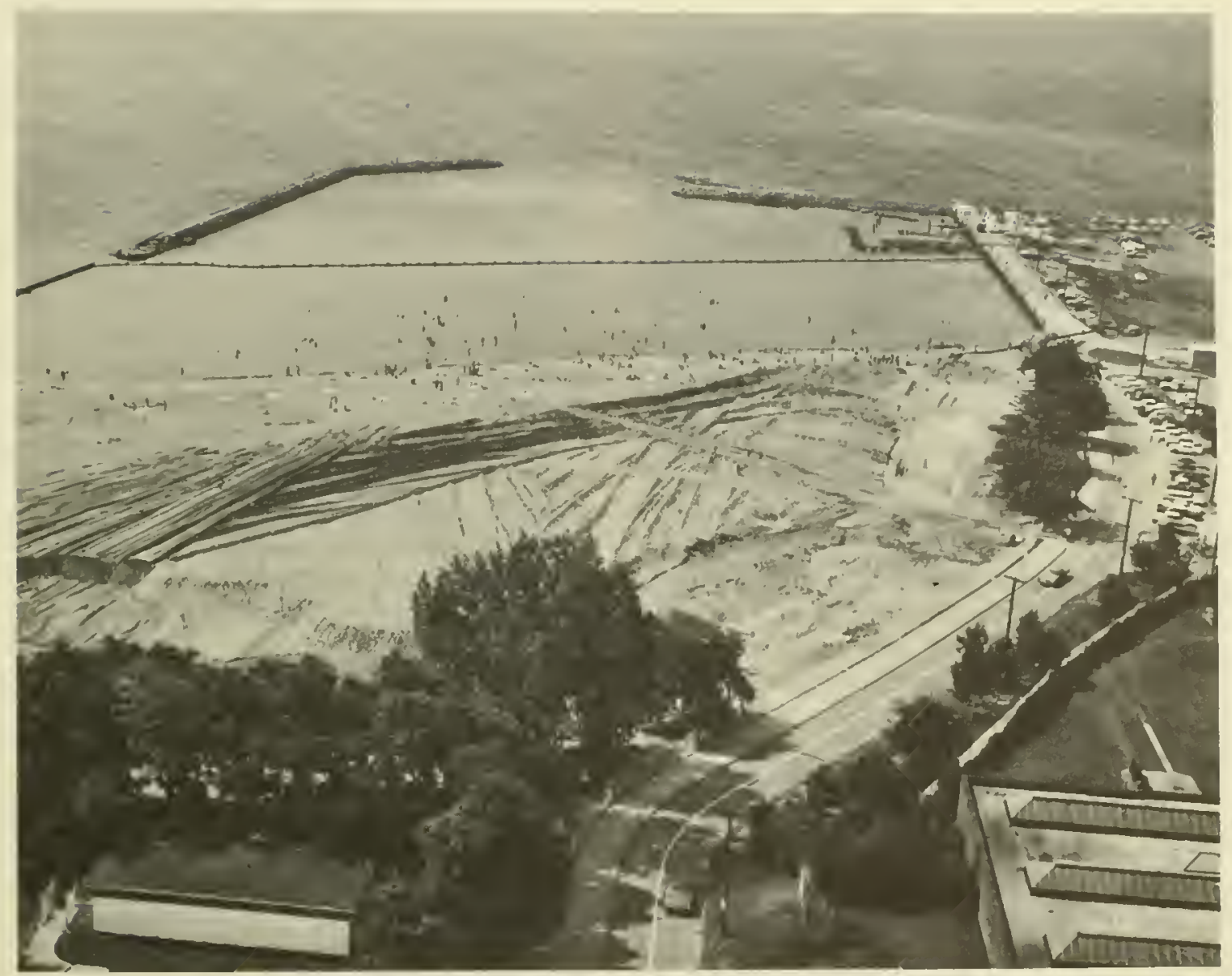

To provide its residenls with a place to swim, the cily of Cleveland hax frnerd and cllorinated a scclion of polluted Lake Eric.

at a late of 4.5 per cent per year despite abatement efforts.

The Commission could not review comprehensively all aspects of the very large and multifaceted pollution problem which extends up our rivers and into the soil and air, penetrating almost erory aspect of omr mational life. The problem of pollution must be viewerl and combatted in the context of a total waste management system-a task which extends beyond the Commission mandate and the Commission urges that this broader task be assumed by others. The Com- mission, however, has sought to identify the principal characteristics of the problem as it affects the marine enviromment and to adrance recommendations to deal with those aspects of pollution migue to the coastal zone and the sea.

\section{Characteristics of Coastal Zone Pollution}

The Great Iakes and ocenus are the final receptacle for most of the Tation's wastes. Pollutants carried down the rivers or deposited directly from the shores may be trapled permanently within the estuarine 
system and may work clamage that camnot be reparied. Estuarine pollution has a more farreaching, although perhaps less visible inpact on our national life than the pollution of streams and rivers. Action to abate oceanic and lake pollution has lagged behind the abatement of river pollution, because marine problems are more complex.

Marine pollution takes many forms. Municipal sewage, a notorious source, still is one of the simplest to treat, although the waste treatment problem is becoming increasingly complicated. Industrial wastes are difficult to treat. In many cases, sewage treatment plants are of no use, because certain industrial wastes neutralize the chemicals used in the treatment process. However, industrial wastes are generated at known and fixed locations, and at least they can be identified by source.

The most difficult pollution control problem is posed by wastes which do not come from a point sonlce: chemicals spread on icy roads; pesticides, herbicides, and fertilizers sprayed in fields: lead oxide in the exhanst of automobiles. These also find their way to streams, to rivers, and eventually to the ocean in ever larger amounts. Some experts think that such pollutints are even more dangerous than the more readily identified municipal and industrial wastes, but data to evaluate this riew are grossly inadequate.

Physical modifications also may be classed as pollutants. Physical changes may be beneficial or deleterious. The heating of coastal waters hy the electric power industry provicles an example. Warmer water may implove an area's recreation potential, and it also may stimulate aquaculture programs. However, increased temperatule decreases the oxygencarrying capacity of the water and may change the ecology of the area.

Quite often marine activities pollute the marine envilonnent. A dredging operation pollutes the water as it stirs up the bottom silts. Oil spillages and boat toilets are two of the most. publicized sources of marine pollution. There are more than 12,000 oil wells off the U.S. coasts, and the number is increasing by more than 1,400 per year. Despite the careful safety measures of the industry, well blowouts, pipeline leaks, operator carelessness, and storm damage still can cause serjous damage. The total number of boats with toilets in the United States is estimated by the Department of the Interior to be 1.3 million.

One of the least understood processes of pollution is the manner in which organisms concentrate pollutants. In a natural environment, oysters accumulate zinc and copper in concentrations sevel'al million times greater than found in sea water. Marine animals also may concentrate manmade chemicals. Concentrations of DDT have been found in commereially important fish. Excessive levels of radioactive phosphorous have been found in seagulls off the mouth of the Columbia River"; the phosphorous was traced to muelear plants at Hanford, Wash., 300 miles upstream. Significant quantities of a known cancer-causing petroleum derivate have been found in mussels in France.

To many the oceans are the nltimate repository of all pollutants. The oceans' ability to assimilate waste material is immense; for every person on earth there is the equivalent ocean rolume of one square mile, 500 feet thick. But the oceans are not infinite, and they must not be considered the nltimate solntion for waste disposal problems.

\section{Objectives for Pollution Control}

The first signs of pollution in a boty of water are rather subtle, and a strong public reaction usually does not set in mutil pollution becomes intolerable. By this time, it is very difficult to slow down the process, let 
alone reverse it. This is the situation today in some of our Great Lakes and some estuaries.

The level of acceptable water quality is determined partially by the use society wishes to make of the water. If the water is to be used only for commerical transportation, perhaps people can even tolerate its eutrophication. ${ }^{1}$ However, accelerated eutrophication, as exhibited in Lake Erie, must be aroided if residential and certain recreational use is to be made of the shoreline. For the waters themselves to be suitable for swimming, the standards must be even higher. To be useful as a nursery for marine life, the water must be still purer. Finally, if selected marine preserves are to be safeguarded for future ecological studies, at least the major effects of man must be eliminated from these areas.

The requirement in the Water Quality Act of 1965 that each State must prepare water quality standards for its rivers and coastal waters recognizes the need to consider practical trade-offs in establishing objectives for pollution control. Standards, adopted to water use in the 1970 's, have been prepared by the 50 States, and the Department of the Interior is completing its review of them.

The State Coastal Zone Anthorities and Coastal Zone Laboratories can be of great assistance to governments in maintaining estuarine water quality. The Commission envisages that some States might make their Coastal Zone Authorities responsible for preparing standards and perhaps even initiating enforcement actions in the estuarine areas.

\footnotetext{
1 Eutrophication is the process of the aging of a lake which can be accelerated by man through the orerenrichment of waters hy excessive concentrations of nutrients which lnduce prolific growths of aquatic organisms (especlally ohnoxlous weeds and alcal scums), depletion of dissolred oxygen, and extensive decas. This is the last stage in the genlogical life cycle of a lake in which the lake is transformerl into a marsh and eventually into a meadow.
}

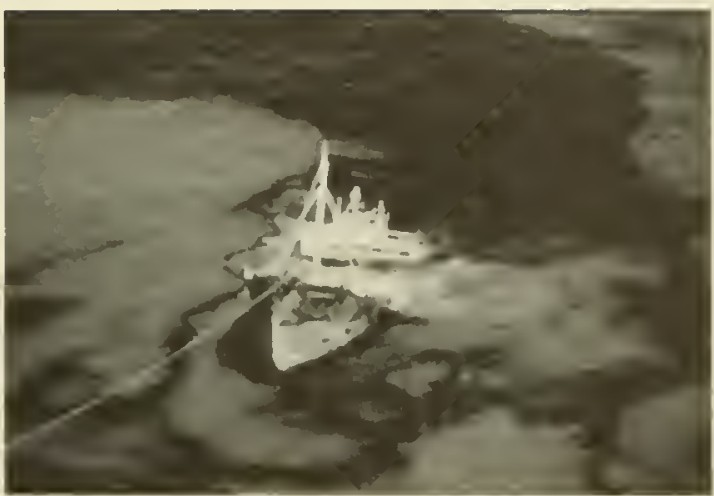

Major oil spills, like that from the tanker Ocean Eagle off Puerto Rico in 1968, llave focused international attention on the serious problem of oil pollution of the seas.

In other States these functions might be shared, or the Coastal Zone Authority might operate in an advisory role to the State polIntion control agency. In every case the existence of an agency exclusively concerned with the effective planning and managing of the State's coastal zone should help to focus attention on the difficult problems of estuarine pollution and water quality and water and land use planning.

Beyond the limits of State jurisdiction there are now no water quality standards and few programs for pollution control. The dramatic oil spills of the past year focused international attention on the problem of oil pollution of the high seas. This problem is being considered by the U.N. International Maritime Consultative Organization. The elements of a comprehensive program for protecting U.S. coastal regions from the effects of high seas spills of oil and other hazardous materials have been detailed in the National Multi-Agency Oil and Hazardous Materials Contingency Plan of September 1968 .

In summary, water quality objectives necessarily represent a balancing of many fac- 
tors. Improved understanding of estuarine processes and the economic values of alternative uses of the coastal zone will assist in developing more sophisticated standards and long-term plans for bringing them into being.

The Commission recommends increased emphasis, particularly by the Federal Water Pollution Control Administration, on research into the identification of specific pollutants and their effects and immediate action by FWPCA with the assistance of the National Oceanic and Atmospheric Agency to develop and to deploy instrumentation to detect and record pollution loads as part of an overall estuarine monitoring network.

\section{Action Programs for Achieving Water Quality Objectives}

Estimates of the funcls required for the present backlog of water pollution control projects and for keeping pace with population growth through the year 2000 run as high as $\$ 40$ billion. By any account, a national effort is required, guided by a firm set of priorities. It must embrace Ferleral, State, and local goremments and the private sector, and it must be tailored to reflect growing knowledge and experience. Systems for detecting pollution and riolations of water quality standards must be improved. Existing legal authorities must be tested and clarified. Existing water pollution control legislation is inadequate in dealing with spillage of hazardous materials. Financial responsibility should be assigned to owners and operators of offending ressels and shore installations. Legislation must define the extent to which pollutol's shall hear the cost of abatement. However, although there is still much to be done, the Commission concludes that the pres- ent legislation, coupling Federal and State enforcement authorities, provides a powerful instrument for controlling pollution. If $\mathrm{ex}$ perience should prove that the States lack the will to achice their water quality objectives or that the present legislation is inadequate, the Congress rould have a responsibility to take the necessary action to protect the national interest. So that the public can be kept a ware of the state of water pollution in the Nation,

The Commission recommends that biennial reports to the Congress be made by the Secretary of the Interior regarding the progress of each of the States in their pollution abatement programs.

Action by the Congress is required now to clarify two specific aspects of the Federal authority to prevent monted pollution of coastal waters.

The first concerns the authority of the Corps of Engineer's to consider the environmental effects of construction activities in the Nation's waterways. The Corps' regulations now require that it evaluate "all relevant factors, including the effect of the proposed work on navigation, fish, and wildlife conservation, pollution and the general public interest" in determining whether to grant a construction permit. But its statutory authority to deny construction permits for reasons other than obstructions to navigation is $\mathrm{mn}$ certain and should be extended to include such reasons. It is now contended that statutory authority does not exist. If this contention should be upheld,

The Commission recommends that the Rivers and Harbors Act of 1899 be amended to empower the U.S. Army Corps of Engineers to deny a permit in order to 
preserve important recreation, conservation, or aesthetic values or to prevent water pollution.

The second concerns the authority of the Atomic Energy Commission to consider the thermal effects of nuclear power plants. The AEC, supported by the Department of Justice, has held that it lacks authority to consider the potentially deleterious effects of thermal pollution in deciding whether to grant applications for private power plant construction. Power to consider such effects should be granted to the AEC.

The Commission recommends that legislation be enacted to enable the AEC to consider the environmental effects of projects under its licensing authority.

More aggressive action by all Federal agencies is needed to enforce the provisions of Executive Order 11288, which empowers agencies to require their grantees, borrowers, and contractors to conform with State water quality standards. There is obvious precedent for effective provisions to be included in Federal loan and contract instruments to achieve important national goals, and pollution abatement is such a goal.

More funds will also be needed for approved programs. One such program, initiated in Executive Order 11288, requires construction of adequate waste treatment facilities at Federal installations to bring them within State standards. Implementation has lagged for lack of funds. A second funding deficiency hampers the program of grants-in-aid to States and localities to assist in construction of municipal waste treatment plants. Legislation has been proposed (S. 3206 of the 90 th Congress) to provide new financing arrangements for this program, which the Commission hopes will overcome the difficulties.
The Commission recommends (1) a review of enforcement procedures by Federal agencies with the objective of strengthening enforcement of existing law and Presidential Orders concerning pollution abatement and (2) Federal assistance to States and localities adequate to permit the construction of waste treatment facilities at the rate already authorized by law.

\section{New Technology}

New engineering approaches to the treatment and disposal of wastes should be explored. It has been suggested, for example, that useful products might be developed from processed wastes. New excavation and tunneling techniques may permit construction of more economic systems for larger regions to collect and convey wastes to practical disposal sites. The 1968 Federal IVater Pollution Control Administration research and development program of $\$ 66$ million is inadequate to permit exploration of bold new approaches, which may hold the key to far more efficient waste management than present methods.

\section{Water Quality Restoration in the Great Lakes}

Although first priority must be given to curbing the inflow of pollutants, it is important to begin now to explore the feasibility of restoring the quality of some of the $\mathrm{Na}$ tion's most seriously damaged waters. This will be an extraordinarily difficult and expensive task-underlining the importance of preventing the spread of pollution before accelerated eutrophication occurs.

Although careful analysis must precede financial commitment of such great magnitude, the Commission concludes that the national importance of the Great Lakes warrants testing the feasibility of restoration techniques. The knowledge obtained from a pilot pro- 
gram wonld be applicable to many fresh water bodies and to seriously polluted estuaries.

The Commission proposes a National Project to assess the feasibility of restoring the Great Lakes. There is evidence that restoration is possible, but it must be further amplified through scientific research and through development and testing of new technology.

Although several investigations are now underway, they are not coordinated, and no common goal has been established. A National Project would reinforce current investigations and bring additional competence from inclustry, academic institutions, and Federal laboratories.

The Commission's Panel on Marine Engineering and Technology has developed the concept of a fresh water restoration project to be pursued on a lake of manageable size as a feasibility test. Scientific research into the ecology of the lake would be followed by technological development of pollution measuring devices, inflow and outflow design and control, aeration techniques, large-scale mixing techniques, thermal pollution control and enrichment, artificial bottom coating, methods of artificial destratification, thermal upwelling techniques, filtering, mass harvesting of living plants and animals, restocking, and ecological manipulation.

It is probable that new industries for contimuing lake restoration and control operations would result if the preliminary programs show promise. The results from such a pilot study should permit evaluation of the feasibility of attempting restoration of damaged portions of the Gieat Lakes.

The Commission recommends that the National Oceanic and Atmospheric Agency launch a National Project to explore the techniques of water quality restoration for the Great Lakes. Once feasibility has been established, the Federal Water
Pollution Control Administration should assume responsibility for implementation.

In the case of the Great Lakes restoration, procedures would be coordinated with the International Joint Commission for the Great Lakes.

\section{Waste Management: A Total View}

An attack upon pollution in the coastal zone cannot be entirely separated from our efforts to reduce pollution in the entire environment. Prevention is more efficient than treatment, and treatment better than seeking to correct the effects of pollution after it has occurred.

The magnitude of our waste management problem is a measure of the affuence and of the economic incentives of our society. Our economy is geared for producing goods for consumption, and we have developed an elaborate marketing and transportation system to get these goods to the consumer. Unfortunately, the consumer consumes very little: at most he transforms the product. New means must be found to encourage producers to place into distribution more truly consumable products and to develop incentives for completing the cycle by retrieving the unconsumed remains from the consumers.

A fragmentary approach to pollution abatement will not be effective. Burning or burying wastes rather than dumping them in streams does not solve the problem; it only changes the jurisdiction. A farmer who sprays his fields with pesticides is not held responsible for the material that drains into the streams, nor does he have any economic incentive for looking for alternative solutions to the problem. Vigorous enforcement in some areas and weak enforcement in others will not help to meet the Nation's waste disposal crisis. Such haphazard action will encourage only relocation of industry. 

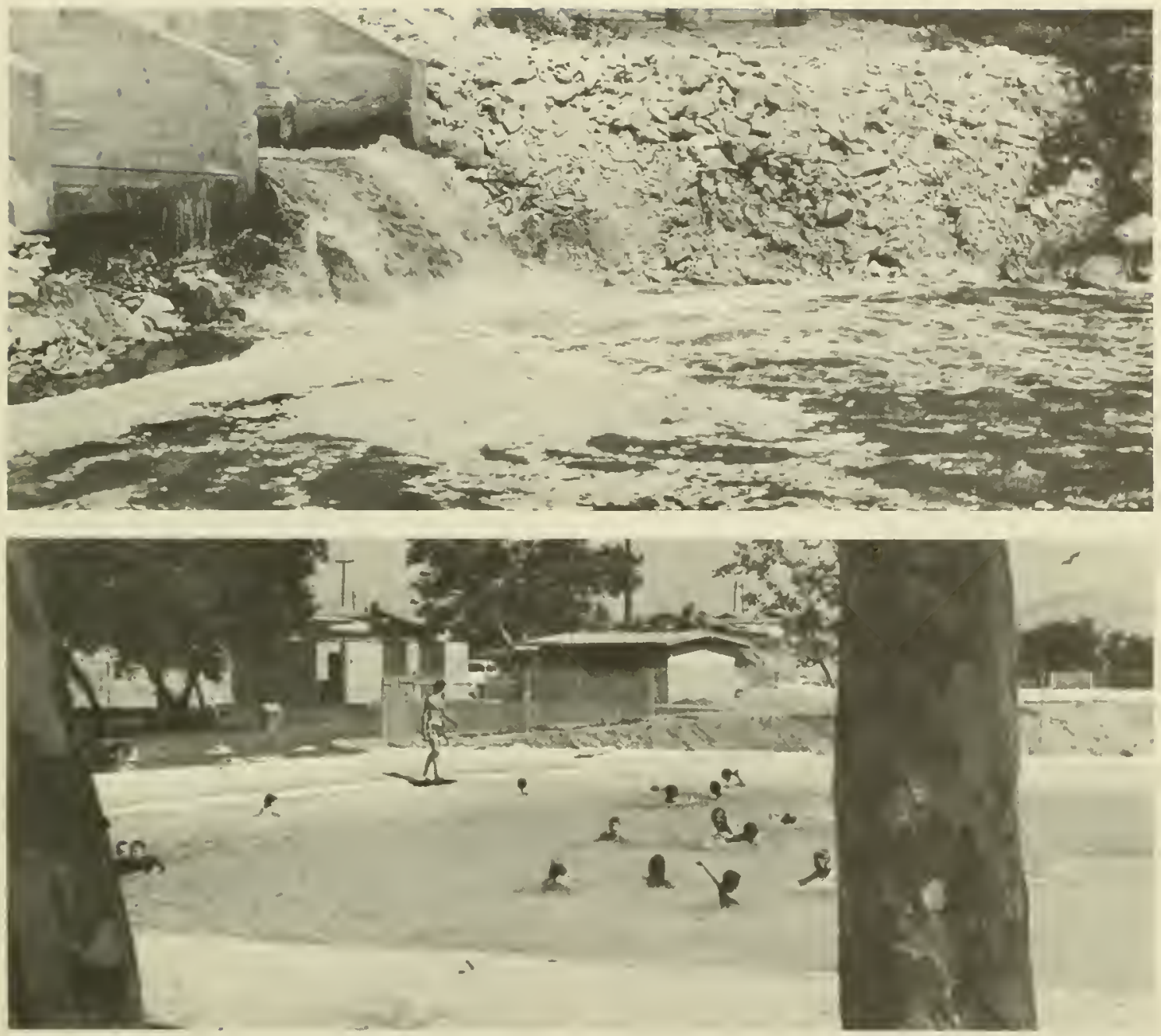

Untreated wastes from meatpacking plants are among the many pollutants of the Sation's waters. In contrast, foltowing chemieal treatment and filtration, waste water from santee, Calif., homes is used for recreational purposes.

The Commission recommends that there be a total, integrated approach to the problems of air, land, and water pollution and that there be established a national commission to study and deal with the total waste management problem.

\section{Program Costs}

The Commission estimates that implementation of its recommendations for coastal zone management would cost the Federal Govermment approximately $\$ 1$ billion over the decade of the $1970^{\circ} \mathrm{s}$. Table $3-3$ shors the categories of expenditure, as described in 


\section{Table 3-3 MANAGING THE COASTAL ZONE ${ }^{1}$}

IIncremental costs in mlilions of dollars]

\begin{tabular}{|c|c|c|c|}
\hline & \multicolumn{2}{|c|}{ Average annual costs } & \multirow{2}{*}{$\begin{array}{c}\text { Total } \\
\text { 10-year } \\
\text { costs }\end{array}$} \\
\hline & $1971-75$ & $1876-80$ & \\
\hline Management and Planning & $\$ 10$ & $\$ 10$ & $\$ 100$ \\
\hline 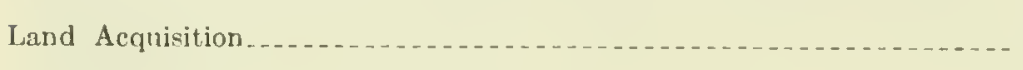 & 11 & 11 & 110 \\
\hline Scientific and Engineering Studies & 50 & 80 & 650 \\
\hline Operation of Coastal Laboratories & 10 & 20 & 150 \\
\hline Estuarine Monitoring Equipment & 6 & 4 & 50 \\
\hline Pollution Research & 4 & 2 & 30 \\
\hline Coastal Engineering and Technology & 20 & 40 & 300 \\
\hline Ecological Studies & 10 & 14 & 120 \\
\hline National Project-Lake Restoration Project._. & 15 & 20 & 175 \\
\hline Total, Managing the Coastal Zone & 86 & 121 & 1,035 \\
\hline
\end{tabular}

I For explanation of amounts shown in this table, see accompanying text and Chapter 8 .

this chapter, which are covered by that estimate.

The funding necessary for management and planning per se need not be large. The Federal contribution, which by the Commis. sion's estimate wonld remain at about $\$ 10$ million annually, would include NOAA's participation in inventories and studies, the Department of Transportation port stndy, the expenses of the proposed Bonndary Commission, Federal management of the outer continental shelf, and the Federal contribution to the initial operating expenses of the Coastal Zone Authorities and continuing assistance for their enforcement and planning activities. There are, of course, a wide variety of additional planning activities related to the coastal zone currently underway or planned by the Departments of the Interior, Housing and Urban Development, and Commerce; the Army Corps of Engineers; the Water Resources Council; and others. The Commission has not ad- dressed itself to the future funding of those programs. Working closely with such programs will, however, be a major responsibility of the National Oceanic and Atmospheric Agency.

The additional land acquisition programs proposed by the Commission are estimated to require some $\$ 110$ million of Federal funds over the next 10 years. The estimates are geared to acquisition of 1 million acres of wetlands, about 15 per cent of the Nation's total, plus selected urban waterfront areas suitable for recreational use. The Commission has advanced two methods for assisting States in acquiring these lands: matching grants throngh the Land and Water Conservation Fund and guarantees of State bonds, coupled with assistance in meeting interest and amortization charges during the first 5 years. The Commission's estimates assume approximately equal use of both programs. Additional appropriations of $\$ 9$ to $\$ 10$ million per year will be required to the Land 
and Water Conservation Fund. Federal expenditures to assist States in their bonding programs, patterned on the proposal adranced in 1968 for financing waste treatment facilities, are estimated at $\$ 2$ million annually.

Funds for scientific and engincering studies should average approximately $\$ 65$ million per year over current levels. The Coastal Zone Laboratories will be the centers for much of the research ; the Federal contribution to their operating expenses, to be provided through the National Sea Grant Program, will average $\$ 15$ million annually. Development and deployment of estuarine monitoring equipment will require the expenditure of $\$ 50$ million over the decade of the 1970's. The expenditures for research into special marine pollution problems, such as that posed by oil spillages, will decline slowly from an initial $\$ 5$ or $\$ 6$ million annually, and will be spent primarily by the Federal Water Pollution Control Administration.

Finally, there will have to be considerable funding, around $\$ 10$ million annually, devoted to coastal engineering and ecological studies. The coastal engineering funding is an estimated total for projects to be carried out by the Corps of Engineers and NOAA and their contractors and grantees. The estimate for ecological studies covers primarily the scientific research projects in the estuaries to be supported by NOAA. The estimate anticipates that other agencies, such as the Snithsonian Institution, NSF, and AEC, also will continue and expand their sponsorship of research in the coastal zone.
The Commission has advanced a number of recommendations for action to curb coastal and estuarine pollution but, except insofar as they relate to marine science and technology, has not attempted to estimate their implementation costs. Funding for pollution programs needs to be appraised in relation to the totality of air, land, and fresh and salt water problems, which extend beyond the charge to this Commission. Funding requirements for waste treatment facilities depend importantly on whether the new financing arrangements provided in S. 3206 of the 90 th Congress are adopted.

Restoration of the water quality of the Great Lakes is a major challenge to the $\mathrm{Na}$ tion. Existing technology is not adequate immediately to achiere this objective; methods now known must be tested on smaller bodies of water and new methods developed to establish the most practical means for proceeding with the major task. The Commission has proposed a National Lake Restoration Project for this purpose. Funding for the project is estimated at $\$ 175$ million over the 10 -year period, with most of the costs concentrated in the mid-1970's. The funding estimate anticipates that during the period actual restoration operations will be undertaken in limited areas-small lakes and bays and coves of the Great Lakes. However, the Commission is unable to foresee at what point it may become practical to attempt a program to restore one of the Great Lakes as a whole and therefore has not provided for such a program in its estimates. 
Chapter 4

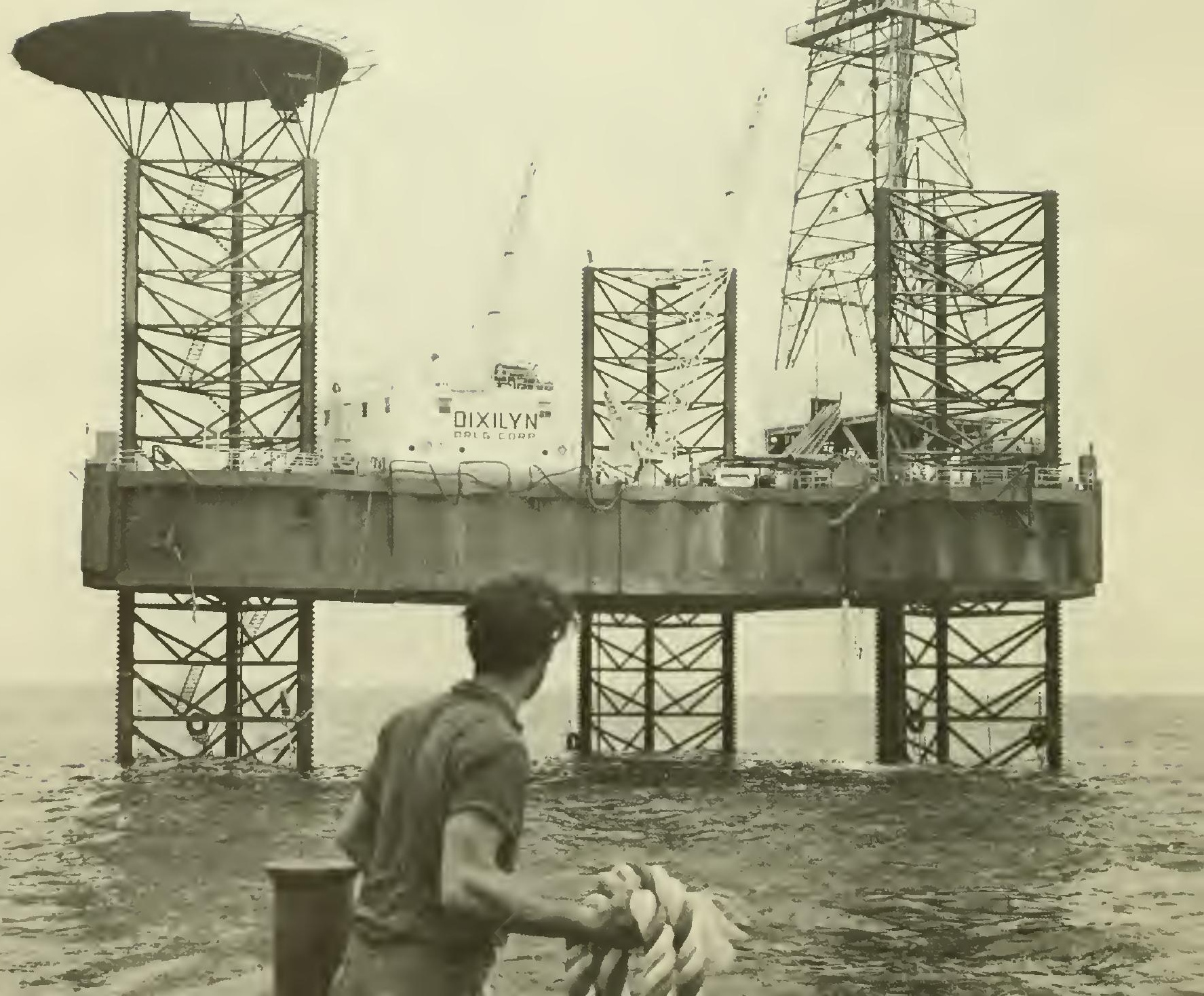


The lope that new scientific knowledge and technical capability will open the way for the Inited States and the nations of the world to yain new wealth from the sea has fired mucl of the heightened interest in marine aflairs. 'The Commission's enabling statute specities one of its major tasks as the review of "known and contemplated needs for natural resources from the marine environment in order to maintain this Nation's expanding economy." The objectives of the statute include "the accelerated development of the resources of the marine environment" and "the encouragement of private investnent enterprise in exploration, technological development, marine commerce and the economic utilization" of the sea's resources.

The Commission has approached its assessment of marine resollres with two overriding concerns: (1) that the United States not ise confronted with a critical shortage of any raw material and (2) that both marine and nommarine resources be developed through a policy which will advance economic efficiency. Further, the Commission recognizes that the U.S. interest in marine resource derelopment must be viewed in terms of world needs and capabilities. The sea is a global source of goods and services for all mankind.

Sot all resource needs have the same urgency. The Nation and the world face a few truly critical problems, a number of significant opportunities to advance both national and international interests, and other situations which can currently be accepted as relatively satisfactory.

It is impossible to deal with derelopment and managenent issues in terms of marine resources as a whole, although general policy considerations must be accommodated. The Commission, therefore, has considered sepanately the economic and legil problems associated with such areas as fisheries, oil, gas, and hard minerals and has made numerous recommendations (in Parts II and III of this chapter) for change in national and international policies and law.

In our society, the economic uses of the sea are primarily within the province of the private sector. The Commission recognizes the need for Goverument to strengthen industry's role in expanding the scope and scale of narine operations.

The character of the Government-industry relationship) will have an important bearing on the Nation's effective nse of the sea. The Commission's views on Government and industry roles and the steps to encourage prirate investment. in marine enterprises are out lined at the end of this chapter.

\section{National Resource Policy}

There is no single national policy uniformly applicable to all resources, just as there is no single defense, economic, or foreign policy. Rather, there is only a body of experience and general objectires which guide decisions on specific issues at specific times. Policy decisions on natmal resources require evaluation of long-term estimates of supply and demand, opportunities to develop' sulstitutes, access to foreign sources, and the adequacy of data for long-term planning and resource management.

The rate at which the world's natural resources are being used poses impressive challenges to lumman ingenuity to find and derelop new sources. Accelerating resource nse emphasizes the dire need to halt the profligate waste of many resoures. Consumption of metals in the next 35 years is expected to exceed that of the last 2,000 years. Enelgy use in the next 20 years is estimated at three times that of the last 100 years. Even more sobering, world food production must inrease $b y$. 50 per rent over the next 20 years to keep pace with growing populations; food

The hope that new knowledge and technology may leat to increased. teellh. from the sea has heightened global interest in marine affairs. offshore oil production is second only to fish as a source of marine resource 


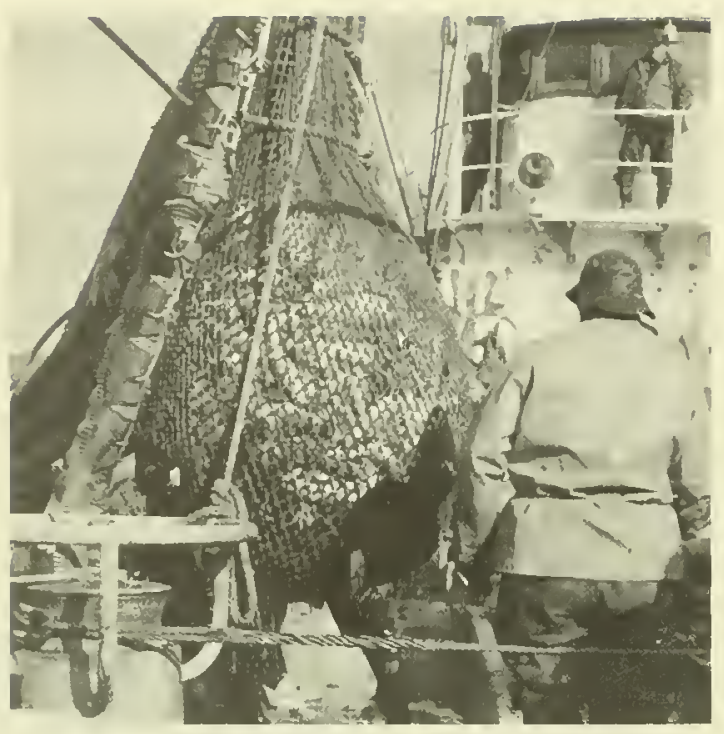

A nctful of fish is swung aboard

a trawler at sea. Such food resources must be brought to fuller use to mect protein deficiencies in certain regions; for all nations fish offer promise of a richer, more varied dict.

needs will double in India, Pakistan, and certain Latin Ainerican nations.

Experts are optimistic that we will meet these resonice needs, as we have met them in the past. The prices of most basic commodities in the Tnited States actually have declined slightly relative to overall price levels-indicating conficlence in the future as well as present abundance. But this should not be taken as a signal to relax efforts to develop new sonrees. Thongh on a. global basis the estimated supply of most hard minerals from land sources appears adequate to meet estimated requirements at least until the year 2000, such estimates are fraught with much uncertainty. Appropriate action now will permit us to prepare in an orderly way to meet needs in the coming decades and to enlarge the options for furnishing new streams of raw materials to sustain our growing economy.
Marine sources already contribute importantly to our supplies of oil and gas; onr dependence on the sea for these materials is certain to grow. The sea's food resources must be uscd more fully to orercome protein deficiencies in certain regions of the world; they offer all nations the promise of a richer, more raried diet.

The availability to the United States of specific resonrces often is threatened by mismanagement, natural disasters, and politica] developments. Therefore, the Uniter States must have alternative sources of supply. Prudence demands contimning exploration of new regions; improvement of new extraction, harvesting, and processing technology; and proving of new reserves. It must be remembered, too, that accurate assessment of resource potentials requires some experience in their production.

The Commission, in evaluating marine resource potentials, has considered the duality of U.S. interests reflected by its national and international roles. Accordingly, the Commission rejects the idea that self-sufficiency in natural resources is a desirable goal for American policy. U.S. national policy clearly recognizes the benefit to the intemational community of expanding commerce in raw materials. U.S. national policy recognizes this fact in aiming to rednce progressively the restrictions on international trade. Measures to assure some minimum level of domestic production may be needed in certain cases to protect the United States from politically motivated actions that conld curtail supplies of petroleum or other key minerals. But it is incumbent on the opponents of a policy favoring a reasonable degree of freedom in international trade to weigh the alternatives and justify their costs to the American consumer. Ellorts to faror certain domestic indnstries are not in the national interest if they raise production costs to levels which 
$\longrightarrow$ U.S.

$\leadsto$ REST OF WORLD
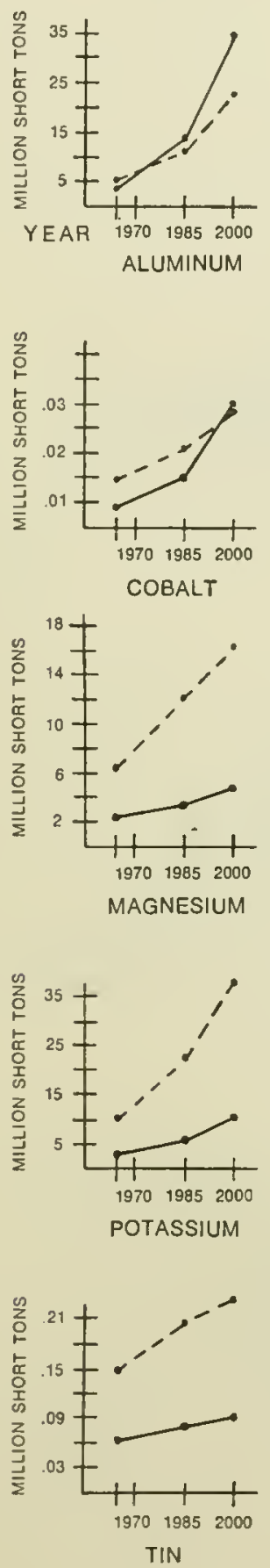

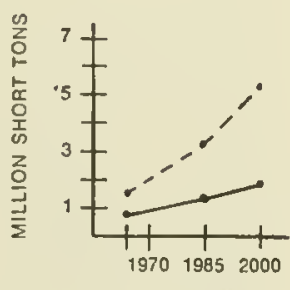

BARIUM
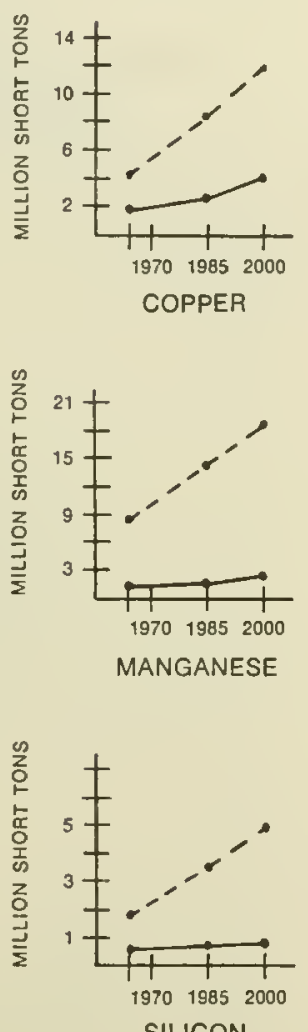

SILICON

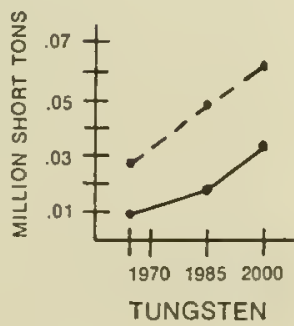

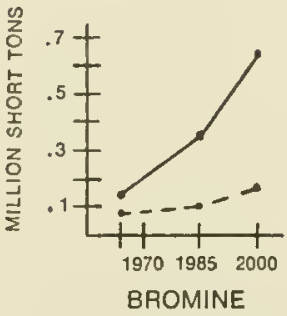
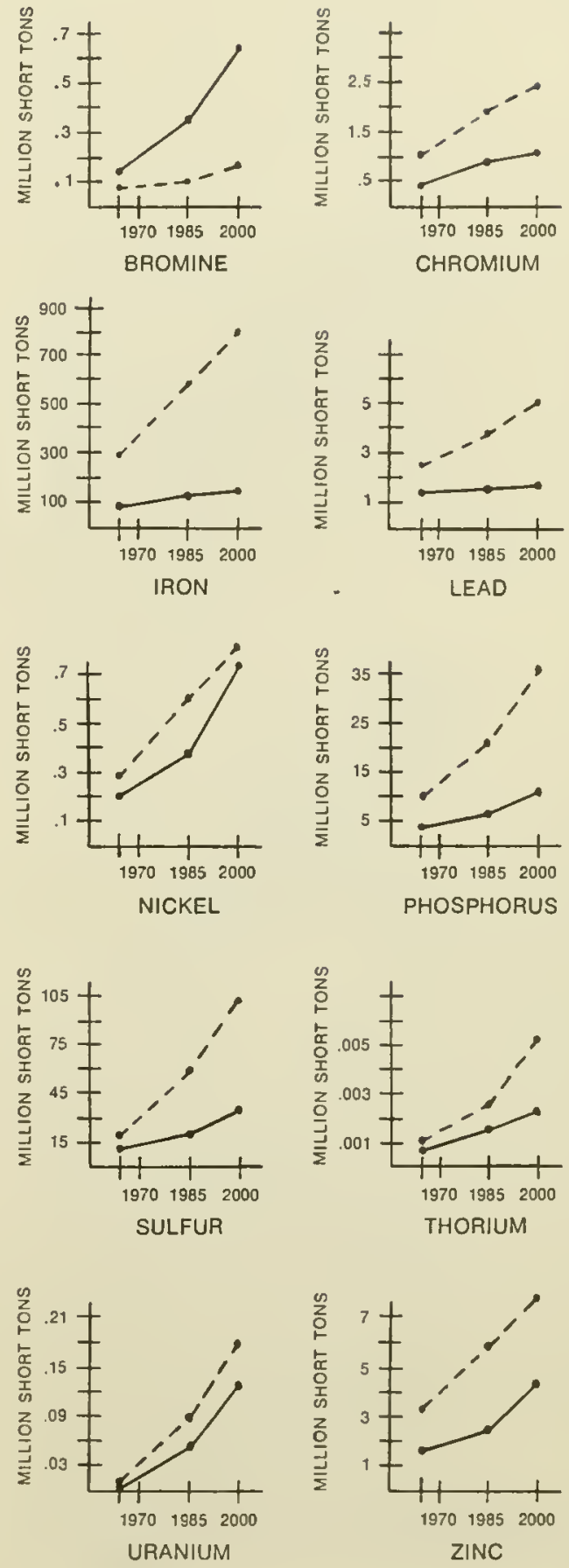

DAta souncE: Deprrtment of the Interlor. 
burden other segments of the domestic economy or proroke retaliatory action by other nations. In the long run, actions that strengthen the Nation's industrial base and productivity will also strengthen its defense calpacity.

Nor is the need to improve the U.S. balance of payments a proper guide for long-range programs affecting marine resources. That need must be viewed in terms of the overall pattern of commodity and service trade, financial transactions, and international commitments. Piecemeal substitution of domestic production for imports simply reverts to the costly policy of self-sufficiency.

The Federal Government bears responsibility for negotiating international legal frameworks within which all nations may share equitably in using the sea's resources. Such arrangements may also have critical impact on efficiency of resource use. The Enited States has much to offer other nations in providing more effective techniques for tapping the sea's resources and will need their help in implementing international programs to permit all nations to use the sea to their benefit.

Government also bears a responsibility for establishing a framework of domestic law to undergird our private enterprise system. Currently many marine resources are treated as common property, available to all for the taking but exclusively available to no one. The common property system is no obstacle to economic development if resources are abundant, technology simple, and investment minimal. But it is not appropriate for large-scale industrial activities in a highly technological, mobile, and capital intensive economy, and it is slowly yielding to arrangements to assign resource development rights.

In sum, the national interest in resources and their development place a premium on having a range of sources to which the
Nation may turn. The leadtime to appraise and define resources for future use and to develop the necessary industrial organization and technology demands forward planning. A global perspective and a high measure of reliance on private enterprise are necessary to assure flexibility and efficiency in meeting resource demands within the discipline of the market system.

\section{Development of the Sea's Living Resources}

The living creatures of the sea have served man since the dawn of history. Today's renewed thrust seaward for food, for raw materials, and for drugs is an extension of ancient practices which today assumes new importance with the growth in population and improvements in ships and gear that bring the world oceans within the reach of all major fishing nations. The extension of national fisheries beyond traditional grounds, made necessary by demands for food, have brought new problems to the international community.

Among the harvests of the sea, those of living resources must have a primary place in a plan for marine development.

\section{Marine Fisheries}

Our Nation has a strong interest in adrancing development of the sea's food resources. The race between population and food supply has potentially explosive consequences; every avenue must be employed to control this race. The living resources of the sea are relatively cheap in many parts of the world; they frequently are marketable with very little expensive processing and marketing equipment, and the development of local fishing industries can, in many cases, be achieved at low cost. 
The Increasing Gap Between World Food Needs and Food Supply

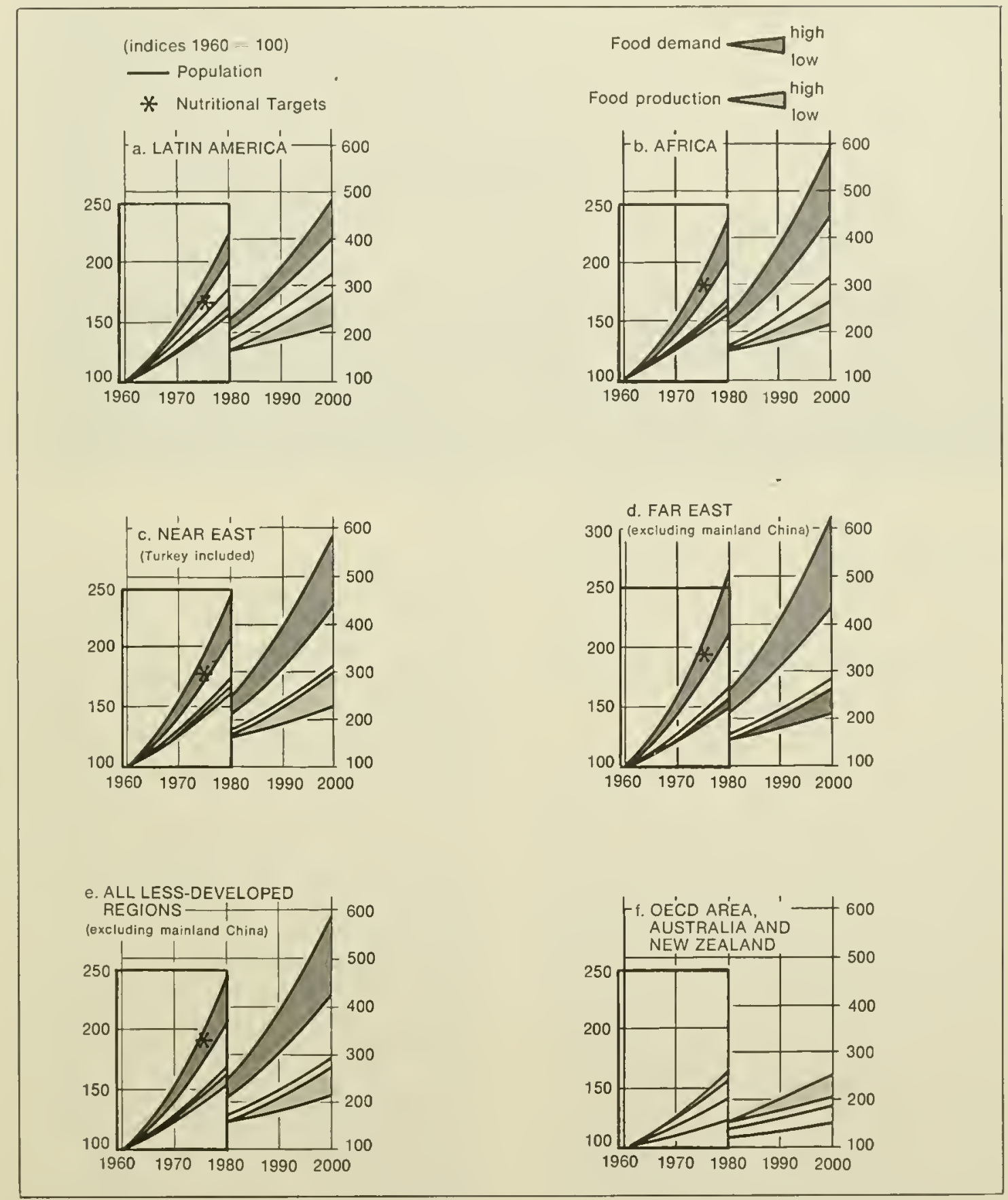

Socher: "The World Fond lopulation: Its Implications for OECD Countries" The OECD Obserier. June 1966, Dp. 29-311. 


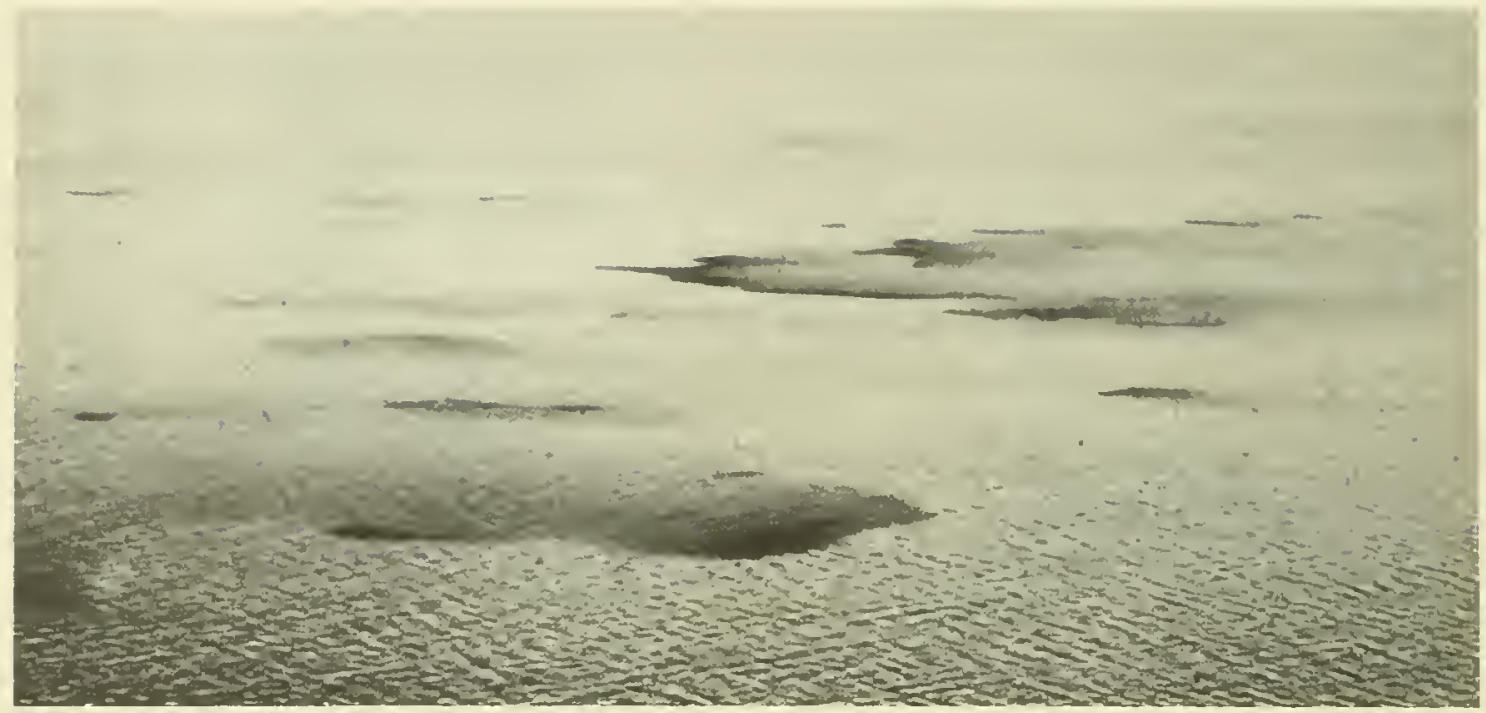

Expansion of warld fisheries production is a matter of advancing on several fronts at once, for example, greater efficieney in harvesting hnown stochs. Here schools of thread herring are spotted by aireraft off the uest coast of Florida.

Fishing is important to our Nation in terms both of providing Americans with a more varied diet and of providing the basis for profitable industrial activity.

\section{The Ocean's Food Potential}

The ultimate potential for food from the sea remains unknown. The total annual world harvest from the oceans is orer 50 million metric tons. Fish provide about 3 per cent of man's direct protein consumption, but because fishmeal is fed to land animals, fish are the basis of about 10 per cent of all animalprotein food production.

Expansion of world fisheries production is a matter of advancing on several fronts at once--improving the technical efficiency of harvesting known stocks, locating and defining new stocks, recasting the institutional setting for fisheries management, developing new end products from presently unused or underutilized species, and opening up the new field of aquaculture.
If man's fishing activities continue to be confined to the species now utilized, to the locations now regarded as exploitable, and to the equipment now available, it is unlikely that production could be expanded much beyond 150 to 200 million metric tons-three to four times present levels. But if man's activities were not so confined, far greater quantities of useful, marketable products could be harvested to meet the increasingly urgent world demand for protein foods.

It is, therefore, more realistic to expect total annual production of marine food products (exclusive of aquaculture) to grow to 400 to 500 million metric tons before expansion costs become excessive. Even this estimate may be too conservative if significant technological breakthroughs are achieved in the ability to detect, concentrate, and harvest fish on the high seas and in the deep ocean.

It is important to recognize that there are biological limits on the productivity of indi- 
vidual stocks of fish and shellfish. Wise use of living marine resources is not only a matter of expanding output from underutilized or unused species and areas but also of effective management of those subject to overfishing. The management system must be structured to preserve the productivity of heavily fished populations withont discouraging the technological and marketing progress required to push productive activity into new areas and into the use of new species.

As demand grows, it will become increasingly important for the United States, alone and in cooperation with other nations, to establish more accurately the dimensions of the many living resources usable to man and to estimate the production that can be taken from them without impairing future yields.

The Commission recommends that the United States continue its own research programs aimed at improving stock and yield estimates, cooperate with other nations in programs for this purpose, and explore new techniques for preliminary assessment of stock size and potential yield where new fisheries are contemplated.

\section{World Production and Demand}

Dramatic changes have marked the world's fisheries in recent years. With fleets ranging across the globe and developing stocks heretofore not economically accessible, the exploitation of fisheries has assumed new dimensions as an activity of international interest and concern.

Aggregate figures conceal the changes occurring within the industry. Total output has been growing at a rate of more than 6 per cent per year since the end of World War II, the sharpest growth occurring in recent years.

The growth has not been evenly distributed among the various fisheries. There have been tremendous increases in some areas, like the Perurian anchory and the South African sardine fisheries, and actual declines in others as a result of overexploitation, deterioration of spawning areas, and natural causes. If expansion in the nse of liring resources of the sea is to continne, improvements in technology, market development, and processing must keep pace with the needs to move farther afield and to utilize lower-valued species. The rapid increase in fishmeal use for livestock feeds and the potential derelopment of fish protein concentrates from heretofore unmarketable fish foreshadow both the needs and the opportunities to utilize lower valued species.

Rapid growth in the harrest of living resources of the sea reflects the strong world demand for animal protein foods. Although per capita consumption of sea foods tends to level off at the income levels attained in highly developed nations, population growth and in-

\section{Trends in the U.S. and World Catch \\ of Fish (including catch from fresh water)}

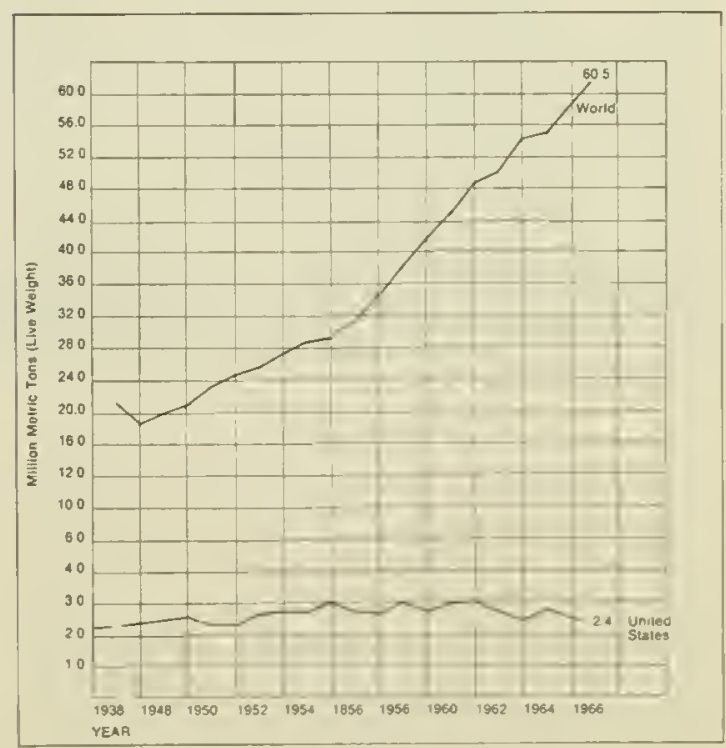

Sovnce: United Nations Food and Agriculture Organization, Yearbook, 1967. 
creased use of fishmeal in livestock feeds continue to expand demand for a broad range of fish and shellfish products. Demand for these products has grown eren more spectacularly in the less dereloped areas, where protein deficiencies are chronic. These are precisely the areas in which population growth is greatest. There can be little doubt that the world demand for food from the sea will continue to press production capacity for the foreseeable future. Moreover, as modem technology provides the means for altering the form, texture, and keeping qualities of fish, the increased diversity of food products from the sea should lead to even stronger demand.

Although revolutionary developments in high seas fishing technology have greatly expanded the range and efficiency of modern fishing equipment, harvesting techniques in many parts of the world are still extremely primitive. The processing and marketing sectors of the industry are considerably more advanced, but they still have far to go before they reach the techmical level of other segments of the food industry. Full utilization of the potential for food from the sea requires full attention to the research and development that will convert the worldwide fishing industry into a modem segment of a modern food industry.

The spectre of hunger and malnutrition, haunting mankind from the beginning of time, threatens to become more acute over wider areas of the world. Considerable attention and publicity have been given to the use of the ocean's resources to combat world food problems. Although marine food sonrces will never be sufficient to solve these problems, they should play an important role in the solution. The mutritional qualities of marine food products, their worldwide distribution, and the relative ease with which they can be prodnced in areas of critical need make it vitally important that the world use them efficiently. Only a handful of highly developed nations are capable of providing adequate diets for the bulk of their populations. Until world population growth is brought under control, all possible sources of food from land and sea must be exploited.

For the foreseeable future, overall calorie requirements of the human diet can be met from land production. But ocean food production is important in world nutrition as a sonrce of edible oils and proteins with a wellbalanced amino acid structure. These needs of themselves are sufficiently large and urgent to compel a greatly accelerated effort at both national and international levels, and within both government and industry to overcome scientific, teclunologic, and institutional barr'iers to a more efficient and expanded harvesting of the ocean's food resources.

The United States can give strength and momentum to this effort through the example of its own policies and programs and through vigorous support of multilateral fisheries development programs of the Food and AgricnIture Organization of the United Nations, the United Nations Development Program, the World Bank, and other international agencies. Action by the United States to upgrade the technical capability of its own fisheries will develop new techniques and products, such as fish protein concentrates, that will benefit the entire world industry. Furthermore, U.S. firms can expect both to participate in the expanding markets of the developing nations and to contribute to their programs to overcome deficiencies in protein foods.

\section{Principles of Fisheries Management}

Sensible fisheries management must prerent overexploitation of heavily utilized species and, at the same time, provide incen- 


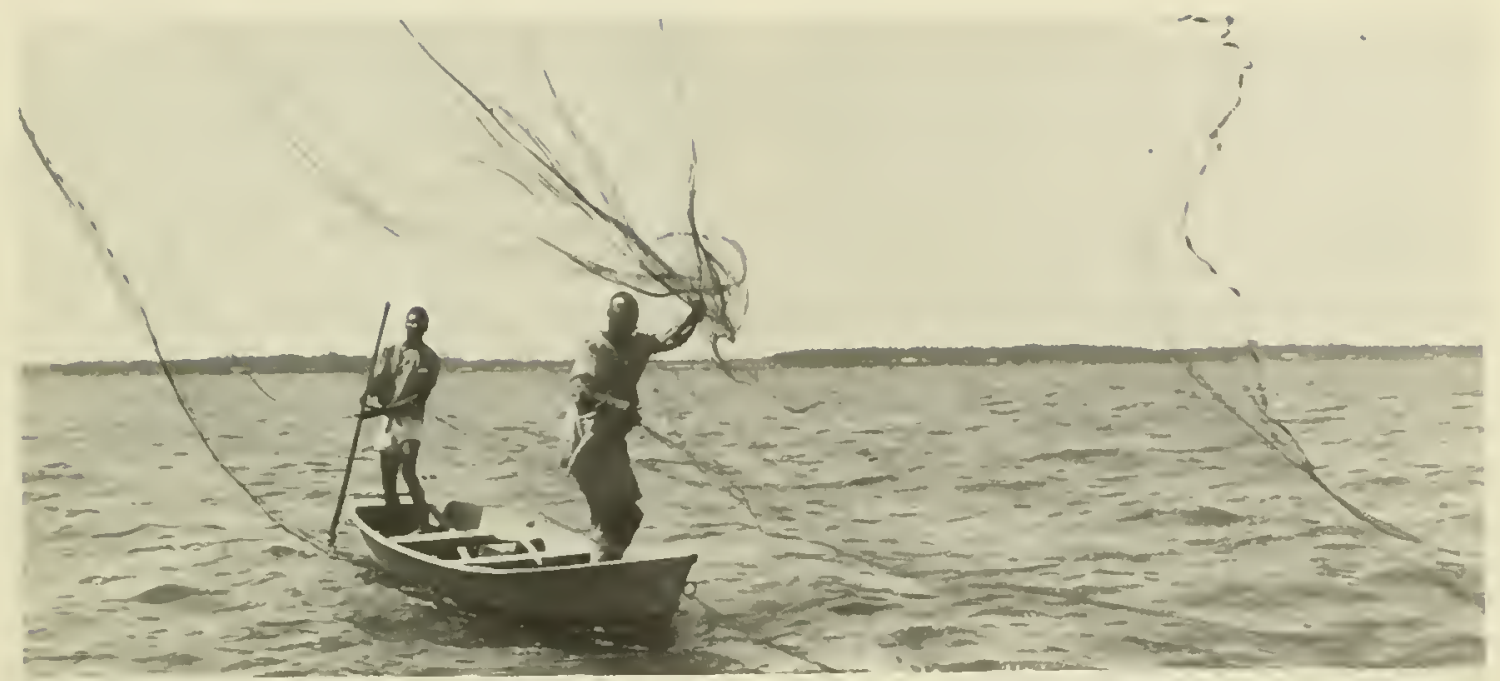

Full utilization of the sea's food potrutial weill mean conversion of the fisbing industry, worldivide, into "segment of a modern foor industry. Through programs of the Food and Auricultur Organization, Duhomel fishermen (upper photograph) will rereile new ressels chebling them to stall at sea for longcr periods, ana? the ancel marlet at Iede Amsterdem. riuymana, will be replaced by a morlern eenter.

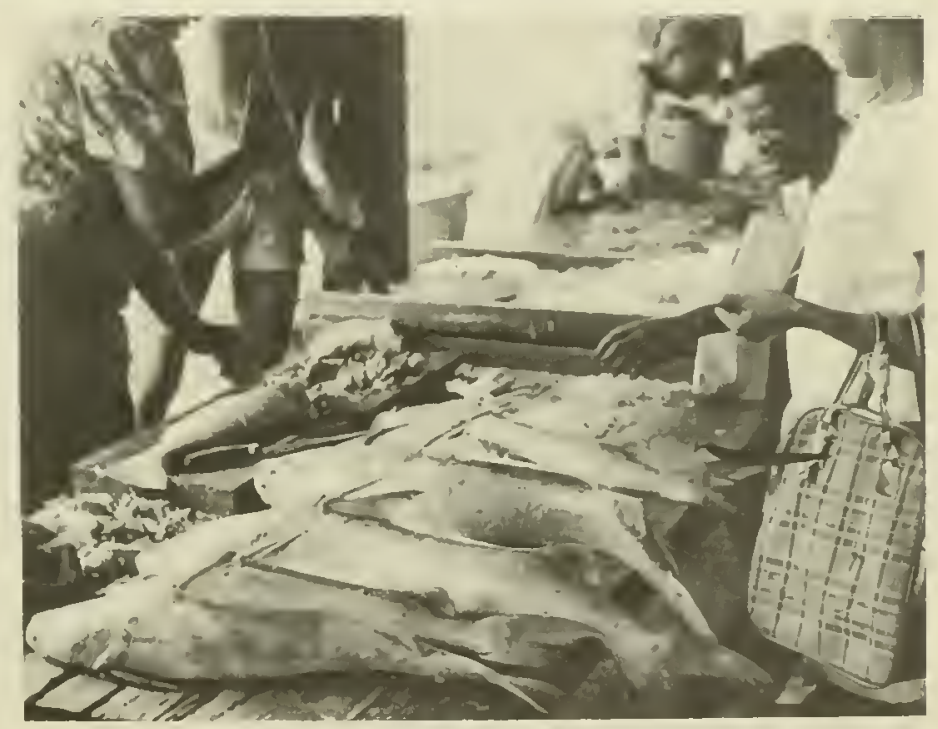

tives to expand tatelies of underntilized species.

Most existing proglants (o) rowulate fisherofes, whether mational or international, seek to limit exploitation to lovels that provide the maximum sustainable vield of the species in question. Harrest in excess of these physical linits will result in depletion of the resonree.
Underexploitation will also result in permanent losses to mankind berause natural moltality will eliminate the biologieally smplus fish.

The preservation of the stocks should not be the sole aim of fisheries manatement. Indeel, it is mearly inposible to allherestretly to the maximum sustainathe phrsical yield 
concept if two or more ecologically interdependent species are being exploited. Of necessity, the biological objective then must be accompanied by an economic objective-to maintain the maximum sustainable composite yield producing the greatest economic return.

Furthermore, fisheries are common property in that no fisherman has exclusive access nor may he keep others from sharing in their exploitation. Fishing situations in which total revenues exceed total costs induce additional fishermen to enter the fishery and encourage additional effort by those already in the fishery. As a result, no individual fishing unit has the incentive to restrict fishing effort to that which will maximize economic return over the long term. The more competitive the fishery, the more destructive the race to catch fish before others can take them. The result is an industry with excess capacity relative to what is required to catch the maximum sustainable yield. This situation restricts fishermen and vessel owners to low, unstable incomes and may result in total production less than that obtainable with less investment and effort.

It is not only possible but also normal for such excess capacity to develop quickly, particularly in a new fishery, and to persist over long periods of time because of the traditional immobility of labor in the fisheries and the related ability to maintain capital equipment at little or no real cost.

The Commission recommends that fisheries management have as a major objective production of the largest net economic return consistent with the biological capabilities of the exploited stocks.

More fish can be taken by pushing effort beyond the point at which marginal revenues will equal marginal costs. But because costs will then increase more than revenues, the additional fish will not be worth the additional effort required to produce them.

Many measures employed in fisheries management, including those called for in international fisheries agreements-for example, limitations upon the areas in which and the time when fishing may be conducted, the prohibition of specific types of fishing gear, and overall catch limits-achieve their conservation objectives by increasing the costs of operation and thereby, hopefully, decreasing the incentive to fish. To the extent that these measures attain their conservation objectives withont raising prodnction costs, they simply encourage more unnecessary fishing effort.

Conservation regulations affecting the minimum age and size of the fish that may be caught can be sound from an economic as well as conservation point of view because they tend to reduce the costs of operations. But if successful, they increase the profitability of the fishery and again encourage an intensification of the fishing effort that threatens to dissipate the potential improvement in net economic yield.

Fisheries management usually reacts to greater fishing effort by shortening the fishing season. So, for example, the conservation program in the Puget Sound salmon fishery succeeded in increasing physical yields, but this success has produced such an influx of boats and gear that fishing is allowed only 2 or 3 days per week. Probably no more than half the gear now in use could harvest the catch at a saving of perhaps 40 per cent of the gross value of the landings.

Similarly, the Pacific Halibut Commission restored the halibut yield and raised the total catch limit by about 25 per cent over a period of 20 years. This induced a 300 per cent increase in the number of participating vessels. Consequently, the original 9 -month season 
was shortened drastically-at one time to 24 days on one major fishing gromn-with substantial undesirable eflects on fishing and marketing costs.

Boats and men must find off-season employment, which invariably involves some loss in labor time and idleness of equipment that cammot be recovered. Processing capacity must be enlarged to handle the production peaks and it remains underntilized for much of the year. Higher storage costs are incurred, and the risks involved in holding frozen inventory orer longer periods of time ultimately are borne by the fishernen in the form of lower incomes. The resulting higher costs of the products of these fisheries make them vulnerable to price competition from imported fish and other lower priced protein foods.

Finally, the ecomomic absurdity of deliberately imposing higher costs on the fishing fleets involved provokes resentments which lead to violations of the conservation regulations and to great difficulty in enforcing them.

The Commission recommends that voluntary steps be taken-and, if necessary, Government action-to reduce excess fishing effort in order to make it possible for fishermen to improve their net economic return and thereby to rehabilitate the harvesting segment of the U.S. fishing industry.

The goal of domest ic fisheries management must be the development of a technically ardranced and economically efficient fishing fleet with the minimum number of units required to take the catch orer a prolonged perion of time. 'This goal must be achieved in fisheries which are now heavily nvercapitalized without seriously dislocat ing those fishermen who entered the indust ry in gond faitl.
The existing intermational law of fisheries makes it impossible for the Thited States alone to move toward the ecommic objective of maximizing the net economic return of IT.S.-flag fishing ressels participating in intemational fisheries. If, for example, the [nited States alone sought to limit the number of its ressels in such fisheries, other nations could increase the number of their vessels and prevent the [nited States from increasing its share per unit of effort.

Within those fisheries to which the Tnited States has exclusive access, action might be taken at the Federal or State level, as appropriate, to control the input of fisheries effort. But any action to limit entry must be tailored to local conditions and needs and designed to accommodate local practices. Fishing is an ancient business, and its practitioners often are less concerned with economic efficiency than with the simple fact of making a living from the sea. Fishermen may be perfectly aware that a half-dozen modern, efficient ships could harvest the permissible crop with high monetary return, but they still may prefer a system under which a number of fishing families can eke ont what, to them, is an adequate living of the kind they prefer. Becanse such fishing communities form the constitnencies of important elements in State legislatures, their. desire to maintain the status quo has a strong influence on fishing legislation and on regulations of State agencies.

The Commission recognizes that needed changes must be made, in the interest of simple equity, at a pace which does not compel individuals to leave an established way of life. Steps to improve fishery management should be carefully derised, tested prior to implementation, and applied in selected fisheries as they become ready for such action. The Federal (rovernment can assist by providing both opportunities and incen- 
tives to the states and regions to carry ont such programs.

The discussion above necessarily is couched in general terms with empluasis on economically sound principles of management. I number of more specific proposals to achiere the goal of improring fishermen's net economic return are discussed in the Report of the Commission's Panel on Marine Resources.

\section{Rehabilitation of U.S. Domestic Fisheries}

Steps to rehabilitate UT.S. domest ic fisheries cannot await the full implementation of the manugement principles adranced above, nor would such a systen of management fulfill all the needs of [.... industry. It would not. for example, derelop profitable IT.S. fishing operations on the huge underutilized stocks off' U.S. coasts.

The situation of the U.S.-flag fisheries stands in sharp contrast to the record growth of the world's high seas fisheries. Landings by I.S. ressels have remained ilmost constant over the past three decades, and during that period the United States has dropped from second to sixtly among the world's fishing nations. I.S. ressels land abont one-third of the total fish consumed in the United States and harvest less than one-tentl of the total production potential available over the [.S. continental shelf. Itthongh these are areas of successful performance-most notably in the tuna and shrimp fisheries-and although the [.S. catch is third or fourth if measmed by dollar value, the T.S. fishing

The V.s. fishing flect is. by and barge, technically outmoded. There he, houreter, such nolable: excenlions as the Preifie roast tuma flect. Purse seine ler is staclied on the tuma rliphere West Point, and the furue clipper. J. M. Martinac stund.s sul from Tacoma, IVashinglon.
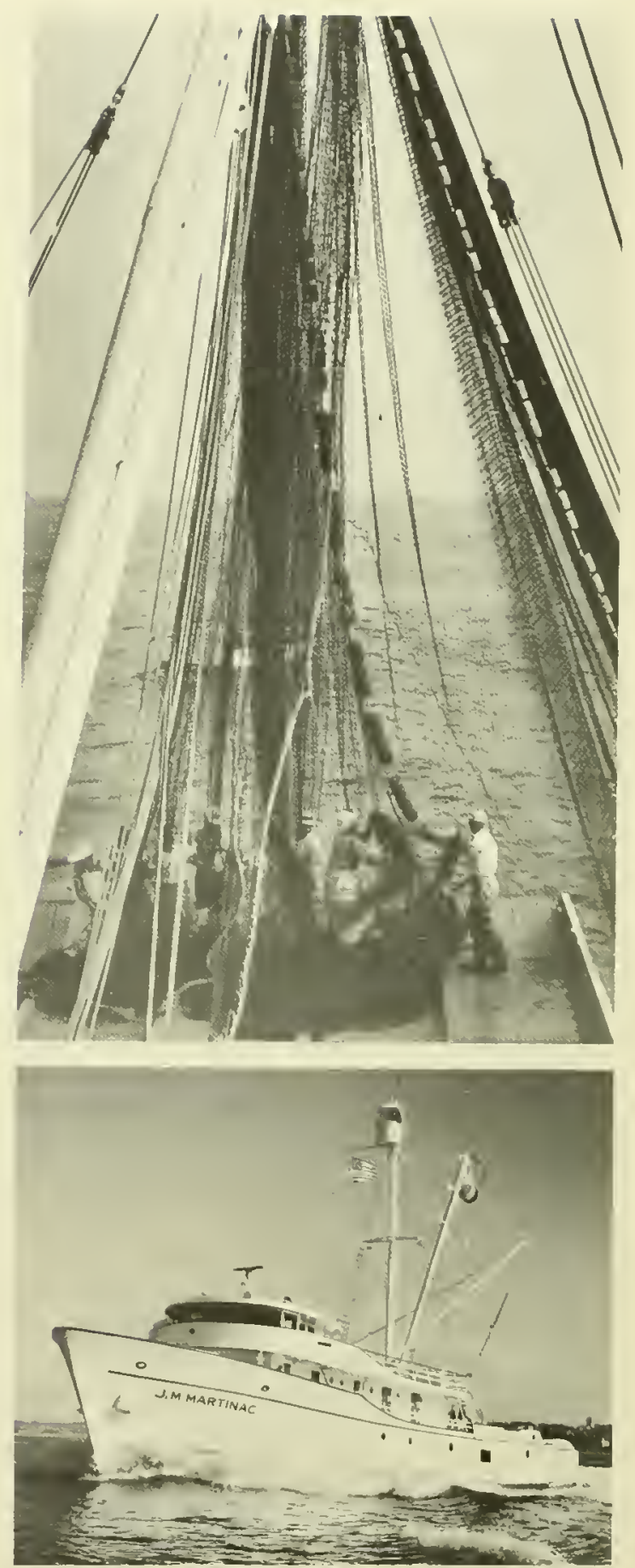
Heet by and lange is technically outmoded. It camnot mount the high seas effort required to maintain a position of world leadership, and it is incapable of attracting a stable and eflieient labor supply.

'The decline in the U.S. fishing industry is even more surprising in riew of the strength of domestic demand for fish and shellfish produets. Ilthough per anpita direct consumption has remained virtually stable over' the past 30 vears, population growth provides a contimously expanding maket, and L.S. agriculture has made extremely efficient use of the cost-reducing possibilities of fishmeal as an ingredient in livestock feeds. As a result, total L.S. consumption has risen sharply since 1950 , but all of the increase has been met by expansion of imports rather than increased domestic production.

There is no reason why the United sitates should be completely self-sufficient in fishery produets any more than in any other products. 'The argregate welfare of the fishing industry, including its processing and marketing sectors, and of the Imerican consumer dictate the desirability of purchasing marine products from the cheapest and best source. It is noteworthy that the two healthiest segments of the T.S. industry, the tma and shrimp operations, ale among the largest importer's of fish hut have also expanded the demand for domestic production.

The Conmission believes that important sogments of the [..S. fisling industry can be restored to competitive, profitable operation. 'To do so will necessitate overoming a complex of obstacles to efficient operation that have severely hampered the T.S. fleet eren in areas where IT.S. technology and capital should have given it a conpetitive advantuge.

\section{Federal and State Management Roles}

I major impediment is the welter of (a)tflicting, overlapping, and rest rictive laws and legulations applying to fishing operations in the United States. With jurisdiction ores fishery management and development langely in the hands of the states and witl lines of authority between State and Federal Gorermments ill defined, the responsibility for action is hopelessly splintered. Moreover, the tendeney toward parochialism in the individual States has led to a mass of protective legislation that militates against researeh, development, and innovation. Consequently, the fishing industry has been slow even to borrow useful techniques from other industries, much less to pursue a progressive program of its own.

In part, the difficulty reflects the pressures on the States to find some way to limit the take from overexploited fisheries without excluding any of the participants. The inevitable result has been rules which increase cost, are awkward to administer, and are cumbersome to enforce. But this is not the whole difficulty. Although fish miglate freely across State lines, the Commission was umable to identify a single instance of systematic programs being prepared jointly by two or more States for the management or development of their fisheries resonces. Rather, Nitate laws are a patchwork which lead to confusion and enconrage violations. Lobsters too small to be landed legally in Massachusetts may be sold in Rhode Island. The waters of the Chesapeake Bay are partly in Vircinia, partly in Maryland. Athough the fish fol the most part are miglatory and move freely from one State to another, the basic management philosophies and fishery laws of the two States ditfer in sereral fundamental respects. Even the oyster industry would benefit from modemization and coomdination of the States laws, lut few States have reviewed their fishing laws to eliminate outmoded and conflicting provisions. 


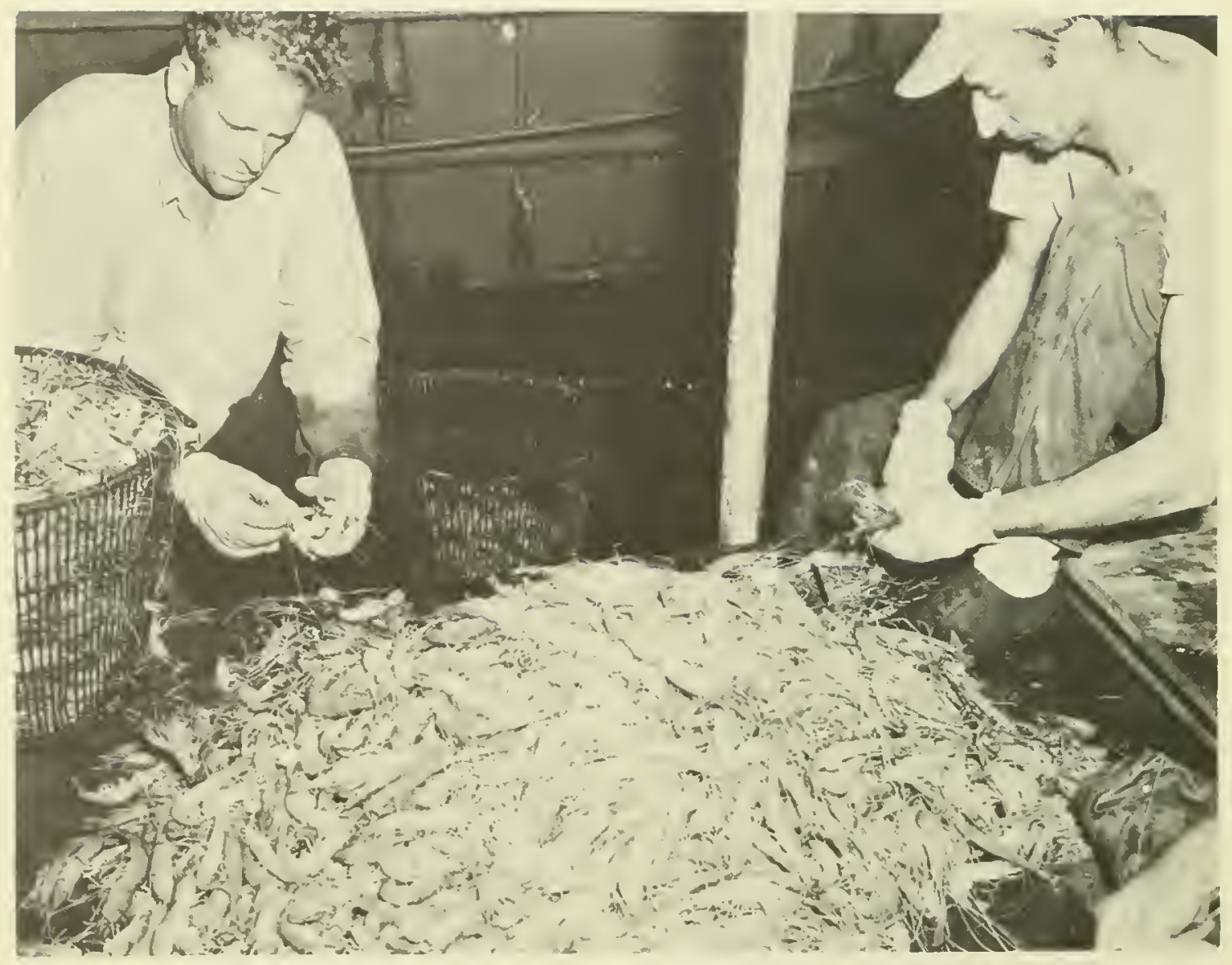

The Nation's sucecssful shrimp industry contributes signifieantly to the tolal dockside value of liting and nonliving marinc resourecs 1 akcn from the contincntal shetf and uaters adjacent to the United states raeh year.

Interstate conperation in fisheries has been relatively unsuccessful. Three interstate commissions exist-the Atlantic States, Gulf States, and Pacific Marine Fisheries Commissions. But none has regulatory powers nol' adequate staff. Their function is to exchange information on common problems and to recommend legislation and administrative action to the executive and legislative branches of the member States.

Under existing statutes, the Federal (rov- ermment has no explicit role in the management of fisheries within U.S. territorial waters. In riew of the discouraging lack of coordination among State programs, the Commission conclndes that Federal leadership and guidance-and when necessary, regulatory power-must be asserted.

The Commission recommends that the National Oceanic and Atmospheric Agency (BCF) establish national priori- 
ties and policies for the development and utilization of migratory marine species for commercial and recreational purposes in cooperation with other Federal agencies, States, and interstate agencies.

The National Oceanic and Atmospheric Agency (BCF) should encourage interstate cooperation for regulation and conservation, sponsor research on the impact of institutional barriers inhibiting the efficient development of our commercial fisheries, and encourage enactment of improved State laws relating to the regulation and conservation of such fisheries. The Federal Government also should reorient its own fisheries research and survey activities in support of specific fisheries missions.

The measures proposed above should strengthen the U.S. fishing industry and improve the fisheries programs of the various States. However, the Commission anticipates that these measures alone may be inadequate to meet the development and management needs of certain fisheries.

The Commission recommends that the National Oceanic and Atmospheric Agency (BCF) be given statutory authority to assume regulatory jurisdiction of endangered fisheries when it can be dem. onstrated that:

- A particular stock of marine or anadromous fish migrates between the waters of one State and those of another, or between territorial waters and the contiguous zone or high seas, and

- The catch enters into interstate or international commerce, and

- Sound biological evidence demonstrates that the stock has been significantly reduced or endangered by acts of man, and
- The State or States within whose waters these conditions exist have not taken effective remedial action.

\section{Vessel Subsidy Program}

Althongh the U.S. fishing fleet is the world's second largest, about 60 per cent of the vessels are over 16 years old and 27 per cent have been in service over 26 years. Some fisheries, like tuna, shrimp, and Alaska king crab, have fairly modern fleets, but advances in fishing technology during the past few decades have made most of the U.S. fleet economically, if not physically, obsolete.

Important obstacles to building a modern U.S. fishing fleet are existing laws on registration of fishing vessels and on the landing of fish in U.S. ports. Under one of these laws, U.S. fishermen are unable to register foreignbuilt fishing vessels; another prohibits the landing of fish in U.S. ports directly from fishing grounds unless landed in U.S.-registered vessels. In combination these laws effectively prevent our fishermen from taking advantage of lower foreign shipyard costs.

Rather than remore the vessel registration limitation, Congress enacted a vessel construction subsidy act. But the subsidy lias not achieved its objectives. A provision requiring a finding that the grant of subsidy not cause economic hardship to others in the fishery has resulted in denial of subsidy to those parts of the industry most in need of aid to modernize their fleets. Because there is no provision for retiring obsolete ressels, the program has operated in other cases simply to add to the problems of fisheries already heavily overburdened by excess capacity. Statutory limitations on annual expenditures prevent approval of all qualified applications, and the subsidy generates new inequities as it corrects old ones. 
The Commission recommends that legislation be enacted to remove the present legal restrictions on the use of foreignbuilt vessels by U.S. fishermen in the U.S. domestic fisheries.

If the recommended action is not taken, the ressel construction subsidy program should be expanded and used to modernize segments of the U.S. fisheries that conld then compete effectively with foreign producers. This would require, however, modification of the present program as outlined in detail in the Report of the Panel on Marine Resources.

\section{Research and Technical Programs}

The Bureau of Commercial Fisheries historically has placed greater emphasis upon biological research than on exploratory fishing and gear development. The Bureau spends nearly $\$ 20$ million annually on general life histories, on investigations of the environment, on effect of enviromment on the availability and distribution of resources, and on management theory. By comparison, between $\$ 600,000$ and $\$ 1.5$ million has been spent annually on exploration, and less than half of that amount has been devoted to gear development. These funds, furthermore, have been so committed to continning, geographically dispersed projects that the Bureau's ability to mount new programs has been restricted severely. Consequently, it has not been able to provide industry with the assistance necessary to keep pace with the rapid strides in fishing efficiency so evident in other major fishing nations.

It is essential that the National Oceanic and Atmospheric Agency (BCF) concentrate its efforts on areas and species which offer the greatest opportunities for successful economic expansion. These might include midPacific tuna, demersal and other fish and shellfish resources in the Gulf of Alaska, an- chovy off the southern California coast, clupeids in the Gulf of Mexico, alewives (and their predators) in the Great Lakes, and Pacific hake. Development in these highpotential fisheries can be profitably pursned along well-defined lines:

- Surveys and exploratory fishing programs to establish the potential of latent stocks

- Basic biological studies to provide a basis for yield assessment

- Development of new harresting techniques and strategies

- Development of more efficient methods for processing and handling fish products, including quality control and increasingly diversified product ntilization.

The Commission recommends that the National Oceanic and Atmospheric Agency (BCF) analyze each major fishery and develop integrated programs designed to exploit those fisheries where opportunities for expansion exist.

Research and Surveys Despite a substantial effort extending over many years, knowledge of the stocks available off U.S. coasts and of the factors determining their yield is far from adequate, particularly for relatively low-valued species. A key need in developing new fisheries is for an exploratory effort to establish the dimension of the resources which U.S. fishermen can reasonably expect to harvest profitably.

Such an expanded survey program must be Govermment supported. No single fishing enterprise or group of fishing enterprises could afford to undertake this work because of the high cost of the operations required and becanse they could not expect to capture more than a small proportion of the economic bellefits generated. 


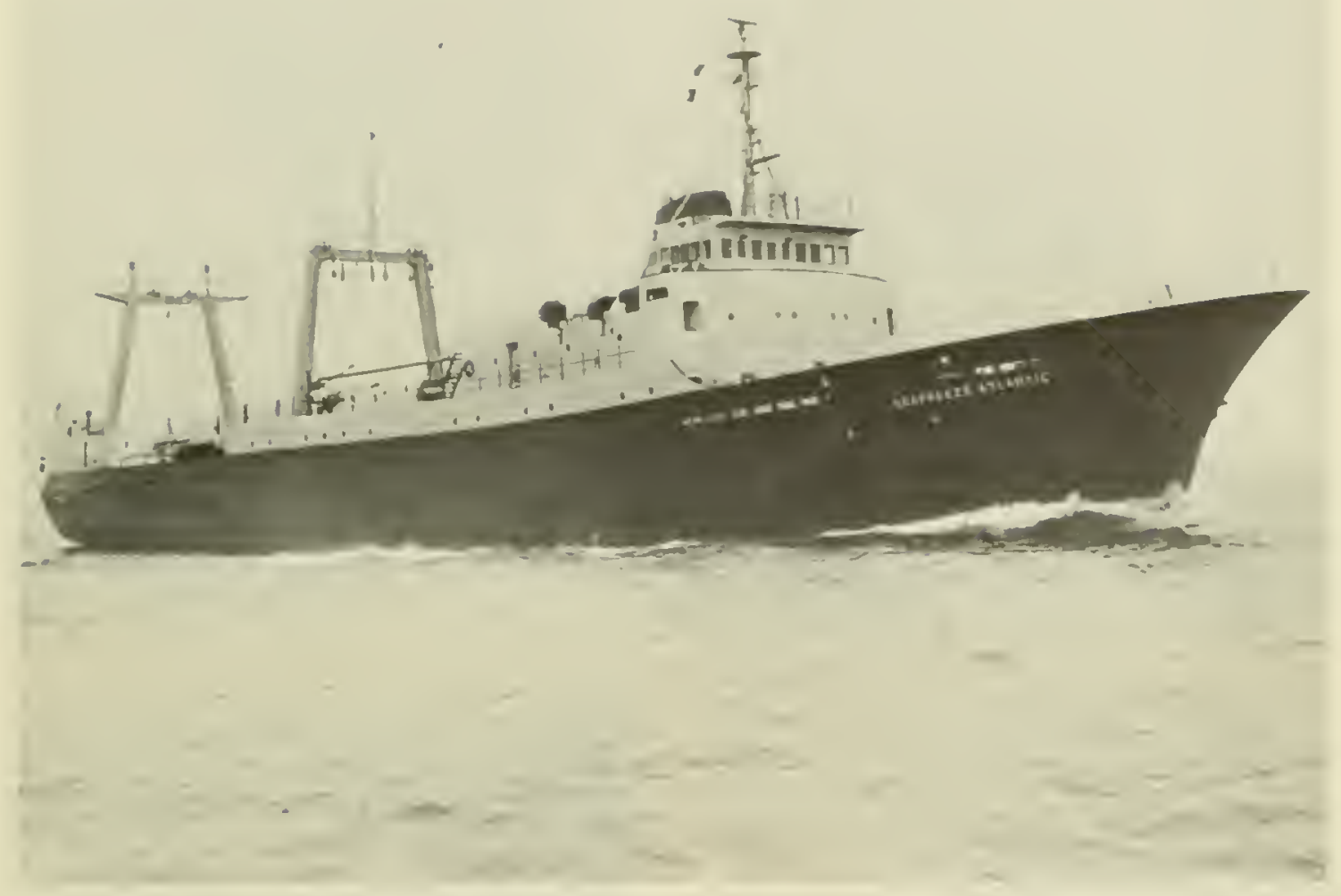

The I.S. Goternment assisted in construetion of the 297-foot, 3,121-10n frecace stern trauler Seafreeze Atlantic and her sister ship the Seafreeze I'acitic under the 196: Fishing Fleet Improvement Act. 'thristened in 196s, they are the largest in the U.S. fishing flect.

The program is needed also to establish the basic datum for managing fish resources on a rational lasis. Only lyy delineating resonrce potentials can orerfishing be detected before the damage is done and new fishing gromnds he inlentified to relieve the pressures on the old.

The speed with which potential fishing areas ("au be systematically evaluated depends on funding, persomel, the avilability of ship time. and the efliciency of smvey technirues. I smrey program which gives priority to species and aleas in which. U.S. ressels might have a strong rompetitive advantage has been ontlined for the Commission by the Bureau of Commercial Fisheries (BCF). By adding 11 cluartered ressels to its fleet, BCF could map conpletely the gromolfish and shellfish resources of the U.S. continental shelf and complete preliminary work on pelagic and midwater fisheries within 10 years. The ('ommission endorses this proposal.

Sinveys and exploratory fishing designed to reveal potentially exploitable stocks must be accompanied by basic studies in population dyumics in order to evaluate the long-term value of a new fishery. The abmatance of the 


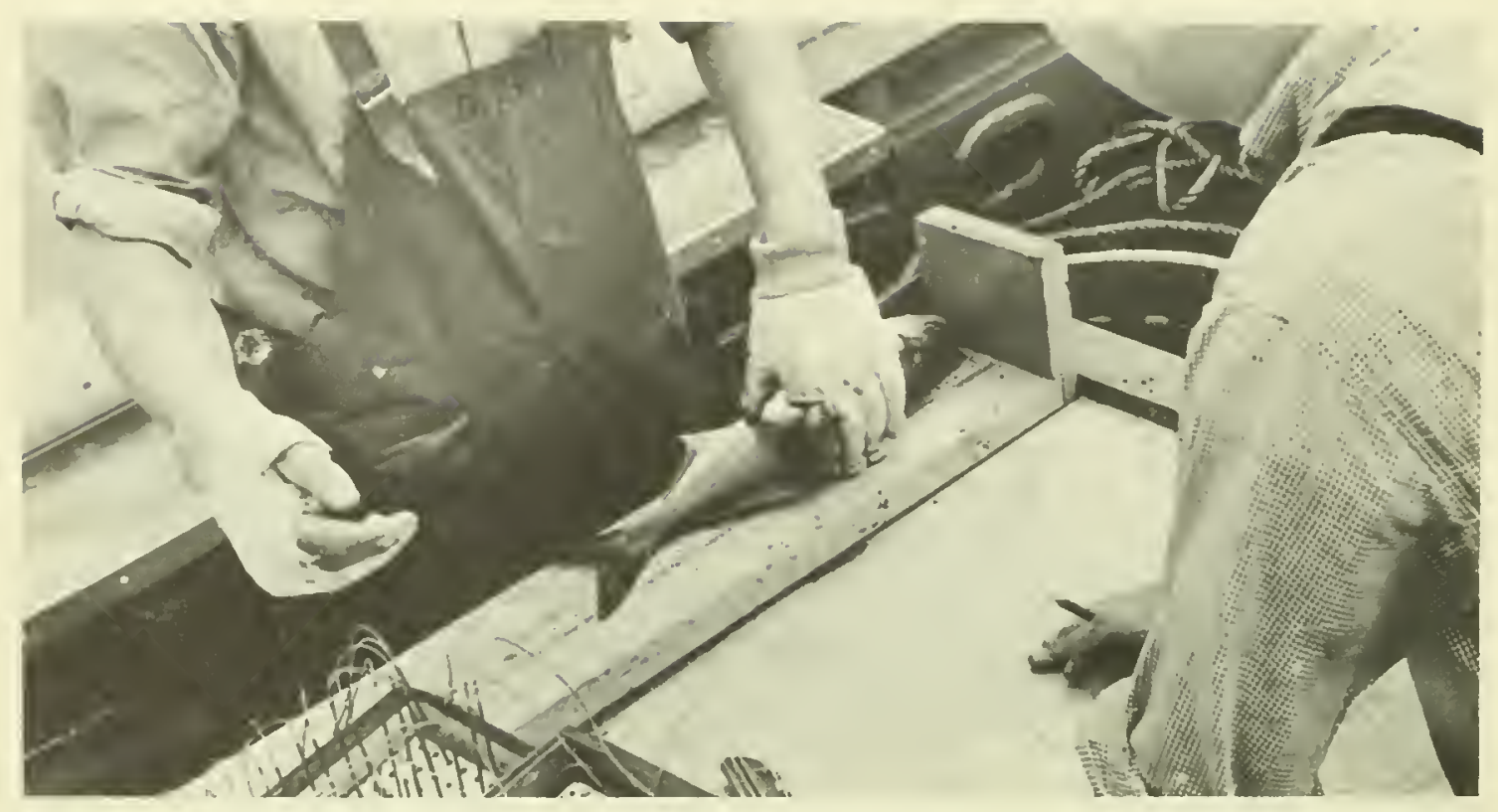

Scientific urork to cstablish the biological basis for sustainable yielt estimates necds to be coupled with cxploratory fisherics rescareh, like that being undertalicn by the Bureau of Commereial Fisticries new $\mathrm{R} / \mathrm{I}$ Oregon II. In the top photograph, bluefish are measured and tagged off the New Jersey coast.

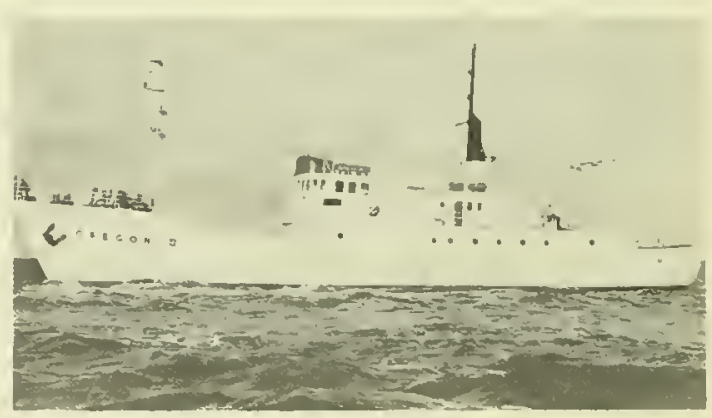

The Commission recommends that the National Oceanic and Atmospheric Agency $(\mathrm{BCF})$ :

- Develop means for rapid assessment of fish stocks

- Conduct surveys and exploratory fishing programs to identify and establish the dimensions of latent fisheries off the U.S. coast

- Continue to support basic studies relating to fish habitats, population dynamics, and the effects of environmental 


\section{conditions}

- Give priority attention to development of improved statistical data and analytic techniques.

\section{Technical Programs Improvement of con-} ventional fishing gear and the use of equipment developed in other countries ofler' opportunities for cost reduction in U.S. fisheries. BCF's resign and ronstruction of a large midwater trawl, conpled to a simple but highly affective electronic sensing device, provided the necessary first step toward a potentially large new hake fishery. Development of a rapirly sinking purse seine that will take snch fast-swimming fish as skipjack tmin promises to open new opportmities for tumal ressels. I'.S. ressels latre hardly benun to use the varions types of conrentional sonar gren already standard aboard many foreign fishing vessels. Work on a selective shrimp trawl that would reject most of the trash fish while protecting the quality of the desired catch promises more economic production of pandalicl shrimp.

luvestigation of more radical approaches to fisheries problems also is a legitimate and important part of a balanced program to rehabilitate the [.S. fisheries. Intriguing possibilities exist to agregate fish into areas where they conld be taken by highly efficient, mechanized harresting systems; marine resources miglit be tapped at lower trophic levels and their high protein value put to practical use. Adranced dati handling systems, coupled with systems to detect and forecast productive fishing areas, might reduce the time which fishermen must spend hunting for harvestable fish schools by as much as 50 per cent.

The Commission recommends that the National Oceanic and Atmospheric Agency (BCF) establish an expanded program to develop fishing technology by improving the efficiency of conventional gear and developing new concepts of search, detection, harvesting, transporting, and processing.

Details of a recommended program are set forth in the Reports of the Conmuission's Panels on Marine Engineering and Technology and on Marine Resources.

Extension Services The best research and teehmology development will be of no avai] if not put to effective use. The fragmented character of the I.A. fisling industry and the large number of independent operators aceustomed to established fishing techniques pose a considerable challenge to any technology transfer program. Yet the Commission believes such a program to be a vital complement to the strengthened scientific and technical effort which it has proposed, and it urges early action to estab]ish appropriate extension activities.

The Commission recommends that fisheries extension services, analogous to the Agricultural Extension Service, be established in order to facilitate transfer of technically useful information to fishermen at the local level.

The Sea Grant Program and the State Technical Services Program of the Department of Commerce can provide some of these services. Also, the Intergovermmental Cooperation Aet of 1968 (P.L. 90-5Ti) provides general authority for the Federal Goverment to assist State and local governments in their technical service activities. We would expect the proposed new agency to survey the existing needs in this area, examine the extent to which current programs are adequate to such needs, and take appro- 
priate measures through the Sea Grant or other programs to bring concerted attention (1) the transter of information to fishermen.

\section{Fish Protein Concentrate}

I program is mnderway to perfect low-cost commercial processes for the production of fish protein concentrate (FPC) as one eleanent in the attark on the worldwide problem of animal protein deficiencies. Inwever, il anmber of serions misunderstandings about the mature of the program still exist, as do a number of discontaging obstacles to largesoale prorhutions.

The telm fish protein concentrate covers a liuge family of porducts, some already weed in large quantities while others remain in the embryonice stage. Fishmeal nsed in livestock feed is a form of fish protein conrentrate. World production of fish protein concentrate in this form has grown fom about 500,000 tons in 196 it to more than 4 million tons in 1966.

The objective of the present Federal FPC program is production of a concentrate that can he used als a protein supplement in soups. breads, and beverages for direct human consumption. 'This use reruires a substantially' la roer redurtion in oil content and in certain other types of undesired elements and more stringent sanitary standards than are reruired for fishmeal production.

Thus far, research and development efforts by both I.S. industry and the Federal Govermment have concentrated on prodncing a tasteless, odorless commodity that conld he stored orer long periods of time, could be transported cheaply, could orcreome aesthetic objections, and conld lave the widest range of uses as a dietary supplement. The research eflort has concentrated on processes using such lean fish as hake that are readily avilable and lend themselves to the production of the desired kinds of concentrate.
Tastes vary throughout the world, and many different kinds of fish protein concentrate ultimately will be developed to meet the demand. There is no fixed degree to which taste and odor must be remored or grittiness reduced. The keeping qualities of the product need not be miform, and the product will not be consumed in the same form all over the world. The rery high standards initially established as a research goal may not need to be followed in the production of all kinds of fish protein concentrate for all purposes.

FPC will find its most important use as a dictary supplement in areas of the world where consumption of proteins, especially mimal proteins, is chronically below minimum nutritional requirements. Unfortunately, these are the very areas where sophisticated market derelopment techniques and organization are searce and where demand for a tasteless, odorless, colorless dietary supplement is particularly difficult to develop. It is likely, therefore, that FPC will be used to alleviate protein malnutrition through institutional feeding programs, supported by govermments, for some time to come.

The United States has mdertaken to supply limited ruantities of FPC to foreign countries through the Agency for International Development. This commitment may be very difficult to fulfill, for neither industry nor BCF has ret resolved all the technral problems that stand in the way of commercial production at competitive prices. Both of the processes approved by the Food and Drug Administation still require the derelopment of a technique for efficicnt recovery of the solvent used and less dematuration of the protein to permit more flexilulity in blending with formulated foods.

There are no insuperable barricrs, but the ludget of the FPC program must be increased sufficiently to carry through its present plans, adapt the initial concentrating 

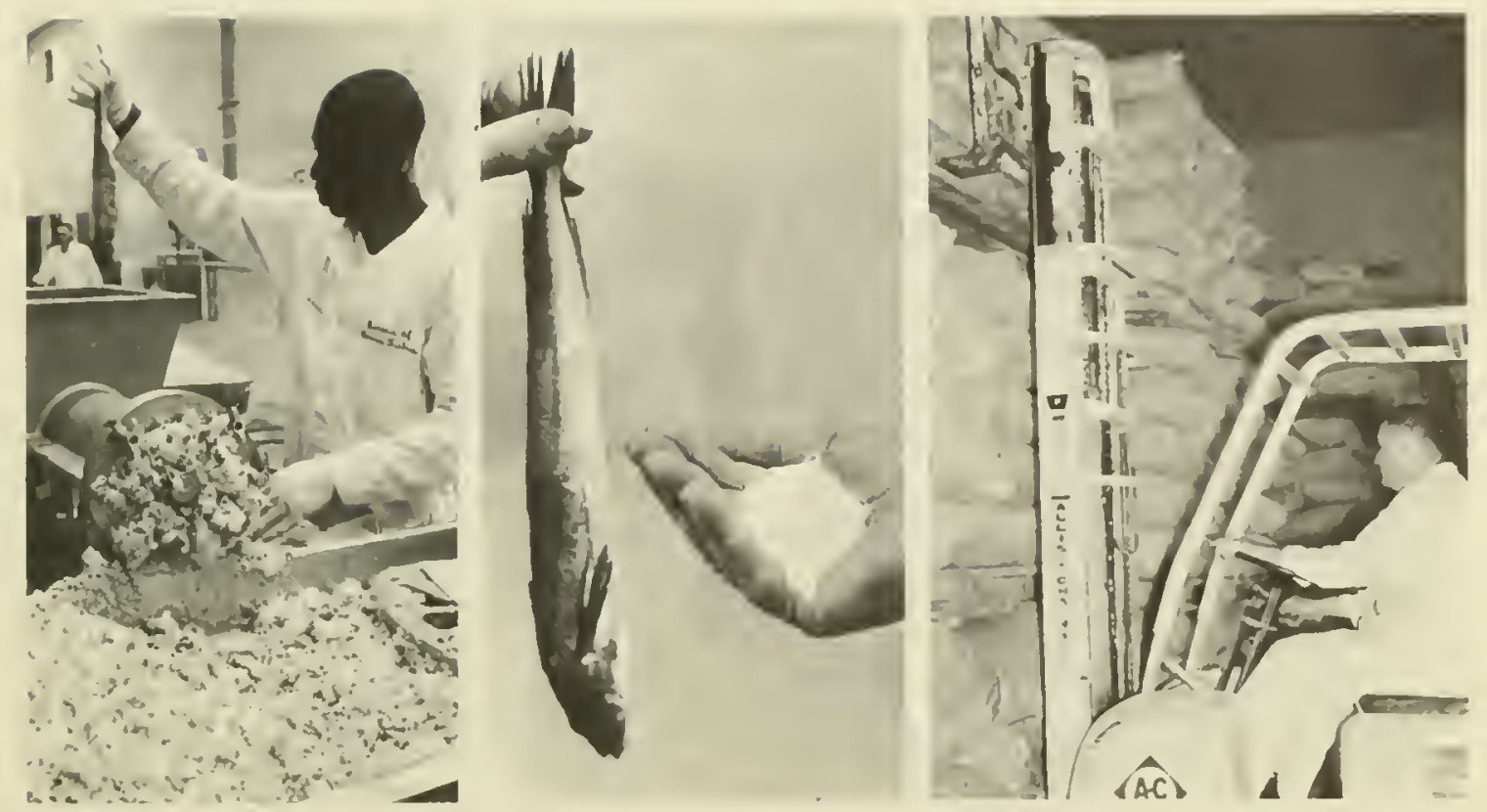

Nive monds of fish, like the Allanlie red hake, will produce one pownd of fish protrinconernirate (FPC). In terms of world consumption, Ihe most importanl use of FPC is likely to be as a dielary supplement in areas uhere proteins are below minimum nulrilional requirements.

process to fatty fish, and investigate other production methods.

The Commission does not regard the FPC program as a major element in rehabilitation of the [.S. fishing industry at this time, although it may stimulate some new fishing activity for hake, thread herring, anchory, or other latent or nuclemtilized species. I.S. firms participating in the T.S. Government development program shonld be best able to realize the potential of FPC technologr: In the inmediate future, their lost opportunities will he in the establishment of processing plants in regions throughout the world where the neer for FPC is the rreatest and rheap supplies of fish are avilable. Itowerer, the Commission reeornizes that in future years it may become economically feasible to produce FPC domestically for domestic consumption and for export.

The Commission recommends expanded support for the National Oceanic and Atmospheric Agency (BCF) program to develop fish protein concentrate tech. nology.

Emphasis should be placed on achieving more effective collaboration with industry s) that ['. bringing adranced FPC technology to bear on production problems and in dereloping commercial markets for virious types of FPC. Is requirements dietate, the Inited states should be prepared to assist in under- 
writing the use of FPC in institutional feeding programs.

\section{International Fisheries Management}

Any intermational legal-political framework for exploiting the living resources of the oceans must be judged by the extent to which it achieres the following objectives:

- It must encourage the development of the rast fond reserves of the sea at the lorrest possible cost in order to combat world hunger and maluutrition.

- It must promote the orderly and economically efficient exploitation of these living resources, with adequate regard for their conservation.

- It must not provole international conflict but rather contribute positively to international order, welfare, and equity.

The Commission concludes that the existing framework is seriously deficient when judged by these standards.

\section{Existing Framework}

Each coastal nation, unless limited by treaty, has the right of permanent, exclusive access to the living resources found in its internal or territorial waters and contignous fishing zone as recognized in international law. The freedom of all nations to fish on the high seas is one of the freedoms specified in the Convention on the High Seas. Nevertheless, this freedom is beclonded by the extrayagant claims made by a few nations with respect to the breath of the territorial sea and the exclusive fisheries zone. It also is limited ly bilateral and multilateral treaties and agreements and is restricted by the constal nation's right of exclusive access to the living, sedentary species on the continental shelf.

The Truited States is a party to the worldwide Convention on Fishing and Conservation of the Iiving Resonces of the High
Seas and to the following five multilateral fishery agreements which are more limited in scope-the international conventions for the Northrest Atlantic Fisheries, High Seas Fisheries of the Nolth Pacific Ocean, Conservation and Protection of North Pacific Fur Seals, and Inter-American Tropical Tuna and the International Agreement for Regulation of Whaling. The United States also will be a party to the International Convention for the Conserration of Atlantic Tuna, which is expected to come into force before 1970 .

The United States and Canada are also parties to three bilateral conventions-Preservation of the Halibut Fishery of the Northern Pacific Ocean and Bering Sea; Protection, Preservation, and Extension of the Salmon Fishery of the Fraser River System; and Great Lakes Fisheries. In addition, the Inited States has agreements with Japan atfecting king crab in the North Pacific and other tisheries in waters adjacent to U.S. coasts; with the Soriet Union affecting king crab and other fisheries in the North Pacific and fisheries in the western mid-Atlantic Ocean; and with Mexico on certain fishing matters of common interest.

The United States also belongs to a number of Tnited Nations organizations, principally the Food and Agriculture Organization and certain of its subsidiary bodies, the Intergovernmental Oceanographic Commission, the U.N. Development Program, and the Irorld Bank, which play an active role in the derelopment of commercial fisheries all ovel the world.

It is difficult to estimate the value of the T.S. catch of fish and shellfish in areas governed by international fishery conventions to which the Enited States is a party. But it accounts for an appreciable portion of the value of the total U.S. catch and is growing 
in importance. Moreover, the fishery conventions also atlect I..S. imports from the areas covered hy the conventions, a portion of which mily be accomted for by IT.S. companies operating muler foreign flags.

\section{Evaluation of Existing Framework and Recommendations}

The Commission has considered and rejected the following principal alternatives to the existing framework which have been proposed to govern exploitation of the living resources of the high seas:

- To give each coastal nation permanent exchusive access to the living resources of the waters superjacent to its continental shelf.

- To give the United Nations, in the name of the international community, title to the living resources of the high seas beyond the 12-mile fisheries limit so that it may cither operate the high seas fisheries itself or auction to the highest bidders exclusive rights to exploit specified stocks of fish or specified areas of the high seas.

These alternatives are discussed in the Report of the Commission's International Panel.

The Commission conchudes that U.S. objectives regarding the living resources of the high seas can best be attained by improving and extending existing intermational arrangements. in the development of which the Inited States has participated for more than i) vears.

\section{National Catch Quotas \\ for the North Atlantic Cod and Haddock Fisheries}

The dominant objective of practically all the fishery conventions is to maintain the maximum sustainable vield of the fish stocks muker their gorernance. We have previonsty stressed the inadvisability of regarding this biological result as the only aim of international fisheries management and urged that, at the least, such management should not make it impossible for fishing nations to conduct profitable operations.

The Commission concludes that fixing national catch quotas is a promising way to make it possible for participating nations to improve the profitability of their operations in certain important fishing areas of the world. We do not suggest that a national catch quota system should be instituted immediately in every high seas fishery. It should be attempted first where it is most likely to succeed, and its effects should be assessed before it is more widely used.

The cod and haddock fisheries of the Northwest Atlantic are ripe for such an attempt. Fourteen nations, including the Enited States, adhere to the International Convention for the Northwest Atlantic Fisheries (ICN.IF). Moreover, many fishing fleets in the ICNAF area also operate in the area governed by the Northeast Itlantic Fisheries Convention (XEAFC), to which 13 nations. but not the [nited States, belong. Nine countries are parties to both conrentions. Consequently, adoption of national catch quotas for the ICX $\perp F$ area alone conld increase fishing pressure upon the NEAFC area. which also faces a grave situation, and vice versa, nullifying any potential economic gain from national cateh ruotas for fleets operating in both areas. For this reason, the proposed quota system must embrace the cod and haddock fisheries of the entire North Atlantic.

The Commission recommends that the United States seek agreement in ICNAF to collaborate with NEAFC in fixing a single annual overall catch limit for the cod and haddock fisheries of the North Atlantic, including the whole ICNAF area 


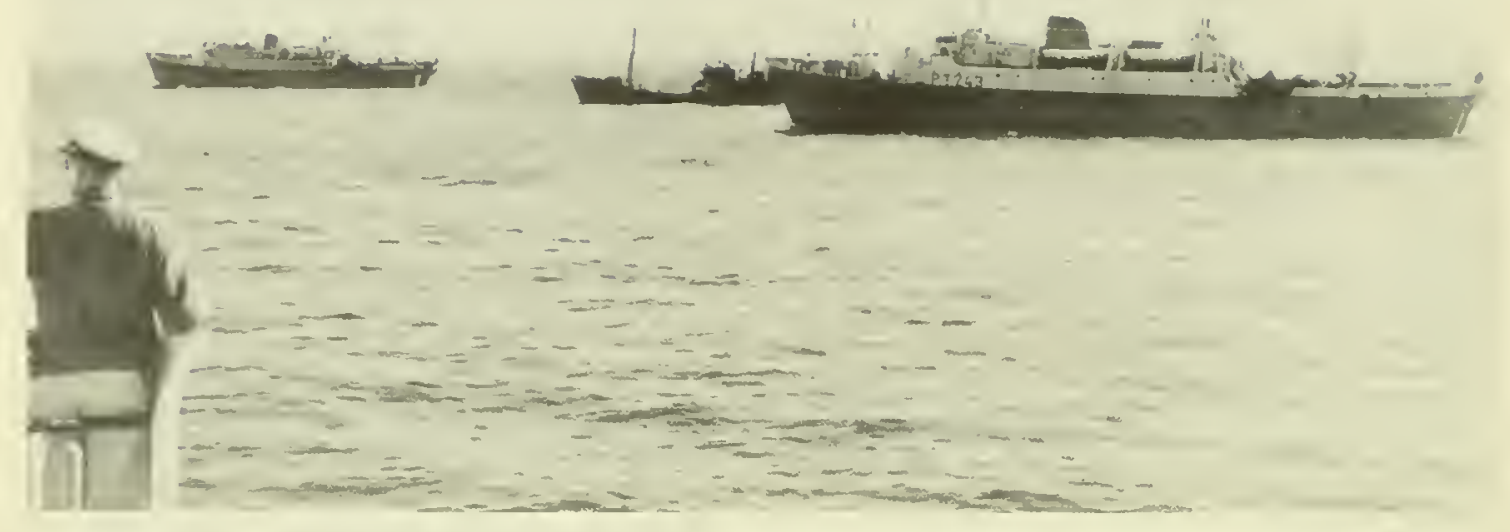

Fourteen nations, ineluding the United States, adhere to the International roncention for the Northuest Atlantic Fisheries. The United States faces strong competition from the Soviet fishing fleet in this area.

and Region 1 of the NEAFC area (East Greenland, Iceland, and the Northeast Arctic). This single annual overall catch limit should be designed to maintain the maximum sustainable yield of the fishery and, in turn, should be divided into annual national catch quotas. The overall catch limit should be adjusted regularly to take account of such factors as yearclass fluctuations of the stocks, recovery of the stocks due to conservation measures, and errors in setting prior limits.

Every participating nation should be authorized to transfer all or part of its quota to any other nation.

The idea of national catch quotas is not new. Such quotas in a variety of forms are now used by the United States and Canada in the salmon fishery of the Fraser River system; by the United States, Japan, and the Soviet Union in the agreements relating to king crab; and, in effect, by the United
States, the Soviet Union, Canada, and Japan in the conservation of North Pacific fur seals. There also are various informal international agreements fixing national catch quotas to which the United States is not a party.

Catch quotas wonld satisfy the felt needs of the nations participating in the cod and haddock fisheries of the North Atlantic. At the high level of fishing intensity reached duriug 1962-65, mortality in these fisheries exceeded limits that would maintain the maximum sustainable yield. Indeed, a reduction in total fishing effort of 30 to 40 per cent in the case of some stocks and of 10 to 20 per cent in the case of others would sustain the catch over the long term and perhaps even increase it. If total effort in these fisheries is reduced 10 to 20 per cent, it is estimated that aggregate annual sarings of $\$ 50$ to $\$ 100$ million can be realized by all participants.

The position of the United States in these fisheries is particularly serious. Because of 
heary catches of haddock by the soviet fishing Ifeet and the limited mobility of the I.s. tlawlel lleet, the I'nited States has suflered declining catches. It is estimated that the maximum sustainable catch of Georges bank hadklock (an be taken with a shally] y reduced fishing etlort which, in the long run, would increatse the arelate catch per unit of effort by alout bo prer" (ent ovel the 196;:-6it level.

let a sturly he the ()ronization for lemonic (oopreation and l)evelopment ( () Ie(1)) inclicates that, if nothing is dome to recluce it. fisling edlort in the North Atlantic may further increase by as muel as 15 to 30 pel cent by 1!70. This polnaly will result in a decrease in the total catch as well as reduction in the eatch per unit of effort.

ICX.AF has discussed the idea of national "atch runtas since 196\%. The irlea was endorsed and elaborated in 196i by an ICX.IF Working (ronp on . Joint Biological and Eeonomic Issessment of Conservation Aetions. I standing Committre on Regulatory lleasures rontinmes to examine its economic and administrative aspects. It ICX IF's 1968 meeting, the l mited states proposed the estalblishment of national catch quotas as an appopriate solution of the eritical problems facing the North Atlantic fisheries. ICNAF is still studying the matter.

The ICX.LF Working Group concluded in 196it that a system of national eatch quotas was teasible and enforceable. The Working Group recognized fully that greater benefits comld be olstained if each seprable eod and haddock population could be managed as in independent unit. It conld not, however, rlevise any enforcenble procedures of this type, since there is no way of identifying the area of capture with sulfirient accuracy.

The fixing of lutional catreh puotas does not gualantee that each nation participating in the fisheries will actually realize the reonomic gatins matle possible ly the quot: system. If a nation does not restrict its fishing units to the minimum number reguired to take its quota over a prolonged period of time and if each of these units is not of maximum efficiency, it will clissipate the potential gains. Fol example, the ICNAF Working (xpoups study of IT.S. operations on Georges Bank haddock revealed that if the number of fishing days per ressel were reduced by 30 per cent, leaving unchanged the number of ressels and manpower clevoted to the fishery, only very small long-term benefits would be achieved by eatch quotas and short-term losses would be inflicted on both ressel owner and crew. But if the injut of capital and labor is curtiiled to allow full ntilization of the remaining fishing capacity, an immediate and substantial improvement of the economic situation is certain, and, in the long l'un, the industry would hecome highly profitable.

To assure that each nation rationalizes its fishing effort, it has been proposed that ICNAF directly allocate to each participating nation the maximum amount of fishing efiont that it may derote to the fisheries in question, making certain that the total amount of fishing ettort allocated will maximize the net ecomonic return from these fisheries.

There ale both practical and policy objections to this alternative. Is a practical matter, it is presently impossible to derise a workable proerram to restrict fishing effort directly. Total fishing effort is a function of many factors-the number of ressels emphoyed their size, power, and type of gear: the number of hours spent in fishing and the particular season and grounds fished. 'To date. there is no internationally aceepted mit of fishing effort which combines all these filcors. Fven if there were, it would be virtually impossible to enforee direct limits on the anomut of fishing, particularly the 
number of hours fished by vessels fal from lome.

Furthermore, the variations among comntries of fishing methods and economic and social conditions produce different cost structures and market preferences which make it difficult to determine objectively at what level of total fishing effort the maximum net eeononic return would be obtained.

Even if these difficulties could be surmounted, this alternative would be undesirable, because it would force every nation participating in the fisheries to adopt maximization of net economic return as its domestic policy. By contrast, the recommended national catch quota system will enable each uation to use its quota in the mamner it rlecides is best suited to its internal conditions. It may seek:

- To maximize its net income from the fisheries

- To prerent serions memployment in fishing communities with no viable alternative

- To provide fish at the lowest possible price to collsumers

- To improve its balance of payments

- To pursue two or more of these aims in rarying degrees.

The Commission recommends that the United States take advantage of the opportunity presented by a quota system to rationalize its fishing effort in the North Atlantic.

We have previously discussed the problem of rationalizing L.S. fishing efforts generally, and this discussion also is applicable to C.S. participation in the North Atlantic cod and haddock fisheries.

\section{Early Consideration of National Catch Quotas for High Sea Fisheries of the North Pacific}

The problems confronting the nations participating in the North Atlantic cod and haddock fisheries are not mique. The situation in the North Pacific is rapidly approaching that of the North Atlantic.

The Commission recommends that early consideration be given to instituting national catch quotas for the high seas fisheries of the North Pacific.

Canada, Japan, and the United States adhere to the International Convention on the High Seas Fisheries of the North Pacific (INPFC). The recommended quota system would help to resolve the impasse over the abstention doctrine that confionts INPFC.

INPFC is the only fishery convention in which member nations agree to abstain from fishing for specified stocks of fish (salmon, halibut, and herring) in specified areas of the high seas. The abstention principle has been strongly adrocated by the United States and justified on the ground that the nation through whose investment a high seas fishery has been developed, and through whose regulatory efforts (and consequent restraints upon its fishermen) it is being conserved, should have priority in its exploitation and, if the stocks are being fully utilized, even the right to exclude other nations which made no similar contributions to the fishery. In the case of Pacific salnon, for example, the United States maintains that it has restrained its own fishermen for more than 50 years and spent hundreds of millions of dollars for pollution control, fish ladders, fish hatcheries, artificial propagation, and research to protect and enhauce the salmon population.

The abstention doctrine has been attacked on many grounds. While it is ac- 


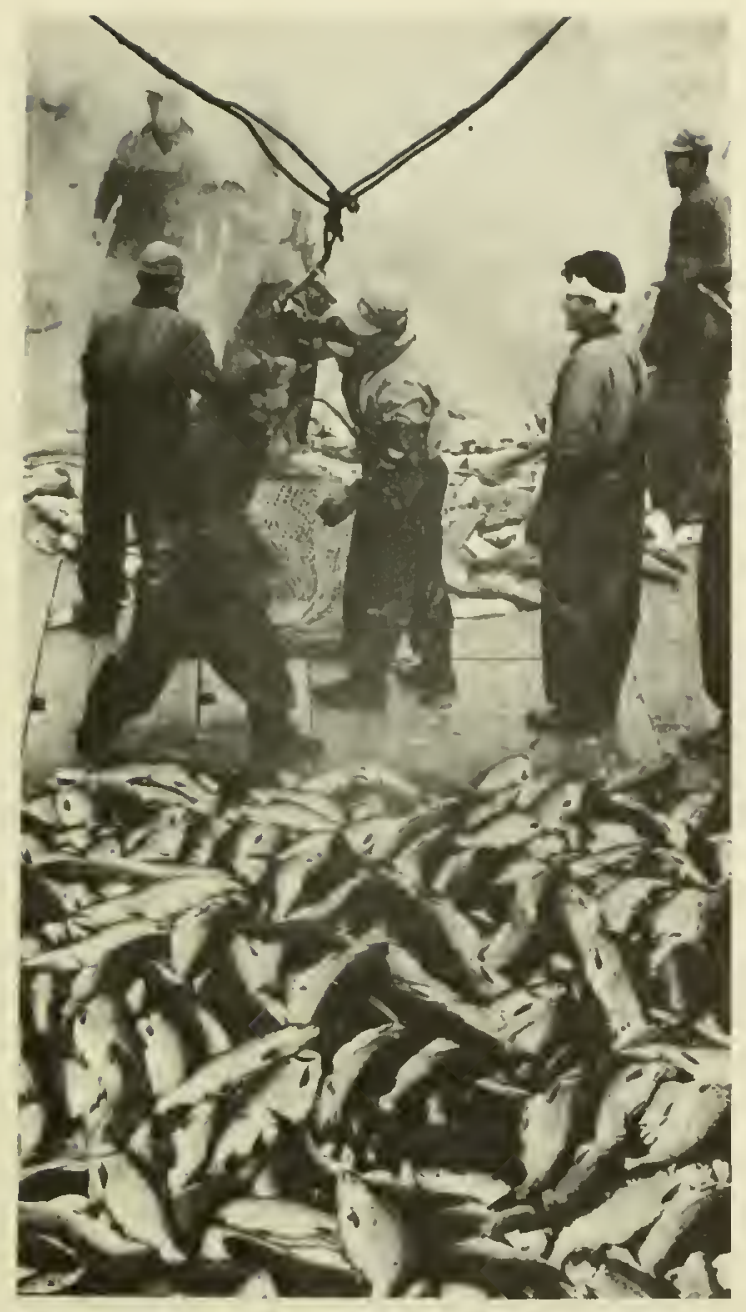

Fishermen from Japan, a parly to the Intermational. Concention on the IIIgh Seas Fisheries of the North Pacific, land salmon on a florting cannery in the Pacific.

knowledged that a nation which keeps its fishermen from depleting a resouree has an equitable claim to the cooperation of all other nations in its conserration efl'orts, it is denied that it also has an equitable claim to exclusive aceess to the resomree. The latter claim, it is argued, seeks to preserve a status quo that diseriminates against the derelop- ing nations and that confliets with the freedom of the high seas.

However the equities may be judged, it is most unlikely that the abstention doctrine will be aceeptable as a means of excluding new entrants from fisheries already being exploited fully. The doetrine was rejeeted when the United States proposed it during the deliberations that preceded adoption of the Convention on Fishing and Conservation of the Living Resourees of the Sea. Its application in the North Pacifie has engendered controversy between. Japan, on the one hand, and Canada and the United States, on the other. The United States also must eonsider that it, too, may be a prospective entrant into the fisheries of many areas of the world from which it would not like to be barred by the abstention doetrine or have the doctrine used to justify admitting it on unfavorable terms.

\section{Preferential Treatment of the Coastal Nation}

Expanding claims with respect to the breadth of the territorial sea and the exelusive fisheries zone have provoked a series of acrimonious international disputes. Of gravest concern to the United States is the dispute between it and certain Latin American countries.

Eeuador, Mexico, Honduras, Panama, Peru, and Colombia have seized U.S. ressels for fishing in waters in which these countries claim exclusive fishing rights but in which the T'nited States claims the freedom to fish. Since 1961, half of the IT.S. tma ressels have either been chased, shot at, or seized. 'Through .June 1967. a total of $\$ 392,702$ has been paid to the named conntries to secure the release of ressels and rrews. The Department of State has not succeeded in recorering any part of this money from the seizing govermments.

The Fishermen's Protective Ict, originally 
passed in 1954 and significantly amended in 1968 , entitles [.... vesse owners to reimbursement for any tines, license, or registration fees they mint pay to secure the prompt release of their seized ressels and arrested crews. It also anthorizes a temporary, 4-year voluntary insurance proglan under which the Secretary of the Interior will reimburse:

- 'The participating ressel owner for the destruction of or damage to the ressel, its fishing gestr, or other eguipment directly resulting from the seizule

- The owner and crew for the market value of fish caught before the seizure and confiscated or spoiled during the period of detention and for 60 per cent of the potential income Inst hecause of the interruption of fishing time.

Tessel owners participating in the insurance proglam will pay the expenses of its administration and at least one-third of its cost, which is estimated at $\$ 506,668$ for the 4-year period. Finally, the Act requires the Secretary of State to withhold from any forrign aid funds an amomnt equal to the mpaid T.S. claim against a comtry that seized a [.S. fishing ressel.

The Commission concludes that, as a genelal principle, coastal nations should be given preferential access to the living resources nearest their coasts as a means of lessening the intermational tension provoked by the kind of situation just described. It is not easy, however, to apply this principle in particular. cases.

For example, the Latin American countries seizing T.S. tma ressels take relatively small quantities of tmua. To the extent that the existing international framework safeguards the freedom of distint water fleets to fish for stocks which coastal fishermen are not exploiting fully, it encourages the derelopment of the vast food reserves of the sea withont hurting the coastal nations. Wre assume, as is the case in Iatin America, that the distant water fleets are not orerfishing, interfering with coastal fishing by gear conflict, or "1psetting the ecological balance.

This fundamental and desirable feature of the existing frimework should not be sicrificed to allay groundless fears of the coastal nation.

The Commission mraes that serious considelation be given to assuring coastal nations a reasonable opportunity to participate in the exploitation of fish stocks nearest their consts. This assurance should take the form of an agreement to allocate national catch quotas whenerer the coastal nation requests such quotas. The quotas should be allotted to guarintee the coastal nation a minimmm amount or percentage of the catch.

Eflectuating this proposal may necessitate the requirement that the coastal nation catch its quota witl ressels carrying its flag.

It is impossible to predict whether these assurances and programs would suffice to indnce the Latin Amcrican conntries in ques-

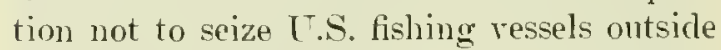
the 12-mile limit. But it is also difficult to see what else the [Tnited States can reasonably be expected to offer.

The Commission recommends that until the existing disagreements with the Latin American countries are resolved, the policy of indemnification embodied in the Fishermen's Protective Act be continued. However, the Commission also recommends repeal of the Act's requirement that the amount of aid a country is scheduled to receive from the United States must be cut by the total of unpaid U.S. claims against it for seizing U.S. fishing vessels.

The latter requirement restricts the flexibility the P'resident must have in exercising his responsibilities. It subordinates all for- 
rign policy objectives of the [nited States to the one aim of resisting mnwarmted claims to exclusive alcess to certain fikhery resomres. It will exaceldate relations between the l nited states and the Latin American comntries to the detriment of their conmon gronls. The total amounts paid under the Aet will not be wreat and may even be much less than the losses l'. S. interests will sustain if other rotalintory measures or diplomatic ruptures result from compliance with this requirement.

\section{The Territorial Sea}

If the sugesested means of proforing the coastal nation proves to be acreptable, it may also serve the important purpose of removing the impetus to extension of the territorial sea that derives from concern over acess to fisleries. It may then become possible to secure agreement on a narrow territorial sea consistent with the totality of I.S. interests in the oceans.

The Commission recommends that an attempt be made to reach international agreement on the maximum breadth of the territorial sea along with arrangements that would protect the right to pass through and fly over international straits.

\section{Strengthening International Fishery Organizations}

Coverage Many of the existing conventions (lo not encompass all the waters in which the resonrees in question ane to be found. Furthermorc, they seek to regulate designated species of fish while the increasing sophistication, lange, and flexibility of mokem high seas lishing equipment tend to make species rerulation unrealistic. Even if eflective, spe("ies regulation tends to shift fishing pressure to other species or to restrict development of underutilized fish in the same area.

Finally, taken together, the existing conrentions cover only a small part of the actual, and even a smallew" lart of the potential, eateh from the world's fisheries.

The Commission recommends that the geographical area subject to international fisheries management be large enough to permit regulation on the basis of ecological units rather than of species and, when necessary, include the territorial seas. Fisheries commissions should be authorized to manage ecological units whenever they conclude that the additional gains from such management are likely to outweigh the increased costs of undertaking it.

Idoption of the recommended quota system in the North Atlantic, and possibly the North Pacific as well, will shift fishing pressure to other areas of the world. 'To the extent that capital and hobr made redundant as a result of a quota system are shifted to the exploitation of nnused or molerutilized fisheries, the quota system will help to achieve the primary world objective of maximizing the nse of the living resources of the sea. But redundant capital and libor also ma be shifted to areas that are beginning to show signs of depletion and are not covered by any fishery convention. This illustrates the need for a worldwicle system of regional fishery "onventions, each tailored to its particular biological, envirommental, and economic conditions but all integrated in a truly international framework of analysis.

The Commission recommends that an appropriate existing international organization be entrusted with the tasks of 


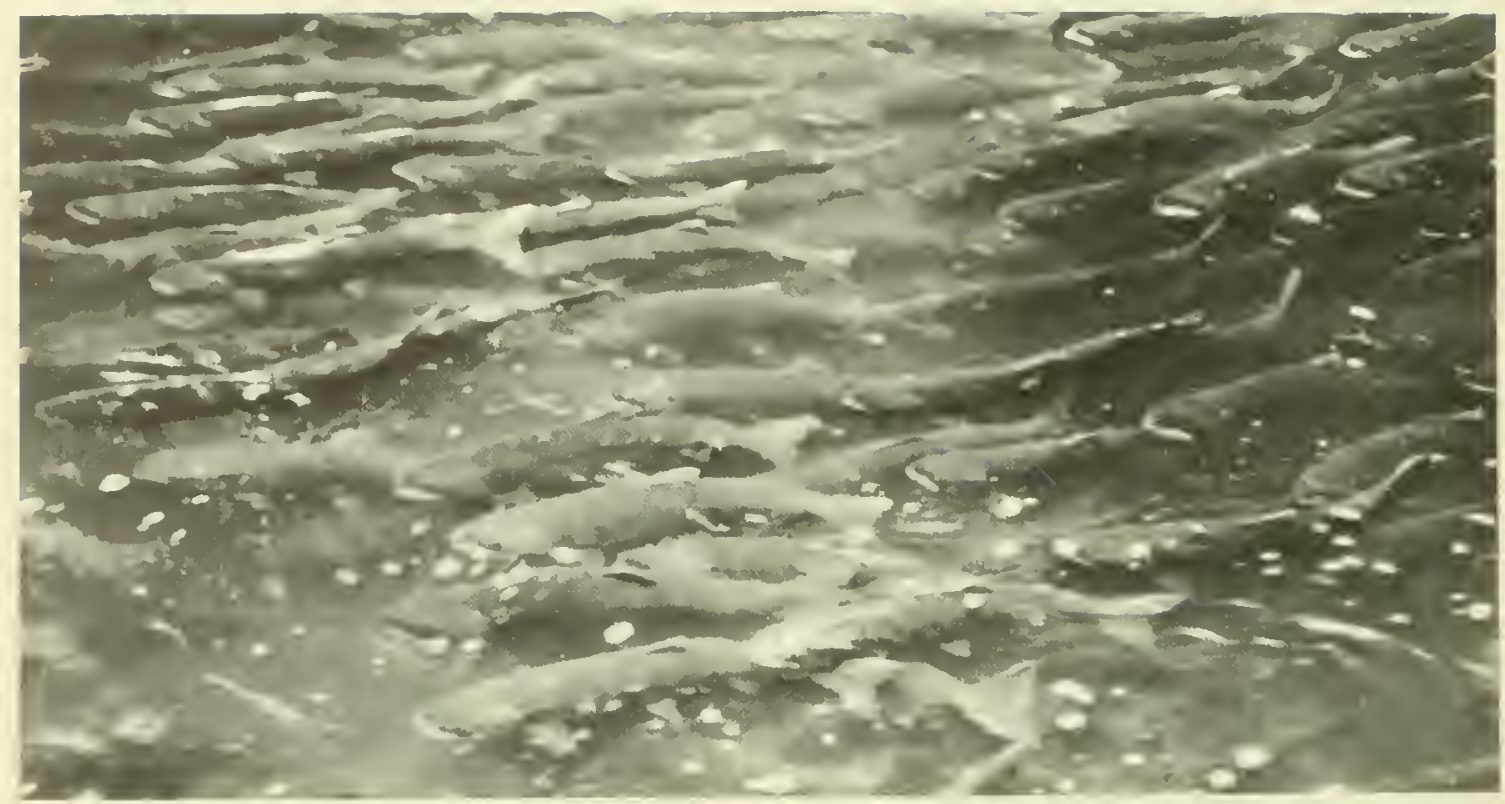

Fish like the soekeye salmon secn here waiting to spawn in inland waters of British Columbia are the subject of international conscrvation and management measures involving scrcral fisheries nations.

evaluating the operations of existing fisheries conventions, suggesting measures to improve and coordinate their activities, and recommending the establishment of new conventions. The establishment of new conventions should not await the threatened depletion of particular fish stocks.

The commissions created by these conventions should recommend measures to maximize the utilization of fish stocks, consistent with their conservation, and aid the developing countries in promoting their fisheries and in training scientific and technical personnel for this purpose.
Duty To Comply with Conservation Regulations The fisheries commissions - the administrative agencies created by the fisheries conventions to implement their purposesgenerally have only the power to recommend conservation regulations to the member nations. To become effective, the regulations generally must be approved nnanimously.

The Convention on Fishing and Conservation of the Living Resources of the High Seas attempts to orercome some of the difficulties that stem from this requirement of unanimity. It forces consideration of the nced for conservation of a fish stock if insisted upon by (1) a nation participating in the fishery, 
(2) a nonparticipating coastal nation, or (3) under somo (نireumstances, a noncoastal, nomparticipating nation. If ngreenent is not reached, the Convention anthorizes any such nation to invoke the rispute settlement ma('linery it establishes. Mean while, the coastal nation to invoke the dispute settlement manondiscriminatory conservation measures which govern foreign fishermen, subject to the sane dispute settlement machinery. Derisions of the sperial rommission created to settle the disputes are binding on the nations (oneerned.

'The Convention provides the means to bolster all existing fishery conventions. Its procedures conld be invoked to prevent depletion of certain fish stocks mutil a convention specifically dealing with these stocks is adopted. They also could be employed if a nation belonging to an existing convention refuses to accept a commission recommeudation $O r$ if a nation which is not a member enters the conrention area and disregards the existing conservation regulations. The coastal nation could then act milaterally and probably conld take effective action to enforce its conservation regulations.

Infortumately, however, it is doubt ful that the Convention on Fishing and Conservation of the Living Resources of the High Seas has been accepted by a sufficient number of the important fishing nations of the world to have become part of international law. The combined catches of the countries adhering to the Convention amounted to only 14 per cent. of the world catch in 1965, and the United States, the United Kingdom, and South Ifrica, the only major fishing nations in this sroup, accounted for more than two-thirds of this 14 per cent.

It is difficult to say, therefore, that a coastal nation would be clearly justified to inroke the Convention as the sonrce of its anthority to impose its conservation measures upon any nation which is not a party to the Convention. 'The refusal of any important fishing nation to cooperate in a multinational conservation effort, although it participates in the fishery aflected by that effort, reminins a threat to the conservation and economic objectives of international fisheries management.

The Commission recommends that renewed diplomatic efforts be made to persuade all important fishing nations of the world to adhere to the Convention on Fishing and Conservation of the Living Resources of the High Seas.

For similar reasons, it is important that all nations interested in the fisheries of a particular area become parties to the applicable convention.

\section{Administrative Organization and Budget}

The fisheries commissions to which the Inited States belongs will spend approximately $\$ 3,313,000$ in the Fiscal Year 1969. The Tnited States will eontribute $\$ 2,064,000$ of this total, of which $\$ 1,029,400$ will go to the work of the Great Lakes Fisheries Commission. In addition, the United States will spend abont $\$ 2,700,000$ in Fiscal 1969 on research of interest to commissions which do not have their own scientific staffs.

The Commission estimates that the total amount spent in Fiscal 1969 on fisheries by all intemational organizations, including those in the United Nations family and the fisheries commissions to which the Inited States is not a party, will equal no more than a small fraction of 1 per cent of the $\$ 10$ billion which is the estimated value of the total catch from the world's fisheries in 1968.

'The small buclgets with which some of the fisheries commissions operate reflect the deliberate choice of their member nations to rely on their own fisheries research agrencies and not to supply the commissions with full- 
time scientific, technical, and economic staft's to acenmplish their objectives. While impressive scientific work has been accomplished in this manner, there is always the danger that scientific opinion may tend to serve, or be suspected of serving, national interests on issues of great moment. In international staf may serve to enhance the acceptability of commission recommendations.

Equally serious, many nations belonging to fisheries conventions or to the regional fisheries councils of the T'.N. Food and 1 grirulture Organization lack the necessary scientifir personnel or the resources to employ them. They are mable, therefore, to do the research required to establish the scientific basis for the conservation work of the fisheries commission ol council in question. Iet the commission or enuneil may have un stafl of its own to do the work.

The Commission recommends that inter. national fisheries commissions, particularly in those areas where some member nations lack the personnel or the resources to employ them, should be adequately financed by the member nations so that they can employ full-time, competent staffs to provide the scientific, technical, and economic data and analyses needed to accomplish the objectives of the conventions.

Enforcement Most fisheries conventions leave it to each member nation to enforce the provisions of the convention and the commission regulations implementing them against its own nationals and ressels. Some go further and anthorize officials of any member nation to boand, search, and seize the ressel of any other number nation suspected of a riolation, but the seized ressel and arrested crew must be turned orer for trial and punishment to the nation to which they belong.

It is difficult to say whether these weak provisions lave ereated serious en forcement problems. Once the nations adhering to a fisheries convention igree to adopt conserration measures of importance, it is to the advantage of each to comply. Nevertheless, stronger enforcement provisions might reduce mutual suspicions of noneompliance and nonenforcement which encourage fishermen of all nations to disregard conservation regulations whenever they think they ean do so with impunity. Stronger provisions also will be required to enforce the reeommended guota system.

The Commission recommends that enforcement of the provisions of international fisheries conventions and implementation of regulations of the fisheries commissions be strengthened.

Dispute Settlement The 1958 Genera Conrentions on the Iaw of the Sea were aceompanied ly an Optional Protocol anthorizing any ratifying nation to bring before the Intemational Court of . Justice any dispute involving it and another nation also adhering to the Protocol, if the dispute arises ont of the interpretation or application of any provision of any of the Conventions. The Optional Protocol excepts disputes subject to the arbitration machinery created by the Convention on Fishing and Conservation of the Living Resonrees of the High Seas. The Inited States has signed but has not ratified the Optional Protocol.

The Commission recommends that the United States ratify the Optional Protocol Concerning the Compulsory Settlement of Disputes and support compulsory arbitra- 
tion of disputes arising under fisheries conventions when that seems preferable to settlement by the International Court of Justice.

Idoption of this recommendation will enable the nations participating in fisheries (onventions to choose that form of settlement machinery which fits the particular case.

\section{Aquaculture}

Aquaculture, the cultiration or propagation of water-dwelling organisms, is nearly as old as civilization and is practiced extensively in many parts of the world. The greatest diversity and quantity of production are found in Asia.

The application of the techniqnes of agriculture and animal husbandry to the rearing of some types of aquatic animals and plants under controlled conditions has produced enormous per acre yields of protein (Table 4-1). Unlike the fisheries where the harrestable stock is finite, cultured species for all practical purposes are limited only by the acreage that can be farmed and by cost of production in the competitive market. For this reason, some observers conclude that aquatic culture of certain especially efficient and productive species can make a substantial contribution to the war on hunger.

The three-dimensional character of the marine environment permits several noncompeting stocks to be farmed at once. For example, mollusks, crustacea, and finfish can be cultured in the same area. One combination might be rafted oysters, bay scallops, lobsters, flatfish, and marine algae. Eren without such combinations, the potential returns are large. If 1,000 square miles of tidelands between California and Alaska were diked for sea farms and were cultivated to produce 3,000 pounds of fish per acre per year, the harrest would be equivalent to 50 per cent of the total U.S. fish catch of 1967.

Howerer, realizing the potential of aquaculture will require overcoming certain legal and institutional constraints as well as advancing scientific knowledge and developing teehnology to permit production at competitive costs.

\section{Present Status of U.S. Aquaculture}

Activity in the United States today is at a low level compared with aquaculture in other parts of the world, but it is showing signs of lapid growth. A variety of olganisms is under some kind of cultivation.

It is estimated that aquacultural products in 1967 reacher a wholesale level of $\$ 50$ million, but the level is uncertain because of wide viriations in the definition of aquaculture. Much of domestic aquaculture is in fresh water: both trout and catfish farming have been very snceessful. Cultivation of bait fish is a several million dollar business. Among the marine organisms, oyster cultivation has the largest dollar volume.

Research is in progress with a number of high-value species including pompano, sal-

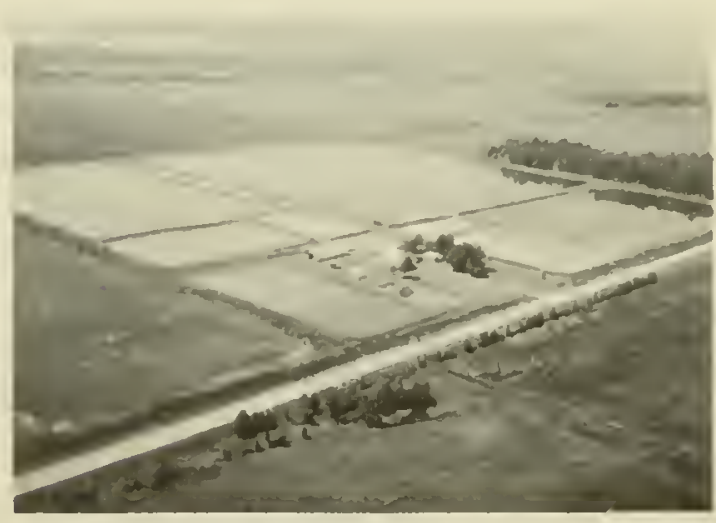

Present domestio aquaculture has been developed largely in fresh water. Both trout and eatfish farming have been very successfulan aerial view of an Arkansas eatfish farm. 
mon, redfish, abalone, New England lobsters, spiny lobsters, crabs, shrimp, oysters, bay scallops, and hard clams. Nevertheless, technological development of aquaculture has just begun in the United States. Research has revealed many areas of potential improvement including predator control, genetic control (to improve quality, growth rate, and adaptability of rarious species), and the possibility of using presently wasted sources of nutrients and heat to effect economical control of local culturing environments. One technique which shows potential for replenishing natural stocks of marine plants is to transplant heattolerant species to waters warmed from electrical power plants.

\section{The Future of Aquaculture}

Aquaculture has much the same relationship to a fishing economy that agriculture bas to a hunting economy. Obviously, controlled production has many advantages over harresting wild stocks. Planting, quality control, feeding, and harvesting can be suited to the needs of the organism with resulting high productivity. With a growing demand for seafood, an uncertain natural supply of some species to meet the demand, and the potential for vast improrements in aquaculture technology, prospects for profitable aquaculture are increasing rapidly.

Aquaculture can be a valuable supplement to natural harvesting, enabling aquaculturists to move stocks into the market at times when natural supplies are seasonally low or unavailable for other reasons. Further, aquaculture offers the possibility for species improvement by selective breeding to meet human tastes and marketing requirements.

Knowledge, however, is still incomplete. Considerable research and development will be necessary before aquaculture can be brought to a major place in the seafood economy. For the near future, it appears that em-

\section{Table 4-1 Summary of Aquacultural Yields with Ascending Intensity of Cultural Methods}

[Units in fresh weight, shells of molluses excluded]

\begin{tabular}{|c|c|c|c|c|}
\hline Location & Species & $\begin{array}{c}1.000 \mathrm{~kg} / \\
\text { hectare } / \\
\text { yr" }\end{array}$ & tons/acre/yr & $\begin{array}{l}\text { Local Wholesale } \\
\text { value \$U.S./acre }\end{array}$ \\
\hline
\end{tabular}

I. TRANSPLANTATION OF SPECIES

Denmark

plaice

(No data available)

II. STOCKING OF HATCHERY-REARED JUVENILES

Great Britain _...... plaice, sole.

Japan _............ shrimp, crab, abalone, sea bream, puffer fish, Pacific salmon, others

United States
Cost: benefit $1: 3 \frac{1}{2}-5 \frac{1}{2}$ based on hatchery costs and return to commercial fishery. 


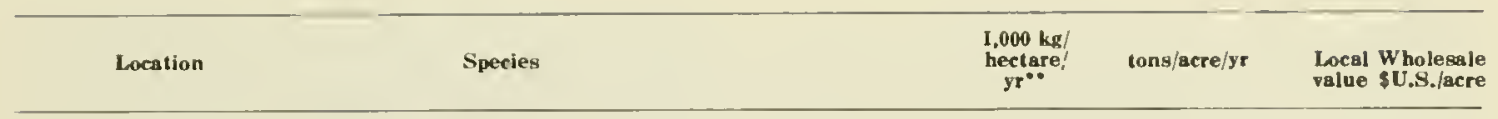

III. CULTIVATION OF STOCKED OR NATURAL POPUlations, No FERTILIZATION OR FEEDING

United States _..... oysters (national avg.) _.................

United States ....... oysters (best yields) .................

France........... flat oyster (national avg.) ..............

France . . . . . . . . Portuguese oyster (national avg.) ...........

Australia . ......... oysters (national avg.) _................ oysters (best yields) .....................

Japan* (Inland Sea) oysters

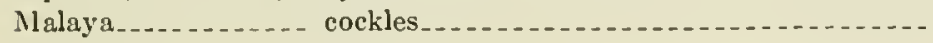

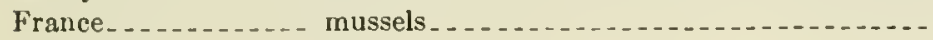

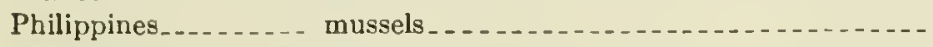

Spain*_. _._._._. mussels_...

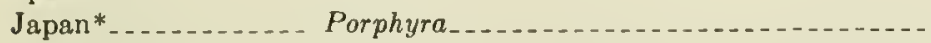

Japan*_.......... Undaria _... _...

Singapore (elsewhere shrimp.

in Southeast Asia)

$\begin{array}{rrr}0.009 & 0.004 & 16 \\ 5.00 & 2.00 & 9,000 \\ 0.40 & 0.16 & 2,000 \\ 0.935 & 0.37 & 1,500 \\ 0.150 & 0.06 & 170 \\ 5.40 & 2.20 & 6,250 \\ 58.00 & 23.30 & 28,000 \\ 12.50 & 5.00 & 800 \\ 2.50 & 1.00 & 750 \\ 125.00 & 50.00 & 8,000 \\ 300.00 & 120.00 & 20,000 \\ 7.50 & 3.00 & 3,000 \\ 47.50 & 19.00 & 850 \\ 1.25 & 0.50 & 600\end{array}$

\section{STOCKINO AND CULTIYATION: FERTILIZATION, NO FUEDING}

\begin{tabular}{|c|c|c|c|}
\hline 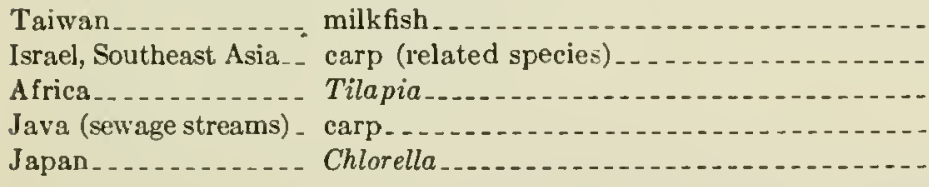 & $\begin{array}{r}0.10 \\
0.125-0.70 \\
0.40-1.20 \\
500-750 \\
325\end{array}$ & $\begin{array}{r}0.04 \\
05-0.28 \\
16-0.48 \\
200-300 \\
130\end{array}$ & none \\
\hline v. STOCKING AND CULTIVATION: FEHTILIZATION AND & SUPPLEMENTAL & FEEDING & \\
\hline $\begin{array}{l}\text { United States._. } \\
\text { China, Hong Kong-- carp (related species) } \\
\text { Israel. }\end{array}$ & $\begin{array}{l}\text { 3. } 00 \\
\text { 3. } 00 \\
\text { 2. } 10\end{array}$ & $\begin{array}{l}\text { 1. } 20 \\
\text { 1. } 20 \\
0.84\end{array}$ & 1,000 \\
\hline
\end{tabular}

\section{STOCKING AND CULTIVATION, RUNNING WATER, INTENSIVE FEEDING}

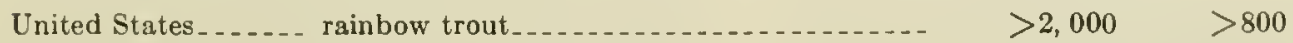

Japan ......... carp.

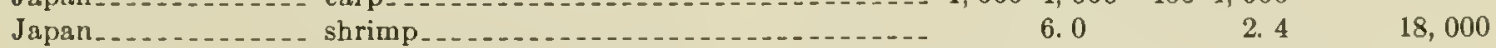

- Rast-culture calculations based on an area 25 per cent covered by ralts. To obtain yields for area actually Involved in production, multiply by 4.

$\because 1,000 \mathrm{Kg} .=2,204.6 \mathrm{lbs}$.

I beclare $=10,000 \mathrm{~m}^{2}=2.47$ acres

SOURCE: John H. Rytber and Jobn E. Bardach, Status and Potential of Aquaculture, American Institute of Biological Sciences, WashingIon, D.C., May 1968, vol. I, p. IL.
} 
phasis will be on high value species for the quality market in the United States. However, as knowledge and technique improve, it should be possible to develop means for high volume production of lower valued species, suitable both for table use and for processing into new food forms in which protein content is the dominant element. Fish protein concentrate is only one of several possibilities.

To cultivate marine organisms, brackish or saline water is needed. This means that a major aquaculture program must have available estuarine and shore areas to a greater extent than is possible under most present State laws and regulations. States vary widely in their sea-bottom leasing or rental practices, and in many States exclusive use of water areas is not permitted. To many qualified observers, it is these legal and institutional problems which are the greatest barrier to a viable commercial aquaculture program in the United States today. When decisions are made on how the coastal zone is to be used, aquaculture must be given appropriate weight as a contributor to the economy.

The Commission recognizes the high potential for user conflict. Established interests, including commercial and sport fishing, recreation, conservation, and navigation, tend to regard aquaculture as an interloper that may interfere with traditional activities. Often the conflict is based more on emotion than on reason. The Commission has noted several cases in which aquacultural investment was thwarted on legal or political grounds, although the conflicts of use were minimal, and only an infinitesimal fraction of the available water area was involved. Aquaculture in the open ocean appears possible for the future and raises the problem of how exclusive commercial rights may be obtained. The Federal Government should examine the various considerations involved.

The Commission recommends that:

- The National Oceanic and Atmospheric Agency (BCF) be given the explicit mission to advance aquaculture

- NOAA (BCF) assist and encourage States through the Coastal Zone Authorities to remove the legal and institutional barriers that may exist in individual States and that inhibit aquaculture

- NOAA (BCF and Sea Grant) support more research on all aspects of aquaculture, economic and social as well as technical.

\section{Sea Plants}

Sea plants already have proven of value as a source of chemicals. Potash and jodine were extracted from seaweed for many years before other sources were developed. In recent years, hydrocolloids known as carageenans and algins have made possible many convenience foods and have served as homogenizing and smoothing agents in toothpastes, pharmaceuticals, and cosmetics. Industrial applications include ink, paint, and tire production. In fact, the use of marine colloids is so widespread that the supply of raw material has become a problem and the artificial culture of highly productive seaweeds is indicated.

Research has shown that marine plants also contain useful fractions of many other chemicals, including vegetable oils, chelating agents, and vegetable proteins. It is highly probable that, as marine biological research continues, unanticipated uses of marine plant organisms will be found. Agencies funding such research should be alert to new possibilities and make every effort to ensure that results are communicated fully and quickly. 

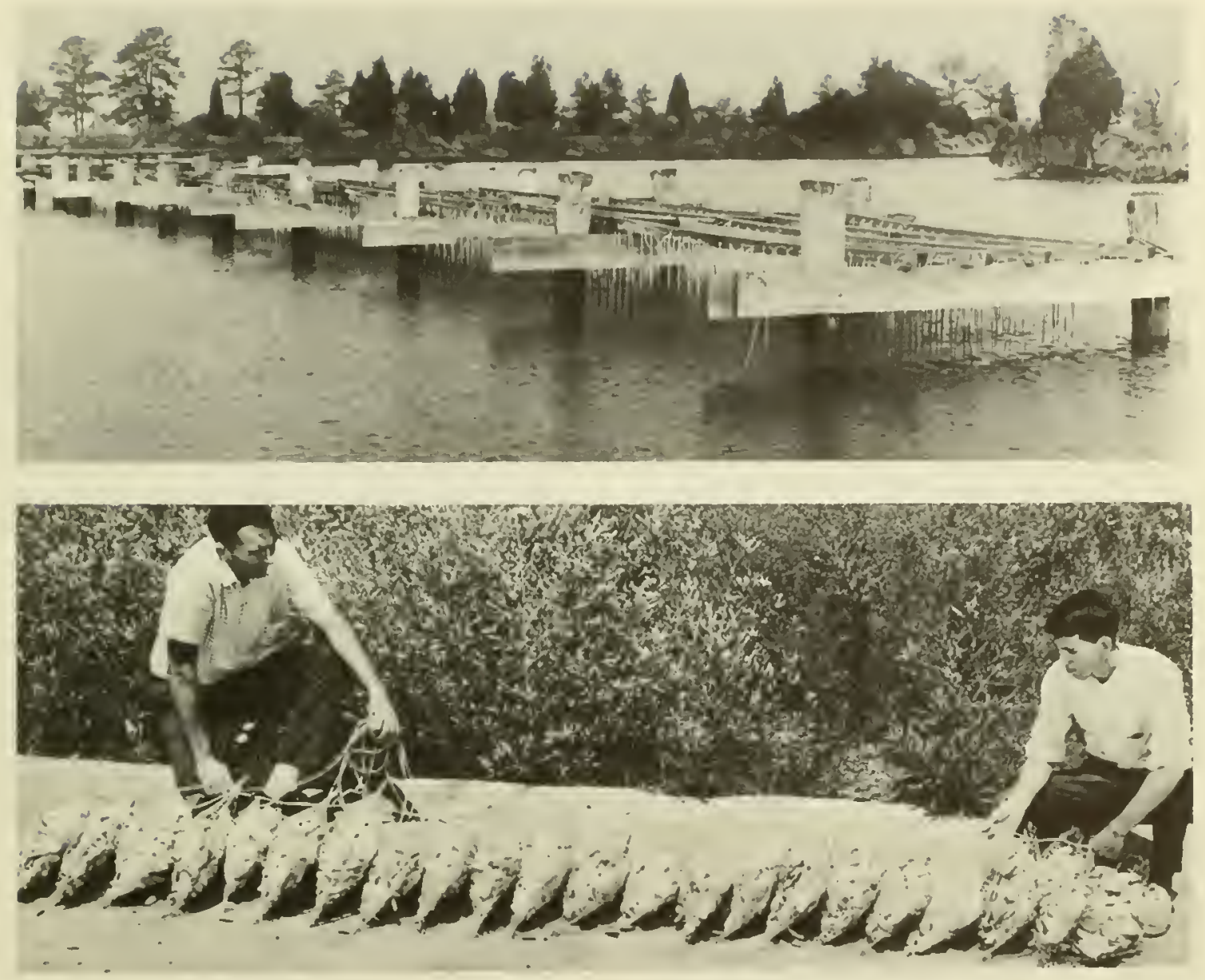

The Bureau of Commercial Fisheries, presently engaged in such uork as experimental oyster farming, should be given more cxplicit Federal responsibility for investigating aquaculture potentials.

\section{Extracting Drugs from the Sea}

Groups concerned with the health sciences must carefully evaluate the sea as a source of new and useful medicinal raw materials.

The medical history of people bordering the seas is replete with evidence that products with pharmacentical applications can be obtained from the plants and animals of the sea. However, the present use of these products is small compared with similar products obtained from land organisins. With some exceptions, most of the marine drugs are used in rather crude dosage forms by peoples of some developing nations, just as the majority of crude botanical and zoological drugs were used in this country more than 40 years ago.

Practically no research is presently being conducted by government or industry on marine bioactive substances as possible sources 
of new commercial pharmacentical products.

Most active substances from the sea now under study may be divided into two broad classes:

- Autibiotics, which are used to coutrol and destroy the organisms that cause diseases

- Systemic drugs, which act directly on parts of the body to alleviate pain, stimulate or relax, promote liealing, vary the speed of such biochemical reactions as blood clotting, influence the operation of certain organs, or act as antidotes to poisons.

Nearly all of these drugs are poisons at certain concentrations, including the antibiotics which, presumably, kill only pathogenic bacteria. There are more kinds of animals in the sea than on land, and a greater proportion of them use poisons as part of their equipment for survival. So far, less than one per cent of all the sea organisms known to contain biologically active materials have been studied.

Antibiotics from the marine world will become more important as the older drugs upon which medical practice has relied for the past 20 years become less effective against new generations of resistant germs.

Contemporary experimental marine biology has indicated that other pharmacologically active substances, categorized as toxins or poisons, also can be obtained froln marine organisms. Study of poisonous marine organisms is required also to understand marine ecology, to protect against the illnesses caused by eating poison-laden fish foods, and to help develop new protein foods from the ocean.

A poison is merely an intense inhibitor or stimulator of critical biological processes. Diluted, a poison is highly useful and often a very effective therapeutic agent. Research among toxins for antitoxins has unearthed a lost of fascinating pharmacological properties varionsly described as antiviral, antibiotic, antitumor, hemolytic, analgesic, psychopharmacological, cardioinhibitory, fungicidal, and growth inhibitory. Indications are that some marine toxins rank among the most toxic substances known. Chemicals isolated from certain toxic marine fishes are 200,000 times more powerful in blocking nervous activity than drugs currently used in laboratories for nerve and brain research. A substance extracted from the primitive hagfish has been used experimentally to slow down the heart during openheart surgery making it easier to operate. Antitumor and antimicrobial agents are present in such common organisms as clams and oysters.

Attempts to find useful, active substances in the sea by searching folklore, studying biological activities of marine plants and animals, and studying or interviewing native witch doctors produce little and are costly. It costs even more to use traditional methods to screen natural products at random. Drug companies have many more research opportunities than they possibly can undertake because of limited manpower and capital. Yet there is a vast array of marine biochemical agents having potent biological activity, and many of them may be useful therapeutic agents.

The Commission recommends establishment of a National Institute of Marine Medicine and Pharmacology in the $\mathrm{Na}$ tional Institutes of Health to effect a methodical evaluation of the sea as a source of new and useful active substances. The new Institute should:

- Inventory presently known bioactive substances

- Examine those factors which relate to the ecology of marine organisms and their pharmacology 


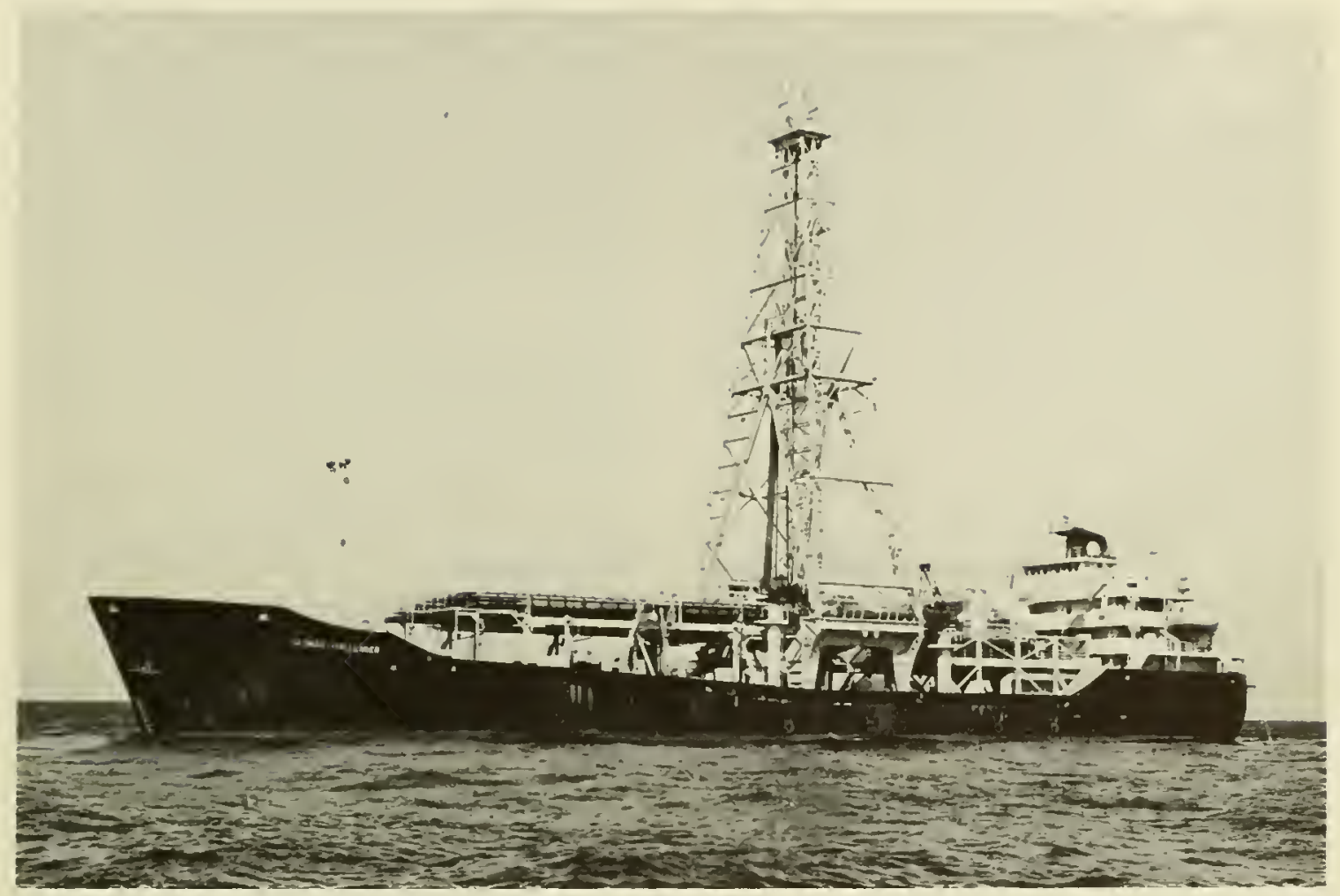

The national occan program requires a systematic, Government-

supporled mo!n am of geological sure eys which might draw, in part, upon

the exploratory funds of the National sediment Coring Program being

roudurefed abrard thr drilling ship Glomar ('hallenger.

- Determine present pharmacological evaluation problems

- Develop inexpensive screening methods

- Institute a national system of information storage and retrieval

- Provide regional facilities for collecting, storing, and distributing bioactive material to universities, research institutes, and industry.

\section{Development of Nonliving Marine Resources}

Oil, natural gals. and minerals in various forms-dissolved, placer, nodule, and lodeand the water itself constitute the inventory of nonliving resources in and under the sea. The energies of the oceans at some future time also may gain economic importance if commercial means to harness them are found.

Athough each of the industries engaged in the recovery of nonliving marine lesources presents unique problems, they share certain needs. Of particular importance are improred rata on the bathymetry, geophysical chanacteristics, and geology of the ocean floor. Certain of the National Projects recommended by the Commission will assist the resource industries to derelop the specific systems which they will need as operations crow in scale and complexity in the vears ahead (see Part IV). 
The resource industries have a common interest in the clarification of marine boundaries and jurisdictions. Although there is no question of U.S. control over minerals production within the 200 -meter isobath, the areas beyond are subject to much uncertainty and controversy. The Commission deems it essential that the present ambiguities which becloud investment in marine-based mineral exploitation be resolved at the international level. Specific recommendations are advanced in subsequent pages.

\section{Petroleum}

Twenty years from now, it is estimated, world petroleum consumption will be three times present levels. This estimate, with the growing concern about the political stability of some of the Middle East countries which furnish the major supplies of this mineral, has resulted in a mammoth worldwide search for oil and gas. Twenty-two countries now produce or are about to produce, oil and gas from offshore sources. Investments of the

\section{Number of Successful New Offshore Wells, by Year}

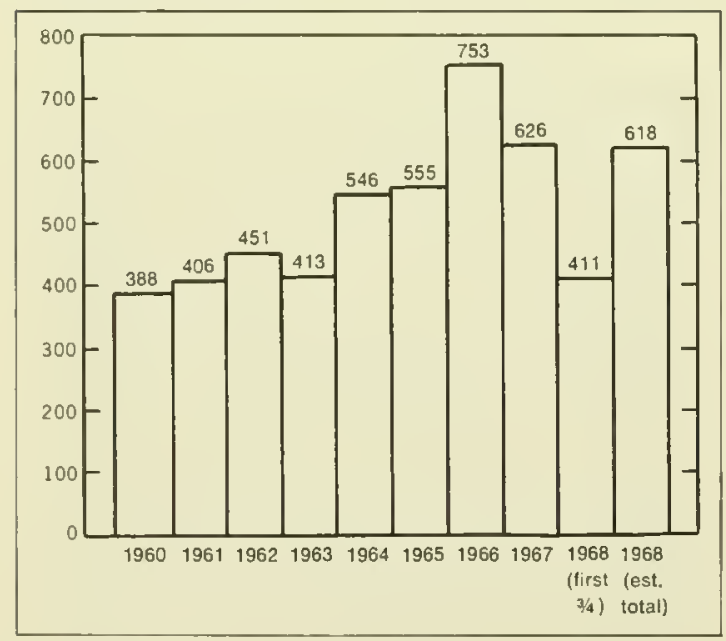

Source: American Petroleum Institute. domestic offshore oil industry, now running more than $\$ 1$ billion annually, are expected to grow an average of nearly 18 per cent per year over the coming decade. Current free world offshore oil production is about $5 \mathrm{mil}$ lion barrels per day or about 16 per cent of the free world's total output. Although the development of alternative energy sources, particularly oil shale and tar saud, may place a limit on its growth, the offshore oil industry generally is expected to contimue to grow and to account for at least 33 per cent of total world oil production in 10 years.

All commercial quantities of offshore petroleum to date have been produced from wells in waters 340 feet deep or less. Exploratory wells have been drilled in water depths of 1,300 feet and leases have been taken to 1,800 feet. But petroleum may occur wherever sedimentary sequences are found. Within the continents and their shelves and slopes, these sedimentary strata accumulate to thicknesses of at least 5 to 6 miles. Conversely, the deeper ocean basins generally have thinner layers of

\section{Record Water Depths for Producing and Exploratory Wells}

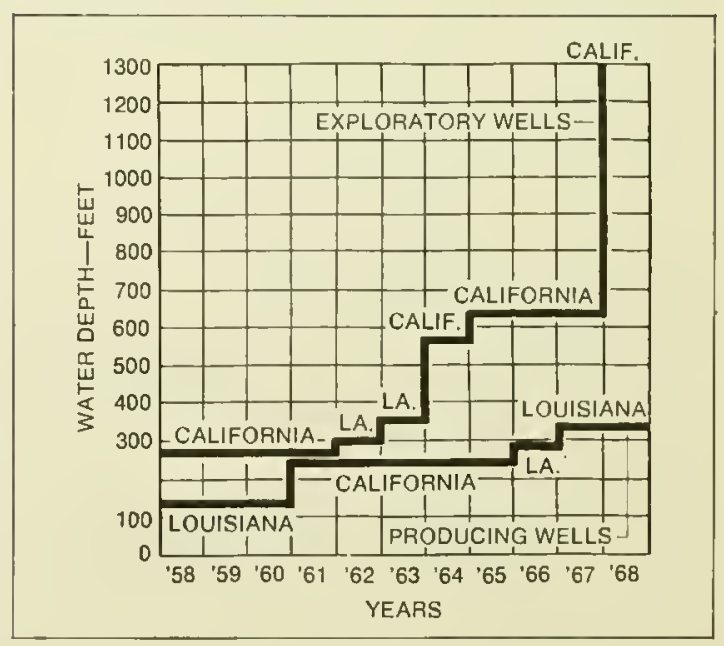

Sotrce : Rlchard J. Howe (Esso Production Research Co.), "Petroleum Operations in the Sea-1980 and Beyond," ocean Industry, August 1968. 
sediment averaging perhaps one-half mile thick. There is 110 reason to expect that oil and gas are not formed within these thin deep ocean sediment layers, but it is unlikely that they could be present in the same quantities that they occur in the thick sedimentary basins of the continents and their shelves and slopes.

Obviously, there are exceptions to these generalizations. Some deeper ocean areasthe Gulf of Mexico is an example-are surrounded largely by exposed continental rocks. Consequently, they receive a much greater proportion of continental debris than the large open ocean regions. Thus, it is not startling that oil and gas were discovered recently in nearly 12,000 feet of water in the Gulf during the JOIDES deep sea drilling project. But since the Gulf of Mexico contains an unusually thick accumulation of sediments and the discovery was associated with unique intrusions of salt, it is not reasonable to assume without further study that these same conditions exist in the larger oceanic areas nor even in other confined oceanic areas.

\section{Technical Considerations}

In proceeding onto the continental shelf, the petroleum industry has surmounted one obstacle after another and has succeeded in developing exploration and exploitation technologies for working at sea. Exploratory drilling has begun in water depths of 1,300 feet; the feasibility of core drilling in 20,000 feet of water will be tested shortly. Within 10 years, undersea core drilling may be accomplished by remote control, and an increasing number of production wells will be completed beneath the water's surface.

Recovery of oil offshore is necessarily more expensive than on land, even though certain exploratory tasks can be accomplished at lowel cost. Nevertheless, many companies anticipate that new oil fields in the comparatively virgin marine areas will be sufficiently large and productive to be competitive with oil fields on land. With continued improvement in technology, such as the building of platforms to service multiple wells, offshore production costs can become increasingly competitive with onshore costs.

\section{Table 4-2 Domestic Offshore Expenditures}

[Billions of dollars]

\begin{tabular}{|c|c|c|}
\hline & $\begin{array}{c}1968 \\
\text { (Estimate) }\end{array}$ & $\begin{array}{l}\text { Cumulative } \\
\text { (through 1968) }\end{array}$ \\
\hline Lease bonus and rental payments & $\$ 1.25$ & $\$ 4.00$ \\
\hline Royalty payments... & .25 & 1. 85 \\
\hline Seismic, gravity, and magnetic surveys & .10 & 1. 10 \\
\hline Drilling and completing wells & .35 & 3. 10 \\
\hline Platforms, production facilities, and pipelines & .25 & 1. 85 \\
\hline Operating costs & .15 & .85 \\
\hline
\end{tabular}

Source: Richard J. Howe (Esso Production Research Co.), "Petroleum Operations in the Sea-1950 and Bejond." Ocean Industry, A ugust 1968, p. 29. 
Otlshore oil production has benefited many other nsers of the oceans. The oil industry"s technology orerlaps that required by the U.S. Nary, seientifie inst itutions, and other marine enterprises. Its mapping of the ocean floor and development of materials and equipment for use at sea also will benefit those outside the oil industry. The relationship is reciprocal, of contse; the petrolem prodneers benefit from the skills and knowledge produced by universities and other researeh organizations and fiom military technical developments. It is extremely important, therefore, that the arrangements for information interchange among Gorernment ageneies, academie inst it utions, and the petroleum industry be strengthened and expanded.

The Commission recommends that appropriate mechanisms be established to assure timely exchange of scientific and technological information among the Federal Government, the petroleum industry, and the scientific community consistent with security and proprietary considerations.

\section{Legal and Regulatory Considerations}

The competitive leasing system established under the Onter Continental Shelf Lands Aet has worked well for the petrolemm industry and the Government. Howeres, the i-year term allowerl by the let for exploration and development may be too short for profitable derelopment as the industry moves farther ofl'shore into deeper waters and mose lostile envirmments.

The pressures to maximize short-roun Federal incone from continental shelf lands may lead to exploitation that is ton rapid from the standpoint of the industry's welfare and the national interest.
Line Profiles of the Continental Shelf off Different Points on the U.S. Coast
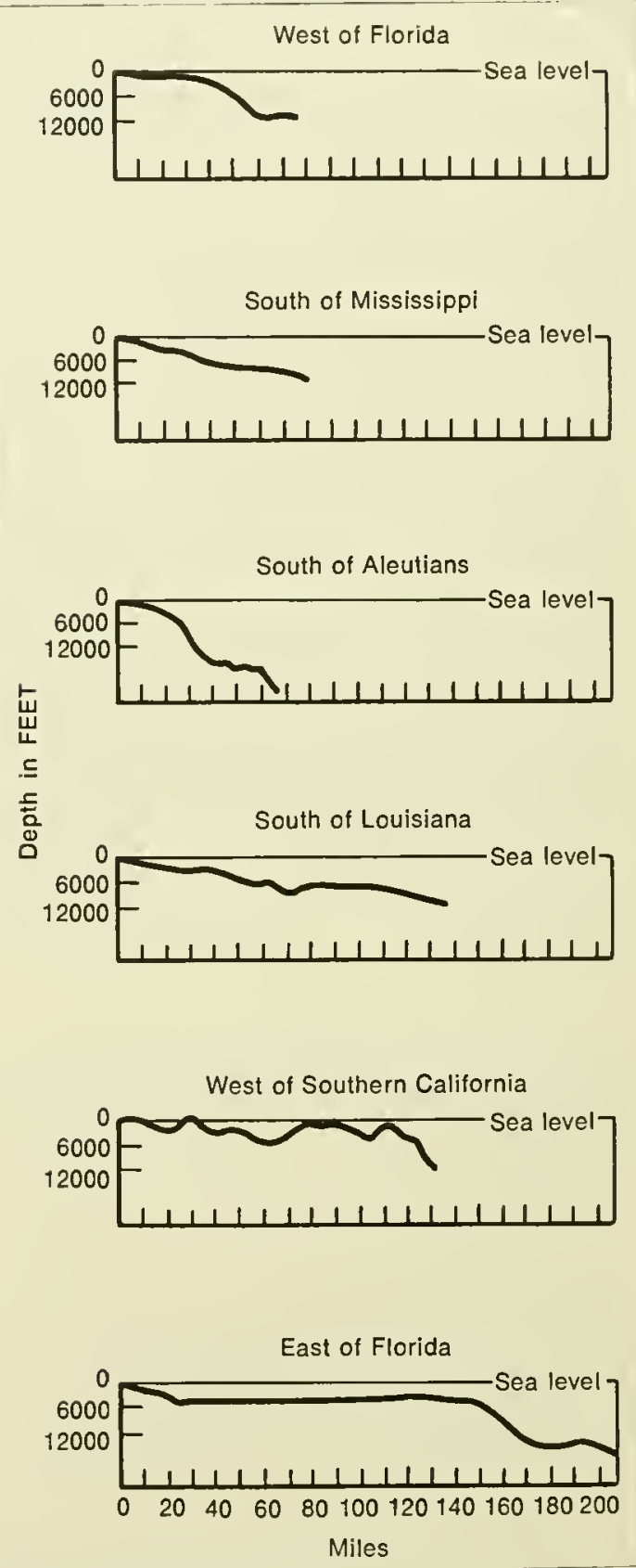

Sotrce: U.S. Nary, Center for Naval Analyses (Projert Blue Water). 

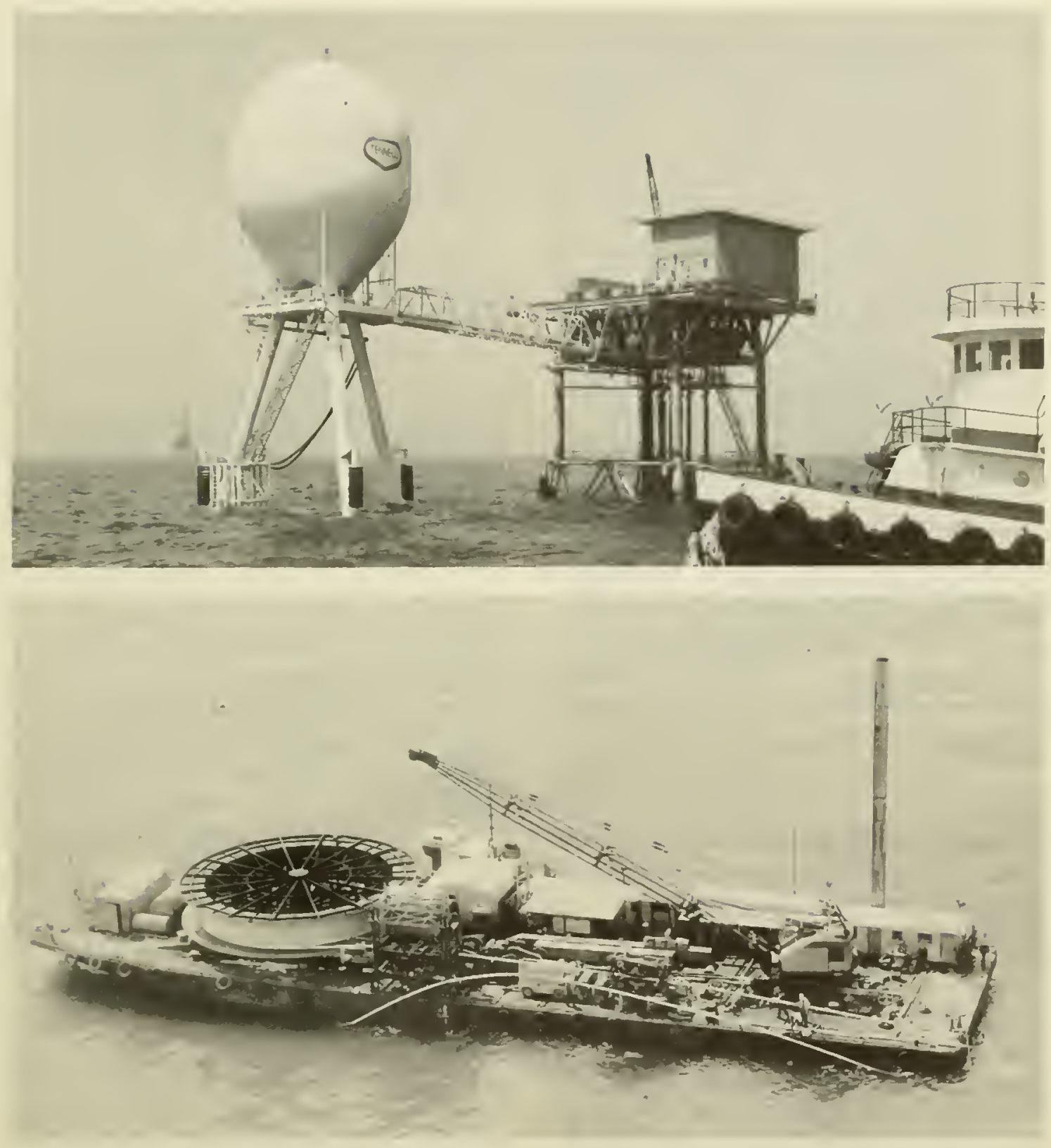

In pushing outward onto the

continental shelf, the U.S. petroleum

industry has surmountcd one

obstacle after another in developing

requireal technology like at-sca

"rude wil storage structures (top)

photograph) and barges laying

4-inch pipclines from rcels. 


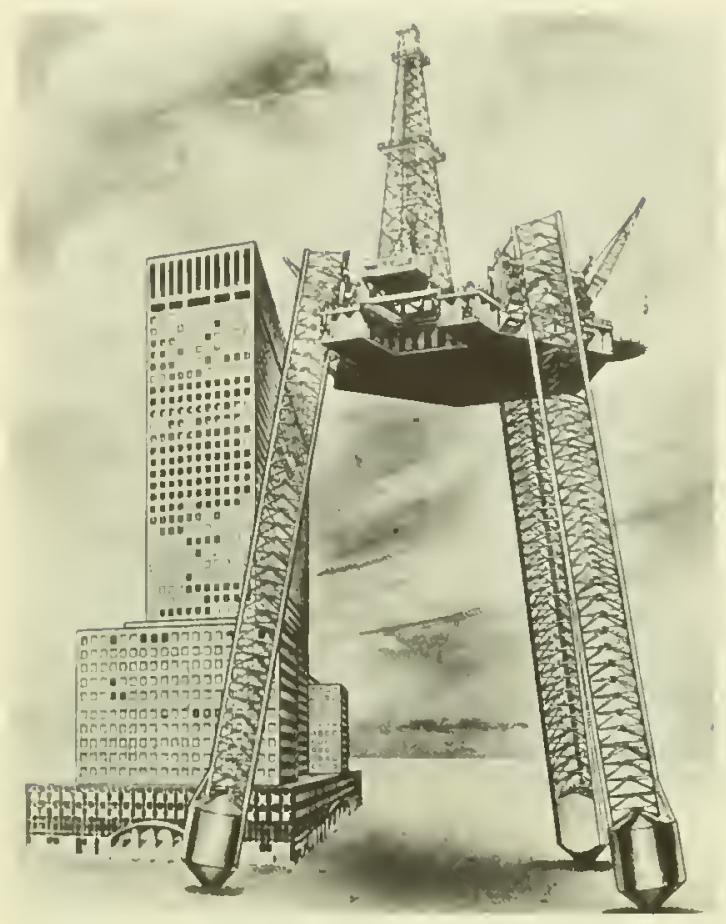

Comparing the height of this large rig uith a modern office building indicates the tromendous depths in which the offshore platforms are now opcrating.

The uncertainty that surrounds the leasing schedules of the Federal Government makes it difficult for the industry to plan ahead. Earlier notice of lease sales would help the industry to plan its exploration and development programs in a more orderly and effective fashion.

Determination of the proper rate of domestic offshore oil development requires consideration of highly complex factors affecting national defense and conservation programs designed to prevent too rapid exploitation. At present, import quotas are used on the grounds that they are necessary to encourage the exploration and development of domestic supplies in order to prevent undue reliance on foreigu supplies that might be cut off at any time.
Conservation considerations and the desire to balance supply and demand have led to the prorationing of production in some States. Similar systems have been used by the Federal Government with respect to oil production from offshore areas in the Gulf beyond State jurisdiction. To eliminate prorationing of production on such offshore lands would add an incentive to explore and develop these sources. However, it would also pose difficult adjustment problems for the industry and the oil producing States and might result in an msound depletion of reserves. By the same token, there are longer range and complex implications for the national security of a program that stimulates rapid development and production from domestic sources. It may be wise to consider new methods for emphasizing incentives for exploration that do not concurrently produce pressures for unduly rapid, short-term exploitation.

The petroleum industry operates within a complex framework of law and regulation which compels thorough analysis of all aspects of the national interest-economic, political, and military-in projecting longterm programs for development and leasing of subsea oil and gas bearing lands on the continental margins. In particular, very careful attention must be given to the broader public interest in maintaining a national reserve.

The Commission has not been equipped to make such an analysis. Recognizing that energy policy is an object of continuing public concern, the Commission, nonetheless, urges a thorough new assessment of the adequacy of the Nation's offshore and land oil reserves. Only such an assessment can provide the foundation for shaping the incentives to explore and develop subsea oil reserves and for establishing an orderly, rational leasing policy pacing development at a rate that is in the public interest. 
Becanse petroleum production from offshore wells in shallow waters has a long history, its operational, legal,. and economic problems are well understood and, for the most part, have been resolved. However, as industry moves into deeper, more hostile waters, the Government shonld become increasingly atware of the importance of regulatory and fiscal policies which will ensure industry's continued investment and ability to meet exploration and production requirements.

The Commission recommends that leasing and regulatory policies for offshore oil be geared to a rate of development reflecting all aspects of national interests. Strong support should be given to accomplishing the analysis necessary to provide a basis for decisions on development rates. In scheduling its Federal lease sales, the Government should give adequate consideration to industry's need to plan its exploration and development programs in an orderly and effective fashion. For example, it is recommended that longer periods of advance notice be provided for Federal lease sales.

\section{Natural Gas}

Bringing natural gas to the consumer involves three sequential functions: production, transmission, and distribution. Petroleum companies normally explore for and produce the gas. Transportation in interstate commerce is handled by companies regulated by the Federal Power Commission (FPC). Distribution to consumers involves a separate group of companies regulated at the State or municipal level. Although the three functions commonly are accomplished by independent companies, a combination may be performed by one company through subsidiaries. Taken together, the gas transmission and distribution industry is among the 10 largest U.S. industries in terms of capital investment.

Sales of natural gas in the next decade are expected to increase about 4 per cent per year. In fact, the percentage of total energy consumption represented by natural gas is expected to increase slightly, in spite of the growth of nuclear and other new competitive primary energy sources. As for oil, the offshore areas offer great potential for new gas reserves; gas producers and transmission companies are making heary commitments there. In 1967 , about $\$ 300$ million was paid to petroleum companies for natural gas produced offshore.

Offshore oil and natural gas operations share many technical and regulatory problems. Unlike the situation in the petroleum industry, however, the maximum prices that the producer and wholesale distributor of natural gas may charge are subject to regulation by the FPC, and FPC permission must be obtained before new interstate gas pipelines can be laid.

\section{Reserves}

The national reserve-to-production $(R / P)$ ratio of natural gas has been declining steadily, falling from a reserve adequate to cover nearly 27 years of production in 1950 to slightly less than 16 years in 1968. The optimum level of reserves cannot be authoritatively stated. Some companies believe that the national $\mathrm{R} / \mathrm{P}$ ratio can continue to decline for an additional period without causing undue concern. However, individual companies have already felt the pressure of decliming reserves, and it is doubtful that it would be in the national interest to allow much further reduction. Although the $R / P$ ratio for oil is about 10 years, valid reasons exist for maintaining natural gas reserves 
at a higher level.

With growing demand for natural gas, it is important to encourage a greater rate of exploration and development than presently exist. Nthongh conventional and perduaps completely new types of land sources will provir!e some reserves, it appears that the offshore areas will be of vital importance for several decades.

Two categories of FPC regulatory policy should be morlified to help encourage additionil exploration and development of gas reserves: pipeline construction and wellluarl price.

\section{New Pipeline Construction}

Inder current procedures, a gas transmission eompany will not receive permission to construet a new pipeline muless it can prove to the FPC that, among other things, sufficient reserres will be available to satisfy the consumer's who will come to rely on the new pipeline. However, transmission companies sometimes find it difficult to furnish such proof to the FPC because they are unwilling to commit thenselves firmly to purchase gas from undeveloped reserves, and producers are reluctant to make the considerable expenditures necessary to develop the new reserves unless they are assured of customcrs. They cannot be assured of customers until the FI'C approves construction of the new pipeline. Further, producers are unwill. ind to reveal their proven reserves to the FPC because public disclosure may hurt them in bidding for offshore leases.

This problem does not lend itself to simple resolutions. The Commission urges that the FPC study every possible solution, including the acceptance of enntracts between gas producers and gas transmission companies in substitution for geological evidence of reserves. The FPC also should examine its policies to determine the extent to which efforts to establish proven reserves result in disclosure adverse to a company and devise methods by which such impact, if any, can be legitimately minimized.

\section{Wellhead Price Regulation}

The maximum price a transmission company can pay for gas at the wellhead is regnlated by the FPC. The FPC recognized the importance of encouraging the search for supplies by adopting a two-price system in the Permian Basin rate case and a inultiprice system in southern Lonisiana that fixes higher prices for all new gas-well gas. Iifferences between offshore and onshore operations were mentioned in the case involving south Louisiana, an area of great potential for offshore reserves. But the rates fixed, according to the petroleum companies, do not reflect adequately the increased costs assnciated with offshore operations. Consequently, the petroleum companies say that they have little financial incentive to search for off shore gas, except when they are certain of finding large quantities.

The Commission recommends that the Federal Power Commission reexamine its differential price policies for natural gas and make such adjustments as it deems advisable to reflect adequately the increased cost of offshore production.

\section{Technology}

The increasing costs of natural gas should furnish a strong incentive to the transmission companies to reduce pipeline costs through improved techmology. In spite of this incentive, lowever, the transmission industry has had a very low level of research and development expenditures. The gas transmission companies have heen discour- 
aged from undertaking lesearch by the regnlatory accounting treatment of research expenditures prescribed by the. Federal Power ('ommission.

When resenrch is successful, resulting in useful plant or equipment as a part of a specific pipeline project, it is clear that transmission companies can eapitalize the cost. However, if the research is not successful $o r$ is of a general nature, the accounting treatment of the cost is not as clearly defined. In some cases the expenditure can be capitalized, or in many other eases, allowed as an expense. But several transmission companies have indicated that the uncertainty as to which treatment will prevail inhibits research expenditures. These companies also have indicated concern that certain large, general research activities not resulting in clearly identifiable improvements might be disallowed in determining the maximum permitted return on investment. This concern makes such expenditures difficult to justify, as the risk camnot be equated with a potential for increased profit because the benefits of successful projects now are passed largely to the customer or, in some cases, to the producer. The net result is an extremely low research and derelopment expenditure in the industry and a reluetance to undertake the large, uncertain expenditures necessary for technological advance.

To account for research and development expenditures after the fact in terms of success or failure appears to be an aceounting praetice inconsistent with the basic premise of research itself. Even if initially anticipated results are not achieved, the research has eliminated one option and provided much useful information in the process. Consideration of this principle conld resolve the lack of agreement between the gas transmission industry and the FPC concerning accounting treatment for research expenditures.
The Commission recommends that in order to encourage innovative research and development activities, the Federal Power Commission review its accounting regulations relating to research and development to determine whether such regulations are consistent with the legitimate need of the gas transmission industry for clear and realistic guidelines.

With appropriate enconragement, the gas transmission industry could foster new technology that would increase the eeonomic feasibility of gas production and transmission farther offshore and in deeper waters and contribute to the overall ability to work in the ocean. For example, improved techniques for laying large-diameter pipelines in deepel waters may well depart from the concept of the traditional pipelaying barge and introduce totally new seafloor construction techniques.

\section{Planning}

Recognizing the vital role of the offshore areas as a source of natural gas, the FPC has recently undertaken to enconrage industry planning to achieve greater efficiency in the construction and use of facilities to transport naturnl gas from offshore areas. Although in 1967 a major proposal submitted by an industry consortium for sharing offshore pipelines was tnrned down by the FPC, recent FPC policy statements indicate that FPC will require joint industry planning of offshore pipelines. It is hoped that cooperation of producers, pipeline companies, and the FPC will :

- Expedite the planning and processing of joint-use proposals

- Contribute to the more orderly development of offshore areas

- Encourage exploration 
- Provide economies benefiting both the industry and its customers.

\section{Other Marine Minerals}

The hard mineral resources of the shelf and deep sea have assumed public prominence only recently, unlike oil and gas, which have been taken from the continental shelves for more than 30 years. Ocean minerals have been hailed by some as a nearly inexhaustible treasure trove. To other's, the inaccessibility of most marine minerals and the expensive technology required for their recovery place them on the far horizon of the future in comparison with minerals from more conventional sources.

The Commission finds that the truth lies somewhere between these extremes. There is no urgent necessity to develop subsen hard minerals with maximum speed regardless of cost. Nevertheless, an early start in offshore exploration and development of the required technology is warranted to determine reserves and to establish a basis for future exploration. The lead time required to dehineate the resources and to develop the necessary technology, the very great costs involved, and the diverse character of the benefits resulting make it proper for Government to play a large role in this exploratory and developmental phase.

\section{The Present Resource Picture}

World demand for many key minerals is expected to double by 1985 and triplo by the year 2000 ; competition for the available supply will become severe as industrialization of the developing comtries progresses. It is essential that the Nation ensure an adequate and dependable supply of minerals by increasing the rate of discovery.

Despite the tone of urgency that permeates many discussions of future U.S. demands for minerals, the present supply outlook is not foreboding. In a research-oriented and technically progressive nation, advancing technology finds ways continually to replenish depleted reserves. Year by year, it becomes possible to mine minerals of lower and lower grades, to develop less expensive operating techniques, and to improve processes for reclaiming scrap metals. For example, it is possible that ores having one-half or one third the copper content of the grades presently required for commercial operation could be mined profitably in the future. Similarly, substantial amounts of aluminum, copper, lead, and zinc are already being reclaimed, thus cutting the demand for new supplies.

The United States is almost totally dependent on foreign sources for such minerals as chrominm, manganese, nickel, cobalt, industrial diamonds, and tin. Forty of 72 str'ategic commodities come from politically unstable areas. In addition, domestic sources supply only a small part of other important minerals, including aluminum, zinc, and tungsten. Hence it is important to assess the sea as a potential source of these materials.

Resources to meet our mineral demands may come from several basic elements of the marine environment. The chemical constituents of sea water make an impressive total, but they are generally found in concentrations so low that only a few are presently or prospectively exploitable. Salt, bromine, and magnesium metal and compounds are already being obtained profitably from sea water. For all practical purposes, the source is inexhaustible, and production is limited only by demand and the competition of land-based sources. But for the foreseeable future, the economics of extracting other metals and chemical compounds from the sea water are such that at present or prospective prices there is litele commereial opportunity for production. 

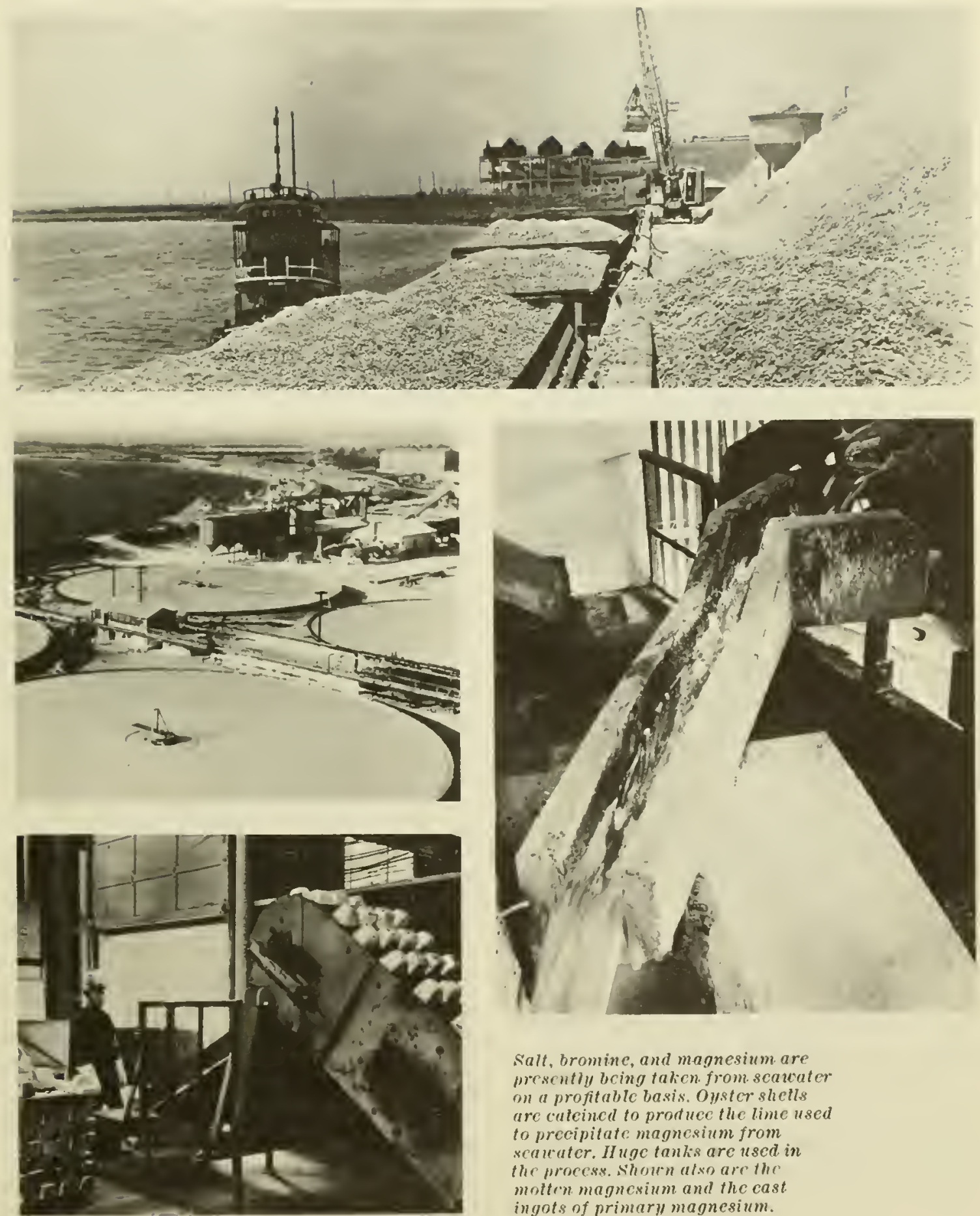

Salt, bromine, and magnesium are wresently being taten from scauater on a profitable basis. Oyster shells are cuteined to protuce the lime used to precipitate magnesium from scaleuter. II uge tanks are used in the brocess. shown also are the motten magnexium and the cast. ingots of primary magnesium. 
Submerged placer deposits may be a more promising source of minerals. These deposits, accumulated in the past ages by the effects of bottom topography, offshore eurrents, and beach and allurial processes, are confined mainly to the inner edge of the continental shelf. It is unlikely that significant placer deposits will be found on the continental slope or beyoud. Sand and gravel deposits are now being utilized for commereial production in the Inited States. Serious investigation is warranted of the prospects for commercial utilization of the placers, particularly gold, platinmm, and chromite on the west coast (including Mlaska) and phosphorite, ilmenite, and zircon on the east coast.

Inother source of minerals is the subbottom, including the substrata of the continental shelves and slopes from which oil, gas, and sulfur are recovered. The seabed also may vield coal, potash, phosphatic rock, iron ore, hanxite, and possibly metallic rein deposits.

Coal has been mined (working from onshore shafts or artificial islands) off the coasts of Canada, the I'nited Kingdom, .Japan, and Taiwan. Commercial grades of iron ore have been mined to a much lesser extent off Newfoundland and Finland. Onshore lode or bedrock deposits are sufficiently abundant near the shoreline in Llaska, the west coast, and New England to suggest the presence of oflshore deposits of similar character in rock formations of the continental shelf. Very little is known about the potential of buried consolidated roek deposits in the seabed. Unless accessible from onshore sites or artificial islands, exploitation of these deposits presents formidable problems and thus lies well into the future.

Beyond the continental slopes, the only deposits currently seeming to have potential eeonomie importance are nodules, crusts, and oozes. The nodules have stirred active commercial interest, not only because of the manganese content but also because they contain significant amounts of copper, cobalt. and nickel. The rocks beneath the abyssal ocean floor remain far beyond our present technical capacity to explore. They are thought to contain minerals associated with basic and utrabasic rocks of igneous origin, such as chromite and nickel.

The discovery of rich brines in depressions on the floor of the Red Sea may indicate another source of exploitable minerals. It has been speculated that similar brines may occur elsewhere.

\section{The State of Ocean Mining}

The marine mining industry is in its infancy. Exclusive of oil and gas, the total 1967 value of offshore world inineral production was estimated at nearly $\$ 1$ billion, of which about 20 per cent came from U.S. waters. However, about 35 per cent of the world total was accounted for by coal recovered through tunnels from the shore, and about 40 per cent was chemicals recovered from the sea water column. Worldwide, less than $\$ 200$ million worth of mineral products was mined directly from the ocean floor annually. If common sand, gravel, oyster shells, and sulfur are excluded, this figure reduces to $\$ 50$ million, which is the present annual world value of tin, iron, heavy minerals, and diamond production from offshore sources.

Torldwide, there were in 1967 approximately 300 marine mining operations of all tyles. 11 of these operations were nearshore, and almost all such operations involving profluction of hald minerals from the ocean floor are hased abroad.

Ilthough the reend of actual exploitation is relatively modest. Govermment agencies and a fairly large number of private firms are engagred increasingly in exploration and 
technological development aimed at recorcry of marine hard minerals.

\section{Obstacles to Industry Action}

The Commission finds that the obstacles to grreater commercial development of subsea hard minerals are economic, technical, and institutional.

The basic differences between the fossil fuels industry and the hard minerals industry have important implications for Government policy. The fossil fucls industry has been fortunate in that the geological structures controlling the distribution of deposits generally extend without interruption seaward from the land. This permits easier identification of promising areas for exploration and will facilitate the gradual seaward extension of existing production technology. Howerer, only a few types of hard mineral deposits extend from the land offshore, making the projection of favorable target areas much more difficult. Further, the exploratory techniques are more expensive because the horizontal dimensions of most hard mineral deposits are smaller. The steps from discovery to production of hard minerals also involve considerably more effort and, except for nearshore operations, involve new, costly technology.

\section{Technological Considerations}

The lack of operating experience increases the risks of ocean mining ventmres. Ocean mining recovery presently can be accomplished from a number of ore deposits at depths as great as 150 feet in calm weather. However, dredging operations, eren in relatively shallow waters, cost more than twice as much as similar operations on land.

The difficulties of locating, proving, and developing reserves in deeper, improtected waters are formidable. Indeed, despite intense interest in ocean mining, most recent activities have been conceptual and explora-

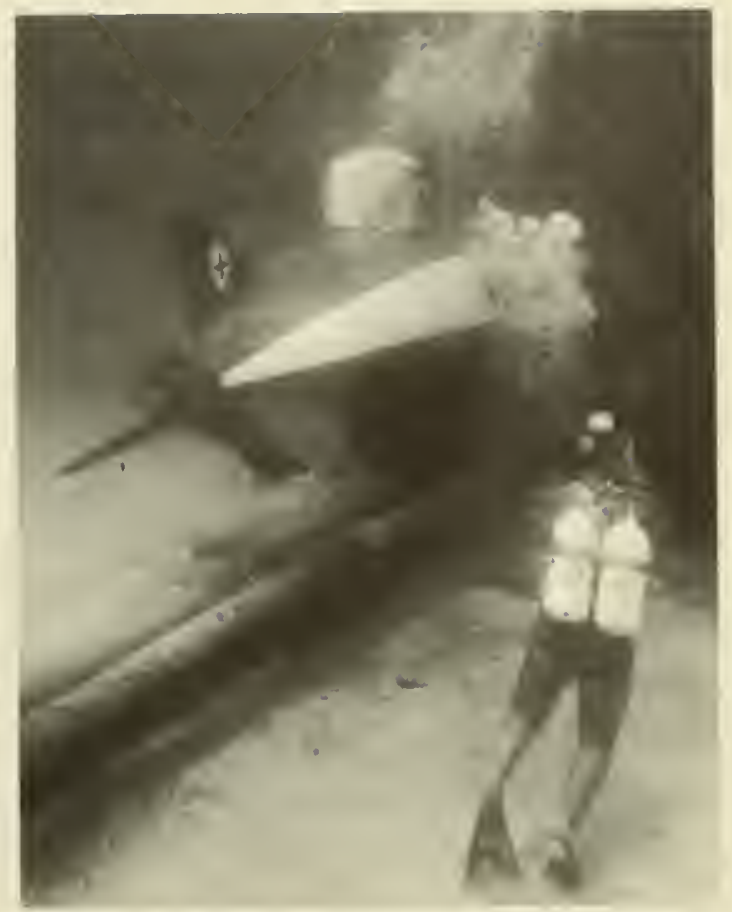

With increasing depths the tcehnological difficultics involved in locating, proving, and dcveloping marine mincral reserves will be formidable; submarine crawlers, bottom-hovering tehicles, and flcrible dcep water pipcs are among the equipment that will be reguired.

tory. Consequently, it is unlikely that with present techmology major private capital outlays will be forthcoming unless spectacularly rich deposits become available or unless the prices or lack of a vailability of landbased sources dictate unusual measures.

The technology for future ocean mining, as in deep water, will require such equipment as :

- Submarine crawlers and bottom-hovering vehicles for exploration and recorery of deposits

- Stationary or nentrally buoyant platforms

- Drilling rigs on the occan floor

- Submarine dredges 
Basic Dredge Types for Marine Mining

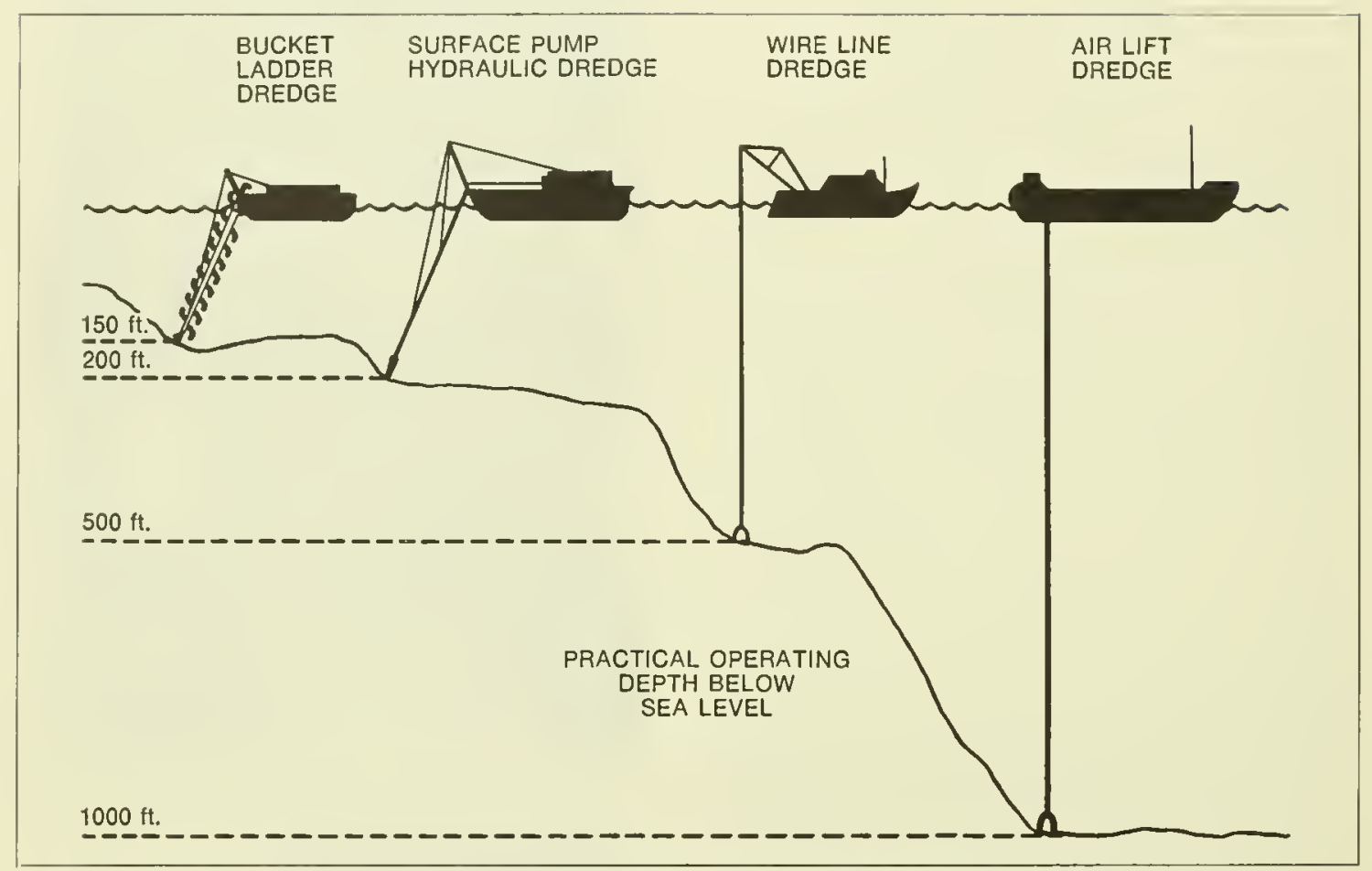

Source: G. T. Coene, "Recovery of Ocean Resources," Ocean Industry, November 1968, p. 55.

- High-capacity, low-cost vertical transport systems

- High capacity equipment for horizontal transfer between sea surface platforms.

Such technological developments will be very costly. Nevertheless, it is anticipated that industry will wish to develop mineral recovery systems in situations where the risks of achieving an acceptable rate of returns are not excessive. The Commission's recommendations will not preclude industry from undertaking this task; on the contrary, they will encourage industry to do so.

Just as reconnaissance scale mapping by the Government will encourage industry to follow with more detailed delineation of deposits, so also Government support of basic marine engineering knowledge will encour- age industry to follow with investment of its own in developing operational mining hardware to recover the resources.

Examples of typical basic engineering needs of deep ocean mining include :

- Sufficient power to lift thousands of tons of minerals from great depths

- Ultrahigh-strength, corrosion-resistant hoisting cables capable of withstanding cyclic stresses

- Long, flexible pipes for deep water that can withstand the bending and shearing stresses

- The ability to provide for the simultaneous flow of solids, liquids, and gases through long pipes.

Development of tools for more rapid geophysical exploration and improved deposit 
sampling equipment will be of crneial importance to the success both of foremment geophysieal and geologie survey activities and of the mining industry"s investigations of the economic potential of specific deposits. l'resent terhnology for such activities is now wholly inadequate in cost and performance. Xew sensor's and plat forms are needed for direct and inferred observations of sediment structure, rock trpes, outcrops, and faults. Seismic, electric, magnetic, and optical sensors are now in use or under development to supplenent the older methods of mapping, taking samples, and eoring. Computer techniques are coming into use to analyze data and to project the most likely targets for investigation.

The potential for developing less costly exploration technology, however, is quite promising, and in the Commission's view, the value of the resonrces potentially arailable justifies the effort to develop the technology. Is in the calse of the reeomaissance survey work and for the same reason, the Gorernnent must help develop the new techmology. Identification of fundamental technology problems meriting invest igation and development of tools and instrumentation required for exploration shonld be undertaken jointly between the private sector and the Federal Government in a properly coordinated program.

The Commission recommends that strong Federal support be provided for a program to advance the fundamental technology relevant to marine minerals exploration and recovery. Government and industry should work in close cooperation to develop more rapid geophysical exploration tools and improved marine sampling equipment. The Government should have the function of testing new tools and equipment developed mainly by private industry and in cooperation with industry should be responsible for setting standards for the mining industry.

\section{Legal and Regulatory Considerations}

The georraplice areas of rrreatest immediate conceln to the lT.S. mining interests fall clearly within either State or Federal jurisdiction. The industry's contention, vigorously presented to the Commission, is that the competitive procedures of the 1953 Onter Continental Shelf Lands Act are inappropriate and that the Act is not attuned to the minique problens likely to be encomntererl in developing marine minerals, which will require major investments in exploration and re"over'y muder conditions of very high risk. Speeifieally, industry urges that a firm which discovers commereially exploitable deposits should have the privilege of developing these deposits, subject to stipulated terms and conditions, withont hidding for the privilege.

The ratio of exploration eosts to potential profit, the industry points out, looms much larger with most hard minerals than with oil. Although statistical data are woefully inadequate, the ratio of targets explored to deposits discovered ashore may be as great as $1.000 ; 1$, and the ratio may be higher in the offshore environment. Exploration of the shelf for hard mineral deposits will be a very high risk speculation for the foreseeable future, and mineral explorers will need strong incentives to apply their energy and skills in an activity in which good fortume is also required. Inst important mineral commodities are products of world trade, and a mineral dereloper must evaluate any exploration venture in the light of the world market. The deredoper must weed ont prospects with low geologric or economic potential and concentrate on the most pronising. Farorable land and ocean mining laws of other comntries 
rompete directly with the L.S. offshore exploration dollars. Our continental shelf will not be explored by private industry, if it appears that ore deposits can be discovered and more profitably recovered elsewhere.

The Commission recognizes the ralidity of these arguments, given the present state of our knowledge of subsea minerals and current means for their discovery and recovery. At the present level of risk, it is unlikely that sufficient interest could be generated on Onter Continental Shelf Lands Act mining leases (except perhaps for known deposits) to support competitive bidding. On the other hand, the present situation will not continue forever. The survey and technology programs recommended by the Commission are designed to open opportunities for profitable exploitation attractive to many firms. The procedures established under the Outer Contimental Shelf Lands Act have worked well under these threshold conditions and should not be lightly: abandoned.

Furthermore, the entire subject of mineral development rights on public lands and the outer continental shelf is currently under intensive reriew. The Public Land Law Review Commission (PLLRC) will report to the President and the Congress in June 1970. Important questions have been raised before the PLLRC ' as to the desirability of continuing claim-staking on public lands ashore. We would hesitate in this situation to recommend the system's extension into a new enviromment.

As illustrative guidelines for an improved system to assign exploration and development rights for hard minerals on the U.S. continental shelf, the Commission offers the following:

- The system should seek to encourage exploration.

- The systems primary objectire should not

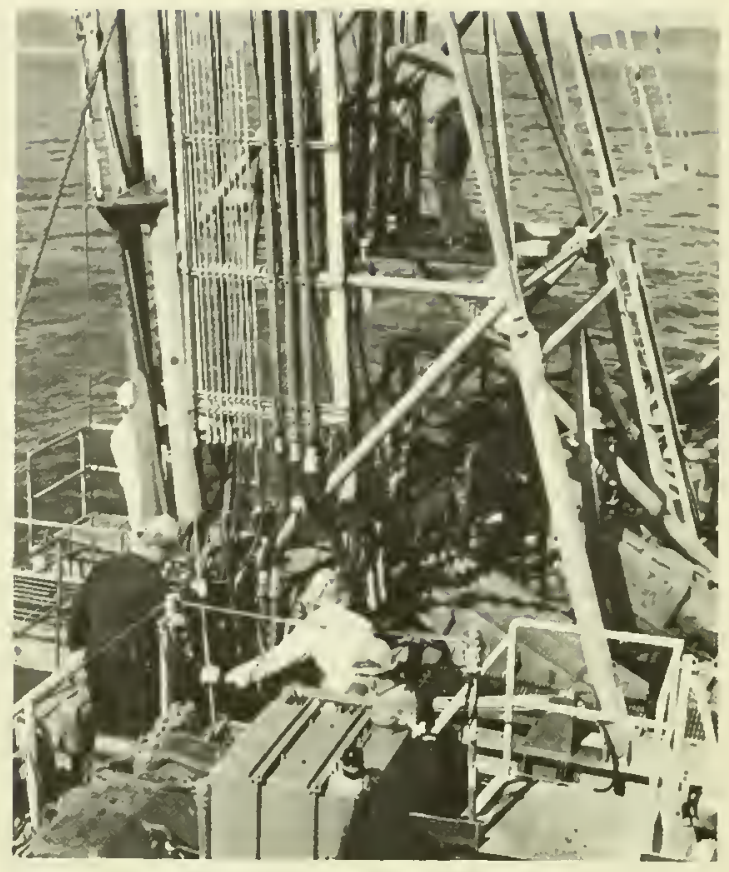

The Fcieral Government should continue its role in the assessment of marine mineral resource potentials. As an example of such worl, the Burcau of Mine's rescarch iesuel Virginia City lies recently been sureying seafloor mineral deposits off Alaska.

he to maximize near-term Federal income from rents, royalties, or bonuses but rather the aggregate net economic return to the nation from ocean mining activity. This objective can be accomplished only by building a healthy ocean mining industry. - The system should take into account the fact that the United States faces competition from other nations that may offer to lease their offshore mineral rights on terms more attractive to U.S. capital.

The Government will face diversified situations with respect to the derelopment of hard minerals on the outer continental shelf for which it will need a rariety of policies. For example, Government-sponsored scien- 
tific expeditions may discover deposits of sufficient commercial interest to warrant early competitive bidding. In other cases, the Govermment's survey activities may identify areas of sufficient minelial potential to cause a number of firms to plan followu investigations. 'The terms for acquiring exploitation rights in such situations must be establisher in adrance to protect all the part ies involved, including the United States.

In still other instances, the Department of the Interior may determine that the national interest compels it to sponsor further inrestigations because of the lack of private interest or some other reason. Rights to minerals discovered in this manner clearly should be awarded on the basis of competitive bidding. Yet by far the most common circumstance, at least for the immediate future, will be one in which private industry undertakes the detailed exploration and inrestigation. Such initiative ordinarily should be rewalded with exclusive rights to develop the deposits discovered under an appropriate concession system.

The key factor is that the Secretary of the Interiol should have sufficient flexibility to respond to this variety of situations.

The Commission recommends that when deemed necessary to stimulate exploration, the Secretary of the Interior be granted the flexibility to award rights to develop hard minerals on the outer continental shelf without requiring competitive bidding. The Federal rule in this matter also would provide a suitable model for the States.

The Commission emphasizes strongly the need for orderly action now to establish the basis for future mining of ocean minerals, not because the mineral situation is critical but because it will take a long time to pre- pare for widespread use of the sea's mineral resources. To define and appraise the resonrces and to develop the necessary technology to recorer them may well take two decades or more. A beginning can be made by proper definition of the information required and by rescheduling existing operations to initiate the necessary programs. An expansion of Government effort to delinente potentials should be accompanied by private industry action to assess them economically. The combined efforts of both will establish a strong foundation for U.S. participation in ocean mining.

\section{Fresh Water Resources}

One of man's oldest dreams is to "harvest" fresh water from the sea to leclaim arid lands and to supplement existing water supplies to meet expanding needs. But as with other resources, the potential for fresh water from the sea must be appraised in light of the supply available on land. The outlook, then, las been mixed.

On the one hand, there are many areas of the world-some of them in the United States-in which economic growth is inhibited by the high cost of water from conventional sources. While the situation is not critical in the United States, it is critical in many developing countries. The Nation's interest in these countries makes water technology, including desalination, a matter of legitimate national concern.

Brackish and salt water are being converted to fresh water in many parts of the world. In humid or moderately humid areas, the cost of such water is higher than that of surface and ground water. Several lines of research are being pursued to reduce cost and to provide greater flexibility in the use of brackish and salt water. We are by no means at the end of the search for cheaper and better techniques. Efforts of the Federal Government, States, and universities must be continued. 


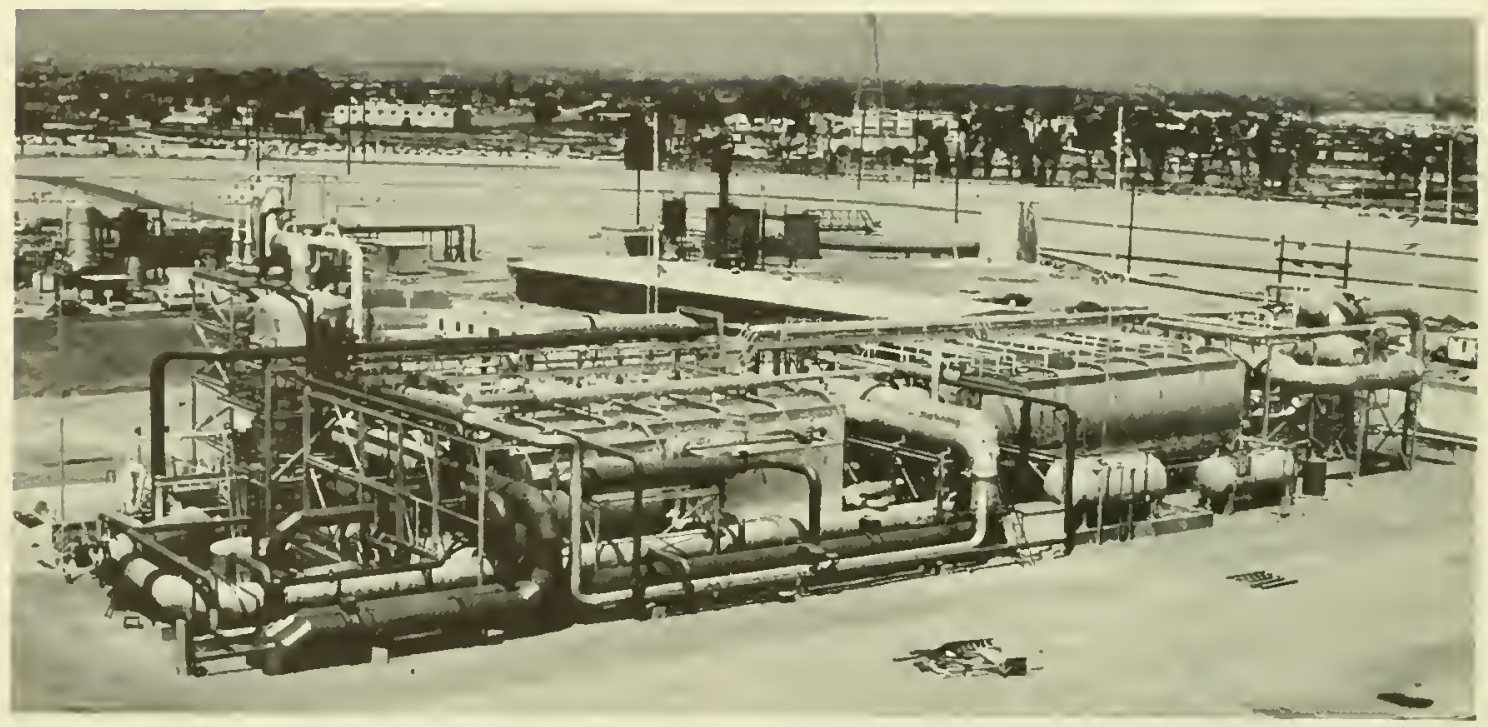

Fresh water is becoming an inereasingly more valuable natural resouree.

The uond's largest experimental desalting unit, produeing some 2.5

million gallons of fresh water per day at the Offiee of Saline Water's

San Diego Test Fueility, is designed to provide data for desalting plants of the future.

The significance of desalination lies not in the average cost of producing water, but in the incremental costs. Even in the semiarid western States, ground and surface sources provicle water at lower average cost than now appears likely for any type of desalination. lut as increasing numbers of people move to the Pacific coast, the problem of provicling additional increments of water will become acute. One of the major advantages of desalination is the ability to locate plants in the areas of greatest need and to produce water and electricity in dual-purpose power plant-sea water couversion complexes. Other types of desalination plants, particularly those processing brackish water, can provide modest supplements to the water supplies of small and medium-sized urban areas in rolumes adjusted to population growth. Desalination, therefore, may prove to be a more flexible way of adding water supplies in the Sonthwest and one requiring less capital investment than the only other known alteruative-massive interregional water trausfer projects.

Desalination also can be used to purify polluted as well as brackish water. Conversely, the consequences of discharging the effluent of desalination into coastal waters must be studied carefully by the Coastal Zone Authorities before large desalination plants are installed.

The Commission finds that the desalination program is being conducted in a satisfactory manner. Research and derelopment now underway reflect a close, effective partnership among Federal, State, and local governments and the academic community. More useful attention could be given to such secondary applications of desalting processes as extracting chemicals through concentration of brines. Although progress in achieving economic technology for large plants having capacities above 25 million gallons per day 
would be accelerated by an expanded effort, the need for desalted water is not so critical as to require a crash program.

The Commission concludes that a halanced desalination program should direct additional attention to three key areas:

- Techniques for meeting large-scale regional water needs, especially those of metropolitan coastal populations

- More reliable and efficient smaller plants for isolated shorefront sites and islands and for inland communities which must depend upon brackish or polluted water sources

- Systems for industrial and municipal reuse of waste water.

The Commission recommends that the Department of the Interior continue an aggressive and diversified desalination research and development program with increased emphasis on very large-scale applications, smaller plants for such purposes as tapping brackish water supplies for inland communities, and systems permitting re-use of waste water.

Althongh desalination is the most significant way to produce fresh water from the sea, there are other possibilities. In particular, the potential of geological formations producing fresh water in strata underlying coastal waters needs further investigation. Conceivably, such sources of fresh water could supplement local water supplies continuously in very dry areas at relatively low (a)pital costs.

\section{Pre-Investment Surveys}

$A$ Government-supported program is necessary to delineate the gross geological configuration of the continental shelves and slopes adjacent to the Lnited States and to identify in general terms their resonrce potential and areas of greatest commercial promise. This is of particular importance to the mining industry, but it also would be helpful to the petroleum industry as oil and gas exploration and exploitation proceed into deeper waters and remote areas where even general geological characteristics remain unknown. In such cases industry cannot reasonably be expected to undertake the necessary studies.

Geological reconnaissance surveys would be tremendously expensive for any indivichal firm to mdertake, and it conld hope to realize only a small fraction of the total benefit fiom this type of exploratory juvestment. Furthermore, the survey costs will be much lower if made in the course of a broad, systematic, Government-sponsored mapping and coring program than if made by individual firms.

The reconnaissance surveys will uncover a variety of new industrial opportunities and provide the foundation for more detailed investigation and commerical evaluation of the marine resources by industry.

The Federal Government conducts similar geological surveys on land. As on land, the recommended geological surveys should be preceded by preparing general purpose maps of topography and geophysical characteristics. Specific recommendations for conducting such bathymetric and geophysical surveys, which also will serve needs other than those of the nonliving resource industries, are discussed in Chapter 6 .

The Department of the Interior has proposed a marine geological survey involving extensive dredging, coring, heat probes, examination of outcrops, and shallow and deep core drilling into the seabottom. The Commission endor'ses this program but urges that it be condinated closely with the marine geophysical surveys planned by the Environmental Science Services Administration and 


\section{Profile of the Continents and Oceans}

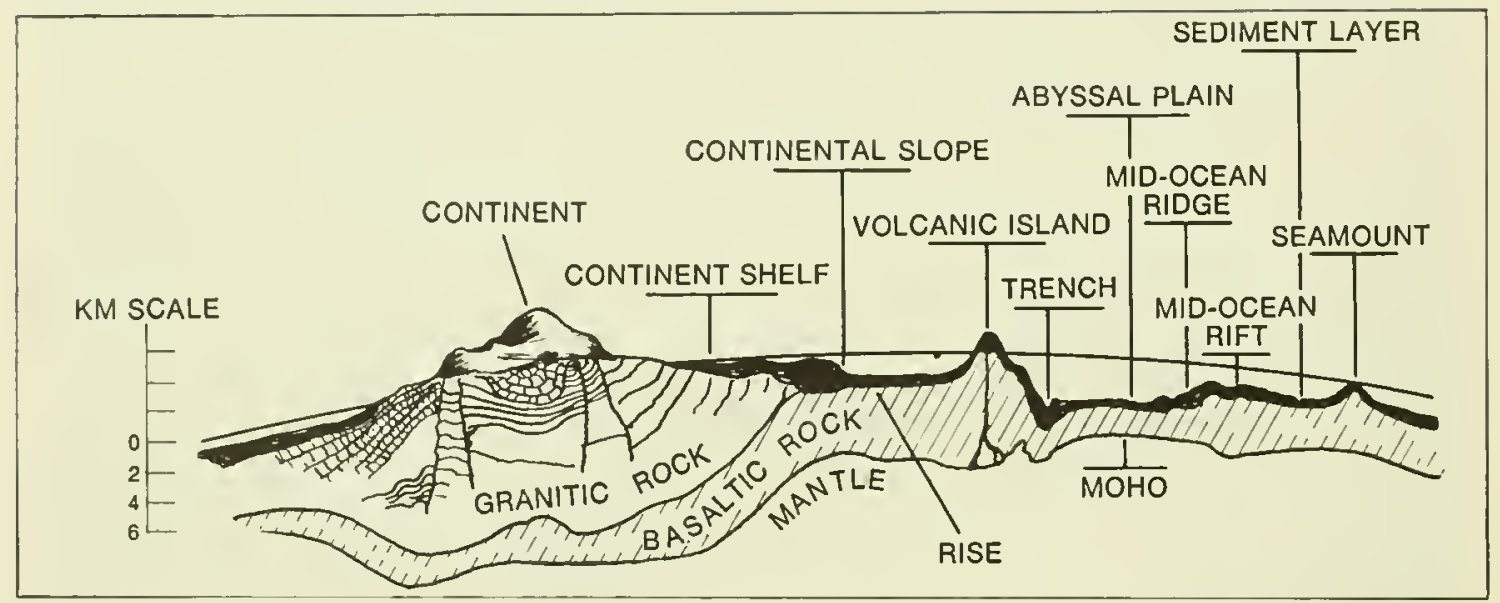

the current National Sediment Coring Program sponsored by the National Science Foundation.

These activities will yield basic information for scientific understanding of our continents and ocean basins and for future minerals development. Since coring is expensive, it is importint that the cores be analyzed not only for mineralogical and geological data but also for information regarding past climates, sedimentation, and aquifers. Provisions must be made for prompt and complete analysis of cores, a process that now takes too long.

The objective of the marine geological and coring programs should be a complete geologic analysis of the structure of the continental shelres and slopes on a mapping scale of $1: 250,000$, refined to $1: 62,500$ in illeas of high interest. These scales are adequate to identify minerial potentials in gross terms. Completion of the surveys within 15 to 20 years should keep pace with an overall proglam for marine mineral resources derelopment.

The Commission recommends that the National Oceanic and Atmospheric
Agency provide the reconnaissance surveys and analyses necessary to prepare three-dimensional maps at a $1: 250,000$ reconnaissance scale of the geological configuration of the continental shelf and slopes adjacent to the United States. This program should be geared to achieving a comprehensive analysis at reconnaissance scale within 15 to 20 years. These surveys should be conducted by the Government and by industry and universities under contract with the Government. Nonproprietary information available from private industry should be utilized to the maximum extent to supplement information gathered.

Research on geologic plocesses that form and modify the earth's crust should be carried out in critical areas concurrently with the geologic mapping to develop new criteria and methods of searching marine and terrestrial resonrces.

The geological mapping and analysis program is keyed to a 15 - to 20 -year completion goal, while basic bathymetric and geophysical mapping, which should precede geologic analyses, is proposed for completion within 
10 years (see Chapter 6 ). It is important that the plaming of these two programs be closely coordinated and the geologic.program concentrate first in :

- Offshore areas having highest potential for minerals

- Areas of scientific significance (determined initially by knowledge of the geology on land) to enhance onr mnderstanding of the geologic history of the continental shelves and slopes

- Coastal areas where the population is expanding rapidly and where plaming and management groups will need sound basic information on which to make judgments on the best use of marine areas.

\section{Roles of the Department of the Interior and the National Oceanic and Atmospheric Agency in Marine Minerals Development}

The Department of the Interior is responsible for fostering the development and utilization of the Nation's minerals, including those of the outer continental shelf. The Department analyzes mineral needs and rates of use, identifies resources, evaluates their potential for exploitation, and assists States and industries in exploiting mineral resources.

The hard minerals inderlying the high seas are virtually untapped. The Department's Geological Survey and the Burean of Mines spend only $\$ 7$ million annually on problems of discovering and recovering marine minerals.

The responsibility for funding and conducting the recommended geological surveys of the bed of the high seas and its subsoil should be assigned to National Oceanic and Atmospheric Agency. However, the new agency should work closely with the Geological Survey in carrying out this function.

The National Oceanic and Atmospheric
Agency also shonld develop the basic technology to assess the feasibility of seabed mining and should secure the assistance of the Burean of Mines in this task. The Department of the Interior should continue to assess the national interest in ocean minerals and decide whether the results of mineral investigations and technological developments warrant specific action to provide further encomragement to industry to mine the seabed.

\section{An International Legal-Political Frame- work for Exploring and Exploiting the Mineral Resources Underlying the High Seas}

Exploration and exploitation of the mineral resources of the deep seas offer significant opportmities to benefit all nations and to promote international peace and order. For in these vast areas of untold riches, few, if any, national economic interests have been vested. Nor, as yet, have the nations of the world any fixed political positions or attitudes on the legal-political arrangements that should be made for such exploration and exploitation.

To realize these opportmnities, President Jolnson has warned:

Under no circumstances must we ever allow the prospect of rich harvest and mineral wealth to create a new form of colonial competition among the maritime nations. We must be careful to avoid a race to grab and to hold the lands under the high seas. We must ensure that the deep seas and the ocean bottoms are, and remain, the legacy of all human beings.

Any international framework for the conduct of minerals exploration and exploitation must be judged by the extent to which it achieres the following additional objectives: - It must encourage scientific and technolog- 


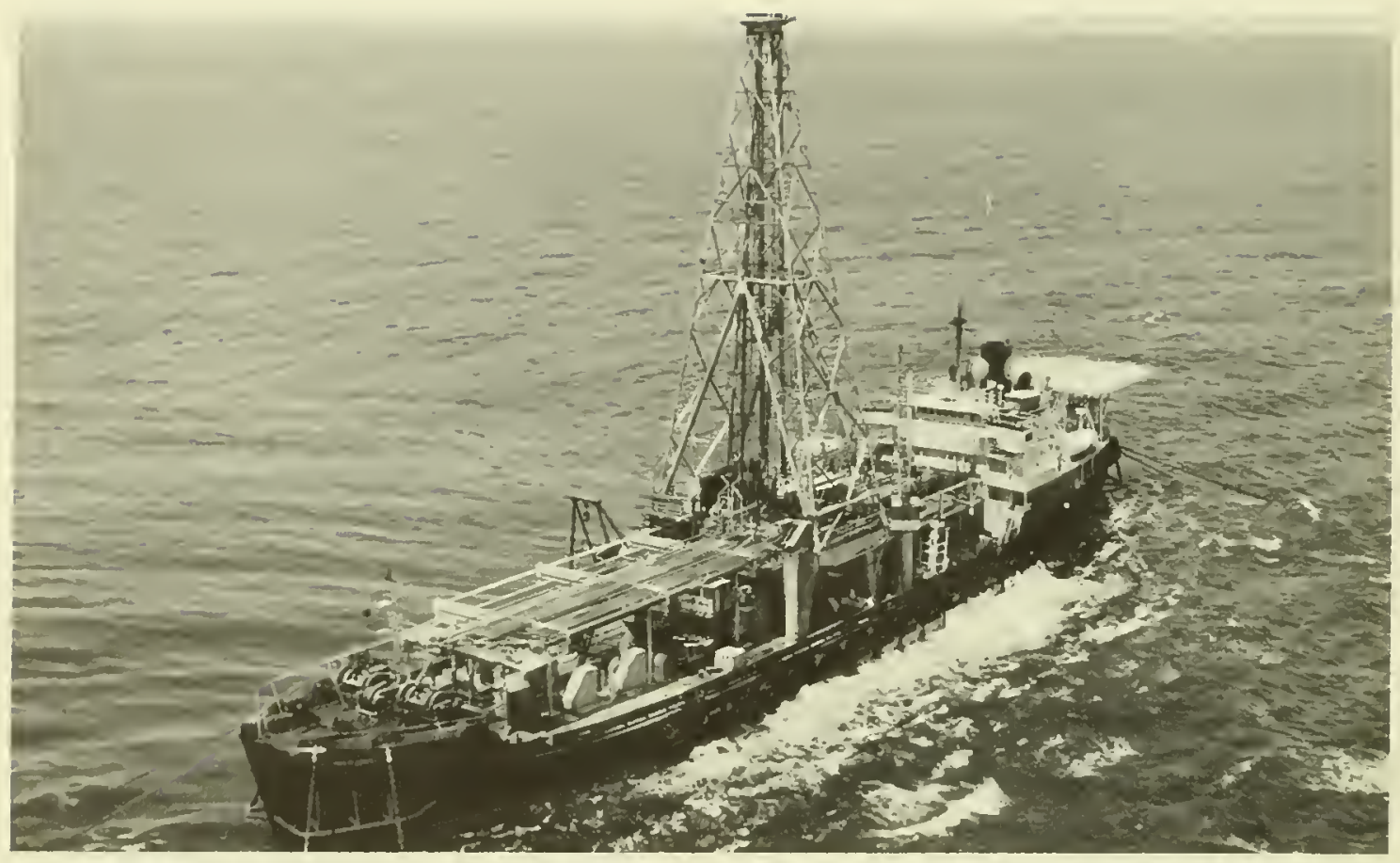

Under existing international law, each eoastal nation has "sovereign rights" over its continental shelf for the purpose of cxploring it and exploiting its natural resources. A drilling vessel and jack-up platform are seen on loeation in the Gulf of Merieo, which for dccades has been the principal offshore source of U.S.-produced oil.

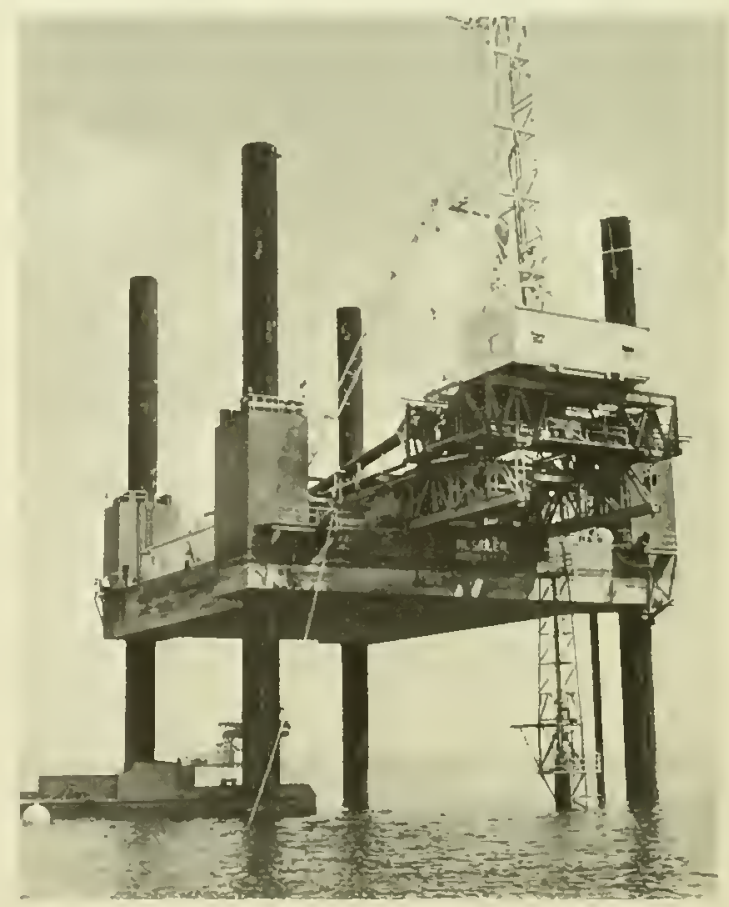


ical efforts and the other major capital inrestments needed for such explorition and exploitation by making it possible to conduct these aetivities in an orderly and economic minner.

- It must give the United States and all other nations a fair chance to engage in minerals exploration and exploitation.

- It must minimize the creation of vested interests that will inhibit changes in the framework decmed desirable in the light of unfolding experience with actual exploration and exploitation.

- It must seek to avoid and not to provoke international confliet.

To achieve these objectires, the framework must provide means to recognize exclusive claims to explore and exploit the mineral resources of large enough subsea areas for long enough periods of time to furnish the incentive to undertake this activity. It must protect recognized claims and at the same time require the relinquishment of claims that are not properly explored or developed within fixed reasonable periods of time. It also must provide for the peaceful settlement of disputes that arise.

The Commission concludes that the existing international framework does not provide the necessary means to achieve these objectives.

\section{Existing Framework}

Each coastal nation, as indicated in Chapter 3, has the right of permanent, exclusive access to the nonliving resources found in its territorial waters, on their beds, or in their subsoil. In addition, the International Convention on the Continental Shelf grants to each coastal nation "sovereign lights" over the continental shelf "for the purpose of exploring it and exploiting its natural resources."

The Convention contains provisions to as- sure that the exereise of these sovereign rights will not interfere unduly with other uses of the seas. Chief among them is the provision that the exercise of these rights shall not "affect the legal status of the superjacent waters as high seas, or that of the air space above those water"s."

Only general principles of international law govern exploration and exploitation of the mineral resources of the bed and subsoil of the subsea areas beyond the outer limits of the continental shelf as defined by the Convention on the Continental Shelf. These genelal principles abound with uncertainty.

\section{Uncertainties in Existing Definition of the "Continental Shelf" and a Recommended Redefinition}

Private enterprise will be deterred from exploring and exploiting the mineral resources of the bed and subsoil underlying the high seas unless it is assured of exclusive access to such resourees in a large enough area for a long enough time to make the activity profitable. Yet no one can reasonably say that the existing framework assures such security much beyond the 200-meter isobath. The principal uncertainty derives from the Convention's definition of the continental shelf, which extends the shelf "to the seabed and the subsoil of the submarine areas adjacent to the coast but outside the area of the territorial sea, to a depth of 200 meter's or, beyond that limit, to where the depth of the superjacent waters admits of the exploitation of the natural resources of the said areas ***." It should be noted that this legal definition of the shelf does not correspond to its geological definition.

Even the coastal nation's right of perinanent, exclusive access to the natural resources of the continental shelf up to the 200 -meter isobath is not entirely free of doubt, because in some parts of the world the geological 
continental shelf (at depths less than 200 meters) extends so far from the coast that at some point, it may reasonably be argued, it is no longer "adjacent" to it and, therefore, not within the Convention's definition.

At the other extreme, it has been argued that the arljacency criterion is not a limitation even upon the exploitability criterion, but that as soon as it becomes techmologically possible to exploit mineral resources to any ocean depth, the seabed of all the submarine areas of the world-totaling more than 128 million square miles beyond the 200-meter isobath-will belong to the coastal nations. They would then divide these areas among themselves in accoldance with Article 6 of the Convention on the Continental Shelf; in effect, it would give each coastal nation sovereign rights to the natural resonrces of the seabed and subsoil from its coasts to the median line, that is, the line every point of which is equidistant from the coasts of the nearest nations.

Other suggested interpretations of the continental shelf definition are presented in the Report of the Commission's Intermational Panel. We think it important to consider bere only the riew presented in the Intcrim Report of the National Petroleum Council's (NPC) Committee on Petroleum Resonrces Inder the Ocean Floor, which was adopted on July 9, 1968. The NPC Interim Report maintains that the exploitability and adjarency criteria, taken together, give coastal nations "sovereign rights" orer" the natural resonrces of the continental land mass seaward to where the submerged portion of that land mass meets the abyssal ocean floor, that is, over the natural lesources of the geological continental shelves, continental borderlands, continental slopes, and at least the landward portions of the geological continental rises.
Where the continent drops off sharply from near the present constline to the abyssal ocean floor, the NPC. Interim Report would add to the legal "continental shelf" an area of that floor cont ignous to the continent.

On the basis of the studies of its International Panel, the Commission concludes that the NPC position is not warranted either by the language of the definition of the "continental shelf" or its history. We do not think that there is any reasonable way to interpret the Conrention's definition that would place a precise outer limit on the existing legal "cont inental sbelf."

To eliminate the uncertainty, the NPC Interim Report proposes that the United States declare to the world that it will exercise sovereign rights over the "continental shelf" as defined by the NPC, and invite all other roastal nations to issue similar declarations.

This proposal, at first, may seem attractive. The United States has the power to effectuate it and acquire permanent, exchusire access to the mineral resources of an additional 479,000 square statute miles of seabed and subsoil. It already has approximately 850,000 square statute miles of continental shelf up to the 200 -meter isobath. Very rich oil and gas deposits are expected to be found in this additional rast area, and the United States would make itself the sole beneficiary of their exploitation. Furthermore, some T.S. oil companies seemingly would prefer to continue to face the known perils of the exercise of exchusive authority by coastal nations around the world rather than the unknown perils of international legal-political arrangements yet to be negotiated.

Nevertheless, the Commission rejects this proposal as contrary to the best interests of the United States. It would benefit other constal mations of the world proportionately more than the United States and give them 
exclusive authority over the natural resources of immense subsea areas. In light of recent history, it is shortsighted to assume that U.S. private enterprise would be better off to deal with these coastal nations for permits to derelop these resources in the absence of any recognition of the interest of the intermational community in them.

At the same time, the NPC proposal would create the danger that some coastal nations without important mineral deposits on or moler their continental slopes and rises will feel justified in claiming exelusive access to the superjacent waters, the living resources in them, and the air above them.

The danger that rights of exclusive access for one purpose may expand to claims of territorial sovereignty or exclusive access for all purposes materialized as an unforeseen and undesirable consequence of the Truman Proclamation of 1945 . Reacting to this $m$ ilateral U.S. claim to sovereign rights over the natural resources of its geological continental shelf, Chile, Ecuador, and Pern each proclaimed its "sole sovereignty and jurisdiction over the areas of the sea adjacent to the const of its own country and extending not less than two hundred mantical miles from the said coast." Earlier in this chapter, we examined the consequences of this policy for the U.S. distant water fishing fleet and the general relations between the United States and these Latin American countries. Recently, too, Feuador issued a decree that appears to attach restrictions upon the right of foreign naval vessels and aircraft to transit or fly over its claimed 200-mile territorial sea.

Such developments are obviously contrary to traditional U.S. policy to limit national claims to the sea in the interest of the maximum freedom essential to the multiple uses, including military uses, which the United States makes of the oceans. National security and world peace are best served by the narrowest possible definition of the continental shelf for purposes of mineral resources development.

The NPC proposal is also unfair to the inland nations of the world which will not comprehend why the rich mineral deposits on and under the continental slopes and rises should belong only to the coastal nations. U.S. action to effectuate the NPC proposal would be regarded as a "grab," even if all the coastal nations followed suit.

The Commission recommends that the United States take the initiative to secure international agreement on a redefinition of the "continental "shelf" for purposes of the Convention on the Continental Shelf. The seaward limit of each coastal nation's "continental shelf" should be fixed at the 200-meter isobath, or 50 nautical miles from the baseline for measuring the breadth of its territorial sea, whichever alternative gives it the greater area for purposes of the Convention.

If the same continental shelf, as redefined, is claimed by two or more nations whose coasts are opposite each other or by two or more adjacent nations, the boundaries should be determined by applying the "median-line" principles set forth in Article 6 of the Convention.

With the use of the best available bathymetric surveys, the recommended definition should be translated into geographical coordinates for each coastal nation and not be subject to change because of subsequent alterations in the coastline or revelations of more detailed surveys.

The redefined "continental shelf" would be a "narrow" shelf with precise outer limits, thus serving the interests of the United States as previously delineated. Two hundred 
meters is the arerage depth of the onter edges of the world's geological continental slielres: 50 nantical miles is the average width of the shelves. I3y providing the 200 meter/s()-mile alternative, the inequity of a definition in terms of the 200 -meter isobath alone will be aroided for those coastal nations which either are not on a geological continental shelf, as in the Persian Gulf, or hare coasts that drop to great depths almost immediately, as off the west coast of South Imerica.

\section{Uncertainties Concerning Subsea Areas Beyond the Continental Shelf and Recom- mended Legal-Political Arrangements for Such Areas}

Assuming there are limits to the legal "continental shelf" as presently defined, incertainty also characterizes the general principles of international law governing exploration and exploitation of the mineral resources of the subsea areas beyond these limits. The different positions that have been taken regarding these principles are set forth in the Report of the Commission's Intelnational Panel.

International lawyers seem to agree that any nation may explore the seabed and subsoil beyond the limits of the continental shelf and keep any minerals it may find and extract. Iowerer, there is no agreement that such a nation may also exclude "poachers," that is, operators of other nations who wait until a riscovery has been made and then, having avoided the costs of exploration, move in and work the deposit.

The NPC Interim Repont argues that adoption of its proposal would remove any urgency in the foreseeable future to create a new international framework for exploration and exploitation of the mineral resources beyond the "continental shelf" defined in accordance with its proposal.
It may be true, if the NPC proposal is adopted, that some coustal nations may not feel this meney. But this is not sufficient reason to adopt an otherwise unacceptable proposal. Moreorer, it also may be true that if the coastal nations are satisfied with the legal-political framework for the exploration and exploitation of the nineral resonrces leyond the continental shelves, as redefined in accorlance with the Commission's recommendation, they may readily accept the reconmended redefinition. As a practical matter, therefore, the question of fixing the outer limits of the continental shelf is inseparable from that of the framework applicable beyond these limits. The two questions will bo intertwined in international negotiations.

Just as it takes time-and planning-to prepare the scientific, technological, and economic bases for exploring and exploiting the mineral resources lying deep under water, it it also takes time-and plamning-to make hospitable international arrangements for such exploration and exploitation. Conscious and appropliate lawmaking will encoura ge the steps necessary to build the scientific, technological, and economic foundations for the desired activity. The nations of the world must not molerestimate the pace of technological advance in the face of such encouragement and increasing human needs.

Tnless a new international framework is devised which removes legal uncertainty from mineral resources exploration and exploitation in every area of the seabed and its subsoil, some renturesome govermments and private entrepreneurs will act to create faits accomplis that will be difficult to undo, even though they adrersely affect the interests of the United States and the international community.

The Tnited Nations also is immersed deeply in oceanic mattcrs and has taken significant steps toward the creation of a new 
framework. The I.N. Ad Hoc Committee to Study the Peaceful I'ses of the Sea-Bed and the Ocean Floor Beyond the Limits of $\mathrm{Na}$ tional. Jurisdiction has reported to the twenty-third (1968) Session of the U.N. General Issembly. It should be reealled, too, that Article 13 of the Convention on the Continental Shelf permits any nation adhering to it to request its revision at any time after June 10, 1969. The T.X. General Assembly must then decide what to do about the request.

The Commission recommends that the United States seize the opportunity for leadership which the present situation demands and propose a new international legal-political framework for exploration and exploitation of the mineral resources underlying the deep seas, that is, the high seas beyond the outer limits of the continental shelf as redefined in accordance with the Commission's recommendations.

The Commission recognizes that any proposed changes in the existing international framework will be subject to international negotiations, and this makes it hazardous to venture specific proposals. Nevertheless, we do so. Our particular recommendations may not survive the process of negotiation nor perhaps even the test of debate, but only by being specific is it possible to subject to critical examination the kind of framework we hat ve concluded the present situation requires.

ITe also should like to stress that our major recommentations are interrelated. Rejection of any one of these recommendations would raisc serions questions in the minds of the Commission as to the adrisability of continuing with the others.

The Commission has considered and rejected a number of alternatives that have been suggested to govem mineral resources exploration and exploitation beyond the contineutal shelf. These include proposals to grant sovereign rights over any area to the nation which is the first to discover and exploit its minelal resonrces and to give title to the mineral resources beyond the continental shelf to the Inited Nations in the name of the international commmity. These alternatives, which are considered in detail in the Report of the Commission's International Panel, were rejected becanse no one of them attains the objectives that must be accomplished in the immediate future.

Nevertheless, the following recommended framework incorporates particular elements of some of these alternatives and others which have not hitherto been proposed.

The Commission recommends that new international agreements be negotiated embodying the following provisions:

- An International Registry Authority

- An International Fund

- Certain powers and duties of registering nations

- Limited policing functions for Registry Authority

- Dispute settlement provisions

- Creation of an intermediate zone.

The sereral elements of this recommendation are discussed in the pages that follow. An International Authority To Register National Claims Beyond the Redefined Continental Shelf

All claims to explore or exploit particular mineral resources in particular areas of the cleep seas should be registered with an International Registry Anthority. Every nation adhering to the agreements should undertake not to engage in, or authorize, ex- 


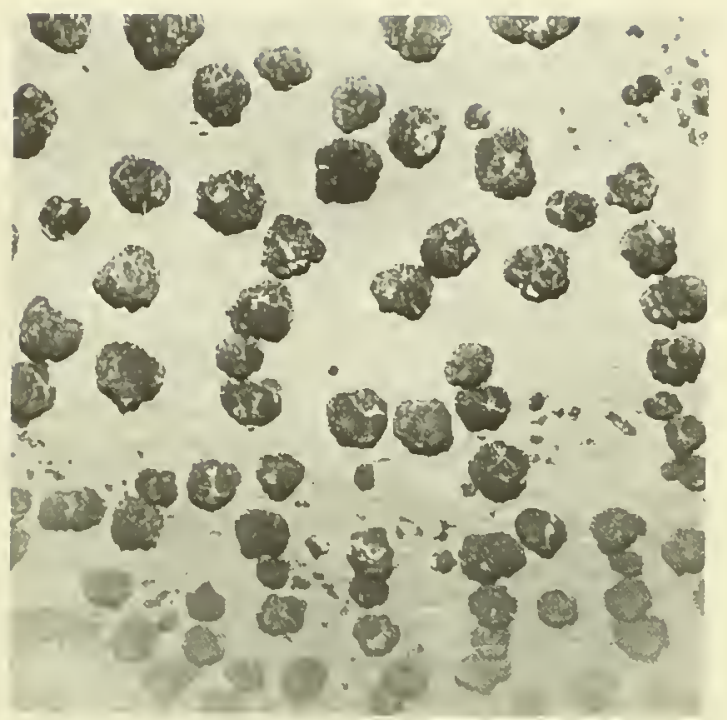

Manganese nodules photographed at 2,735 meters. The Commission proposes negotiation of an international agreement to establish "In international anthority to register rlaims to explore or exploit sueh. derp sea mineral resourees.

ploitation except under a registered claim. Sations thus will be free to engage in or anthorize preliminary investigation to determine whether it is worthwhile registering a claim to explore. However, as will become clear later, every nation will have a great incentive to register a claim to explore as quickly as possible.

Only a nation, or an association of nations, should be eligrible to register a claim. If the claim pertains to an area within some coastal nation's "intermediate zone," as defined below, only that nation should be anthorized to register it.

The International Registry Iuthority should be required to register claims with respect to specified mineral resources, e.g., oil and gas, or all minerals other than oil and gas, or all mineral resources, in a specified area of the deep seas on a "first-come, first-registered" basis, subject only to the following condition: The nation registering the claim must satisfy the Authority that the individual, association, corporation, or mational organization that will undertake the exploration or exploitation is technically and financially competent and willing to perform the task. The entity undertaking the task may or may not be a national of the registering nation; that should be a matter for each nation to decide for itself. But for the condition mentioned, which is necessary to prevent claim registration from being used to "sit on" the rights derived therefrom, the Authority shonld be given no discretion to deny registration of any claim.

Registration of a claim to explore for particular mineral resources in a particular area of the deep seas should confer upon the registering nation the exchusive right to engage in or anthorize such exploration.

[pon proof of discovery, the Internationa] Registry Authority should be required to convert the registered claim to explore into a registered claim to exploit.

Regristration of a clain to exploit particular mineral resources in a particular area of the deep seas should confer upon the registering nation the exclusive right to engage in or authorize such exploitation in a large enough area and for a loug enough time to enable the producer to operate economically and not wastefully and to recover its original investment as well as an adequate return thereon. The size of the area covered by the claim and the term of years for which it is registered should be fixed by the Authority.

i registered clain to explore or exploit should be subject to conditions specified by the Intermational Registry Authority to as- 
sure that clains are not registered solely for the purpose of "sitting on" rights derived therefrom but actually will be wrorked. Failure to comply with these conditions shonld subject the registration to revocation.

$A$ registering nation should be anthorized to transfer any registered claim to any other uation which adheres to the agreements embodying the new framework.

No unregistered claim slould be entitled to any of the benefits derived from registration, and in any conflict between a registered claim and an unregistered claim, the former should prevail.

These provisions should furnish all nations with incentives to adhere to the recommended agreements and to register claims with the International Registry Authority.

Upon expiration of the period of registration of a claim to explore or to exploit, further exploration or exploitation of the resources covered by the claim should be subject to whatever. international legal-political framework is in effect at that time. The mation which registered the expired claim should not acquire, by virtue thereof, a rested right to continue to explore or exploit the particular resources covered hy that claim, or even a preference orer any other nation with respect to such exploration or exploitation.

The membership of the International Registry Authority and the manner of choosing its governing body shonld be specified in the agreements emborlying the new framework. The Anthority should find its place in the family of the Inited Nations but should be as autonomous as the World Bank. We propose that it be organized on a "multiple principle" representation, based on the teclmological capacity of its members as well as on their geographic distribution.

To cover the costs of the International Registry Authority, every nation should be required to pay to the Authority a fee for each claim to explore which it registers and an additional fee if and when that claim is conrerted into a claim to exploit. The $\Lambda 11$ thority slould be emporered to fix the fees.

\section{An International Fund}

Every nation registering a claim to exploit should be required to pay a portion of the value of the production, if any, into an Intermational Fund to be expended for such purposes as financing marine scientific activity and resources exploration and development, particulary food-from-the-sea programs, and aiding the developing countries throngh the World Bank [*.X. Development Program and other international derelopment agencies. The proceeds from these payments slonld not be expended for general purposes of the Tuited Nations.

The International Registry Authority should receive the payments from the registering nations and turn the proceeds over to the International Fund but should have nothing to do witl the Fund's managenent.

The membership of the International Fund and the manner of chosing its governing body should be determined by the L.N. General Assembly.

The Commission's proposals for an International Fund do not constitute just another way for the rich nations to aid the poor nations. They are intended to compensate the common owners of the mineral resonces of the deep seas by using the "economic rent" for purposes that the intemational community agrees will promote the common welfare.

Howerel, the Commission must caution against any optimistic assmmption that the sums at the disposal of the International Fund will be so luge as to make it munecessary in the coming decades for rich nations to aid the derelopment of poor nations in any 
other way. The International Registry Anthority will also have to keep in mind that its purposes will be defeated if it fixes the rates of payment so high as to discournge exploration and exploitation of the mineral resonrces of the deep seas.

\section{Powers and Duties of Registering Nations}

Each Nation registering a claim should agree to enact domestic legislation to assure that:

- The business entity on whose behalf the claim is registered complies with the conditions imposed by the International Registry Authority and reasonably accommodates other uses of the subsea area covered by the registered claim, the superjacent and surface waters, and the air above them along the lines specified in the Convention on the Continental Shelf.

- The specified fees and payments are submitted to the Intemational Registry Authority.

- Its civil and criminal laws are applied to protect exploration and exploitation activities under its registered claims, including the personnel involved, and the necessary installations and other devices against piracy, theft, violence, and other unlawful interference.

The registering nation's failure to discharge these obligations effectively should subject its registered claims to revocation by the Intemational Registry Authority.

'The registering nation, of course, will be able to apply any other of its domestic laws not inconsistent with the recommended framework to the exploration and exploitation activities mder its registered claims, such as laws concerning working conditions; the production and marketing of the extracted minerals; and the taxation of the income from such activities.

\section{Limited Policing Functions for the Registry Authority}

The Commission does not recommend that the International Registry Authority be given initial policing functions. However, becanse we recommend that the Authority be empowered to cancel a registered claim if the registering nation fails to discharge its obligations properly, the Authority must have the means to perform this function fairly and with full knowledge of the facts. Accordingly, the Authority should be empowered to inspect all stations, installations, equipment, and other devices used in operations under a registered claim and to conduct appropriate hearings.

\section{Dispute Settlement}

The International Registry Authority initially should settle disputes arising under the recommended framework. At the request of any party to the dispute, however, the Authority's initial decision, including a decision to revoke a registered claim, should be subject to review by an independent arbitration agency possessing expertise in resolving the kinds of issues likely to be presented.

The Commission's recommendations set forth abore are intended to create international machinery for the international recognition of claims to exelusive access to subsea minerals in large enongh areas for long enough periods of time to make operations profitable. In this way, nations and private entrepreneurs will be encouraged to make the scientific and technological efforts and the other major capital investments needed to develop the mineral resources of the deep seas.

The recommendations will minimize international conftict. While the "first-come, firstregistered" principle governing the International Registry Authority may stimulate a 
"race" among nations to register" claims, the recommendations greatly temper the natme of this race. Most important of all, registered craims are limited in time; when they expire, further exploration or exploitation of the minelal resourees in the area covered by the expired claim will be subject to whatever legal-political framework may then be in effect. 'The recommended framework can be changed at any time in the light of experience with mincral resources exploration and exploitation in the deep seas. Only the claims already registered will be immune from such clange and then only until they expire by their own terms. Stability is achieved without unduly inhibiting change.

Through the recommended International Fund, the poor and developing nations of the world will share the benefits of subsea minerals exploitation.

\section{Creation of an Intermediate Zone}

The uncertainties surrounding the present definition of the continental shelf may have raised the expectations of some coastal nations to the point at which they may refuse to accept the Commission's recommended redefinition of the shelf without the preferential rights of access to the mineral resources of a reasonable subsea area lying beyond the shelf. It is also recognized that, in the language of the Truman Proclamation of 1945 , "self-protection" may compel "the coastal nation to keep close watch over activities off its shores which are of the nature necessary for the utilization of" the mineral resources lying reasonably beyond the shelf.

At the same :ime, however, the Commission remains of the view that the mineral resources of the deep seas cannot, in fairness or law, be said to belong to the coastal nations so that all other nations should be entirely excluded from the benefits of their exploitation.

These considerations lead the Commission to recommend that intermediate zones be ereated encompassing the bed and subsoil of the deep seas, but only to the 2,500 -meter isolatl, or 100 mantical miles from the baselime for measuring the breadth of each coastal nation's territorial sea, whichever alternative gives the coastal nation the greater area for the purposes for which intermediate zones are created.

Only the constal mation or its licensees, which may or may not be its nationals, should be anthorized to explore or exploit the mineral resources of the intermediate zone. In all other respects, exploration and exploitation in the intermediate zone should be governed by the framework recommended above for the areas of the deep seas beyond the intermediate zone.

If the same intermediate zone is claimed by two or more nations whose coists are opposite each other, or by two or more adjacent nations, the boundaries should be determined by applying the "median-line" principles set forth in Article 6 of the Convention on the Continental Shelf.

The 2,500-meter isobath is considered by authorities to be the average depth of the basis of the world's geological continental slopes: 100 nautical miles is the average width of the continental shelves and slopes.

The Commission proposes that the bonndaries of each coastal nation's intermediate zone be fixed in terms of geographical coordinates for each nation and not subject to change because of subsequent alterations in the coastline or revelations by mole detailed surveys. The coordinates should be recorded with the International Registry Authority.

The Commission's recommendations regarding an intermediate zone emborly a compromise between the position that the conti- 


\section{Approximate Delineation of Con- tinental Shelves and Intermediate Zones as Proposed}

These rhists are illustretive and do not unruorl to shou actual national lines of juristiteion. No rffort has been malle to sholl luteral boundaries hefuech nations ") millusint lines. The seacurl boundary of the continentul shelf is traten at the $200-m e t e r$ isobnth or 30 miles from the busetine for measuring the ferritorial seu, whicherer is further from shore. The seaudel boundary of the intermediate aone is chroun ut the 2,300-meter isobuth or 100 miles, whichcece is farlher from shore.

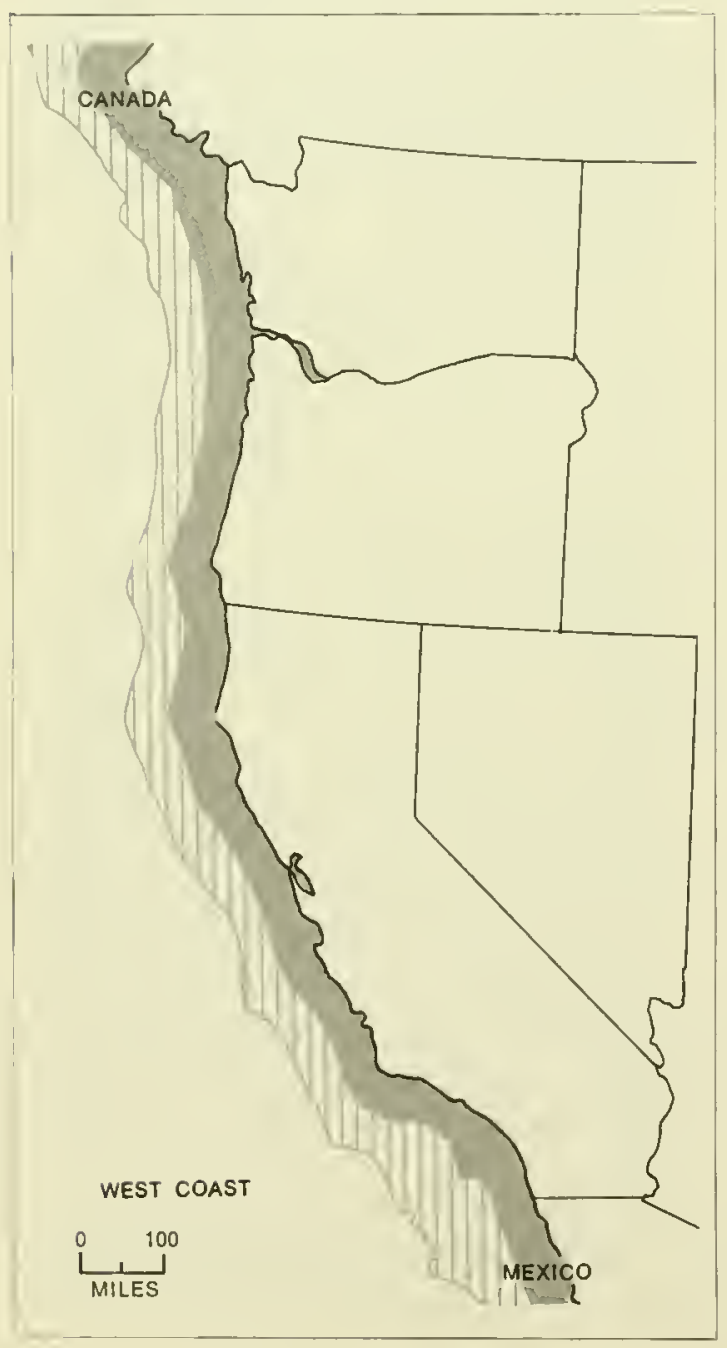

nental shelf should be redefined to include the intermediate zone and the position that the intermediate zone should be treated in every respect like the areas of the deep seas beyond it.

Thder these recommendations, only the coastal nation will have access to the mineral resources of the intermediate zone. It may decirle not to register any claim to explore or exploit mineral resonrces in the zone, in which case every other nation and business entity will be barred from engaging in such activities in the zone. But claims to explore and exploit in the intermediate zone must. be registered with the International Registry Anthority under the terms and conditions applicable to areas of the deep seas beyond the intermediate zone.

The creation of the intermediate zone will not raise the dangers the Commission saw in the proposal to redefine the continental shelf to inchude the zone. It will not encourage claims of exclusive access to the zone for purposes other than general resonrces development.

I nation which registers a claim in the intermediate zone (or beyond) will not thereby acquire the "sovereign rights" of a coastal nation over its continental shelf. It will liave only the rights accorded it under the new framework. Thus, for example, its right of exchusive access will be limited in time. It will pay a portion of the value of production into the International Fund. The international commmnity will thereby acquire a significant interest in the zone. Scientific inquiry concerning the bed of the intermediate zone and undertaken there will not require the coastal nation's prior consent.

Under no other alternative framework suggester will the exploring or exploiting 
nation, of the international agencies given a significant but limited role in these activities, have less justification to.interfere with other uses of the bed of the deep seas, its subsoil, its superjacent or surface waters, or the air above them.

\section{Relations Between the United States as a} Registering Nation and the Business Entities on Whose Behalf It Will Register Claims

These relations are the domestic concern of each nation. New legislation will be necessary in the United States to fix these relations and to implement the recommended framework. The Commission recommends that the new legislation fixing these relations be based on the policies the United States follows in leasing mineral resources on its outer continental shelf, with some important modifications.

\section{Policies Applicable to Alt Registered} Claints Business entities, domestic, or foreign, which seek to have the United States register claims on their behalf with the International Registry Authority should apply to the Department of the Interior, which should be designated the U.S. agency for this purpose. The business entity on whose behalf a claim is registered should pay to the United States the specified fees to corer the costs of

\section{Approximate Delineation of Con- tinental Shelves and Intermediate Zones as Proposed}
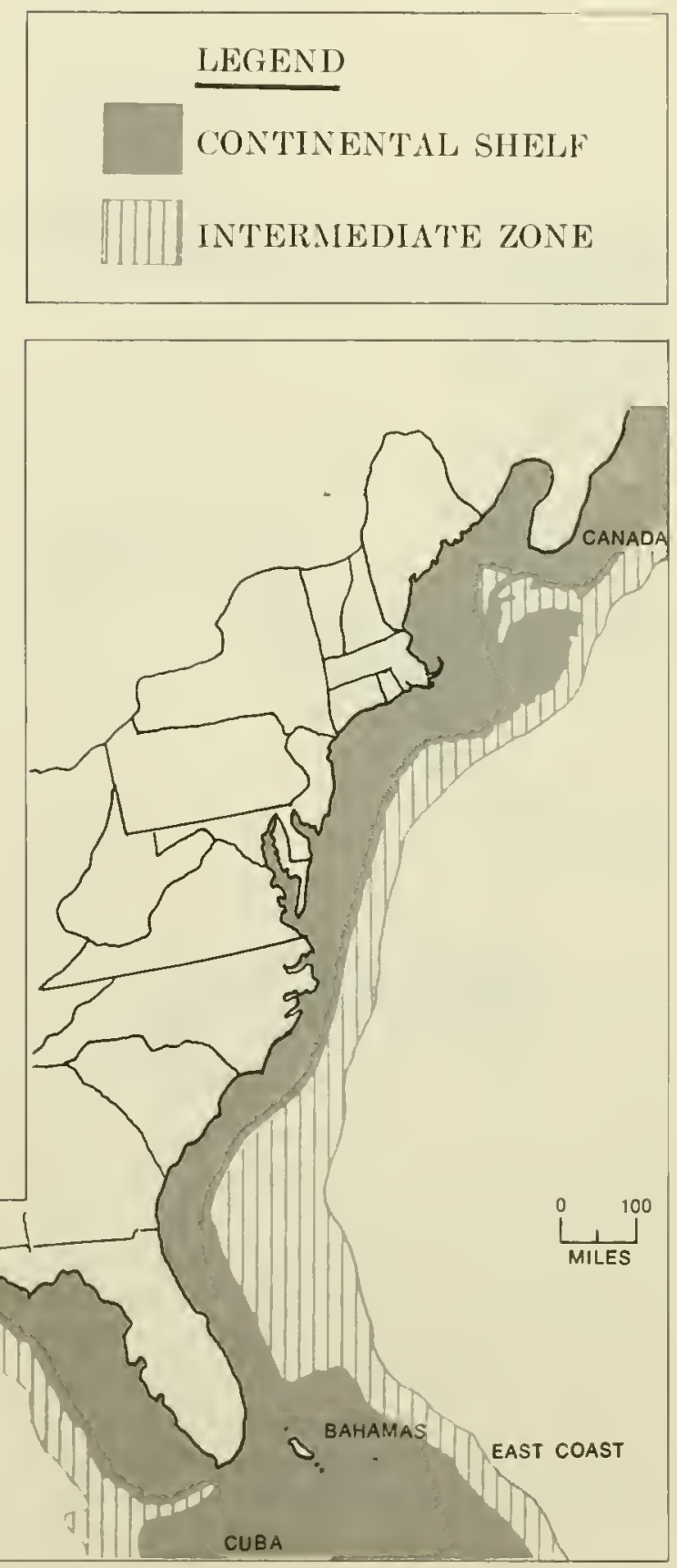


\section{Approximate Delineation of Con- tinental Shelves and Intermediate Zones as Proposed}

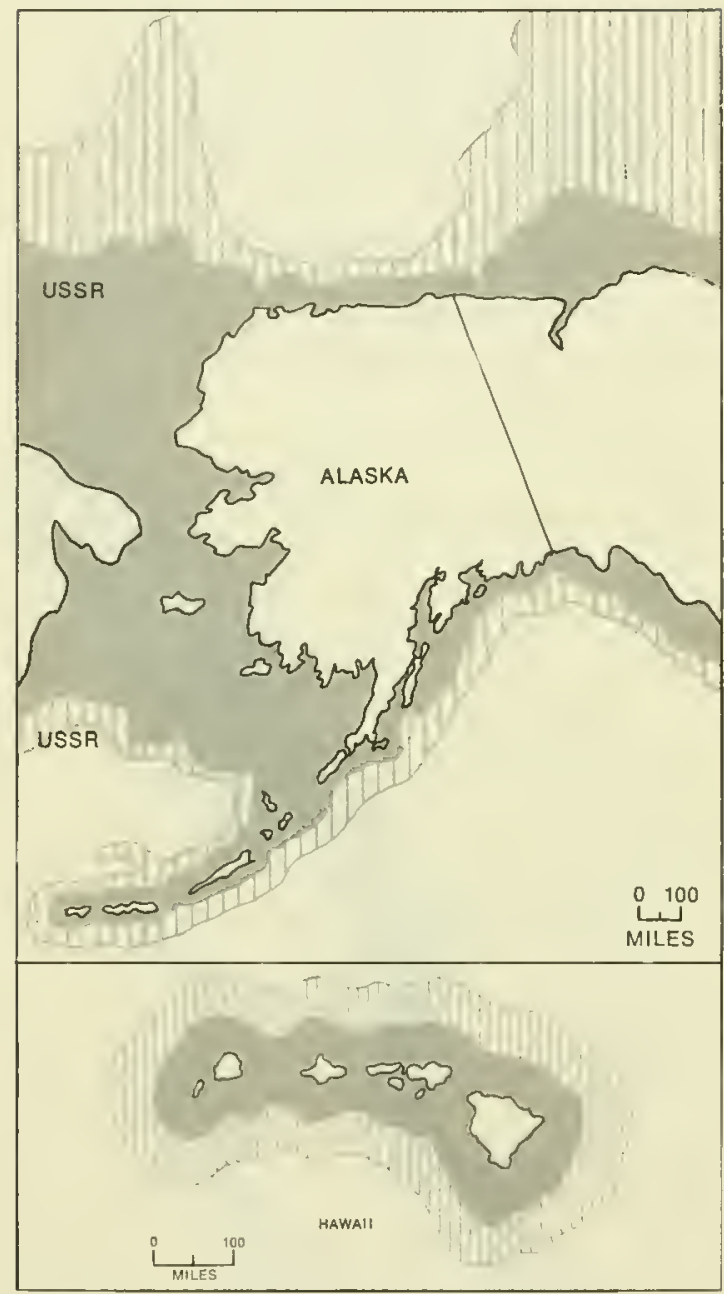

the International Registry Authority which the United States is obligated to pay to the Authority. The business entity on whose behalf a claim to exploit is registered should pay to the Inited States the portion of the value of the extracted minerals which the [nited sitates is obligated to pay to the International Registry Authority on behalf of the International Fund.
'This latter payment should take the place of both the fixed annual rent per acre or square mile and the royalty on the value of production which must now be paid under mineral leases on the outer continental shelf. In this way, the rights of the international community to the mineral resources of the deep seas will be recognized without unduly burdening IT.S. private enterprise.

The payments for the International Fund, which the U.S. representative on the International Registry Authority will participate in fixing, may be greater or less than the combined rents and royalties paid for the same mineral value extracted from the outer continental shelf. In the intermediate zone, such differences probably would be reflected in different levels of competitive bidding.

Additional Policies Concerning Claims in the Intermediate Zone If competitive bidding is employed by the Secretary of the Interior, as would be generally equitable because the Inited States is disposing of its valuable right of exchusive access, the claim to explore should be registered on behalf of the first responsible qualified business entity that applies therefor. Upon discovery, the registered claim to explore should be converted into a claim to exploit on behalf of the responsible qualified business entity that bids the highest cash bomus, or percentage of profits, therefor.

If competitive bidding is not employed, as will sometimes be the case upon adoption of our prior recommendations to encourage mineral resources exploration (see page 137), the claim to explore should be registered on behalf of the first responsible qualified business entity that applies therefor. Upon discovery, the registered claim to explore should be converted into a claim to exploit on behalf of that same entity. 
Additional Policies Concerning Claims in Areas of the Deep Seas Beyond the Intermediate Zone For claims in these areas, the United States should not use competitive bidding, but should adopt the same poliey of "first-eome, first-registered" that will guide the International Registry Muthority. It should register a claim to explore on behalf of the first responsible qualified business entity that applies therefor. Upon diseovery, the claim to explore should be converted into a claim to exploit on behalf of thit same entity.

The Commission seeks to prevent a "flagof-eonvenience" problem from arising. No such problem can arise in the intermediate zone beeause the coastal nation will have exelusive aecess to its mineral resources. But this problem could arise if the United States used competitive bidding in deep sea areas beyond the intermediate zone. All nations have equal aceess to these areas. Explorers and exploiters would then have an incentive to request nations which charged less or nothing therefor, to register claims on their behalf. The United States could forbid its nationals, or foreign business entities controlled by them, from having any other nation register claims on their behalf. But this would establish a most undesirable precedent. The Commission prefers to a wait experience with the recommended alternative of no competitive bidding.

\section{A Proposed Course of Interim Action}

It will take years to arrive at a new framework; therefore, it is importint to secure the earliest possible agrcement on the principles by which the nations of the workd will be guicled in conducting interim mineral resources exploration and exploitation in the deep seas. The principles should not foreclose the opportunity to build the recommended framework.
The Commission supports the principles which the United States has proposed for adoption by the U.N. General Assembly.

These principles, which are set forth verbatim in the Report of the International Panel, are consistent with the framework which the Commission proposes. Essentially, they :

- Call for reclefinition of the onter limits of the continental shelf

- Exclude any claim or exereise of sovereignty or sovereign rights over any part of the seabed or subsoil beyond the redefined limits

- Recognize the interest of the international community in the development of mineral resonres beyond the redefined shelf through the "dedication as feasilile and practicable of a portion of the value" of these resources to "international community purposes"

- Call for a new framework to be established "as soon as practicable" which will be condueive "to the making of investments necesary for the exploration and exploitation of resources" berond the redefined continental shelf.

Another important principle proposed by the United States is that exploitation "of the natural resources of the ocean floor that occurs prior to establishment of the boundary [of the continental shelf] shall be understood not to prejudice its location, regardless of whether the coastal [nation] considers the exploitation to have oceurred on its 'eontinental shelf." This principle quite properly. seeks to reserve the areas beyond the 200meter isobath for future international decision. But it gives no indication of what the coastal nations should reasonably consider to be the limits of their "continental shelf" until such time as the shelf's boundary is fixed. 
In the absence of such an indication, coastal nations may claim wider continental shelves than would be consistent with U.S. interests and thereby influence the ultimate location of the shelf's boundary.

The Commission recommends, therefore, that the United States propose the principle that no nation, in the interim, should claim or exercise sovereignty or sovereign rights over any part of the seabed or subsoil beyond the 200 -meter isobath.

However, the Commission recommends also that the United States continue to authorize exploration and exploitation of the mineral resources of the seabed and subsoil underlying the high seas beyond the 200-meter isobath, provided such authorization explicitly states that any such exploration or exploitation shall be subject to the new international framework agreed upon.

No other policy will achieve the objective of the Marine Resources and Engineering Development Act to preserve "the role of the United States as a leader in marine science and resource development."

The Commission recognizes the apparent dilemma in the recommendation just made. To proceed with exploration and exploitation beyond the 200-meter isobath is to run the risk that the operation may ultimately find itself in an area beyond the redefined continental shelf and perhaps gorerned by a less favorable framework than now applies on the outer continental shelf. But if private enterprise should avoid the risk by failing to explore and exploit beyond the 200-meter isobath, U.S. objectives would not be met.

If the framework the Commission recom- mends is eventually adopted, private enterprise would actually rum little risk by proceeding with such exploration and exploitation. But there is no guarantee that the Commission 's recommendations will be adopted, and a means of protecting private enterprise against undue loss is therefore necessary.

The Commission recommends that the Congress enact legislation to compensate private enterprise for loss of investment or expenses occasioned by any new international framework that redefines the continental shelf so as to put the area in which it is engaged in mineral resources development beyond the shelf's outer limits.

The scope of the Outer Continental Shelf I ands Act is as mcertain as the existing definition of the continental shelf. It is important, however, that entrepreneurs should know when they must seek the Government's permission to engage in exploration and exploitation of subsea minerals. It is equally important that the United States hare adequate control over the evolving situation until a new framework is adopted.

The Commission recommends that the Outer Continental Shelf Lands Act be amended to require permission from the Secretary of the Interior to engage in mineral resource exploration or exploitation in any subsea area beyond the 200meter isobath upon such terms and conditions as the Secretary deems appropriate. The amendment should make clear that this requirement is not intended to constitute a U.S. claim to exercise sovereignty or sovereign rights over any subsea area beyond the 200 -meter isobath. 
In deciding whether to grant permission, the Secretary of the Interior should be guided by the Secretary of State's judgment as to the foreign policy implications of the particular situation in question.

The recommended international legalpolitical framework for the exploration and exploitation of the mineral resources of the bed of the high seas and its subsoil is intended to meet the needs of the immediate future, not to suffice for all time. It does not foreclose the adoption of other alternatives that experience may indicate to be preferable. For the immediate future, the Commission concludes, the recommended framework and accompanying national policies will help to achieve U.S. objectives in the oceans.

\section{Government-Industry Relationships in Support of Resource Development}

\section{Government and Industry Roles}

The key role of the marketplace in maintaining healthy, vigorous private activities in our economy emphasizes the need for carefully designed Government programs to accelerate development of marine resource industries.

The report of the President's Science Adrisory Committee (PSAC) Panel on Oceanography, "Effective Use of the Sea," stated that industry was greatly concerned about the Federal Government's role in developing the Nation's marine program. The Presirent's Science Advisory Committee Panel recommended that the Government perform several functions in achieving the goals of the national ocean program. The Report of the Commission's Industry and Private Inrestment Panel discusses these functions or roles in greater detail, stating that it was substantially in agreement with the roles stated in the PSAC report. The analysis of the Industry and Private Investment Panel, which the ('ommission endorses, concludes that the Government's proper role is to:

- Establish and enunciate national policies and objectives concerning U.S. marine interests

- Assist in planning for optimum use of limited public resources, including the resolution of conflicts among users of the sea which camnot otherwise be adjudicated

- Adopt regulatory policies which will not discourage private investment

- Provide special incentives to encourage certain embryonic marine industries if it is in the national interest

- Undertake and improve the description and prediction of the marine environment and assess possibilities of modifying it beneficially

- Initiate, support, and encourage márine education and training programs

- Protect life and property at sea

- Sponsor programs to obtain basic information for industry's subsequent delineation and development of marine resources and for ensuring their proper conservation

- Aid in advancing the science and basic technology necessary to operate within the marine environınent

- Negotiate acceptable international arrangements to conduct marine industrial and scientific activity, to conserve marine resources, and to prevent pollution of the seas

- Ensure that national security is given proper consideration in ocean development policies.

Government determines the climate for industrial growth through the manner in which it implements its responsibilities outlined above. However, discovery of new resource potentials will be of no benefit without the 
capability to exploit them economically. Derelopment of an efficient marine industry can make the resources of the seas accessible to the Nation and to the world, can assist U.S. economic development, and can strengthen the Nation's position in international trade.

In the execution of its roles listed above, the Government would set in motion a sequence of activities that would lead to industry's greater involvement in exploration, techmological development, and subsequent economic utilization of marine resources. In this way, a major objective of the Marine Resources and Engineering Development Act would be attained.

More specifically, industry would be particularly encouraged to generate additional ideas, methods, and risk capital for the detailed surreying, delineating, producing, and marketing of marine resources. These, of course, would be done within the constraints of proper conservation practices and equitable solutions to multiple-nser problems. Industry will continue to be the ultimate producer of the equipment required for exploring and exploiting the oceans. Finally, under a favorable climate, industry would have the incentives to participate in developing the manpower required for ocean operations through in-house training programs and through aid to university education and research and the incentives to contribute to the support of scientific research and the devel. opment of fundamental technology.

\section{Industrial Activities and Attitudes}

Ocean industry embraces an extraordinarily heterogeneous complex of activities with different operating requirements, levels of investment, degrees of competition, and relationships with Goverument. Government action must not deal only with the common problems all marine enterprises share; it also must take account of the special needs and characteristics of particular industries and their components.

Table 4-3 depicts the present status of domestic ocean industries in two broad categories - existing industries and future industries. It lists only those industries that use the ocean directly, excluding support industries such as diving or instrument manufacture.

The dockside value of the resources taken in 1967 by U.S. firms from the shelf and waters adjacent to the United States has been estimated by the Commission at $\$ 2$ billion per year. Of this amount, 50 per cent was from petroleum, 15 per cent from gas, 20 per cent from fish, and 15 per cent from other activities. But these amounts do not measure the full contributions of the sea to the economy. For example, although dockside value of fish taken by U.S. firms from nearby waters was only some $\$ 400$ million annually, the retail value of fish products--both domestic and imported-marketed by U.S. firms was six and one-half times this amount or more than $\$ 2.6$ billion.

The Commission encountered severe difficulties in its efforts to obtain accurate data to describe industry activities in the oceans, and it found little agreement on their overall contribution to the Nation's economy. Improvement of industry-related statistics will be an important task of the proposed NOAA.

In general, the Commission found that ocean industry seeks from government primarily :

- Strengthening of basic services to improve the efficiency and safety of their offshore operations

- Clarification of the legal status of their activities in order to reduce investment risks

- Provision of pre-investment reconnaissance scale surveys and support of basic technology. 


\section{Table 4-3 Present Status of Domestic Marine Resource-Based Industries}

\begin{tabular}{ll} 
Existing industries & \multicolumn{1}{c}{ Examples } \\
Mature, healthy, and growing &
\end{tabular}

U.S. marine industries are heavily involved in activities thronghont the world. Access to foreign markets and raw materials to supplement domestic sources is a critical requirement for many of the larger firms. It is important in framing policies to encourage private investment enterprise that government agencies avoid mmecessarily restrictive regulations that might inhibit capabilities to operate successfully within a highly competitive international enviromment.

\section{Capital Sources and Requirements}

Raising capital is not a different problem for marine ventures than for terrestrial ventures. The normal capital matrets are available, and the criteria for sonnd investment are applied.

In general, capital has not been lacking to linance industrial ocean plojects. In fact, the iurestment community has been greatly intrigued by ocean endearors. The rolume of publicity and advertising in the popular press and business journals, the creation of mutual funds specializing in ocean industries, and the numerons symposia and publications sponsored by brokerage houses are evidence of this.

The U.S. offshore petrolem industry has invested abont $\$ 13$ billion to date, part of which has heen internally generated and part raised by the sale of securities to the public. Many of the Nation's larest industrial firms outside the petrolem industry also have inrested heavily in ocean projects. Tenture capital sources have fostered numerous small companies, often in the more glamorous fields of adranced technology. Private financial inst itut ions, howerer, have hesitated to invest in or extend credit to small fishing enterprises, which often have had to rely on Government-insured mort gages on their ressels, and in some calses, on direct loans. Yet adequate amounts of private capital have heen arailable to the profitable shrimp and tuna industries. The Department of Commeree's Economic Ievelopment Idministration and the Small Business Administration 
have provided additional capital in special situations, as have State programs for industrial development.

Is the rate of ocen development increases, the capital requirements will increase accordingly. It is anticipated that with a few exceptions the existing supply of private capital in the Inited States will he adequate to finance this expansion without relying on special arrangements or direct Government subsidies.

The Commission recommends that since direct Government subsidies are not required at this time to induce industry to generate capital for marine investments, Government policy should instead be directed to providing the research, exploration, basic technology, and services (as recommended elsewhere by the Commission) to encourage private investment in the exploration and exploitation of marine resources.

\section{Legal and Regulatory Framework}

Large-scale technological applications simply cannot be undertaken in marine industries if property rights, market access, labor regulation, taxation, and the many other elements of the legal and regulatory environment remain in their present uncertain condition.

A framework of laws and regulations that permits forward planning, simplifies cay-today operations, and creates confidence in the Nation's determination to move ahead is a key area in which govermment can give support to ocean industry. Nevertheless, this is now lacking in many areas pertaining to the ocean.

The Commission recommends that a framework of policies and laws be established that will allow predictability and, therefore, increased confidence and investment activity by industry. An important responsibility of the National Oceanic and Atmospheric Agency should be to work on a sustained basis with other agencies of Government and in consultation with the private sector to achieve these aims and to ensure that the policies are published periodically.

There are several general implications of such a policy :

- The number of agencies and authorities which confront marine interests must be reduced.

- The mique characteristics of the marine environment must be recognized in formulating administrative rules and policies.

- The respective roles of Federa], State, and local governments in regulating marine industry must be clarified.

- Contracting procedures should be simplified.

- Every effort should be made to keep all regulations current-that is, adapted to present technological conditions. 'The Commission is aware that this task is very difficult, but it is also very important.

- Such economic and financial measures as taxation and leasing policies shonld be announced as far in advance as possible so that industry can plan for the future. However, the measures should not be so inflexible as to preclude the modifications that will be necessary as development progresses.

- Channels are needed for industry to advise Government on the adequacy of present services and the need for new ones.

- Insofar as possible, Government should be explicit regarding its intentions and shonld periodically update and publish its plans for a mational marine program. 


\section{Technology and Services To Support Industry Activities}

Government gives positive support to industrial actirities in many ways. For ocean industry, one of the most important kinds of assistance is providing the basic pre-investnent information, technology, and services necessary to expand operations at sea. The propriety of government assistance to scientific and technological adrancement commensurate with the national interest and industrial needs is well established and widely accepted. Furthermore, this means of accelerating industry's marine effort is cost-effective and impartial, and it can be terminated as objectives are attained.

\section{Industry Use of Fundamental Technology}

Technological innovations that reduce an ocean operation's cost will improve profit outlooks and accelerate marine resources derelopment. Consequently, a fundamental (or multipmpose) technology program oriented toward reducing costs relevant to a wide variety of user interests will expedite the utilization of the sea's resources.

Chapter 2 states that a 10 -year program of intensive undersea development is in the national interest and recommends that it begin immediately, emplusizing fumdamental technology. A major purpose of Federal participation in a fundamental technology development program is to enlarge the national base for future productive activity by industry. The Commission empluasizes that the application of fundamental technology to industrial opportunities is the responsibility of industry, not of govermment.

It will be difficult but essential to establish a reasonable dividing line between what industry should do for itself under profit motivation and what the Govermment should do to assist. In most instances, programs that bene- fit only a specific industry more properly should be carried out by that industry.

The process of selecting specific programs must take into account needs of the Government, scientific community, and industry and must observe the role of indust ry. 'The advice and counsel of a broadly based advisory committee should be of particular value in determining more precisely the Federal role.

Chapter 6 of the Report of the Panel on Marine Engineering and Technology describes in great detail the present status and trends, future needs, and recommendations regarding industrial technology in the derelopment of ocean resources.

\section{Power Sources for Resource Development}

Undersea operations, fixed or mobile, depend on power supplies. No single type of power source is known or is likely to be feasible for all power level, endurance, and ambient pressure requirements of undersea tasks. A family of porrer sources with different characteristics will be needed.

Is resource industries expand deeper. into the ocean and farther from shore, the need for self-sustaining power supplies will become increasingly critical. This need may be met by one or a combination of cables, batteries, fuel cells, isotopes, thermal conversion, and other systems. Technological development of such systems should be strongly supported by the National Oceanic and Atmospheric Agency.

Because continental shelf resource development ulimately will require large quantities of power, the Commission proposes as a National Project the construction of an Experimental Continental Shelf Submerged Nuclear Plant. Initially, the project might provide power for one of the continental shelf laboratories proposed below. It also would enable scientists to inrestigate artificial upwelling and the effects of artificial 
heat on the ecology and micrometeorology of the area.

The project wonld make it possible to test the economic and technical feasibility of furnishing large-scale power to metropolitan centers from oflshore nuclear generating stations. The intensive derelopment of coastal regions greatly limits the arailability of the large land tracts necessary for nuclear power facilities. Reduction of thermal pollntion and increased safety would be additional adrantages of using offshore sites. The Atomic Energy Commission should supply funds for the prototype development, and NO.L.I should proride the undersea technology development and the sea operational sipport.

The Commission recommends that the National Oceanic and Atmospheric Agency support technology development of power systems necessary for undersea operations and resource development and that an Experimental Continental Shelf Submerged Nuclear Plant be constructed to pilot test and demonstrate the economic and technical feasibility of nuclear power for resource development operations and of the underwater siting of nuclear facilities to provide power for coastal regions.

\section{Continental Shelf Laboratories}

Is indicated eardier, Government support of fundamental technology will become increasingly important to industry as it moves into the deeper, ligher-risk areas of the ocean. In addition, it will be important for Govermment to make costly test facilities ar ailable for leasing by industry.

'Io provide the facilities and the focus to implove and expand the Nation's capability to ntilize the ocean, the Commission has pro- posed a National Project encompassing Continental Shelf Laboratories.

This project is based on the premise that, if man is to conquer the sen, he must go into the sea. The Nary Sealab and French Conshelf projects have been impressive demonstrations of the ability of man to go into the sea for short periods of time. The next step is to make it possible for man to stay with a degree of permanence and to provide him with facilities for research and derelopment at continental shelf depths.

The Commission recommends that the National Oceanic and Atmospherir Agency launch a Continental Shelf Laboratories National Project to provide a national capability for research, development, and operations on the continental shelf. The National Project should be jointly planned and operated in consulta. tion with industry and the scientific community.

One element of the National Project, as suggested in the Report of the Panel on Marine Engineering and Technology, might be a program of fixed continental shelf laboratories. These laboratories, conceived as permanent structures emplaced on the shelf bottom, would include living and working quarters for 15 to 150 men.

Some compartments would be maintained at a pressure of 1 atmosphere, and other's would be pressurized to support diver's performing long-enclurance saturation dives. Itocks for easy access to undersea work areas and a complex for comfortable decompression would be included. Ttilities would be supplied from shore or the surface via umbilicals or from submerged power sources. 


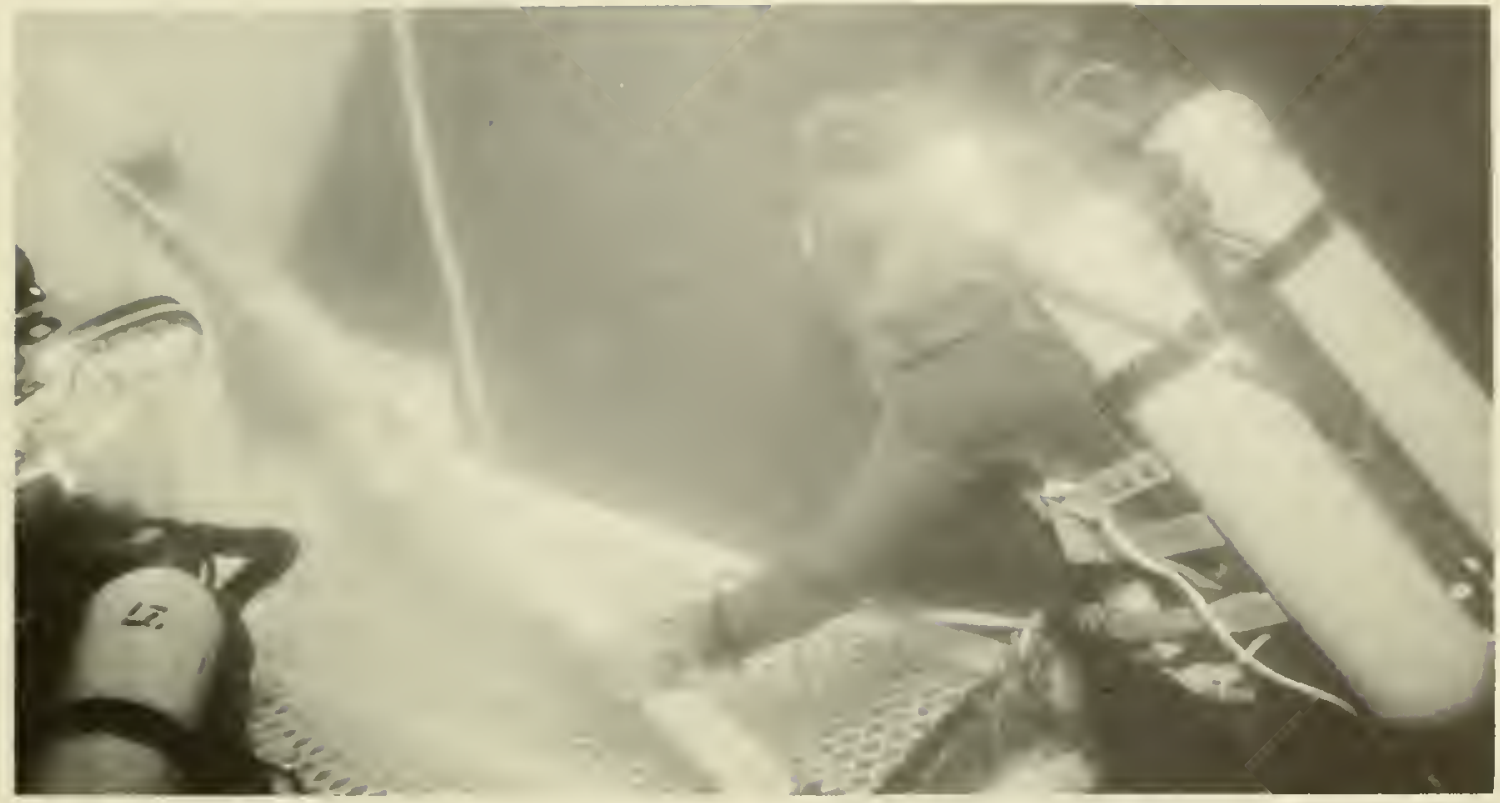

A Continental Shelf Laboratorics National Project, in rolving scabed facilities, portable laboratorics, and support vehieles and cquipment, is recommended to provide the facilitics and foeus to improve and expund the nalional capability to use the oceans.
Idditional logistic support would be provided by submersibles eapable of mating with the molersea laboratory.

The laboratories will serve many purposes and many elements of the marine community. 'They will provide valuable facilities for botli military and eivil development. The Sary should share in the development and use of the facilities and should supplement NO.1.1 funding to provide the eapabilities mique to Ning needs.

The laboratories will advance such aspects of divine technology as putection, commn-

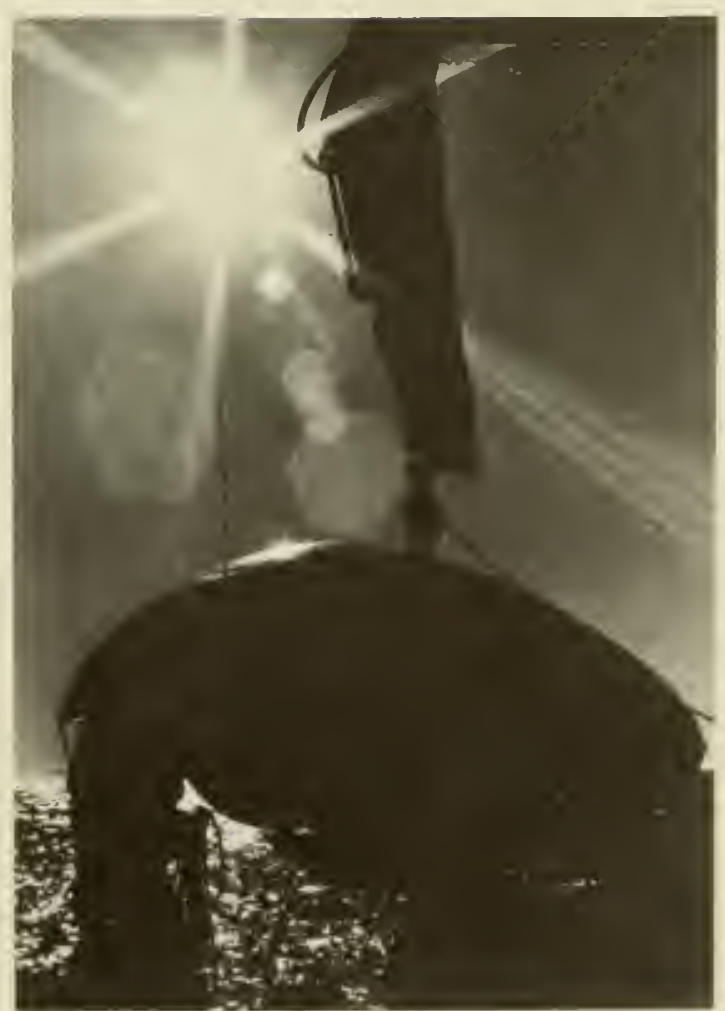


nications, tools, and physiology. They will facilitate investigations of soil meehanies, stiuctural behavior at shelf depths, prevention of fouling and eorrosion over long and short periods, altermate power sources, and problems of transfer and research vehieles mating with mudersea structures. They will lelp in the development of the technology of undersea narigation, anchoring and mooring, aeoust ics, free-flooding machinery and equipment, and instrument development. Utilization of such marine mammals as porpoises, whales, and sea lions for tasks suitable to their intelligence and abilities could be further investigated.

Many users would be able to lease the laboratories to test the eeonomic and technical feasibility of new undersea developments in bottom-based fishing systems, oil production, pipeline emplacement, in-bottom mining, dredging, overburden handling, pumping, molersea transport and work vehicles, bottom-loeated storage, plant harvesting, and aquaculture.

Scientific research should be integral to all teehnology derelopment, and there shonld be facilities both for diving and nondiving scientists to study current cycles and behavior, mutrient cyeles, pollution dispersion, seasonal distribution of organisms, biology of loeal species, area ecology, human and animal behavior, human group interactions, geology, geophysies, and sediment eomposition and transport.

Another element of the Continental Shelf Laboratories National Projeet involves portable continental shelf laboratories which shonld be developed either conenrrently or after constrution of the fixed shelf laboratories. Portable laboratories are envisioned to support from 5 to 75 men. Both normal atmospheric and ambient pressure ehambers would be provided. The laboratories would have many of the eapabilities of the fixed station, plus the ability to deballast for towing to another loeation. Portability would support resonrce exploration and development anywhere on the continental shelf and would offer the adrantage of quick-reaction investigation in areas requiring intensive examination for any eivil or military reason.

Essentially, the portable laboratories would extend the eapability developed in the fixed laboratory to different environments, gradually adraneing toward the 2,000-foot goal.

By providing the continental shelf laboratories as a focus for many activities, the state of knowledge and teehnology eould be advanced most rapidly. Strong industry participation wonld ensure the continuous transfer of new information and techniques to commereial applications.

\section{Technology Transfer}

Industry's ability to assimilate new scientific findings and technology will be eritical to the success of the research and development programs proposed above and elsewhere in this report to adrance the Nation's eapabilities at sea. The petroleum industry with its own funds already has made very important contributions to marine technology and is generally capable of assimilating future developments as they occur. Industry is fully alert to the potential of sueh Governmentsponsored derelopment programs as desalination and gear improvement for the major eommercial fisheries. Yet firms lacking suffieient in-house competence, especially small businesses, seldom profit fully from Gorernment-sponsored teehmology unless there is an accompanying and well-designed effort to bring about its use.

Considering the compling of teehnology to industrial use involves an important distinction anong three eategories of marine industries : 
- Those engaged in the direct use of the seal, such as resourees, transportation, and recereition inclustries

- Those participating in a supporting role through the development and production of halriwate

- 'Those which provide such services as greophysical exploration, diving, construction and salvalge.

These distinctions are in some measure yiolding to a growing tendeney for companies to crugage in two or three of these categories of activity. 'Thus, the oil industry and its contractors produce much of their ow hardware, while some hardware and serrice companies are beginning to engage in resomrec development.

Mlthough hardwale and service companies are likely to assme a key role in adrancing techology, this work must be geared realisti"ally to the needs of the resource industries. Hence, there is a strong need to ensure that the resonce industries participate in planning the proposed marine technology progranss and Sational Projects in order to ensure that techmology does not become an end in itself. It is hoped that the National Idrisory Committee for the Oceans will foster the required interchange of information to ensure that the technology programs are chameled where the needs are most pressing.

Many recent studies demonstrate the great importance to the Nation of ensuring an adequate level of technology transfer and emphasize the enormity and complexity of the task. There are sereral important factors which bear on the transfer process:

- Training programs can help interested firms, but actual participation in technical programs is more effective. A winding snlrey and development eontracts to industry fosters the growtl of more companies (ap)able of nsing the new knowledge in commercial markets.

- Patent policy has strong effects on the process of transferring some forms of knowledge to commercial applications. The policies of Ferleral agencies with respect to the patentability of developments achieved muder Government research and development contracts are of particular interest and importance. It is vital that the patent aspects of the National Oceanic and Itmospheric $\Lambda$ gency's techmology pregrams be administered in a mamer to stimulate commercial applications of new developments and cause participation in the proglam to be attractive to industrial contractors.

- Access to unpublicized or restricted Department of Defense information at the earliest possible time consistent with mational security is also important. Such access is most readily achieved by large firms that have a continuing contractual relationship with the military services. Procedures have been developed in the atomic energy field for industry-Government collaboration in assuring the maximmm dissemination of information consistent with security requirements. The Commission believes that similar procedures might be adopted appropriately to facilitate transfer of nurine technology.

- Active and continuing conmmication must. be maintained between the producers and users of technology. Suggestions for stimulating such communication have been adranced in Chapter 2.

\section{Supporting Services}

In adequate background of supporting technical services, as outlined in Chapter 6 . also is necessary to industry sentry into the sa. The Commission found particularly strong industry interest in improred marine wather servies and serere storm warnings. 


\section{Collaboration in Planning}

Finally, collaboration by the Federal and State governments and industry in planning marine programs and projects will help to protect and increase the efficiency of industry investments. Such plamning is needed to minimize conflicts among potentially incompatible coastal zone uses. For example, stable and uniform water quality standards will prevent umnecessary costs in acting to prerent pollution: shoreline zoning will help to stabilize the setting for recreation development, and agreement on shipping fairways will permit recovery of oil and gas in areas which otherwise would not be available.

The existence of a Government agency specifically charged with aiding the devel- opment of marine resources can do much to assure that continued attention is given to maintaining the best climate for prirate enterprise and permit the accelerated development of marine resources.

\section{Program Costs}

The expenditures which will be necessary to implement the recommendations made in this chapter are summarized in Table 4 4 .

Substantial increases have beell proposed for the management and derelopment of marine fisheries, reflecting the importance which the Commission places on improved utilization of the ocean's food resources. The estimates for management and technical assistance include payments to international fisheries commissions, administration of the

\section{Table 4-4 Marine Resource Development ${ }^{1}$}

[Incremental eosts in millions of dollars]

\begin{tabular}{|c|c|c|c|}
\hline & \multicolumn{2}{|c|}{ Average annual costs } & \multirow{2}{*}{$\begin{array}{l}\text { Total } \\
\text { 10-year } \\
\text { eosts }\end{array}$} \\
\hline & $1971-75$ & $1976-80$ & \\
\hline Living Resourees & $\$ 62$ & $\$ 88$ & $\$ 750$ \\
\hline \multicolumn{4}{|l|}{ Fisheries: } \\
\hline Management and Technical Assistanee & 10 & 16 & 130 \\
\hline Harvesting and Proeessing Technology & 20 & 30 & 250 \\
\hline Research and Surveys & 13 & 17 & 150 \\
\hline Aquaculture Research and Development & 15 & 20 & 175 \\
\hline Marine Medieal and Pharmaeology Program & 4 & 5 & 45 \\
\hline Nonliving Resourees & 39 & 66 & 525 \\
\hline Continental Shelf Geologieal Survey & 12 & 18 & 150 \\
\hline Development of Survey Equipment. & 15 & 25 & 200 \\
\hline Basie Mining Technology & 10 & 20 & 150 \\
\hline Special Desalination Teehnology Programs & 2 & 3 & 25 \\
\hline National Projeets_... & 60 & 86 & $: 30$ \\
\hline Continental Shelf Laboratories & 40 & 60 & 500 \\
\hline Pilot Continental Shelf Nuclear Plant & 20 & 26 & 230 \\
\hline Fundamental Technology $\rightarrow$ Underwater Operating Capabilities, 2,000 feet_- & 30 & 50 & 400 \\
\hline Total, Resource Development & 191 & 290 & 2,405 \\
\hline
\end{tabular}

1 For explanation of amounts shown in this table, see aceompanying text and chaptcr 8 . 
proposed domestic fisheries management program, extension serrices, and improved statistics. The estimate for harvesting and processing technology is intended to cover the entire spectrum of possible inprovements in the technological capabilities of the fishing industry. It includes search and detection, derelopment of FPC teclnology, and techniques for more rapid assessment of fish stocks. The estimate for research and surreys is based principally on data furnished the Commission by the Burean of Commereial Fisheries. The amount proposed for aquaculture programs, although much more than has been spent on the subject to date, may be modest in terms of what later might prove worthwhile. Funding for these programs would be principally by NOAA; their execution will, involve the States, miversities, industry, and international groups.

The Commission has recommended that American fishermen be permitted to use foreign-built ships in U.S. domestic fisheries. If this recommendation is adopted, the figures shown here would be partially offset by the resulting $\$ 6$ million per year sarings in the present ressel subsidy program. If not, the subsidy program should be expanded, and the figures would be higher. Cost projections include a total of $\$ 15$ million orer the decade for establishing institntional arlangements and for conducting the necessary resenreh on the potential of drugs from the sea.

The genlogical mapping program, to be funded by NOA A, is estimated to inrolve a total cost of between $\$ 300$ and $\$ 400 \mathrm{mil}-$ lion spread orer 15 to 20 years. NOAג also will he the principal sponsor of technologieal programs related to monliving resomre development, particularly in the inprorement of resource survey equipment and basic mining technology. The estimate for development of surey equipment will permit echo somnders. heat probes, samplers, corers, and other exploration tools to be improved in sensitivity, efficiency, and depth capability. Federal support of basic mining technology will provide the basic engineering information which industry needs for minerals recorery.

The continental shelf is, of course, the area of most interest to our resource industries, and in this chapter, the Commission has proposed two National Projects to improve our operating capabilities at shelf depths. The Commission believes that the Continental Shelf I aboratories Project and the Pilot Continental Shelf Nuelear Plant merit funding by NOA $\mathrm{A}$ in the range of $\$ 700$ to $\$ 750 \mathrm{million}$ dining the $1970^{\circ} \mathrm{s}$. This estimate is geared to the construction of one fixed and three portable laboratories during the 10 -year period; it also assumes that the Navy will share in the development and use of the continental shelf laboratory facilities and will supplement the proposed NOAA funding to provide capabilities unique to Navy needs. The estimate for the underwater melear plant covers NOAA derelopment of technology necessary to underwater siting, construction, and logistic support; it assumes additional Atomic Energy Commission funding for derelopment of the necessary nuclear technology.

These National Projects are designed to provide a focus for adrancing underwater operating capabilities. To be fully effective, they must be supplemented by a broadly based program of fundamental technology to inrestigate a rariety of possible porer", propulsion, life support, anchoring, mooring, and related systems for use at depths to 2,000 feet. Mastery of this fundamental technology will enable industry to conduct its resonrce operations on of within the seabed, a way from the difficulties which characterize surface operations. 
Chapter 5

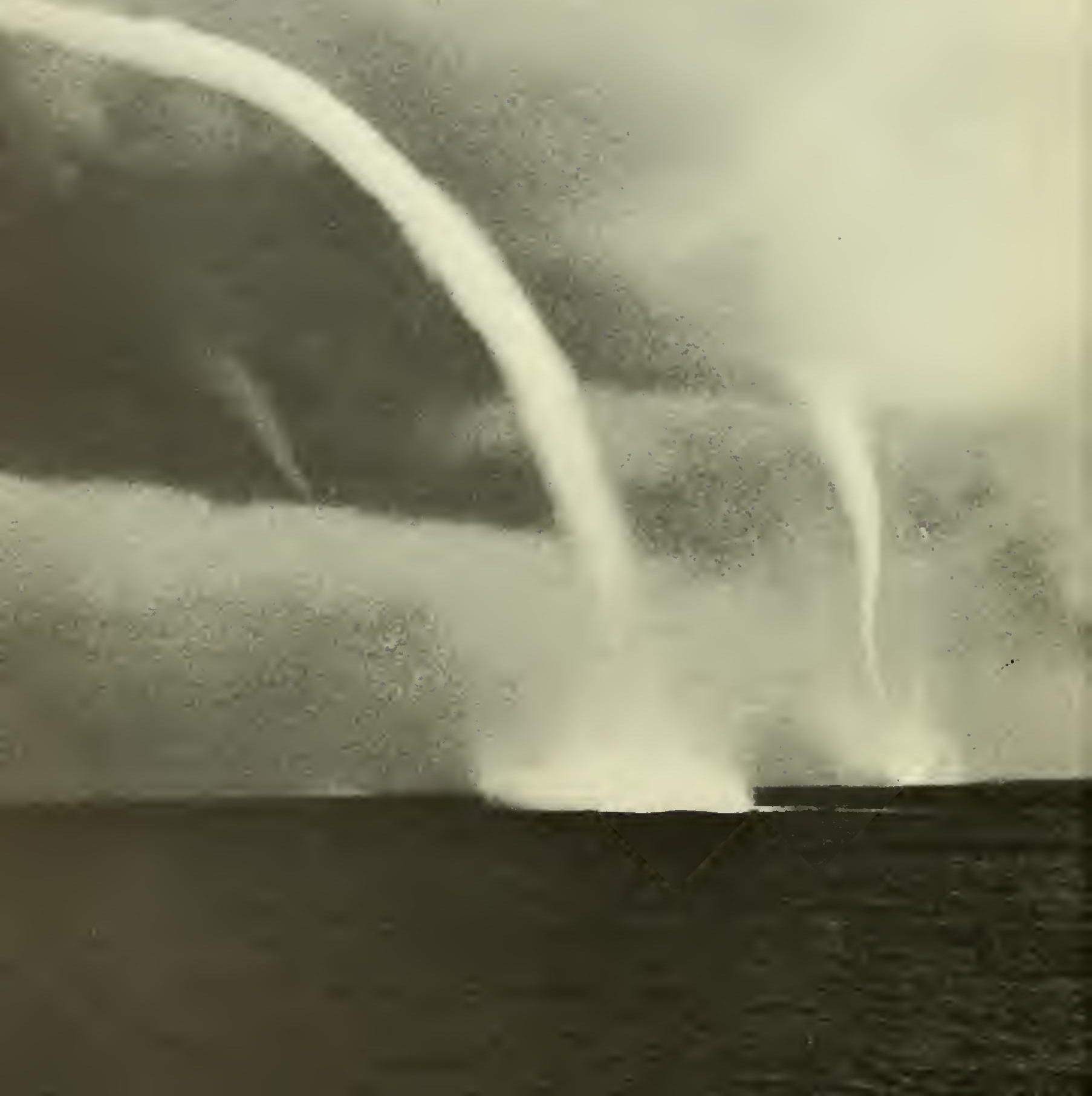


The Nation's interest in the seas, the land beneath, and the atmosphere, alsove require that it attain the capability to observe, deseribe, understand, and predict oceanic proeesses on a global hasis. The Nation is engaged or must be prepared to engage in operations in all of the world's oceans at increasing depths and in increasingly hostile environments. It has a vital stake in the living and nonliving resouree of the global seas. Its industry, commerce, and agriculture are critically dependent on the weather eontrolled in large measure by global ocean conditions. The safety and well-being of its people and their property must be protected against the hazards of air and ocean.

The envirommental information the $\mathrm{Na}$ tion requires for these purposes ranges from deseriptions of the topography, geophysies, and geological strueture of the deep sea floor to the understanding of the normal conditions of the oceans' chemistry, biology, thermal structure, and motions, and the prediction of the rapidly changing ocean and atmospheric phenomena recognized as our daily weather and sea state.

Major efforts already are underway to accomplish these formidable tasks. Men have journeyed briefly to the deepest parts of the ocean. Scientists routinely obtain photographs of the world's cloud cover from sate]lites. The United States participates with other nations in such international organizations as the World Meteorological Organization and the Intergovernmental Oceanographic C'ommission for the study of the oceans and the atmosphere. Some of these international activities have been organized for almost a century to provide real-time data deseribing weather and sea conditions in many parts of the world. Others of more recent origin lave heen organized to explore and. understand the processes of the global scals. Efforts to kate, although extensive, are but at token of what needs to be done.

The Commission concur's in the views expressed by the l'resident's Science Mrisory Committee Panel on Oceanograplyy that the need to consider the enviromment as a whole is a scientific imperative, for the oceans and atmosphere and solid earth are interacting parts of a single geophysical continumm.

Eventually, man must understand the sea, the air, and the land as a single, incredibly complex system. The currents of the oceans and the roughness of the sea's surface are principally the result of the winds in the lower atmospluere and of the shape of the ocean floor and its coastlines. Large ocean swells breaking on the Pacifie const of the Tnited States may be generated by winds blowing over the sonthern At\}antic Ocean. 'The tsunami-a series of long-period, energypacked wares which can wreak havoe along a coast-is generated by shifts of the earth's solid erust. I hurricane receives much of its destructive energy by absorbing heat directly. from the ocean and by condensing the water vapor supplied by the sea. On a longer time scale, the oceans play a large role in the global circulation of the atmosphere, and shifts in large-seale weather conditions and climate are related to changes in the ocean conditions.

The size of the oceans makes it difficult to aequire the observations needed to understind the global environment. Expanding present programs will help, but existing systems, even if expanded, camnot provicle all the types of data needed. Fortunately, radically new technology are arailable to help us acquire, communicate, and analyze data. Satellites, data huoys, deep submersibles, moderm oea:m resenroh and survey ressels, and an array of sensing equipment and terhniques to acompany them promise that eventually 
we may explore every aspect of the global enviromment and monitor its characteristics and motions in real time.

The Commission's recommendation to observe and describe the global environment adequately will require a balanced effort in research, exploration, technology, and by the latter part of the coming decade, the development of a global envirommental monitoring and prediction system. New institutional aruangements and inproved intemational cooperative arrangements will be required. Near-term improvements based on rapid expansion of particular programs using available teclmology also are possible and are recommended.

The need for improved environmental knowledge and forecasts reaches deep into

\section{The temperature, salinity, and} biological patterns of the oceans must be understood if modern somar, litie that housed in the rubber bow dome of the destroyer leader

Willis $\mathrm{A}$. Lee, is to be effective in

antisubmarine warfare operations.

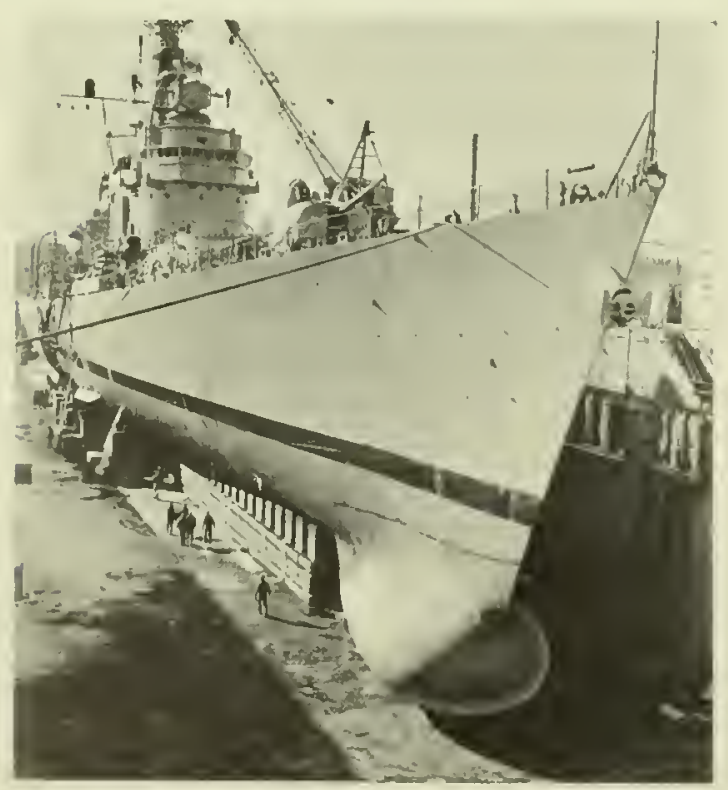

the fiber of our national life. National security requires that those who deploy and operate naval ressels have detailed data describing the state of the oceans' surface, the currents at different depths, and the topography of the ocean floor. Use of sonar requires detailed understanding of the temperature, salinity, and biological patterns in the oceans and forecasts of their changes. For amphibious landings, naval forces require forecasts of tide, tidal currents, and surf conditions.

The national economy will be served in muny ways by an improved capability to forecast changes in the oceans and the atmosphere as well as by a comprehensive knowledge of the geology, geophysics, ecology, and chemistry of the ocean areas of the world.

The fishing industry will be served by knowledge of ocean currents and temperatures, the topography of the ocean floor, and the patterns of life in the oceans, as well as by forecasts of hazardous ocean and weather conditions. The petroleum, gas, and mineral industries will be serred by a knowledge of the broad geological and geophysical characteristics of the deep ocean floor as well as by real-time forecasts of wind and wave conditions. Ocean transportation will be served by improved marine weather and sea state prediction and by improved techniques oi routing ships safely and efficiently.

Improved forecasts of weather and climate have tremendous implications for protection of life and property and for the national economy. Land and air transportation also will benefit from improved predictions of weather and ocean conditions. Agricultural interests will be served by better weather forecasts. The ability to track hurricanes and issue warning has inproved over the years, but an increased capability to forecast hurricane motion and changes of intensity 
would serve to protect life and property. The data gathered for these various purposes also will be available to the scientific community for research purposes.

Better environmental data will yield important dividends in the efficiency and reliability of the materials and structures we use in the sea, and in the engineering of marine and atmospheric systems, including the system to observe the sea itself. Determining the feasibility of such intriguing long-term possibilities as generating power from the sea, creating upwellings for fish farming, and using underwater currents to dissipate pollutants similarly requires detailed knowledge which is not yet in our hands.

Much evidence summarized in recent reports of the National Academy of Sciences and the National Science Foundation Commission on Weather Modification indicates that man is on the rerge of being able to alter the behavior of the atmosphere. In addition to the likelihood in the near future of significantly changing natural patterns of rain, hypotheses have been advanced for altering the intensity of a hurricane, reducing hail, and redistributing snowfalls. To test these hypotheses, greatly expanded data collection networks are required.

The need to understand man's effects on his environment also is great. Pollutants affect the photosynthetic life in the sea and thereby may influence the oxygen balance in the atmosphere. Carbon dioxide generated by fossil fuel consumption may lead to a warming of the earth. These global processes must be understood, for they govern man's existence. Thus, the problems of environmental modification, both conscious and inadvertent, are inseparable from the problems of understanding and predicting the state of oceans and atmosphere.

Finally, the oceans and the atmosphere provide a unique stage for international cooperation. Continued participation in these international efforts will advance the common interests of mankind in mastering its environment.

The Commission recommends that the National Oceanic and Atmospheric Agency initiate and lead an intensive national program to explore the global environment, monitor its motions and physical and biological characteristics, and investigate the feasibility and consequences of its modification. The programs should be focused on:

- Exploration of the biology, geology, geophysics, and geochemistry of the deep seas

- Development of a comprehensive national system to monitor and predict the changes of the sea, the air, and certain aspects of the solid earth, integrated with the systems maintained by other nations

- Conduct of a systematic program of theoretical and experimental research into problems of environmental modification

- Advancement of international cooperation in oceanic and atmospheric activities

- Encouragement of the maximum freedom of scientific research

\section{Exploring and Understanding the Global Oceans}

The Nation seeks to explore and understand the deep ocean to advance knowledge and to "bring closer the day when the people of the world can derelop and use the resources of the seas."

This is easily stated, but difficult of attainment. The oceans are vast and highly inaccessible. No single scientific discipline can 
hope to unravel their complexity. No one approach will suffice. Marine science is no respecter of semantic boundaries; basic studies merge indistinguishably into the applied; exploration blends into research, oceanography into a bewildering variety of disciplines.

\section{Research and Survey Programs}

Effective exploration of the oceans can best be achieved through a balanced program of research and surveys. Programs to solve specific scientific problems as well as programs for systematic collection of data on a world-ocean basis have yielded results of remarkable scientific and material import in the past and will do so in the fut ure.

\section{Marine Geology and Geophysics}

Our views on the structure of the ocean crust and its origin are modified constantly as new data accumulate. Sediments of unprecedented thickness have been found to exist in unsuspected areas along the continental margins. New information about geomagnetic and gravity patterns has revised opinions about the origins and formation of the continents. Research programs sponsored by the National Science Foundation (NSF) and by the U.S. Navy and the systematic SEAMAP surveys of the Environmenta] Science Services Administration (ESSA), have advanced our knowledge of the earth's structure and history.

In the course of the NSF-sponsored program JOIDES to drill deeply into the earth's crust uncler the sea, oil has been discovered in the seabed at water depths of approximately 11,000 feet, although not in exploitable quantities. As noted in Chapter 4 , there are indications that the thin sedimentary layer underlying parts of the deep oceans may contain other minerals as valuable as the norlules known to lie on the ocean

\section{The Theory of Continental Drift}

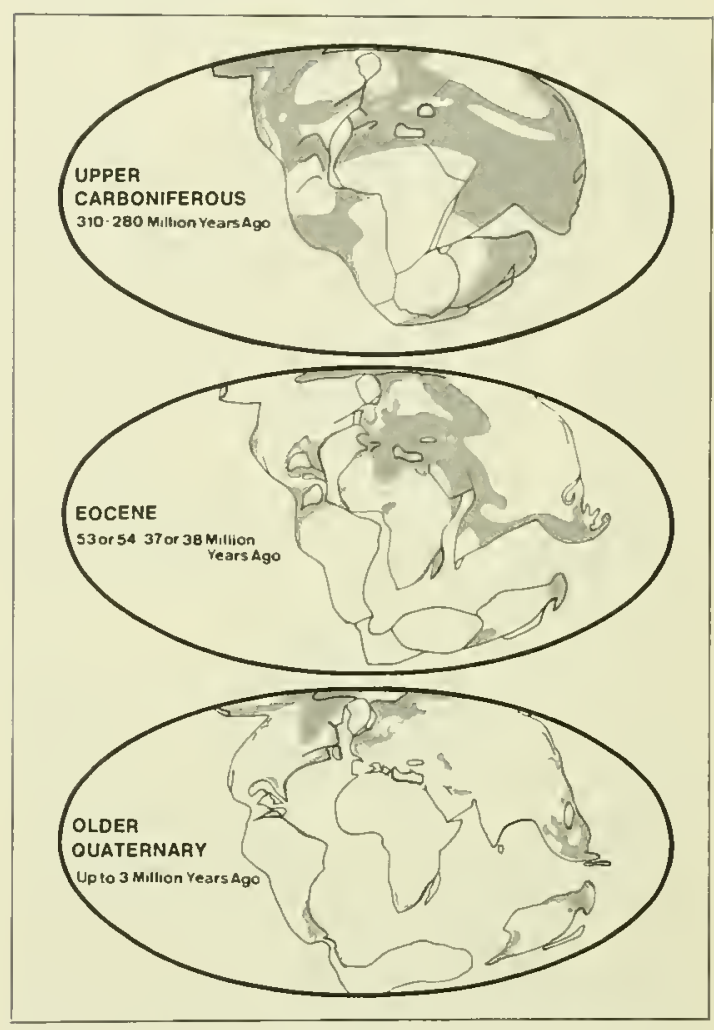

Source : A. Wegener, The Origins of Continents and Oceans (trans. from 3d German ed., E.P. Dutton and Co., 1922).

bottoms. The value of these resources is at this time entirely speculative because of the lack of any systematic knowledge of their location or composition. But their value to man in the 21st century will depend upon the development now of systems to survey their extent and to bring them to shore.

\section{Marine Biology}

The problems to be solved by global oceanic exploration are many and diverse. Man's increasing dependence upon food resources from the sea and his growing ability to modify his environment make it imperative to understand better the ecology of the global oceans. Life in abundance has been discov- 
ered in regions where life was heretofore thought impossible. Without better understanding of the ocean's ecology, man shall be umable to increase in a rational way the yield of food from the oceans.

The ocean presents a lost of unsolved biological problems, many of which may be linked with the goal of increasing the production of food. The core emphasis of marine biological research must be placed on understanding the dynamics of oceanic ecosystems. It is necessary to understand the flow of energy and of matter through them, the utilization of mutrients, the efficiencies of conversion between various trophic levels, and a host of related matters. A comprehensive understanding of ecosystem dymamics would be a major advance toward prediction and ultimate control of biological events. This understanding is closely related to physical, chemical, and meteorological investigations of the mechanisms of environmental change. This understanding is required for constructive management of the living resources of the sea.

Concern with the living creatures of the sea, howerer, must extend beyond the supply of edible species. The phytoplankton in the sea supply by photosynthesis much of the oxygen in the atmospliere. Plankton scatter the light necessary to photosynthesis. Mollusks, bacteria, and other organisms foul underwater machinery and destroy submerged materials. Schools of fish complicate sonar transmission on which we are so reliant. Shellfish and seaweed consume much of the waste materia? dumped into the sen.

In the deep ocean, living matter is found in an environment of remarkable stability and homogeneity under high hydrostatic pressure without light and with unchanging physical and chemical characteristics. Food supply to the deep ocean floor amounts to a mere trickle. Little is known about the fauna of this unique environment and even less about the eflects of the enrironment on the ecology and physiology of the animals living there.

\section{Physical Oceanography}

And what of the sea itself, its phenomena, its current systems, its temperature structure, and its long-period changes? Here the concern is witl a fluid in motion whose variations range the full spectrum of time and space scales. The work of the Woods Hole Oceanographic Institution on the structure of the Gulf Stream has revealed the complex nature of this important ocean current system. The South Atlantic sediment studies of the Lamont Geological Observatory have indicated the possibility of strong deep ocean currents which have hitherto been unsuspected.

Later in this chapter, we advance a proposal for a global environmental monitoring system that will yield much of the information required, and propose research programs essential to its implementation. But there are problems of the deep ocean circulation about which little is known-the mechanisms and rate of exchange of the deep waters, the interaction of the deep oceans with the surface layers and its implication for primary production and fisheries, as well as its relation to changes in surface conditions affecting the weather.

\section{Polar Seas}

The polar seas present special problems. The processes of the polar oceans are closely linked with the global ocean and atmospheric processes. The polar seas are the source of the bottom waters of the oceans.

Exploration of the polar oceans, while less prominent than other national marine efforts, is nevertheless a present national concern. The need for prediction of ice conditions has long been recognized for ocean trade, but 
understanding remains limited as to the behavior of sea ice under stress. Without this understanding, ice breakup camnot be predicted. Studies of the effects of ice and the polar seas on dereloping air mass characteristics are essential to understanding the global weather.

\section{Decade of Ocean Exploration}

The Nation should make a strong commitment to a well-balanced program of deep ocean exploration during the 1970's. Such a program should be international, if only because the problem is so vast that its technological and scientific demands tax the means of any single nation.

The in vestigation of the global oceans long has been built upon the cooperative efforts

\section{The National Science Foundation has responsibility for the U.S. Antarotic rescarch program, while the Navy and Coast Guard provide logistic support. An NSF'-sponsorcd biologist observes Sei whales; crew members from the iccbreaker Glacier obtain Antarctic water samples; and the iccbrcaker Eastwind brcaks a channel to the U.S. Antarctic base at Mc.Ifurdo Sound.}

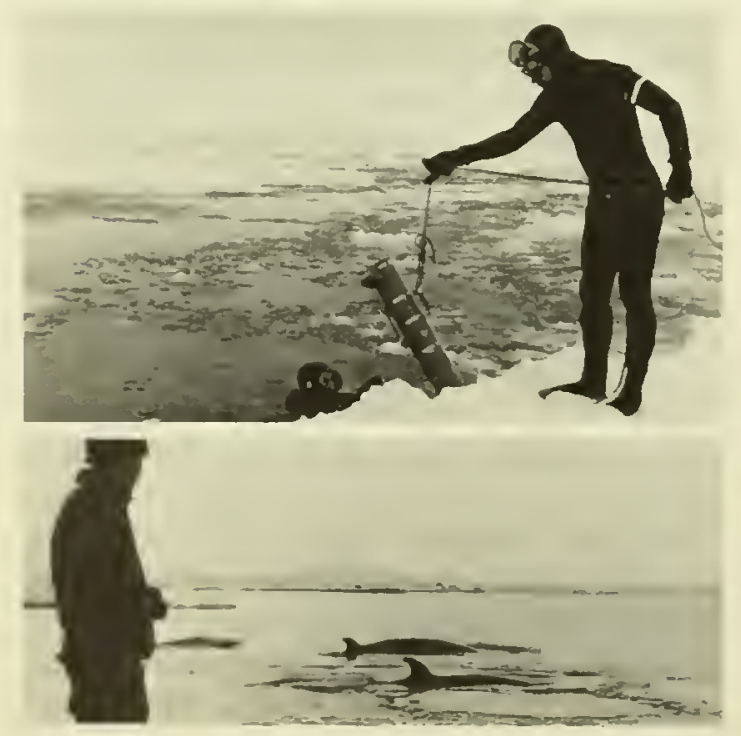

of scientists of many nations. Indeed, common interests have developed in widening circles to embrace industries and govermnents as well.

To give substance to the position that the world community should join to identify the resources of the oceans, the United States recently has proposed an International Decade of Ocean Exploration. The objectives, as stated by President Johnson, would be:

To probe the mysteries of the sea**** to assist in meeting world threats of malnutrition and disease, and to bring closer the day when the people of the world can exploit new sources of minerals and fossil fuels.

The United States so far has deliberately refrained from presenting its detailed views on what should be done so that all nations wil] be encouraged to participate in determining the tasks which the Decade should mdertake and the means of performing them. Many questions remain to be answered. Should some central international group ol organization be charged with the planning and coordination of the Decade? Or should planning and management take place through nation-to-nation negotiations under the auspices of the United Nations? Or throngh direct cooperation among scientists

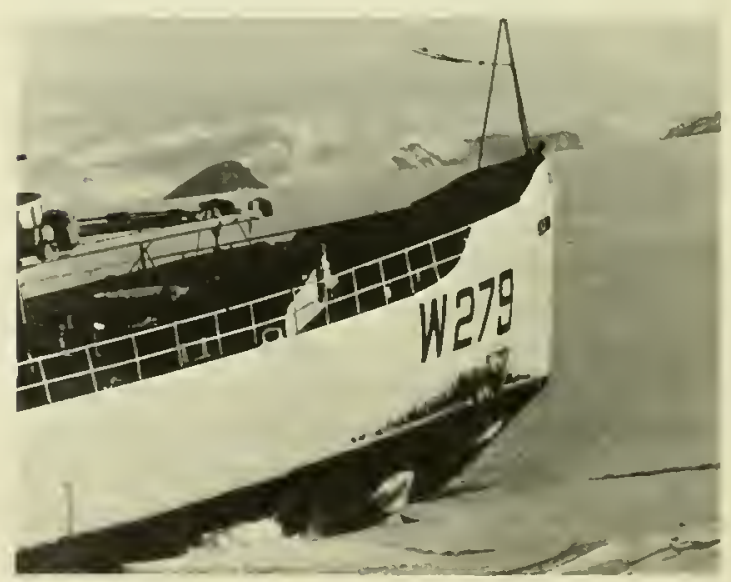


under the aegis of the International Council of Scientific Inions? Or by some combination of the two? What kind of work should the Decade emphasize? 'The Commission is inclined to the view that the Inited States should strive for a program oriented largely to exploratory, survey, and research work rather than to detailed studies aimed directly at resource exploitation.

What should be the nature and magnitude of the U.S. contribution? On the one hand, a contribution consisting only of activities the United States would undertake, even if there were no Decade, may not spur the international cooperation which is the program's aim. On the other liand, international cooperation in activities which would have little other value to the United States may not at tract sufficient support at home. The activities embraced within the Decade should fall between these extremes.

The Commission concludes that the mechanism for coordination and planning on the intemational level exists in the International Oceanographie Commission, working with other international organizations, particularly with the advice and participation of constituent gromps of the Intermational Coumeil of Scientific Inions.

Planning and cooldination of [T.S. activities in the Decarde of Ocean Exploration should be accomplished under the lead of the National Oceanic and Itmospheric I gency (NOA ) with the assistance of other Federal agencies, the applopriate bodies of the National Acadeny of Sciences and National Icademy of Engineering, and industrial gronps. The execution of the U.S. Decade proglam shoukd be focused in NO.. .4 and the University-National Laboratories with assistance by industry.

Each nation must recide what its own contributions to the I decarle will be. 'These decisions, or anticipation of them. will play an important part in determining the objectives and management of the Detarle.

The Commission strongly enclorses the concept of an Intermational Decarle of Ocean Explontion. We commend the decision to refiain from taking milateral action before attempting to specify a plan for the Decarle activitics. We caution particulaly against raising expectations beyond the commitments actually made or forthcoming. We are in fact concerned about the ability of the Uniter States to meet present commitments to such ongoing international scientific programs as the Intermational Hydrologic Decade and the International Biological Program.

In any case, the Nation's program to explore the seas must not be conditioned on international acceptance of the Decarle. Our own national interests dictate that we contimue and expand significantly our present ocean exploration efforts, many of which are already being conducted with extensive international cooperation.

The Commission recommends that the National Oceanic and Atmospheric Agency take the lead in organizing a program to explore and understand the deep oceans to meet the national needs; it strongly endorses the proposal for an International Decade of Ocean Exploration as an excellent vehicle to bring about international collaboration in this effort.

\section{The Technology}

The key to the study of the deep ocean lies in the ability to deploy present technological capabilities effectively and to focus on a number of critical techmological developments which will provicle the capability to do in the futme what cammot be done today. It is the view of the ('ommission that there is no single device or system, manned 
Occan tepths are measured and the shape of botlom structures recorded by a precision graphir recorler abourl a.surface tessel.
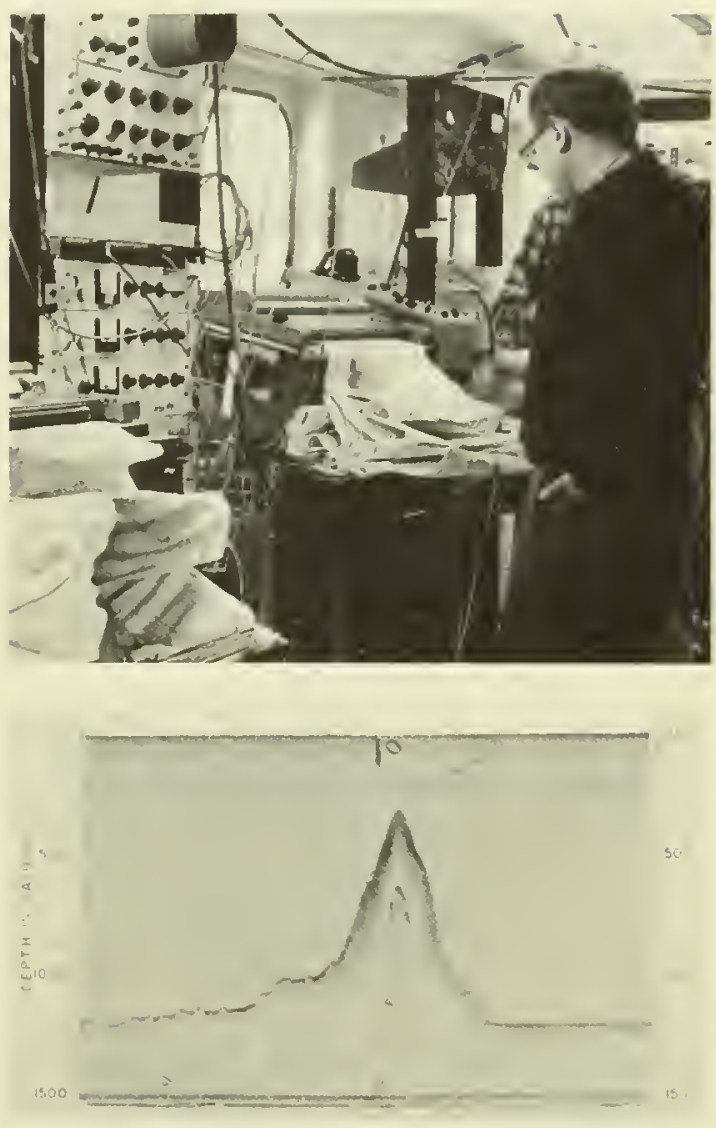

or unmanned, that ean do the job. What is needed is a selected mix of technological systems that will give the nation the necessary capability. Among these are man-in-thesea techniques, manned submersibles, and unmanned instrumentation systems.

Major adrances in modern technology and engineering have greatly increased our ability to conduct research in the oceans, to answer scientific problems, and to ntilize and manage ocean resonces. Scientists are now able to observe, measure, and understand marine phenomena on a scale and scope never- before possible. They can be placed into the oceans with deep rehicles and diving equipment and malie measurements in surface layers as well as deep within the oceans. Improved geophysical tools provide the capability to "see" geological features at greater" depth and in more detail; improved drilling techniques provide the capability to examine sedimentary columns in the deep oceans for the first time. Continuous recording derices make possible the antomatic determination of nutrients in the oceans. Satellites, more and better ships, aircraft, more and better bnoys, improved navigation systems, and computers have greatly increased the ability to collect and analyze data from the oceans.

In the riew of the Commission, probing the deep oceans from the surface must be supplemented by capabilities for direct manned and mmanned probing. The presence of man in the oceans' depths is necessary because present knowledge does not indicate what to observe, and the rersatility and comprehension that man alone can bring to the task of exploration is indispensable.

Operations in the deep ocean present many difficult and mique technological problems. Commercial, high-strength steels, likely to be the principal material for construction of continental shelf systems, are no longer adequate at great depths. 111 experience so far indicates that no velicle with a metallic pressure hull will be able to penet rate the ext reme depths of the ocean without supplementary buoyaney. Special problems are encomtered in achieving bouyancy, in designing highly reliable, free-flooding external machinery and in developing compact power sources suitable for closed-system operation. The fundamental technology needed to provide the solutions today is largely lacking.

Similarly. special design characteristics are required for rehicles to conduct exploration missions at rery great deptlis. Ideally, 
they should have endurance and shonld be able to mate with manned habitats or other submersibles. They should be independent of surface support and have sufficient instrumentation to make their missions usefu]. We are not withont promising arenues of approacl to these problems. Some of these are discussed in the sections that follow.

\section{Man-in-the-Sea Techniques}

In a consideration of the need for global exploration and monitoring, the use of manned habitats and diver transport systems must bo mentioned. Recently, small prototype manned habitats have been developed and put into operation. Their success gives immediate promise to a dream. Scientists soon can work routinely to 600 feet. Gasbreathing divers have been exposed to depths in excess of 1,000 feet with complete success, and operations to 2,000 feet appear to be a reasonable projection of future capability.

Even at shallow depths, diver-investigators can be largely free of surface weather effects. Towed, transported, or self-propelled habitats or sealabs can be taken to any place in the oceans using a surface or submerged route. At the desired location, they can be stationed on the bottom or suspended in the water column to provide an instrumented laboratory capability. If saturation diving techniques are used, there is no presently known physiological limit to their length of stay. The sealal, gives the scientist deeper access and removes most weather contingencies.

Habitats allow investigator's to enter and return from the enviromment they wish to study. While using such pioneer equipment, these investigators can anticipate early and extensive improvements to their working conditions. Personnel in sealabs today must be skilled divers able to cope with a variety of sometimes hostile conditions whenever they venture outside. In aviation terms, they are working at an "open-cockpit" stage of development. In time it shonld be possible to have more control ores the enviromment immediately out side the habitat, for example, by providing low, spacions molersea tents, possibly insulated to contain warm and filtered fresh water. While restricting freedom of movement to some extent, such facilities could be occupied in the same sense that Antarctic snow tunnels are mamned, providing corridors and chambers that protect, house, and store instruments and equipment. Insulation from the environment will tend to free the trained divers, decompression technicians, and medical physiologists to supervise the operation of whole systems and to train the nondiver scientists and technicians to work within these systems.

One-atmosphere habitats with oceasional or no access to the open environment also should be considered, ranging from surface to bottom and subbottom facilities. The highly successful design of the U.S. Navy's FLIP allows a surface craft to be towed to a site, to be upencled, and to remain on station with facilities both above and well below the surface. Variations on this surface platform should be encouraged, as many possibilities for utilization can be envisioned. Similarly, 2,000-foot and 20,000-foot one-atmosphere habitats should be dereloped for long-term routine occupancy by nondiver personnel.

In imaginative proposal, Project Rocksite, is being considered by the U.S. Navy. This project calls for drilling tumnels into the seabed, combining the existing capability of forming mine tummels and shafts beneath the sea floor with a new technology for mating submersibles to a seafloor shaft entrance, thus providing a completely independent subseafloor installation. 
Because of the need for access to the environment, deep sea one-atmosphere habitats may be further in the future than ambient pressure sea labs or continental shelf depth facilities like Rocksite. Mating a deep submersible to a one-atmosphere chamber at 10,000 or 20,000 feet still is difficult to contemplate. Of course, as submersible engineering progresses, this technique will emerge; so too will other techniques for deep ocean access.

Possibly no mole exotic than a man exiting from an orbiting capsule, the development of liquid breathing by divers would offer similar advantages to the ocean investigator. The occasional foray for high priority missions would permit the full manipulative-adaptive capabilities of man to be employed to depths possibly as great as 10,000 feet.

When it is possible to employ much more extensive systems, they will require the whole panoply of logistics support, including personnel transfer vehicles, rescue capabilities, and the like. Although requirements for such civil or military systems still are speculative, efforts must be made to anticipate future needs by conducting fensibility studies concurrently with the exploration and development of basic teclmology. Initial experience in staging diversified operations in the deep ocean environment may be gained concurrently through construction of an ocean station on a seamount for ease of access to the deep ocean. This program would he a realizable sequel to the Commission's National Project for fixed and portahle continental shelf laboratories.

The Commission recommends that the National Oceanic and Atmospheric Agency and the U.S. Navy join in conducting studies of the feasibility of advanced deep ocean stations, initially on seamounts but later on the continental slope, ocean ridges, and finally in the abyssal deep. These studies should also include the feasibility of mobile undersea laboratories and large stable ocean platforms which could be used in conjunction with the fixed ocean stations.

\section{Submersibles}

The art of submersible design is in a state of rapid change and sophistication; it has a long way to go. Present submersibles-expensive; difficult to transport, handle, and control; and short on visibility, endurance, and depth-have seen limited use in marine science. The immense effort already undertaken with such well-known designs as Aluminaut, Alim, Trieste, and Deepstar has shown both the problem and the promise.

The promise is that the inconrenience of pioneer equipment can be elininated, that submersible transport systems will give the investigator the freedom to go deep without restraint, and that once there he will have the option of traveling as far as he wishes.

New designs will enluance greatly this capability. A two-phase derelopment of a manned submersible using a plexiglass capsule to provide nearly total visibility soon will be launched. Operated in clear water, it will give the occupants the effect of being in an underwater helicopter. Operated in murky water, it will allow the pilot to stabilize and orient to an object easily, as ahead-scanning and peripheral rision will be umestrained hy the climensions of viewing ports.

When technology allows glass with its high strength-to-weight ratio to be substituted for plexiglass, this same vehicle design may offer the capability of operating from 2,000 to 20,000 feet while retaining its characteristic of visibility. Such glass vehicles may not be as far in the future nor as expensive as generally estimated.

One design now approaching prototype 
construction aroids the need for continuous power and achieves long range by simply diving to and ascending from great depths, covering 50 miles in each glide cycle, by using a liquid chemical to blow the ballast tanks at the base of the dive. Fifty such cycles cover 2,500 miles, a complete ocean transit with 50 passages from surface to 20,000 feet throngh all of the physical and biological strata en ronte, and with 50 visits to parts of the seafloor never before visited. Allowing three men aboard and 20 days' endurance, the submersible apparently can be built and operated for reasonable costs at least comparable to those for surface oceanographic

The research submersible Deep Quest goes to sea aboard her surface support ship Trans Quest and, onee in the water, receives an external inspection prior to making a dive.
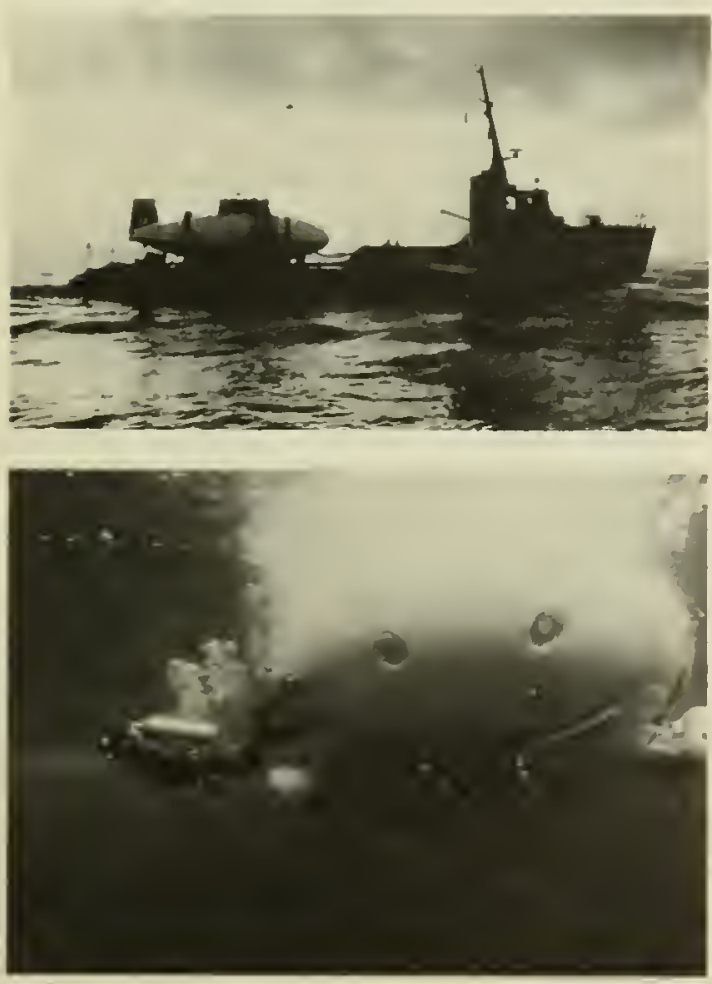

ressels. The combination of depth and visibility inherent in such a vehicle could be invaluable in ocean transits for exploration of the oceans.

Information from expert observers is not enough. Elaborate photographic equipment and lighting complete with pressure housings have been developed for deep sea work. Such equipment can be operated remotely from the surface in conjunction with acoustical listening devices for describing the forms and strata of life.

Submersibles also can be fitted with thermistor probes to record temperature profiles continuously. This information then can be correlated with the photographic observations. Ultimately instruments to monitor the gross chemistry of the passing sea water can be fitted to the hull. Thus, a deep diving, long traveling submersible becomes a complete oceanographic vessel. Although there are constraints on the size and weight of these data collection attachments, the task is considerably less demanding than the task scientists face when instrumenting satellites. Freeflooding equipment can be carried relatively inexpensively if made neutrally buoyant. Fully instrumented, such a vessel with vertical and horizontal freedom in the water column should provide capabilities surpassing those of some larger surface vessels. Perhaps more than anything, the oceanographic submersible would enjoy 24-hour data collection capability on a stable keel in a tranquil environment minterrupted by weather considerations.

How deep? A 20,000-foot deptl capability will pernit operations in more than 99 per cent of the world's ocean volume with access to 98 per cent of the ocean's floor, excepting only the deep trenches. Nearly 10 years ago, the bathyscaphe Trieste went to one of the deepest parts of the ocean, approximately 
36,000 feet below sea level. Restricted in maneuverability, it carried 34,000 gallons of aviation gasoline to provide buoyancy for the pressure capsule and other equipment. The deepest dive for a maneuverable submersible was 8,310 feet in early 1968 .

The Navy presently is building or developing, among others, four types of manned vehicles with operating depths as noted: rescue at 3,500 to 5,000 feet, research at 6,500 feet, search at 20,000 feet, and ocean survey with depth claracteristics still undetermined. The desirable operating depth of a rescue vehicle is established by the depth of a possible rescue mission. The best depth limitation for commercial vehicles is the most economical depth to do the job, probably to 2,000 feet for foreseeable continental shelf and nearshore work.

Successful operations for oceanographic purposes below 2,000 feet require new technical principles which are expected to be valid all the way to 20,000 -foot depths. Although the initial investment may be slightly higher, no immediate improvements in early program schedule or near-term costs would occur if these velicles were designed for depths less than 20,000 feet. The same types of problems must be solved. By going directly to these problems, overall costs wonld be less than for a program having depth goals set in progressive increments.

The Commission recommends that the National Oceanic and Atmospheric Agency sponsor an explicit program to advance deep ocean fundamental technology and proceed with a National Project to develop and construct exploration submersibles with ocean transit capability for civil missions to 20,000-foot depths.

Ideally, several such submersibles should be completed in time for useful assignments in the forthcoming Decade of Ocean Exploration. These vehicles should have hovering, maneuvering, sample-taking, and small object recovery capabilities as well as improved sensing capability. A National Project for a long endurance 20,000-foot exploration submersible will be not only a major U.S. contribution to the Decade, it would be a milestore in the history of exploration and in oceanography.

\section{Instruments}

While man-in-the-sea and manned submersible techniques are essential to true oceanic exploration, by far the largest and most inexpensive source of data will be from unmanned systems. Placement, maintenance, and recovery of such systems will depend on the access that men have to the environment. Otherwise, their effectiveness depends only on their reliability; quality of sensors; and capability to record, store, and occasionally transmit information.

No deep-placed, reliable, accessible instrument plat form is available today. However, such equipment, monitoring oxygen and many other physical and chemical parameters, is both possible and essential. Eventually, many thousands of sucl units may be needed. They must be able to sense a wide lange of physical and chemical characteristics. In order to achieve increasing effectiveness, there also must be a concerted effort to improve the quality and range of the sensors and the reliability and variety of packaging and handling techniques.

Important to such a system will be a whole class of free-fall devices independent of a wire, anchor line, or stationed vessel. These devices could be dropped by passing ships or aircraft. They then may serve their useful life just during the fall to the bottom or remain active on the bottom until picked up 
or released to float again, or they inay stop at some pre-set level and drift with the eurrent until retrieved or expended.

Another class of devices could be self-propelled and automatically or remotely guided along programmed courses. Diesel-driven semisubmersibles could cruise the surface in transocean patterns. Deep-diving torpedo hulls with battery power could dive from surface ressels, rum a search course, and return for recovery. Helicopters, aireraft, drones, and rockets could cover great distanees, carrying sensors with or without the option of water entry.

Other classes of recording devices are not truly instruments, but they are equally important. Unmanned coring and rock sampling techniques ultimately may be useful, for it may not be possible to take good core samples from a deep submersible.

More continuous sampling and data recording certainly are needed, and their technical development is sufficiently advanced to be promising. The Hardy plankton sampler takes a continuous sample of plankton while

\section{New oceanographie instruments, like this salinity-lemperature-depth recorder and sound velocity sensor, are permitting more rapid, better observations of the physical characteristics of the oecan.}

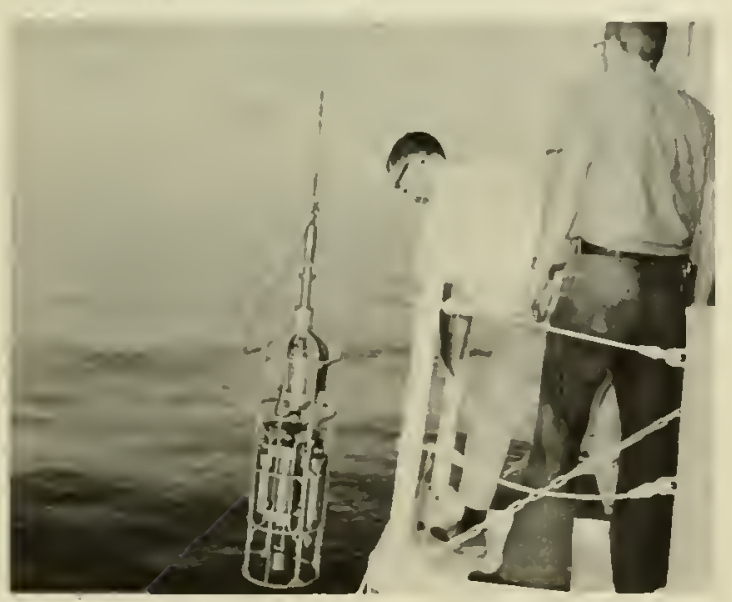

being towed, giving, in effect, a geographic and chronological record of the sample orer a given distance. $\Lambda$ few oceanographic vessels are measuring properties of the sea surface continuously, and some pump water through their laboratories while underwa for chemi(al analysis and for temperature and conductivity measurements at short intervals. Still another recent derelopment that enhances the capability of a ship to collect vita] data at sea is the salinity-temperature-depth recorder; one self-contained, battery-powered rersion records datil on a graphic plotter.

While progress is being made, it should be classified as pioneel work not adequate for today's rapidly escalating needs for global ocean measurements. The measurement of many parameters in many places by many methods must be accomplished. 'The task will not be easy. Although it will require a long time and a large investment, good engineering in ocean instruments must be achieved. Besides retarding progress in field experimentation, the present deficiencies are very costly. In the fields of space or communications, it would be considered unthinkable to initiate expensive operations without properly engineered equipment having reasonably assured dependability. Howerer, in marine science today, it is not unusual to experience a high failure rate of equipment.

The Commission recommends that the National Oceanic and At mospheric Agency take the lead in fostering a wide variety of instrumentation development programs required for ocean exploration.

\section{The Global Monitoring and Prediction System}

'The derelopment of a system for monitoring and predicting the state of the oceans and the atmosphere is critical to all that the Nation would do in the seas. Monitoring the 
state of the oceans and the atmosphere is presently limited by the technological capabilities to observe the global environment. But even if one conld now observe the enviromment everywhere, the ability to predict the future state of the oceans and the atmosphere is seriously limited by incomplete understanding. In particular, the ability to predict the state of the oceans is limited by the lack of knowledge of the motions of the oceans, of their scale and of the canse of their fluctuations.

\section{System Operations and Management Arrangements}

In considering systems for environmental monitoring and prediction, the basic components required to meet multiple needs must be distinguished from components required to meet the needs of special classes of users. The basic system is composed of facilities for observation of air and oceanic data and the data's communication, processing, and dissemination.

The historical erolution of environmental monitoring and prediction activities, both in the Nation and abroad, has brought the development of separate organizations and monitoring systems to deal with each major class of phenomena. Thus, weather data are collected and exchanged internationally through one system; some data on ice conditions are exchanged through a second; and so forth.

Within the United States, the facilities making up the basic system are operated chiefly by agencies of the U.S. Departments of Commerce, Defense, and Transportation. These same departments also are responsible for meeting the needs of most special users. They are helped in this function by bureaus of the Department of the Interior; the Department of Health, Education, and Wel- fare; the Atomic Energy Commission; and others. A detailed description of the functions and programs of all the Federal agencies is given in the Report of the Commission's Panel on Environmental Monitoring.

The formation of the Environmental Science Services Administration (ESSA) in the Department of Commerce in 1965 was an important step toward the integration of environmental monitoring and prediction activities in the United States. In proposing the reorganization which brought the U.S. Weather Bureau, the Coast and Geodetic Survey, and the Central Radio Propagation Laboratory of the Bureau of Standards under single management, President Johnson stated that it would provide "a single national focus for our efforts to describe, understand, and predict the state of the oceans, the state of the lower and upper atmosphere, and the size and shape of the earth."

Within ESSA, steps are underway to integrate the systems under its management. However, these constitute only a part of the efforts within the Federal Government to monitor the global air-sea envelope. The Navy now has a coordinated system through the Oceanographer of the Navy and the Naval Weather Service Command, and the Department of Defense coordinates all military departments' environmental prediction services through the Office of the Special Assistant for Environmental Services of the Joint Chiefs of Staff. Coordination of the overall Federal program is effected, insofar as possible, throngh the Office of the Federal Coordinator for Meteorological Services and Applied Meteorological Research within the Department of Commerce and the Interagency Committee on Ocean Exploration and Envirommental Services of the National Council on Marine Resources and Engineering Development. 
The Office of the Federal Coordinator coordinates meteorological programs only. It is not anthorized to coordinate all environmental programs. It has no anthority to djrect the actions of other Govermment agencies. It has been able to inaugurate a policy of sharing facilities and to forestall the establishment of chplicate facilities in many ases. It also has formulated comprehensive Federal plans in many critical weather operating services. In addition, an Interdepartmental Committee for Atmospheric Sciences coorclinates basic research in meteorology, reporting to the Federal Council for Science and Technology.

The Committee on Ocean Exploration and Envirommental Services is charged with developing a Federal Plan for Marine Environmental Prediction and to see that the plan is carried out. The Conmittee is not in a position to propose any changes in statutory responsibilities but will seek to coordinate projects and plan programs.

The Commission finds that the scattering of responsibilities among many Federal agencies contimues to cause funding and management difficulties.

There are three orerall categories of Federal funding for the marine environmental monitoring and prediction services:

- For the collection, processing, and dissemination of ocean measurements that are not collected in connection with meteorological services

- For associated meteorological and oceanographic data collection and processing that are essential for occan obscrvations and forecasts, but that are also collected to meet more general, nonmarine needs of the national civil and military weather services

- For specialized marine weather data collection and processing that are to meet the exclusive need for support of marine activities.

Approximately $\$ 175$ million is spent annually to provide these services.

The most important products of the system at this time are weather analyses and forecasts, warmings of severe storms and tsunamis, tidal predictions, and sea state reports. Operationally useful forecasts are provided

\section{A single, national cnvironmental monitoring and prediction system. vould provide ata and predictions lescribing large area characteristics of the occan and atmospheric cnviromments. ESS 4 metcorologists prepare to relcase a $h y$ foon (top) photograph), and technicians sertice a Navy Nomad. buoy.}
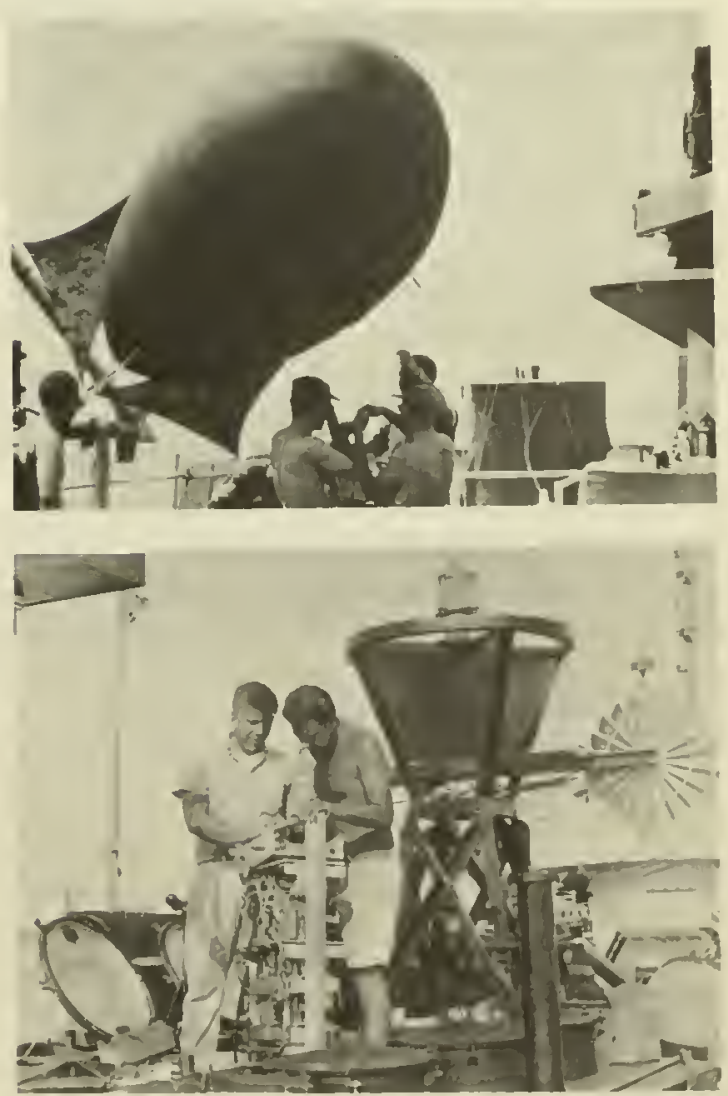
by the U.S. Navy of ocean temperature structure, sound propagation tactical indices, sea state, and shifts in the location and flow of certain major currents.

Generally, the Commission concludes that because of the magnitude of the effort to monitor and predict changes in the oceans and the atmosphere and because of the commonality of much of the science and technology, there must be a single system to observe the oceans and atmosphere and to provide data and forecasts to meet common needs. There is good precedent for combining the oceanic and the atmospheric monitoring elements. For instance, the Navy conducts many of its weather and ocean forecasting functions jointly at the Fleet Numerical Weather Central, Monterey, California. Also, ESSA provides both weather and marine information on storm surges and sea state through a single system and plans to use weather satellites to observe oceanographic parameters.

The single system would provide data and predictions describing large area characteristics of the ocean and atmospheric environments. However, the Department of Defense will continue to require a system to provide specialized outputs fully responsive to rapidly changing military requirements.

Some envirommental service requirements are common to both civil and military users. As the planned services to civil users are implemented, some of the products of the civil agency may meet these common needs. This will free some military resources to concentrate on requirements unique to military operations.

Products designed for military users, if they are appropriate and can be made available, will be used to meet requirements of civil usel's until services to civil users have been expanded. This use of military products will be ad interim except in those cases in which common requirements can be met most effectively and economically by their continued use.

Special consideration also must be given to the relations between local detailed envirommental activities and large area global services. One example of special interest concerns the myriad of activities in the Nation's estuaries. Many local public agencies conduct monitoring programs that include measurements of physical, chemical, and biological parameters to aid in controlling pollution levels; in examining the effects of such pollution on marine life; or in identifying fish stock. These data should continue to be collected by local agencies.

The data collected in these local programs will be on a scale considerably more detailed, and often will be taken with greater frequency, than is required to support the major environmental prediction services considered in this chapter. The behavior of an estuary, however, is strongly influenced by the larger motions of the oceans and the atmosphere. For this reason, the local agencies conducting estuarine-oriented programs must be ensured rapid access to appropriate data collected by the global net work.

The data collected and forecasts issued by the single system would serve as major inputs to the more detailed forecasts and resulting regulatory actions of the estuarine agencies. On the other hand, the special data collected (typically on a relatively fine grid) within the estuary would not be required for the operation of the single system. In some cases, a single data collection station might serve both a local estuary activity as well as the single system.

The Commission recommends that the Nation's civil oceanographic monitoring and prediction activities be integrated with the existing national weather sys- 
tem (as well as certain aspects of the systems for monitoring the solid earth) to provide a single comprehensive system designated as the National Environmental Monitoring and Prediction System (NEMPS).

Activities in NEMPS serving civil interests should be consolidated in the $\mathrm{Na}$ tional Oceanic and Atmospheric Agency (ESSA); specialized activities in support of military operations should be retained in the Department of Defense. NEMPS should be closely coordinated with the systems of the Department of Defense. The civil and military monitoring and prediction activities should develop along the following guidelines:

- A common, shared data acquisition network

- A common, shared communications network, except where national security requires separate systems

- Independent but parallel data processing and forecasting facilities

- Independent, specialized data and forecast dissemination subsystems

The National Oceanic and Atmospheric Agency (ESSA) should take responsibility for overall systems analysis and planning for NEMPS, with the assistance of other agencies as appropriate.

Thus, the Commission has concluded that it is not practical to achieve total consolidation of environmental prediction either in NOAA or the Department of Defense. The former alternative would ignore both vital defense interests and the substantial econonies possible through using in-place military facilities. The latter would either weaken support of military missions or result in inadequate attention to civil needs.

$A$ division of operational responsibilities with NEMPS operation and management vested in NOAA is necessary. Thus, delineation of the basic data collection network to satisfy civil needs would be the new civil agency's responsibility. Both the new agency and the military services would contribute to the total data net. The responsibility for delineation of military data needs, apart from those required for civil needs, would rest. with the Department of Defense. A single civil communications system would be established for the collection and transmission of data by the civil agency, but for purposes of decreasing vulnerability and military security, portions of the network would be paralleled by the Department of Defense.

It is essential that the National Oceanic and Atmospheric Agency and the Department of Defense maintain their separate facilities for processing data and issuing forecasts to users. The necessity of providing the military with capabilities to respond immediately to threats is important. Moreover, military and civil services must tailor their forecasts to particular classes of users.

The civil agency would provide broad forecasts for the general public, broad segments of the economy, and other Federal agencies. If these forecasts must be refined to meet the needs of special industrial interests, the refinement would be the responsibility of the private sector, and agencies with special needs would act to refine the forecasts as necessary.

The military will prepare forecasts to meet all national security requirements. Sharing of data and products is imperative and possible through high-speed electronic computers and associated equipment. In order for major environmental data processing centers to operate in parallel, the data processing and transmission equipment sliould be made compatible.

We propose that the management princi- 
ples that have evolved for gathering and processing meteorological data also be applied to the ocean environment. Armittedly, the principles are not followed always in meteorological activities, but they have worked well, and the proposed reotganization would do much to improve their implementation in both fields. It is particularly necessary to be consistent on arrangenents for handling meteorological and oceanographic data, because the system being proposed would deal concurently with both kinds of data.

It is desirable to obtain oceanographic and meteorological data from the same area si-

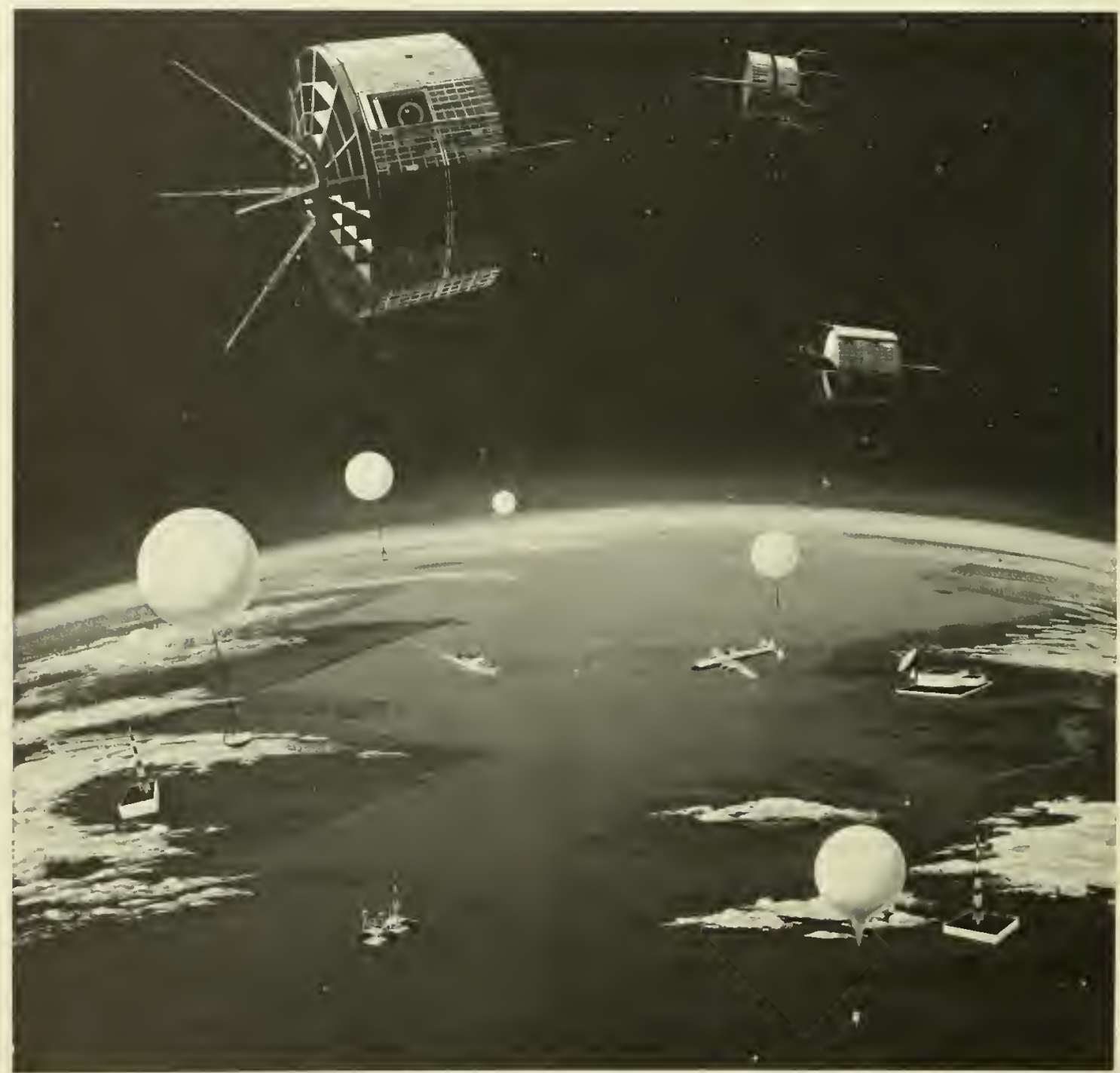

Satellitcs, buoys, and slips will be linked in a global monitoring and prediction systcm to observe the occans and utmosphere and to provide data and forecasts for their many uscrs. 
multaneously; for this reason ocean and atinosphere sensors should be aboard the same platforms. However, the National Aeronauties and Space Administration (NASA) treats the development of ocean sensors as part of its earth resources program; further developments may lead to ocean sensors being coupled with sensors developed to map specific resources.

Conceptually, there is much attraction to arrangements which would permit all aspects of the environment, including the solid earth, to be monitored through a single system. But the Commission has concluded that the time is not appropriate. In the absence of overriding engineering or cost considerations, the Commission does, however, believe that ocean-atmosphere observations should be coupled. Currently NASA and the Navy are working together in a research and development program in spacecraft oceanography, and Navy is separately pursuing a progran in aircraft remote sensors. NASA is also working closely with other Federal agencies in environmental research and development programs involving use of spacecraft.

The development and use of satellites for environmental monitoring requires close cooperation between NASA and the user agency. The relationship of the National Teather Satellite Program to NASA provides an example of a successful working alrangement. NASA now has the responsibitity for the development of new sensors to be carried aboard meteorological satellites; the performance specifications are prepared by ESSA. NASA launches the satellite and places it in the preseribed orbit. When certified as fully operational, ESSA takes over and maintains operational control, receives data through its own read-out stations, and transmits appropriate raw and analyzed satellite data over standard meteorological
Hauned spaccerafi and salellites have already demonstrated their uscfulncss for occan-almosplere obserrations, lile the ricw of II uricane Gladys as secu from A pollo 7 in 1968. Belore, an ESSA weather satellite reccires a prelaunching ehcetioul.
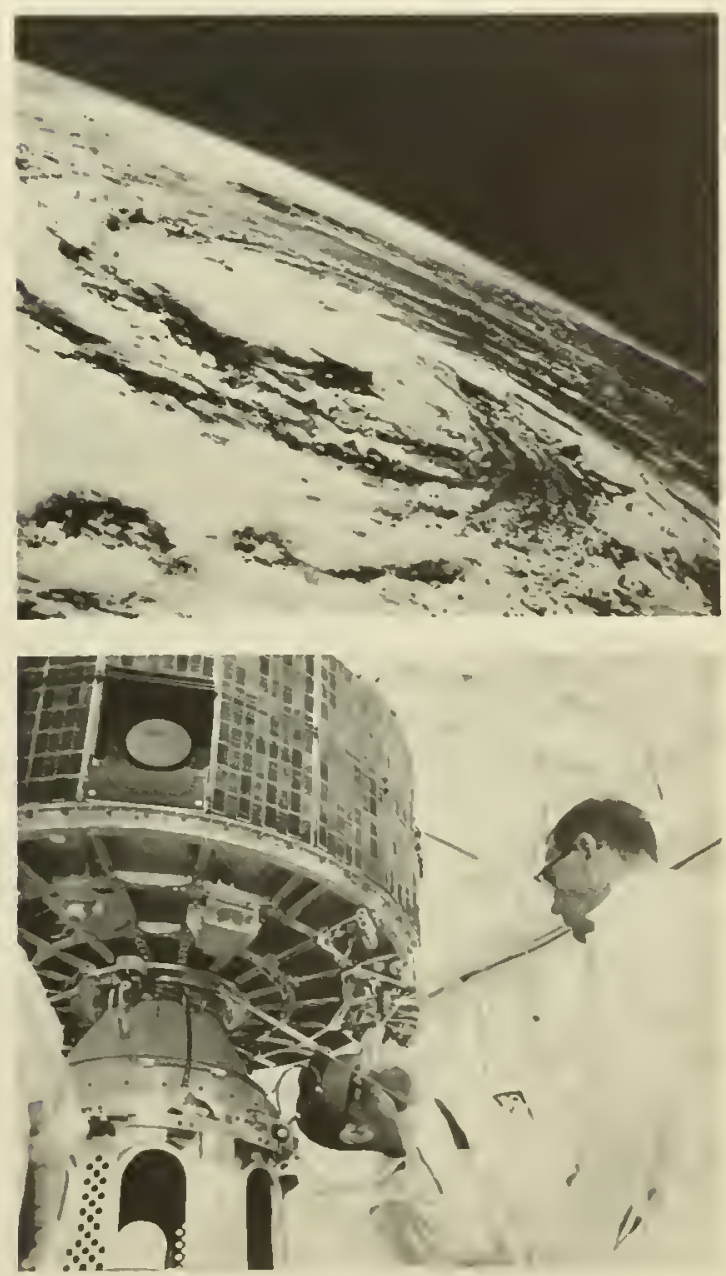

communications and circuits. These arrangements have yielded excellent system performance.

The Commission recommends that the National Oceanic and Atmospheric Agency (NOAA) make arrangements with the $\mathrm{Na}$ - 
tional Aeronautics and Space Administration (NASA) for satellite oceanographic sensor development and operation along lines similar to those established for the national weather satellite system.

\section{A Program for Immediate Improvement}

Important advances have been made in the past decarle in data collection equipment and platforms, and several second generation systems are under development which promise dramatic improvements in our ability to observe the total environment and to process and transmit the resulting data.

It is not yet possible, however, to envision the complete composition of a total system. The proper mix of platforms and instruments must be evaluated on the basis of performance and cost.

However, opportunities exist for immediate improvement in the Nation's environmental monitoring and prediction systems at relatively modest cost. The present ability to analyze and predict sea surface conditions is limited by the scarcity of surface ocean and weather observations.

The vast majority of these reports are made by merchant ships cooperating in the World Meteorological Organization's (WMO) international weather observing program. It is estimated that for a given day there are seven ships at sea for each ship's observation received. Clearly, more data could be received by increasing the number of ships in the WMO cooperative program. This program can be expanded at low cost.

The Navy's program in the analysis and prediction of ocean thermal structure is also data-limited. Of the 125 bathythermographic recordings taken daily, the majority are provided by naval vessels, with some from shipsof-opportunity in a cooperative Navy-Bureau of Commercial Fisheries program. Addi- tional ocean temperature data could be collected by expanding these programs quite inexpensively; this effort should be tailored to overcome at least some of the omissions in data coverage.

In addition to the temperature data in the oceans' near-surface layer's, broader coverage is required of the lower layers of the atmosphere, now limited by the relatively few radiosondes launched by ships. The radiosonde observations are taken from numerous U.S. Navy commissioned ships; from the U.S. Coast Guard ocean station vessels; and by about 15 ESSA teams aboard a limited number of Military Sea Transport Service, ESSA, and merchant ships in the Pacific. Additional ships could be out fitted with relatively inexpensive shipboard equipment to expand this upper air sounding capability. There are great areas of the world's oceans that are not covered, or at best, are sparsely covered, by merchant ships. The WMO is investigating the possibility of obtaining reports from world fishing fleets in these areas. One direction for expansion of this program, therefore, should be the inchusion of ships not now participating-particularly such fishing fleets as those of Japan, Taiwan, and Korea.

In certain coastal areas and the Gulf of Mexico, platforms have been erected for the extraction of oil and natural gas; at present a limited number of offshore platforms are instrumented to provide environmental data for major forecasting programs.

The Commission recommends that the ship-of-opportunity program be expanded immediately to provide more surface ocean and weather reports, additional ocean temperature structure data, and more wind soundings. In particular, vessels operating in regions not covered by major merchant vessel trade routes should 
be included in the ship-of-opportunity program. Additional instrumentation should be placed on offshore platforms.

Another area for immediate improvement is in the T'smami Waming System. The present ability to forecast tsumami arrival times at Pacific Ocean locations appears to be adequite, but run-11p forecasts often are grossly in error. The Tsumani Warning System performance is limited by lack of sufficient nearshore, deep ocean tidal, and seismic information as well as inadequate theoretical understanding of energy-focusing processes. Additional instrumentation is required in the Pacific, possibly at island stations, and further development of deep ocean tidal instrumentation is needed.
The Commission recommends that the National Oceanic and Atmospheric Agency (ESSA) expand the tide and seismic monitoring network in the Pacific basin. International communications from South America and the Southwest Pacific should be improved. Additional research on tsunami generation and run-up problems should be instituted.

Improvements in our capability to forecast hmrricane development and motion and the storm surge are urgently required.

Navy, Air Force, and ESSA aircraft should be augmented by additional high performance aireraft with up-to-date instrumentation. In addition, there is a continning oper-

World Merchant Ship Density, June 12, 1964

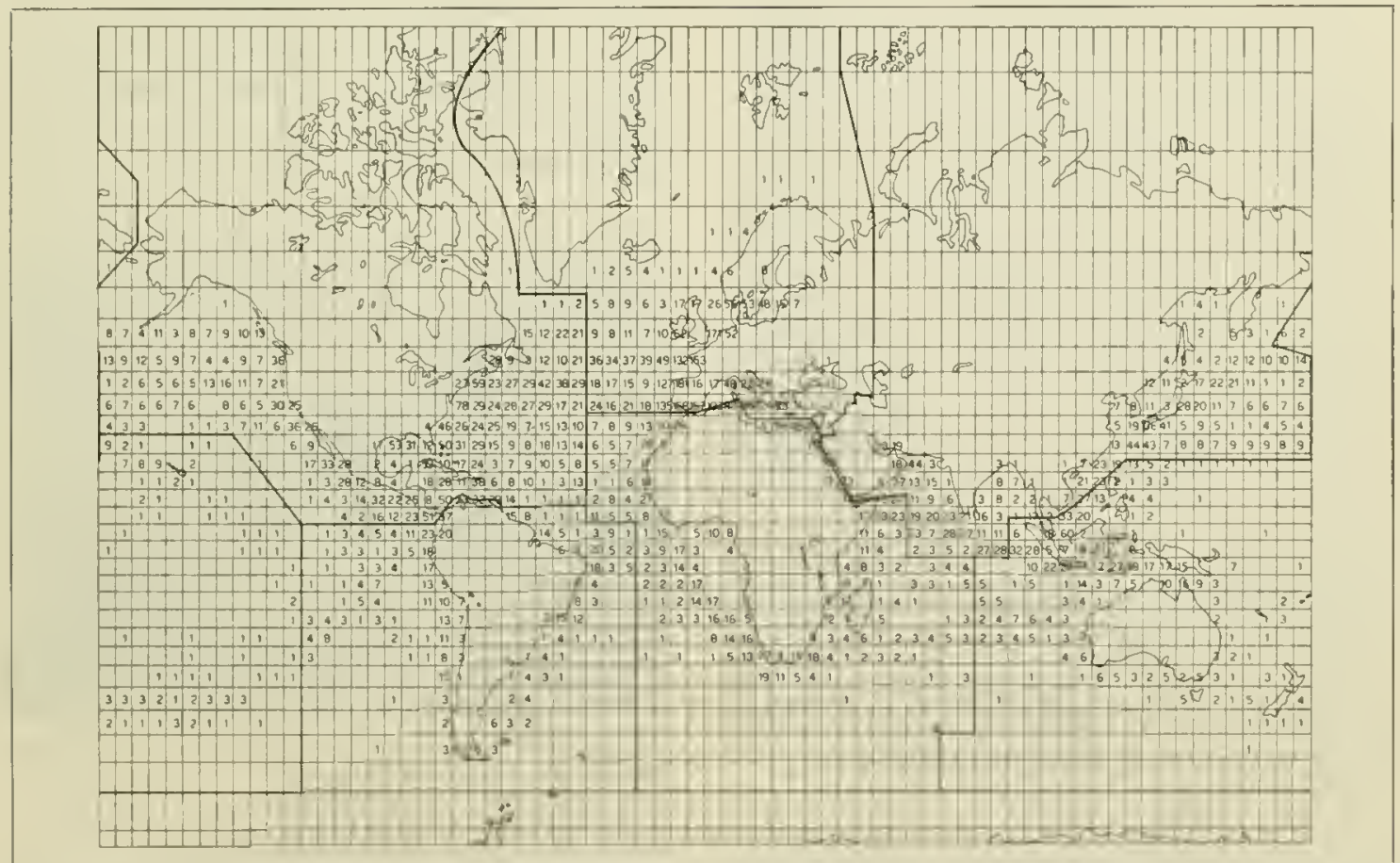

Sorkce: M. Hanzana and 'T. 11. Tourler, System for the Colleetlon of Ships' Weather Reports. World Weather Watch Plannlag Rep. No. 25, World Netcorologlcal Organizatlon, feneva, Swit., 1968. 
ational requirement for more detailed neteorological data over the Caribbean and the Gulf of Mexico. The data collected should be used botly to support day-to-day forecast activities and to test mathematical models and hurricane modification hypotheses.

The Commission recommends that the data networks that support the Hurricane Warning Service be expanded. This service should be accorded high priority to take advantage of the latest technical and operational developments.

In reviewing the Federal programs, we find that iceberg observation services are useful and effective with regard to ship routing in the North Atlantic, but capabilities for predicting iceberg motion and sea ice distribution still are very limited. A fundamental lack of understanding exists in regard to the transfer of lieat and stress from the air above and the water below to the ice interface. Predictions of the subsequent motions and deformation of sea ice require an improved capability to forecast the wind near the ocean surface. Since it is important to study ice during the long polar nights and under adverse cloud conditions, sensor imagery independent of these restrictions acquired by air and satellite remote sensors is a requirement for rapid advances in the understanding of sea ice dynamics.

The Commission recommends expansion of research efforts to improve sea ice forecasting and remote sensing of glacial and sea ice to yield improved models of the formation, growth, drift, deformation, and disintegration of different ice types.

A Govermment-wide plan for systematic improrement of marine weather services, prepared by the Office of the Federal Coordina- tor for Meteorological Services and Supporting Research, has been reviewed by the Commission. It proposes steps to bring our marine weather services in line with national needs by :

- Establishing marine forecast centers and systems for radio facsimile and radio telephone broadcasts of marine forecasts

- Instrumenting additional ships-of-opportumity and installing automatic stations and telemetering equipment along the coast to obtain weather, tide, and ocean data from locations where it is not feasible to use cooperative observers

- Installing additional weather radars

- Providing specialized support to military users

- Extending the range of broadcast facilities for transmitting environmental information to ships on the high seas.

The Commission endorses the existing Federal Plan for Marine Meteorological Services and urges its early implementation.

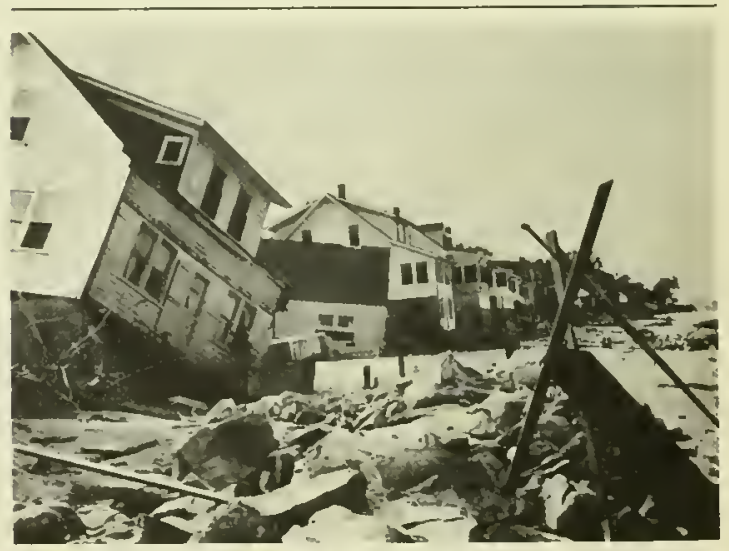

Improvements in our capability to predict hurricanes are urgently required if the United States is to defend itself better against destructive forees of storms like II urricanc Betsy, which left tumbled homes along the Rhode Island coast in 1965. 


\section{The Technology for NEMPS}

In recent years, signiticant advances have been made in data collection devices and their associated platforms. Operational application of these advances and of teehnology now under development promises dramatic improvements in our ability to observe the total enviromment and to process and transmit the resulting data. Extrapolations of present technology make it appear feasible that the future environment monitoring and prediction system will provide automatic processing of data communicated from orer the entire globe in real-time. Some environmental sensors would be in nearly contimuous operation, permitting computer systems to operate in a continuonsly updating mode. At regular intervals the system wonld produce required forecast charts and other processed data which wonld be disseminated to users.

Although one cannot stipulate yet the complete and detailed composition of the anticipated system, the key elements will involve buoys, satellites, aircraft, computers, and high speed communications.

\section{Buoys}

Although buoys have been used widely in research and survey work, they do not yet possess the reliability and service characteristics required of operational buoys. Experience has demonstrated that further test and evaluation are needed to assure reliable transmission of the data and that extensive efforts still are required in the derelopment of reliable anchors, moorings, power supplies, and hulls. Buog instruments to sense pressure. temperature, salinity, sound relocity, current speed, and direction now are available. Operational buoys also ean provide platforms for sensors to collect biological and ehemical data at rery small additional expense.

It is possible also to use drifting buoys and balloons to colleet data to be relayed ria satellite to central collection points. However, a number of problems still must be orercome to assure system reliability. Improred estimates are needed for the number of free-floating bunys and balloons required to obtain world wide observations of sufficient density.

Ifter examining the many fragmented ocean data buoy programs being conducted ly the Federal Government, the National Council on Marine Resonrees and Engineering Development secured the initiation of the National Data Buoy System program uncler the leadership of the U.S. Coast Guard.

The deployment of.an operational coastal and deep ocean system of monred buoys lias been estimated to cost between $\$ 200$ and $\$ 500$ million, plus $\$ 15$ to $\$ 15$ million anmually for systems operation. To design an efficient system will necessitate extensive research, derelopment, test, and evaluation. A decision was reached by the Marine Council that the system's potential warranted preliminary derelopment. A $\$ 5$ million budget to initiate such development was requested for FY 1969 by the Coast Guard, but action on the request was deferred by the Congress pending a better understanding of its relationship to the U.S. Coast Guard's mission and other elements of a national monitoring and prediction system.

The Commission concludes that the investigation of buoy technology should be strongly supported. The objective should be to deploy a pilot network in a limited section of the sea by 1975 . The development and test of such a pilot network should draw upon the skills of industry and the universities as well as the responsible Federal agencies. Therefore it might be appropriately designated and managed as a National Project. Several buoy configurations might be included within the network in order to test alternative 
designs and to obtain data which will describe the spectrum of motions in the ocean. Any special requirements of military bnoys must also be considered.

Based on experience gained through the proposed project, the Nation will be in a position to determine the role which moored buoys should play in the global system, the types of buoys which shonld be used, and the system's optimum configuration.

The Commission recommends that the $\mathrm{Na}$ tional Oceanic and Atmospheric Agency (CG) launch a National Project to develop a pilot buoy network. It should provide for tests of alternative buoy configurations, advanced sensors and equipment, different network spacings, and logistic support methods. The pilot network should be tested and evaluated fully before a com. mitment is made to a major operational system; many of these tests could be conducted in coordination with other oceanographic research efforts.

\section{Aircraft}

The instrumented aircraft, operated as a test bed for satellite instruments and in support of specific research and development projects, has demonstrated its usefulness as an oceanographic data collection platform and in the reconnaissance programs of the U.S. Department of Defense and other agencies. Field accuracies of approximately onehalf degree centigrade have been reported in sensing sea surface temperatures uncler ideal conditions. Devices are being developed or are available that can be placed on air-

Initial Data Requirements for Forecasts of Given Lengths

Estimated initial data requirements to forecast for $a$ point at the 500 -millibar surface (about 6 kilameters) at lati tude $45^{\circ} \mathrm{N}$. For a farecast period of up to 80 haurs, initial data are reguired from o strip at the same altitude guer the Northern ver the Northern. lliemisphere, 30 phere over part of the Northern Hemis phere; 4-5 days, a deep loyer of atmosphere aver the entire Northern and port of the Sauthern Hemisphere plus sea-surface data: 5-10 days, game part af atomshpere as for $4-5$ doy 8 plus the acean to 4 metcrs: and 10 daus-2 months, atmosphero over entire globe plus the ocean to 100 meters.

.

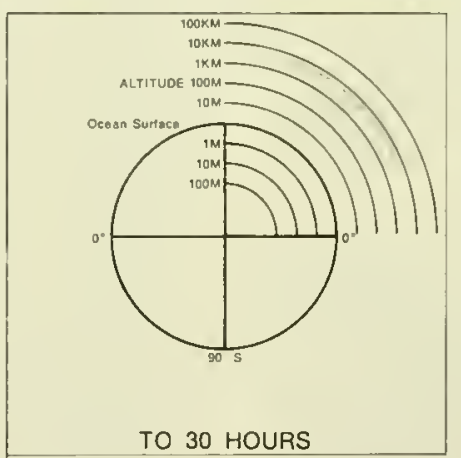

TO 30 HOURS

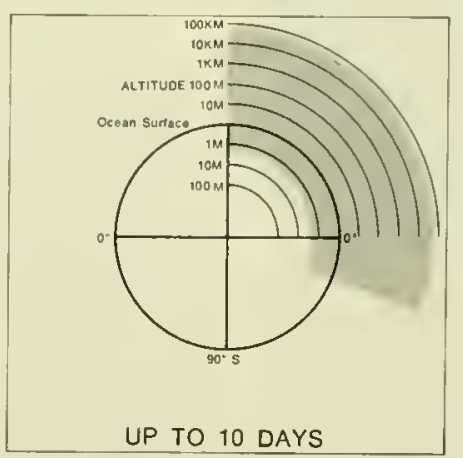

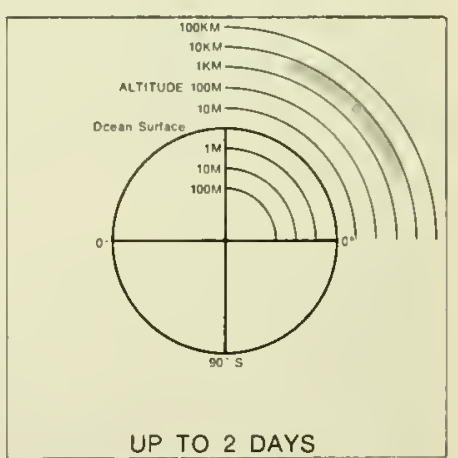

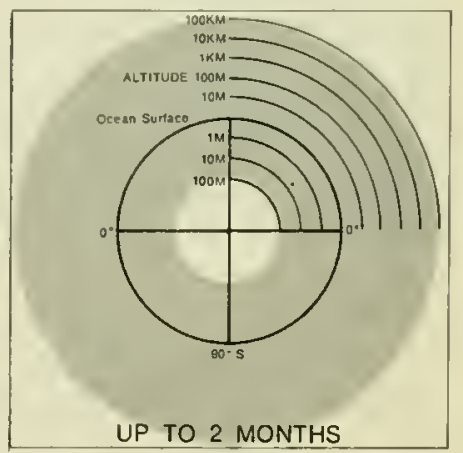

Socrce: Adapted from R. E. Hallgren, "World Weather Program," TRW Space Lag, spring-summer 1968. 
craft. Several agencies are proceeding with studies of the use of aircraft for collecting oceanoglaphic data. It appears desirable to examine the feasibility of an aircraft-ofopportunity program as part of an overall observational system.

The Commission recommends that the role of aircraf $t$ in collecting oceanographic data be reviewed with the aim of establishing an aircraft-of-opportunity program.

\section{Satellites}

Among the most dramatic recent developments is the ability to collect useful ocean data from remote platforms in space. Earth orbiting satellites long have demonstrated an operational capability to provide global weather photographs; they now have demonstrated a capability to collect and transmit oceanographic data and act as a data communications relay.

The TIROS, NIMBLS, and ESSA series of satellites have demonstrated amply the operational capability to provide useful global photographs showing elouds and limited indications of sea ice; other applications are under development. The Applieation Technology Satellite series in earth-synchronous orlbits has shown the ability to keep major parts of the atmosphere and ocean under constant surveillance.

Progress is being made in development of advanced satellite instrumentation. Sea surface temperature discontinuities have been detected from aireraft using sensors in the visible, infrared, and microwave regions of the spectrum. Infrared instruments have been used to map and measure areas of strong thermal contrast. Under nighttime, cloudfree conditions, such areas of sharp tempera- ture contrast as currents and up wellings have been detected by NIIIBUS imagery.

Most sea state information is inferred from wind data. Possible methods for determining sea state from orbital altitudes are based on changes in the reflective properties of the ocean surface. Photographs of sun glitter or sun glint have been made from aircraft and satellites. The elond cover constraints on optical techniques have stimulated study of passive microwave radiation and radar reflectance for determining sea state. Both of these measurements can be made in the presence of storms and clouds with no appreciable attenuation.

Several developments are undejway to demonstrate the feasibility of using satellites to locate, interrogate, and relay data from meteorological and oceanographic buoys, stream gauges, drifting balloons, ice islands, and other environmental data platforms. One of these programs is Omega Position Locating Equipment (OPLE), a prototype of which has flown on the synchronous satellite, ATS-3. This equipment is capable of interrogating thousands of separate surface units deployed at random, of accurately fixing their position, and of recording their data twice daily. This system would provide a means of obtaining data from instrumented buoys. Another related program is the Interrogation, Recording, and Location System (IRLS), planned for flight testing aboard a future polar-orbiting NIMBUS satellite. Other approaches to satellite interrogation of free-floating platforms are being examined by France.

A distinction must be maintained between the responsibilities of the National Aeronautics and Space Administration for research and development of new satellite systems and of user agencies for the funding and management of operational satellite systems. Such arrangements have worked effectively 
for the National Wreather Satellite Program. Similarly, the agency responsible for NEMPS should fund and manage civil operational satellite systems for oceanographic monitoring.

This review has identified only a fraction of the useful improvements in present observational systems which can be achieved through an expanded and sustained development effort. Other opportunities are present in the communications and processing segments of the system. These opportunities need to be pursued fully before making commitments to derelop major new systems of less established reliability.

The Commission recommends early implementation of plans to place oceanographic sensors on board operational satellites and continued rapid development of advanced sensors and techniques for the satellite interrogation and location of remote platforms, and transmission of data from them.

The techniques of systems analysis must be widely applied to the examination of alternatives in expanding the Nation's environmental monitoring and prediction programs. These techniques are particularly relevant to this area of marine science, because the costs of installing and operating a global system are large. Analyses shonld proceed with advances in technology to provide a suitable decision-making framework when adranced major elements of the system are ready for deployment.

The Commission recommends that the National Oceanic and Atmospheric Agency (ESSA) undertake extensive analyses of alternative system designs of NEMPS and the resulting benefits of im- proved predictions. Such analyses are required before decisions are made regarding operational deployment of major new system components.

\section{Research}

The Commission finds that the Nation is at an early stage in the development of a true scientific capability for predicting the state of the oceans. It is important that a number of limitations stemming from our lack of basic understanding of certain physical processes be removed by a well-formulated program of basic research into key problems in physical oceanography. Earlier reviews by the National Academy of Sciences Committee on Oceanography and the President's Science Advisory Committec have indicated similar needs.

\section{Dynamics of Ocean Currents}

Ocean currents may be compared superficially to the winds of the atmosphere but, except for the trade winds, they are significantly different in their persistence and behavior. In the temperate and polar regions of the earth, storms tend to drift from mest to east around the earth, bringing with them weather patterns that commonly persist only for a few days. Ocean current systems, at least on the largest scale, persist for much longer periods in the same geographical areas. Tho meridional transfer of heat by these persistent ocean currents has far-reaching effects on climate, and fluctuations in the transport of these current systems probably are one of the causes of major shifts in the world's weather.

Oceanographic cruises have been the traditional means by which the marine scientist has sought to observe physical oceanographic phenomena, but the methodology and instrumentation used are inadequate to define small-scale motions. 
The gencral positions of the oceans' major current systems have been fairly well established for more than 50 years: As more detailed observations are made of the current systems, however, scientists are increasingly impressed by their diflerences. Recent observations have shown, for example, that the pattern of permanent ocean currents near the equator in all the oceans is highly complex. The broad equatorial currents flow westward

\section{Wave Analysis Diagrams}
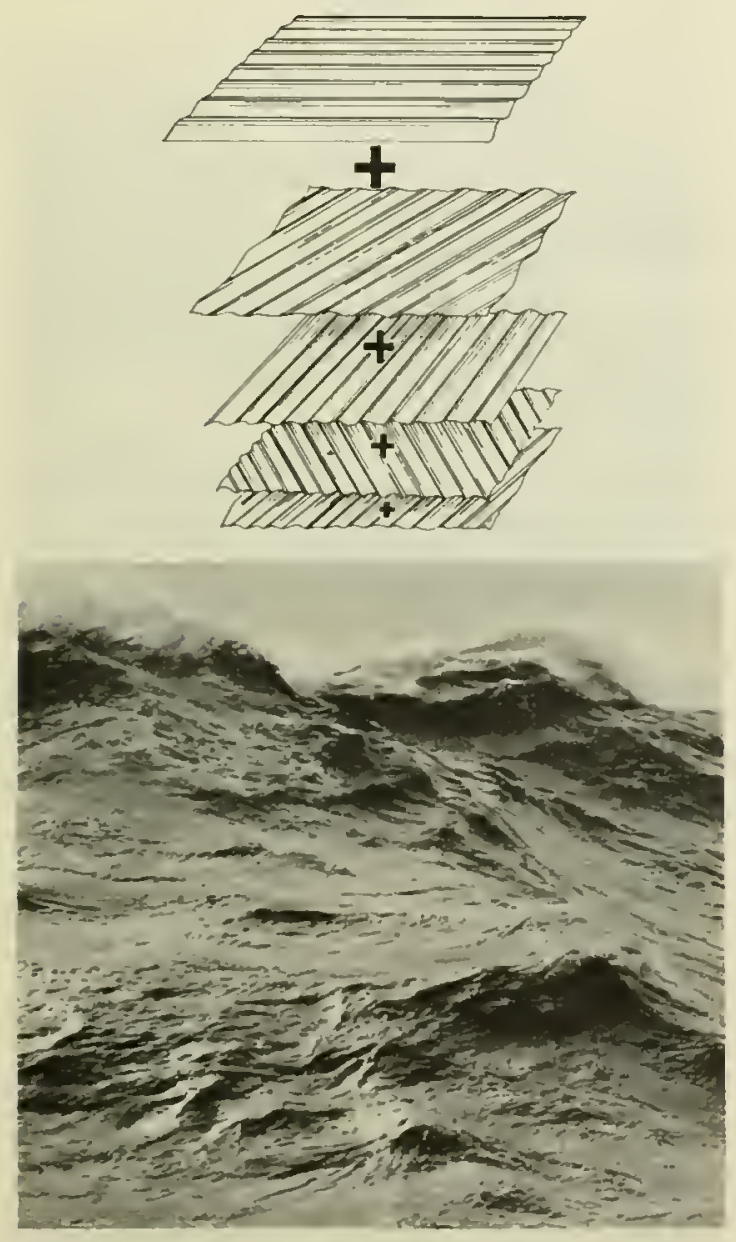

SOU\&CE : Willard J. Plerson, Jr., et al., Practical Methods for Observing and Forecnsting Ocean Wares, U.S. Navy Oceanographlc Office Pub. No. 603, 1955, p. 24. in a inanner that would be expected as a response to the westward component of the trade winds on both sides of the equator. But, in addition, an intricate system of powerful countercurrents exists at the surface and at relatively shallow depths below the surface. Although various mathematical models have been proposed to account for these current systems, they are at best only approximate steady state models. An attack on the problem of predicting the fluctuations of major ocean currents will require more detailed data, improved understanding of the air-sea energy exchange, and insight into the effects of bottom topography on ocean movements and of the interrelationships among the currents themselves.

The Commission recommends that the National Oceanic and Atmospheric Agency take the lead in organizing a series of systematic studies of the ocean's current systems through cooperative field investigations, employing ship, buoy, and aircraft arrays.

\section{Sea-Air Interaction}

Research on the interactions between the atmosphere and the oceans is necessary for progress in weather forecasting and in predicting conditions in the upper layers of the ocean.

A theoretical upper limit for predicting the behavior of individual midlatitude weather details is estimated to be about two weeks in winter and somewhat longer in summer. A rongh estimate for the practical limit in the foreseeable future seems to be about one week with an indication that trends could be extended for longer periods. The fluxes of energy, momentum, and water vapor to and from the atmosphere for these time intervals (normally neglected for short-range forecasting) become important. Many aspects of 
sea-air interaction are under continuing research. Howerer, in the view of the Coinmission, much more remains to be done.

The most obvions interchanges between the sea and the atmosphere are those of heat, water vapol, and momentum. There are, however, many other types of exchange; together they form exceedingly complex subtle patterns. Although progress has been reported, the development of theoretical solutions is difficult.

A major limitation in this field is the lack of adequate instrumentation to measure directly the ocean-atmosphere exchanges. Because these fluxes occur on scales of motion very much smaller than the scale of any existing or economically feasible observing system, it is very difficult to relate them to data collected on a much larger scale. In a laboratory flask, this would not matter; the exchanges could be directly inferred from the more familiar measurements such as temperature and humidity. On the open sea, the problem is far more complicated.

Observations of air-sea interactions will require large-scale field experiments in which a variety of observation platforms are marshaled to provide a comprehensive picture of phenomena within the test area. The Federal agencies and research institutions already have planned the Barbados Oceanographic and Meteorological Experiment (BOMEX) to be conducted later this yeas. However, more extensive efforts of this kind (as now plamned in conjunction with the World Weather Program) will be needed. The Commission belieres that the consolidated planning and operating capabilities for such field programs, which should be centered in the National Oceanic and Atmospheric Igency, constitute major advantages to be gained from the formation of this agency.
The Commission recommends that the National Oceanic and Atmospheric Agency (ESSA) place continued high pri-

During her first mission in 1969 ,

the rescarch submarinc Ben

Franklin will drift northward from.

Florila to New England while

her crew conducts a detailed incestigation of the Gulf Stream.

Hot meals during the underseas royage uill be prepared from dehylratcd foods reconstituted from ncar-boiling water carried in the galley in insulated vacuum tanks.
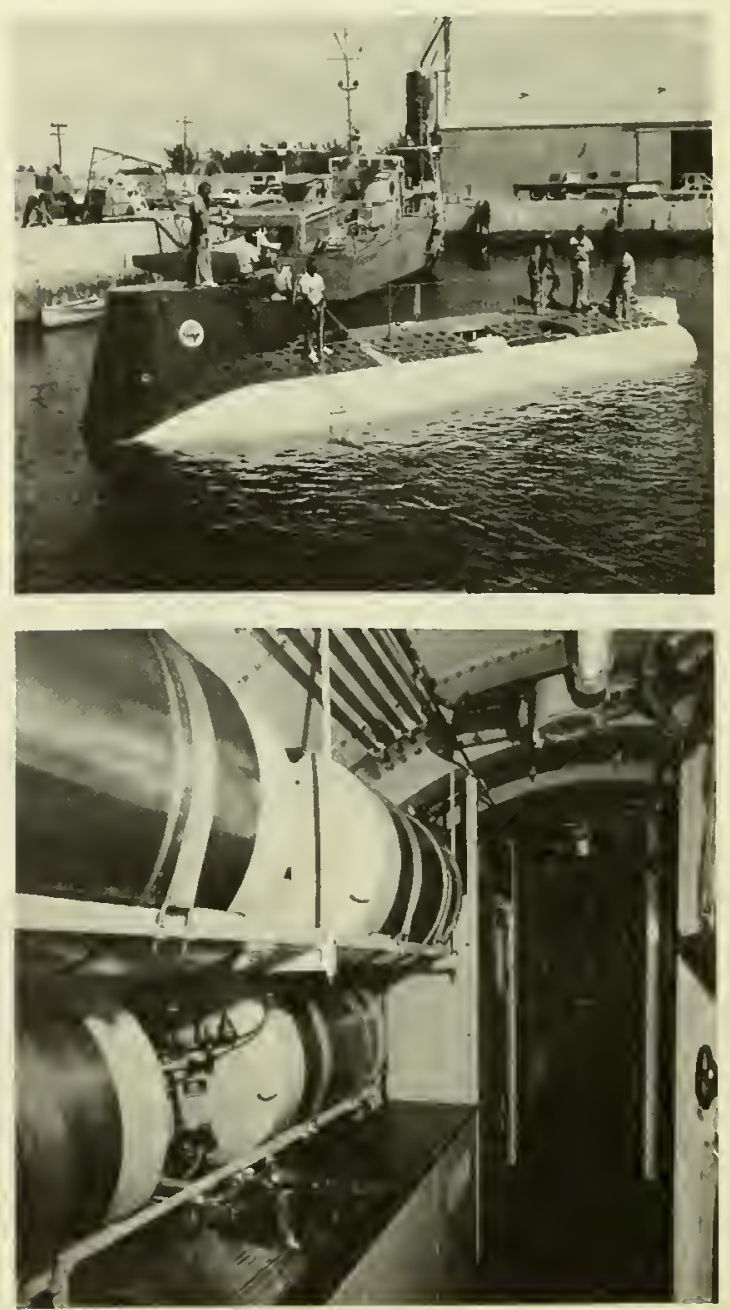
ority on improving the understanding of sea-air interaction processes and use its extensive capabilities in cooperation with other Federal agencies, universities, and foreign scientists to mount the needed major field experiments.

\section{Scales of Motion}

Is additional data describing near-surface and deep ocean currents become available, it is found that the observed currents have only a weak relation to the mean currents. Studies of the characteristics of these motions have revealed that appreciable energy is involved on every space or time scale that has been investigated. The problem is fundamental to the ability, not only to understand oceanic processes in order to simulate these processes, but also to determine the sampling interral required for ocean observation net rorks. Giren the decision of the Government to move forward with a major ocean buoy development program, technology will permit a major assault on the problem.

The Commission recommends that the National Oceanic and Atmospheric Agency as rapidly as possible organize a well-defined program to study oceanic scales of motion. Such a study should be one of the early foci for the test of the elements of the National Pilot Buoy Network Project.

Man's increasing dependence on food resources from the sea and his growing capacity to modify the environment lend urgency to the requirement for improved biological prediction. Accurate forecasts of the abundance and distribution of major marine biota must be made. Rates of production and mortality and the interactions with the environment must be predictable for development of new food resources, for evaluation of the effects of man's modification of the environment, and as possible indicator's for monitoring and predicting the dynamics of ocean interaction.

The Commission recommends that the National Oceanic and Atmospheric Agency (BCF) mount intensive research efforts to provide the understanding of oceanic processes and biological-physical environmental relationships needed to develop prediction capabilities.

\section{Environmental Modification}

Modification of weather and ocean conditions by interference with natural environmental processes is a growing reality which the Nation is only beginning to confront. Such modification can be inadvertent, resulting from such activities as the burning of fossil fuels with its consequent effects on atmospheric temperatures and atmospheric pollution, or it can be the result of man's con-
Marine researchers and their instruments must operate in an extremely harsh cnironment, as eridenced by this storm-damaged surface float of a dcep-anchorcd current meter system.

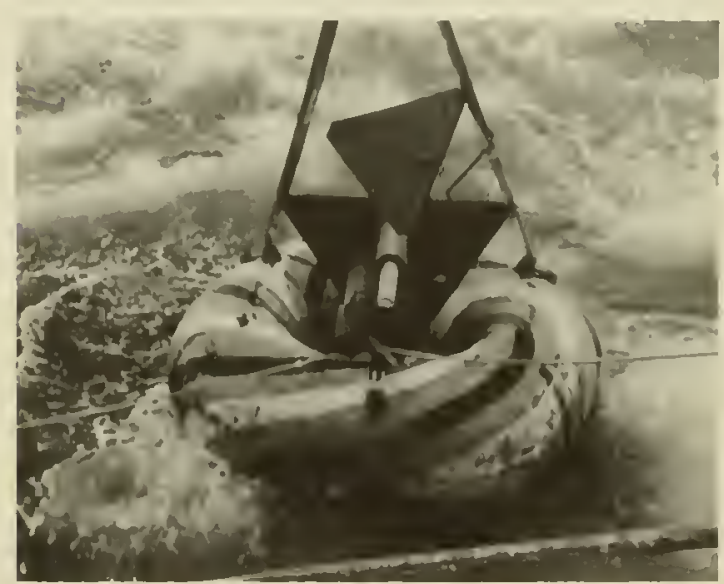


scious interference, for example, by silver iodide sceding to change rainfall.

The scientific community is increasingly conficlent that it is now possible, rationally and systematically, to investigate a wide range of environmental modification possibilities.

Envirommental modification problems are inseparable from those of environmental monitoring and predicting. Several recent reports on weather modification, issued by a special Commission on Weather Modification of the National Science Foundation (NSF) and by the National Academy of Sciences Committee on Atmospheric Sciences, have suggested the need for the Federal Government to undertake the research, development, and experimentation required to explore the broad spectrum of weather modification possibilities. More recently, in amending the enabling legislation of the National Science Foundation, the Congress eliminated NSF's statutory responsibilities in the field of weather modification, apparently because of the view that these responsibilities should be assumed by ESSA.

Man is already in the process of modifying his ocean environment, both consciously and inadvertently. By the construction of breakwaters he has modified the flow of nearshore ocean current systems. $\Lambda$ s a result of the introduction of pollution into estuaries and the near coastal zones, he has modified the quality of the water. There have been numerous proposals for the creation of artificial upwellings to enbance the productivity of certain ocean areas. Studies of the biological consequences of man's major manipulations of the enviromment by thermal additions, construction of sea level canals, dredging of waterways through marsh areas, and construction of major highways on the seashores lave become essential. Recent analytical refinements have established beyond doubt that manmade pollution already has affected the entire ocean. Prime examples of this are the finding of DDT and products of DDT degradation (probably distributed by air into the oceans) in the organs of animals throughout the oceans and the identification of lead from lead-treated gasoline burned by internal combustion engines in the surface layers of the occan.

The Commission recommends that the National Oceanic and Atmospheric Agency (ESSA) undertake a comprehensive program of research and development to explore the feasibility of beneficial modification of environmental conditions and the effects of inadvertent interference with natural environmental processes.

\section{An International Framework: Organizational and Legal}

The case for deploying an operational system for global environmental monitoring rests basically on the proposition that only through such a system is there any possibility of being able to advance substantially our ability to provide reliable forecasts of transient oceanic and atmospheric phenomena. It must be global, because the physical systems under observation are linked around the globe. It must provide for frequent synoptic observations to establish the initial state from which future states can be predicted. It must be integrated from sensor to finished forecast, because the vast amount of data permit no other approach, and it must operate in real time, for there are real-time needs for its products.

Because of the high cost of such a global system, the building of which would be prohibitive for even the United States to undertake alone, it is essential that the system be multilaterally planned and supported. Many 
elements of such a system ale alrendy in place, having crolved over many years.

The international exchange of real-time data through the World Meteorological Organization is an important part of the system. Almost all nations support air and sea surface observing and forecast systems, and withont aceess to theil data IT.S. services would be seriously impaired. Because observations must he obtained over the continents as well as the sea, the global system involves all nonmaritime nations as well.

Integration of planning activities at the international level has not adranced as lapidly as at the national level. But years of cooperation in oceanic and atmospheric activities have yielded a legacy of common interests among the world's scientists and a large net work of international organizations. The Cuited States and its citizens are active in most of them.

\section{International Organizations}

At the Government level, the principal marine science organization is the Intergovernmental Ocennographic Commission (IOC) of the United Nations Education, Scientific and Cultural Organization (UNESCO), founded in 1961. UNESCO also operates an Office of Oceanography, which provides staff support to the IOC and conducts some activities of its own. Such activities as the recent. Indian Ocean and Tropical At lantic expeditions were sponsored by IOC. The International Hydrographic Burean assists in the standardization and dissemination of ocean survey data. The World Meteorological Organization (WMO) and the Food and Agricultural Organization (FAO) are involved in the sciences related to the problems of meteorology and fisheries.

The principal nongovernment international body which provirles a form for all sciences is the International Council of

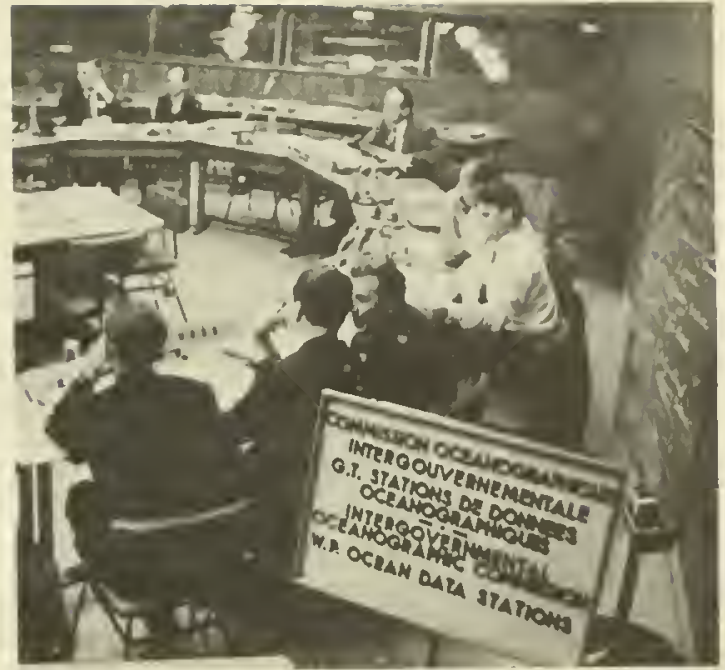

The Intergovernmental Oceano. graphic Commission, at present the principal intergovernmental marine science organization, is assisting nations in planning for an Intcgrated Global Occan Station System to monitor and predict the statc of the oceans.

Scientific Unions (ICSU). The constituent croups of ICSU which are of particular importance to the marine sciences are the Scientific Committee on Oceanic Research and the International Union of Geodesy and Geophysics.

In general, the Commission finds that the present govermment and nongovernment international organizations have served well in facilitating collaboration on marine science problems. However, as the pace of research and exploration intensifies and their scope broadens and becomes increasingly ent wined with related scientific interests, the strengthening and perhaps restructuring of both goremment and nongovernment organizations will be needed. This need is particularly pressing if derelopment of worldwide systems for earth, air, and occan monitoring are to be coordinated.

It is clear to the Commission that IOC's 
present strength is inadequate to the task of planning and coordinating a program of the scope of the International Decade of Ocean Exploration. This has been recognized both by the IOC and UNESCO, and steps now are being considered to strengthen it. To the Commission, this is essential. The IOC requires additional staff, budget, and expertise.

Because IOC is a part of UNESCO, it is difficult for it to obtain the necessary budgetary support; the IOC is in competition with all other educational and cultural programs of UNESCO. Its subsidiary position also makes it difficult for it to deal effectively with other treaty-level organizations of the United Nations system, such as the FAO and the WMO.

The diversity of international organizatious participating in some manner in marine science and engineering, and in particular the parallel interests of the IVMO and the IOC in environmental monitoring and prediction, have been matters of coucern to the Commission.

The World Weather Program, a plau to improve the global system for monitoring and predicting the state of the atmosphere, is being developed under TVMO's sponsolship. The Integrated Global Ocean Station System (IGOSS) is being planned by IOC to monitor and predict the state of the oceans. The latter plan includes many elements also included in the World Weather Program, and coordination procedures have been established between IOC and IVMO. IOC also has international cooldinating responsibility for the Pacific 'Tsunami Warning System. Other' international organizations are responsible for such additional activities as the Ocean Station Vessel Program and the Intermational Ice Patrol. There is general recognition that present arrangements for coordination of the activities of these international organizations, though commendable as far as they go, are inadequate. The Secretary General of the U.N., in fact, has noted the unique character of the job to be done and the lack of experience among international organizations in taking joint action on matters of such complexity. However, because there are a variety of alternative approaches and no clear solution to the problem, he refrained from recommending a specific course of action.

It is a perplexing problem. The IVMO has gained the most experience with operational systems and has established a systems planving staff and precedent-breaking financing arrangements to develop the World Weather Program. The IOC's orientation in the past has been more toward education and research, but it has successfully organized a varioty of field programs, some of substantial scale. It also has undertaken important tasks for the Fisheries Department of the $\mathrm{FAO}$, which is heavily involved in marine biology, and for other smaller organizations.

The Commission concludes that the integration of NEMPS into a global system would be facilitated if all international ocean and atmospheric monitoring activities were under the purview of a single international organization at the treaty level. This step, howerer, is not immediately critical to the successful development of the proposed monitoring and prediction program because of the existing measures of coordination.

The nations of the world ultimately must establish an intergovermmental organization dealing with ocean matters at the treaty level and having adequate authority, personnel, and financial resonrces. It is not clear whether it would be better (1) to establish an additional intergovernmental body dealing with the oceans in parallel with the other specialized agencies of the U.N. system (such as WMO and FAO) by raising IOC to the status of another specialized agency or (2) to form a new body incorporating the functions 


\section{Marine Science Organizations in or Related to the United Nations}

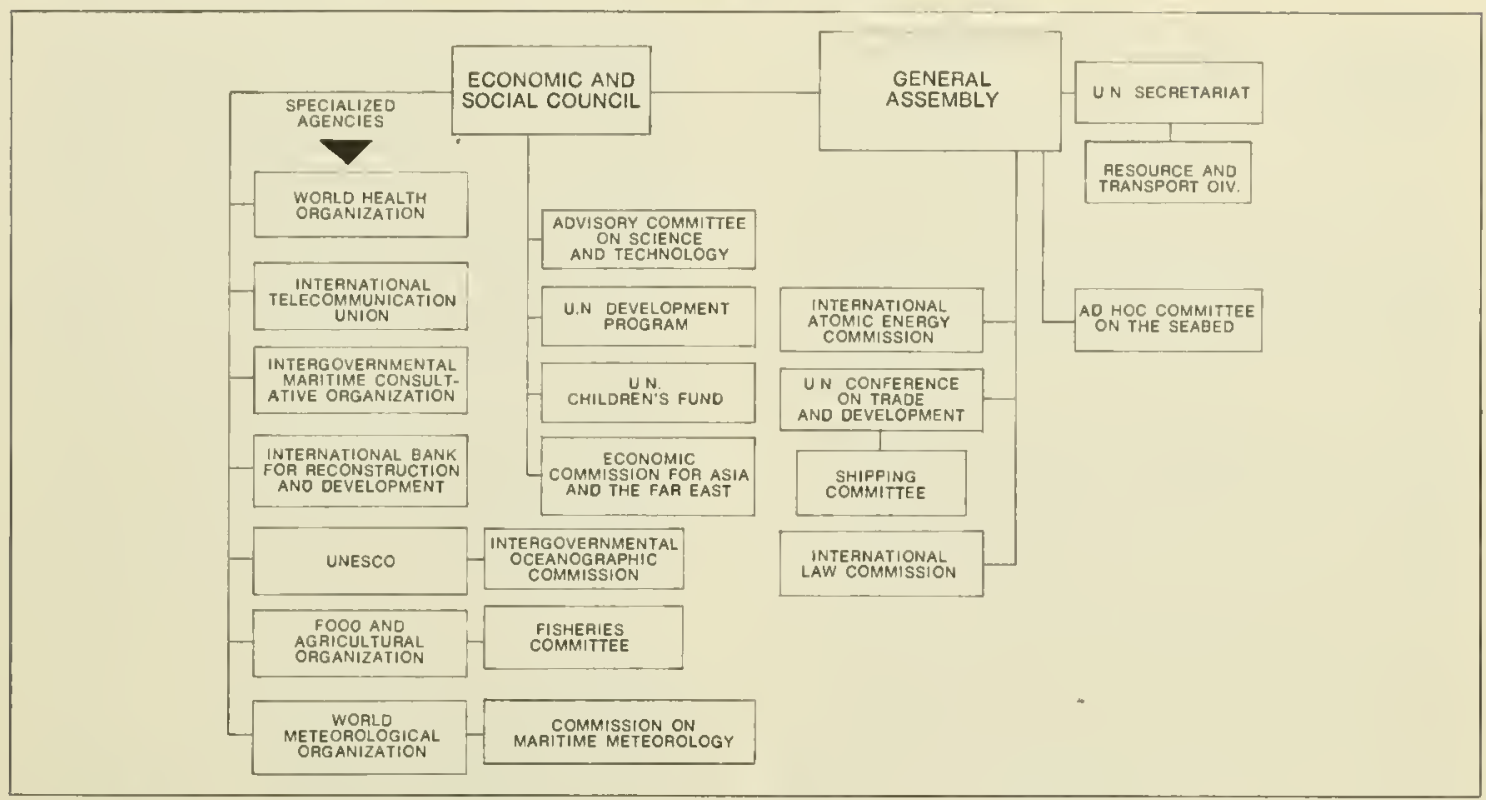

Sounce: Marinc Science Affairs, The Second lieport of the President to the Congress on Marine Resources and Engineering Development, March 1968, p. 24.

of existing international bodies to deal with a great range of environmental problems. The formation of the new National Oceanic and Atmosphere Agency would lend impetus to the latter solution.

The Commission recommends that NEMPS be planned and developed on a global basis in concert with the World Weather Program to assure a well-coordinated and nonduplicating global oceanatmosphere monitoring and prediction system. The National Oceanic and Atmospheric Agency (ESSA) should coordinate the U.S. participation in the planning and deployment of such a global system.

\section{A Legal Framework for the Conduct of Marine Research}

To observe, describe, and understand the physical, geological, chemical, and biologi- cal phenomena of the marine environment, the marine scientist must conduct investigations on a global basis. But the existing international legal framework does not facilitate these in vestigations.

The prior consent of the coastal nation is required to conduct scientific investigations in its internal or territorial waters, to emplace installations for research purposes on the beds underlying these waters, to conduct fishery research in its exclusive fisheries zone, or to conduct research concerning its continental shelf.

Coastal nations also claim territorial seas of breadths varying from 3 nautical miles to 200 miles or more, and they define their internal and territorial waters in ways that serve to extend them. The seaward limit of the continental shelf is uncertain. All these factors tend to enlarge the areas of the oceans in which scientific inquiry cannot 
be conducted without the coastal nation's permission.

Althongh most nations have been liberal in the courtesies accorded scientific parties, some havo viewed scientists with suspicion and have refused them permission or imposed hampering restrictions. Some scientists are deterred from seeking the necessary permission because of the length of time it takes to obtain permission and becanse the nncertainty of a farorable ontcome makes it impossible for them to plan their expeditions.

To prevent the existing legal framework from becoming a serious obstacle to worldwide scientific inquiry, the Commission urges the United States to join with other nations to effectuate the principle of maximum freedom for scientific inquiry. To this end, a new international legal framework is required. However, recognizing that it will take time to negotiate a new framework, the Commission also proposes a policy of easy access for scientific inquiry even within the existing flamework.

\section{Recommendations for a New Interna- tional Convention}

The freedom to conduct scientific investigations in the higlı seas, including inquiries concerning the bed of the high seas and its subsoil, is a freedom recognized by general principles of international law. Nevertheless, this freedom is limited in the exclusive fisheries zone and by the requilements of the Convention on the Continental Shelf.

Coastal nations, including the United States, prohibit fisheries research in the exclusive fisheries zone without their consent. Because the coastal nation has anthority to do so only to the extent necessary to protect its fishing rights in its exclusive fisheries zone, the definition of such fisheries research presents a difficult but crucial question.
To avoid the possibility of unpleasant international incidents, scientists are well aclvised to seek permission from the coastal nation to conduct almost any study of living resources in the exclusive fisheries zolle.

This restriction on research can become particularly serious if the coastal nation bars the researcher from studying marine animals which inhabit the exclusive fisheries zone as well as the high seas beyond that zone.

The Convention on the Continental Shelf provides also that the prior consent of the coastal nation must be obtained for "any research concerning the continental shelf and

To obscrec, describc, and understand the physical, gcological, chemical, and biological phenomena of the marinc environment, the marine scientist must conduct investigations on a world wide basis. A core sampler is launched during the recent global cruisc of the Oceanographer.

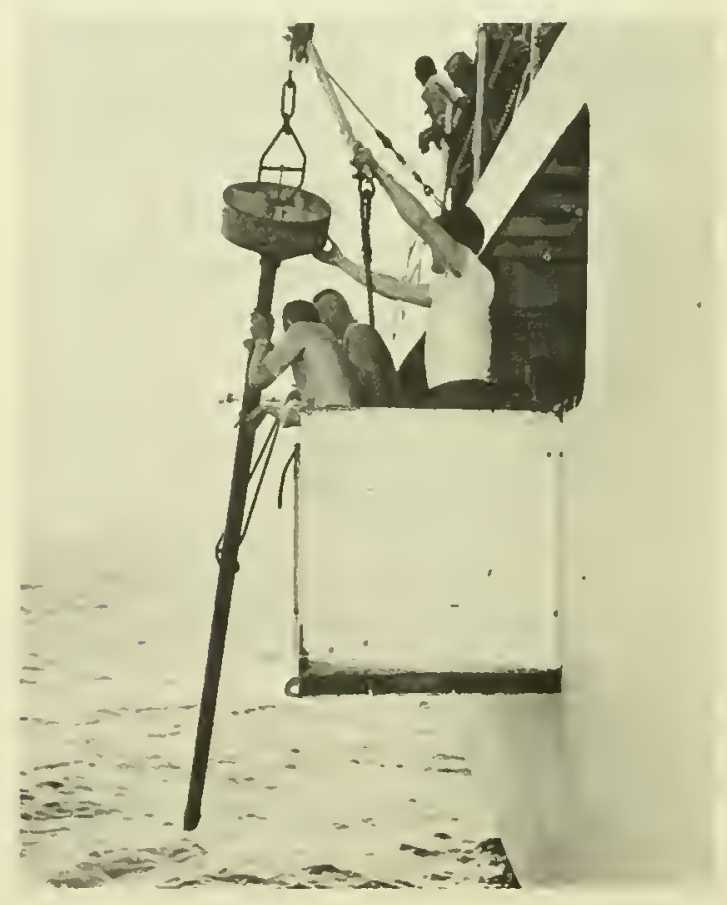


undertaken there." But the coastal nation is enjoined not to "normally withhold its consent if the request is submitted by a qualified institution with a view to purely scientific research into the physical or biological characteristics of the continental shelf, subject to the proviso that the coastal nation shall have the right, if it so desires, to participate or to be represented in the research, and that in any event the results shall be published."

There are many ambiguities in this admonition which coastal nations may interpret to enlarge the restrictions on scientific inquiry. What is research "concerning" the continental shelf? When is such research "undertaken there"? When are conditions "not normal"? What is "purely" scientific research? What is the line between "exploring" the continental shelf, for the purpose of which the coastal nation exercises "sovereign rights" under Article 2 of the Convention, and "fundamental oceanographic or other scientific research" with which, according to Article 5 (1) of the Convention, neither the exploitation of the continental shelf nor the exploitation of its natural resources may interfere? A new international convention is needed to eliminate these ambiguities and provide a solid foundation for the freedom of scientists to explore the world's oceans.

The Commission recommends that the United States take the initiative to propose a new convention embodying the following essential provisions:

(1) Scientific research in the territorial waters or on and concerning the continental shelf of a coastal nation may be conducted without its prior consent, provided that it is notified of the objectives and methods of the research and the period or periods of time during which it will be conducted, in sufficient time to enable the coastal nation to decide whether it wishes to participate or be represented in all or part of the research; and provided that the investigators agree to publish the results of the research.

(2) Fisheries research (including the limited taking of fish specimens) may be conducted in the exclusive fisheries zone of any coastal nation under the same conditions.

(3) Research submersibles may be used in the conduct of authorized scientific research in territorial waters, even if they do not navigate on the surface as the Convention on the Territorial Sea and Contiguous Zone now requires them to do, provided that the coastal nation is also notified of the time, place, and manner of their use sufficiently in advance to assure safety of navigation.

(4) Research buoys may be placed in any coastal nation's territorial waters. Buoys so placed, as well as those placed in the superjacent waters of the continental shelves or in the high seas beyond the continental shelves, shall be protected against unwarranted interference from any source. The coastal nation, however, may specify reasonable requirements for location, lighting, marking, and communications with respect to buoys placed in its territorial waters.

It will not be difficult to prevent abuse of the recommended new conrention. From its ressels or aircraft, the coastal nation can observe all activities carried on in the name of scientific inquiry. It also has the practical power to inspect buoys and other ummanned devices used for research purposes.

Whether a ressel or installation is engaged in mineral resources exploitation or in scientific research can readily be ascertained by olserving the gear or equipment it carries and the overboard operations in which it is 


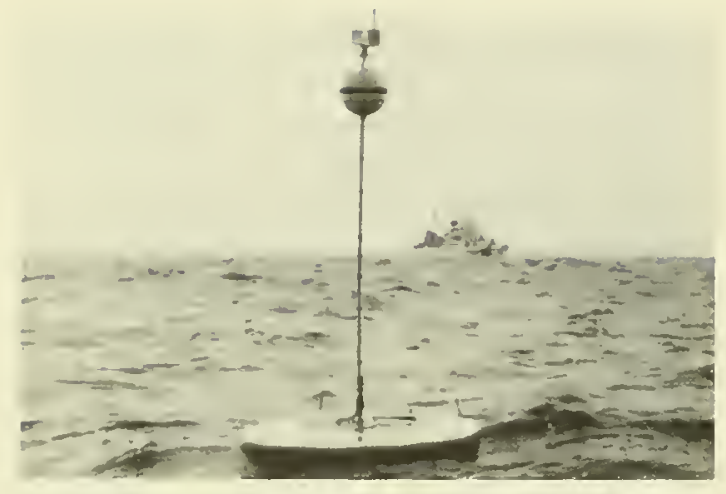

A new international convention on the conduct of marinc researeh should include the provision that research buoys may be placed in any coastal nation's territorial watcrs, in the supcradjaecnt waters of the contincntal shclves, or in the high scas bcyond the continental shelves.

engaged. It may not be so easy to determine by such an examination whether a vessel is engaged in commercial fishing or scientific research, although the quantity of fish taken in the former activity should be significantly groater than in the latter. However, the coastal nation has an additional safeguard. It always may decide to participate or to be represented in the research itself. Taken together, these safeguards also assure that scientific inquiry will not become a cover for espionage.

The Commission has not recommended that the new convention apply generally to the internal waters of nations. Secnrity concerns in internal water's generally are too sensitive to be allayed by the safegmards provided in the case of other waters. However, the territorial waters of a coastal nation should be taken to include waters which were once part of the territorial sea but are now internal waters becanse of the use of a system of straight baselines to measure the breadth of the territorial sea or the closing of bays in accordance with Article 7 of the Convention on the Territorial Sea and the Contiguous Zone.

\section{Interim Policies}

Pending the negotiation of the new convention,

The Commission recommends that the United States seek to enter into bilateral and regional agreements embodying the provisions recommended above for the new convention and take other initiatives to encourage freedom of scientific research and international scientific cooperation.

Such initiatives might include the following:

- The United States might interpret broadly the terms, "qualified institution" and "purely scientific research," and so, for example, consent to scientifically valuable exploration for mineral resonrces while still retaining its sovereign right to exploit the natural resources of the continental shelres and exclude others from exploiting them.

- The United States might state that it will grant applications by foreign scientists for permission to conduct broad categories of research without requiring them to make repeated requests for consent to engage in individual projects falling within an approved category, stating that its prior consent is required only for research concerning the continental shelf which involves physical contact with it. Even if physical contact occurs, as when an installation for scientific research is placed on the continental shelf, it could stress that its prior consent is not required if the research concerns the superjacent waters and not the continental shelf.

Of course, the United States would retain its light under the Convention to participate or be represented in the research, 
and the results of the inrestigation would still have to be published.

- The United States could state that it will consent to the conduct of any proposed foreign scientific investigation certified by the Intergovernmental Oceanographic Commission (IOC) as meeting the requirements of the Convention on the Continental Shelf. In performing this task, IOC should be guided by the criteria set forth in the Convention.

- The United States might announce unilaterally that, upon proper notice, it will consent to the conduct in its territorial waters and exclusive fisheries zone of scientific research (including the limited taking of fish specimens) which is part of an international cooperative project sponsored or endorsed by the IOC, provided that it may participate or be represented in the research and that the scientists involved agree to publish the results of the research" and to make available upon request the basic data acquired.

The Commission also endorses the principles which the United States has presented for adoption by the Inited Nations General Assembly to encourage international cooperation in the scientific investigation of the bed and subsoil of the high seas beyond the outer limits of the continental shelf.

These principles would call upon all nations to disseminate plans for and results of such national scientific programs in a timely fashion, to encourage their nationals to follow similar practices concerning dissemination of such information, and to encourage personnel of different nations to cooperate in such scientific activities.

\section{Program Costs}

Exploring and monitoring our global environment is an enormous task. Table 5-1 presents the incremental expenditures esti- mated by the Commission as necessary for the programs recommended in this chapter. Estimates for research and exploration activities have been built on a growth assumption of 15 per cent per year over the first 5 years, and 10 per cent per year in the second 5-year period.

The Commission believes that Federal support of the Nation's major oceanographic institutions will need to be sharply increased during the next several years to enable their full participation in the recommended programs. A basic need is to provide adequate institutional support to meet basic operating expenses of the proposed University- $\mathrm{Na}$ tional Laboratories, which will have a key role in research and exploration. The Commission has not attempted to specify how many laboratories should be brought within this system; for purposes of the funding estimate, a dozen such laboratories have been assumed. The capital costs for these laboratories are shown in Chapter 2. In this chapter we have provided estimates for costs of operation and maintenance and the laboratories' research and exploration programs, as shown under the appropriate entries in Table 1. The institutional support for these laboratories, to be provided by NOAA, would be supplemented by funds for specific research projects and programs provided by other a gencies as well.

The new agency will assume responsibility for a large number of existing Federal laboratories which, as the Commission has pointed out in Chapter 2, are inadequately staffed and funded. To bring such laboratories, as well as those of other Federal agencies, to a level adequate to meet their role in the total global exploration, monitoring, and prediction program, increased funding is required as indicated in the table.

The Commission has noted that the present diversity of scientific institutions is good 
and slould be nurtured. Support for the wide variety of participants in the programs outlined in this chapter will require increased Federal funding. Such funding will be provided chiefly by the National Science Foundation, Navy, and NOAA, but also by such organizations as the Atomic Energy Commission and the National Aeronautical and Space Administration. The estimates shown in Table 5-1 do not include Navysponsored research to meet military needs but assume that the Navy will continue and strengthen its present basic research support.

Technological development is crucial to the success of future research and exploration programs. At present, support for such programs is provicled almost exclusively by the Navy; the Commission believes that the $\mathrm{Na}$ tional Oceanic and Atmospheric Agency should provide major additional funding. Table 5-1 anticipates three categories of developmental expenditures by NOAA: manin-the-sea techniques, scientific instrumentation, and a National Project for development and construction of long-endurance, 20,000foot exploration submersibles. In addition, the table includes an estimate for support of the broad base of fundamental technology needed to design systems for operation at great depths. Funds for feasibility studies of such possible future National Projects as deep sea habitats and mobile submerged laboratories were included in Chapter 2.

For the work envisioned by the Commission for development of man-in-sea techniques and research instrumentation, approximately $\$ 250$ million (in addition to the funds for study of the feasibility of future projects) will be required over the next decade. The Deep Exploration Submersible Systems National Project will require a major effort estimated to cost $\$ 285$ million for the 10-year period.
Fundamental technology which must be developed to support deep ocean operations includes buoyant materials, power systems, and free-flooding machinery suitable for 20,000 -foot operations, life support systems, anchoring and mooring devices, and techniques for underwater viewing. This technology has many potential applications, and the Commission has reflected a portion of its estimated cost in Chapter 4 . The $\$ 400$ million estimate included in this chapter reflects the need for pressing undersea operating capabilities to great depths in order to explore and understand the deep ocean environment.

The Commission has not attempted to as. sign specific projects and costs to the Decade of Ocean Exploration. This task remains to be accomplished by those responsible for planning the U.S. contributions to the Decade. It feels, however, that expenditures provided in these estimates will be adequate to carry out the probable U.S. commitment to this program.

The expenditures recommended by the Commission to adrance a system for global environmental monitoring and prediction are assigned to three categories: immediate improvements, buoy development, and system component development and test. The funds to carry ont the research required to support this program have been included in the research and exploration entries of Table $5-1$.

The Commission has stated that it is possible to achieve immediate improvements in environmental monitoring and prediction with existing technology and at relatively modest costs. The estimated costs of such improvements, drawn largely from existing agency plans, would be $\$ 115$ million; most of this amount should be expended during the first half of the coming decade. Costs have not been included in the table for the general development and improvement of national 
weather services not specifically addressed in the Commission recommendations.

The s55 million estinate shown in Table 5-1 for the National Pilot Buoy Netrork Project is based on data prepared by the ('oast Guard. The estinate covers only the costs of carrying the buoy program through its operational test phase and does not inchude the large expenditures which will be required later for procurement, deployment, and mantenance of an operational buoy network.

A wide valiety of other component development and systems studies for the $\mathrm{Na}$ tional Fnvironmental Monitoring and Prediction System are estimated by the Commission to require an additional $\$ 115$ million ovel the next 10 yenrs.

\section{Table 5-1 Global Environmental Programs}

[Incremental costs in millions of dollars]

\begin{tabular}{|c|c|c|c|}
\hline & \multicolumn{2}{|c|}{ Average annual costs } & \multirow{2}{*}{$\begin{array}{r}\text { Total } \\
\text { 10-year } \\
\text { costs }\end{array}$} \\
\hline & $1871-75$ & $1976-80$ & \\
\hline Research and Exploration & $\$ 81$ & $\$ 162$ & $\$ 1,215$ \\
\hline \multicolumn{4}{|l|}{ Laboratory Operations and Irograms } \\
\hline University-National Laboratories $\ldots \ldots \ldots \ldots \ldots$ & 20 & 45 & 325 \\
\hline Fcderal Laboratories & 9 & 22 & 155 \\
\hline Research Grants and Contracts & 12 & 28 & 200 \\
\hline \multicolumn{4}{|l|}{ Technology Devclopment: } \\
\hline Man-in-the-Sea Techniques $\ldots$ & 5 & 10 & 75 \\
\hline Instrumentation & 15 & 20 & 175 \\
\hline National Project-Deep Exploration Submersible Systems _........... & 20 & 37 & 285 \\
\hline Global Monitoring System & 48 & 15 & 315 \\
\hline Near-Term Improvements & 15 & 8 & 115 \\
\hline National Project-Pilot Buoy Network & 15 & 2 & 85 \\
\hline 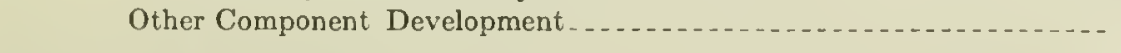 & 18 & 5 & 115 \\
\hline Environmental Modification Program & 20 & 45 & 325 \\
\hline Fundamental Technology-Underwater Operating Capabilities, 20,000' ....... & 30 & 50 & 400 \\
\hline Total, Global Environment Programs & 179 & 272 & 2,255 \\
\hline
\end{tabular}

1 For explanation of amounts shown in this table, see accompanying text and chapter 8. 
('hapter 6

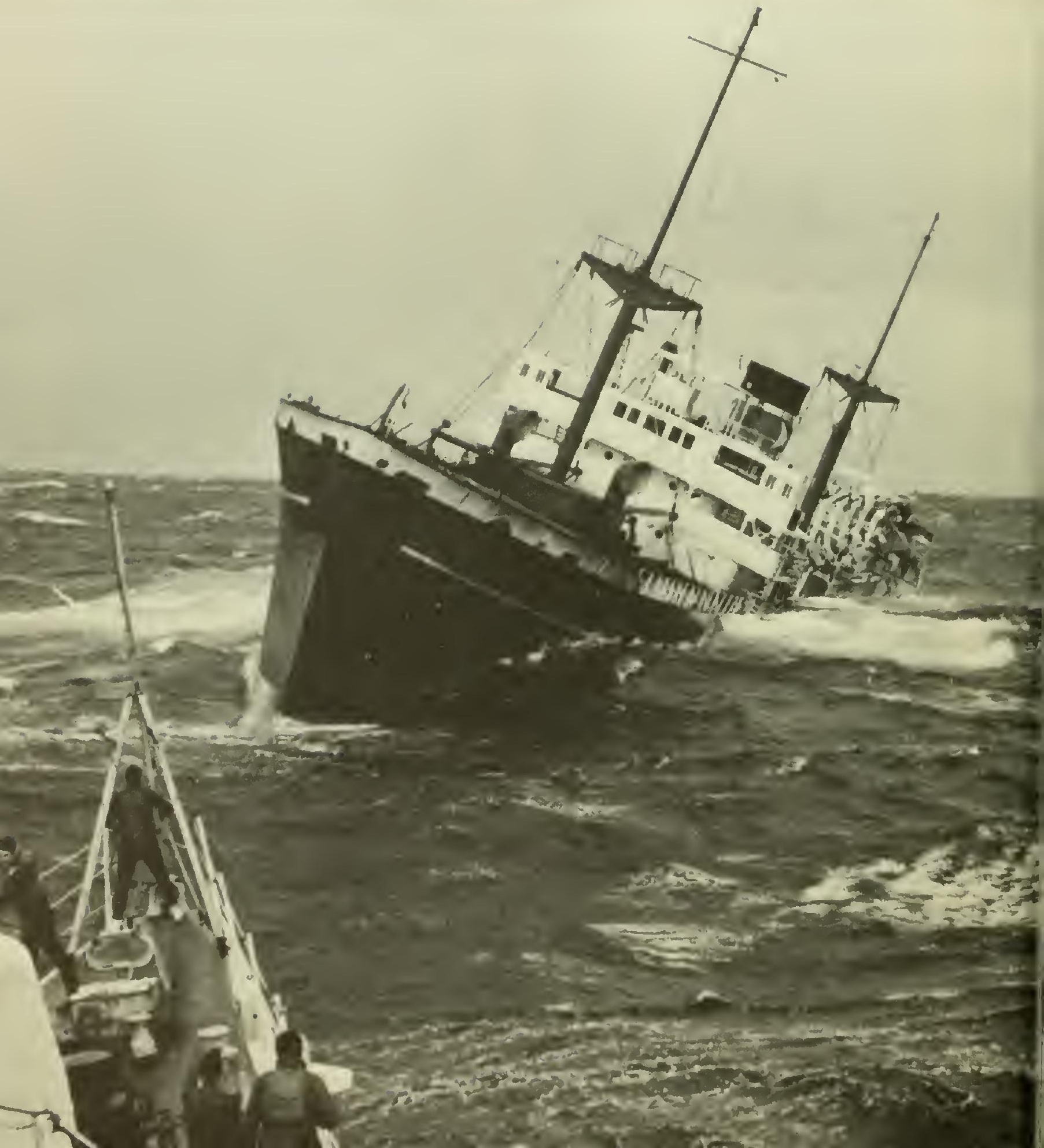




\section{Technical and Operating Services}

Operations in the seas for any purpose require certain indispensable technical and operating services, chiefly provided by the Government. To move from one place in the oceans to another requires nautical charts and aids to navigation. Safe operation on, under, and over the oceans calls for search and rescue facilities as well as adequate law enforcement. Other critical services, such as monitoring and prediction of atmospheric and oceanic conditions, were discussed in Chapter 5; needs for resource surveys and geological analysis were outlined in Chapter 4.

As the Nation moves to implement the marine programs proposed by the Commission, the Government also must proride improved general purpose maps of the oceans' topography and geophysics; data storage, retrieval, and dissemination services; and instrument calibration and standardization services.

The major users of these technical and operating services include the marine transportation and fishing industries, the offshore oil and mineral producers, recreational boaters, the U.S. Department of Defense, and the scientific community.

The principal agencies currently providing them are the Department of Transportation (U.S. Coast Guard), the Department of Commerce (Environmental Science Services Administration), and the Department of Defense (U.S. Navy and the U.S. Army Corps of Engineers). Each of these agencies, in turn, is dependent upon the services prorided by the others. Ther also share in the use of certain facilities and coordinate their operations and plans informally. Coordination of routine operations has been effective, but the agencies have been less successful in efforts to coordinate new programs, to use each other's data, and to make maximum use of their ships and facilities.

\section{Mapping and Charting the Oceans}

Mapping and charting provide graphic descriptions of the marine environment in terms of the various properties of paramount interest to users. $A$ map is a graplical representation of certain features or properties; a chart is a specialized map intended primarily for navigational use. Nantical charts provide information about bottom depth and shape, shoreline configuration, and the location of dangers, manmade features, and navigational aids. Marine maps provide information about such features as bathymetry, magnetics, gravity, and sediment type and thickness.

The National Academy of Sciences Committee on Oceanography has observed, "Maps are basic tools for all the sciences that deal with the earth. To understand and use the oceans, we first must map them." Yet if the existing mapping and charting programs of the Federal Government are continued at present levels, the national marine objectives set by the Commission will not be met for another 30 to 50 years.

\section{Agency Responsibilities and Industry Role}

Both the Environmental Science Services Administration (ESSA) and the Navy are responsible for acquiring and mapping basic geophysical and topographical data, including subbottom profiling. Although the Navy has statutory responsibility to conduct surreys in support of civil marine activities, it is concerned primarily with its own defense requirements and concentrates on the deep ocean. ESSA is primarily civil-oriented and concentrates most of its activities on U.S. continental shelves. ESSA and the Department of the Interior's IT.S. Geological Surrey (USGS) depend in part on the Coast Guard and the Nary for position-fixing and nariga- 
tion assistance. Satellites furnished by the National Aeronautics and Space Administration (NASA) and the Navy, already in use to establish the basic geodesy of the planet, promise to have wider application. The National Science Foundation and the Navy share in the support of university ships.

ESSA's Coast and Geodetic Survey is responsible for publishing the wautical charts, sailing directions, and rełated navigational publications, Coast Pilots, and tide and current tables for U.S. waters. The Navy's Oceanographic Office publishes a wide variety of nautical charts, mostly for the world oceans. The U.S. Army Corps of Engineers and its Lake Survey provide charts for the Great Lakes and certain inland waters.

The private sector also has many ships useful for survey work and available for charter. Contracting many of the survey tasks to the private sector will facilitate rapid completion of the surveys and, perhaps more important, will help build the industrial capability required for further resource delineation and exploitation.

\section{Basic Bathymetry and Geophysics}

Strategy for mapping involves difficult choices for which there is no unequivocal basis for decision, since one deals largely with unknowns. To date, neither the Government nor the private marine science community has come to grips with the problem of civil priorities. Divergent views have been expressed by the National Academy of Sciences and the President's Science Advisory Committee on the importance of systematic surveys. Consequently, a succession of proposed mapping and survey programs have yielded only sporadic and inadequate results.

Ultimately, maps will be required to depict all properties of the world's oceans which may be of economic or scientific importance. The Commission concludes that this require-

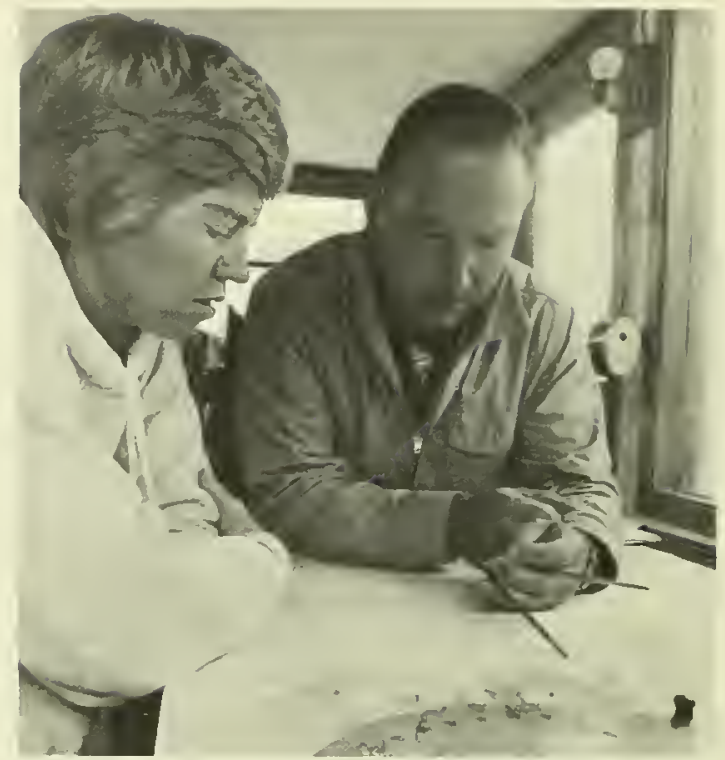

To understand and use the occans, we must first map them. Here oceanographers aboard a university research vessel cxamine a Coast and Geodetic Survey chart in selecting the site for an off shore experiment.

ment is sufficiently urgent to justify the immediate beginning of a systematic general ocean mapping program. The Commission's proposals for deep oceau surveys were presented in the preceding chapter. This chapter is concerned with the mapping of coastal waters and the continental shelf.

Mapping the bathymetry and the geophysical characteristics of the continental shelves and slopes is a top-priority task. The Commission estimates that it could be accomplished over the next 10 years by seven properly equipped and supported ships devoted exclusively to the task and augmented by a fully responsive vessel data processing and map compilation system. The ships obtaining bathymetric data should conduct concurrent gravimetric, magnetic, and subbottom surveys, all keyed to the same navigational control in order to carry out an 
efficient integrated survey program. Supplemental activities could be conducted concurently to obtain limited biological data, sediment samples, and shallow cores to help illuminate resource potentials.

The Coast and Geodetic Survey has proposed a 70 ship-year progran to provide the initial topographic and geophysical maps of the U.S. continental shelves and adjacent slopes to a depth of 2,500 meters, compiled at a scale of $1: 250,000$. This scale will satisfy the needs of the Federal agencies charged with management of marine resources and of industries engaged in resource development. It also will portray adequately the essential descriptive information required by the scientific community.

A considerable volume of bathymetric and geophysical clata already exists for the continental shelf. Unfortunately, much of the data having measurement and position accuracies that meet mapping standards cannot be made public, because they are either proprietary or classified for national security reasons. Every effort should be made to obtain these data and thus avoid unnecessary resurveys. New surveys should be restricted to areas which are economically and scientifically important and have not been previously surveyed with the requisite density and precision.

The Commission recommends that the National Oceanic and Atmospheric Agency (ESSA) undertake the systematic mapping of the bathymetry and geophysics of IT.S. nearshore waters and continental shelves and slopes to a depth of 2,500 meters. The program should be funded at a level to provide 1 : 250,000 scale continental shelf and slope maps of bathymetry, magnetics, gravity, and sediment depth and type within 10 years. Every effort should be made to declassify existing data which are of mapping accuracy and thereby avoid the need for resurveys.

\section{Nautical Charts}

Nautical charts have not always been available. In the earliest days of this country, mariners were left to learn from the shipwrecks of others. To correct this condition and to advance the economic potential of a young country, an early Congress established and funded a Federal program of nautical charting. This program retains its importance today, because charting is not a job that can be done once and then forgotten. Not only must manmade and natural changes be continually resurveyed and recharted, but chart format, level of detail, and scale of portrayal must be modified constantly to reflect changing user needs in the light of changing technology. Any survey made more than 50 years ago was done by leadline or sounding wire; it has been only during the last 10 years that surveys have been required to meet the particular needs of submersibles and deep-draft supertankers.

Nautical charting surveys must be expanded substantially if present and future needs for accurate and up-to-date charts are to be satisfied. Only about 10 per cent of the total requirement for nantical charting bathymetry can come from the continental shelf and slope mapping program described in the previous sections. Requirements, priorities, and procedures for the two programs are sufficiently different that in large part they must be carried out separately.

ESSA, which is responsible for domestic civil nautical charting, has proposed that resurveys be performed on a 50 -year cycle in 80 per cent of the areas for which charts are maintained and on a 5-, 10-, or 25-year cycle 
in the less stable areas which comprise the remaining 20 per cent. Such a program would require a capability equivalent to 16 mediumsized surrey ressels, a capability substantially in excess of ESSA's present hydrographic survey fleet. The processing, compilation, and reproduction functions would have to be correspondingly augmented, since existing shore facilities cannot process all data even at the present rate of acquisition.

Althongh nantical charting has been conducted in U.S. coastal waters for more than 100 years, there still remain many areas which have not been surveyed and very substantial areas which have been surveyed to obsolete standards. The existing chart survey capability for nautical charting is so limited that contemporary survey projects must be concentrated largely on resurveys of critical areas which have undergone rapid manmade and natural changes.

The Commission recommends that the National Oceanic and Atmospheric Agency (ESSA) accelerate nautical charting activities in U.S. coastal waters to ensure up-to-date charts of all areas of moderate to heavy marine activity. The civil nautical charting capability should be expanded within 15 years to a level which will sustain a basic resurvey cycle of 50 years with more frequent surveys in important areas of rapid change. The capability of the private sector should be utilized whenever possible.

\section{Survey Technology}

A historic problem of mapping and charting organizations is that they offer a relatively small and specialized market for equipment and instrumentation. Wuch of today's hydrographic surveying equipment was developed within Federal organizations because it was not available commercially.

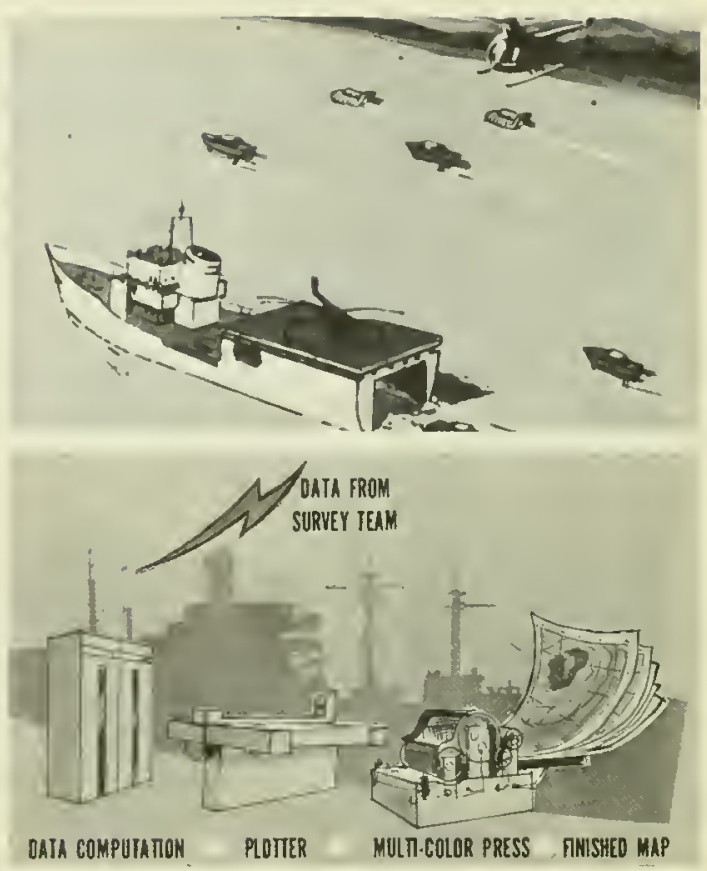

Project Hysureh-a new system for improving the specd and accuracy of mapping activitics, relics on small sea-and aircraft, opcrating from a mother ship, to generate survey data.

This situation has improved since the entry of scientific institutions and petroleum companies into ocean operations; however, many problems remain to be solved if survey quality is to be improved and cost reduced. A few examples of needed items are:

- Digital output echo sounders which compensate for effects of sea and swell

- Inexpensive telemetering or recording tide gauges and magnetometers

- Gravity meters which function properly on small ships in high sea states

- Seismic profiling hyclrophone arrays effective at survey speeds of 15 knots or more

- Improved systems to acquire shallow cores and dredge simples while underway

- Inexpensive inertial navigation systems to monitor position between satellite fixes and 
to provide accurate ship's motion corrections for underway graty measurements in midocean areas.

Submersibles and helicopters have unique arrantages over surface vessels for many applications, but their operational costs must be reduced and significant advances made in positioning technology before they may be used routinely for mapping and charting surveys.

The Commission recommends that the National Oceanic and Atmospheric Agency take the lead in accelerating development of survey equipment for high resolution measurement of bathymetric and geophysical features. Funds should be provided for present and projected Federally operated or funded ocean research and survey vessels to equip them fully with the most advanced sensor and data processing systems relevant to their missions.

\section{Navigation}

The past 30 years have brought enornous improvements in the convenience and accuracy of marine navigation systems. 'The U.S. Coast Guard has the major responsibility to provide and maintain narigational aids in I.S. waters and to establish the rules of the road. Its systems include LORAN A, IORAN C, and a network of abont 41,000 local visual, electronic, and audio aids. Additionally, the ('oast Guard issues permits for and monitors some 23,000 private aids which mark privately maintained channels, offshore oil rigs, and piers. The Nary has been the major force in narigation systems development, usually tuming the systems orer to the Coast Guard for operation, and has pioneered satellite narigation. Nayy's TR.LNSIT system now permits fixes to be obtained over most of the earth's surface at no more than

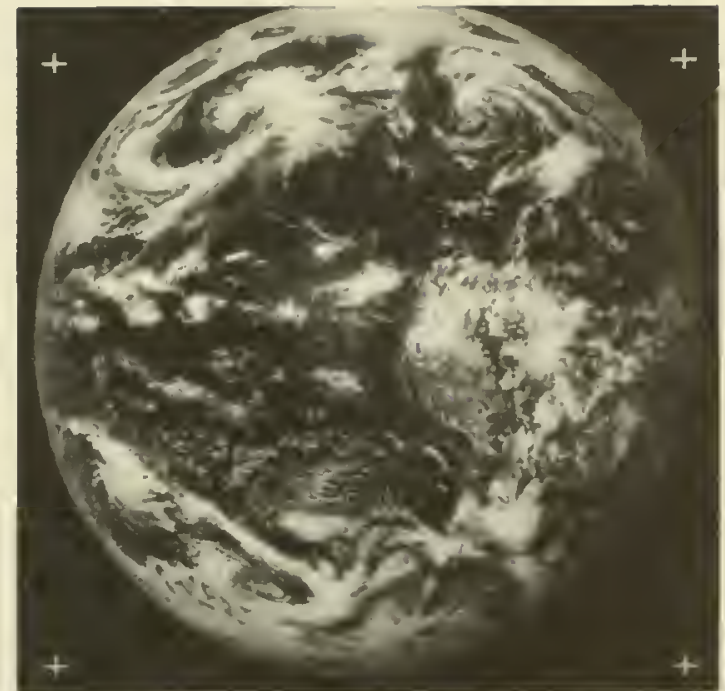

NASA satellites, like the Applica. tions Teehnology Satellite from uhich this vicw of the carth was takch, may contribute to the

Nation's navigation services by offering a mcans for the provision of continuous positioning information.

90 -minute intervals to an accuracy better than \pm 0.2 nautical mile. TRANSIT is being made available for general use, and the Nary is stimulating development of low-cost receivers and devices to interpolate between fixes. The Nary also has dereloped OMEGA, a highly accurate, rery low-frequency, continuous wave system, and is establishing it on an operational basis. Thus, the Nary has dereloped systems adequate to most global narigational requirements, although precise surreys will require other systems as well.

The Commission has found, as did the National Academy of Sciences Committee on Oceanograply and the President's Science Idrisory Committee before it, that the most urgent needs for improved positioning systems are in the zone lying within 200 miles of the C.S. coast but beyond the range of visual navigation. A fully reliable, convenient, and low-cost system which permits fixes within 
approximately 50 feet is urgently required in this zone for such activities as surveys, traffic control, mineral resonrce development, salrage, and scientific research. Such a system is within the state-of-the-art; however, the best design for meeting cost, reliability, and accuracy criteria is not known.

Navigation for subsurface vehicles presents an even more difficult problem which must be solved as submersibles are brought into wider scientific and commercial use. Submersible navigation needs appear unlikely to be met by use of electromannetic transmissions. The Nary's inertial navigation system, which has proved so effective under polar ice, shows the way to systems for civil submersible use, if cost can be reduced. The Navy also is developing navigation systems for its deep submergence rescue rehicles, the nuclear powered research vehicle NR-1, and others. New techniques probably will be required as civil undersea activity increases. The pro- posed Continental Shelf Laboratories National Project should include test facilities for new undersea navigation techology.

The Coast Guard is assigned the responsibility for integration of all marine navigation services into a national navigation system. This system still is in the developmental stage, and the Commission urges that its planning be expedited. Development of the system should permit identification of obsolete elements which might be phased out or replaced by more adranced technology. Further, as integration of various plan elements is accomplished, determination of priorities will become easier and funding levels for improvement and maintenance can be established on a realistic basis.

\section{The Commission recommends that the National Oceanic and Atmospheric Agency (CG) give priority attention to providing a system yielding navigation}

The Coast Guard is responsible for integration of all marine navigational services into a national navigation systcm. From left to right, the Ambrose Lightship after commissioning of the permanent Ambrose Off shore Light Tower outside New York harbor in 196\%; the interior of Coast Guard LORAX transmitting station; and a buoy being hoisted aboard the coastal buoy tcuder Red Wood for overhaul and repair ashore.
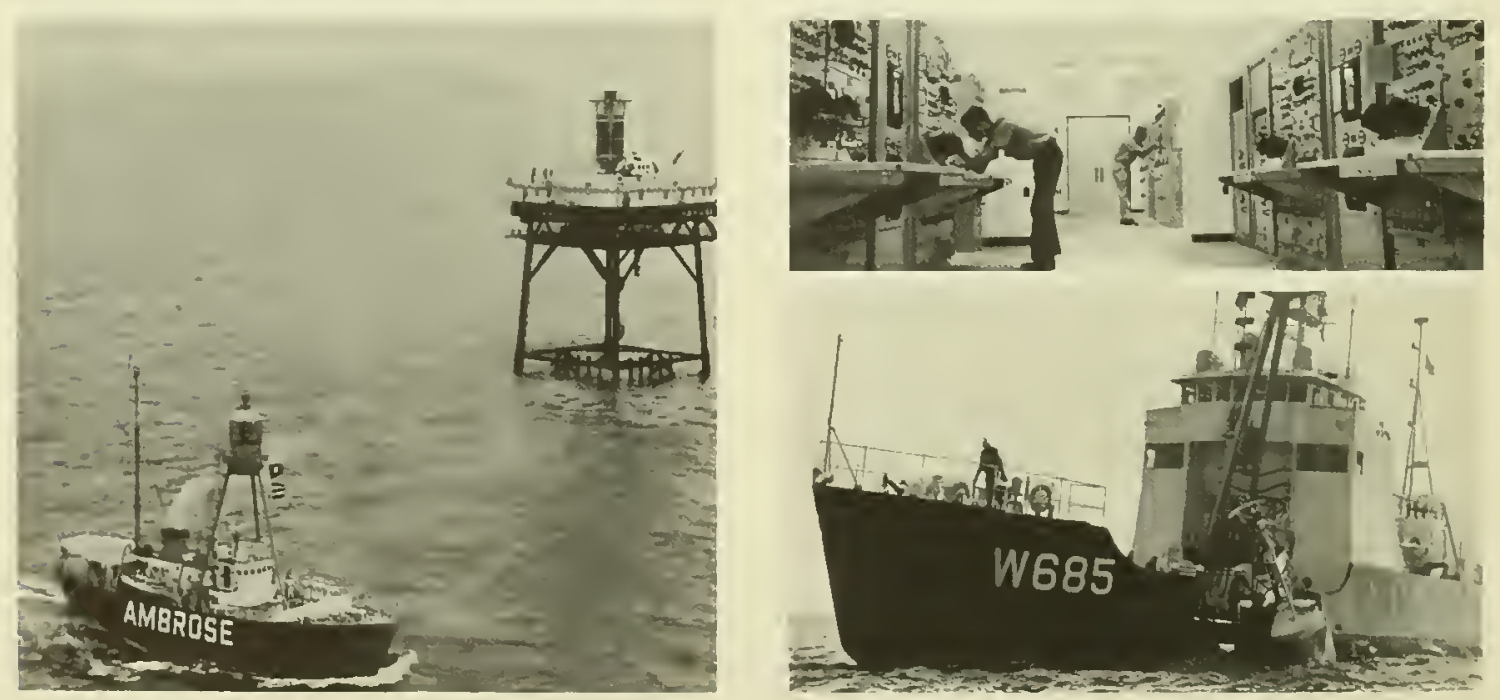
accuracies on the order of 50 feet in the zone within approximately 200 miles of the U.S. coast. Development 'work should be focused on low-cost systems to permit undersea navigation of civilian submersibles. The Coast Guard's efforts to develop a national navigation plan are strongly endorsed. Systems studies should be initiated immediately to define an optimum system to meet needs for off shore precision positioning in the late 1970's.

\section{Safety at Sea}

During 1967, 1,500 commereial vessels suffered collisions and other accidents in U.S. waters. In addition, there were some 5,274 acciclents involving lecreational boats which resnlted in 1,452 fatalities. As more persons go to and under the sea, the problem of assuring their safet $y$ becomes more diflicult.

\section{Control of Offshore Traffic}

The great size of merchant vessels, their transport of cargoes which create a hazard to the environment, and the intensified use of the coastal zone combine to present an increasing danger. Proposals have been advanced for traffic control systems analogons to those used in the U.S. airways. In addition, plans are being developed to set aside shipping lanes which will separate inbound and ontbound traffic and provide a fairway clear of obstructions to navigation. The Commission strongly endorses these steps. Advance planning will avert a crash program following a disaster at some future date. Coastal waters already are sufficiently congested to surgest that the Coast Guard should subject to triffic control all ships carrying hazardous cargo near U.S. coasts and in congested areas.

\section{Certification}

'The Coast Guard is the major' Government agrency for certifying the safety of marine vessels and equipment and for licensing its persomnel. It is assisted by sueh private organizations as the American Burean of Shipping and by the States in the recreational boating field.

Federal laws regulating vessel safety standards are badly ontclated and often unclear or conflicting. 'The prospect of larger and more numerous vessels carrying even greater quantities of hazardons cargoes emphasizes the urgent need to reconsider these laws. The American Bureau of Shipping and the Coast Guard cooperatively should review and update construction standards.

The large number of accidents to fishing vessels, which now-are generally exempt from Coast Guard regulation, suggests that safety standaris should be framed for them also. The inciustry should participate in this task.

Standarls also are needed for the constuction of civilian submersibles. Legislation has been introduced by the Coast Guard to a uthorize extension of its certification program to include such undersea ressels. The Conmission endorses the Coast Guard proposal, but urges that a distinction be made between standards for experimental and research submersibles and those for all other submersibles. Arivances in the technology of civil submersibles could be unnecessarily handicapped by requiring researeh and experimental models to meet the stringent standards necessary for general public safety. Expanding marine teclnology will result in new experimental surface craft and other devices. This will necessitate reeraluation of present Coast Guard certification procechures to promote public safety without posing undue restrictions in researeh and technology.

The Commission recommends that the National Oceanic and Atmospheric 


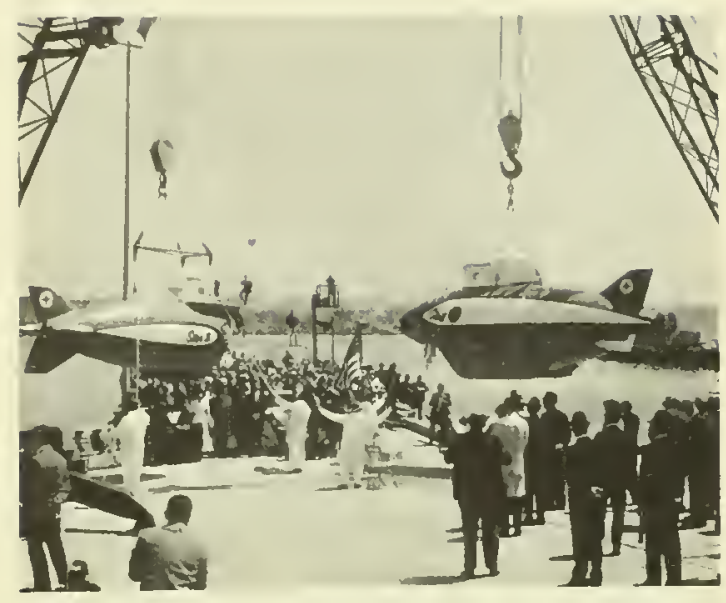

The numbcr of civil submersibles, like the Star II and Star III secn at their simultancous launching in 1966. is growing, and the Coust Guard's ecrtification program, accordingly, should be extended to include commercial underseas rehicles.

Agency (CG) undertake to reexamine and update existing laws relating to vessel safety standards and extend its certification program to include civil submersibles. Safety standards should also be framed for commercial fishing vessels in cooperation with the fishing industry.

\section{Search and Rescue}

A]though the Navy and other Federal agencies may assist in major disasters, the Coast Guard is responsible for providing rescue services to merchant ships, fishing ressels, offshore structures, pleasure boats, nonmilitary submersibles, and transoceanic aireraft. In 1967, the Coast Guard responded to more than 42,000 requests for assistance, rescled more than 3,000 persons, gave medical aid to more than 2,500 persons, provided some form of help or information to almost
124,000 , and assisted in matters involving property valued at almost $\$ 3$ billion.

Because no one can predict when or where disaster will strike, the Coast Guard must maintain a large organization in a constant state of alert. Its own resources are importantly supplemented by the private sector. The Automated Merchant Vessel Reporting System (AMVER) provides an example of effective public-private collaboration. Cooperating ships report their courses, speed, current positions, and other operational details to AMVER, which stores the information in a computer for rapid recall when an emergency situation requires coordination of assistance efforts. The AMVER system is voluntary, not all ships participate, and it is not global. But on a given day, the AMVER computer unay have the positions of severa] hundred ships of 60 nations in the North Atlantic alone. Eventually, the Commission believes that an international system should be developed in which reporting of ship position data will be compulsory.

\section{Recreational Boating}

The safety of recreational boating is a joint Federal-State responsibility. In most States, anyone can buy a boat and operate it. A liceuse for the boat usually is required, but the operator does not need to demonstrate competence or even familiarity with the rules of the road.

The Coast Guard has songht to assist the States in adrancing recreational boating safety, principally through educational programs and inspection services by the Coast Guard's highly effective Auxiliary. In some areas, the Auxiliary assists local authorities in off shore patrols. Members also are qualified to inspect pleasure boats and equipment. Many boaters take advantage of the service. but many do not. In addition, the U.S. Power Squadron, at private organization of dedi- 
cated yachtsmen, conducts similar activities, but they are more aligned to education than inspection. Its educational programs are an important part of the Nation's recreational boating safety program.

The Commission recommends that the States adopt and enforce the Model State Boat Act prepared by the National Association of State Boating Law Administrators and tinat the Congress enact legislation recently proposed by the Coast Guard to establish minimum safety standards in the manufacture of pleasure boats.

\section{Underwater Safety}

The number of sport divers is rapidly approaching two million and may be expected to increase rapidly as equipment becomes less expensive and as persons become arrare of the pleasures of safe diving. Sport diving should be recognized as a permanent and growing part of American recreation, and suitable provision should be made for safety by assuring that the diver has the option to select Federally certified equipment.

Safety in sport diving is primarily the responsibility of the individual. The Commission notes that such organizations as the Underwater Society of America, the Professional Association of Diving Instructors, the YMCA, many sport diving clubs, and many stores selling diving equipment have made a strenuous effort to ensure proper training for sport divers. However, these commendable roluntary activities would be strengthened by some minimum Government oversight to monitor the quality of diving equipment and to assure that the users of this equipment have appropriate training.

Fien with these precations, the number of scuba accidents is likely to increase with the growth in the popularity of the sport and in the work of commereial divers. In order to minimize fatalities, specialized equipment and medical care will be needed. Cumently, only the Nary is equipped to deal with diver emergencies. The Commission urges that the Coast Guard and Public Health Service cooperate with private groups to assure the avaibability of equipment for emergency decompression and treatment.

The Commission recommends that the National Oceanic and Atmospheric Agency (CG) provide for certification of sport diving equipment at the option of the manufacturer and cooperate with the various diving associations to ensure adequate diver training and emergency medical facilities and services.

\section{Policing and Enforcement}

The Coast Guard originated as an agency to enforce customs and immigration laws. It remains the Federal Gorernment's principal marine enforcement agency, but its mission has been expanded to include enforcement of marine safety regulations, pollution and sanitation measures, procedures governing dangerous cargoes, and provisions of international fisheries agreements.

The Amy Corps of Engineers promulgates and enforces regulations pertaining to new construction in navigable waterways. The Department of the Interior oversees the industrial safety aspects of offshore drilling and also has the lead role in Federal pollution control. The U.S. Nary polices military sea areas. The Public Health Service and the Food and Drug Idministration have important but limited enforcement functions concerning food and drugs from the sea.

Many of the enforcement activities in tidewater areas are in the hands of the States. Most have fisheries and wildlife agencies with 


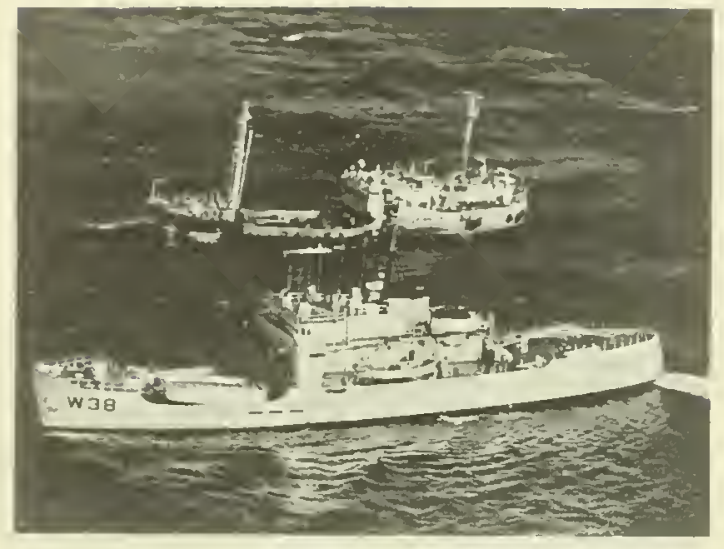

The Coast Guard, which originated as an agency to enforce customs and immigration laws, is the Government's marine enforeement agcncy. Here the eutter Storis is seen overtaking and sei ing $a$. Sovict shrimp trawler operating within the U.S. fishery eontiguous zone off the Aleutian Istands in 1967 .

enforcement functions. The States also enforce regulations pertaining to the use of State water's for boating, diving, and other aquatic activities. Some do a good job; others leave much to be desired.

As ocean activities intensify and the regulations to govern them become more elaborate, law enforcement may be expected to become a major problem.

The Commission recommends that the National Oceanic and Atmospheric Agency (CG) have primary responsibility for Federal marine law enforcement. The States should review the effectiveness of their marine law enforcement and take necessary steps to ensure adequately staffed and equipped professional enforcement organizations.

\section{Data Services}

Oceanographic data are collected at great expense and with great difficnlty by the
Federal Govemment, private institutions, and foreign govermments. All users of the seas and the scientific community look to the Federal Govermment to establish and maintain appropriate data centers for the storage retrieval, and dissemination of such data, including measurements of the physical and chemical states of the oceans and atmosphere, as well as geological and biological samples not rearlily amenable to numerical storage in computer systems.

There is no coordinated system of data centers for storing and retrieving oceanographic data. Inless such a system can be established quickly, the agencies liteially may be overwhelmed by the volumes of new data generated by expanded research programs and the increased use of continuous: sensing and recording devices on lesearch and survey ressels, hnoys, submersibles, and satellites.

A major study is underway to determine the needs for maxine data, to appraise current data haudling, and to propose action to process more efficiently the data to be generated in the futmre. This study, initiated by the National Council on Marine Resources and Engineering Development, is scheduled for completion in 1969. In view of this study, the Commission has not molertaken to prepare a cletailed proposal for national marine data service activities.

It present, a number of centers handle envilonmental data and specimens, including the National Oceanographic Data Centel (NODC), the National Ireather Records Center (NITRC), and the Smithsonian Oceanographic Sorting Center (SOSC). In addition, there are a number of geophysical data repositories for information such as magnetic, gravity, and geodetic information and bathymetry which provide essential information for marine activities. In the sections that follow, the Commission has dis- 
cussed only those data services presently leing provided by NODC, NITRC, and SOSC. Full rationalization of a total geophysical dala service system shonld be considered by the new andency with assistance of other interested ageneies after the Marine ('omeil's study on marine data needs is completed. The great variety in quantity, quality, and uses of these data suggests that total enrirommental data eannot be handled readily by a single center and that a number of centers will be necessary for the foreseeable future. At the same time, overall policy direetion of the different center's is needed to define elearly their responsibilities and relationships in order to prevent redundaneies and gaps in the system and to detemine priorities.

At present, also, there is not even a comprehensive index which ean tell a potential user what data exist and where. Both the Environmental Dita Service of ESSA and the National Oceanographic Data Center, however, are seriously considering the establishment of such indexes.

\section{National Oceanographic Data Center}

The NODC now stores a varjety of marine envirommental data and furnishes information in varions forms to Federal agencies, industry; and researeh groups on a cost reimbursement basis. The Center was established in 1960 by agreement of the Navy. Coast and Geodetic Survey, Bureau of Commereial Fisheries, National Seience Foundation, Atomie Energy Commission, and the Weather Bureau. $\Lambda$ total of 10 agencies now fund the NODC jointly and are represented on its advisory board; the Navy operates it.

The funds provided have been insuffieient

\section{Workings of the Data System}

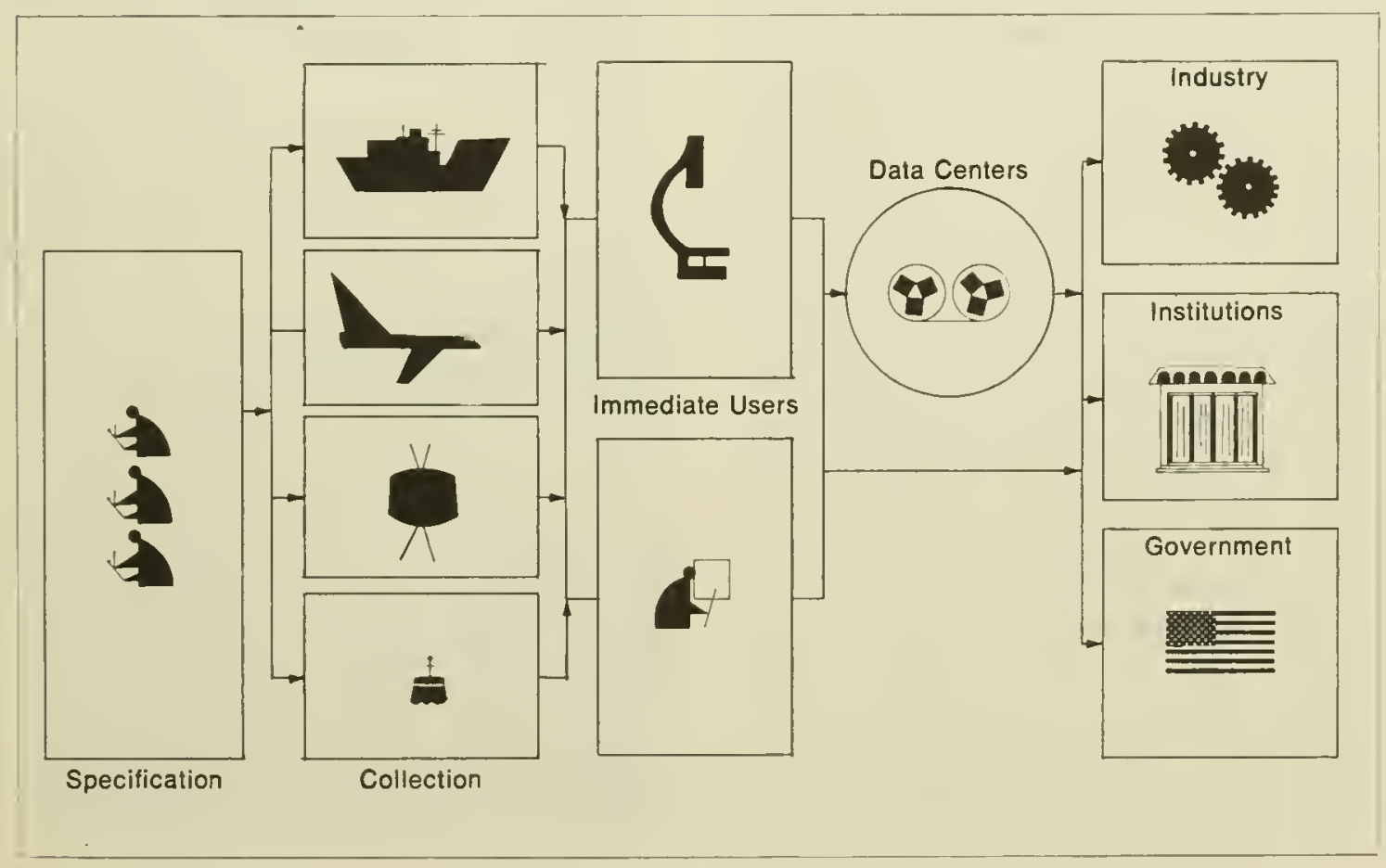


to meet the needs of NODC. Recently the Navy offered to assume the entire fiscal responsibility for its work. The Commission concludes that NODC should be administered by a civilian agency to which the necessary funds for its operation should be appropriated. Costs of work performed for other agencies, including the Nary, should be paid by these agencies in accordance with existing Federal law and practice. Similarly, the costs of retrieving and reproducing data for non-Government groups should be paid by these groups.

In the Commission's riew, the already overloaded general-purpose data centers should a void involvement to the extent possible in any aspect of the data problem which might have logical affiliation with existing mission agencies. Thus, whereas such multipurpose data as subbottom profiles and photography should be stored by NODC, ESSA and the U.S. Nary should be the prime repositories of worldwide bathymetric data: the portrayal of such data should take the form of published bathymetric charts at appropriate scales. Biological data relating to taxonomy should continue to be concentrated with the museum and miversity specialists who are concerned with these aspects of science. Certain time-independent, multipurpose data such as subbottom profiles and photography should be stored by NODC. NODC, of course, shonld be fully aware of these sources of information and maintain liaison with the curators to facilitate the referral of inquiries.

Generally, NODC also should not undertake the processing of raw data nor become involved in the management of real-time ocean monitoring and prediction systems. Any future systems for monitoring and prediction, however, should rake into account the requirement for data formats compatible with the NODC system. The system's primary function should be the acquisition, storage, retrieval, and dissemination of historical data.

\section{National Weather Records Center}

Unlike the NODC, the National Weather Records Center has been in existence for half a century. Its primary mission is to store national and international reather records. Its marine functions inclucle the storage and retrieval of all ocean weather, sea state, and sea surface temperature data. Funded by the Department of Commerce, it performs work for other agencies on a reimbursable basis. Large parts of its marine programs are supported by the Nary under such agreements. It also retrieves and reproduces information at cost for all non-Federal users.

The National Weather Records Center has suffered over the years from the same lack of funds as NODC and is unable to meet fully the growing demands upon it.

\section{Smithsonian Oceanographic Sorting Center}

The Smithsonian Ocennographic Sorting Center is a service organization which analyzes biological and geological samples. Plankton samples, for example, may include representatives of more than 50 major animal groups, each requiring examination by specialists to assure proper analysis. The Center is supported by direct appropriation and throngh contracts with several Federal agencies, including the Department of the Interior, the National Science Foundation, and the Nary. Its present appropriations permit it to sort only approximately 35 per cent of the samples it receives.

Current legislation requires that all biological and geological specimens obtained with Federal funds be tumed over eventually to the Smithsonian Institntion. The Institution, however, is not equipped to handle prop- 
erly the rast quantities of marine material that conld be left at its roorstep under this law. At present, the Smithsonian insists on compliance only when it believes collections will otherwise be lost. The Commission concurs in this interpretation of the law.

On the other hand, biological and geological investigations carried on by mission-oriented agencies, universitics, and ocennographic institutions frequently result in the collection of large and diverse samples. In many instances, only a small portion of the collection is studied: for example, only the fish eggs and larvae may he connted, identified, and subjected to appropriate analyses. The remaining portions of the sample, which const itute more than 90 per cent of the collection, are raluable for fut ure reference. Judgment of the impact of environmenta] change and determination of long-term trends depend upon the a vailability of collect ions made either prior to the change or over long periods of time. Adequate storage facilities and appropriate curatorial responsibility must be

Staff nembers at the Smithsonian Institution:s Zooplankton Sorting Laboratory in Tashington, D.C. classify, catalogue, and store marine biological specimens from the irorld's oceans.

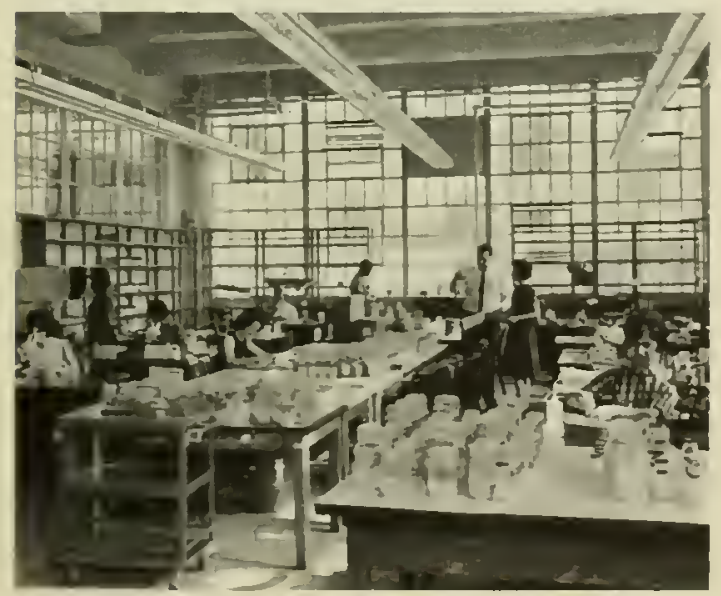

assigned to ensure that ralnable materials will not be lost. Costs of maintenance are small relative to the original costs of making the collection, and they shonld be considered a part of the operating expense of the national oceanographic progran. The Commission concludes that the Smithsonian Institution is the proper agency to perform this function. The organization that collected the material should be encouraged to make it avalable to the Smithsonian, at the Smithsonian's expense.

\section{A Coordinated System of Data Centers}

The needs for marine data require that the Federal Govermment ensure that the activities of its principal data centers operate as part of a coordinated system.

The Commission recommends that the National Oceanographic Data Center, the National Weather Records Center, and the Smithsonian Oceanographic Sorting Center be adequately supported to enable them to keep up with the growing volume of marine data and to take advantage of modern storage and retrieval technology. The NODC and NWRC should be lodged in and funded by the National Oceanic and Atmospheric Agency. NOAA also should be charged with coordinating the various components of the overall marine data system and establishing priorities for data production and storage.

\section{Instrument Testing and Calibration}

At present, there is a wealth of data within the Nation that is of limited ralne because of low confidence in the data quality or becanse the data came from diverse sonrces and are not comparable. This is not only a national problem, but it increasingly is becoming an international one.

Mnch of the national investment in ocean 
programs is and will be deroted to measuring the characteristics of the marine environment. The NODC and the SOSC establish criteria for data formats and thus in some cases influence collection and processing techniques, but they do not influence instrument design or operational procedures necessary to produce truly reliable and comparable data.

There is no national or international capability to define in a common language the desirable characteristics of an oceanographic instrument, to test and calibrate an instrument to assure that the operational measurements will be within acceptable tolerances, nor to develop laboratory tests properly simulating ocean use conditions.

Standard instruments are not desired; in fact, the process of measuring environmental characteristics is changing so rapidly that any attempt to standardize design would inhibit technological progress. What is needed is the definition of standards against which instruments can be calibrated, the definition of performance and test criteria, and the development of field and laboratory facilities and techniques to test instruments against. these standards.

Several instrument manufacturing and user groups have attempted to perform many of the functions described above, and although their efforts have been important first steps, the size of the task and its truly national and international character now are becoming apparent.

The National Bureau of Standards has not yet undertaken the development of reference standards or test procedures for marine instruments, although some of these functions appear to be properly within their cognizance. But the Bureau is showing an increasing awareness of the problem, and the ( ommission urges it to assist in the difficult task alhead.
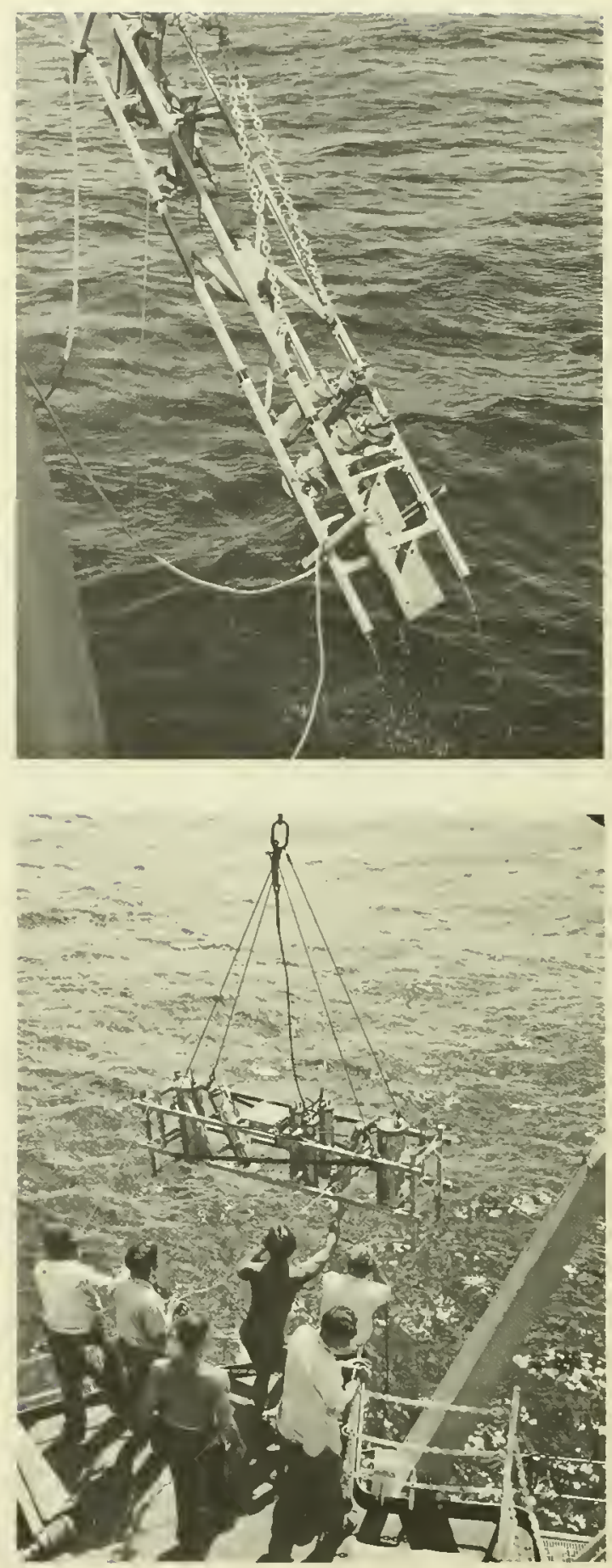

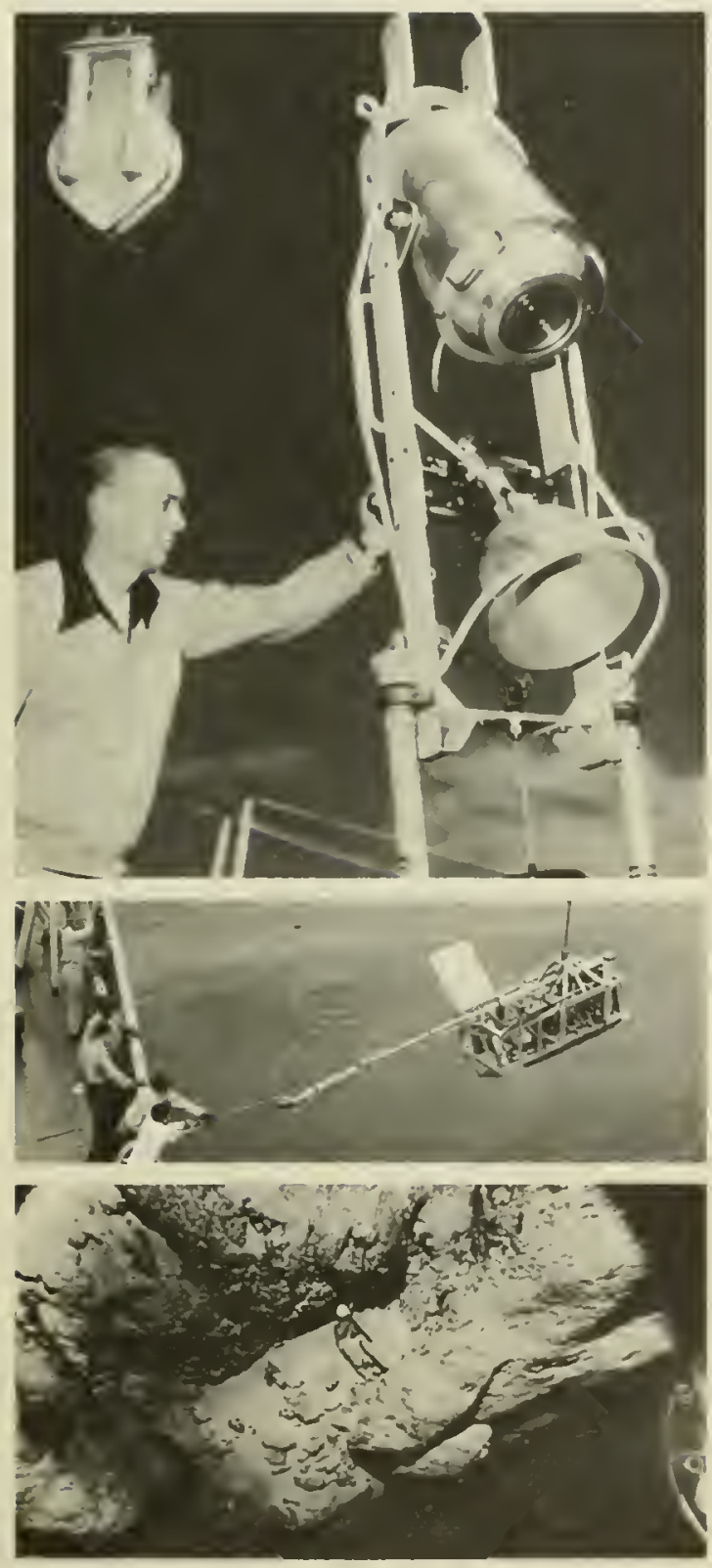

Better national instrument and calibration serviccs should bc "arable to users of highly spcciatized, expensive at-sea rescarch instruments tike these decp sea cameras; below, a vicw of the Alluntic Occan floor 10,000 feet bencath the surface.
The Navy, to date, lias been the largest purchaser of oceanographic instruments and user of oceanographic data and has established tho Naval Oceanographic Instrument Center (NOIC) of the Naval Oceanographic Office as a test and calibration facility. NOIC has helped to establish criteria and procedures for testing and calibrating certain types of instruments. But NOIC's effort is not adequate to satisfy the rapidly increasing demands for such services.

The Commission recommends that the National Oceanic and Atmospheric Agency assume responsibility for sponsoring programs to provide the reference standards, test and calibration procedures, and test facilities necessary to improve marine data reliability and comparability. It also should publish at periodic intervals a list of those test facilities at government, industry, and academic centers which are competent to test and calibrate ocean instrument systems.

Standards and procedures developed by NOAA for test and calibration of marine instruments should be related to the primary standards maintained by the National $\mathrm{Bu}$ reau of Standards and also should be responsive to Navy needs. A strong reference standards program within the United States also should help to obtain necessary international standards agreements.

The National Oceanic and Atmospheric Igency should not attempt to do the entire job alone. All the facilities and experience of the National Burean of Standards, the Navy, and private industry shonld be tapped. In particular, the Commission suggests that the Naval Oceanographic Instrument Center might comprise the mucleus upon which to build a national inst rument conter. 


\section{Program Costs}

The Commission's recommendations for technical and operating services are estimated to involve annual costs of about $\$ 4 t$ million abore present levels during the early 1970 's and about $\$ 7 t$ million anmually thereafter. An analysis of these amounts is shown in Table 6-1. On this table, technological development for all service activities is shown in a single entry. Major in restments in new technology will be necessary to prepare to meet requirements for exanded and improred services in years to come.

The proposed bathymetric mapping and nautical charting programs will be accomplished using existing and new Government ressels and contractor-operated ships. The Commission's $\$ 180$ million estimate includes \$3t million for construction of these bathymetric surrey ships, $\$ 33$ million for construction of 8 nautical charting vessels, $\$ 53$ million for operation of the Gorermmentowned ships, and $\$ 60$ million for operation of chartered ressels.

NOAA will have a major responsibility for marine safety and enforcement functions-boating safety, certification of diving equipment, marine traffic cont rol, and similar activities. The Commission anticipates that incremental expenditures averaging $\$ 10 \mathrm{mil}$ lion ainually will be necessary throughout the coming decade.

The Commission's recommendations for the improvement of environmental data services probably could be satisfied with incremental funding totaling $\$ 60$ million over 10 years; about half of this amount would go to the National Oceanographic Data Center. Since the Marine Comcil's study is not complete, however, this figure is no more than a very rough estimate.

The improvements of the techniques for mapping and charting nust be undertaken quickly, and specific needs for survey instrumentation have been noted by the Commission. To improve navigational services, two technological programs are recommended by the Commission. One is to develop a system to improve navigational positioning within the zone extending roughly 200 miles off the U.S. coast. The other, much more difficult requirement is to develop new systems to improve the reliability and lower the cost of narigation far from shore and under the surface. Engineering studies also will be required to devise new and improved standards for vessel construction and certification of recreational boating and diving equipment. A major opportunity exists to apply technology to the improvement of data storage and retrieral systems. Though the necessary expenditure is relatively modest, it should receive high priority.

The Commission has recommended that NOAA assume responsibility for sponsoring programs to provide reference standards, test and calibration procedures, and test facilities. Funds for this program also are included in the $\$ 250$ million estimate shown in Table 6-1 for technology development.

The technical services supporting marine operations are being furnished by the Federal Goverument with a minimum of fanfare. The prevailing efficiency with which the services are operated minimizes public clamor for bold new programs and tends to conceal the vital functions being performed. Yet it is erident that technology is not being adequately applied to improve the efficiency of the services. Conversely, the services are not being reoriented rapidly cnough to meet the challenges posed by new technology.

The growing size, complexity, and essentiality of these services calls for thorough- 


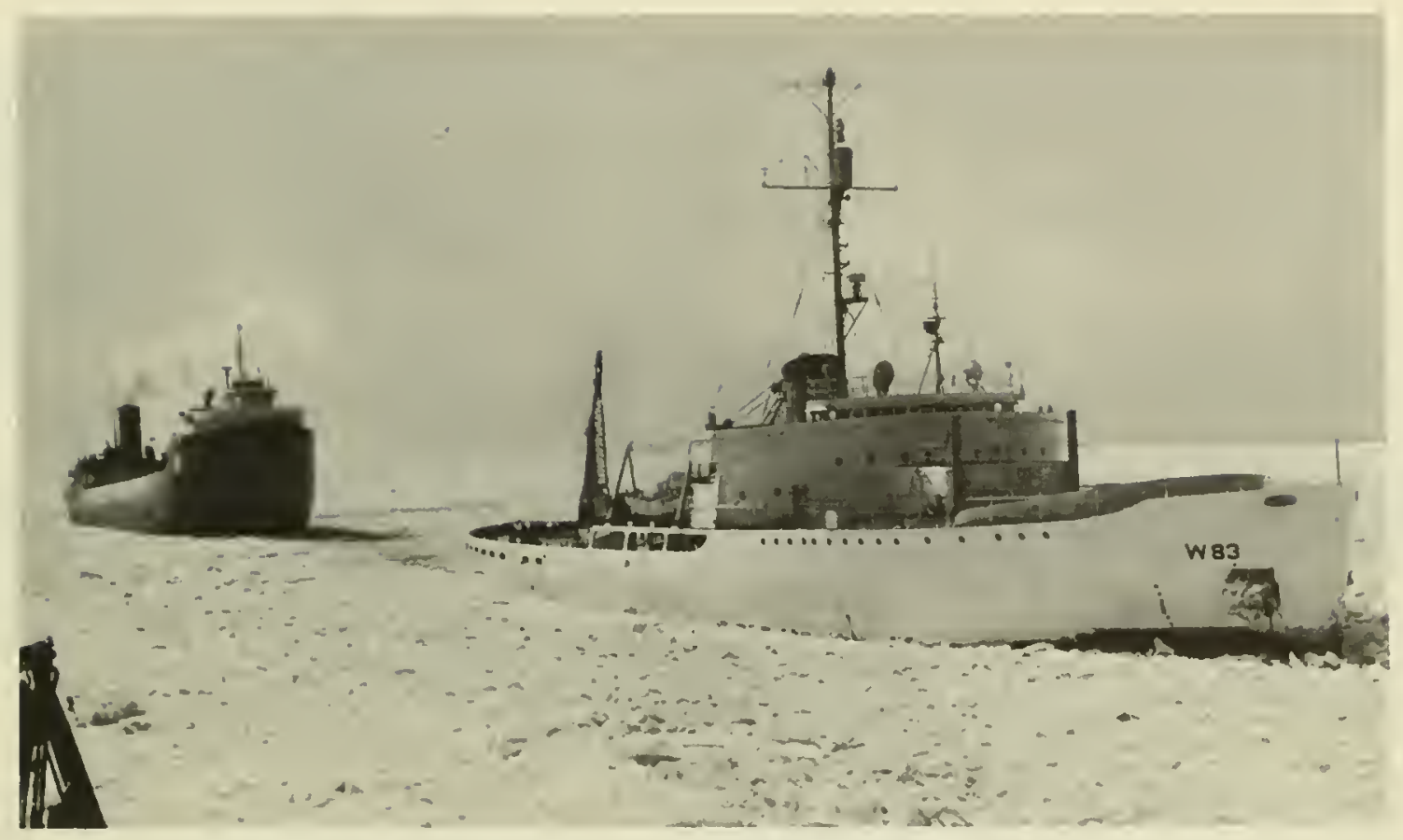

The Coast Guard iecbreaker Mackinaw elears a path for winter

shipping on the Great Lakes. If the Nation's supporting services are to

continue to meet $U$.S. needs efficientlll, thell will require eoordination

by a strong ecntral ageney possessed with both authority and

adcquate ocean-going capabilitics.

going coordination in their planning and conduct. This will require leadership from a Federal agency possessed with authority and adequate ocean-going capabilities. The Commission conchndes that $\mathrm{NOAA}$ can provide this leadership.

\section{Table 6-1 Supporting Services ${ }^{1}$}

[Incremental costs in millions of dollars]

\begin{tabular}{|c|c|c|c|}
\hline & \multicolumn{2}{|c|}{ Average annual costs } & \multirow{2}{*}{$\begin{array}{c}\text { Total } \\
10 \text {-year } \\
\text { costs }\end{array}$} \\
\hline & $1971-75$ & $1976-80$ & \\
\hline Mapping and Charting $\ldots . . . . . . .$. & $\$ 16$ & $\$ 20$ & $\$ 180$ \\
\hline Operations & 6 & 16 & 113 \\
\hline Ship Construction $\ldots \ldots \ldots$ & 10 & 4 & 67 \\
\hline Marine Safety and Enforeement $\ldots \ldots$ & \& & 12 & 100 \\
\hline Data Services & 5 & 7 & 60 \\
\hline Development of Service Systems and Equipment........ & 15 & 3.5 & 250 \\
\hline Total, Supporting Services $\ldots \ldots \ldots \ldots \ldots$ & 44 & 74 & 590 \\
\hline
\end{tabular}

\footnotetext{
1 For explanation of amounts shown in this table, sec accompanying text and Chapter 8.
} 
Chapter 7

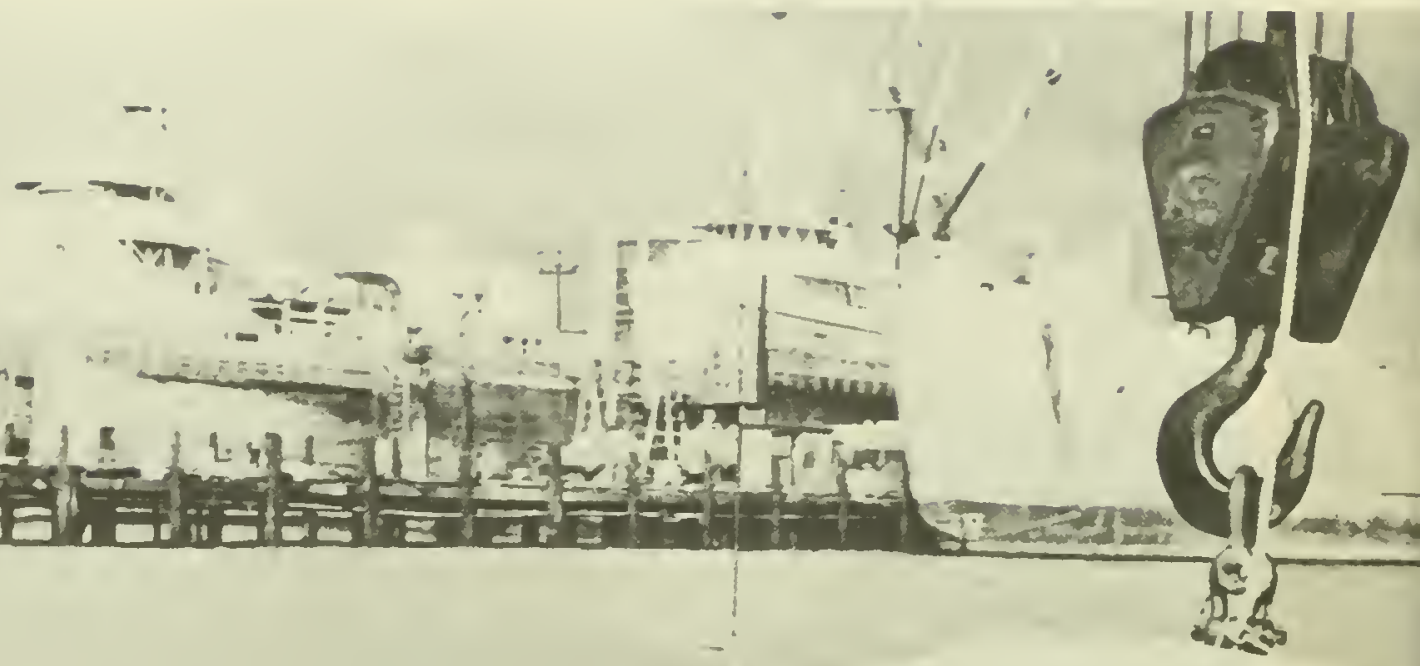

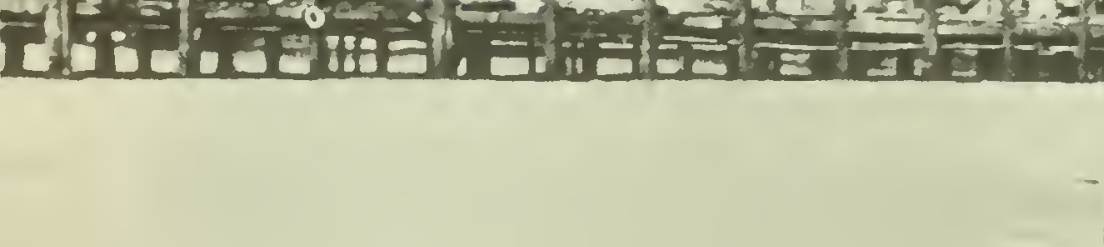
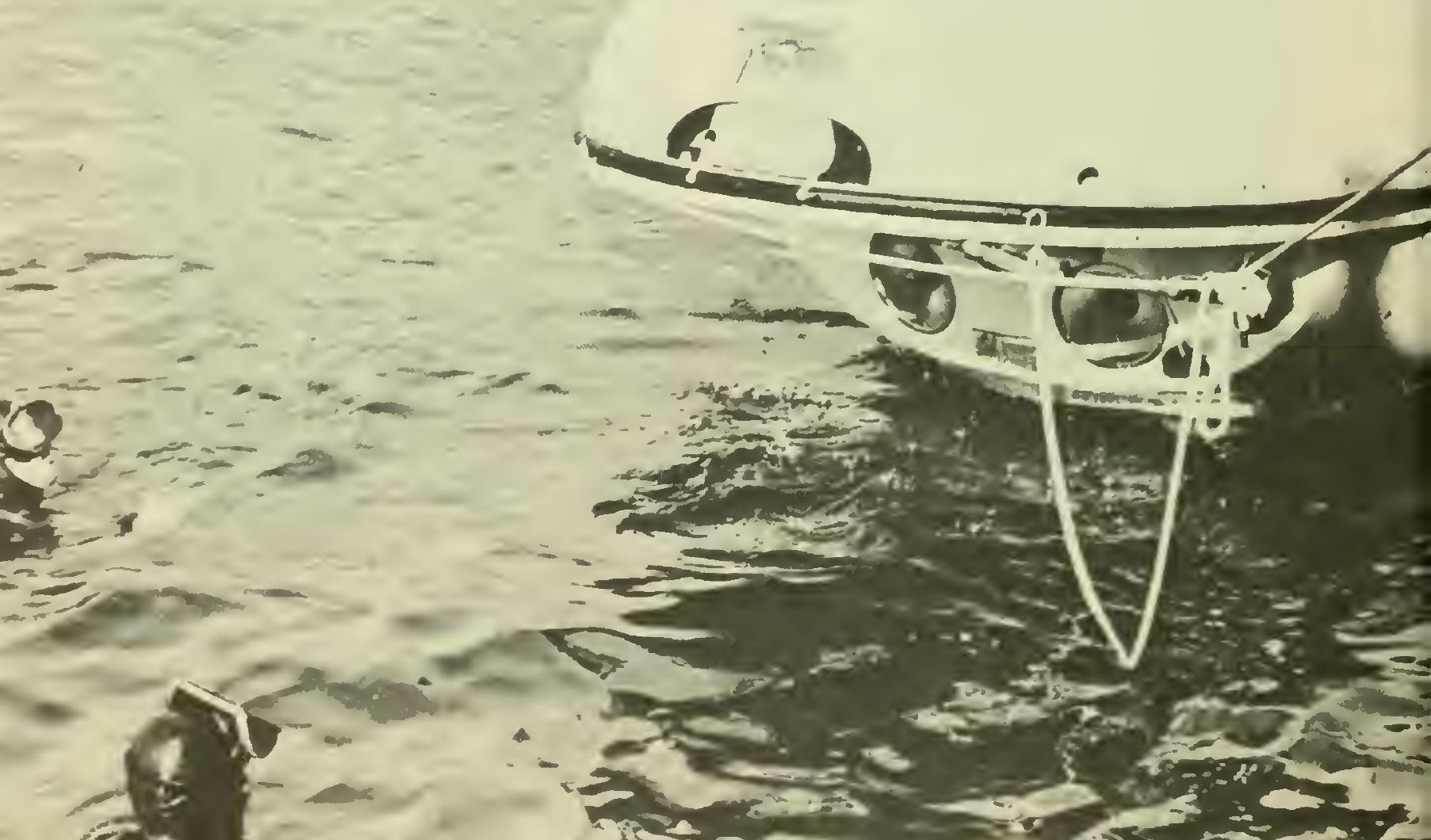


\section{Organizing a National Ocean Effort}

In previous chapters of this report, the Commission las recommended specifie aetions to adrance national eapabilities to develop marine resourees; to maintain the quality of the coastal zone; and to explore, monitor, and predict the global ocean and atmospheric environment.

Organization is required to earry ont the Commission's recommended national ocean program. As an essential first step, the Federal Government must mobilize its forces to provide leadership, incentives, and support.

\section{Federal Organization for Marine Affairs}

Present Federal marine activities have grown over the years largely without plan to meet specific situations and problems and are scattered among many Federal ageneies. Such a seattering of effort in Government reflects a more general disarray. Imbedded within many Federal departments are important activities which relate only marginally to the central missions of the department.

There is general concern whether modern gorernment, as now constituted, has become unmanageable and maccountable. In developing a plan for management, the Commission has attempted not anly to advance the national marine program but also to design an organization which can easily fit into a more fundamental restrueturing of the Federal Government.

Within Federal agencies, strong elements do exist for carrying out marine aetivities. Some of them should maintain their identities and be strengthened further as essential contributors to the national marine effort. Others should be combined with weaker elements to provide a new central focus of strengtl.

The L.S. Nary necessarily must be directly involved in many aspects of marine science and engineering in support of its mission. Becanse of farsighted recognition of the in- fluence of the total marine environment on naval operations, the Navy has been the principal supporter of ocean seience and teehnology. Its laboratories and test facilities represent the strongest existing element in the program for marine technologieal developinent.

The National Science Foundation supports marine and atmospheric science as a part of its basic mission to foster the Nation's scientific endeavors. It has funded the development of marine and atmospherie research facilities, including oceanographic ships, has sponsored a broad spectrum of research activities, and has supported the education of environmental scientists of all kinds. The Foundation's discipline-oriented marine seience and education programs are inseparable from its programs in other scientific fields, and they represent a primary resource in developing the capability for a national ocean program.

The Department of the Interior, responsible for many of the Nation's resources, has taken construetive action in many program areas impinging on marine development. It has made great strides in recent years in developing a comprehensive program for fresh water management, one of the Department's primary concerns. Its efficient, dedicated national park and wildlife services have preserved many miles of seashore for recreation and conservation of wildlife habitats. Interior also is responsible for management of the Nation's mineral resources and has in the U.S. Geological Survey one of the Federal Government's most competent seientific groups, which supports mineral and other resource investigations.

The U.S. Army Corps of Engineers, because of the needs of its civil works program and its responsibilities for protection and maintenance of the coast and waterways, has dereloped the Nation's primary competence

If the lation:s busic goal of

maximum effertixe usc of the sca to mert $L$.. necds and purposes is to be achicted, the Federal Goternment must mobilize its forces to provide lealcrship, incentives, and support. 


\section{Federal Agencies with Major Marine Responsibilities}

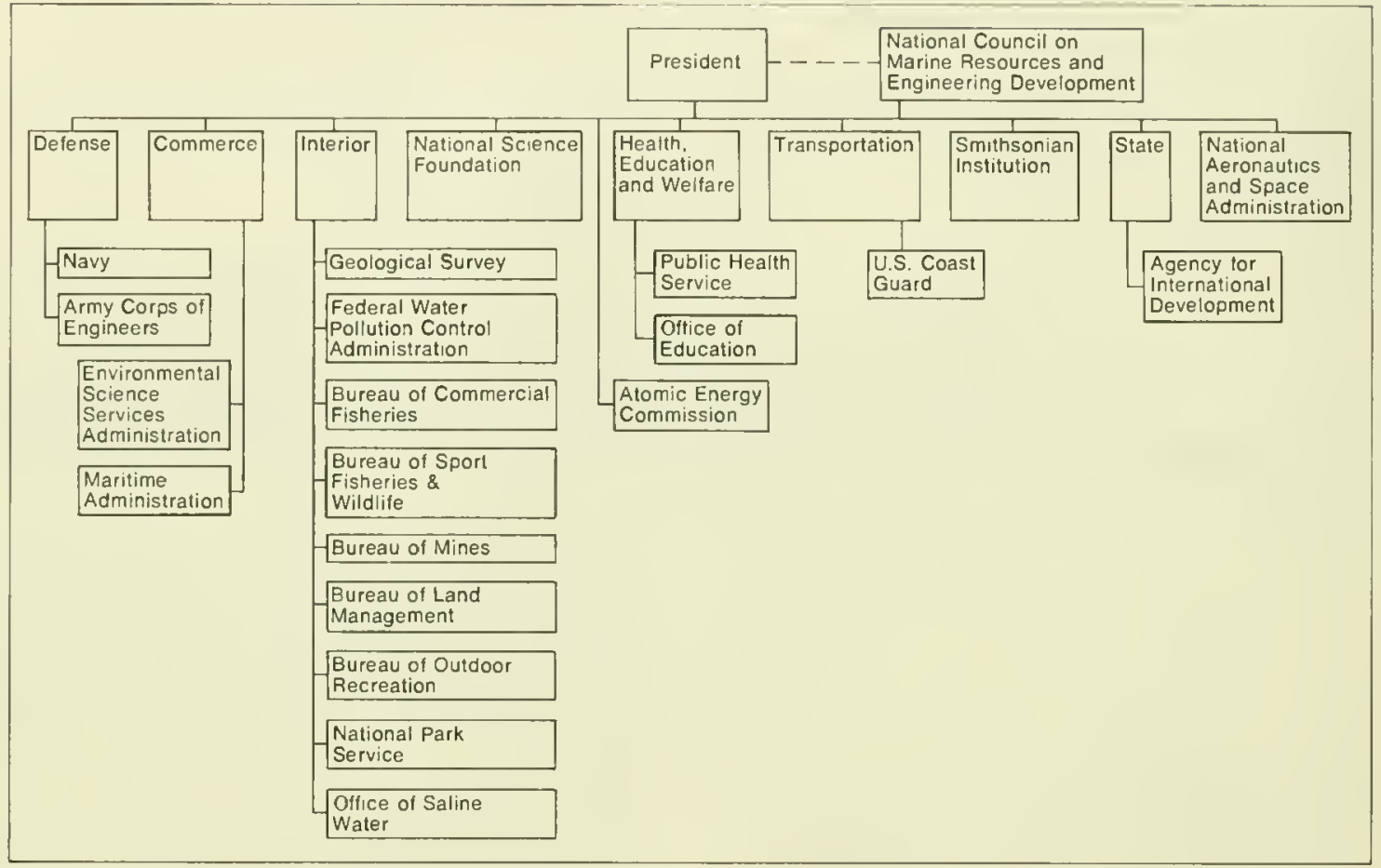

in coastal engineering; its Coastal Engineering Research Center is the key element of Federal capability in this field.

The Smithsonian Institution engages in worldwide research in biological and geological oceanography and in assembling and managing the national collections of biological and geological specimens.

In contrast, within the Federal Government there are also many marine activities which, in the view of the Commission, are peripheral to the parent agencies' primary missions. As a consequence, these activities have not acquired the visibility and attendant support necessary to be effective. Many of the scattered marine programs are too small to have impact. Equally important, their isolation from each other, which coordinating
Bccause of farsighted recognition of the infuence of the total marine cntironment on naval operations, the Navy has bccn the principal supporter of ocean science and tcchnology and will continue a strong program in support of its national security mission.

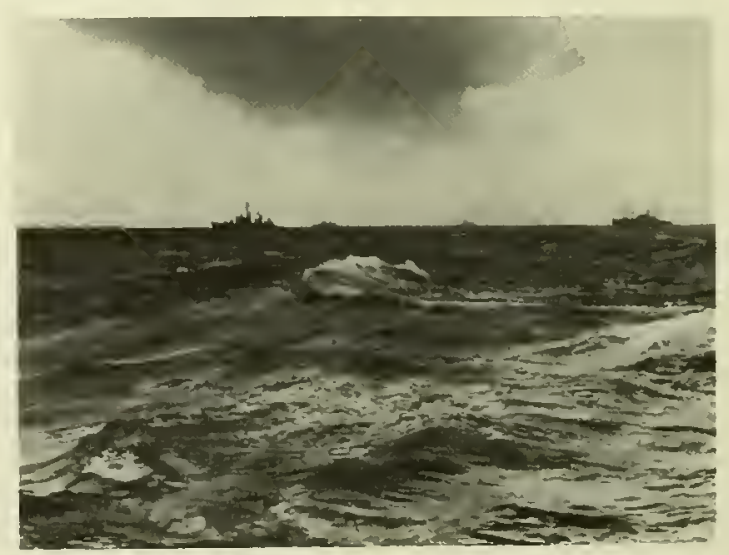


mechanisms are never able to overcome, has caused an incritable degree of insularity, overlap, and competition. But perhaps most significant, their isolation has made it rery difficult to launch a comprehensive and integrated program to remove the obstacles that stand in the way of full utilization of the oceans and their resources.

The proliferation of marine activities places an unnecessary burden on the President and the Congress. Through the National Council for Marine Resources and Engineering Development, commendable progress has been made in the plamning and coordination of Federal marine activities. But Federal councils are limited in their power to act and cannot fully compensate for fundamental shortcomings in the organization of operating agencies. Nor can a President's staff, for long, be the active proponent of a national ocean program which may be in competition with other urgent national programs.

It is our conviction that the objective of the national ocean program recommended by this Commission can be achieved only by creating a strong civil agency within the Federal Government with adequate authority and adequate resources. No such agency now exists, and no existing single Federal agency provides an adequate base on which to build such an organization. For the national ocean effort we propose, unified management of certain key functions is essential.

Analysis of marine requirements and programs shows a number of general-purpose activities, like envirommental monitoring and prediction, that serve common needs of many government and private users and of the general public. Many of these activities are strongly interrelated, are based on common technology, and are conducted on a global scale; their effective implementation requires orerall systems management which can be achieved only if they are brought together under a single head. In other cases-fisheries development is an example-the objective is so dependent upon knowledge of the sea environment that an association with other elements of an overall marine program promises major advances in effectiveness.

The Federal agency created to implement the national ocean program must be of a size and scope commensurate with the magnitude. importance, and complexity of the problems it seeks to solve, the services it seeks to render. and its potential contribution to the wellbeing of society. Only in this way can the organization become an effective claimant for the funds needed to cary out the program or derelop the strength neerled to give leadership and coherence to the total national effort. $A$ broad mission to adrance the more effective use of the sea and our understanding of the total sea-ail envilomment will assure flexibility for the agency to meet new needs and opportunities as they arise. Bringing together functions now spread among several agencies would create a national capability to attack oceanic and atmospheric problems which will be far more effective than can be achiever through today's scattered parts.

Existing marine programs, however, do not cover the full spectrum of functions necessary to meet the Nation's needs. New plograms must be created, and it is important that there be in the Federal Government an agency with a sufficiently broad mission and capabilities to provide for their initiation and guide their derelopment. Integration of old and new elements will yield an organization with the rigor and flexibility needed to carry out Federal responsibilities in the Commission's recommented plan.

A strong operating agency with a broad and coherent mission in marine, atmospheric. and certain other geoplyysical sciences would 
contribute powerfully to the achierement by other agencies of their central missions and obriate their need to initiate sea activities oriented to their specific interests. The central agency, when its capabilities are proven, should then tend to displace the marginal activities of a number of agencies and prerent inefficient proliferation.

The Commission examined many alternative forms of Federal organization. We are convinced that a system relying upon co-

The sca, whether secn in a mosaic of satellite hurricanc photographs (taken.Sept. 14,1967) or from the deck of a storm-driven ship, is the dominant element of the total global sea-air system. Accordingly, a new ageney for the Nation's occan program should advance understanding of the total sca-air cnelope.
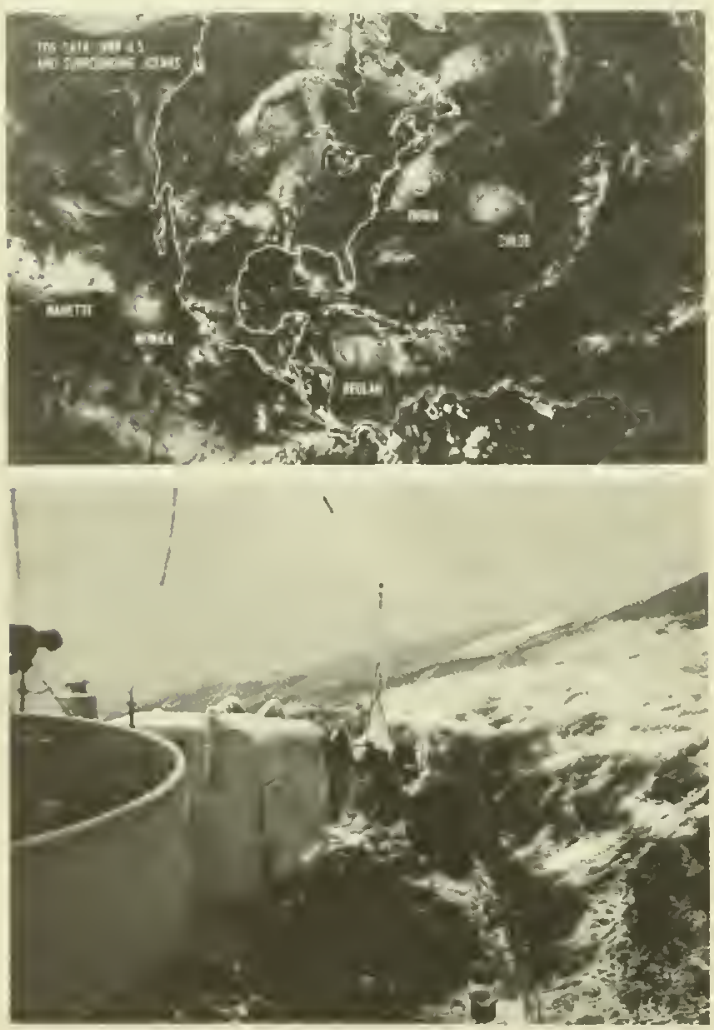

ordination of organizationally dispersed activities, no matter how well administered, is not a substitute for a single operating agency having authority and capability commensurate with the scope and urgency of the national ocean program.

The advancement of this Nation's capability to use more effectively its marine enviromment deserves recognition as a major mission of Government. Because the sea is the dominant element of the total global airsea system, a new marine agency should embrace atmospheric sciences as well.

The Commission recommends the creation of a major new civilian agency, which might be called the National Oceanic and Atmospheric Agency, to be the principal instrumentality within the Federal Government for administration of the $\mathrm{Na}$ tion's civil marine and atmospheric programs.

\section{A National Oceanic and Atmospheric Agency}

\section{Organization and Functions}

The primary mission of the new agency is to ensure the full and wise use of the marine environment in the best interests of the United States. The National Oceanic and Atmospheric Agency should be entrusted with the following functions :

- To advance the marine and atmospheric sciences and, for this purpose, to explore the global oceans to determine their characteristics and behavior and the effects of human activities upon them

- To assist in rehabilitating U.S. fisheries through research, development, encouragement of improved management practices, and the establishment of a framework that will enable U.S. fishermen to harrest economically the resources of the sea. The new 
agency also would engage in research and exploration for the purpose of locating stocks of living resources and determining the maximm harest of stocks, consistent with conservation objectives.

- To engage in research on and exploration for virious ocean minerals in order to determine the general location, extent, and character of marine mineral resources, thereby enabling industry to perform more efficiently the detailed prospecting and evaluation of resources that must precede their economic exploitation

- To enhance the national capability to use the mariue environment through programs of scientific research and fundamental technology

- To launch the National Projects recommended by the Commission

- To help assure that the availability of educated and trained manpower is adequate to meet the needs of the national program

- To develop and maintain National Envirommental Monitoring and Prediction System (NEMPS) for the purpose of providing weather and oceanic forecasts for the general public and various user groups

- 'To develop the knowledge to predict the effects of man's activities on his total environment and thereby avoid delcterious environmental modification. The new agency would also explore the feasibility of modifying oceanic and atmospheric processes for man's benefit.

- To provide essential services to all users of the marine environment, including navigation, mapping, charting, safety, data, and instrument standardization and test ser'vices, and certain geophysical services to provide seismic, geodetic, geomagnetic, gravimetric, hydrologic, ionospheric, and solar information

- To help enforce Federal marine laws and regulations and to promote marine safety
- To promote and adrance the field of aquaculture as a new source of foorls and materials

- To minimize use conflicts by providing advice and counsel to Federal and State agencies on questions of multiple use of the marine environment and by developing an overall plan for the use of areas beyond the territorial seas

- 'To support, assist, and coordinate the activities of the State Coastal Zone Anthorities as recommended by the Commission

- To improve and coordinate scientific and technical liaison with international govermmental organizations concerned with marine and atmospheric affairs

- To carry out these functions in a manner to encourage private investment enterprise in exploration, technological development, marine commerce, and economic utilization of marine resonrces

- To coordinate, as directed by the President, the activities of other Federal agencies which relate closely to the National Oceanic and Atmospheric Agency's (NOAA) proposed central functions

- To advise the President and the Congress on the measures and the funds needed to carry through the programs for which it is responsible

- To continue the performance of all functions of existing agencies which may be assigned to it.

The proposed new agency would carry out a broad program of direct public services. In developing marine technology, NOAA would work closely with the industries that eventually will undertake the commercial exploitation of marine resources. It would work closely also with State and local gorernments in carrying out the recommended coastal zone and fisheries programs. NOAA would not be the instrument of a crash 
program, but it would work for orderly and evolutionary progress into the sea.

The Commission concludes that the new agency should be composed of organizat ional elements concerned primarily with scientific, technical, and service functions necessary for expanding planned use of the sea and its resources, for monitoring and predicting the state of the total air-sea environment, and for exploring the feasibility and consequences of environmental modification.

New plograms will be needed to fulfill some of the functions which the Commission ploposes be discharged by the new agency; others are being performed today by existing agencies. Their transfer to the National Oceanic and Atmospheric Agency will permit NOAA to make a strong beginning in discharging the functions assigned to it.

The Commission recommends that the National Oceanic and Atmospheric Agency initially be composed of the U.S. Coast Guard, the Environmental Science Services Administration, the Bureau of Commercial Fisheries (augmented by the marine and anadromous fisheries func. tions of the Bureau of Sport Fisheries and Wildlife), the National Sea Grant Program, the U.S. Lake Survey, and the National Oceanographic Data Center.

Each of these proposed transfers is discussed in greater detail later in this chapter. In addition to the recommended organizational transfers,

The Commission recommends that the $\mathrm{N}$ at ional Oceanic and Atmospheric Agency assume immediate responsibility for:

- Institutional support for UniversityNational Laboratories and Coastal Zone Laboratories
- Development of fundamental marine technology

- Formulation and implementation of National Projects and grants to States for coastal zone management

- Development and coordination of weather modification activities.

Once established, NOAA could appropriately assume responsibility also for funding the National Center for Atmospheric Research and the Antarctic research program of the National Science Fomndation, for leading a program of Arctic research, and for providing logistic support for polar programs.

In considering the composition of the proposed National Oceanic and Atmospheric Agency, the Commission rejected the idea of consolidating all Federal marine and atmospheric functions into a single, massive organization. Some such functions which will remain outside NOAA are integral to the agency which performs them. Although they should be strengthened and should be fully utilized by NOAA, they are best left where they are. The National Aeronantics and Space Administration's (NASA) oceanograpliy-from-space program and the Atomic Energy Commission's (AEC) various marine-related nuclear energy programs are examples, as are the strong marine programs of the Navy, the Corps of Engineers, the National Science Foundation, and the marinerelated watel management programs of the Department of the Interior.

Nonetheless, the size and scope of the program recommended by the Commission to be conducted by NOAA are such as to require that NOAA, at least initially, be an independent agency reporting directly to the President, rather than an agency of one of the existing departments. Especially in getting a major and diverse effort underway, 


\section{Proposed Make-Up of the National Oceanic and Atmospheric Agency}

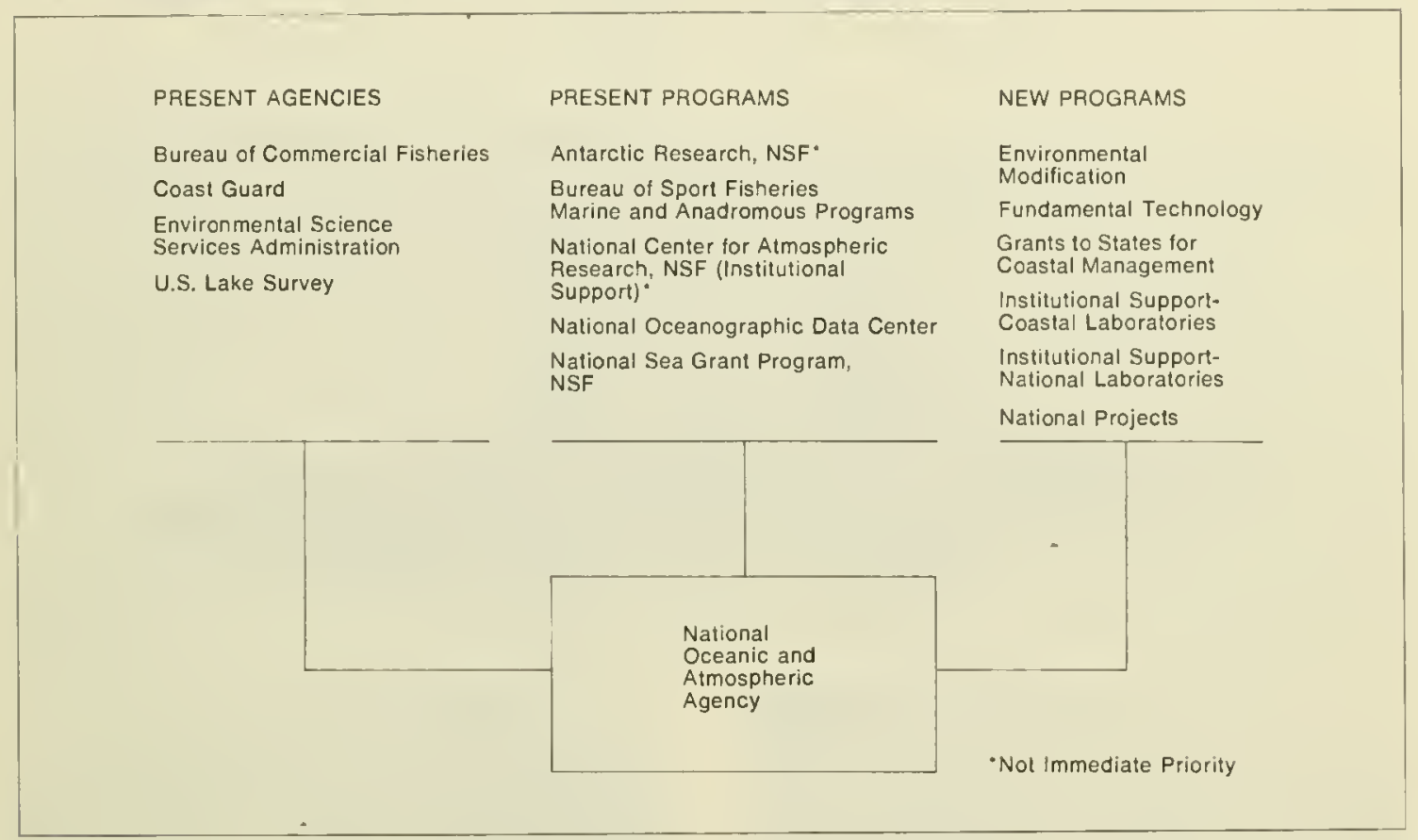

the case for independent status is compelling. In independent agency can bring a freshness of outlook and freedom of action difficult to achieve within an existing department. Its greater public visibility would draw stronger public interest and support. The head of an independent agency would be better able to organize the agency's activities to achieve the multiple purposes of a nutional ocean program than would an officer of a larger organization in which other interests are represented and perhajs dominant. He also would be farorably positioned to assist the President in the coordination of those technical and operational activities of other Federal agencies which relate directly to the marine mission. Furthermore, no existing department now has sufficiently broad responsibilities to embrace the full scope of functions proposed for NOA. $\mathrm{A}$ or to accommodate all of the organizations which the Commission believes should be brought into the new aurency.

The Commission recommends that the National Oceanic and Atmospheric Agency be established as an independent agency reporting directly to the President.

I basic consideration in any current reorganization is to regard the formation of a new agency as a step in a building process. The action must be adequate to the job that needs to be done in the oceans and the atmosphere. Howerer, it need not be regarded as the ultimate answer but rather as a step in an orderly progression of actions to achieve more effective organization of the Executive Branch. It such time as the departmental structure of the Federal Government may be changed, it may then be de- 
The Nation's ocean program requires adequate scagoing capability. and the new ageney will bring together the ships of Coast Guard, ESSA, and BCP into a fert of some 320 seagoing vessels, ineluding the high enduranee Coust Guard cutfer Dallas and ESSA's research ship (lceanographer, fitted with a woll extending from her maindeck habatory down through the hull.

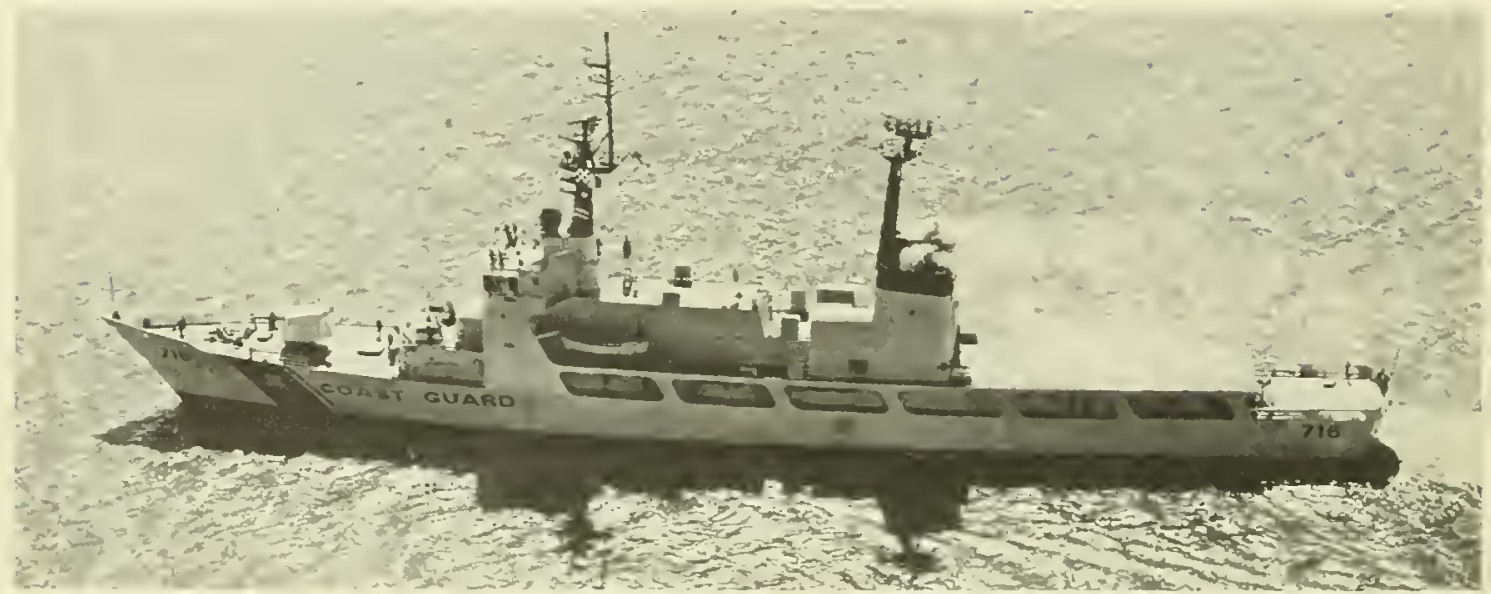

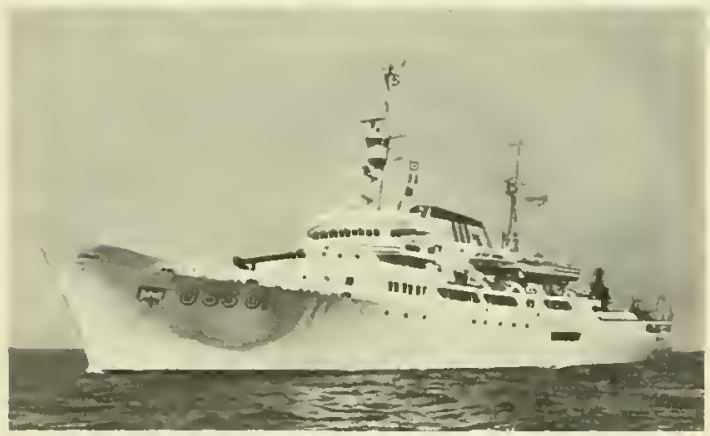

sirable to bring NOAL into some larger grouping of achinistrative fumctions.

\section{Capabilities of the New Agency}

Combining the Environmental Science Services Administration (ESSA), the T.S. Coast Guard (USCG), and the Bureau of Commercial Fisheries (BCF) in the $\mathrm{Na}$ tional Ocennic and Atmospheric Agency will bring togrether in the new agency about 55,000 enployees. About one-fifth will be highly trained professionals and two-fifths will be specially trained technicians. This total complement will constitute the base for a major,

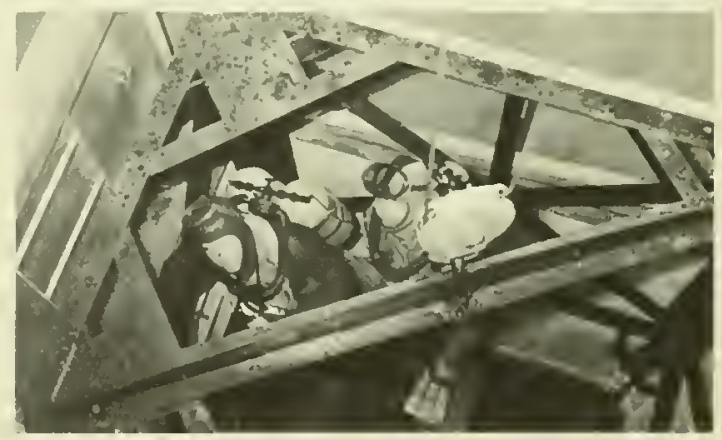

viable Government agency. The skills represented will ensure an appropliate response to the demands of the Nation's marine objectives, bringing to bear the scientific disciplines and other specialized knowledge required to initiate a diverse, broad-gauged effort.

The new agency also will combine the fleets now operated by ESSA, USCG, and BCF, a total of 320 seagoing vessels. It will be able to merge the systems for collection of marine and atmospheric data, thereby reducing the costs of collection. It will be able to facilitate the application of satellite monitoring tech- 
nology to environmental and marine resources problems.

However, going down to the sea in ships is not enough. The Inited States must be able to operate in the ocean's third dimension. The very impressive surfice fleet must be complemented with the new undersea capability that is being dereloped.

Combining the I'.S. Coast Guard, the U.S. Lake Survey, and ISAS aircraft will provide ail capability to measure oceanographic changes and conduct linge-scale weather modification experiments. It will also result in more efficient operational employment of aircraft.

Environmental monitoring activities of ESSA, the Const Guard, and BCF can be merged into a mified system. ESSA's national weather records, geophysical data, and aeronomy data centers, and the National Oceanographic Data Center will be consolidated in one network of environmental data storage and retrieval facilities.

All NOA A marine and atmospheric activities will benefit from the Coast Guard's logistic capabilities and its worldwide network of supply depots, shipyards, marine inspection, and LORAN facilities.

NOAd's research arm will be a major scientific establishment comprising BCF"s 15 marine biology laboratories and 6 technology laboratories, BSFIr's 5 coastal laboratories, and EASA's 12 physical envirommental science labolatories. NOA A's resulting research rapabilities and facilities will be global and applicable to any environment above, on, and below the planet's oceans. The potential quality of its research will be enhanced by the improved communications between the professionals trained in the marine and atmospheric science disciplines.

The new agency will be equipped to proride a broad range of important environmental, technological, safety, and other services to marine industry. It will draw on industry by contracting with industry for the rlevelopment of technology. The contract system has proved to be a most effective way to bring new technology into practical use. The new agency will have a base on which to build sufficient in-house capability to give proper guidance to technological development. It will be in a position to utilize effectively the NASA, AEC, and Navy laboratories through various cooperative arrangements.

Transfer of the National Sea Grant Program to NOA will bring the new agency into immediate touch with a variety of multidisciplinary marine research programs and educational activities, several of which inrolve partnerships between industry and academic institutions. This transfer will facilitate NOAA's task in helping to build the needed Coastal Zone Laboratories. It will give NOAA access to the academic community.

NOA. will be in a strong position to assist the States in managing their coastal waters. It will be able to provide scientific and technical support for this purpose as well as financial assistance to State Coastal Zone Authorities. Additionally. NOAA will be a focal point for marshaling all the resources of the Federal Government in aid of coastal zone objectives.

NOAA will have the ability to participate in plamning I.S. participation in international marine and atmospheric attairs. It will be a central point on which the Department of State can clraw for the scientific and technical advice it needs in this international area.

In sum, NOAA will have the competence, the facilities, and the size to carry out and develop further the mational ocean program.

The Commission has not suggested how the National Oceanic and Atmospheric Agency 
should be organized internally. If its full potential is to be realized, its head will need to weld the constituent units brought into the new structure into a single, functioning whole. This task will be accomplished only by a superb manager who knows the myriad problems and interrelationships of sea programs and who appreciates NOAA's potential to advance man's mastery of the seas.

\section{Considerations Relevant to the Recom- mended Agency Transfers}

A proposal to reorganize the Federal Gorernment should not be made lightly. Inevitably for a time, it will upset existing programs and personnel. And it is difficult to be certain that any particular proposal will provide the best way to accomplish desired ends. Proponents of such proposals, therefore, should carry a burden of justification. The Commission sets forth below certain considerations which led to its principal conclusions.

\section{Coast Guard}

The most difficult question faced by the Commission in design of a plan of organization was whether to recommend the transfer of the Coast Guard from the newly formed Department of Transportation to NOAA.

The Coast Guard Today The Coast Guard now has the duty

- To enforce or assist in the enforcement of all applicable Federal laws upon the high seas and waters subject to the jurisdiction of the United States

- To administer all Federal laws regarding safety of life and property on the high seas and on waters subject to the jurisdiction of the United States, except those laws specifically entrusted to some other Federal agency

- To develop, establish, maintain, operate, and conduct, with due regard for the re-
Within NOAA, the Coast Guardwhieh presenlly is engaged in such diversified work as the international iee patrol, polar research, search and reseue, law enforeement, and inilitary assignments abroadwould contribute to a civil sea service of a size, stature, and professional eompctence worthy of the rorld's leading sea nation.
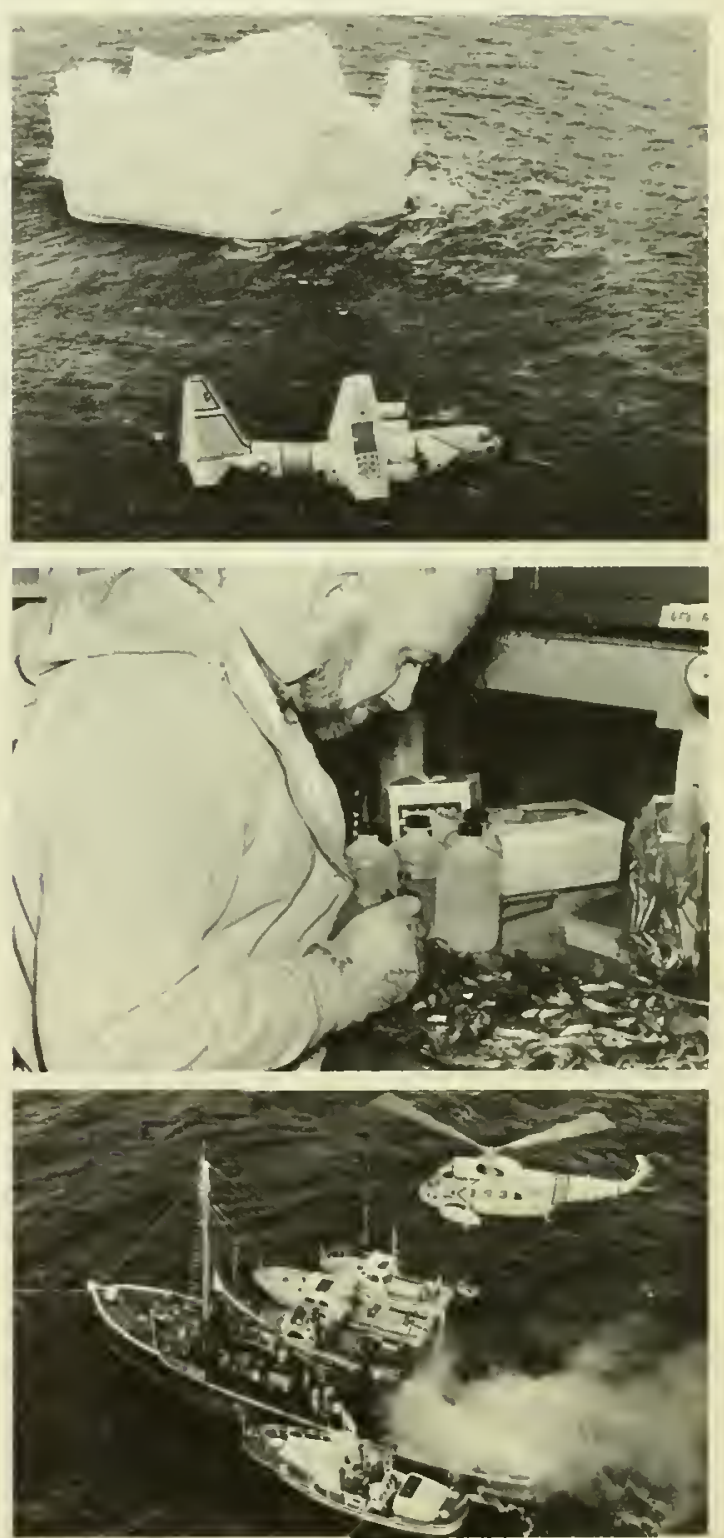

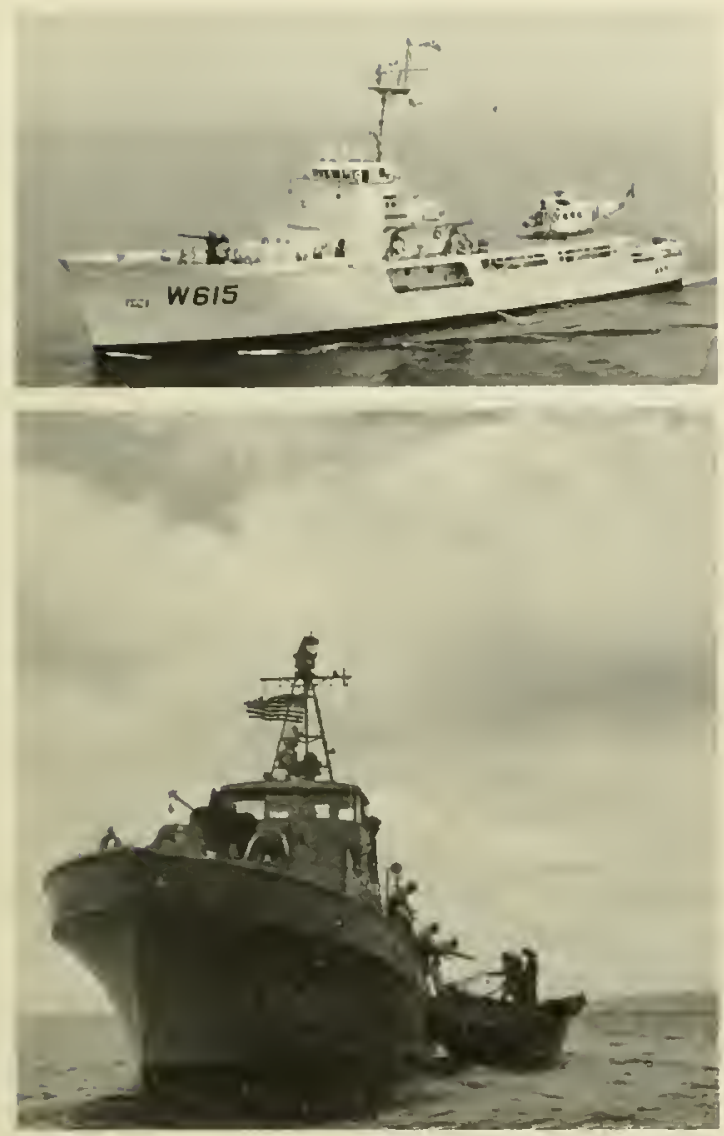

quirements of national defense, aids to maritime navigation, ocean stations, icebreaking facilities, oceanographic research, and rescue facilities for the promotion of safety on and over the high seas and waters subject to the jurisdiction of the United States

- To maintain a state of readiness to function as a specialized service in the Navy in time of war.

An analysis of Coast Guard activity prepared for the Commission indicates that of its program funding 70 per cent is related to multipurpose search and rescue, na vigational, port security, and enforcement activities: 13 per cent to oceanography, meteorology, icebreaking, and other marine sciences; 13 per cent to military preparedness activities; and + per cent to merchant marine inspection and safety. Thus, although most Coast Guard activities relate to transportation, they are similarly related to other uses of the seas. Search and rescue functions, which require 35 per cent of total Coast Guard funding, are required most commonly in support of recreational boating. Provision of aids to navigation, which requires 28 per cent of the agency's budget, is critical to the whole span of marine activities. The law enforcement activities, 7 per cent of the budget, inchude enforcement of fisheries and recreational boating laws as well as port security. Only in merchant marine safety and inspection are tasks solely related to transportation.

The Coast Guard's tremendous physical and manpower resources-a complement of approximately 5,400 officers and 31,000 enlisted men supported by 5,900 civil service personnel-are at the disposal of many kinds of users, responding to routine needs and grave emergencies with a high and admirable professionalism. In the broad and often dangerous reaches of the sea, the Coast Guard does just about everything but guard the coast in the military sense. In a wider sense, the Coast Guard is indeed the Nation's guardian against the hazards of marine operations, serving the entire marine community, from swimmers to petroleum explorers, in so many ways that it often is impossible to define the proportion of Coast Guard effort attributable to any one category of needs. In fact, a principal characteristic of the Coast Guard's ressel and shore station operations is their multipurpose nature. A single Coast Guard vessel may tend buoys, enforce fisheries and pollution laws, search for lost pleasure boaters, rescue endangered fishermen and their vessels, conduct oceanographic investigations, or perform other services, all within a single year. 
At present, the Coast Guard is considered one of the armed services and would be placed under the U.S. Nary in case of major armed conflict. Certain Coast Guard ships are today attached to the Nary in Vietnam. There are indications that the role of the Coast Guard in national clefense is changing, accelerated by the glowing sophistication of military operations and weapons technology. The Vietnam experience has shown that Coast Guard elements can be detached for special service without placing the entire agency in full wartime status. Careful study is meeded, because the changing relationship of the Coast Guard to national defense requirements should be reflected in its internal organization and mission.

The charactes of the Coast Guard itself is changing under the pressure of growing uses of the sea. The needs of marine nsers in addition to those of the merchant marine often strain facilities. Offshore mineral operations pose new requirements and new hazards. The tremendous growth of marine recreation has created safety and enforcement problems for the Coast Guard of a magnitude unforeseen a decade ago. Increased oceanographic responsibilities from the Arctic Ocean to the shores of Antarctica are adding still a new dimension.

\section{The Coast Guard Role in a National Ocean}

Program The Commission believes that changes in the Coast Gnard and its mission should be encomraged and accelerated by bringing it within the framework of the national ocean program to be led by NOAA. In our view, the Coast Guard represents an enormously raluable national marine resource that is at present underutilized because of traditional constraints on its mission and lack of a propes milieu for its operations. Although it is a uniformed service, the Coast Guard's services are preponderantly civil in character, and it provides an established national sea service of great potential value for a major national ocean program.

The Coast Guard is moving in the direction of increasing its oceanographic competence; this would be accelerated greatly by placing the ageney in an organization devoted to marine science, technology, and service. Within NOAA, the Coast Guard would be directly supported by a broadly based scientific and technical program which would be of great assistance to the Coast Guard in modernizing its own technical services. The basic point is that within NOAA the Coast Guard can be used to a much greater degree in a more broadly gauged role than is possible within a solely transportation context and that this can be achieved without curtailing its important transport-related functions.

The transfer of the Coast Guard to NOAA would also benefit NOAA greatly. Largescale scientific investigations could be supported by the ships, planes, and other facilities of the Coast Guard. Location of marine resources could be assisted by instrumentation on board its ships and by precise navigational aids. Tests of ocean technology and marine and atmospheric monitoring and prediction programs could utilize the Coast Guard capabilities. There could be better utilization of ship facilities in mapping, charting, and other technical services.

NOAA must have education and training facilities for orientation programs, multidisciplinary courses, and seminars for agency executive personnel, contractors, and grantees. Under NOAA, Coast Guard Academy functions could be expanded to serve the need for the professional orientation and training of those with critical roles in managing the national ocean program. Conduct of such activities on the Academy's campus would also offer many opportunities for broadening and enriching its basic program of training career officers.

The advantages of placing the Coast 
Guard within NOAd could be fully realized only by a real merger. 'The fact that the Coast Guard is a uniformed corps does not pose musurnountable difficulties. 'The Coast Guard's miformed officers would benefit from the expanded opportunities that operations under NOA t would offer.

\section{Fisheries Programs, Department of the Interior}

The Federal Govermment's support of marine living resource development is at present concentrated mostly in the Bureaus of Commercial Fisheries ( $\mathrm{BCF}$ ) and Sport Fisheries and Wildlife (BSFW) of the Department of the Interior. The National sea Grant Program sponsors some applied fisheries research. BCF's programs can be broadly categorized as:

- Financial and technical assistance to industry

- Biological research on individual species of fish.

Its industry assistance activities include financial aid, technical assistance, haresting studies and techniques, and economic analysis. Its biological research includes studies of marine finfish and shellfish and habitat investigations. The Bureau's annual budget of approximately $\$ 50$ million is divided about equally between industry assistance and biologrical research.

The Bureau of Sport Fisheries and Wildlife is a larger organization responsible for laboratory and field investigations to develop, manage, and maintain a national system of fish hatcheries and wildlife refuges; regulate the taking of migratory birds and game; and develop a national program to provide public opportunities to understand, appreciate, and use fish and wildlife resources. The empluasis on wildlife conservation is particularly pronounced in the programs of assist- ance to the States, which include a small program of matching grants to the States for approved anadromous fishery projects. There is an annual expenditure of only about $\$ 900,000$ for in-liouse biolorical research related to marine sport fish species.

The marine components of other Department of the Interior programs are relatively minor extensions of activities oriented to the Nation's interior. In contrast, BCF's interior interests are concentrated upon a handful of fresh water species and are minor adjuncts to its essential salt water orientation.

The rehabilitation of $\mathrm{C}$.S. fisheries, which is a major Congressional objective, depends upon good sea science and new, improved marine technology to define, locate, manage, and harrest the living resources of the sea. Fisheries research involves physical and chemical oceanography and marine geology and biology. Modern marine technology, including adranced instrumentation, deep sulbmersibles, and underwater habitats must be used to adrance fisheries research.

In Chapter $t$, the Commission proposed a number of important actions to rehabilitate
A BCF lagging team eollects menhaden samples in waters off Torll Carolina. The proposed transfer of eommercial and related marine fishing functions from the Department of the Interior to NOAA reognizes the need for extensite occan capabilities in developing the living resourees of the sea.

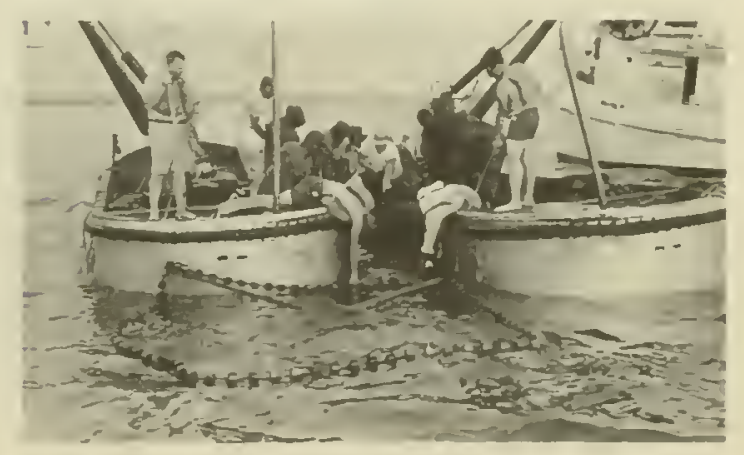


the U.S. fisheries. The many-sided aspects of these proposals require that they be concentrated within NOAA.

The Commission concludes that the Federal programs relating to marine and anadromous fisheries should be managed within a single administrative structure, as was the situation prior to the creation of the separate bureaus for commercial and sport fish in 1956. The separation has created more problems than it las solved. Integrated plans are now necessary to save some species threatened with decline. Both sport and commercial fishing interests should participate in research and management plans. The combination of marine commercial and sport fishing functions in NOAA will best accomplish these objectives.

Commercial fishing sometimes conflicts with sport fishing. Some species are valued by both groups, but other species are of either sport or commercial interest. Sport fishermen become commercial fishermen when they

ESSA is much like the Coast Guard in providing a great varicty of services-like tide mcasurcments, mapping and charting, oceanographic data collection, and ucather forecasts - to the gencral public and specialized uscrs. At lower right, a weather balloon is inflated at sca; second from right, a large-volume water sampler is recovercd aboard ship.
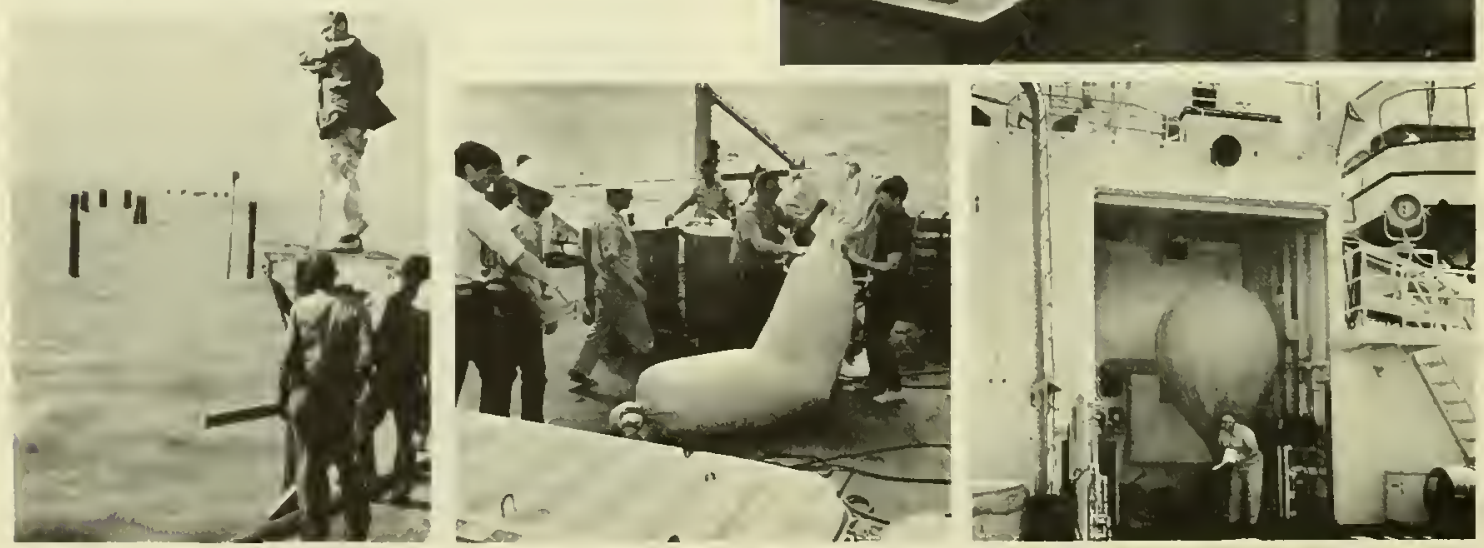

sell some or all of a catch to dealers or restaurants.

BSFW laboratories for study of marine and anadromous fisheries are separate from its other facilities and conduct much valuable research. An excellent program conducted by BSFIV's Sandy Hook Marine Laboratory charts the location of species by monthly temperature variations along the Atlantic coast, relying on the Coast Guard to provide temperature monitoring and photography aircraft. Such research has obvious value to all aspects of living resources development.

Aquacultural research for both plant and animal species now is conducted or sponsored by BCF and the National Sea Grant Program. Close cooperation has prevented duplication, but with the two programs under single management in NOAA, coordinated planning can take place to develop the full potential aquaculture offers.

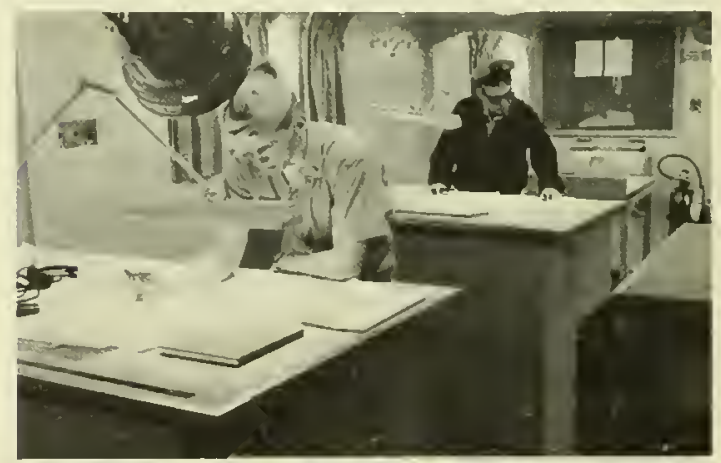




\section{Environmental Science Services Administration}

The formation of ESSA brought under single management the U.S. Weather Bureau, the U.S. Coast and Geodetic Survey, and the Central Radio Propagation Laboratory of the National Bureau of Standards. In this way, a consolidation was effected of the U.S. Department of commerce's programs concerned with the description, understanding, and prediction of the state of the oceans and atmosphere and the size and shape of the earth.

Like the Coast Guard, ESSA provides a great variety of services to the general public and specialized users. ESSA conducts both research and technical service programs to provide:

- Weather and marine forecasts and warnings

- River and flood forecasts and warnings

- Earth deseription, mapping, and charting

- Marine description, mapping, and charting

- Telecommunications and space services

- A national elurironmental satellite system.

ESSA also performs work for other agencies and non-Federal organizations on a reimbursable basis and has well-established relationships with NASA, the Department of Defense, and other agencies. It has important land responsibilities stemming from its role as the central weather, flood, seismological, geodetic, and geomagnetic agency.

ESSA would provide NOAA with a broad capability in atmospheric, oceanic, and other greophysical acrivities. The agency maintains a close working relationship with its counterpart organizations in other nations of the world and represents the Lnited States in the World Meteorological Organization, which coordinates all of the atmospheric and many of the marine forecasting services for the entire world.
Under the Commission's proposed organization, ESSA would provide the base for conclucting ocean surveys to inap and chart the sea. By consolidation of several existing fleets of ships and aircraft, NOAA could expand its essential charting and mapping services with great efficiency in use of facilities and manpower. NOAA's obligation to surrey the geology of the seabed, as outlined in Chapter 4, would fit rery well with ESSA's present responsibilities in geodesy, seismol. ogy, geomagnetics, and geopliysics.

Joining ESSA's monitoring and prediction capabilities with those of the U.S. Coast Guard and the Bureau of Commercial Fisheries would enable the Nation to develop and manage rationally the National Environmental Monitoring and Prediction System, as recommended by the Commission.

\section{U.S. Lake Survey}

The U.S. Lake Survey of the U.S. Corps of Engineers is concerned with charting and studying the waters of the Great Lakes. It undertakes:

- To prepare and publish navigational charts and related materials

- To study elements affecting lake levels and river flow

- To advise international bodies charged with managing the use of borcler waters

- To conduct scientific investigations of the physical aspects of fresh water

- To compile maps for the Army Map Service.

All these activities, except the last, are confined to the Great Lakes and nearby navigable waters. In brief, the Lake Survey does in the Great Lakes about what ESSA, in part, does in the salt waters. It is a small organization with a large mission.

The Great Lakes need more concentrated attention than the Lake Survey alone can 
provide. The T.S. Coast Guard is active in the Great Lakes, and its resources in the region are much greater than those of the Lake Survey. ESSA and BCF have strong capabilities which should be brought to bear on Great Lakes problems. Combining the eapability of all four under NOAA would permit efficient and expeditions accomplishment of the intensified work warranted by the importance of the Great Lakes as a national resource.

\section{Sea Grant Program}

Under its broad legislative mandate, the National Sea Grant Program has already launched a number of valuable programs in a variety of marine areas. The Commission has recommencled that the Sea Grant Program be the rehicle to support the Coastal Zone Laboratories. It conld be the means of support of the recommended UniversityNational Laboratories. The full role of the Sea Grant Program will have to be evaluated by the new agency.

The transfer of the Sea Grant Program to NOAA would not impair the National Science Foundation's (NSF) capabilities to perform its normal functions of research and science education support. However, it would enable NOAA in conjunction with its other functions to sponsor a wide range of highly useful applied marine science and training activities in cooperation with unirersities and industry.

\section{Institutional Funding for University- National Laboratories}

At the present time, no system exists to assure the continuity of institutional support for the Nation's major marine science laboratories. Informally, NSF and the Nary's Office of Naval Research (ONR) have assumed a commitment to assist in providing the funds necessary for their operation. In
Chapter 2 the Commission has recommended adoption of a more systematic way to support university laboratories at levels appropriate to the needs of big science and to accelerate research on the problems of the coastal zone. Proposals for UniversityNational Laboratories and Coastal Zone Laboratories call upon NOAd to support the acquisition and maintenance of major facilities and a core staff. Such institutional funding would be augmented by supplemental grants and contracts for specific projects from any Federal agency or prirate source.

The National Science Foundation bears principal responsibility for university support and should continue to so do through strengthened programs and increased funding. NSF now also provides block funding for oceanographic ressels but, except under the Sea Grant Program, has not otherwise given institutional support for broad marine programs. The Commission would place responsibility for institutional support of University-National Laboratories in NOAd. This should free NSF to use its limited funds to support project research activities.

The Office of Naval Research has also been a major source of support for marine science, and particularly for the large ocean laboratories. Like NSF, ONR has supported ships and operations (though not with block funding) and has assisted mniversities to acquire research submersibles and special research platforms. With institutional support of the University-National Laboratories provided by NOAA, ONR could achieve an even greater diversity in its marine sciences program. NSF and ONR support of individual investigators and specific projects would, of course, continue, and the Commission urges that there be increased funding for such support.

The Commission is of the view that NOAA also should be assigned Federal responsi- 
bility to plan and coordinate large-scale oceanic scientific investigatious, such as past international programs involving U.S. participation in the Tropical Atlantic and Indian Ocean expeditions and U.S. participation in the proposed International Decade of Ocean Exploration.

\section{National Center for Atmospheric Research}

The National Center for Atmospheric Research (NCAR) is a major laboratory operated under a contract with the NSF by a nonprofit corporation representing member universities. The Center has interdisciplinary programs in the atmospheric sciences and provides extensive facilities to support scientific

\section{Prexent National scicnce Foun- dation responsibility for Antarctic rescarch includes support for the rexeareh ressec Eltanin and for specific projects like this submerged, under-ice observatory for the study of uctdell seals.}

investigators. NCAR is an atmospheric science analogy to the University-National Laboratories proposed by the Commission, and transfer of funding responsibility for NCAR from NSF to NOAA would be a logical step once NOAA is firmly established.

\section{Polar Activities}

Programs supported by NSF, Navy, ESSA, and the Coast Guard range literally from pole to pole. Most of the polar scientific programs are directed to marine and atmospheric investigations. It present, only the Antarctic program is formally coordinated within the Federal structure, but steps are underway to establish a somewhat comparable national effort in the Arctic region.

NSF now has responsibility for the support and coordination of Antarctic research. It supports two oceanographic research vessels in Antarctic waters as part of this program. The Nary handles logistics for Antarctic operations, with some assistance

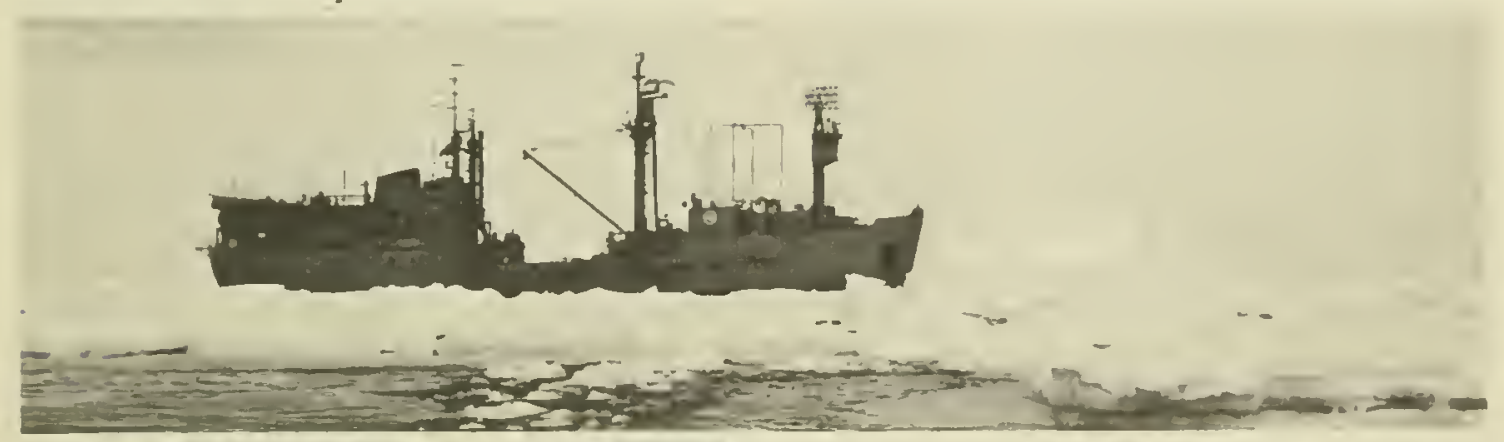


from the Coast Guard. Federal scientific personnel for Antarctic programs are drawn principally from ESSA, Navy, and the Geological Survey, although many other agencies are also involved.

Arctic programs are chiefly the responsibility of the Coast Guard and the Department of Defense. The Coast Guard supports Arctic investigations and has international responsibility for the Iceberg Patrol in the North Atlantic; Navy submarines and surface craft have also conducted extensive Aretic investigations. Additionally, ESSA operates weather and geophysical observing programs, as well as extensive ocean mapping and charting activities.

The Commission believes that the civil aspects of polar scientific research and support would benefit from consolidation in a single agency. To achieve the consolidation within NOAA would free NSF from concern with logistic matters and release the Navy from the burden of supporting a civil program. However, it would take time for the Coast Guard to develop the logistic support capability now provided by the Nary in Antaretica, and the Commission does not believe that the consolidation of polar research activities is an immediate need of the same nrgency as the other elements of its recommended organization plan.

\section{Overseeing the National Program}

The national effort to open up the marine frontier requires informed and firm leadership at the top levels of the Executive Branch to accomplish the following objectives:

- Planning-Articulato objectives and develop plans for their orderly attainment, including the delineation of responsibility among the various participants

- Advocacy-Promote action to advance the national ocean program

- Evaluation-Assess the progress of the
Nation in meeting objectives and inform the Nation thereof

- Coordination-Coordinate policies and basic procedures to assure consistent actions in meeting common objectives

- Communication - Facilitate cooperation among the various marine interests, including groups within the Federal Government, by ensuring effective communication.

It would not be sound to place all the above functions in any single organization. Some may be handled best by an operating agency which is directly involved in the marine program and can draw on its technical staff. Others need to be carried out through advisory machinery, drawing upon broad elements of the marine community. Still others require the broad perspective that can best be provided by staff agencies within the Executive Office of the President.

\section{Operational Planning and Coordination}

A principal result of establishing a strong operating agency concerned witl marine activities would be to permit the head of that agency to assume responsibility for interagency planning and coordination, at the direction of the President, in areas closely related to the agency's mission. There is ample precedent for the heads of agencies with broad operating missions to exercise such a lead role within the areas of theil agencies' technical competence. The fields of health services and reactor technology provide examples. In addition, the head of NOAA would naturally assume responsibility for several existing mechanisms for interagency coordination which relate to functions proposed for consolidation into the new agency. One such mechanism is the system for meteorological coordination now lodged by Bureau of the Budget directive with the Secretary of Commerce but delegated to the 
Administrator of ESSA. A second relates to planning the U.S. participation in the World Weather Watch, which also is an ESSA function.

Coordination of Federal coastal activities, now handled through a committee of the $\mathrm{Na}$ tional Council on Marine Resources and Engineering Development, would be a responsibility of the head of NOAA. He also wonld coordinate the use of waters ontside the States' jurisdictions. Such activities would complement those of State Coastal Zone Authorities.

Coordination in matters of this sort requires a strong base of technical cxpertise and extensive staff support. The problems to be resolved, by and large, relate to bureau-level interests. To the extent that more vital agency interests are involved, procedures can be provided to identify selected issues and bring them to higher levels for attention. The prerogitive of heads of agencies to seek the President's counsel and support would be preserved intact.

The Commission recommends that the President vest the head of the National Oceanic and Atmospheric Agency with responsibility for coordinating the planning and execution of Federal civil marine and atmospheric programs closely related to its central functions.

Continuing coordination will be needed also between the civil and military aspects of the Nation's total marine activity. In selected fields, formal provision for coordination of civil-military activities along the lines of those applicable in meteorology also may be appropriate.

\section{National Advisory Committee for the} Oceans

A truly national effort in the oceans requires organizational arrangements for ob- taining information and advice from the broad marine community. Participation by principal elements of the community should be part of the process for formulating major programs and evaluating progress in achieving national objectives in the oceans and atmosphere. An overall assessment of the state of the Nation's marine and atmospheric effort should be furnished biemially to the President and the Congress and should be made public.

The Commission recommends the establishment of a committee, which might be designated the National Advisory Committee for the Oceans (NACO):

- To advise the head of NOAA in carrying out his functions and coordinating responsibilities

- To report to the President and the Congress on the progress of government and private programs in achieving the objectives of the national ocean program.

The Committee should be composed of individuals drawn from outside the Federal Government and should be broadly representative of the Nation's marine and atmospheric interests. The members of NACO, approximating 15 in number, should be appointed by the President with the advice and consent of the Senate.

The Chairman should be designated by the President. Members would serve for fixed overlapping terms and be drawn from States, industry, science, and other appropriate areas.

Each of the principal agencies concerned with marine and atmospheric matters should designate a senior policy official to participate as observer in the work of the Committee. This designation would permit the Conmittee 
to draw on the expert information and views of the agencies without surrendering the independence that an ontside committee can provide.

In riew of the broad mission and coordinating responsibilities proposed for $\mathrm{NOAA}$, the Committee should be administratively attached to that agency.

The Committee should have a small, fulltime staff under a director selected by the chairman with the concurrence of the Committee. In addition to comprehensive biennial reports, the Committee could from time to time submit other reports on specific matters.

A principal function of $\mathrm{NACO}$ would be to provide two-way communication between Federal and non-Federal interests. The establishment of the National Advisory Committee for A lemautics in 1915 was responsive to a similar need to bring together government, industry, and academic experts as the

\section{University marine science programs woull be among the many activities that would benefit by inmproved communication betuecn Federal and non-Federal occan interests through a National Advisory Committee on the Oecans.}

Tnited States entered the aeronatical age. Similarly, the creation of NACO will help assure participation by the entire marine community in a national effort in the oceans.

The Committee would respond to requests for advice from the President, the head of the new marine agency, and others within and outside govermment. The Committee would be expected to assess the performance of the new agency as well as all of other parties participating in the national ocean effort. The Panel on Marine Engineering and 'Technology has suggested a number of specific activities which might be assigned to the committee in Chapter $t$ of its report.

\section{Executive Office of the President}

Establishment of a central marine and atmospheric agency and of a broadly representative advisory committee would go far toward providing the organizational arrangements needed to oversee a national program. However, functions of leadership and control remain that can be exercised only within the President's own office. Presidential staff gromps will, of course, intercede as necessary on the President's behalf to iden-

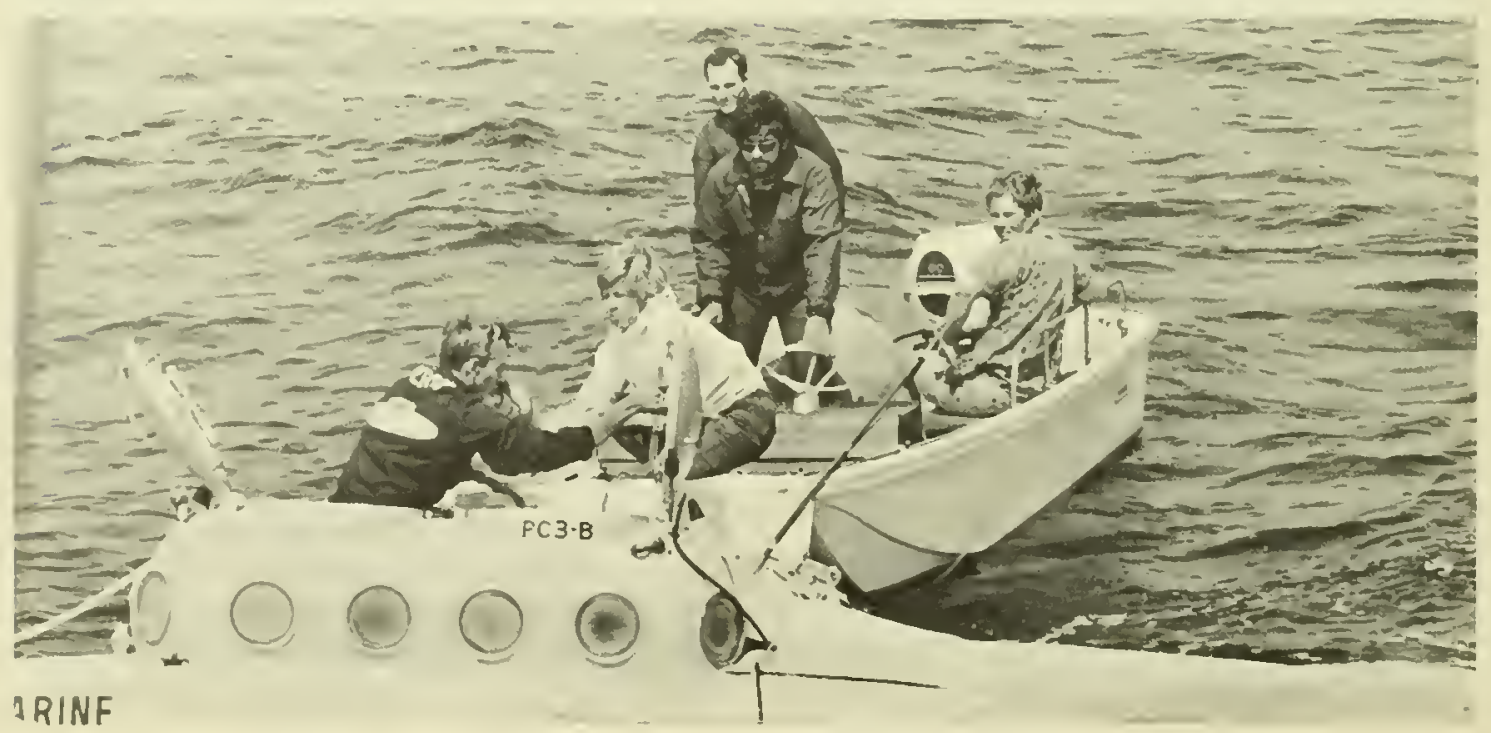


tify problems not being addressed, to mediate issues, and to exercise leverage in getting agrencies to work togrether on matters of common concer'n. 'The marine programs need to be related to other program activities at the Presidential level.

The Marine Resources and Engineering Development Act of 1966 rested continuing responsibility in the President for planning and coordinating Federal marine activities and reporting annually to the Congress on their progress and proposed budgets for the coming year. The Act also created the $\mathrm{Na}$ tional Council on Marine Resources and Engrineering Development to assist him in these tasks.

The National Comncil on Marine Resources and Engineering Development and its staff have responded with vigor and imagination to the challenge of griving coordination and direction to the present fragnented marine activities. Issues have been raised and actions set in motion which would have been delayed or overlooked in the absence of the Council and its capable and dedicated staff.

The Commission recommends that the National Council on Marine Resources and Engineering Development be continued until decisions are reached on the Commission's organization plan.

Upon its formation, NOA , with the $\mathrm{Na}$ tional Advisory Committee on the Oceans, would be assuming many of the Council's present policy initiative, reporting, and coordinating activities. The principal marine agencies would be participating as observers in $\mathrm{NACO}$, and the new marine agency could administratively establish interagency mechanisms to facilitate coordination in matters related to its central functions. The preparation of an anmual report on marine affairs, as required by Public Law 89-454, might either be terminated or delegated by the President to the head of NOAL. Consequently, when NOAA and NACO are established, there should be no further need for an interagency body concemed with marine matters within the Executive Office.

\section{Congressional Oversight}

The dispersion of marine activities within the Executive Branch is reflected in the committee structure of the Congress. Reorganization of Federal agencies to provide coherent focus for marine activities can be successful only if adjustments are made in the jurisdiction of Congressional committees. This was not achieved in the creation of ESS 1 , and the resulting necessity for the agency to report to three separate legislative committees of the Honse of Representatives has complicated development of a balanced program.

Establishment of the proposed marine agency with broad scientific, technological, resource, and service functions shonld lead to adjustments in the jurisdiction of existing Congressional committees. Activities of the new agency now under the cognizance of several committees should, if possible, be the responsibility of a single legislative and appropriation committee in each house.

The delegation of responsibility from the President to the head of the new agency to provide leadership in undertaking a national effort and achiering Govemmentwide coordination wonld be very helpful to the Congress. The head of the agency conld be available to testify on marine and atmospheric matters that extend beyond his own agency's activities. In addition, the periodic report to the Nation by the adrisory committee would provide a vehicle for broad review by the Congress of progress in achieving national objectives. The hearings at- 


\section{Congressional Committee Jurisdiction over Executive Agencies in Marine Science}

\section{HOUSE SUBSTANTIVE COMMITTEES AND SUBCOMMITTEES \\ Armed Services Research \& Development Public Works Rivers \& Harbors}

Merchant Marine and Fisheries Coast Guard, Coast \& Geodetice Survey, \& Navigation Merchant Marine Fish and Wildlife Conservation Oceanography

Interior and Insular Affairs Mines and Mining Public Lands Irrigation \& Reclamation National Parks and Recreation Interior and Foreign Commerce Commerce and Finance Public Health and Safety

Science and Astronautics Science, Research, \& Development

Education and Labor Education

\section{Foreign Affairs}

A Standing Committee

- Subcommittee

\section{EXECUTIVE AGENCY}

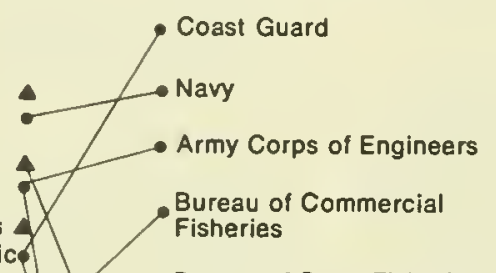

Bureau of Sport Fisheries
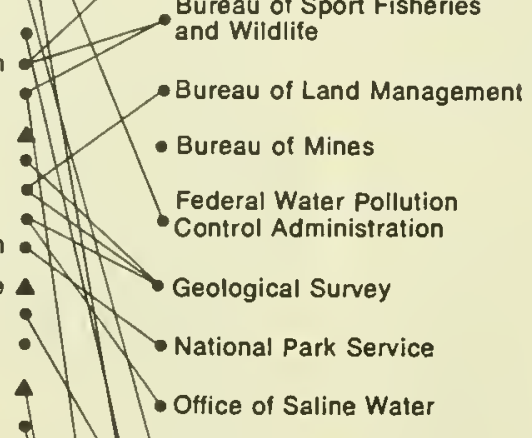

Coast \& Geodetic
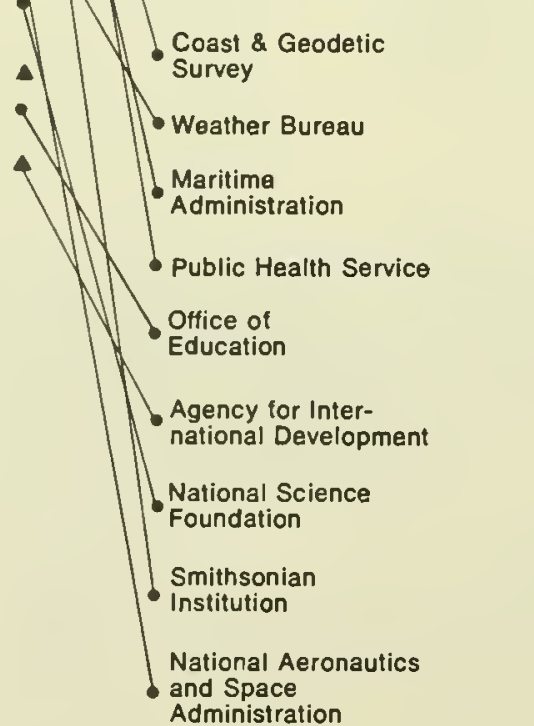

SENATE SUBSTANTIVE COMMITTEES AND SUBCOMMITTEES

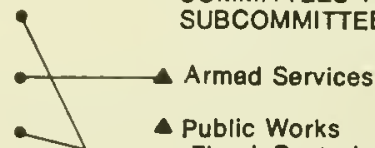

Flood Control-Rivers Harbors

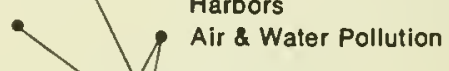

Commerce

20rchant Marine \& Fisheries

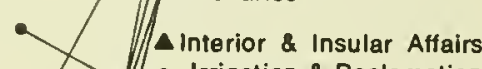

A Interior \& Insular Affairs

Irrigation \& Reclamation

Public Lands

Mining, Materials, \& Fuels

Parks and Recreation

A Rules and Administration Smithsonian

Aeronautics \&

Space Sciences

Labor and Public Welfare Education

- Health

\section{Foreign Relations}

Atomic Energy

Commission

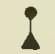

Joint Committee on Atomic Energy 
tendant to such reviews would be expected to develop information and expert views for a number of interested committees of the Congress, both legislative and appropriation.

The Commission suggests that Congress review juristictions of the legislative and appropriation committees in the light of such division of responsibilities for marine activities as may result from reorganization within the Executive Branch.

\section{Conclusion}

The difficulties confronting the Commission in ariving at its organizational recommendations are not unique to marine affairs. Government machinery at all levels is under critical examination. Tre have examined existing Federal machinery in the marine area and have proposed an organization that would, in our judgment, prove adequate to the national ocean task as the Commission has conceived it.

The Commission has been aware that the recommenclation for creation of an independent Federal agency poses problems, but our judgment is that this is the best choice among altelnatives. The alternative route of proposing a grouping within an existing department or agency was carefully considered, but none could accommodate the range and dimensions of programs needed for a concerted attack on the oceans. Piece- meal adjustments are not sufficient. It is necessary to place togrether the central civilian functions under single management in order to have a coherent effort.

The Commission cannot appropriately recommend or even foresee the nature of future hasic reorganizations of the Executive Branch. However, we can perceive the principal alternatives that fice the President and the Congress in considering reorganizations affecting marine activities. The recommendations contained in this chapter are believed to be consistent with any of the several fundamental reolganizations that might evolve over the next several years.

The overriding consideration is that only through creation of a major marine agency with attendant atmospheric responsibilities can a national effort be launched. Even if fiscal constraints require that this effort begin on a modest scale, action to establish the necessary reorganization is warranted to provide the basis for future expansion. Reorganization cannot be a substitute for new programs, but neither can programs be launched with maximum effectiveness through our existing machinery of Government. Because of the importance of the seas to this Nation and the world, our Federal organization of marine affairs must be put in order. 
Chapter 8

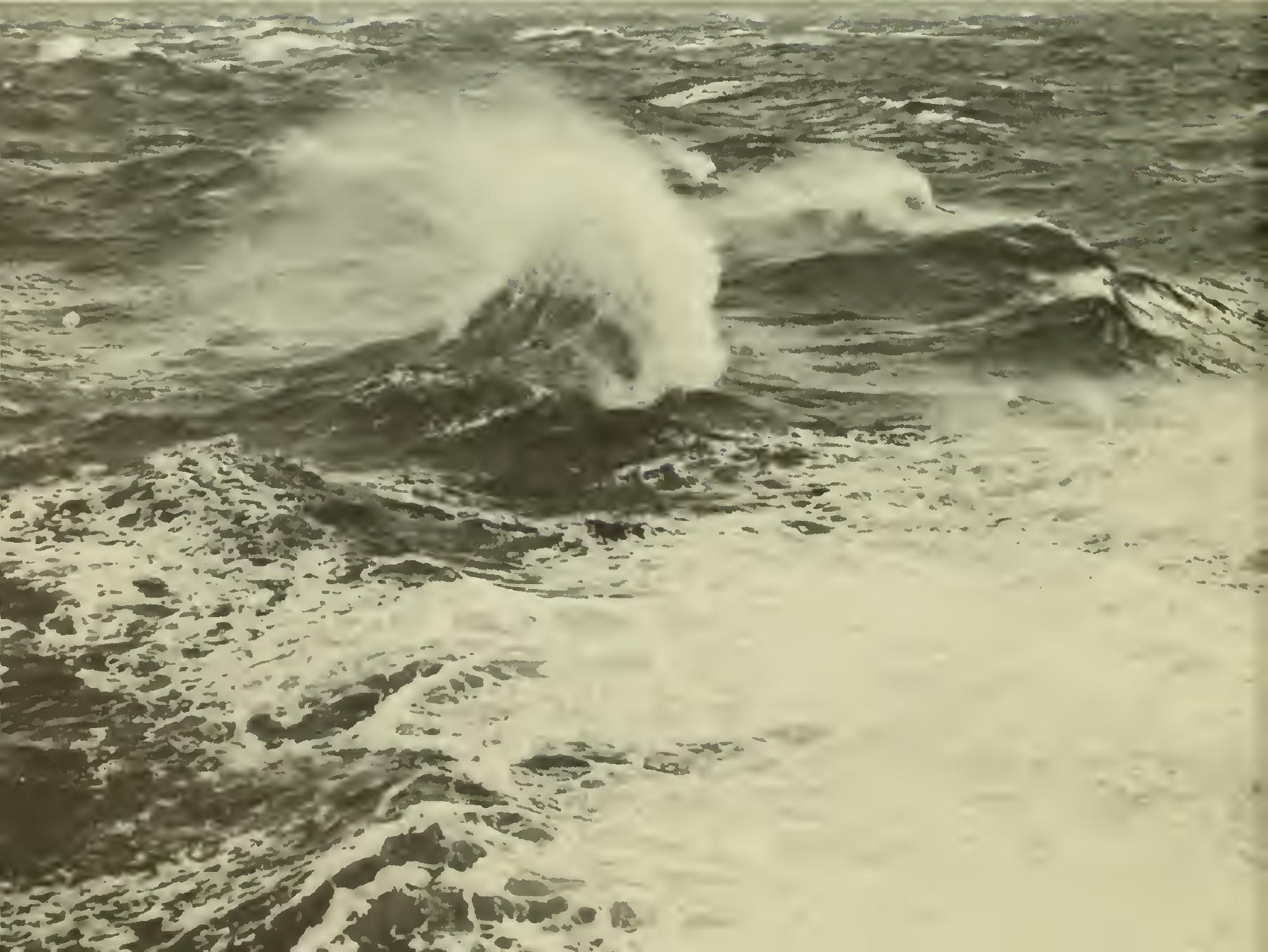




\section{A Financial Plan for Marine Science}

The Commission has not been asked and has not undertaken to judge where a marine program should stand on the list of national spending priorities. This is for the Congress and the President to decide. However, the Congress requested the Commission to propose "an overall plan for an adequate national oceanographic program *** with estimated cost." Although we found it difficult to comply with this mandate, we recognized its importance and have done our best. Cost estimates have been provided throughout our report; this chapter brings the estimates from the previous chapters together into an overall financial plan.

The Commission recognizes the difficulty of planning programs or assuring proper funding levels under a system of annual program justifications and appropriation. In examining the history of Federal support for marine activities, the Commission has been reminded many times of the difficulties caused by substantial changes in appropriations from year to year. In some cases, severe budget cuts for a single year have effectively nullified the value of years of work and expenditure.

To mount the national effort recommended by the Commission will require a buildup over the years of qualified personnel and suitable facilities. The Commission fecls strongly that the buildup should take place at a rate which can be sustained. Attempting too ambitious a start could cause the program to face erratic support in later years.

\section{The Commission's Approach to Cost Estimates}

The cost estimates presented by the Commission are necessarily subject to a number of definitions, assumptions, and limitations; these should be made explicit.
The methods of costing the individual parts of the reconimended program differed widely one from the other. In some cases we have simply identified a desired level of effort. In other cases we have relied on our knowledge of similar projects in Government or industry. Estimates for research support are geared to a large extent to estimates of the scientific man power likely to be available. There is therefore an inevitable uncertainty surrounding the Commission's cost estimates.

The figures prepared by the Commission are presented in terms of constant 1969 dollars and represent the incremental amounts over existing budget levels which appear likely to be required over the next 10 years to carry out the Commission's recommendations.

The Nation is already spending large sums for marine and atmospheric scientific investigations and services and will continue to spend large amounts regardless of the action taken on our report. The Commission has recommended expansion of several programs and initiation of others, but its recommendations also are designed to assure the most efficient use of whatever amounts may become available in the future.

The funding problem for the marine program is quite different from that which accompanied the launching of the space program. The National Aeronautics and Space Administration was entrusted with the organization of a new program which had very few antecedents and which was placed on a timetable requiring a very rapid buildup of scientific and engineering effort. The objective of the Commission's proposal, in contrast, is to emphasize and rationalize programs which, for the most part, are already in existence and which are already returning benefits to our people.

Furthermore, the programs which would be brought within NOAA already are orow- 
ing at a rate of roughly 6 per cent per year. During the past 5 years the budget for Coast Guard operations has increased an average of 6 per cent annually, excluding funds to meet rising cost and pay levels; ESSA's operating budget has increased an average of 8 per cent; $\mathrm{BCF}$, an average of 5 per cent. The expansion in funding proposed by the Commission is not greatly in excess of these recent growth rates. Also, changing conditions permit some shifting in the internal programming of agency funds. To some extent the new programs recommended by the Commission may be able to be financed through curtailment of activities which are no longer necessary.

The Commission wishes to emphasize that its estimates are keyed only to the costs of implementing the specific recommendations advanced in its report. It should be understood that there are funding needs for essential parts of a total national effort in oceanic, atmospheric, and related activities for which estimates have not been included in the Commission's totals. For example, the Commission is aware that many agencies of the Federal Government have serious requirements for funding to maintain such ongoing programs as for replacement of obsolete ships, facilities, and equipment of the Coast Guard, ESSA, and BCF, but we have not felt that in this area we could improve upon the projections included in existing agency plans.

As further examples, there are such programs as the water pollution control activities of FWPCA, the dredging activities of the Corps of Engineers, and the weather service programs of ESSA which are well established, of reasonable magnitude, and respond to a variety of needs. Although we have not attempted to provide estimates for strengthening such activities, we recognize that there will be substantial additional funding requirements. 'The fact that such costs have not been included must not be taken to imply that these needs are regarded by the Commission as having a lesser priority.

In particular, it should be noted that the estimates for Department of Defense progranis have been provided only for selected activities which relate intimately to civil functions. The Commission has assumed that Defense support for marine science and technology will continue to expand in response to military needs and has not attempted to project the costs which may be incurred in carrying forward their marine-related military programs. Funds for such other special-purpose activities as the shellfish sanitation program of the Public Health Service and the Atomic Energy Commission's studies of the use of nuclear technology for harbor excavations have also been excluded from the estimates.

Finally, the Commission notes that it has addressed only Federa! expenditures. Commensurate investment will be required of industry to build the systems needed to harvest the sea's resources, and State and local govermments will need to commit additional funds to meet their responsibilities under the Commission's recommended plan. The Commission expects that action at the Federal level to implement its recommendations will, however, stinulate additional private in restment and the necessary State and local government efforts.

\section{Present Funding Levels}

The Commission encountered considerable difficulty in determining the present level of effort in marine science, engineering, and resource development. One problem is that the definitions of these terms vary from person to person and agency to agency. Another is that the budget information from the agencies often does not show the distinction between 
marine and nommarine activities, let alone the distinctions among fields of marine endeavol. Worse still, the situation is unstabledefinitions and budget classifications change somewhat each year. No one description of the field could be comprehensive or agreed to by all parties.

The National Council on Marine Resources and Engineering Development, through its :11nual reports and its efforts at coordination, has made an admirable effort to bring order to the situation. In determining the budget figures for the present level of effort, the Commission turned first to the Council for up-to-date information.

'To comply' with its separate statutory mandate, however, the Commission adopted its own definitions and categorizations, and they differed somewhat from those used by the Council. A detailed rendering of the differ- ences would serve more to confuse than illuminate, but in general, the Commission has given less consideration to matters relating to national security and ocean transportation, and it has given much broader consideration to matters relating to enviroumental monitoring and prediction, activities in the coastal zone, and marine technical services.

On net, the level of Federal spending for programs now in existence which fall within the Commission's frame of reference is substantially larger than the $\$ 516$ million program estimated by the National Council in its 1968 report. The Council's figures covered a narrower base; whereas over lıalf of the expenditures reported by the Council are made by the Department of Defense, the activities which provide the base for the Commission's projections are almost wholly civil in nature.

\section{Comparison of Present and Recommended Programs}

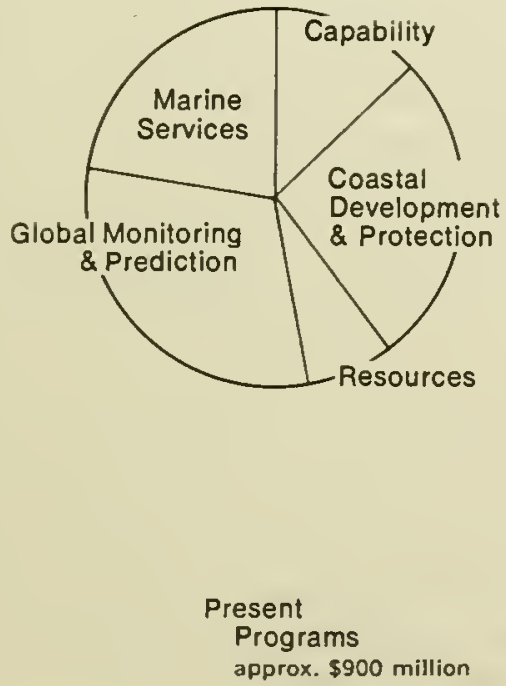

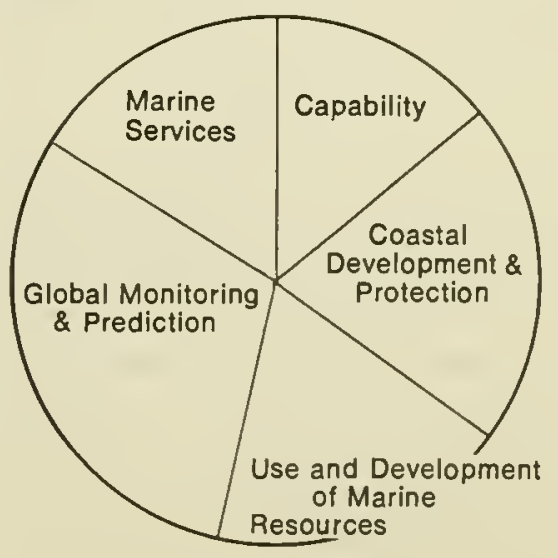

Anticipated 1980 Program

approx. $\$ 1,800$ million 


\section{The Commission's Estimates: An Overview}

Programs recommended by the Commis. sion are estimated to involve an annual expenditure growing by 1980 to roughly $\$ 1$ billion per year orer and above current program levels. This approximate doubling of present efforts could be achieved by maintaining a $i$ to 10 per cent rate of growth over the 10-year period, depending mpon the size of the expenditure base upon which the proposed program may be considered to be built. Howerer, the Commission's estimates assume a more rapid growth early in the coming decade and a leveling off of expenditure in later years as the program reaches maturity and overcomes the current backlog of unmet needs.

Tables 8-1 and 8-2 show two different perspectives on the estimated costs of the Commission's recommendations. Table $8-1$ shows the expenditures classified by major program area; it is simply a condensation of the five tables presented in the earlier chapters. Table 8-2 presents the same expenditures recategorized by the type of activity or function which must be performed in carrying ont the national program.

Each estimate must be viewed in the context of the entire marine program, for there are many interrelationships among its several elements. Land acquisition unguided by a rational management system will not yield full benefits; expanded research programs must be accompanied by expanded systems for processing and disseminating information; major projects will proceed more smoothly if deliberate provision is made for fundamental technologieal adrances. The Commission has considered this problem of internal balance quite carefully; it is one reason why many of the estimates are projected as "levels of effort" rather than as itemized cost calculations. Thus, although the figures shown in this report are not individually definitive, we believe they are appropriately related to one another.

The early phases of the program advanced by the Commission will concent rate on meeting immediate needs and on providing the capital facilities and basic data needed to provicte a sound foundation for future expansion. Thus, expenses for such activities as the coastal and estuarine inventories, the National Test Facilities Project, equipping marine laboratories, and the near-term improvements in environmental monitoring systems are needed early in the program and shonld terminate or decline after the first few years, while the funds for research and exploration projects, manpower development, and data services will have to keep expanding as our involvement with the sea increases. A few programs, like the mapping of the continental shelves and the acquisition of land in the coastal zone, represent a conscious decision now to spread a large expenditure evenly over an extended time period.

The nature of the Commission's cost estimates has not permitted a fully accurate differentiation between capital and operating expenses, and indeed, for many programs this distinction is rery difficult to draw. On an overall basis, capital outlays represent about one-fourth of the total estimated expenditure and include funds for assisting States to acquire coastal wetlands as well as for acquisition of laboratory facilities, ship construction, and the capital component of recommended Natioual Projects. Capital outlays constitute a larger portion of the overall program in the carly years, whereas funds for research and exploration, fundamental and applied technology, surreys, and laboratory and facility operations grow progressively throughout the decade. 


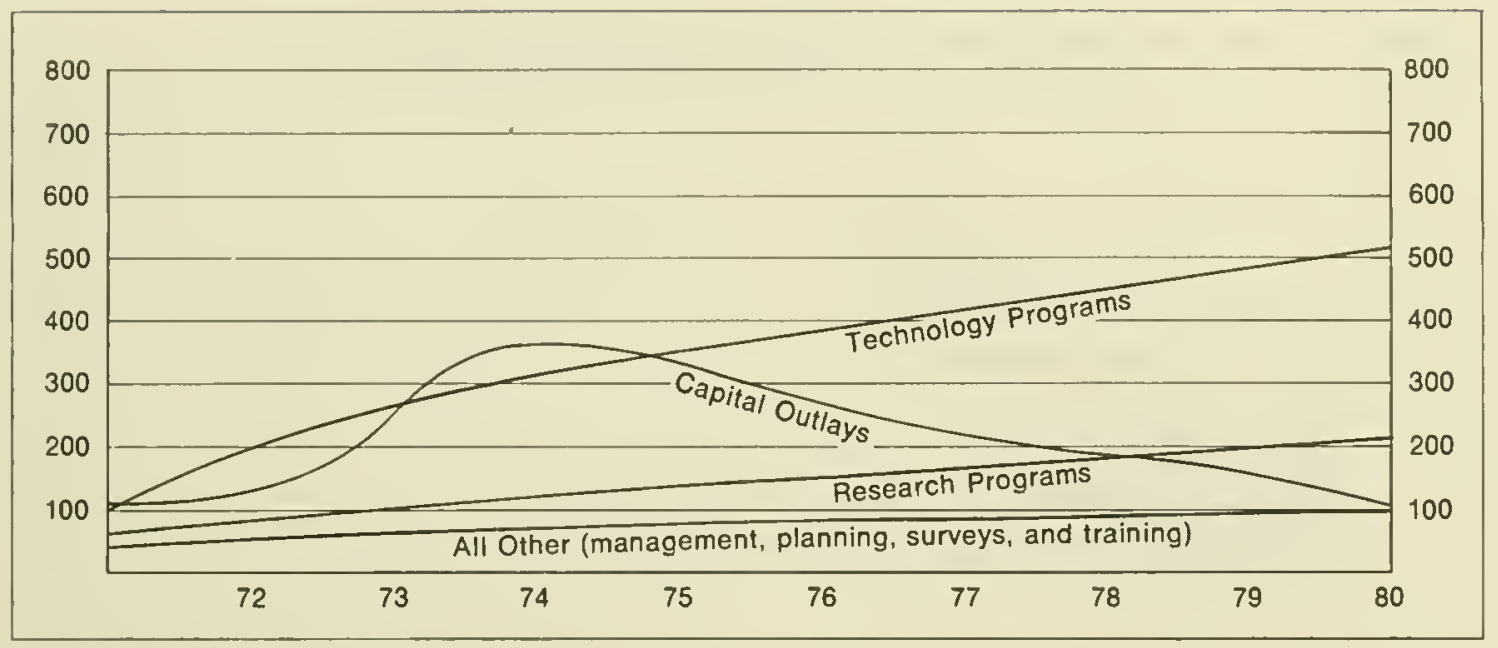

Projected Costs of the Commission's Recommended Programs

Although the timing of some capital inrestments can be adjusted to reflect a vailability of funds, it is important to recognize the need for a proper sequencing of expenditure. The productivity of marine science depends on properly equipped facilities drawing on the most up-to-date technology. Progress in technology, in turn, requires adequate test facilities and ranges. In another field, marine geological surveys must be sequenced to follow basic bathymetric and geophysical mapping. Both depend on adequate navigational control.

Some of the expenditures proposed by the Commission are for pilot projects and studies designed to establish the feasibility of a larger, future undertaking. Examples include the National Pilot Buoy Project and the National lake Restoration Project. Feasibility studies of possible future National Projects have also been recommended. Although the Commission has not attempted to estimate the cost of the programs and projects which might be developed through such studies, it does wish to point out that large new requirements for expenditure will in all likelihood emerge in future years us our knowledge and use of the oceans enlarge.

Expanding expenditures for civil marine programs will need to be accompanied by increasing support for military programs. Because the Nary now has an active program and extensive capital facilities, funding for such activities may not need to increase in percentage terms as rapidly as on the civil side, where the eurrent level of activity is lower in reference to current needs. But it is obvious that the requirements of the Department of Defense for marine and atmospheric science, technology, and services will have to keep pace with the increasing sophistication of military systems operating on, under, and over the seas. 


\section{Table 8-1 Cost for Commission Recommendations by Program Area}

[ Incrementa] costs in millions of dollars]

$\frac{\text { Average annual costs }}{1971-75 \quad 1976-80} \quad \begin{gathered}\text { Total } \\ \text { I0-year } \\ \text { costs }\end{gathered}$

Total, All Commission Recommendations

\begin{tabular}{rrr}
$\$ 652$ & $\$ 948$ & $\$ 8,000$ \\
\hline \hline 152 & 191 & 1,715 \\
\hline 32 & 14 & 230 \\
50 & 70 & 600 \\
60 & 90 & 750 \\
7 & 11 & 90 \\
3 & 6 & 45 \\
\hline \hline
\end{tabular}

Managing the Coastal Zone

\begin{tabular}{rrrr}
- & 86 & 121 & 1,035 \\
\hline & 10 & 10 & 100 \\
- & 11 & 11 & 110 \\
50 & 80 & 650 \\
\hline & 15 & 20 & 175 \\
\hline & 191 & 290 & 2,405 \\
\hline & 62 & 88 & 750 \\
- & 39 & 66 & 525 \\
- & 60 & 86 & 730 \\
& 30 & 50 & 400 \\
\hline \hline & 179 & 272 & 2,255 \\
\hline & 81 & 162 & 1,215 \\
- & 48 & 15 & 315 \\
- & 20 & 45 & 325 \\
& 30 & 50 & 400 \\
\hline \hline & 44 & 74 & 590 \\
\hline & 16 & 20 & 180 \\
\hline 8 & 12 & 100 \\
& 5 & 7 & 60 \\
- & 15 & 35 & 250
\end{tabular}

Management and Planning

Land Acquisition

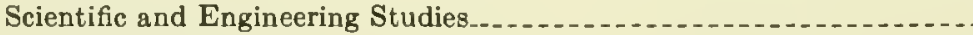

National Project

年

Resources

Living Resources Programs...

Nonliving Resources Programs.

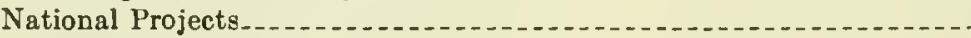

Fundamental Technology

Global Environment

Research and Exploration

Global Monitoring System

Environmental Modification Program

Fundamental Technology

Supporting Services

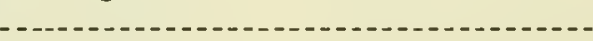

Mapping and Charting

Marine Safety and Enforcement

Data Services....

Development of Service Systems.

15 


\section{Table 8-2 Costs for Commission Recommendations by Activity}

[Incremental costs in millions of dollars]

\begin{tabular}{|c|c|c|c|}
\hline \multirow{2}{*}{ Activity } & \multicolumn{2}{|c|}{ A verage annual costs } & \multirow{2}{*}{$\begin{array}{c}\text { Total } \\
10 \text {-year } \\
\text { costs }\end{array}$} \\
\hline & $1971-75$ & $1976-80$ & \\
\hline Total, All Commission Recommendations................. & $\$ 652$ & $\$ 948$ & $\$ 8,000$ \\
\hline Management and Operations & 62 & 70 & 660 \\
\hline Services. & 36 & 41 & 385 \\
\hline Land A cquisition & 11 & 11 & 110 \\
\hline Planning . . & 15 & 18 & 165 \\
\hline Research and Education & 142 & 226 & 1,840 \\
\hline Laboratory Facilities and Operations. & 71 & 101 & 860 \\
\hline Research Programs & 64 & 114 & 890 \\
\hline Education and Training & 7 & 11 & 90 \\
\hline Specific Technology Programs... & 124 & 182 & 1,530 \\
\hline Coastal Fngineering & 20 & 40 & 300 \\
\hline Resource Development......... & 45 & 68 & 565 \\
\hline Research and Monitoring Equipment & 44 & 39 & 415 \\
\hline Service Systems Development. & 15 & 35 & 250 \\
\hline National Projects & 160 & 215 & 1,875 \\
\hline 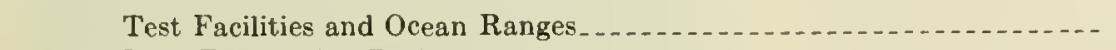 & 43 & 57 & 500 \\
\hline Lake Restoration Project & 15 & 20 & 175 \\
\hline Continental Shelf Laboratories & 40 & 60 & 500 \\
\hline Pilot Continental Shelf Nuclear Plant & 20 & 26 & 230 \\
\hline Deep Exploration Submersible Systems & 20 & 37 & 285 \\
\hline Pilot Buoy Network & 15 & 2 & 85 \\
\hline Feasibility Studies of Future Projects & 7 & 13 & 100 \\
\hline Fundamental Technology & 130 & 210 & 1,700 \\
\hline Capability $\ldots \ldots \ldots$ & 60 & 90 & 750 \\
\hline Resources & 40 & 70 & 550 \\
\hline Global Environment. & 30 & 50 & 400 \\
\hline Mapping, Charting, and Surveying & 34 & 45 & 395 \\
\hline
\end{tabular}




\section{A Budget for the National Oceanic and Atmospheric Agency}

Although the main burden of achieving the goals proposed by the Commission for a national ocean program will be assumed by the National Oceanic and Atmospheric Agency, NOAA will not be responsible for all of the expenditure estimated by the Commission, nor do these estimates embrace the totality of NOAA's responsibilities. Such other agencies as the National Science Foundation, the Army Corps of Engineers, the Navy, and the Departments of the Interior and of Health, Education, and Welfare will continue to have fiscal responsibility for portions of the recommended program.

The 1969 budgets for the agencies and programs which would be immediately transferred to NOAA under the Commission's organization plan total $\$ 773$ million. Other activities which might be transferred to the agency at a later date would add an additional $\$ 36$ million. The Commission projects that the National Oceanic and Atmospheric Agency might liave an operating budget of approximately $\$ 2$ billion annually by 1980 . The projection is necessarily a combination of both recommended increments (approximately $\$ 850$ million) and an arbitrarily projected 7 per cent growth rate for programs not reviewed by the Commission. However, the estimate is useful in providing a tangible prospect of the likely scope of the new agency.

\section{Conclusion}

Arriving at these cost estimates was among the most difficult aspects of the Commission's analysis. In spite of the uncertainties attendant on these estimates, they nevertheless are a measure of the kind of commitment which the Commission feels the Nation must make. Yet they do not tell the full story. There are some stakes, such as a livable environment or the security of the Nation, which are priceless. Some of the least expensive recommendations, like the establishment of the State Coastal Zone Authorities and the new international convention on the seabed, are among the most important ones. Benefits to the Nation will come not only from additional programs but also from the redirection of some current expenditures into more productive uses.

The Commission's cost estimates must be viewed in this light. They simply represent, as do the other parts of this report, our best judgment of liow to respond to the needs and opportunities which relate our Nation to the sea. 


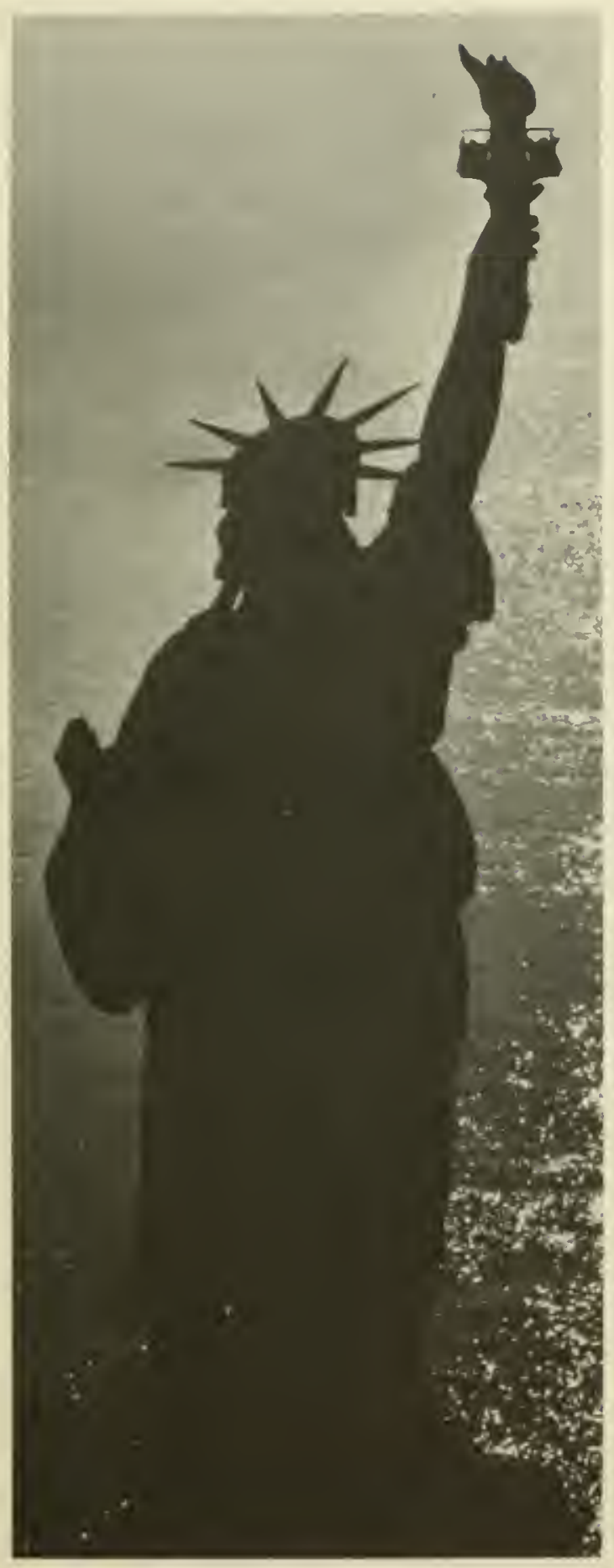




\section{Epilogue}

It is worth remembering that America began, or rather almost didn't begin, with a commission on marine science. In 1484, King John II of Portugal, intrigued by a project to sail west to the Indies and Japan proposed by a Genoese navigator named Christopher Columbus, appointer a commission of distinguished scientists to hear him and report on the worthiness of his proposal. One year later, this commission turned thumbs down on the whole iclea; it considered a western route to the Indies to be too long and too hazardous to merit support. The king accepted this report.

Columbus, of course, went to Spain where Ferdinand and Isabella appointed the Talavera Commission to consider the project. A number of hearings were held but no report was made until 1491; it expressed this conclusion:

This Committee judged his promises and offers uere impossible and vin and worthy of rejection: that it was not a proper object for their royal authority to favor an affair that rested on such weak foundations and which appeared uncertain and impossible to any educated person, however little learning he might have. ${ }^{1}$
The sovereigns neither approved nor rejected this report and told Columbus that his proposals might again be brought to their attention when the war with Granada had come to an end. In the meantime, a second committee of experts was appointed. Columlous appeared before it and, in January 1492 , was told that his project was "absolutely and definitely rejected." Columbus was persistent, however, and through sources close to the queen he managed to convince her that his project was a good risk. The voyage "to The Indies" began, and here we are.

In reference to the stated aims of the Indies project, the Talavera Commission's appraisal was correct. But even the most learned and enlightened men can seldom anticipate great discoveries in new fields of endeavor. Like that earlier marine commission, we have tried to give full weight to realistic appraisals and practicality. Because we know of the impact of the unexpected, from Columbus to computers, we have also tried to balance practicality with an optimistic and wide-open view of the future and allow room for the unforeseen. If we have erred, we hope wo have erred on the side of optimism, for ultimately that may prove to be no error at all. 
Public Law $89-454$

89th Congress, S. 944

June 17, 1966

\section{An Act}

Th provide for a comprehensive, long-range, and coordinated national program in marine science, to establish a National Council on Marine Resources and Engineering Development, and a Commission on Marine Science, Engineering and Resources, and for other purposes.

Be it enacted by the Senate and House of Representatives of the United States of America in Congress assembled, That this Act may be cited as the "Marine Resources and Engineering Development Act of $1966 "$ ".

\section{DECLARATION OF POLICY AND OBJECTIVES}

Marine Resources and Engineerlng Development Act of 1966 .

SEc. 2. (a) It is hereby declared to be the policy of the United States to develop, encourage, and maintain a coordinated, comprehensive, and long-range national program in marine science for the benefit of mankind to assist in protection of health and property, enluancement of commerce, transportation, and national security, rehabilitation of our commercial fisheries, and increased utilization of these and other resources.

(b) The marine science activities of the United States should be conducted so as to contribute to the following objectives:

(1) The accelerated development of the resources of the marine environment. ment.

(2) The expansion of human knowledge of the marine environ-

(3) The encouragement of private investment enterprise in exploration, technological development, marine commerce, and economic utilization of the resources of the marine environment.

(4) The preservation of the role of the United States as a leader in marine science and resource development.

(5) The advancement of educational and training in marine science.

(6) The development and improvement of the capabilities, performance, use, and efficiency of relicles, equipment, and instruments for use in exploration, research, surveys, the recovery of resources, and the transmission of energy in the marine environment.

(7) The effective utilization of the scientific and engineering resources of the Nation, with close cooperation among all interested agencies, public and private, in order to avoid mnecessary duplication of effort, facilities, and equipment, or waste.
80 STAT. 203.

S0 STAT. 204. 
(8) The cooperation by the United States with other nations and groups of nations and international organizations in marine science activities when such cooperation is in the national interest.

THE NATIONAL COUNCIL ON MARINE RESOURCES AND ENGINEERING DEVELOPMIENT

SEc. 3. (a) There is hereby established, in the Executive Office of the President, the National Council on Marine Resources and Engineering Development (hereinafter called the "Council") which shall be composed of-

(1) The Vice President, who shall be Chairman of the Council.

(2) The Secretary of State.

(3) The Secretary of the Navy.

(4) The Secretary of the Interior.

(5) The Secretary of Commerce.

(6) The Chairman of the Atomic Energy Commission.

(7) The Director of the National Science Foundation.

(8) The Secretary of Health, Education, and Welfare.

(9) The Secretary of the Treasury.

(b) The President may name to the Council such other officers and officials as he deems advisable.

(c) The President shall from time to time designate one of the members of the Council to preside over meetings of the Council during the absence, disability, or unavailability of the Chairman.

(d) Each member of the Council, except those designated pursuant to subsection (b), may designate any officer of his department or agency appointed with the advice and consent of the Senate to serve on the Council as his alternate in his unavoidable absence.

(e) The Council may employ a staff to be headed by a civilian execu-

78 Stat. 416. 5 USC 2211. 80 STÁT. 204.

80 STAT. 205 . 63 Stat. 954. 5 USC 1071 note. 79 Stat. 1111. 5 USC 1113. tive secretary who shall be appointed by the President and shall receive compensation at a rate established by the President at not to exceed that of level II of the Federal Executive Salary Schednle. The executive secretary, subject to the direction of the Council, is authorized to appoint and fix the compensation of such personnel, including not more than seven persons who may be appointed without regard to civil service laws or the Classification Act of 1949 and compensated at not to exceed the highest rate of grade 18 of the General Schedule of the Classification Act of 1949 , as amended, as may be necessary to perform such duties as may be prescribed by the President.

(f) The provisions of this Act with respect to the Council shall expire one hundred and twenty days after the submission of the final report of the Commission pursuant to section $5(h)$.

\section{RESPONSIBILITIES}

SEC. 4. (a) In conformity with the provisions of section 2 of this Act, it shall be the duty of the Presiclent with the advice and assistance of the Council to-

(1) survey all significant marine science activities, including the policies, plans, programs, and accomplishments of all depart- 
ments and agencies of the United States engaged in such activities;

(2) develop a comprchensive program of marine science activities, including, but not limited to, exploration, description and prediction of the marine enviromment, exploitation and conservation of the resources of the marine environment, marine engineering, studies of air-sea interaction, transmission of energy, and communications, to be conducted by departments and agencies of the United States, independently or in cooperation with such non-Federal organizations as States, institutions and industry;

(3) designate and fix responsibility for the conduct of the foregoing marine science activities by departments and agencies of the United States;

(4) insure cooperation and resolve differences arising among departments and agencies of the United States with respect to marine science activities under this Act, including differences as to whether a particular project is a marine science activity;

(5) undertake a comprehensive study, by contract or otherwise, of the legal problems arising out of the management, use, development, recovery, and control of the resources of the marine environment;

(6) establish long-range studies of the potential benefits to the United States economy, security, health, and welfare to be gained from marine resources, engineering, and science, and the costs involved in obtaining such benefits; and

(7) review annually all marine science activities conducted by departments and agencies of the United States in light of the policies, plans, programs, and priorities developed pursuant to this Act.

(b) In the planning and conduct of a coordinated Federal program the President and the Council shall utilize such staff, interagency, and non-Govermment advisory arrangements as they may find necessary and appropriate and shall consult with departments and agencies concerned with marine science activities and solicit the views of non-Federal organizations and individuals with capabilities in marinesciences.

\section{COMAISSION ON MARINE SCIENCE, ENGINEERING, AND RESOURCES}

SEC. 5. (a) The President shall establish a Commission on Marine Science, Engineering, and Resources (in this Act referred to as the "Commission"). The Commission shall be composed of fifteen members appointed by the President, including individuals drawn from Federal and State governments, industry, universities, laboratories and other institutions engaged in marine scientific or technological pursuits, but not more than five members shall be from the Foderal Government. In addition the Commission shall have four advisory members appointed by the President from among the Members of the Senate and the House of Representatives. Such advisory members shall not participate, except in an advisory capacity, in the 
formulation of the findings and recommendations of the Commission. The President shall select a Chairman and Vice Chairman from among such fifteen members. The Vice Chairman shall act as Chairman in the latter's absence.

(b) The Commission shall make a comprehensive investigation and study of all aspects of marine science in order to recommend an overall plan for an adequate national oceanographic program that will meet the present and future national needs. The Commission shall undertake a review of existing and planned marine science activities of the [nited States in order to assess their adequacy in meeting the objectives set forth under section $2(\mathrm{~b})$, including but not limited to the following:

(1) Review the known and contemplated needs for natural resources from the marine enviromment to maintain our expanding national economy.

(2) Review the surveys, applied research programs, and ocean engineering projects required to obtain the needed resources from the marine environment.

(3) Review the existing national research programs to insure realistic and adequate support for basic oceanographic research that will enbance human welfare and scientific knowledge.

(4) Review the existing oceanographic and ocean engineering programs, including education and technical training, to determine which programs are required to advance our national oceanographic competence and stature and which are not adequately supported.

(5) Analyze the findings of the above reviews, including the economic factors involved, and recommend an adequate national marine science program that will meet the present and future national needs without unnecessary duplication of effort.

(6) Recommend a Governmental organizational plan with estimated cost.

(c) Members of the Commission appointed from outside the Government shall each receive $\$ 100$ per diem when engaged in the actual performance of duties of the Commission and reimbursement of travel expenses, including per diem in lieu of subsistence, as authorized in section 5 of the Administrative Expenses Act of 1946, as amended 60 Stat. 808; (5 U.S.C. 73b-2), for persons employed intermittently. Members of 75 stat. 339, the Commission appointed from within the Government shall serve 340 . without additional compensation to that received for their services to the Government but shall be reimbursed for travel expenses, including per diem in lieu of subsistence, as authorized in the Act of June 9, 63 Stat. 166. 1949, as amended (5 U.S.C. 835-842).

(d) The Commission shall appoint and fix the compensation of such personnel as it deems advisable in accordance with the civil serv63 Stat. 954 . ice laws and the Classification Act of 1949, as amended. In addition, 5 UsC 1071 note. the Commission may secure temporary and intermittent services to the same extent as is authorized for the departments by section 15 of 5 Usc $55 a$. the Administrative Expenses Act of 1946 (60 Stat. 810) but at rates not to exceed $\$ 100$ per diem for individuals. 
(e) The Chaiman of the Commission shall be responsible for (1) the assignment of duties and responsibilities among such personnel and their continuing supervision, and (2) the use and expenditures of funds arailable to the Commission. In carrying out the provisions of this subsection, the Chairman shall be governed by the general policies of the Commission with respect to the work to be accomplished by it and the timing thereof.

(f) Financial and administrative services (including those related to budgeting, accounting, financial reporting, personnel, and procurement) may be provided the Commission by the General Services Administration, for which payment shall be made in adrance, or by reimbursement from funds of the Commission in such amounts as may be agreed upon by the Chairman of the Commission and the Administrat or of General Services: Provided, That the regulations of the General Services Administration for the collection of indebtedness of personnel resulting from erroneous payments (5 U.S.C. $46 \mathrm{~d}$ ) shall apply to the collection of erroneous payments made to or on behalf of a Commission employee, and regulations of said Administrator for the administrative control of funds (31 U.S.C. $665(\mathrm{~g})$ ) shall apply to appropriations of the Commission: And provided further, That the Commission shall not be required to prescribe such regulations.

(g) The Commission is authorized to secure directly from any executive department, agency, or independent instrumentality of the Government any information it cleems necessary to carry out its functions under this Act; ancl each such department, agency, and instrumentality is authorized to cooperate with the Commission and, to the extent permitted by law, to furnish such information to the Commission, upon request made by the Chairman.

(h) The Commission shall submit to the President, via the Council, and to the Congress not later than eighteen months after the establishment of the Commission as provided in subsection (a) of this section, a final report of its findings and recommendations. The Commission shall cease to exist thirty days after it has submitted its final report.

\section{INTERNATIONAL COOPERATION}

SEc. 6. The Council, under the foreign policy guidance of the President and as he may request, shall coordinate a program of international cooperation in work done pursuant to this Act, pursuant to agreements made by the President with the advice and consent of the Senate.

\section{REPOR'TS}

SEc. 7. (a) The President shall transmit to the Congress in January of each year a report, which shall include (1) a comprehensive description of the activities and the accomplishments of all agencies and departments of the United States in the field of marine science during the preceding fiscal year, and (2) an evaluation of such activities and accomplishments in terms of the objectives set forth pursuant to this Act. 
(b) Reports made under this section shall contain such recommendations for legislation as the President may consider necessary or desirable for the attainment of the objectives of this Act, and shall contain an estimate of funding requirements of each agency and department of 80 STAT. 207. the United States for marine science activities during the succeeding fiscal year.

SEC. 8. For the purposes of this Act the term "marine science" shall be deemed to apply to oceanographic and scientific endeavors and disciplines, and engineering and technology in and with relation to the marine environment: and the term "marine environment" shall be deemed to include (a) the oceans, (b) the Continental Shelf of the United States, (c) the Great Lakes, (d) seabed and subsoil of the submarine areas adjacent to the coasts of the United States to the depth of two hundred meters, or beyond that limit, to where the depths of the superjacent waters admit of the exploitation of the natural resources of such areas, (e) the seabed and subsoil of similar submarine areas adjacent to the coasts of islands which comprise United States territory, and (f) the resources thereof.

\section{AUTHORIZATION}

SEc. 9. There are hereby authorized to be appropriated such sums as may be necessary to carry ont this Act, but sums appropriated for any one fiscal year shall not exceed $\$ 1,500,000$.

Approved June 17, 1966.

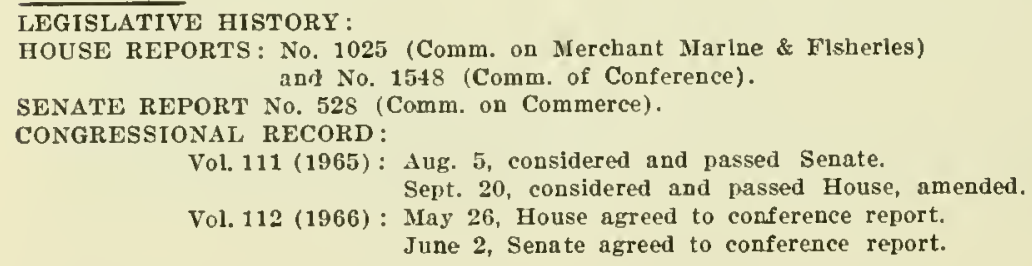


This Appendix highlights the main findings of the Commission and references each of the Commission's recommendations. The notation following the brief paraphrase of the substance of the recommendation indicates the type of action required for its implementation as follows:

Leg.--legislation

Admin.-administrative action

Org.--reorganization plan or legislation

Int'l.-international

Non-Fed.-State or local government

Leg./Admin.-legislation desirable but not essential to buttress administration action.

Where recommendations are directed to a specific Federal agency, the agency is either identified in the paraphrase of the recommendation or indicated in parentheses immediately following. Where NOAA is designated but there also is an existing agency which could appropriately take action, both NOAA and the existing agency are shown, divided by a slash.

The listing of major findings and recom- mendations is organized by chapter with page references to the text of the report.

\section{Chapter 2 National Capability in the Sea}

There are needs for seientific and engineering knowledge common to nearly all marine programs. The Nation must have very broad capability to satisfy all these needs.

Arrangements for marine science are well established. The needs for support of marine science run to provision for concerted attack on big problems, a greater degree of coherence, and greater continuity in funding. In contrast, there is no strong civil marine technology program that provides the knowledge required to make decisions on alternative courses of action on use of the resources of the seas, many of which will require major investment. A national program in technology and marine science should emphasize activities basic to a wide spectrum of potential applications. The large costs, uncertainty, and general benefits of such a program require the Federal Government to assume a major role.

\section{Marine Science}

Establish increased understanding of the planetary

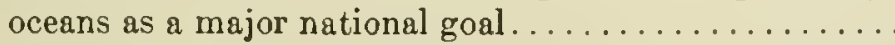

Establish University-National Laboratories to undertake global and regional programs in acean science (NOAA).

Establish Coastal Zone Laboratories (NOAA/Sea Grant) and amend Sea Grant legislation to authorize grants to

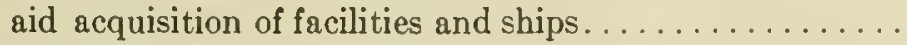

Move toward fewer but stronger laboratories with adequate funds and staff.

Expand Navy oceanographic research, particularly in acoustics. 


\section{Marine Technology}

Achieve capability to occupy the bed and subsoil of U.S. territorial sea and learn to utilize continental shelf and slope to 2,000 feet. . . . . . . . . . . . . . . . . .

Leg./Admin.

Achieve capability to explore depths to 20,000 feet by 1980 and utilize the depths by the year $2000 \ldots \ldots \ldots \ldots \ldots$

Leg./Admin.

Initiate a comprehensive fundamental technology pro$\operatorname{gram}(\mathrm{NOAA}) \ldots \ldots \ldots \ldots \ldots \ldots \ldots \ldots \ldots \ldots \ldots \ldots \ldots \ldots \ldots$

Leg./Admin.

Establish National Projects to focus marine effort on specific areas of opportunity and need (NOAA).......

Establish a National Project of test facilities for undersea systems (NOAA) . . . . . . . . . . . . . . .

Leg./Admin.

Admin.

Involve private industry in planning and conducting $\mathrm{Na}$ tional Projects (NOAA) . . . . . . . . . . . . .

Admin.

Plan and administer programs to advance marine technology so that industry can assume early responsibility for development. . . . . . . . . . . . . . . . .

Utilize Navy development capabilities for fundamental technology through cooperative arrangements with NOAA

Admin.

\section{Manpower Development}

Assign oversight of marine manpower to NOAA ........ postdoctoral and midcareer orientation (NSF) . . . . . .

Org.

Expand support for ocean engineering and marine tech-

Admin. nician training and establish new graduate-level marine programs in social sciences (NOAA/Sea Grant) . . . . . . .

Admin.

\section{Scientific and Technical Information}

Establish scientific and technical information and exten-

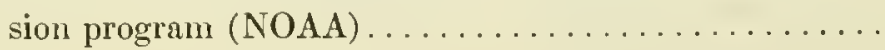




\section{Chapter 3 Management of the Coastal Zone}

The coast of the United States is, in many respects, the Nation's most valuable geographic feature. As snch, it generates critical issues in use of waters and adjacent lands, involving all levels of government and a great rariety of private users. Rapidly intensifying uses, often competing with each other, have already outrun the capabilities of State and local governments to plan orderly development and resolve conflicts.

The key to more effective use of our coastland is the introduction of a management system which permits conscious and informed choices among development alternatives and provides for proper plamning. The present Federal, State, and local machinery is inadequate for the task of preserving the quality of this productive region.

\begin{tabular}{lcc}
\hline Recommendations & Action through & $\begin{array}{l}\text { Page } \\
\text { Ref. }\end{array}$ \\
\hline
\end{tabular}

\section{Coastal Management}

Enact a Coastal Management Act to establish policy objectives and authorize grants-in-aid for State Coastal Zone Authorities (CZA) to manage the coastal waters and adjacent lands.............

Permit each State to decide the form of organization of its

Leg.

CZA as long as it has necessary powers, has broad representation, and provides opportunities for hear-

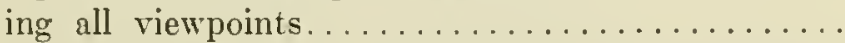

Utilize Land and Water Conservation Fund more fully for coastal land acquisition (BOR) and authorize Federal guarantee of State bonds for acquiring wetlands...

Place responsibility in NOAA for administering grants to CZA, resolving differences, monitoring compliance with plans, and developing plans for use of coastal zone beyond State jurisdiction................

Leg.

Admin. \& Leg.

\section{Information Needed for Management}

Establish a commission to fix baselines for seaward boundaries and boundaries between States...........

Effect participation in and coordination by NOAA of

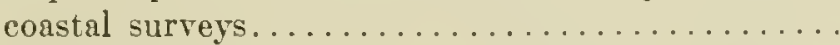

Identify areas which should be set aside for ecological

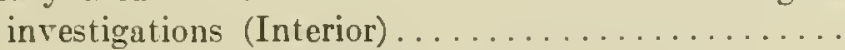

Examine system for justifying projects and formulas for Federal-local cost-sharing (Corps of Engineers).....

Leg.

Admin.

Admin.

Admin. 
Conduct study of the Nation's port and waterways system under the leadership of the Department of Transpor-

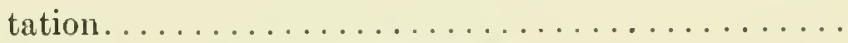

Leg./Admin.

Provide more attention by Federal and State agencies to research on coastal problems under leadership of

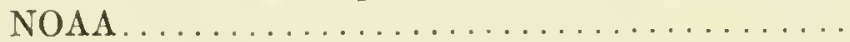

Develop instrumentation for monitoring coastal zone phenomena under leadership of NOAA...........

Provide for training and assistance to State officials uhrough universities affiliated with Coastal Zone Laboratories (NOAA/Sea Grant).................

Admin. \& Non-Fed.

Admin.

Admin.

\section{Coastal Development}

Support feasibility studies and fundamental engineering for development of offshore terminals, storage facilities, and nuclear power plants (NOAA with other

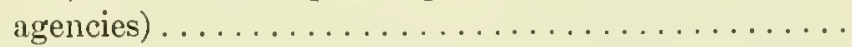

Admin.

Increase opportunities for recreation and public access to the water in the planning and funding of projects...

Achieve simplified leasing procedures by States for the development of offshore areas

Leg./Admin.

Non-Fed.

\section{Pollution Control}

Increase research on pollutants and expand programs to develop and deploy instrumentation to detect and record pollution loads (FWPCA)............

Report to Congress on progress in pollution abatement

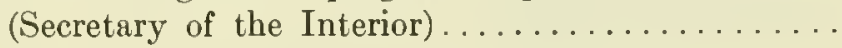
Authorize Corps of Engineers to deny a construction permit in order to protect the environment..........

Enable the Atomic Energy Commission to consider environmental effects of projects under its licensing au-

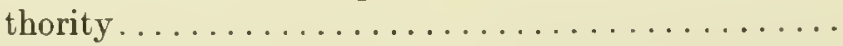

Strengthen enforcement of laws and Presidential Orders concerning pollution abatement and provide adequate Federal assistance for waste treatment plants...... Explore feasibility of Great Lakes restoration techniques (NOAA with operational implementation by

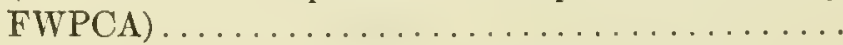
Establish a National commission on waste management. .

Admin. 76

Leg./Admin.

Leg.

Leg.

Admin.

Admin.

Leg./Admin. 


\section{Chapter 4 Marine Resources}

Interest in marine affairs has been heightened by our increasing scientific and technical capability to gain new wealth from the sea. However, attention to marine resonlces camnot bo viewed in isolation from competitive resources. Policies should be directed to assuring that there is no eritical shortage of any raw material and adrancing economic efliciency in the production and use of both marine and nommarine resources.

Economic uses of the sea are primarily a responsibility of the private sector. There is, nevertheless, a large role for government to assist industry in expanding the scope and scale of marine operations. Government bears a responsibility for establishing a framework of domestic law to undergird our private enterprise system. Further, the Commission recognizes that the U.S. interest in marine resource development must be viewed in terms of world needs and capabilities. The Commission has therefore considered both the national and international economic and legal status of fisheries, oil, gas, and hard minerals industries and has made a number of recommendations for changes in national and international policies and law.

\section{Living Resources}

Continue research on fish stocks and yields, cooperate with other nations in such programs, and explore new techniques for rapid stock assessment............

Aim fisheries management at largest net economic return consistent with biological capabilities of fisheries stock.

Improve economic return through eurtailing excess fishing

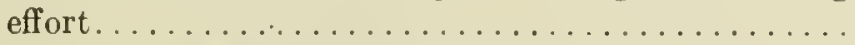

Establish national priorities and policies for migratory marine species $(\mathrm{NOAA} / \mathrm{BCF}) \ldots \ldots \ldots \ldots \ldots \ldots$

Authorize NOAA/BCF to assume regulation of endangered fisheries under specified circumstances........

Remove restrictions on use of foreign-built fishing vessels

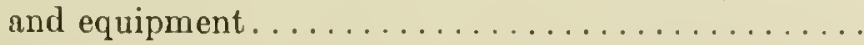

Analyze each major fishery and develop program for exploitation (NOAA/BCF) . . . . . . . . . . . . .

Develop rapid means for stock assessment, conduct surveys and exploratory fishing, and support basic studies $(\mathrm{NOAA} / \mathrm{BCF}) \ldots \ldots \ldots \ldots \ldots \ldots \ldots$

Develop expanded program for fishing technology (NOAA/ $\mathrm{BCF}$ ).

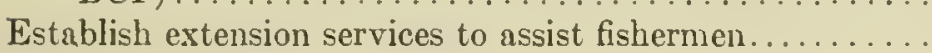

Admin.

All levels

92

All levels

93

Admin.

96

Leg.

97

Leg.

98

Admin.

Admin.

Admin.

101

Leg./Admin. 
Expand support for developing FPC technology (NOAA/ $\mathrm{BCF}) \ldots \ldots \ldots \ldots \ldots \ldots \ldots \ldots \ldots \ldots \ldots \ldots \ldots$

Fix a catch limit for cod and haddock fisheries of North Atlantic through international agreement.

Rationalize U.S. fishing effort in North Atlantic........

Give early consideration to national catch quotas for high seas fisheries of North Pacific.................

Continue, with amendment, indemnification for seizure of fishing vessels.

Attempt to reach international agreement on maximum breadth of territorial sea.................

Manage international fisheries on basis of ecological units

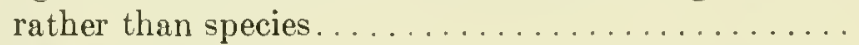

Empower an appropriate existing international body to evaluate operations of existing fishery conventions and suggest measures to improve and coordinate their

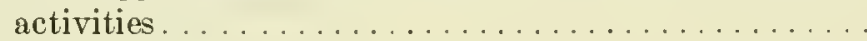

Renew diplomatic efforts to persuade all important fishing nations to adhere to Convention on Fishing and Conservation of Living Resources of the High Seas... . Finance adequately the international fisheries commissions. Strengthen enforcenent of international fisheries conventions and implementing regulations..........

Ratify protocol on settlement of disputes and support compulsory arbitration of certain fishery problems....

Strengthen activities related to aquaculture (NOAA/BCF and Sea Grant) . . . . . . . . . . . . . . . .

Establish a National Institute of Marine Medicine and Pharmacology $(\mathrm{HEW}) \ldots \ldots \ldots \ldots \ldots \ldots \ldots$
Admin.

103

Int'l 105

Admin.

108

Int'l

108

Leg.

Int'l

Int'l

Int'l

Admin.

Int'l

Int'l

Leg. \& Admin.

Leg./Admin.

Leg.

\section{Mineral Resources}

Establish mechanisms for exchange of information among the Federal Government, the petroleum industry, and scientists . . . . . . . . . . . . . . . . .

Admin.

Reexamine and improve leasing and regulatory policies for offshore oil (Interior) . . . . . . . . . . . . .

Adnin.

Reexamine differential price policies for natural gas production $(\mathrm{FPC}) \ldots \ldots \ldots \ldots \ldots \ldots \ldots \ldots \ldots \ldots \ldots$

Adnin.

Review accounting regulations for gas transmission industry R\&D (FPC)

Admin. 
Support fundamental technology relevant to marine minerals exploration and recovery (NOAA aided by Interior) . . . . . . . . . . . . . . . . . . . . . . nental shelf without competitive bidding (Interior) . . . Continue support for desalination R\&D (Interior) . . . . . . . Conduct geological surveys and analyses of continental shelf and slopes adjacent to U.S. (NOAA aided by Interior) . . . . . . . . . . . . . . . . . . .

Seek an international agreement to redefine the continental shelf.

Propose international framework for exploration and exploitation of mineral resources underlying deep seas. .

Negotiate new international agreement establishing an International Registry Anthority and Fund and providing for zones adjacent to each nation's continental shelf in which only the coastal nation and its licensees would be authorized to explore for or exploit mineral resources.

Propose interim principle that no nation claim or exercise sovereignty over seabed beyond 200-meter isobath but authorize exploration and exploitation of seabed beyond 200-meter isobath, with explicit understanding such exploration and exploitation to be subject to

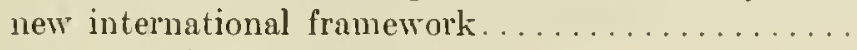

Compensate private enterprise for losses from any redefinition of the continental shelf.

Require approval of Secretary of the Interior to explore or exploit subsea area beyond 200 -meter isobath.......
Admin.

Leg.

Admin.

Leg./Admin.

Admin. \& Int'l

Adnin. \& Int'l

Admin. \& Int'l

Admin. \& Int'l

Leg.

Leg.

\section{Government-Industry Relations}

Develop research, exploration, basic technology, and services as basic means to encourage private investment. . . . . . . . . . . . . . . . . . .

Simplify and clarify policies and laws affecting business and continually update and publicize them.........

Admin.

support technology for power systems for undersea operations and resource derelopment and an experimental submerged nuclear plant (NOAA).

Admin.

Establish a National Project for Continental Shelf Laboratories (NOAA) 


\section{Chapter 5 The Global Environment}

Effective use of the sea requires capability to observe, describe, understand, and predict oceanic processes on a global scale. Requirements for environmental information range from descriptions of the characteristics of the deep sea floor to data on the normal conditions of the oceans' chemistry, biology, thermal structure, and motions, to predictions of rapidly changing ocean and atmospheric phenomena.

Much progress has been made as a nation and through international cooperation; however, the size of the oceans makes it difficult to acquire the observations needed. But now we are achieving technological capability to monitor the sea, the air, and the land as parts of a single, complex system and to communicate and analyze the attendant data. The Commission has noted opportunities for near-term improvements and proposed appropriate actions. Howerer, a long-range program of research, technology, and exploration also needs to be undertaken on a major scale to achieve benefits in many areas of man's activities, including planned modification of the environment. The scale and nature of enrirommental activities provide a unique opportunity for international cooperation.

\section{Recommendations}

Action through

Page
Ref.

\section{Research and Exploration}

Undertake programs through NOAA to explore global environment, monitor its motions and biological characteristics, and determine feasibility of its modification.

Leg./Adnin.

Mount a program to explore and understand the deep oceans (NOAA)

Admin.

Study feasibility of advanced deep ocean stations (NOAA and $\mathrm{Navy}) \ldots \ldots \ldots \ldots \ldots \ldots \ldots \ldots \ldots \ldots \ldots \ldots \ldots . \ldots \ldots$

Admin.

Sponsor a program to advance deep ocean fundamental technology and construct exploration submersibles (NOAA).

Admin.

Foster instrumentation development for ocean exploration

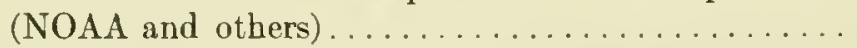

Admin.

\section{Global Monitoring and Prediction}

Integrate, through NOAA, civil ocean monitoring and prediction activities with existing weather system to provide single national system. . . . . . . . . . .

Make arrangements between NOAA and NASA for satellite oceanographic sensor development and operation. .

Org./Admin. 184

Admin. 187

Expand ship-of-opportunity program and provide greater use of offshore platforms (NOAA and others).......

Admin. 
Expand tide and seismic monitoring network and attendant communications and support additional research on tsumami (NOAA/ESSA) . . . . . . . . . . . .

Expand and improve data networks supporting Hurricane Warning Service (NOA $/$ ESSA and others).......

Expand research to improve sea ice forecasting, remote sensing of ice, and understanding energy transfers...

Admin.

Implement Federal plan fol marine meteorological services. .

Admin.

Establish pilot buoy network as a National Project (NOAA/Corst Guard) . . . . . . . . . . . . . .

Admin.

Review feasibility of establishing an aircraft-of-oppol-

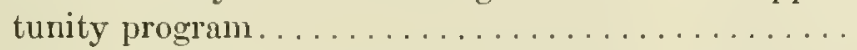

Admin.

Implement plans to place oceanographic sensors on operational satellites and develop advanced sensors and techniques for use (NOAA/ESSA and NASA)......

Admin.

Analyze NEMPS design trade-offs in deciding deployment

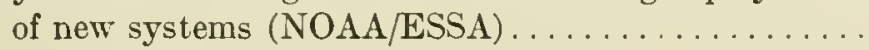

Admin.

Study ocean current systems through cooperative field investigations under NOAA leadership............

Admin.

Give high priority to understanding sea-air interaction processes with field experiments led by NOAA.........

Admin.

Study oceanic scales of motion through NOAA and use results in testing National Buoy Project...........

Mount intensive research to understand ocean processes and biological-physical relationships (NOAA/BCF)...

Admin.

Admin.

\section{Environmental Modification}

Undertake research and developnent to explore beneficial modification of environmental conditions and effects of inadvertent interference (NOAA/ESSA) ........ Leg./Admin.

\section{International Arrangements}

Develop NEMPS in concert with World Weather Program. Charge NOAA/ESSA with coordinating U.S.

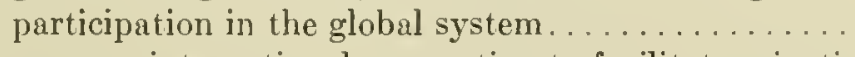

Propose new international convention to facilitate scientific research in territorial waters or on and concerning

the continental shelf $\ldots \ldots \ldots \ldots \ldots \ldots \ldots \ldots \ldots \ldots \ldots$
Pending negotiation of such an agreement, seek bilateral and regional agreements to encourage freedom of international scientific research. 


\section{Chapter 6 Technical and Operating Services}

Sea operations require a variety of services provided chiefly by the Federal Gorernment. Some have been covered in previous chapters; this chapter covers generalpurpose mapping and charting, navigation, safety and policing, data management, and instrument calibration and standards services. Major users of these services include the marine transportation and fishing industries, offshore oil and mineral producers, recreational boaters, the Department of Defense, and the scientific community. The principal agencies providing the services are the Coast
Guard, the Environmental Science Services Administration, the Nary, and the Army Corps of Engineers.

These services are marked by their interrelationships and a high degree of interagency cooperation in the sharing of facilities and services. There has been less suceess in coordinating the staging of new technical service activities so that programs are nndertaken in proper sequence, nse compatible data, and make maximum use of existing ships and facilities. New technology is not being sufficientiy brought to bear in improvement of the services, nor are the services being reoriented sufficiently upidly to meet challenges posed by new technology.

\section{Recommendations}

Action through

Provide maps of bathymetry and geophysies of continental shelves and slopes to 2,500 meters at $1: 250,000$-scale within a decade (NOAA/ESSA) . . . . . . . . . .

Leg./Admin.

Accelerate Federal nautical charting activities to ensure current charts of all coastal areas of moderate to heavy marine activity (NOAA/ESSA) .

Admin.

Develop survey equipment under NOAA lead and fully equip ocean research and survey ressels with the most advanced sensor and data processing systems.......

Increase navigational accuracies and develop low-cost systems for undersea navigation of civilian submersibles (NOAA/Coast Guard).

Admin.

Recodify laws on vessel safety standards, extend certification to civil submersibles, and provide safety standards for commercial fishing vessels (NOAA/Coast Guard) . . . . . . . . . . . . . . . . . . . . . . . . .

Adopt and enforce the Model State Boat Aet and adopt
legislation proposed by Coast Guard to establish minimum safety standards in the manufacture of pleasure boats.

Admin.

Leg.

Certify sport diving equipment and assure training and emergency medical care facilities and services (NOAA/ Coast Guard)

Admin. 
Place responsibility for Federal marine law enforcement in NOAA/Coast Guard; improve State enforcement..... Strengthen data centers and provide coordination through. NOAA

vide standards, calibration, and test facilities and more effective procedures to ensure reliability and comparability of marine data (NOAA)....

\section{Chapter 7 Organizing a National Ocean Effort}

In previons ehapters the Commission has recommended actions across a broad spectrum of marine activities to achieve effective use of the seas. Such an effort requires restructuring of present scattered organizations to permit the Federa] Government to provide the necessary leader'ship and support. Those marine activities which provide close operational support to existing departments and agencies with marine missions should be continned and strengthened. Those which are peripheral to parent agencies' missions need to be brought together to establish a new central focns for seientific, technical, and service functions related to the air and sea.

However, consolidation is not sufficient: new programs mnst be ereated under the guidance of an operat ing ageney with a broad and coherent mission in marine, atmospherie, and eertain other geophysical sciences. A means needs to be found for eliciting the views of the marine commmnity in planning and assessing Federal activities. Responsibility for coordination has to be lodged in appropriate machinery at both operating and Presidential staff levels.

\section{Recommendations}

Action through

Page

Establish a major civilian ageney (NOAA) for administration of Federal eivil marine and atmospherie programs.

Transfer certain existing ageneies and programs to NOAA.

Vest additional functions in NOAA.

Org.

Org.

232

Org.

232

Establish NOAA as an independent ageney . . . . . . . . .

$\mathrm{Ol} \stackrel{\mathrm{g}}{\mathrm{g}}$.

233

Vest the head of NOAA with coordination of Federal programs related to its central functions.............

Establish a broadly constituted advisory committee (NACO) to adrise on progress in meeting national objectives.

Leg.

Continue the National Marine Council until decisions on $\mathrm{NOA} A$ are reached. 
The Commission on Marine Science, Engineering and Resources was established under provisions of Public Law 89-45t, enacted "Tune 17, 1966, to "make a comprehensive investigation and study of all aspects of marine science in order to recommend an orerall plan for an adequate national oceanographic program that will meet the present and future national needs." "Tnder the Act, the President appointed 15 members to the Commission, including individuals from Federal and State governments, industry, universities, and laboratories engaged in marine scientific or technological pursuits. In addition, the President appointed fom advisory member's from among the members of the Senate and the House of Representatives. The Act provided that these Congressional member's not participate, except in an advisory capacity, in the formulation of the Commission's findings and recommendations.

President Johnson amounced appointment of members to the Commission on Jan. 9,1967 . In addressing the first meeting in February, the Vice President urged the Commission to think broadly, to be imnorative, and not to be constrained because of fixed attitudes inside or ontside gorernment, on what needs to be done. As Chairman of the National Council on Marine Resonrces and Engineering Development, the Vice President pledged the Council's cooperation in the work of the Commission.

\section{Events Leading to the Commission's Formation}

Appointment of the Commission culminated a decade of growing interest in the sea and concern that the Nation was not making the most of its marine opportmnities.
The Nation's interest in the sea was rekindled 10 years ago with the publication by the National Academy of Sciences Committee on Ocennography of the summary volume of its historic 12-volume report, Oceanogmplyy, 1960-1970. In this report, a group of eminent scientists described the status of the Nation's marine activities and set forth specific recommendations for the decade in areas of science, technology, education and manpower, supporting services, logistics, resources, and international cooperation. A I.S. Navy report, Ten Years in Oceanogra$p h y$. published in 1959, called attention to the crucial role of the seas in mational security and proposed an expanded program for the decade ahead.

The new wave of interest brought extended Congressional hearings and a resurgence of activity in both public and private circles. Within Govemment, the Federal Council for Science and Technology formed the Interagency Committee on Oceanography. Shortly after coming to office in 1961, President liemedy sent a message to the Congress to propose an expanded effort in ocean sciences and request additional funds; the Congress responded farorably.

Despite competition for public attention from the burgeoning space program, medical research, and other" areas of science and technology, interest in the oceans contimued to grow during the $1960^{\circ}$ s. In 1965 , the President's Science Advisory Committee formed a Panel on Oceanograpliy to draft goals for a national program, assess current and planued actirities, and recommend measures to effect a program consonant with national needs. In .June 1966, the Panel issued an important report, Effective $I$ se of the Sea. which inclnded among other recommendations a proposal for reorganization of the Executive 


\section{The Operations and Task of the Commission}

Branch to deal more eflectively with marine affairs. Concurrently the Committee on Oceanograply of the National Academy of Sciences was also reviewing progress in oceanography and made new recommendations of a program and organization nature in its report, Oceanography 1966. Additional studies were initiated by committees of the newly formed National Academy of Engineering and the National Security Industrial Issociation.

Congressional concern about the adequacy of the Federal organization in providing leadership and managing marine-related activities was reflected in a number of bills introduced during this period. Some would have consolidated activities within an operating agency. Others were directed to strengthening the Executive Office of the President. In 1962, Congress passed a bill, H.R. 12601, designed to vest the new Office of Science and Techuology with specific responsibilities in oceanography matters. President Kennedy pocket-retoed this bill as an encroachment on Presidential authority.

By 1965 it had become evident that lack of agreement within Government as to priorities among programs and the preferred form of Federal organization was leading to an impasse. New bills were introduced in both the House of Representatives and the Senate in an effort to provide a means for achieving more intensive and coordinated Government attention to the Nation's marine interests. The Marine Resources and Engineering Development Act, as agreed to in conference between the two Houses in .June 1966, established over-all goals for a national ocean program and provided both for a Council comprised of ('abinet-level oflicials to assist the I'resident in planning and coordinating Federal programs and for an adrisory Commission to make a comprehensive study that would develop the background information and recommendations needed to achieve consensus for moving ahead.

The Commission was required in this legislation to submit its final report to the President, via the Conncil, and to the Congress within 18 months-later extended to 2 years-of its establishment. Although establishing in the National Council an interim mechanism to get action underway, the Congress explicitly directed the Commission to recommend both a national oceanographic program and a plan of Government organization, with estimated costs, for its implementation. To give emphasis to its intent and freedom to the Commission to adrance a plan representing its best judgment unconst rained by any prior action, the Congress provided that the authority for the Council should expire 120 days after submission of the Commission's report, later extended to June 30 , 1969. The Commission ceases to exist 30 days after its report is filed.

\section{Organizing the Study}

No precedent existed for the comprehensive review of marine matters which was requested of the Commission; previous reports had concentrated largely on scientific and technical aspects. $I^{\top} n$ like the space and nuclear energy programs, marine programs are characterized by private investment far exceeding Federal effort, and State and local activities, though difficult to cuantify, are obviously vast. Further, some marine activities are inseparable from land institutions and problems and for the foresceable future cammot lo treated simply as marine matters.

In view of its very hroad charter, the Commission: attention was necessarily focused first on organizing to get on with the job. The 
Commission's approach was to form seven working panels, with two to four Commissioners and an Executive Secretary assigned to each. The panels were as follows:

Panel on Basic Science

Robert M. White, Chairman

John A. Knauss

Panel on Environmental Monitoring and on Management and Development of the Coastal Zone

John A. Knauss, Chairman

Frank C. DiLuzio

Leon Jaworski

Robert M. White

Panel on Manpower, Education, and

Training

Julius A. Stratton, Chairman

Richard A. Geyer

David A. Adams

Panel on Industry and Private Investment

Richard A. Geyer, Chairman

Charles F. Baird

Taylor A. Pryor

George H. Sullivan

Panel on Marine Engineering and

Technology

John H. Perry, Jr., Chairman

Charles F. Baird

Taylor A. Pryor

George H. Sullivan

Panel on Marine Resources

James A. Crutchfield, Chairman

David A. Adams

International Panel

Carl A. Anerbach, Chairman

Jacob Blanstein

Leon Jaworski

The panels became the principal mechauism for assessing the status of marine matters in their respective areas, for identifying the opportunities and problems, and for proposing measures that need to be taken.

\section{The Work of the Commission}

It is difficult to describe adequately the magnitude of the effort by the panels and the full Commission in the preparation of this report. Each of the panels conducted its work in its own manner; however, the activities of the Panel on Envirommental Monitoring and on Management and Development of the Coastal Zone provide a typical example. Working with the Panel on Basic Science, it held hearings in various parts of the country, during which it heard a total of 126 witnesses from Federal and State governments, research institutions, and industry. Additionally, over 600 individuals were interviewed or contacted through correspondence by that panel. Consultants advised the panel throughout its investigations, preparing papers, reviewing draft materials, and responding to queries on particular matters. The panel conducted visits to gain firsthand knowledge of activities related to its mission. The panel finally distilled an enormous mass of material into the 291 pages of its two reports, one on the coastal zone and the other on environmental monitoring.

After fact-gathering and initial evaluation, the panels prepared material for consideration at meetings of the full Commission. This process aided the panels in identifying the need for additional information, for clarification, or for reassessing tentative views and provided a means for coordinating efforts among the panels to assure coverage in the overall study. Moreover, panel use of the full Commission as a sounding board served as an educative process that prepared members for the drafting and final approval of its report. 
In addition to reviewing materials prepared by the panels, the Commission utilized reports and papers prepared by contractors. 1 number of consultants also prepared papers especially for the use of the Commission and made available other relevant unpublished material. Staff prepared reports and other materials for the use of panels and the full Commission. A number of these materials are cited in Appendix 4.

In every sense of the word this has been a working Commission. The full Commission usually met mouthly and in total held 19 meetings of 2 to 4 days each. Conmission members were diligent in their attendance, all or almost all members attending each meeting. They traveled to meet with experts in their areas of interest. Much of their time has been consumed in assessing voluminous materials and in preparing materials for the panel reports and the Commission report. Members have been immersed in the work of the Commission since their appointment.

The Commission operated with a minimal staff until the panels were organized and qualified individuals became available to serve. In addition to staff for the seven panels, a small central staff served the full Commission. The total full-time staff eventually grew to number some 15 professional and 10 secretarial and other supporting personnel. In addition, a few part-time staff members were utilized as their expertise was needed. Like the Commission itself, staff were drawn from all parts of the country and from industry, universities, and Federal agencies; they included scientists, engineers, lawyers, administrators, editors, and other specialists.

Throughout the Commission's work, there was close and cordial cooperation with the
National Council on Marine Resources and Engineering Development and its staff. Yet each body has maintained its separate role. The Commission has been free from the influence of the Council, enabling it to provide its own assessment of Federal activities and organizations, including the effectiveness of the Council arrangement itself. The Council has preserved its separate identity because it is charged with advising the President on the report of the Commission.

Independence has been maintained at the same time each body has informed the other of its work. The Commission has benefited particularly from riews expressed by an ad hoc committee of the Council convened on two separate occasions to review drafts of Commission material. The Commission has been free to deal directly with the Federal agencies and has done so often, while keeping Council staff informed of such contacts.

One of the most rewarding aspects of the Commission's work has been the interaction with groups and individuals from within and outside the marine community. In the conduct of its study, the Commission has sought to involve the principal organizations and leaders in all sectors of the country concemed with the oceans and has invited comment through hearings, informal meetings and seminars, correspondence, and a general invitation for comments placed in the trade press. Helpful assistance has been received from agencies and individuals at all levels of government; from industrial associations and officials of individual companies: from scientific organizations, the heads of laboratories, and working seientists; and from unirersity administrators and individual professors. In all, more than 1,000 individuals were persomally contacted by the Commission. Most of these persons are listed and their 
contributions gratefully acknowledged in appendices to the reports of the Commission's panels.

Assistance rendered the Commission by private and professional groups often extended well beyond the normal statement of views or preparation of documentary material. The Oceanic Foundation, a nomprofit foundation dedicated to the advancement of marine science, organized a special Marine Commission Support Group to provide an additional means for drawing upon persons from the universities and industry to assist the Commission and its panels. The National Academy of Sciences Committee on Oceanography prepared a complete revision and updating of its 1966 report and responded at length to a series of questions posed by the Commission in order to inform it fully of the views and needs of the scientific community. The National Academy of Engineering volunteered the continuing consulting assistance of its Committee on Ocean Engineering. Resources for the Future, Inc., a nonprofit research organization, sponsored two intensive seminars to develop methodologies for appraising national interests in ocean resources. The National Security Industrial Association's Ocean Science and Technology Committee submitted a series of reports on the activities and needs of ocean user industries, on Government-private sector loles, and on means for providing continuing liaison and arranged a series of meetings with industry groups so that the Commission might have the benefit of their views. Large regional meetings, tapping other industry groups, were organized by both the Tniversity of Texas and the University of Southern California to appraise inrestment opportunities. Certain local sections of the Marine Technology Society, at the suggestion of its President, prepared analyses of the particular marine resources and needs of specific regions of the Nation. These contributions, all provided as a public service at little or no cost to the Government, were of enormous benefit to the Commission.

The final products of the Commission's work are this report, the reports of the panels published separately, and other papers cited in Appendix 4 . 
The majol products of the Commission are this report and the panel reports, published separately and a vailable as a set from the I.S. Govermment Printing Office. In addition, the Commission sponsored several studies and report which are or will shortly be arailable upon request. It should be noted that the riews expressed in these supplementary materials do not necessarily reflect the views of the Commission.

These studies and reports are being published through the Clearinghouse for Federal Scientific and Technical Information or through other channels. Materials available through the Clearinghouse should be ortered by number from: Clearinghouse for Federal Scientific and Technical Information, U.S. Department of Commerce, Springfield, Va. 22151 ; almost all documents are priced at $\$ 3$ for paper copies and $\$ 0.65$ for copies in microfiche.

\section{Contract Studies and Reports}

Federal Authority for Conduct of Marine Letivities, law firm of Elliott and Naftalin, March 13, 1968, available as a Colnmittee Print from the Committee on Merchant Marine and Fisheries, U.S. House of Representatives. A comprehensive, indexed survey of authorities of Federal agencies for conduct of marine aetivities by funetion and by agency.

A Perspective of Regional and State Marine Environmental Activities: A Questionnaire Sumey, Statistics and Observations, John I. Thompson \& Company, Washington, D.C.. Feb. 28, 1968, Clearinghouse No. PB 17665. Report of a survey of regional and State government activities and organizational arrangements for dealing with marine problems.

State and Loeal Government Activities and Roles in Marine Science, Engineering and Development. John I. Thompson \& Company, Washington, D.C., Feb. 14, 1968 , Clearinghouse No. PB 177764. A briefly annotated catalogne of published studies and reports on organizational arrangements and aetivities in marine seience, engineering, and resource development in the constal States and States bordering the Great Lakes.

The following three studies were prepared under the aegis of the Program of Policy Studies in Science and Technology, the George Trashington Iniversity, Washington, D.C.: Highlights from the Literature on Organization for Federal Programs in Science and Technology. Fred R. Brown and Stephen R. Chitwood, Jan. 15, 1968, Clearinghouse No. PB 182603. Report of a survey of literuture on organization and administration muler four major headings: organizational structure as a determinant of program effectireness, contemporary organizational theory and practice, strueturing of organizations generally in the Federal Government, and perspectives on organization of Federal programs for science and technology.

Interdependencies Between Public and Private Interests in the Adrancement of $\mathrm{N}^{\mathrm{e}} \mathrm{e}$ Technologies, Clarence H. Danhof, Oct. 20 . 1967, Clearinghouse No. PB 182600. Report on the processes by which new teehnologies have been generated by the Federal Govermment and disseminated through transfer mechanisms, based upon an interpretation of the Goremment's experience orer the last quarter century.

Civilim-Militnry Interests in Iew Techmologies. Enid Curtis Bok Sichoettle, September 1968, Clearinghouse No. PB 182601. Report of problems and experiences in handling civilian-nilitaly interdependencies in programs of marine seience, engineer- 
ing, and resources and analogous experiences in other areas, acempanied by a slort paper by Clarence $\mathrm{H}$. Danhof commenting upon basic policy considerations in structuring such relationships.

Environmental Quality and Natural Resoures Wanagement. Robert D. Teeters, .June 13, 1968, Clearinghouse No. PB 180903. An analytic paper discussing considerations in trying to organize Federal activities around the concept of "environment," particnlarly the difficnlties in relating protection of envirommental quality to the management of natural resources.

Great Lakes Restoration-Rerieu of Potentials and Recommendations for Implementation. Battelle Memorial Institute, Richland, Washington, Jme 17, 1968, Clearinghouse No. PB 180904. A review of factors which have led to deterioration of water quality in the Great Lakes, technologies presently available to overcome such deterioration, and institutional arrangements required to implement large-scale restoration measures.

Planning and Coordinating Oceunographie Programs. Comelins W. Vahle, Jr., April 17, 1968, Clearinghouse No. PB 182602. A study of the creation, organization, function, and effectiveness of the interagency machinery used to plan and coordinate oceanographic programs from 1959 to 1966 , focusing on the Federal Coumeil for Science and Technology, the Interagency Committee on ()eamograplyy, and the Office of Science and Technology.

Several papers relating to Government organization were prepared for the Commission through contract for use in a seminar jointly sponsored by the Commission and the Institute for the Study of Science in Hu- man Affairs of Columbia Unirersity. The Institute is considering publication of certain of these papers.

\section{Papers Submitted to the Commission for Its Use}

Selecting Policics for the Derelopment of IIrine Resources. Resources for the Future, Inc., March 1968, Clearinghonse No. PB 180905. In analytic paper, prepared following discussion in two seminas, to identify and test concepts and procedures for making choices among alternative policies in shaping a national ocean program.

The Prepuration of Article 1 of the Convention on the Continental. Shelf. Bermard H. Oxman, October 1968, Clearinghouse No. PB 182100. In exhanstive description of the views of participants in international meetings on the Convention, reflecting a comprehensive review of primary source materials.

Goals. New Emphasis. Laboratory Relationships, Education and Training Needs. and Scientific Achicrements in Marine Science, informal papers submitted to the Commission by the National Academy of Sciences-National Research Council Committee on Oceanography, Clearinghouse No. PB 182606. The papers include an updating of the NASCO report, Oceunography. 1366, an informal report on scientific achievements resulting from Government support over the past decade, and other comments.

Industry and the Continental Shelf, National Security Industrial Association, Ocean Science and Technology Adrisory Committee, Nov. 15, 1967, Clearinghonse No. PB 182607. In informal summary report, inchding a discussion of activities, problem areas, and recommendations concerning industry's interest in the continental shelf. 


\section{Staff Papers}

Defense Interests and the Vational Oceanographic Program. A. Denis Clift, February 1969, Clearinghouse No. PB 182604. An analytic paper, dlawing on materials prepared by Irilliam .J. Ruhe and other's, that lighlights current and future military implications of technological and other developments aflecting use of the oceans.

Technied supporting Serrices for the. $\mathrm{Va}$ tional Ocean Program. William .J. Ruhe, June 1965, Clearinghonse No. PB 180902. A study of present and planned technical supporting services and implications for the futme, with findings and recommendations for making these services adequate to changing needs.

Marine Regions of the United States. Lewis M. Alexander, Sept. 9, 1968, Clearinghouse No. PB 182605. A description of the geographic characteristics of nine marine regions, attendant socioeconomic factors, and certain managenent implications of the variations. 


\section{Credits}

\section{Photo Credits}

corer-M. Woodbridge Wrilliams, National

Park Serrice, Department of the Interior opposite pago 1-National Park Service, De-

partment of the Interior

page $3-\mathrm{Navy}$

page 5-

(top) The Johns Hopkins University

(bottom) Glasheen Graphics, La Jolla, Calif.

page 9-left to right

(top) National Petroleum Conncil, American Airlines

(center) Coast Guard, National Park

Service, Department of the Interior

(bottom) National Park Service, De-

partment of the Interior

page 13-Ocean Science and Engineering,

Ine., Washington, D.C.

page 15 -General Dynamics

page 16-Grumman Aircraft Engineering

Corporation

page 20 - Woods Hole Oceanographic Insti-

tution

page 22-General Electric

page 24-Navy

page 26-University of Rhode Island

page $34-$

(top) Lockheed Missiles and Space

Company

(bottom) Navy

page 36- Westinghouse Electric Corporation page 39 - The British Petroleum Company page 40 -Westinghouse Electric Corporation

page 41-University of Miami

page 45 - Coast Guard

page 48-National Park Serrice, Department

of the Interior

page 52-Department of Housing and LTrban

Development page $55-$

(top) Maritime Administration

(bottom) Committee of American

Steamship Lines, Washington, D.C.

page 58-Port of New York Authority

pa ge 61-National Park Service, Department

of the Interior

page 61-Army Corps of Engineers

page 69-Sonthern California Edison Com-

pany

page 73-City of Cleveland

page 75 -Coast Gnard

page 79-Federal Water Pollution Control

Administration, Department of the In-

terior

page 82--Shell Oil Company

page $81-F i s h$ and Wildlife Service, Department of the Interior

page 88-Bureau of Commercial Fisheries,

Department of the Interior

page 91- United Nations Food and A gricul-

ture Organization

page 94

(top) Bureau of Commercial Fisheries, Department of the Interior

(bottom) Richard's Studio, Tacoma, Tisl].

page 96-Fish and Wildlife Service. Department of the Interior

page 90-Maritime Administration page $100-$

(top) Bureau of Sport Fisheries and Wildlife, Department of the Interior (bottom) Bureau of Commercial Fisheries, Department of the Interior page 103 -

(left and center) Burean of Commercial

Fisheries, Department of the Interior (right) Alpine Geophysical Associates,

Inc., Norwood, X.J.

page 106-Coast Guard

page 109-Trorld Health Organization 
page 112-Burean of Commercial Fisheries,

Department of the Interior page 115-Bureau of Commercial Fisheries,

Department of the Interior page 119-Bureau of Commercial Fisheries,

Department of the Interior page 121-National Science Foundation page 125-National Petrolenm Council page 126-Mobil Oil Corporation page 131-Dow Chemical Company page 133-General Dynamics page 136 -Burean of Mines, Department of the Interior page 138-Office of Saline Water, Department of the Interior

page 142-National Petroleum Council page 148- National Science Fonndation page 163

\section{(top) Navy}

(bottom) Westinghouse Electric Colporation

page 168-Environmental Science Services

Administration

page $170-\mathrm{Nary}$

page 174

(top left.) Coast Guard

(bottom left) National Science Foundation

(right) Coast Guard

page 176- Woods Hole Oceanographic Institution

page 179-Lockheed Missiles and Space Company

page 181-Environmental Science Services

Administration

page 183 -

(top) Environmental Science Services Administration

(bottom) Nary

page 18f-Environmental Science Services

Administration page 187 -

(top) National Aeronautics and space Administration

(bottom) Fnvironmental Science Services Administration

page 190-Environmental Science Services

Administration

page 105-U.S. Naval Institute

page 196-Grumman $\Lambda$ ircraft Engineering

Corporation

page 197-Woods Hole Oceanographic Insti-

tution

page 199-United Nations Education, Seien-

tific and Cultural Organization

page 202-Environmental Science Services

Administration

page 201-Environmental Science Services Administration

page 208-Coast Guard

page 210-Tniversity of Rhode Island

page 212- Nary

page 213-National Aeronantics and Space

Administration

page 214 - Coast Guard

page 216-Genera] Dynamics

page 218-Coast Guard

page 221-Smithsonian Institution

page 222

(top) Woods Hole Oceanograplic Institution

(bottom) Environmental Science Serrices Administration

page 223-Nary

page 225-Coast Guard

page 226- Westinghouse Electric Corpora-

tion

page 228- $\mathrm{Navy}$

page 230 -Envirommental Science Services

Aclministration

page 234

(top) Coast Guard

(bottom) Environmental Science Services Administration 
page 236-Coast Guard page 237-Coast Guard page 239-Burean of Commercial Fisheries, Department of the Interior page 240-Environmental Science Services Administration page 243

(top) National Science Foundation (bottom) Navy page 246-University of Rhode Island page 250 - Navy

page 258-M. Woodbridge Williams, National Park Service, Department of the Interior

\section{Design and Layout}

Jack Lefkowitz, Graphics 


\section{A}

Ad Hoc Committee To Studs the Peaceful Uses of

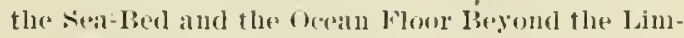
its of National Jurisdiction, U.N., 146, 147

AEO (see Atomic Energy Commission).

Air Force, Department of, Aireraft meteorological instrumentation, 189

Aireraft :

Commission recommendation: Aireraft-of-opłprtunits program, 193

Oceanographic data collection, 192. 19:3

American Bureau of Sllipping, Vessel certification, 215

AMVER (see Automated Merchant Vessel Reporting System).

Applications Technology Satellites (ATS):

ATS-3 omega position locating equipment, 193

Oceanographic research capabilities, 193

Aquaculture :

Coastal zone activity, 54

Commission recommendation: advancement, encouragement, support, 118

Definition, 115-117

Future possibilities, 12, 116, 118

Goverument support, 240

Present status in United States, 115, 116

Summary of yields, chart, 116,117

Arms Corps of Engineers (see also Coastal Engineering Research Center).

Channel and harbor improvement financing, 65

Chesapeake Bay research program, 67

Coastal engineering methods, 33,81 .

Coastal erosion studs authorization, 65

Coastal zones:

Management role, $56,61,62$

Monitoring role, 68

Research role, 67

Commission recommendations :

Coastal erosion study reexamination, 65

Offshore development, 70

Rirers and Harbors Act of 1893 amendment, 76,77

Dredging actirities, 252

Gulf of Mexico fairways establishment, 54, 55

Lake Surves charts, 210

Narigable waterways construction regulations enforcement, 217

lollution cont rol, const ruction al tivities efferts, to

l'ort and harbor modernization role, 60;

Relation to Coastal Zone Authorities, in

Respronsibilities in marine actirity, 22.8, 23:2

Atlantic States Marine Fisheries Commission, 96
Atomic Energt Commission (AEC) :

Coastal zone monitoring role, 68

Coastal zone researcl expansion, 81

rommission recommendations :

Offshore development, 70

Pilot continental shelf nuclear phant, 10, 70, 161

Pollution control authority, 77

Federal oceanographs laboratories funding, 205 . 206

Marine research funding, 24

NODC establishment agreement, 219

Nuclear technology for harhor eracuation studies, 252

l'ollution antrol, unclear jower julant effects, it

Power sources for marine resources development. 161,167

Role in Federal marine program, 232, 235

ATS (see Application Technology Satellites).

Automated Merchant lessel Reporting Sisstem (A.lVEIR), description, 216

\section{B}

Barbados Oceanographic and Meteorological Experiment (BOM EX) , 196

BCF (see Bureau of Commercial Fisheries).

liological research:

Extracting drugs from the seil. 119,120

Fisllery rields, 9S-100

Oceanic ecosrstems dynamics. 172, 173

Sea plants sources, $11 \mathrm{~s}$

BOMEX (see Barbados Oceanoginphic and Meteorological Experiment).

Budget for marine seience program, lroposed:

Actirities not included, 252

Cost estimates, 2:4-257

Efficiency considerations, 251

Funding considerations, 251, 252

Levels of funding for recommended activities. 1970-80, chart, 253

Iethods of costing, 251

Non-Federal expenditures exclusion, $2 \pi 2$

Present Fereral funding level estimation, 25: 250

Projected costs of program, chart, 255

Buoys (see also National Data Buor Sxstem I'rugram; Pilot Buny Network Project).

Commission recommendation: technologs sup. 16rt, 191, 1!2

Data collection and transmission capaloilities. 191

linrean of Commercial Fisheries (BCF) :

Aipuirilture research, "240

Average hudget increase, 252

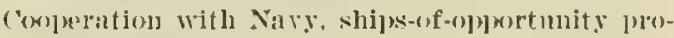
inrill1, 1ht 
Marine fisheries:

Equipment derelopment, 101

Survey program, 99

NODC establishment agreement, 219

Participation in NOAA organization, 232. 234. 235

Proposed responsibilities under NOAA, 239, 240

Research expenditures, 98

Technology development, 33

Bureau of Land Janagement, coastal zone management role, 62

Bureau of Mines, ocean mining responsibilities, 141

Bureau of Outdoor Recreation, establishment, 70

Bureau of Sport Fisheries and Wildlife:

Estuarine study, 63

Proposed responsibilities under NOAA, 239, 240

Sandy Iook Marine Lahoratory progran, 240

Research program, 67

\section{C}

Canada:

Cooperation with United States in international fisheries management, 104, 107-10)

Offshore coal mining, 132

Central Radio Propagation Laboratory, consolidation under ESSA, 241

Chemical research, sea plant sources, 118

Chile, continental shelf definition, 145

Clean Water Restoration Act of 1966 :

Coastal zones management aid, 57

Estuaries study anthorization and requirements, 63

Clearinghouse for Federal Scientific and Technical Information (CFSTI), arailability of materials, 283

Coast and Geodetic Surrey, U.S. :

Consolidation under ESSA, 2 41

Continental shelres mapping program, 211

Maps and charts publication responsibility. 210

NODC establishment agreement, 219

Coast Guard, C.S. :

Anxiliary assistance to states in recreational boating safety, 216

Average budget increases, 252

Constal zone:

Management, 56

Monitoring role, 68

Cooperation with Burean of Sport Fisheries and Wildlife, $2+0$

Coperation with Geological surves and Nars. mapping and charting, 210

Gulf of Mexico fairwass establishent, it, is

Marine haw enforcement authority, 217

National Data Buoy System progran, 191
National navigation system responsibility, 213-214

Joliar exploration responsibilities, 244

I ort and ha rbor modernization role, 67

Present status and function, 236-238

Proposed role in NOAA, 232, 234, 235, 235, 239

Radiosonde olsservations, 188

Rescue services, 216

Vessel certification responsibility, 215

Coastal Engineering Research Center, 33. 67, 228

Coastal Management Act, Commission recommenda-

tion, 57

Coastal Zone Laboratories:

Commission reconmendations:

Establishment, 29

Institutional funding, 242,243

Establishment and role, 9,10

Federal laboratories research

coordination, 67

Funding and costs, 40, 44, 81

Objectires, 27, 29

Pollution control, 75

[niversity affiliation, 69

Coastal zones (see also state Coastal Zone Authorities).

Aquaculture, 54

Commission recommendations :

AEC/Corps of Engineers/DOT/NOAA development feasibility studies, 70

Federal and state agencies' role in monitoring and research, 68

Monitoring and research instrumentation development, 68

IIonitoring and research program leadership, 68

NOAA participation in survess and inventories, 63

NOAA responsibilities, 62

Offshore leasing procedures, 72

Recreation development, 71

University training assistance, 69

Description, 49

Development :

Offshore operations, 69,70

Recreation, 70, 71

"Seasteads," 70, 71

Dirision of authority, 51, 52

Environmental problems, 8

Fisheries, 53, 54

Geographic scolle, 51

Great Lakes restoration, 10. 7テ-7\&. \&1

Interim policies 10

Management :

Development framework, 69 
Federal aid to States, 57

Federal mole, 50, 60-62

Federal/State coordination, 61, 62

Local authority, 56

Personnel needs, 68, 69

Planning needs, 62

Program costs, 79-81

Reorganization needs, 49

Responsibility, 8, 9, 56

State authority, 56,57

State boundary determination, 62,63

Monitoring and research :

Ionitoring needs, 68

Research needs, 67, 68

Significance, 67

Oceanic zones (see also Zones under international law).

Offshore water usc, 55,56

Oil and mineral exploitation, 55, 56

Percentage of population living in coastal couvtries, chart, 2

Pollution:

Action programs, 76, 77

Characteristics, $\mathbf{7 3}, \mathbf{7 4}$

Control olbjectives, 74-76

Problem, 10, 72, 73

Recreational activity summary, chart, 52

Relationship of internal waters, the territorial sea, the coutiguous zone, and the continental shelf, chart, 51

Research needs, 27, 67

Resource actirities, 54,55

Resource surress, 13, 139-141

Science and technology, 9, 10

"Seasteads," 70, 71

Shoreline derelopment, 52, 53

Significance, 49

Survers and inventories:

Coastal erosion, 65

Estuarine inventory, 63,65

Ports and harbors, 65,66

Usage intensification, 52

Columbia, marine fishery dispute, 108, 109

Commerce, Department of (see also Enrironmental

Science Services Administration; Office of the

Federal Coordinator for Meteorological Serv-

ices and Applied Meteorological Research).

Marine industry development assistance, 159, 160

Iarine research funding, 24

Tational Weather Records Center funding, 220

State Technical Services Program, 101

Commission on Marine Science, Engineering and Resources :
Activities of the members, 281

Administrative organization, 279,280

Assistance from private and

professional groups, 282

Contract studies aud reports, 283, 284

Establishment, 266, 278

Interaction with other groups and individuals, 281, 282

International Panel, membership, 280

Legislative authorit $y, 279$

Material utilized, 281

Membership, 278

Panel on Basic Science, membership, 280

Panel on Envirommental Monitoring and on Management and Development of the Coastal Zone :

Activity, 280

Functions and programs of Federal agencies, 182

Identification of inerease in coustal zone usage, 52

nembership, 280

Panel on Industry and Private investment, membership, 280

l'anel on Manpower, Education, and Training, membership, 280

l'auel on Marine Engineering and Technology: Fixed continental Shelf Laboratories, 162-164 Fresh water restoration project, 78

lndustrial technology in ocean resources development, 161

Membership, 280

Panel on Marine Resourees:

Fishermen's net economic return improvement, 94

Membership, 280

Papers submitted, 281, 285

Relationship with National Council on Marine Jesources and Engineering Development, 281

Reports, 283

Staff makeup, 281

('ommission on Weather Modification, NSF, atmosphere behavior alteration bs man, 171

Commissions :

Atlantic States Marine Fisheries Commission, :Ki

Commision on Weather Moditications, NSF, 171

Federal lower Commission, 127-130

Grout Jakes Fisherios (ommission, 113

Gulf States Marine lislueries ('ommission, (M)

Jutergorermmental Oceanographir Commission. $169,175,199,2(3), 205$

lutruational Joint commissinn for the cireat Iakes, 7S 
National Swashore IBoundary Commission, 63

l'acitie Halibut Commission, 92, 93

Pacitic IIarine Hisheries Commission, 96

Public land Law Review Commission, 136

Committee on Atmospleric Sciences, XAS, weather modification report, $19 \mathrm{~s}$

Committee on Multiple Use of the Coastal Zone:

Coastal zones management, 56

lort morlernization study, 66

Committee on Ocean Engineering. NAE, assistance to Conmission on Marine Science, Engineering and Resources, (6)

Committee on Oceanography, NAS:

Assistance to the Commission, 282

Ocean maps, 209

Ocean research review, 194

"Oceanography, 1960-1970," 27s

"Oceanography 1966," 270

Committees and boards:

Ad Hoc Committee To Study the Peaceful Uses of the Sea-Bed and the Ocean Floor Beyond the Timits of National Jurisdiction (U.N.), 146,147

Committee on Atmospheric Sciences, NAS. 198

Comnittee on Multiple Uses of the Coastal Zone, 56,66

Committee on Ocean Engineering, NAE, 282

Committee on Oceanograpli, NAS, 1月4, 209, $27 \mathrm{~s}$. 279,282

Conmittee on Petroleum Resources Under the Ocean Floor, 14-146

Disarmament Committee, U.N., 3,4

Interagency Committee on Ocean Exploration and Environmental Services, 182, 183

Interagency Committee on Oceanography, 17, 27s

Interdepartmental Committee for Atmospheric Sciences, 183

National Advisory Committee for the Ocenns (NACO), 19, 39, 40, 16.5, 245-247

Oeean Science and Technology Committee, NSIA, 282

I'resident's Science Advisory Committee, 157, 169, $194,210,278,279$

l'ublic Iand Law Review Conmission, 136

Congress, I'.S.:

l3ill H.R. 12(x)1, l'residential reto, 27!)

c'ommission resommendation: polhtion control status reports from interior Dept., 76

(ommitter juriscliction over executive agencies in marine science, chart, 248

Urersight of marine activities, $247-24$ !)
Conservation (see also Land and Water Conservation Fund) :

coastal zone reereation areas, 60

Fisleries, 12, 90-95

Great Lakes restoration, $10,7 \pi-7 \mathrm{~S}$

interuational fisheries nanagement, 104

Marine resources, 10

Natural preserves for study, 10

Cousluelf project, French, 162

continental Shelf (see also Outer Continental shelf Lands Act of 1953) :

Apnroximate delineation of continental shelves and intermediate zones as proposed, maps, 152, 153,154

Commission recommendations:

Amendment of Outer Continental Shelf Lands Act, 156,157

Guaranteeing prirate investment, 156

Jeasing beyond the 200 -meter isobath, 156

Wew definition, 145, 146

Existing definition, 143

Fixed continental shelf laboratories, 162-164

International Registry Authority:

Creation of an intermediate zone, 151-154

Dispute settlement, 150, 151

Policies on all industry registered claims. 154. 155

Policing functions, 150

l'owers and duties of registering nations, 150 Proposed claims registration procedure, 147-149 l'roposed funding procedure, 149,150

Proposed interim action, 155-157

Jine profiles of different points off the U.S. coast, chart, 124

Mapping, 210. 211

lortable continental shelf laboratories, 164

Subsea areas beyond the shelf and recommended legal-political arrangements, 146,147

Truman Proclamation of 1945,145

Uncertainties and recommended redefinition, $1+3-145$

1.S./industry cooperation on registry elains, 154,155

Continental Shelf Laboratories l'roject:

Capabilities and functions, 162-164

Estimated cost, 167

Ohjertives, 10, 11

Test facilities for undersea navigation technology. 214

Convention on the Continental Shelf:

Definition, 143

"Nedian line" principle, 151

National sovereignty. 50,51, 143 
Research restrietions, 202,203

Seientife investigation requirements, 205

Convention on Fishing and Conservation of the Iix"ing Resources of the lligh Seas:

Adoption, 109

Need for international empliance, 112-114

Conrention on the Territorial Sea and the Contiguous Zone:

National sovereignt $y, 49,50$

Submersible requiremeuts in territorial waters, 203

Territorial sea claritication, 111, 204

\section{D}

Data aequisition, processing, and dissemination:

Commission recommendations :

Coordinated system of data centers, 221

Cost est imate, 224

Data centers' restrictions, 220

Data serrices arailable, 218, 219

Workings of the data s.5stem, ehart, 219

Deep Exploration Submersible Systems Project:

Capabilities and function, 180

Cost estimate, 206

Deep ocean exploration:

Commission reeommendations:

Manner and unmanned probing, 176

National needs considerations, 175

Nary/NOAA deep ocean stations, 178

International cooperation, 174, 175

Landmarks in the development of ocean technology, chart, 6

Technological requirements, $16,17,176,177$

Deep Sea Stations Project, Commission reeommendation, 178

Defense, Department of (DOD) (see also Air Force; Army Corps of Fngineers; Militars Sea Transport Services; Navy; Office of the Special Assistant for Environmental Services of the Joint Chiefs of Staff).

IIarine-related military jrograms, 25:2

Marine resourees development. technology transfer, 165

Marine science resea $r c h, \bar{i}, 30$

vE.rPS data processing and forecasts issuance. 18.5

Polar exploration responsibilities, 244

specialized marine environnental monitoring needs, $18 t$

Department of the Air Force (see Air Force, Department of).

Department of Commerce (see Commerce, Department of).
Department of Defense (see Defense, Department of).

1)epartment of Health, Edueation, and Welfare (see Heilth, Edueation, and Welfare, Department of).

Deprarment of Housing and I'rhan Development (see Housing and I rhan Development. Deyartment of).

Deparment of the Interior (se Interior, Department of).

Department of the Nars (see Nay. Department of).

Department of State (see State, Department of).

Department of Transportation (see Transportation, Department of).

Desalination programs, 137-139

Disarmament Committee, U.N., ocean floor arms limitation, 3,4

Drugs from the sea, $12,119=$

\section{E}

Eeonomie Development Administration:

Marine resources eapital investment, 159, 160

I'ort and harbor modernization role, 66

Ecuador:

Continental shelf definition, 145

Marine fishery dispute, 108, 109

Elucation :

Commission recommendations:

Expansion of support, 43

NOAA responsibility for statisties and coordination, 43,44

Postdoctoral and mideareer orientation, 43,44

Funding sources for principal marine seience institutions, map, 31

Graduates and enrollees in marine science programs, chart, 42

National Sea Grant Program sumport, 43,44

NSF support, 43

Principal marine science laloratories and institntions, map, 28

Elliott and Naftalin, "Federal Authority for Conduet of Marine Activities," $2 \$ 3$

Environmental Data Service, ESSA. 219

Environmental research (see also Marine ecology).

Commission recommendations :

Balanced effort in research, exploration, and technology, 170

Environmental modifieation studs, 195

National monitoring program, 171

Table, 274, 275

Damage by man, 1

J)eple sea exploration, 16-17, 174-17

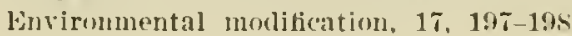


Global enrironmental programs :

Cost estimates, chart, 207

Fundamental technologs programs, 206

Glohal monitoring sfstems, 206

Research and exploration programs, 205, 206

Military/civilian roles, $16,183-185$

Ionitoring and prediction s.stem, 15, 16, 206, 207

Oceanographic effects, $2,3,169-171$

Environmental Science Services Administration

(ESSA) (see also Coast and Geodetic Surves; Environmental Data Services: ESSA meteorological satellites, SEAMAP: Weather Bureau).

Aircraft meteorology instrmmentation, 189

Arerage budget increases, 252

Coastal zone monitoring role, 68

Cooperation with Coast Guard, Geological Survey, and Nay in mapping and charting, 210

Cooperation with NASA in weather satellite program, 187

Establishment and purpose, 182

Mapping and charting responsibilities, 209-212

Participation in NOA $\mathrm{A}$ organization, 232, 234, 235

Planned geophssical surver, 139, 140

Polar exploration responsibilities, 244

Present responsibilities, 241

Proposed responsibilities under NOAA, $2+1$

Radiosonde observations, 188

Weather and marine information system, 184

Weather modification responsibilities, 198

Weather service program, 252

ESSA (see Enrironmental Science Serrices Administration).

ESSA meteorological satellites, oceanographic capabilities, 193

Executive Office of the President :

Establisbment of NOAA, 246, 247

Legislative requirements, reports on marine science accomplishments, 265, 266

Executive Order 11288, 77

\section{F}

FDA (see Food and Drug Administration).

Federal Council for Science and Technology (see also Interagency Committee on Oceanography: Interdepartmental Coumittee for Atmospheric Sciences).

Federal Jaboratories:

Commission reconmendation: strengthening. 29

Consolidation of civil agencies in-house labs, 29

Financial suplrort, 44

Federal Power Commission (F1'C), natural gas regulatory powers, 127-130
Federal Water Pollution Control Administration (FWPCA) :

Coastal zone:

Management role, 62, 252

Research, 67

Commission recommendations :

Pollutant and pollution loads research, 76

Role in Great Lakes restoration, 78

Costs, 81

Estuary survey, 63

Research and derelopment program, 77

River inflow monitoring, 68

Statutory requirement, 29

Fish and Wildlife Serrice (see Bureau of Sport Fisheries and Wildife).

Fish Protein Concentrate Program

Commission recommendation: expanded support, 103

Technology development, 102-104

Fisheries (see also Burea of Commercial Fisheries;

Bureau of Sport Fisheries and Wildlife):

Commission recommendations:

Excess fishing curtailment, 93

Extension services establishment, 101

Fishery analysis and exploitation, 98

Fishing technology program, 101

International agreement on catch limit for cod and haddock fisheries of North Atlantic, 105. 106

International fishery commission financing, 114

Interuational provisions, enforcement and regulations, 114

Management aims, 92

National catch quotas for high seas fisheries of North Pacific, 108

National priorities, policies, and regulation, 96,97

Preferential trentment of coastal nations, 110 . 111

Rationalize I'.S. fishing effort in North Atlantic, 108

Removal of restriction of foreign built ressels and equipment, 98

Settlement of disputes and problems arbitration, 114, 115

Stock assessment, survess, and exploratory fishing, 100, 101

Stock improvement research programs, 89

Strengthening intermational fishery organizations, 111-113

Territorial seas agreement, 111

Domestic fisheries management and rehabilitation : 
Federal and State roles, 95,96

Fishing industry deeline, 94,05 .

Estuarine habitat areas lost to filling operation. chart, 54

Estuarine habitats, 53,54

Extension serviees, 101-104

Food potential, 88, 89

Inereasing gap between world food needs and food supply, chart, 87

International cooperation, 93

International fisheries management:

Administrative organization, 113, 114

Commission evaluation, 105

Dispute settlement procedıre, 114, 115

Existing framework, 104, 105

National eateh quotas, 105-109

Objectires, 104

Regulation enforcement, 114

Total expenditures and U.S. funding, 113

Management :

Need for regulating fisheries, $11,12,90-92$

Objectires, 93, 94

Proposed rehabilitation by NOAA, 239, 210

Research, technology, and survey programs, 12, 98-101

Trends in the U.S. and world eateh of fish, chart. 89

U.S. economic improrement, 11

Tessel subsidy programs, 97, 98

World production and demand, 89,90

Fisherman's Protective Act of 195t, 109, 110

Fleet Numerieal Weather Central, Monteres, Calif., 184

FLIP surface platform, 177

Food and Agriculture Organization (FAO), 90, 111. 199

Food and Drug Administration (FDA) :

Fish protein concentrate program, 102

Marine law enforeement funetions, 217

FPC (see Federal Power Commission).

France (sce also Conshelf project), satellite interrogation of free-floating platforms, 193

FWPCA (see Federal Water Pollution Control Administration).

\section{G}

Genera Conrentions on the Law of the sea isee Convention on the Continental Shelf; Convention on the Territorial Sea and Contiguous Zone; convention on Fishing and Conservation of the Iiring Resources of the High Seas).

Geologicul mapping and analysis programs:
Commission reeommendation: reeonnaissanee surveys and analysis, 140

Conrdination of prograuns need, 140,141

Cost estimate, 167

Pre-investment surveys need, 139-141

Geological Survey, U.S. :

Capabilities and responsibilities, 141, 228

Cooperation with Coast Guard, ESSA, and Navy in mapping and charting, 17

River inflow monitoring, 68

George Washington University, program of policy studies in science and technology reports, 263, 281

Great Britain, offshore coal mining, 132

Great Lakes Fisheries Commission, funding, 113

Great Lakes Restoration Feasibility Test Project:

Commission recommendation: establishment and FWPCA responsibility, 78

Funding requirements. 81

Gulf of Mexico:

Fairways establishment, 54,55

JOLDES deep sea drilling projeet, 123

Offshore platforms, envirommental observation instruments, 188

Gulf States Marine Fisheries Commission, 96

\section{H}

Health, Edueation, and Welfare, Department of (HEW) (see also Food and Drug Administration; Institute of Marine Medicine and Pharmacology: Public Health Serrice), marine drugs screening, 12, 119

HEW (see Health, Edueation, and Welfare, Department of).

Homestead Act of 1862, influenee on seastead eoncept, 72

IIonduras, marine fishery dispute, 108, 109

Housing Act of $195+, 57$

Housing and Urban Derelopment. Department of (HUD), role in coastal zones management, 56

HUD (see Housing and Urban Development. Departwent of).

Hurricane Warning Service, Commission recommendation : data networks expansion, 190

\section{I}

Icebergs :

Commission reeommendation: forecasting and remote sensing of sea ice, 190

Ilotion and deformation of sea ice prediction capability, 190

ICNAF (see International Convention for the Northwest Atlantic Fisheries).

ICSU (see 1ntermational Council of Scientific Unions). 
IGOSS (see Integrated Global Ocean Station System).

Industry :

Capital investment and requirements, 159, 160

Federal and State regulations and support, 13, 14

Fishing ressels' exemption from Coast Guard certification regulation, 215

Fresh water resources, 137-139

Fundamental technology support, 5, 6, 35-37, 134, 161

Geological and geophysical surveys, 13, 139-141

Government/industry relationship in developing marine resources, $13,14,83,157-166$

Mapping and charting role, 210

Marine fisheries development, 10, 89-101, 239, 240

Merchant ship instrumentation for environmental observations, 188

Minerals development, 13, 130-137

Natural gas development, 127-130

Oceanographic research effects, 170

Oil, gas, and mineral exploitation, 10, 13, 54, 55

Petroleum development, 122-127

Transfer of technology, 164, 165

United States/industry cooperation on continental shelf claims, 151,155

INPEC (see International Convention on the High

Seas Fisheries of the North Pacific).

Instrument testing and calibration, 221-223

Institute of Marine Medicine and Pharmacology,

HEIV, Commission recommendation, 12, 120, 121

Integrated Global Ocean Station System (IGOSS) :

Description, 200

U.S. participation, 16

Interagency Committee on Ocean Exploration and Environmental Services:

Coordination of Federal environmental monitoring programs, 182

Responsibilities, 183

Interagency Committee on Oceanography, 17, 278

Interagency cooperation :

AEC/Army Corps of Engineers/DOT/NOAA in offshore development feasibility studs, recommendation, 70

Army Corps of Engineers/Fish and Wildlife Service/FWl'CA/NOAA in coastal zone research, 10,67

Army Corps of Engineers/Interior Dept./State Coastal Zone Authoritr/NOAA in coastal zone management, 61

Bureau of Commercial Fisheries/ $\mathrm{Nary} / \mathrm{ESSA}$ in ships-of-opportunity program, 188

Coast Guard/Bureau of Sport Fisheries and Wildlife in fish species charting, 240
ESSA/NASA in national weather satellite program, 187

ESSA/NASA/DOD in environmental monitoring and prediction, 241

FWPCA/Geological Surves in river inflow monitoring, 68

Napping and charting, 210

Marine technology, Nary and others, $7,38-40,235$

Neteorological coordination, 244, 245

NASA/Navy in spacecraft oceanography, 187

Nary/Coast Guard in military preparedness, 238

NODC establishment and funding, 219, 220

Polar exploration, 243, 244

Port and waterway study, recommendation, 66

Interdepartmental Committee for Atmospheric

Sciences, 183

Intergovernmental Cooperation Act of 1968, 101, 102

Intergovernmental Oceanographic Commission (IOC) (see also Integrated Ocean Station System).

Capabilities, 199,200

Deep ocean exploration coordination and planning, 175

Establishment and activities, 199

IGOSS planning, 200

Scientific investigation certification, 205

Tsunami Wraruing System coordinating responsibility, 200

U.S. participation, 169

Interior, Department of (see also Bureau of Commercial Fisheries; Burean of Land Management; Bureau of Mines; Burean of Outdoor Recreation; Bureau of Sport Fisheries and Wildlife; Federal Water Pollution Control Administration; Fish and Wildlife Service; Geological Survey; National Park Service).

Coastal zones management, 56, 61, 62

Commission recommendations :

Estuarine studies, 65

Freslı water desalination program, 137-139

Polution control status report to Congress, 76

Federal regulations enforcement authority, 127

Marine geological survey program, 139, 140

Marine research funding, 23

Ocean mining :

Funding, 141

Guidelines, 136

Pollution control, State regulator standards, $\overline{7}$ Responsibility in marine actirities, 228, 239, 240

Role in marine minerals development, 141

Water poliution from boats, estimates, it

International Agreement for Regulation of Whaling. 104 
International Biological Program, 175

International Convention for the Conservation of Atlantic Tuna, 104

Interuational Convention for the Northwest Atlantic Fisheries (ICNAF) :

Commission recommendations :

National catch quotas, $105,107-109$

National catcl quotas establishment, 105, 106i

U.S. participation, 104

Working Group on .Ioint biological and Economic Assessment of Conservation Actions, 109

International Convention on Inter-American Tropical Tuna, 104

International Convention on the Conservation and Protection of North Pacific Fur Seals, 104

International Conrention on the Great Lakes Fisheries, 104

International Convention on the High Seas, 50

International Convention on the High Seas Fisheries of the North Pacific (INPFC) :

National eateh quotas, 10 , 109

U.S. participation, 104

International Convention on the Preservation of the Halihut Fishers of the Northern l'acific Ocean and Bering Sea, 104

International Concention on the Protection, Preservation, and Extension of the Salmon Fishery of the Fraser River Sistem, 104

International cooperation (see also Intergovernmental Cooperation Act of 1968; Intergovernmental Oceanographic Commission; United Nations; World Meteorological Organization). Agreement for Regulation of Whaling, 104

Canada/United States, fisheries management, 104. $10 \overline{7}-109$

Columbia/United States, marine fishery dis]ute. 108,109

Commission recommendations:

Intergovernmental organization on oceanography, 200, 201

Sational eateh quotas, 105-107

Principle of maximum freedom for scientific inquirs, 20?

U.S. action to encourage freedom of seientific research, 204, 205

Communications improvement, 189

Continental shelf:

Creation of an intermediate zone, 151-15t

bispute settlement, 1:0, 1.1

l'olicing functions for the registry authority, 1, 0

l'owers and duties of registering natjons, 150 l'roposed claims regist ration procedure, 147-149
Proposed funding for International Registry Authority, 149, 1.50

Deep ocean exploration, $174,17.5$

Difficulties arising from Truman l'roclanation of 1945,145

Ecuador/Lnited States. marine fishery dispute. 108,109

Environmental monitoring and prediction, 16

Fish protein concentrate program, 102

Global environmental monitoring system, 198-201

Honduras/United States, marine fishery dispute. 108,109

International fisheries management, 15, 93, 104, 105

International Registry Authority, 15.5-157

Japan/United States in fisheries management. 104. 107-109

Iexico/United states in fisheries management. 104, 108-109

NOAA participation in international programs, 235

Ocean mining legal-political framework, 141-143

Panama/United States marine fishery dispute, 108, 109

Peru/United States marine fishery dispute, 108 109

Preferential treatment of the coastal nation, 108111

Research restrictions under existing legal framework, 201-203

U.N. arms limitations, 3,4

U.N. role in international fisheries management, 90,104

United States/foreign industry cooperation on registry claims, 154,155

U.S.S.R./United States in fisheries management. 104,107

World Weather l'rogram, 3, 16, 200

International Council of Scientific Unions (ICSU) :

Constituent groups related to marine sciences, 19?

Ocean exploration advice, 175

International Decade of Ocean lixploration :

Commission recommendation, 17.)

Proposed NOAA participation, 2242, 243

Submersibles contribution. 180

L.S. expenditures, 206

I.S. proposal, 3, 174, 175

International Hsdrographic Bureau :

Ocean survey data stambarlization and dissemination. 199

I'.S. commitments. 17.,

International Joint Commission for the Great lalies. is 
Interrogation, Recording, and Location Srstem (1RLS) 193

10C (see Intergovernmental Oceanographic Conmission)

IRLS (see Interrogation, Recording, and Location System ).

Cooperation with U.S. in fisheries management, $104,107-100$

Offshore coal mining, 132

JOIDES deep sea drilling project, 123, 172

\section{$\mathbf{L}$}

Lakes Survey, United States:

Participation in NOAA organization, 232, 235

Present responsibilities, 241

Proposed responsibilities, 241, 242

Lamont Geological Observatory :

South A tlantic sediment studies, 173

Status, 25

Land and Water Conservation Fund :

Commission recommendation: utilization for wetland acquisition, 60

Land acquisition funds, 80,81

Large Stable Ocean Platform Project, 38

Latin America marine fishers disputes, 109-111, 144

\section{M}

Manned ocean habitats :

Commission recommendation: adranced deep ocean stations, 178

Cost estimates, 206

Future capabilities, 177, 178

Mapping and charting:

Agencr responsibilities and industry role, 209,210

Bathymetric and geophysical characteristics of the continental shelf, 210,211

Commission recommendations :

General ocean mapping program, 210

Mapping of bathymetry and geophrsies of U.S. waters and continental slielves, 211

Nautical charting activities acceleration, 212

Survey equipment development, 213

Cost estimates, 224

Nautical charting surveys, 211, 212

Survey technology needs, 212, 213

Terminologs, 200

Marine activities:

Commission recommendation: Federal organization, $227-230$

Congressional oversight, 247, 249

Federal agencies currently associated with marine science, chart, 228
National program need, $1,4,17$

National significance, 19

Need for reorganization, 17-19, 247, 249

Orersecing the national program, 244, 245

Propased operational planning and coordination of a Federal program, 244, 245

Marine Council (see National Council on Marine

Resources and Fngineering Derelopment).

Marine ecology :

Aquaculture contributions, 115

Beneficial and detrimental modifications, 198

Commission recommendation : prediction capabilities derelopment, 197

Definition, 266

Poisonous marine organisms, 120

Prediction capabilities, 197

Marine environmental monitoring and prediction services (see also National Environmental Monitoring and Prediction Srstem).

Federal funding catagories, 183

Limiting factors, 181, 182

Products of the present system, 183, 184

Systems operations, 182,183

Marine geology :

Areas of concentration, 141

Earth's crust research and ocean resources surrey, 172

Need for geological survey programs, 139-141

Profile of the continents and oceans, 140

Theors of the continental drift, map, 172

llarine instruments:

Commission recommendation: calibration and testing progran, 223

Testing and calibration standards, 221, 223

Marine resources (see also Aquaculture; Fisheries; Fresh water resources: Industry; Natural gas : Ocean mining; Petroleum).

Conmission recommendations :

Defining a reas heyond continental shelf, $14 \overline{6}$

Government role in support of resource development, 157

Indust rial capital sources and requirements, 1.79. 160

Industry role in sulport of resource development, 157, 158

Legal and regulatory framework for safeguarding industrial investment, 160

Offshore oil leasing and regulation, 12t-127

I'rogram costs, 166, 167

Dockside ralue of resources, 158

I) status, chart, 159

Drugs. 12, 119-121 
Fresh water resources and desalination, 137-139

Hard mineral resourees:

Current state of ocean mining, 132, 133

Delegation of Goverument responsibility, 141

Exploration and development guidelines, 136

International legal-political framework, 141157

Legal and regulatory considerations, 135-137

Necessity for development, 130

Present world resource status, $130-132$

Technological considerations and obstacles, 133 135

Industrial aetivities and needs, $13,158,159$

National resource policy, 10, 83-86

Need for government/industry cooperation, 85, 166

Need for international cooperation, 85

Power source technology for resource development, 161. 162

Proposed 10-year cost breakdown, chart, 166

Research, technology, and surres programs, 12

Resource activities in coastal zone, 54,55

Resource surrers, 13, 139-141

Sea plants, research and uses, 11, 118

Technologs services to support industry activities, Gorernment responsibility, 161

Marine Resources and Engineering Derelopment Act of 1966 :

Annual report requirement, 247

Content summary, 279

Executive responsibility, 247

International cooperation, 3

Text, 261-266

Marine science and technology:

Commission recommendations:

Fundamental technology, 36, 37

Wational ocean program objectives, 23,32

National projects, 37

Nary/NOAA liaison on fundamental technology, 40

Scientific and technical information and extension program, 44

Costs, 4-47

Definition, 266

Federal agencies currently associated with marine science, chart, 228

Federal agencies' laboratories, 29

Fundamental teehnology :

Compa rison with applied technology, 35,36

Government/industry/university cooperation, $36,35-10$

Instrumentation need. 36;

Support needs. 36
Government role, 21, 22, 33, 157

Inclustry role, $33,158,161$

Information dissemination, 44, 164, 165

International apparatus, 199

Materials and instrumentation needs, $5,7,35,36$, 221-223

National capability, 21, 33

National projects, $7,37,38$

Nary role. $7,8,40$

Objectives, $5,23,31,32,37$

Research facilities, $4,5,25,26$

Research support diversity, 30

Significance, $3,4,22,23,30,31$

Marine Technology Society, 282

Marine transportation :

Commission recommendation: study of port and waterway systems, 66

Growth and change, 65 ,

Ports and harbors :

Fact-finding study, 66

Waterway deepening, 65,66

Traffic congestion and control, 66, 215

Maritime Administration, port and harbor modernization role, 66

Medical research :

Drugs dereloped from the sea, estimated cost. 167

Extracting drugs from the sea, 12, 119, 120

Meteorology :

Hurricane development forecasting, 189, 190

Research progranis coordination, 182, 183

Ilexico:

Cooperation with United States, 104

Marine fishery dispute, 108, 109

Military Sea Transport Service, radiosonde observations, 188

Mobile Undersea Support Laboratory Project, 178

\section{$\mathbf{N}$}

XACO (see National Adrisory Committee for the Oceans)

NAF(see National Academy of Fngineering).

Y.AS (see National Acadeny of Sciences).

N.ASA (see National Aeronantics and Space Administration).

Fitional Aeademy of Engineers (NAE) (see also ('ommittee on Ocean Engineering).

National Academy of Sciences (NAS) (see also Committee on Atmospheric sciences; Comnittee on Oeeanography).

Atmospheric behavior alteration by man, 171

leep ocean exploration, 175

IInping and survey programs importance, 210

Statement on marine seience needs and accomplishments. 284 
National Advisory Committee for the Oceans ( $\mathrm{NACO}$ ) :

Commission recommendations:

Administrative make-11), 245,246

Establislnment and functions, 19. 24.5, 246

Government/industry/university participation, 39 . 40

Techuology transfer role, 165

National deronatics and Space Administration (NASA) :

Commission recommendation: cooperation with NOAA on satellite oceanography, 187, 188

Cooperation witl! ESSA in national weather satellite program, 187

Coperation with Nary in spacecraft oceanography, 187

Earth resources program, sensor development, 187 Marine program funding problems comparison, 251

Marine research funding, 24

Participation in NOAA organization, 232, 235

Satellites, oceanographic applications, 210

Spacecraft use in environmental monitoring, 187

Vational Association of State Boating Law Adminis-

trators, 217

National Bureau of Standards, reference standards and test procedures for marine instruments, 222

National Center for Atmospheric Research (NCAR),

transfer of funding responsibility to NOAA, 243

National Council on Marine Resources and Engineering Derclopment (see also Committee on Iultiple Use of the Coastal Zone; Interagency Committee on Ocean Exploration and Environmental Services).

Commission recommendations: continuance, 18 , 247

Coordination of Federal coastal activities, 56, 245

Establishment, 247, 262

Interuational coperation authority, 265

Iarine activities planning and coordination, 229

Marine data needs study, 232

National Data Buoy System Program initiation. 166

Present Federal funding level estimation, 253

Relationship with the Commission, 281

Responsibilities, 17, 247, 262, 263

National Data Buoy System Program. 191

National eeonomy and marine program, effect, 170. 171

Yational Envirommental Monitoring and Prediction System (NEMPS) (see also Marine envirommental monitoring and prediction services).
Commission recommendations:

Development on a global basis, 201

Establishment and activities, 16, 181. 185, 231

Organization and management, 185, 186

Systems analysis, 194

Cost estimate, 207

Data collection devices, 191-194

Formation, 241

Immediate improvements possibility, 188-190

Initial data requirements for forecasts of given lengths, chart, 192

System operations, 184

Systems analysis, 194

National Institutes of Health (NIH), 120, 121

National Multi-Agency Oil and Hazardous Materials Contingency Plan of September 1968, 75

National Oceanic and Atmospheric Agency (NOAA) :

Capabilities, 234-236

Commission recommendations :

Establishment, 230

Independent status, 233

Responsibilities, $\mathbf{2 4 5}$

Considerations dealing with proposed agencs transfers, 236-244

Objectives and responsibilities, 4, 18, 246, 247

Operational planning and coordination of Federal marine activities, 244,245

Organization and function, $230-\mathbf{2 3 4}$

Proposed budget, 258

Proposed make-up, chart, 233

National Oceanographic Data Center (NODC) : Commission recommendations : Administration and financing, 220

Federal support, 221

Functions, 220

Functions, funding, and organization, 219, 220

Oceanographic data indexes establishment, 219

Participation in NOAA organization, 232, 235

National Park Service, shoreline management, 70

National Petroleum Council, Committee on Petroleum Resources Under the Ocean Floor:

Continental shelf redefinition, 144, 146

Evaluation of continental shelf redefinition. 144-146

National Projects (see also Continental Shelf Laboratories Project; Deep Exploration Submersible Systems Project; Deep Sea Stations Project: Great Lakes Restoration Feasibility Project: Large Stable Ocean Platform Project : Iolile Undersea Supuort Laboratory Projeet: Pilot Contiuental Shelf Nuclear Plant Project: Seamount Station I'roject; Test Facilities and Ocean Ranges Project). 
Commission recommendations:

Establishment, 37

Government/industry cooperation, 39

Costs, 47

Definition and objectives, 37

Feasibility studies, 37,38

List, 38

Management and support, 37

National Science Foundation (NSF) (see also Commission on Weather Iodification: JOIDES deep sea drilling project; National Center for Atmospheric Research).

Coastal zone research expansion, 81

Commission reconmendation: expansion of university support, 43

Cooperation with Navy, 210

Growth slowdown, 25

Marine research :

Funding, 23, 30, 205, 206

Program, 24

Support activities, 227,228

NCAR operation, 243

NODO estahlisliment agreement, 219

Ocean crust structure and origin researcb program, 172

Polar exploration responsibilities, 243

Trends in funding, chart, 25

University-National Laboratory support, 5, 242

Weather modification research :

Elimination of responsibility, 198

Report, 198

National Sea Grant College and Program Act of 1966, proposed amendment, 29

National Sea Grant Program :

Aquaculture research, 240

Educational support, 43,44

Iarine science support, $\mathbf{2 5}$

Multidisciplinary cooperation stimulation, 40

Participation in NOAA organization, 232, 235, 242

Public uses of the sea, 17

Research laboratory financial support, 81

Technical services, 101

National Seashore Boundary Commission, Commission recommendation, 63

National security :

Oceanographic requirements, 170

Undersea operations, 3,4

National Security Inlustrial Association, Ocean Science and Technology Committere:

Cooperation with Commission, 282

Report submitted, 2Ss

National Sediment Curing Program, 139, I40
National Weather Records Center:

Commission recummeludation, 221

Iarine functions, 220

National Weather Satellite Program, 187

National Weather service, recommended integration into NEMI'S. 16

Natural Gas:

Current status, 127

FPC planning policy recommendation, 129, 130

National reserve-to-production ratio, 127, 128

New pipeline construction, 128

Research and technology accounting regulations. 128, 129

Wellhead price regulation, 128

Natural resources:

Need to develop new sources, 84

l'rojected demand for given minelals to 1985 and 2000 , chart. 85

Naval Occanograplic Instrument Center:

Functions, 223

Nautical charts publication, 210

Navigation :

Commission recommendations :

Cost estimate, 224

Development work, 214, 215

Current capabilities, 213

National narigation system, 214

Positioning system needs, 213, 214

Submersibles, 214

Nary, Department of (see also Flll' surface platform; Office of Naral Research; Project Rocksite; Sealah projent; TRANSIT narigation satellites).

Aircraft :

Meteorology instrumentation, 189

Remote oceanographic sensors, 187

Civilian technology contributions, 40

Coastal waters ise, military operations, 55

Commission reconmendation: cooperation with NOAA, $7,163,178$

Cooperation with Bureau of Commercial Fisheries in ships-of-opmortunity program. 1sis

Cooperation with Coast Guard. EssA, and Geological survey in mapying and charting. 210

cooperation with NASA in spaceraft exennograluy, 18т

('ooperation with Ns]' in university ships support. 210

Envirommental prerliction eervices conolination. 152

Foderal oceanograply laboratories funding. 20). zon: 
Manned submersibles development, depth capabilities, 180

Mapping and charting responsibilities, 309, 210 Marine research, 5. 7, 8, 23, 24, 33, 227

Military sea areas, policing, 217

Navigationa] systems derelopment, 213,214

NODC establishment, agreement and operation, 219

Ocean crust structure and origin research program, 172

Ocean thermal structure analysis and prediction program, 188

Polar exploration responsibilities, 243,244

Radiosonde observations, 188

Relationship with the Coast Guard, 238

Relationship with NOAA, 232, 235

Satellites, oceanographic applications, 210

"Ten Years in Oceanograph5," 278

Undersea defense operations, 3

NCAR (see National Center for Atmospheric Research).

NEAFC (see Northeast Atlantic Fisheries Convention).

NEIIPS (see National Environmental Monitoring and Prediction System).

Newfoundland, of fshore iron mining, 132

N1H ( see National Iustitutes of Health).

NIMIBUS meteorological satellite:

IRLS flight tests, 193

Oceanographic research capabilities, 193

NOAA (see National Oceanic and Atmospheric Agency).

NODC (see National Oceanographic Data Center).

Northeast Atlantic Fisheries Conrention (NEAFC), 105,106

NSF (see National Science Foundation).

Nuclear arms race, restriction from oceans, 3,4

o

Ocean mining:

Basic dredge types, chart, 134

Continental shelf dispute, 143-146

Current state, 132, 133

Delegation of Government res]1onsibilities. 141

Ferleral support recommendation, 132, 133

Juternational legal-political framework, 141-15i

legal and regulatory considerations, 135-137

orean Science and Technology Committee, assistance to the Commission, 282

Oceanic Foundation, assistance to the Commission, 282
Office of the Federal Coordinator for Meteorological Services and Applied Meteorological Research:

Coordination of Federal meteorological programs, 182,183

Federal plan for marine meteorological services, 190

Office of Naval Research (ONR):

dcoustics research program, 30

Basic marine science research, 29, 30

Commission recommendation: oceanographic program expansion, 30

Growth slowdown, 25

Marine research funding continuance, 30

Trends in funding, chart, 25

Iniversity-National Laboratories establishment effect, 242

Office of Oceanography, UNESCO, 199

Office of the Special Assistant for Enrirommental

Services of the Joint Chiefs of Staff, DOD, 182

Omega Position Locating Equipment (OPLE), 193

ONR (see Office of Naval Research).

OPLE (see Omega Position Locating Equipment). Outer Continental Shelf Lands Act of 1953:

Commission recommendations :

Flexibility to waire competitive bidding, 137

Amendment requiring Federal permission for mining, 156, 157

Competitive leasing system, 124, 136

Industrial criticism, 135

\section{$\mathbf{P}$}

Pacific Halibut Commission, 92, 93

Pacific Marine Fisheries Commission, 96

Panama, marine fishery dispute, 108, 10 ?

I'ersonnel :

Commission recommendations :

NOAA authority, 43

NSF unirersits support expansion, 43

Unicersity training support to coastal zone personnel, 69

Definition and status, 43

Sources, $4+$

Training support, 44, 68, 69

I'eru:

Continental shelf definition. 145

Marine fishery dispute. 108, 109

I'etroleum :

Commission recommendation: derelopment rates, 127

Derelopment of marine resources:

('urrent status, 122, 123

Domestic offshore exprenditures, table, 123 
Industry contributions to teclnology transfer, 164

Iegal and regulatory considerations, 124, 126, 127

Technology advances and benefits, 123, 124

Domestic industry investment, 159

Information exchange, 121

Number of successful new offshore wells, by year, chart, 122

Record water depths for producing and exploratory wells, chart, 122

Physical oceanography:

Basic research, 194

Commission recommendations :

Ocean eurrent systems study, 195

Oceanic scales of motion study, 197

Sea-air interaction processes study, 196

Resea rch areas, 173, 124-197

Sea-air interaction, 195,196

Ware analysis diagrams, 195

l'ilot Buoy Network Project:

Commission recommendation, 192

Cost estimate, 207

Need, 16, 191

l'ilot Continental Shelf Nuclear Power Plant Project :

Capabilities and functions. 70,161

Estimated cost, 167

Objectives, 11

l'ilot Harbor Redevelopment Project, 66

Polar exploration, 173, 174, 243, 244

Pollution (see also Federal Water Pollution Control Administration: Great Lakes Restoration Feasibility 'Test Project; Water Quality Act of 1965).

Action programs :

A EC authority, 77

Army Corps of Engineers authority, 76

Legislation and financing. 76

Characteristics, 73,74

Coastal research, 10

Commission recommendations :

AEC consideration of enrironmental effects of projects, 77

Enforcement review and funding, 75

FWICA detection and analysis of pollutants, 76

Sational Comnission establishment, 79

Rivers and IIarbors Act of 1899. amendment, 76,77

Status renorts to Congress on State pollution abatement programs, 76

Control objectives:

International regulations, 75
Quality acceptability level determination, 75

Recognition, 74, 75

State quality staudards, 75

Federal legislation compliance, 10

Funding requirements, 81

Hazards to marine resources, 2

Problem analysis, 72, 73

Technology status, $7 T$

Waste management, 78

I'opulation explosion:

Economic expansion, 1

Food supply impact, 1, 81, 90

Increasing gap between world food needs and food supply, chart, 87

Recreational needs, 1, 2

Port of New York Authority, 57

I'ower Squadron, I'.S., recreational boating educational programs, 216, 217

President's Science Advisory Committee (PSAC) : Mapping and surver programs importance, 210 Ocean research review, 194

Panel on Oceanography :

Ecology considerations, 169

"Effective Use of the Sea", 278, 279

Government role in support of marine resource development, 157

Project Rocksite, Navy, 177

PSAC (see President's Science Advisory Committee).

Public Health Service:

Coastal zone monitoring role, 68

Marine law enforcement functions, 217

Shellfish sanitation program, 252

Public Land Law Review Commission, 136

Public Law 89-454 (see Marine Resources and Engineering Development Act of 1966).

Public Works and Economic Derelopment Act, regional commissions, 56

Publications (see Appendix 4 for list of materials published by the Commission).

Puget Sound salmon fishery conservation program. n2

Recreation

Boating :

Certification authorits, 215

Safety program, 216, 217

Commission recommendations :

I'nblie provisions in marine plans, 71

Safet regulations for loats, 217

Growth, status, and government support, 70

Iarine parks in the Inited States, map, 7 I

Urlan waterfrouts, 70,71 
Regulatory procedures:

Commission recommendatious:

Enforcement functions cost estimate, 224

Marine law enforcenent, 218

Updating safety standards, 215, 216

Federal and State enforcement activities, 217, 218

Vessel certification standards, 215

Resources for the Future, Inc. :

Oceanographic seminars sponsorship, 282

"Selecting Policies for the Development of Marine Resources," 284

Rivers and Harbors Act of 1899, recommended amendment, 76,77

Safety :

\section{$\mathbf{S}$}

Accident rate, 1967,215

Commission recommendations :

Cost estimates, 224

Diving equipment certification, 217

Recreational boating regulation, 217

Updating safety standards, 215,216

Recreational boating, 216,217

Search and rescle services, 216

Traffic control system, 215

Underwater safety :

Emergency equipment, 217

Equipment certification, 217

Vessel certification, 215

Sandy Hook Marine Laboratory, 240

Satellite oceanography:

Capabilities, 193, 194

Commission recommendations:

NASA/NOAA cooperation, 187, 188

Sensors development, 194

ILapping and charting, 210

NASA/Nary cooperation, 187

Satellites (see Application Technology Satellites;

ESSA meteorological satellites; N1MBUS meteor-

ological satellites; Tiros meteorological satellites;

TRANSIT navigation satellites).

SBA (see Small Business Administration).

Seripps Institution of Oceanographr, 25

Sealah project, Navy, 162

SEAMAP, 172

Seamount Station Project, 178

"Seisteads," 70, 71

Ship-of-opportunity program :

Commission recommendation, 188, 189

Nary/Burean of Commercial Fisheries cooperation, 188

World coverage, map, 189

small Business Administration (SBA) industry aid, 159,160
Smithsonian Institution:

Coastal zone research expansion, 81

Oceanograplic Sorting Center :

Biological and geological samples storage, 221

Commission recommendation, 221

Functions and funding, 220

Legislative requirements, 220,221

Responsibility in marine activities, 228

Southern California University, assistance to the Commission, 282

State Coastal Zone Autluorities:

Commission reconmendations:

Administration of Federal grants, 62

Establishment, 8, 57

Federal grants coordination, 62

Federal legislation aid, 59

Coordination with Federal agencies, 61, 62

Federal financial support, 79

Functions and powers, 57-60

Interstate estuaries management, 60

Pollution control, 75

State response to proposal, 60

State, Department of :

Marine fishery disputes, 100

Relation to NOAA, 235

State Technical Services Progran, 101

Submerged Lands Act of 1953 :

State houndary controversy, 62, 63

State ownership of seabed and subsoil. 51

Submersibles:

Commission recommendation, 180

Construction standards, 215

Depth capabilities, 179,180

Equipment, 179

Navigation needs, 214

Vehicle design, 178,179

\section{T}

Taiwan, offshore coal mining, 132

Technical and operating services, program costs, 225

Test facilities and ocean ranges project, 35,47

Texas University, assistance to the Conmission, 282

Thompson and Co., J. 1., Washington. D.C., "A Perspective of Regional and State Marine Environmental Activities: A Questionnaire Survey, Statistics and Observations," 283

Tiros satellite, oceanographic researcll capabilities, 193

TRANSIT uavigation satellites, Nary, 2 I3

'ransportation, Departuent of (DOT) :

Commission recommendation: port and waterway study initiation, 66

Marine research funding, 24 
Offshore development role, 70

Trieste, U.S.S., depth record, 179,180

Truman Proclamation of 1945, 145

'Tsunami Warning System:

Commission recommendation, 189

Coordinating responsibility, $\mathbf{2 0 0}$

Instrumentation needs, 189

\section{$\mathbf{U}$}

U.N. (see United Nations).

U.N. International Naritime consultative Organization, 75

United Nations (U.N.) (see also Ad hoc Committee To Study the l'eaceful Uses of the Sea-Bed and the Ocean Floor Beyond the Linits of National Jurisdiction; Disarmament Committee; Intergovernmental Oceanographic Organization; office of Oceanography).

Arms limitations, 3,4

International fisheries management, 104-106

Marine science organizations in or related to the U.N., chart, 201

Proposed Declaration of I'rinciples for continental shelf registration, 155,156

Proposed international registry authority, 149

U.S. proposal to encourage cooperation in the scientific investigation of the bed and subsoil of the high seas, 205

University affairs (see also Education).

Coasta] Zone Laboratories, establishment, 9, 10

University-National Laboratories, 5

University-National Laboratories:

Commission recommendations:

Establishment, 27

Institutional funding, 242,243

Establishment and role, 5,27

Funding, 40, 44

International Decade of Ocean Exploration research, 175

Location, 27

Management, 26, 27

Need, 26

Research and exploration Jrogram, cost estinates, 20.5
Unmanned instrumentation system :

Commission recommendation, 181

Cost estimates, 206

Future capabilities, 180, 181

V.S.S.R., cooperation with Inited states in international fisheries management, 104, 107

\section{V}

Vessel subsidy program:

Estimated savings, 167

Recommended repea], 98

\section{W}

Water Quality Act of 1965,75

Water Resources Comncil, coastal zone interest, 56

Water Resoures Planning Act of 1965:

Coastal zones management aid, 57

River basin commissions, 56

Weather, oceanographic êffects, 169

Weather Bureau, U.S. :

Consolidation under ESSA, 241

NODC establishment agreement, 219

WMO (see World Meteorological Organization).

Woods Hole Oceanographic Institution:

GuIf Stream structure research, 173

Status, 25

World Meteorological Organization (WMO) (see also World Weather Program).

Capabilities, 200

ESSA membership, 241

International weather observing program, 188

Meteorology and fisheries studies, 190

Rea I-time data exchange, 199

U.S. participation, 16, 169

World Weather Program sponsorship, 200

World Weather Progran:

Description, 200

U.S. participation, $16,244,245$

U.S. support. 3

\section{$\mathbf{Z}$}

Zones under international law:

Contiguous zone, 50

Continental shelf, $50, \pi 1$

High seas, 50

Internal waters and territorial sea, 49,50 





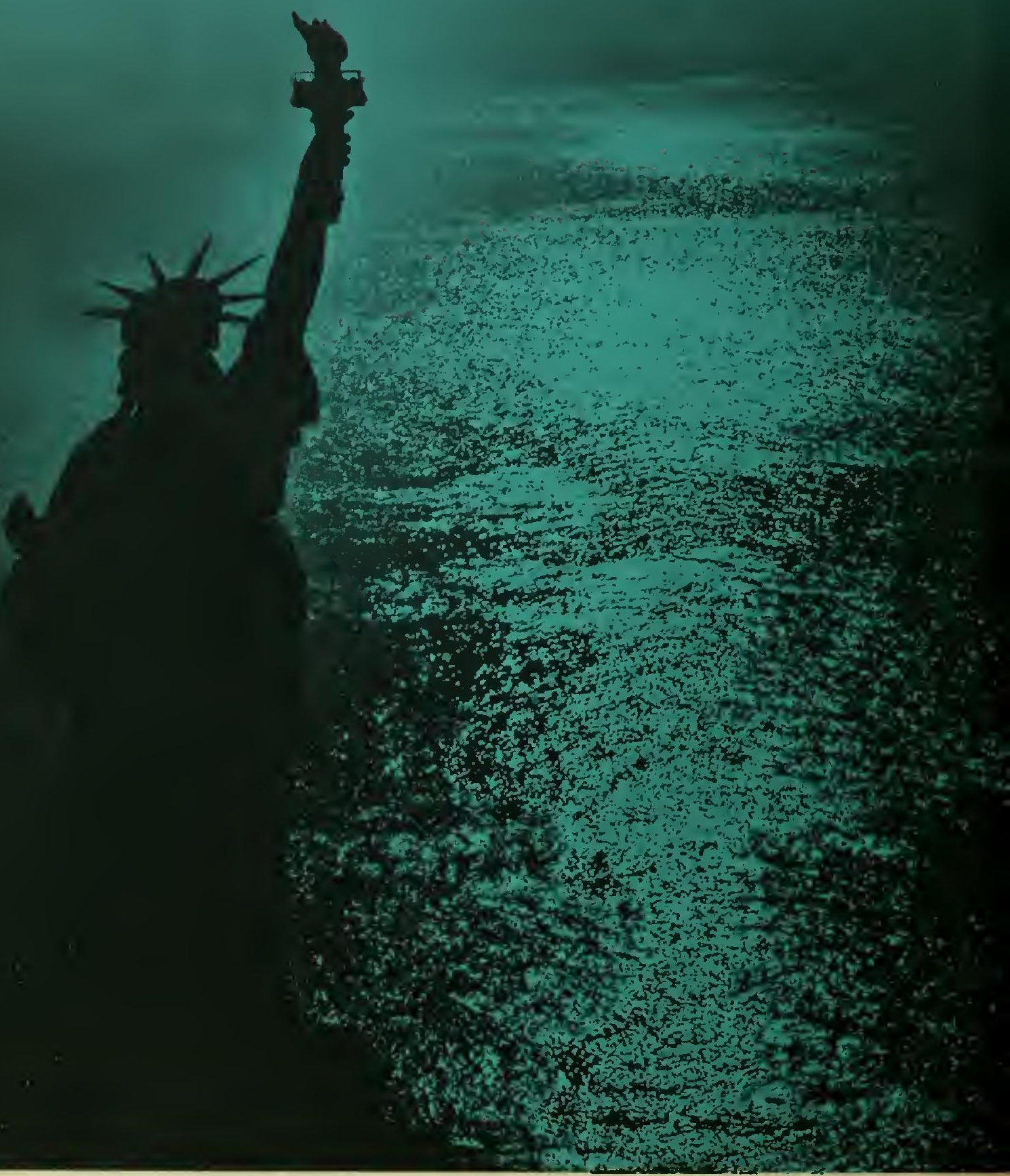

